

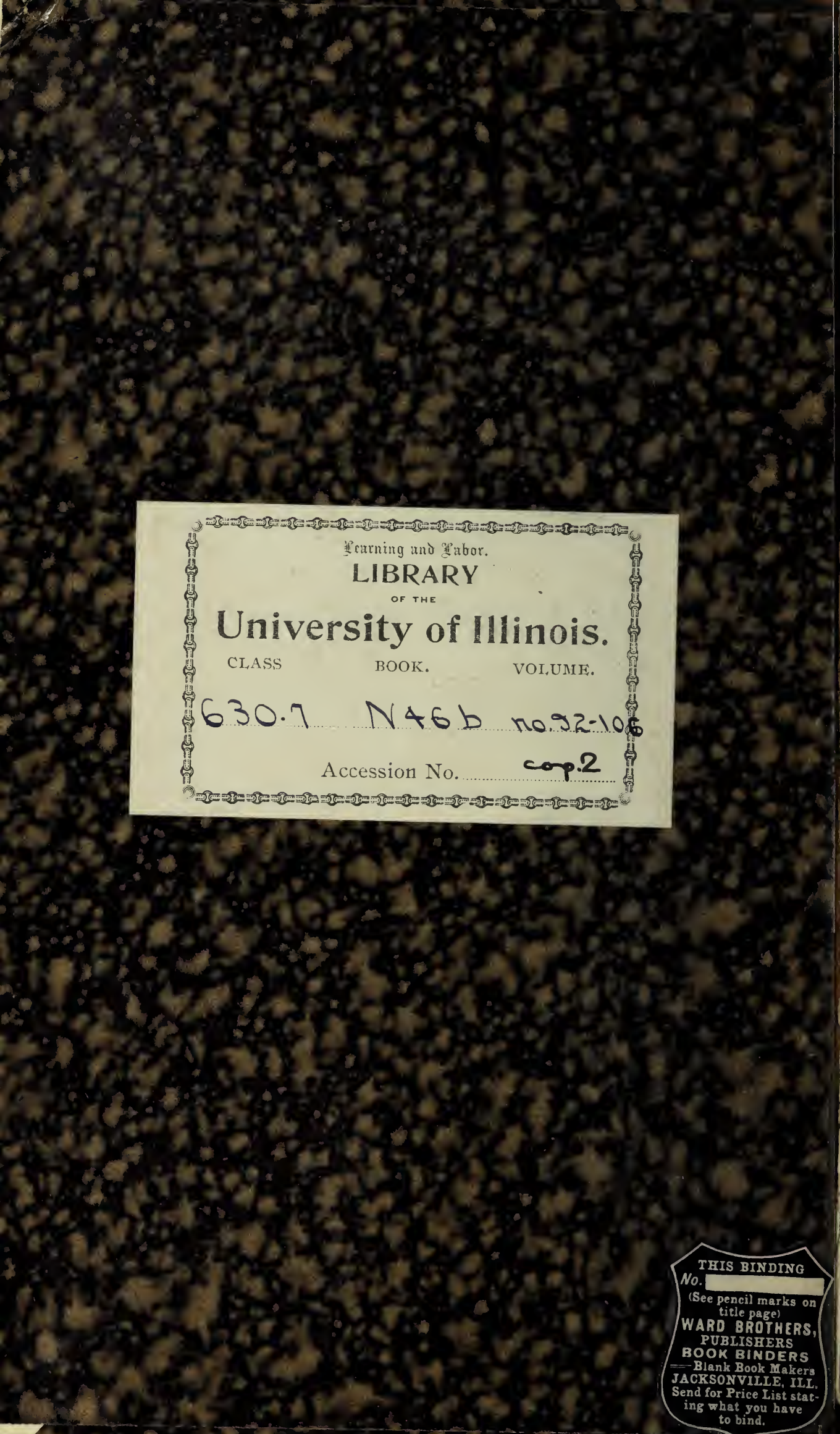


Return this book on or before the Latest Date stamped below.

\section{University of Illinois Library}

OEC A 21363

JUN 061989 
Digitized by the Internet Archive in 2016 with funding from

University of Illinois Urbana-Champaign Alternates 



FEEDING EXPERIMENTS W:TII ERTRERA. DRIED BREWERS' GRAINS VS. OATS.

$\therefore$ :

\title{
NEW JERSEY
}

\author{
AGRICULTURAL
}

\section{Experiment station.}

$$
92
$$





\section{NEW JERSEY \\ Agricultural EXPERIMENT ST'ATIÓN:"}

\section{BULLETIN 92.}

FEBRUARY 1, 1893.

\section{Feeding Experiments With Horses. Dried Brewers' Grains vs. Oats.}

BY EDWARD B. VOORHEES.

LOUIS A. VOORHEES.

The work in connection with this experiment is discussed under six heads, viz. :

1. Feeding experiments with horses.

2. Plan of the experiment; results secured.

3. Chemical composition of the rations used.

4. Economy of the dried brewers' grains ration.

5. Composition of wet and dried brewers' grains ; methods of drying.

6. Estimated output of dried brewers' grains.

\section{1.}

\section{Feeding Experiments with Horses.}

A comparatively large number of the American Experiment Stations have conducted feeding experiments with milch cows, beef cattle, pigs and young stock of all kinds, and much has been learned not only as to their needs, but as to the adaptability of the different fodders and feeds for various purposes of feeding. Practically nothing, however, has been done in studying the food requirements of work-horses. That no work has been done in this line does not prove that the system of feeding in common use is perfect, or that 
the feeding of the work-horse is a matter of comparative insignificance. We have abundant evidence that, on the whole, the feeding of work horses in unistematic, if not wasteful; and the number of horses on farms in New Jersey is one-half as great as the number of milca ws, while the sumber in towns and cities probably exceeds that on farms.

This lack of exfer.imental study in the feeding of work-horses may be due to the difficulty of accurately measuring the results of experiments, and to the extra care and expense required to secure uniform experimental conditions.

In experiments with dairy animals the quantity and quality of the milk produced is a daily guide as to the general effect of the ration used; while in those conducted with young and growing stock the amount and kind of gain made furnishes a fairly accurate statement of the results secured from the different methods of feeding.

In the work-horse a product of an entirely different character is required; it is not a gain in animal product or weight, but rather a maintenance of weight and vigor under conditions which permit of a maximum production of muscular energy.

In a product of this character the actual changes due to differences of feeding are difficult of measurement. A rigid physical examination may not discover considerable variations in the health or vigor of the animal, and an increase or decrease of weight within narrow limits is not conclusive, while the necessary expenditure of muscular energy cannot be readily distinguished from that of nervous excitement. Under ordinary circumstances, too, the work of the horse is more liable to sudden and extreme changes than that of the cow or pig, thus requiring frequent changes in rations, or a greater expense to secure the uniform and comparative conditions necessary in all experimental work.

2.

Plan of the Experiment; Results Secured.

The opinion that hay and oats are peculiarly suitable feeds for horses is universally accepted. In many sections of New Jersey hay is the main money crop. Oats is not regarded as a highly profitable crop in any part of the State, and is raised mainly for horse feed. Under the conditions that exist, therefore, these feeds, though of unquestionable value, are expensive.

In 1890 a number of farmers of the State, acting on the suggestion 
of the Station, substituted dried brewers' grains for oats in a ration for work-horses. The dried grains were cheaper, pound for pound, than the oats, and being richer in the valuable nutrients, protein and fat, permitted of a very material reduction in the cost of the ration. The work performed by the animals was quite as great, and their health and vigor quite as good, as when oats constituted the main part of the ration.

These results, in connection with the recent rapid development of the business of preparing the dried grains, led the Station to plan and conduct an experiment in feeding work-horses, in order to secure more exact data in reference to their food requirements, and also as to the value of dried brewers' grains as compared with oats.

The feeds used in the various rations studied in this experiment were analyzed, thus making it possible to study the effect of different amounts and proportions of the actual nutrients consumed. The actual comparisons of the effect of the dried brewers' grains and oats are made, however, on the basis of a pound-for-pound substitution.

Through the courtesy of Mr. William F. Price, Superintendent of the New Brunswick City Railway, the horses were furnished by that company, and the interest shown by Mr. Price in providing full facilities for the work, contributed in large measure to the successful conduct of the experiment. The advantages were a relatively large number of horses and a practical uniformity in their work.

The dried brewers' grains for the experiment were furnished by the Long Island Drying Company, of Brooklyn; the other feeds were provided by the City Railway, in such quantities and at such times as were desired.

Beginning with July 1st, the dried brewers' grains were fed to all the horses in the stable; with but few exceptions the grains were readily eaten and with apparent relish. The previous ration used at the stable consisted of oats, ground-feed-corn and oats-and hay; the oats were fed alone in the morning and the ground-feed and hay at noon and night.

On July 12th, all the horses in the stable were examined by Dr. E. L. Loblein, a veterinary surgeon of New Brunswick, N. J., and eight animals which showed a sound constitution and vigorous health, were selected for the experiment. These were numbered consecutively, weighed, and divided according to weight and age into two lots of four each. The weight and age of the respective animals were as follows : 
Lot No. 1.

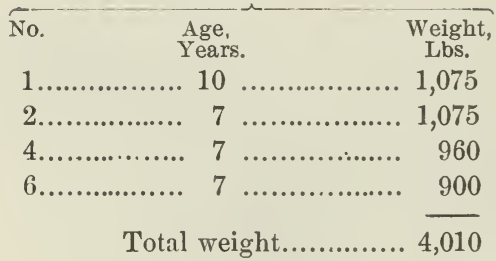

Lot No. 2.

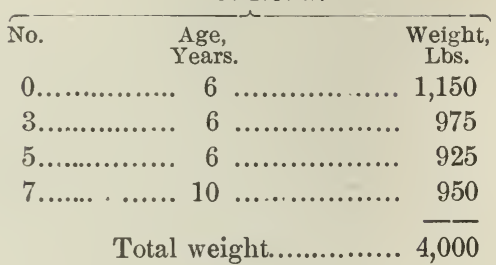

The oats ration which formed the basis of comparison was prepared with the idea of furnishing the nutrients in sufficient amounts and in good proportions for horses moderately worked. The dried brewers' grains ration differed from the oats ration in the proportions, but not materially in the total amount of nutrients furnished. The proportions of feeds used in the rations were as follows:

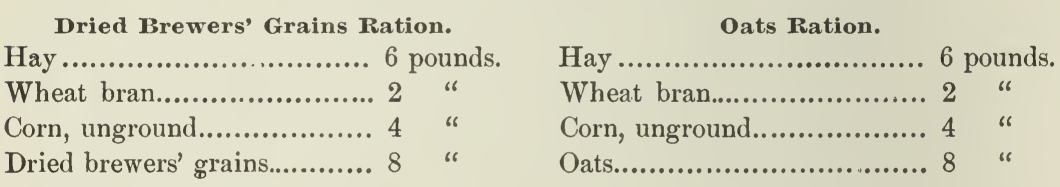

The daily rations were weighed by an employe of the Station, but were fed by the stableman at times convenient for the stable, usually at 5 A. M., 11 A. M. and 5 P. M.; the hay was given uncut at the night feeding.

In each lot the two heavier horses were fed 15 pounds and the others 13.5 pounds per day of the above mixture of feeds.

The daily work of each horse consisted of at least four trips of about six miles each; on Sundays and special holidays the trips were increased to five and sometimes six, though in all cases the work of the horses in the experiment was increased proportionately. Horses No. 4 and No. 5 were used in a team; the others were used singly. The work done was considered moderate, though it was impracticable to determine accurately the actual energy expended.

The experiment proper continued three months, though an interval of twenty days occurred between the end of the second and the beginning of the third periods, during which time all the horses were fed the stable ration. The horses in lot No. 1 were fed the dried brewers' grains ration from July 12th to August 11th, and from October 1st to October 31st, inclusive. They were fed the oats ration from August 12th to September 11th. Lot No. 2 were fed the oats ration from July 12th to August 11th, and from October 1st to October 31st; they were fed the dried brewers' grains ration from August 12th to 
September 11th. Both lots were fed the stable ration from September 12 th to September 30 th, inclusive.

The following tables show the weights of the animals at the beginning and the end of the periods under experiment:

First Period-July 12th to August 11th.

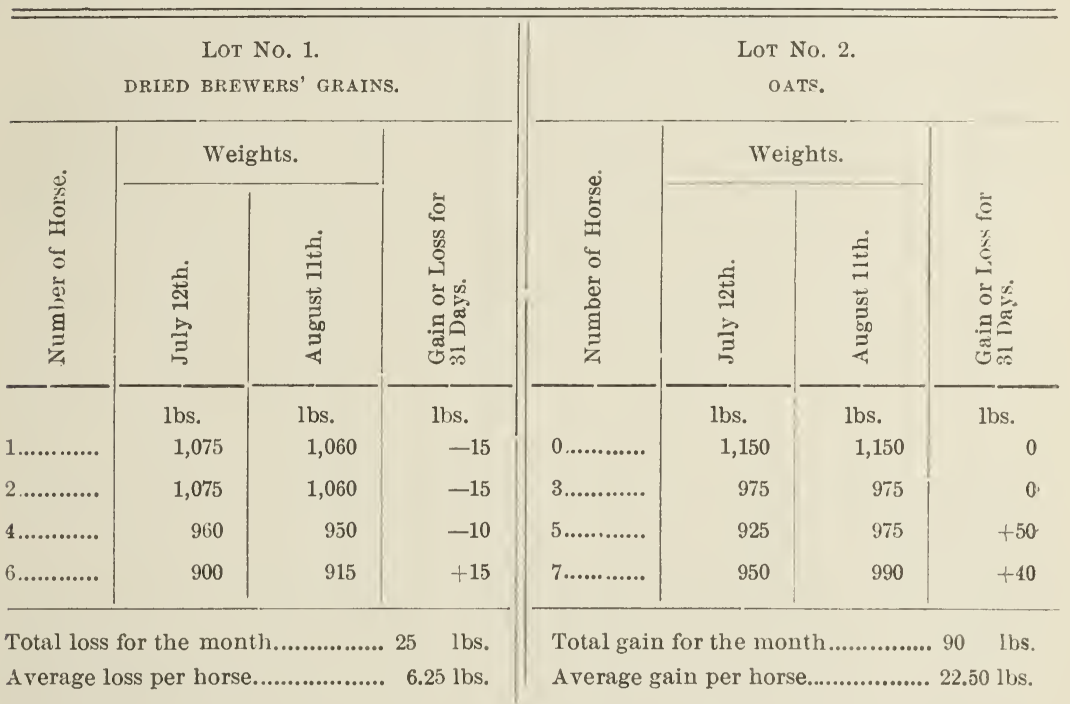

Second Period-August 12th to September 11th.

\begin{tabular}{|c|c|c|c|c|c|c|c|}
\hline \multicolumn{4}{|c|}{$\begin{array}{l}\text { Lot No. } 1 . \\
\text { oATs. }\end{array}$} & \multicolumn{4}{|c|}{$\begin{array}{l}\text { LOT No. } 2 . \\
\text { DRIED BREWERS' GRAINS. }\end{array}$} \\
\hline \multirow[b]{2}{*}{ 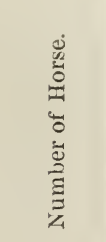 } & \multicolumn{2}{|c|}{ Weights. } & \multirow[b]{2}{*}{ 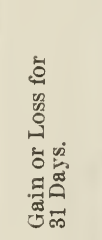 } & \multirow[b]{2}{*}{ 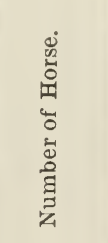 } & \multicolumn{2}{|c|}{ Weights. } & \multirow[b]{2}{*}{ 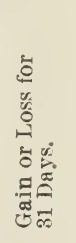 } \\
\hline & 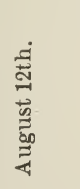 & 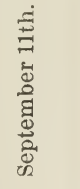 & & & 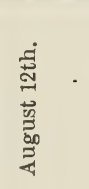 & 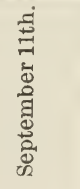 & \\
\hline $1 \ldots \ldots \ldots \ldots$ & $\begin{array}{l}\text { lbs. } \\
1,060\end{array}$ & $\begin{array}{l}\text { lbs. } \\
1,075\end{array}$ & $\begin{array}{l}\text { lbs. } \\
+15\end{array}$ & $0 \ldots \ldots \ldots \ldots$ & $\begin{array}{l}\text { lbs. } \\
1,150\end{array}$ & $\begin{array}{l}\text { lbs. } \\
1,150\end{array}$ & 1bs. \\
\hline $2 \ldots \ldots \ldots$ & 1,060 & 1,050 & -10 & $3 \ldots \ldots \ldots \ldots$ & 975 & 1,025 & +50 \\
\hline $4 \ldots \ldots \ldots \ldots$ & 950 & 975 & +25 & $5 \ldots \ldots \ldots \ldots$ & 975 & 950 & -25 \\
\hline $6 \ldots \ldots . . . . .$. & 915 & 900 & -15 & $7 \ldots \ldots \ldots \ldots$ & 990 & 975 & -15 \\
\hline \multicolumn{4}{|c|}{$\begin{array}{l}\text { Total gain for the month.............. } 15 \text { lbs. } \\
\text { A verage gain per horse................ } 3.75 \text { lbs. }\end{array}$} & \multicolumn{4}{|c|}{$\begin{array}{l}\text { Total gain for the month................ } 10 \text { lbs. } \\
\text { Average gain per horse.................. } 2.5 \text { lbs. }\end{array}$} \\
\hline
\end{tabular}


Period from September 12th to September 30th.

\begin{tabular}{|c|c|c|c|c|c|c|c|}
\hline & \multicolumn{3}{|c|}{$\begin{array}{l}\text { LOT No. } 1 . \\
\text { STABLE RATION. }\end{array}$} & \multicolumn{4}{|c|}{$\begin{array}{l}\text { LOT No. } 2 . \\
\text { STABLE RATION. }\end{array}$} \\
\hline \multirow[b]{2}{*}{ 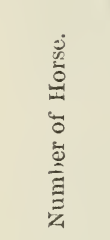 } & \multicolumn{2}{|c|}{ Weights. } & \multirow[b]{2}{*}{ 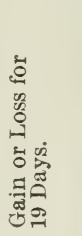 } & \multirow[b]{2}{*}{ 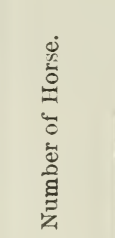 } & \multicolumn{2}{|c|}{ Weights. } & \multirow[b]{2}{*}{ 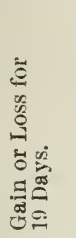 } \\
\hline & 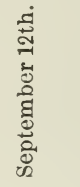 & 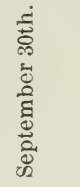 & & & 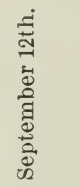 & 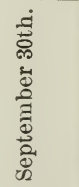 & \\
\hline $1 \ldots \ldots \ldots \ldots$ & $\begin{array}{l}\text { lbs. } \\
1,075\end{array}$ & $\begin{array}{l}\text { lbs. } \\
1,040\end{array}$ & $\begin{array}{l}\text { lbs. } \\
-35\end{array}$ & $0 \ldots \ldots \ldots \ldots$ & $\begin{array}{l}\text { lbs. } \\
1,150\end{array}$ & $\begin{array}{l}\text { lbs. } \\
1,110\end{array}$ & $\begin{array}{l}\text { lbs. } \\
-40\end{array}$ \\
\hline $2 \ldots \ldots \ldots \ldots$ & 1,050 & 1,050 & 0 & $3 \ldots \ldots \ldots \ldots$ & 1,025 & 975 & -50 \\
\hline $4 \ldots \ldots \ldots \ldots$ & 975 & 930 & -45 & $5 \ldots \ldots \ldots \ldots$ & 950 & 930 & -20 \\
\hline $6 \ldots \ldots \ldots \ldots$ & 900 & 900 & 0 & $7 \ldots \ldots \ldots \ldots$ & 975 & 980 & +5 \\
\hline \multicolumn{4}{|c|}{$\begin{array}{l}\text { Total loss for } 19 \text { days........................ } 80 \text { lbs. } \\
\text { Average loss per horse.................... } 20 \text { lbs. }\end{array}$} & \multicolumn{4}{|c|}{$\begin{array}{l}\text { Total loss for } 19 \text { days................... } 105 \mathrm{lbs} \text {. } \\
\text { A verage loss per hcrse................ } 26.25 \mathrm{lbs} .\end{array}$} \\
\hline
\end{tabular}

Third Period-October 1st to October 31 st.

\begin{tabular}{|c|c|c|c|c|c|c|c|}
\hline \multicolumn{4}{|c|}{$\begin{array}{l}\text { LOT No. } 1 . \\
\text { DRIED BREWERS' GRAINS. }\end{array}$} & \multicolumn{4}{|c|}{$\begin{array}{l}\text { Lot No. } 2 . \\
\text { oATs. }\end{array}$} \\
\hline \multirow{2}{*}{ 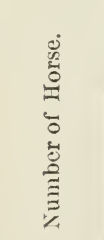 } & \multicolumn{2}{|c|}{ Weights. } & \multirow[b]{2}{*}{ 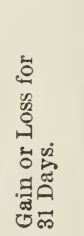 } & \multirow{2}{*}{ 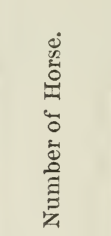 } & \multicolumn{2}{|c|}{ Weights. } & \multirow[b]{2}{*}{ 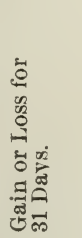 } \\
\hline & $\begin{array}{l}\frac{\overrightarrow{0}}{0} \\
\overrightarrow{0} \\
\frac{0}{0} \\
\frac{0}{0} \\
0\end{array}$ & 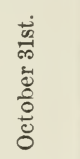 & & & $\begin{array}{l}\frac{\dot{0}}{2} \\
\frac{0}{0} \\
\frac{0}{0} \\
\frac{0}{0} \\
0\end{array}$ & 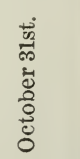 & \\
\hline $1 \ldots . . . \ldots . . .$. & $\begin{array}{l}\text { lbs. } \\
1,040\end{array}$ & $\begin{array}{l}\text { lbs. } \\
1,120\end{array}$ & $\begin{array}{l}\text { lbs. } \\
\quad+80\end{array}$ & $0 \ldots \ldots \ldots \ldots$ & $\begin{array}{l}\text { lbs. } \\
1,110\end{array}$ & $\begin{array}{l}\text { lbs. } \\
1,170\end{array}$ & $\begin{array}{l}\text { lbs. } \\
\quad+60\end{array}$ \\
\hline $2 \ldots \ldots \ldots \ldots$ & 1,050 & 1,080 & +30 & $3 \ldots \ldots \ldots \ldots$ & 975 & 1,090 & $+115^{*}$ \\
\hline $4 \ldots \ldots \ldots . . .$. & 930 & 1,010 & +80 & $5 \ldots \ldots \ldots . .$. & 930 & 970 & +40 \\
\hline $6 \ldots \ldots \ldots . .$. & 900 & 950 & +50 & $7 \ldots \ldots \ldots$ & 980 & 1,020 & +40 \\
\hline \multicolumn{4}{|c|}{$\begin{array}{l}\text { Total gain for the month................ } 240 \mathrm{lbs} \text {. } \\
\text { Average gain per horse.................... } 60 \mathrm{lbs} \text {. }\end{array}$} & \multicolumn{4}{|c|}{$\begin{array}{l}\text { Total gain for the month.............. } 140 \text { lbs. } \\
\text { Average gain per horse................. } 46.7 \mathrm{lbs} \text {. }\end{array}$} \\
\hline
\end{tabular}

* Horse No. 3 was fed dried brewers' grains from October 10th to October 31st; his gain is therefore not included in the total or average.

The weights at the end of the first period showed a gain for horse No. 6 in lot 1, and for horses Nos. 5 and 7 in lot 2 ; a loss for horses 
Nos. 1, 2 and 4 in lot 1, and neither gain nor loss for Nos. 0 and 3 in lot 2. With the possible exception of Nos. 5 and 7 in lot 2, the variations in weight were within the limits of changes due to natural causes for horses of this size. In fact, the weights secured were surprising in that they showed no serious losses, and their uniformity furnished evidence of the good character and adaptability of both rations, as well as of the good management of the horses during the period, in which the conditions other than feed were extremely severe; the mean maximum temperature for the last twenty days was $87.9^{\circ}$.

In the second period lot 1 was fed the oats ration and lot 2 the dried brewers' grains ration. The weights at the end of the period, on September 11th, were again strikingly uniform. Horse No. 3 in lot 2 was the only one that showed a difference in weight large enough to be chargeable to changes in the nutritive effect of the rations.

If the differences in the weights observed for both periods were entirely chargeable to the rations, then oats are shown to be slightly more satisfactory than dried brewers' grains. Still, a comparison of the weights of the horses of both lots, at the beginning of the first period and at the end of the second, indicates that the differences may be due entirely to differences in the character of the individual horses rather than to the feeds; for lot 1 , fed identically the same as lot 2 , shows a loss of 10 pounds for the two months, due to slight variations in the weight of each horse in the lot, while in lot 2 there is a gain of 100 pounds, due to changes in the weights of two horses in the first period and of three in the second.

At the end of the second period the horses of both lots were fed the stable ration until October 1st, in order that this entire month might constitute the third period, thereby enabling a comparison of the effect of the rations when conditions, other than feed, were as likely to be favorable as in any season of the year, the previous periods having been very unfavorable in this respect.

The weights of the horses on October 1st showed a considerable loss during the nineteen days' feeding of the stable ration; the greatest difference, an average loss of 26.25 pounds per horse, was again shown in lot 2.

The conditions other than feed during the third period were unusually favorable, the weather was clear and cool, and free from storms, and the work uniform. Lot 1 were fed the dried brewers' grains 
ration and lot 2 the oats ration for this period. Horse No. 3 in lot 2 developed a sore on his right shoulder, and a necessary surgical operation on October 10th incapacitated him for work for the remainder of the period.

The weights recorded on October 31st showed a total gain of 240 pounds for lot 1 , or an average gain of 60 pounds for each horse on the dried brewers' grains ration. The lowest gain was 30 pounds for No. 2, and the highest, 80 pounds, for both Nos. 1 and 4 . In lot 2 there was a total gain of 160 pounds for three horses, or an average gain per horse of 46.7 pounds on the oats ration. In this period, therefore, when owing to favorable conditions actual gains were to be expected, the increase in weight from the dried brewers' grains ration was greater by 13.3 pounds per horse than that from the oats ration.

The weight of horse No. 3 was the same at the beginning of the first and third periods, his weight having remained stationary on the oats ration, and the gain made on the dried brewers' grains ration being lost on the stable ration in which oats was the chief feed. $\mathrm{He}$ was fed after October 10th, 6 pounds per day of dried brewers' grains. in addition to a liberal ration of hay, and gained while idle 115 pounds in 20 days.

The following tabulation shows the weights of the horses at the beginning and at the end of the experiment:

\begin{tabular}{|c|c|c|c|c|c|c|c|}
\hline \multicolumn{4}{|c|}{$\begin{array}{c}\text { LOT No. } 1 . \\
\text { FED DRIED BREWERS' GRAINS } 62 \text { DAYS } \\
\text { AND OATS } 31 \text { DAY'S. }\end{array}$} & \multicolumn{4}{|c|}{$\begin{array}{l}\text { LOT No. } 2 . \\
\text { FED OATS } 62 \text { DAYS AND DRIED BREWERS' } \\
\text { GRAINS } 31 \text { DAYS. }\end{array}$} \\
\hline \multirow{2}{*}{ 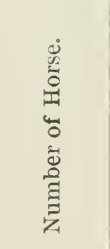 } & \multicolumn{2}{|c|}{ Weights. } & \multirow[b]{2}{*}{ 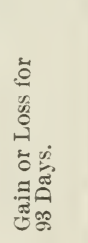 } & \multirow{2}{*}{ 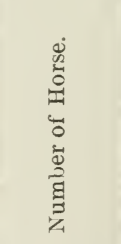 } & \multicolumn{2}{|c|}{ Weights. } & \multirow[b]{2}{*}{ 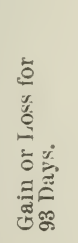 } \\
\hline & 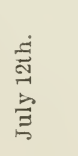 & $\begin{array}{l}\overrightarrow{0} \\
\frac{0}{0} \\
\vec{d} \\
\stackrel{0}{0} \\
\stackrel{0}{0} \\
0\end{array}$ & & & 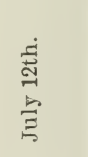 & 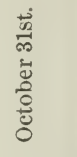 & \\
\hline $1 \ldots \ldots \ldots . . .$. & $\begin{array}{l}\text { lbs. } \\
1,075\end{array}$ & $\begin{array}{l}\text { lbs. } \\
1,120\end{array}$ & $\begin{array}{l}\text { lbs. } \\
+45\end{array}$ & $0 \ldots \ldots \ldots$ & $\begin{array}{l}\text { lbs. } \\
1,150\end{array}$ & $\begin{array}{l}\text { lbs. } \\
1,170\end{array}$ & $\begin{array}{l}\text { lbs. } \\
+20\end{array}$ \\
\hline $2 \ldots \ldots \ldots \ldots$ & 1,075 & 1,080 & +5 & 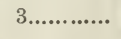 & 975 & $\ldots \ldots$ & ...... \\
\hline 4.................. & 960 & 1,010 & +50 & $5 \ldots \ldots \ldots . . .$. & 925 & 970 & +45 \\
\hline $6 \ldots \ldots \ldots \ldots$ & 900 & 950 & +50 & $7 \ldots \ldots \ldots . . . .$. & 950 & 1,020 & +70 \\
\hline \multicolumn{4}{|c|}{ 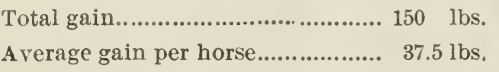 } & \multicolumn{4}{|c|}{ 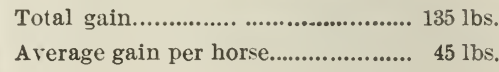 } \\
\hline
\end{tabular}


On October 31st, after more than three months of severe labor, a gain is shown greater than could be expected from ordinary causes. The gain from lot 1 averages 37.5 pounds per horse; for lot 2, 45 pounds per horse, No. 3 not included, though in the two periods under experiment he showed a decided gain when fed the dried brewers' grains ration, and no gain from the oats ration.

The physical examination of the horses was repeated by Dr. Loblein at the end of the experiment. He reported as follows: "I have watched the horses closely from the beginning to the end of the experiment and have failed to discover any ill effects from the use of dried brewers' grains. The horses fed the grains have been as healthy as I have ever known them to be."

The results of this experiment indicate-

1. That in both rations the nutrients furnished were sufficient to maintain the weight of the animals under average work; and

2. That on the whole, a pound of dried brewers' grains was quite as useful as a pound of oats in a ration for work-horses.

3.

Chemical Composition of the Rations Used.

The two rations used were not intended to furnish equal amounts and proportions of digestible nutrients. It was, however, the intention that the composition of the oats ration should correspond as nearly as possible with the standard ration as given by German authorities for moderately worked horses of 1,000 pounds live weight, viz :

\begin{tabular}{lccc} 
& Digestible. & Nutritive \\
\hline Fat, & $\begin{array}{c}\text { Protein, } \\
\text { Lbs. }\end{array}$ & $\begin{array}{c}\text { Carbohydrates, } \\
\text { Lbs. }\end{array}$ & Ratio. \\
0.6 & 1.8 & 11.2 & 1 to 7.
\end{tabular}

The analyses of the feeds used were made after the experiment began, hence the actual composition differed slightly from the standard: 
Analyses of Feeds.

\begin{tabular}{|c|c|c|c|c|c|c|c|c|c|c|c|}
\hline \multirow[b]{2}{*}{ 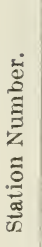 } & \multirow[b]{2}{*}{ FEED. } & \multicolumn{7}{|c|}{ POUNDS PER HUNDRED OF } & \multicolumn{3}{|c|}{ PERCENTAGE OF } \\
\hline & & $\frac{\dot{D}}{\vec{D}}$ & 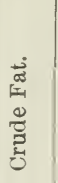 & $\begin{array}{l}\frac{5}{0} \\
\frac{0}{11} \\
0 \\
0 \\
ٍ \\
0\end{array}$ & 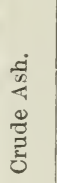 & 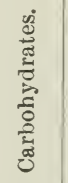 & 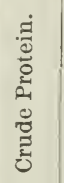 & 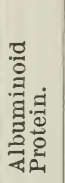 & 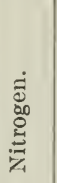 & 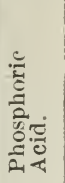 & $\frac{\dot{\pi}}{\stackrel{\tilde{n}}{\tilde{E}}}$ \\
\hline 732 & Timothy Hay.................... & 8.64 & 2.08 & 28.65 & 4.90 & 48.90 & 6.83 & 6.24 & 1.09 & 0.28 & 0.96 \\
\hline 730 & 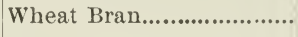 & 11.45 & 4.50 & 7.92 & 7.03 & 52.12 & 16.98 & 14.23 & 2.72 & 3.60 & 1.50 \\
\hline 729 & Corn...........$\ldots \ldots \ldots \ldots \ldots$ & 13.46 & 4.47 & 1.43 & 1.29 & 69.74 & 9.61 & 9.61 & 1.51 & 0.60 & 0.32 \\
\hline 728 & 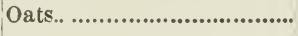 & 10.80 & 5.52 & 8.54 & 3.81 & 59.05 & 12.28 & 10.57 & 1.97 & 0.79 & 0.49 \\
\hline 731 & Dried Brewers' Grains...... & 9.90 & 5.54 & 13.32 & 3.50 & 41.03 & 23.71 & 21.14 & 3.79 & 1.05 & 0.09 \\
\hline
\end{tabular}

The above analyses show these feeds to have been up to the standard in quality. The dried brewers' grains differ from the oats mainly in showing a much higher content of crude protein and a lower content of carbohydrates, including fiber. The fat is practically the same in each. On the basis of dry matter, the dried brewers' grains contain 86 per cent. more crude protein than the oats; the percentage of true protein or albuminoids is also proportionately greater in the dried brewers' grains. These feeds also differ radically in the proportions and amounts of their ash constituents. The brewers' grains contain less than one-tenth of one per cent. of potash, the oats about one-half of one per cent., while the phosphoric acid is one-third greater in the grains than in the oats.

The daily rations fed on the basis of 1,000 pounds live weight consisted of 6 pounds of hay and 15 pounds of feeds, according to the proportions given on page 6 . The following tabulation shows the digestible nutrients furnished by each ration :

Dried Brewer's Grains Ration.

\begin{tabular}{|c|c|c|c|}
\hline 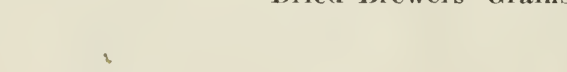 & $\begin{array}{l}\text { Fat, } \\
\text { Lbs. }\end{array}$ & $\begin{array}{l}\text { Protein, } \\
\text { Lbs. }\end{array}$ & $\begin{array}{c}\text { Carbohydrates, } \\
\text { Lbs. }\end{array}$ \\
\hline 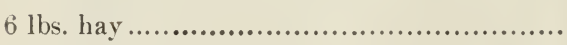 & 0.03 & 0.25 & $2.3 \bar{\imath}$ \\
\hline 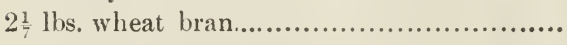 & 0.05 & 0.27 & 0.84 \\
\hline 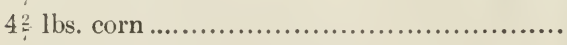 & 0.12 & 0.32 & 2.87 \\
\hline $8 \div$ lbs. dried brewers' grains.................... & 0.38 & 1.73 & 3.7 \\
\hline & 0.58 & 2.57 & 9.85 \\
\hline
\end{tabular}

Nutritive ratio, $1: 4.4$. 


\begin{tabular}{|c|c|c|c|}
\hline Oats Ration. & $\begin{array}{l}\text { Fat, } \\
\text { Lbs. }\end{array}$ & $\begin{array}{l}\text { Protein, } \\
\text { Lbs. }\end{array}$ & $\begin{array}{c}\text { Carbohydrates, } \\
\text { Lbs. }\end{array}$ \\
\hline 6 lbs. hay ............................... & 0.03 & 0.25 & 2.37 \\
\hline 21 lbs. wheat bran............................. & 0.05 & 0.27 & 0.84 \\
\hline 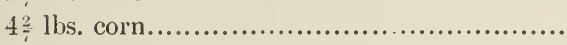 & 0.12 & 0.32 & 2.87 \\
\hline 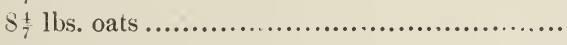 & 0.37 & 0.92 & 4.09 \\
\hline & 0.57 & 1.76 & 10.17 \\
\hline
\end{tabular}

Nutritive ratio, $1: 6.6$.

The dried brewers' grains ration contained 13.0 pounds of digestible dry matter, and the oats ration 12.5 pounds. The difference is due mainly to the amount of protein, the former containing 46 per cent. more than the latter; the fat-a very essential nutrient in a ration for work-horses-and the carbohydrates are practically identical in both. The oats ration contains 1.1 pounds and the dried brewers' grains ration 0.6 of a pound less dry matter than the standard, this loss falling chiefly on the carbohydrates, thus making the nutritive ratios $1: 6.6$ and $1: 4.4$, instead of $1: 7$, as in the standard. The stable ration, which was fed from Septe mber 12 th to 30 th, inclusive, consisted of 6 pounds of hay, 2 of wheat bran, 4 of oats and 8 of corn and oats feed. It furnished 1.51 pounds of protein, 0.46 of fat and 10.56 of carbohydrates, and had a nutritive ratio of $1: 7.5$. The total amount of digestible nutrients was 12.53 pounds, or practically the same as in the oats ration.

It has already been shown that the horses on the oats and dried brewers' grains rations fully maintained their weights under unfavorable conditions and increased in weight under favorable conditions. It was also shown that under favorable conditions there was a loss of weight on the stable ration, that is :

1. That rations which contained at least as much of fat and protein, but less of carbohydrates than the standard, maintained and even increased the weight of the animals; and

2. A ration that contained less fat and protein but more of carbohydrates than either of the others, resulted in a decrease in weight.

These results verify the usefulness of the standard in reference to the amounts of protein and fat, and also indicate that the effect of these nutrients cannot be attained by a substitution for them of the carbohydrates. There was evidently a waste of protein in the dried brewers' grains ration, since the oats ration, containing 30 per cent. less protein but practically the same fat and carbohydrates, gave relatively as good results. 
4.

\section{Economy of the Dried Brewers' Grains Ration.}

By actual trial a pound of dried brewers' grains was shown to be quite as useful as a pound of oats in a ration for work-horses. A comparison of the composition of the feeds indicates that the reason for this result lies in the fact that the dried brewers' grains furnish more of the valuable digestible nutrients than the oats.

The next question which is of importance to the practical feeder is: Will it pay to substitute grains for oats?

This point admits of discussion from two standpoints-1. The economy of a pound-for-pound substitution as in the experiment, and 2. A substitution based upon the composition.

The actual cost, per ton, of the feeds used in the experiment was, hay, $\$ 18$; wheat bran, $\$ 22$; corn, $\$ 22$; oats, $\$ 30$, and dried brewers' grains, $\$ 18$. The amount and cost of the feeds consumed by the four horses in each lot, per period of 31 days, are shown below.

Oats Ration.

Lbs.

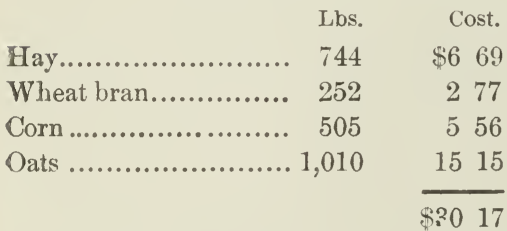

Dried Brewers' Grains Ration.

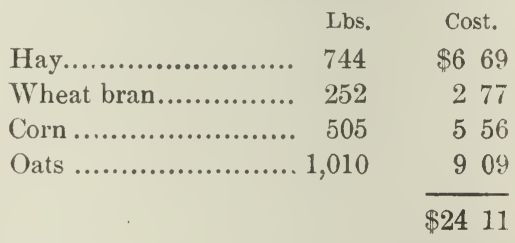

19.4 cents 4.9 cents

Cost per horse per day............. 24.3 cents.
Saving per day per horse from the use of dried brewer's' grains.

The substitution of dried brewers' grains for oats resulted not only in a maintenance of the weight of the animals under equivalent work, but in a saving of 4.9 cents per day per horse, or 25 per cent. of the cost of the ration. This saving, though appearing small in itself, means considerable in the aggregate; if applied to the forty horses at the car stables, it would represent a saving of $\$ 1.96$ per day, or over $\$ 700$ per year, a sum sufficient to pay the interest on a capital of $\$ 12,000$.

Of course, the saving in any case depends upon the relation between the cost of the grains and the cost of the oats. The cost of the grains per ton in car lots has been fixed at $\$ 16$ for the summer, at $\$ 17$ for the autumn, and at $\$ 18$ for the winter and spring months. The cost of freight and handling to point of consumption would probably add, on the average, $\$ 2$ per ton. The manufacturers of the grains claim that these prices will not be materially increased. 
Variations in the cost to the consumer will doubtless occur; the following table of equivalents shows under what conditions of cost the substitution of one for the other may be profitable:

Table of Equivalents.

Dried brewers' grains at......... \$18 00 per ton $=$ oatsat......... 27 cents per bushel

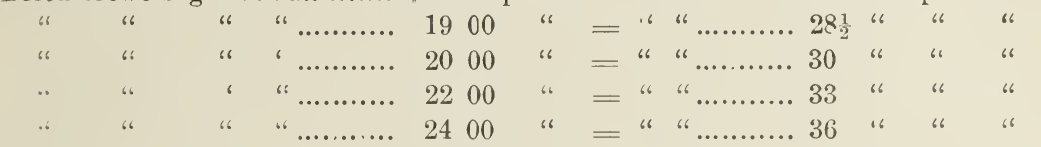

Assuming $\$ 24$ per ton as a maximum for dried brewers' grains, they are then as cheap as the oats at 36 cents per bushel, which is certainly a minimum price to the consumer for oats of good quality. An increase of $\$ 1$ per ton on the grains is balanced by an addition of $1 \frac{1}{2}$ cents per bushel for oats.

Another point which should be regarded, especially by farmers who make the exchange, is the relative content and value of the fertilizer constituents contained in these feeds. A ton of oats sold from the farm carries away, on an average, 37 pounds of nitrogen, 15 of phosphoric acid and 12 of potash. A ton of dried brewers' grains will bring to the farm 77 pounds of nitrogen, 19 pounds of phosphoric acid and 2 pounds of potash; a gain to the farm, by the exchange, of 40 pounds of nitrogen and 4 of phosphoric acid, and a loss of 10 pounds of potash, or a net gain of $\$ 6.19$ on the basis of their fertilizing values. The gain would be proportionately the same if the feeds were used on the farm, since under uniform conditions of feeding the same relative amounts of the constituents would be retained in the manure. At the same cost per ton for the two feeds, therefore, there would be a considerable gain in fertility by a pound-for-pound substitution of the dried brewers' grains for the oats.

A study of the methods of feeding among farmers shows that the usual custom for horses performing ordinary work is to give about twelve pounds of grain per day, with as much hay as the animals will eat. The grain consists usually of corn or oats alone or the two mixed, and is fed ground or unground, as the case may be.

Careful inquiry indicates that the following tabulation of rations would represent average conditions :

No. 1

No. 2 .

No. 3. hay, 12 pounds; oats, 12 pounds corn, 12

corn, 6 "

oats, 6 
The variations in the actual nutrients furnished by these rations, using both timothy and clover, are shown in the following table.

\begin{tabular}{|c|c|c|c|c|c|c|}
\hline & \multicolumn{3}{|c|}{ Digestible. } & \multirow{2}{*}{$\begin{array}{l}\text { Total Digestible } \\
\text { Dry Matter, } \\
\text { Lbs. }\end{array}$} & \multirow[b]{2}{*}{$\begin{array}{l}\text { Nutritive } \\
\text { Ratio. }\end{array}$} \\
\hline & & $\begin{array}{l}\text { Fat, } \\
\text { Lbs. }\end{array}$ & $\begin{array}{l}\text { Protein, } \\
\text { Lbs. }\end{array}$ & $\begin{array}{c}\text { Carbohydrates, } \\
\text { Lbs. }\end{array}$ & & \\
\hline . 1 & \{ Timothy ............ & 0.58 & 1.61 & 11.76 & 13.85 & $1: 8$ \\
\hline & $\{$ Clover ................ & 0.67 & 2.18 & 11.23 & 13.98 & $1: 6$ \\
\hline ation 2 . & $\{$ Timothy ............ & 0.51 & 1.23 & 13.70 & 15.44 & $1: 12.2$ \\
\hline & Clover ............... & 0.60 & 1.80 & 13.17 & 15.57 & $1: 8.1$ \\
\hline tion 3 & \{ Timothy ............. & 0.55 & 1.42 & 12.73 & 14.70 & $1: 9.8$ \\
\hline tion 3 & $\{$ Clover ............... & 0.64 & 1.99 & 12.20 & 14.73 & $1: 6.9$ \\
\hline
\end{tabular}

All of the rations contain more digestible dry matter than the German standard demands. They also eontain more than the oats ration fed in the experiment, which maintained the weight of the horses under moderate work In the clover hay rations, the different nutrients are in good proportion, except in No. 2, where corn is the grain used. The rations containing timothy hay are, with the exception of No. 1, where oats is the only grain used, poorer in protein and fat than the standard, or than was found necessary in the experiment.

The chief criticisms of these rations as a whole are, therefore-

1. That they are too rich in carbohydrates, and

2. That in their preparation the character and composition of the grains used are disregarded, thus giving widely different proportions of the various nutrients for the same work.

The same criticisms apply to the rations for horses employed in government work. These rations consist of 14 pounds of hay and 12 pounds of corn, oats or barley per day, with the addition of 3 pounds of oats for heavy work. The corn ration for ordinary work contains 0.53 pounds of fat, 1.31 of protein and 12.74 of carbohydrates, with a nutritive ratio of $1: 12.2$. The oats ration contains 0.60 pounds of fat, 1.68 of protein and 14.68 of carbohydrates, with a nutritive ratio of $1: 8.5$. If these rations give equally good results, then either the carbohydrates may be substituted for protein and fat, or there is a sufficiency of protein and fat in the corn ration, and a consequent waste of a part of all the nutrients in the oats ration, and of a part of the carbohydrates in the corn ration. 
While it is true that in a ration for work-horses the carbohydrates may, in part at least, substitute the fat, they cannot take the place of the protein; hence, in making a substitution of feeds for the same works, if widely varying amounts of fat and protein are provided, there results either a loss of weight by the animal or a waste of food. The examination of the rations used in the experiment, as well as those in common use, shows that in what are regarded as the best rations, the fat approaches 0.6 of a pound and the protein 1.8 pounds per day, while the carbohydrates range from 10.17 to 14.68 pounds. It seems clear, therefore, that in the preparation of rations for workhorses, particular care should be exercised in reference to the compounds protein and fat. The following daily rations furnish as much fat, and slightly more protein than the oats ration of the experiment, and practically the same amounts of these constituents as are furnished by the rations now in general use by the farmers of the State; the carbohydrates furnished are much less, and with the exception of No. 4, are practically identical in each case :

Furnishing Digestible

Ration.

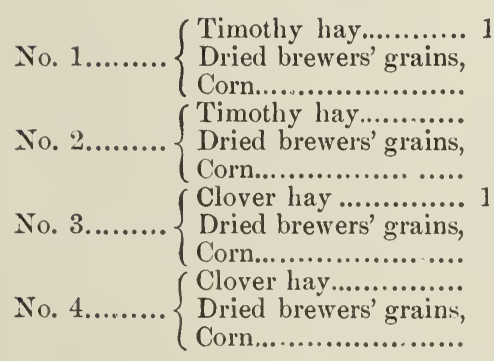

\begin{tabular}{|c|c|c|c|c|}
\hline & Fu & ishing & gestible & \\
\hline 0 lbs. ) & $\begin{array}{l}\text { Fat, } \\
\text { Lbs. }\end{array}$ & $\begin{array}{l}\text { Protein, } \\
\text { Lbs. }\end{array}$ & $\begin{array}{l}\text { Carbo- } \\
\text { hydrates, } \\
\text { Lbs. }\end{array}$ & $\begin{array}{l}\text { Nutritire } \\
\text { Ratio. }\end{array}$ \\
\hline $\left.\begin{array}{ll}6 & 10 \\
4 & " 6\end{array}\right\}$ & 0.55 & 1.85 & 10.05 & $1: 6.2$ \\
\hline $\left.\begin{array}{ll}6 & 4 \\
6 & \text { " } \\
6 & 4\end{array}\right\}$ & 0.58 & 1.84 & 9.42 & $1: 5.9$ \\
\hline $\begin{array}{ll}3 & \text { " } \\
6 & \text { " }\end{array}$ & 0.53 & 1.85 & 9.64 & $1: 6$ \\
\hline $\left.\begin{array}{ll}6 & 6 \\
5 & \text { " } \\
6 & \text { " }\end{array}\right\}$ & 0.57 & 1.90 & 8.72 & $1: 5.3$ \\
\hline
\end{tabular}

Any of these rations is much cheaper than the dried brewers' grains ration used in the experiment, at the same cost of feeds as then used and with clover hay at $\$ 12$ per ton. The most expensive ration is No. 1, costing 18.8 cents per day, and the least expensive, No. 4, costing 14.7 cents. Theoretically these should give quite as good results, under similar conditions of season and work, as were secured from the experimental rations. Where horses average over 1.000 pounds in weight the quantity of each of the feeds should be proportionately increased. If it is desirable to have more bulk than is here given, particularly for winter rations, cut straw may be added to the feeds used; thus increasing the carbohydrates. 
The chief advantages of these rations to farmers are, however, that their use permits first of a saving of timothy hay, a profitable moneycrop in many sections, and of clover hay, particularly useful for dairy cows or sheep; and second, it permits of the sale of oats, where for various reasons it may be advisable to raise them though not ordinarily profitable. A saving of six pounds of hay in a daily ration means over one ton per horse, per year; the saving in the substitution of dried brewers' grains for oats has already been discussed on page 14 .

In many cases it may not be convenient to secure dried brewers' grains. Rations that will permit relatively the same savings may be made up from the concentrated feeds that have already been proved useful in practice, $i$. e.-

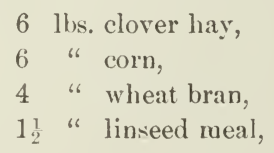

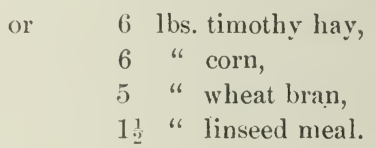

Statistics as to methods of feeding horses have been secured from street railway companies in New York City and elsewhere, and from establishments where heavy horses are used. These show that in all cases the daily rations per 1,000 pounds live weight, and consisting entirely of hay, corn and oats, furnish practically the same amounts of fat and protein as are contained in those indicated in this bulletin, but they vary widely in the proportions and amounts of carbohydrates furnished. It is believed that rations prepared in accordance with the suggestions above given, would in these establishments, too, result not only in a greater economy of food constituents, but in an actual saving in cost.

5.

The Composition of Wet and Dried Brewers' Grains. Methods of Drying.

The material known as brewers' grains is, as the name indicates, a by-product from the manufacture of malt liquors, and consists of the residue from the extraction of the germinated grain, usually barley, with hot water. It contains, together with the husk of the original grain and some unconverted carbohydrates, a large amount of fatty and albuminous substance, upon which its value depends. This product, as discharged from the brewery, is sweet and fit for food for cattle, for which purpose it meets with considerable demand. It is, however, in a very wet condition, containing about 75 per cent. of water, which renders it extremely liable to fermentation and putre- 
faction, whereby its fitness for food is diminished or destroyed. To obviate this loss to producer and consumer, schemes have been devised in the past to remove the water to such an extent as to prevent these destructive processes before they have begun; and renewed activity in this direction is noted at the present day with considerable promise of success.

The utility of drying the grains is undoubted, since, by proper drying, they are preserved in their original sweet condition, with keeping qualities equal to any of the various feeds. The distance to which they may be transported is therefore unlimited, and at the same time the reduction in weight by the removal of over one thousand four hundred pounds of water from every ton effects a corresponding reduction in the transportation charges. A wider market is thus opened to the producer, and feeders, who, by reason of distance, freights, etc., are unable to use wet grains at all, find the same material in a dried condition within their reach. Thus prepared they furnish nutrients as cheaply at $\$ 20$ per ton as the wet grains at twelve cente per bushel, with the further advantage, when carting and handling are considered, of concentration to one-fourth the weight.

In a feeding experiment with dairy cows, conducted by this Station in 1884 , it was shown that practically as good a flow of milk followed the use of the dried grains as of the wet, and this conclusion has been verified by the experience of practical feeders. At the same time the health of the animals and the quality of the product are not impaired, as is frequently the case by the improper use of the wet grains.

In order to study the quality and uniformity of the dried grains, the losses by drying, etc., the Station secured eight samples of the dried grains, representing the various commercial processes now in practical operation, and, for comparison, took a sample of the wet grains from each of five carloads consigned by the Farmers' Feed Company, of New York City, to Mr. Benjamin S. Letson, of Stelton, a dealer in this article.

In three instances the condition of the latter was excellent, and in the other two not bad, one having an acid odor and the other a slight odor of putrefaction, which, however, was not sufficient to affect its analysis. Weighed portions of each lot were preserved without delay by careful drying at a temperature not exceeding $130^{\circ} \mathrm{F}$. The results of the analysis of these and of the dried grains are given in tabular form on page 20 , showing the composition of these materials as received in the laboratory. 

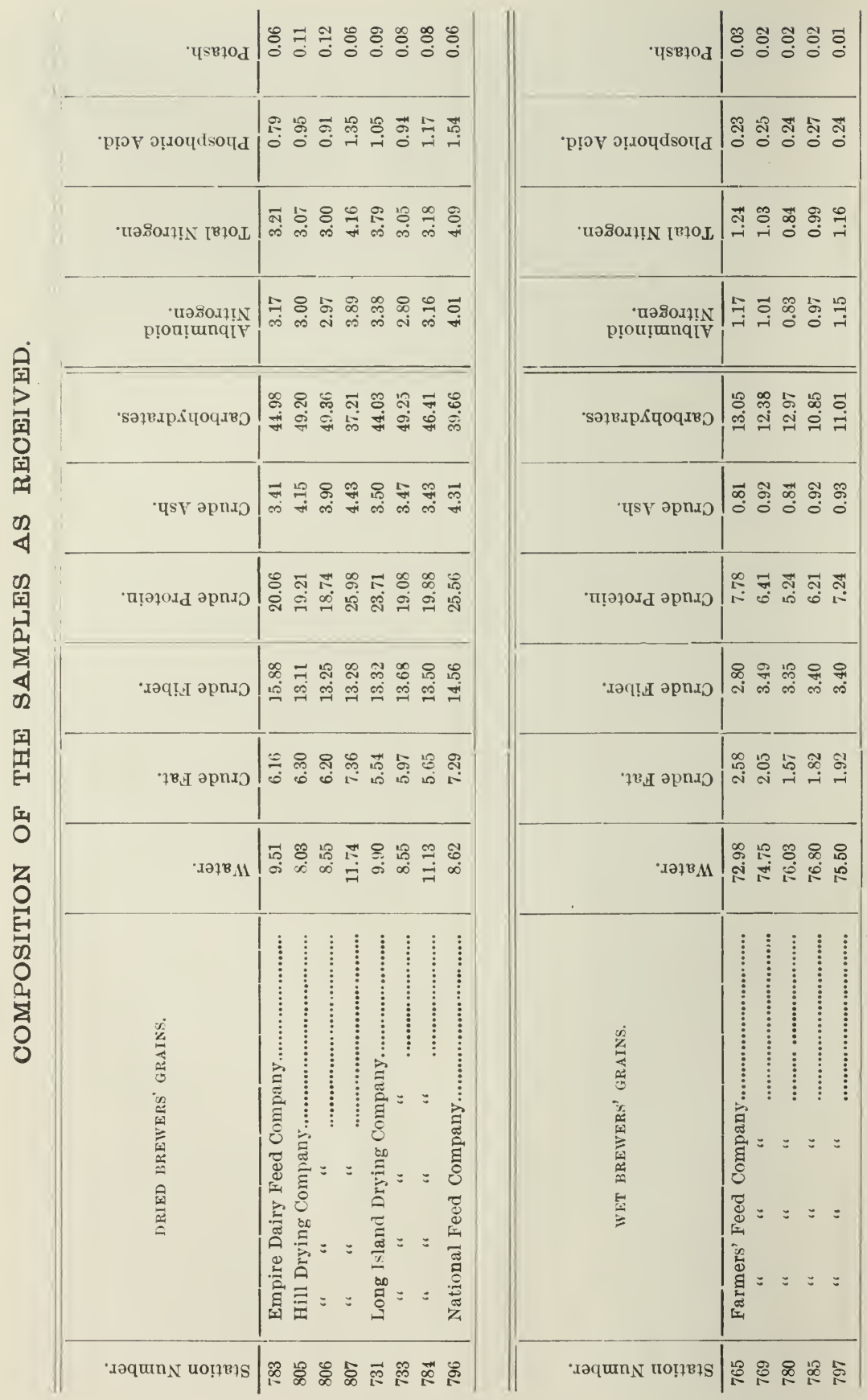

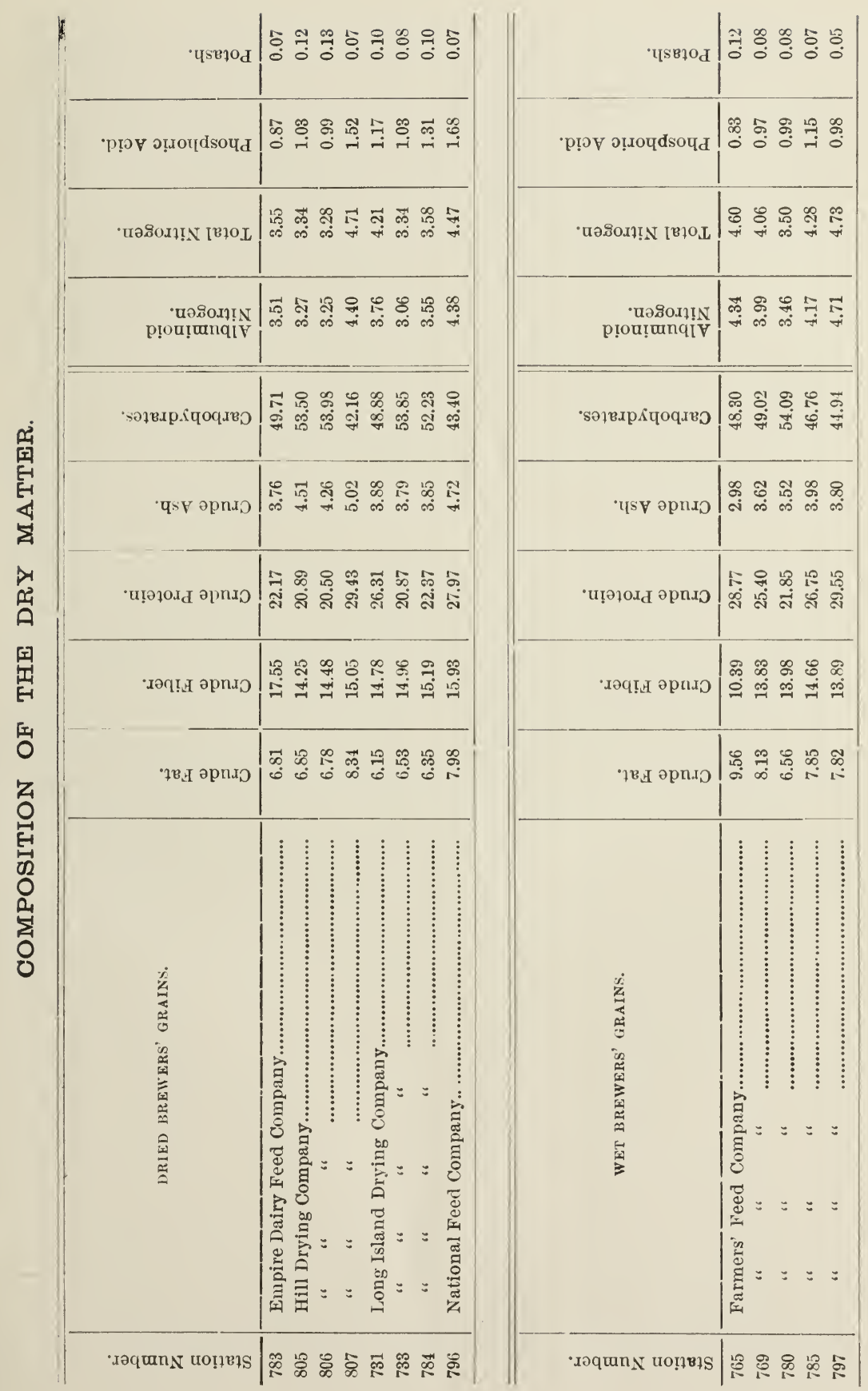
An inspection of the table discloses at once the excessive water content of the wet grains, and the richness of both wet and dried grains in albuminoids and fat. A decided variation, however, will be noticed in their composition. In the dried grains the content of water varies from 8 to nearly 12 per cent., while the protein and fat vary from 18.7 to 26 per cent., and from 5.6 to 7.4 per cent., respectively. But this should by no means be considered a serious lack of uniformity, for all vegetable material varies to a greater or less degree. Wheat flour shows a variation in moisture of from 8.2 to 13.6 per cent., and wheat bran from 7.4 to 15.8 per cent., while so uniform a product as corn meal is considered to be varies from 8.0 to 27.4 per cent. of moisture.

The variations in moisture in these materials, however, are almost always accompanied by corresponding variations in the constituents of the dry matter, the composition of which is practically uniform. The latter variations, therefore, usually disappear when the analyses are calculated to the basis of water-free material. The tables on page 21 , in which this calculation has been performed, show that with grains this is not the case. On the contrary, the samples now range from 20.5 to 28.0 per cent. of protein, and from 6.2 to 8.3 per cent. of fat, and the high protein in almost every case is accompanied by the high fat. In the wet grains, calculated in the same manner, a corresponding variation exists, the protein and fat increasing together, the one from 21.9 to 29.6 per cent. and the other from 6.6 to 9.6 per cent. Grains of this higher composition are of but recent occurrence. High amounts of both protein and fat were first noted by this Station in No. 568, a sample of dry grains analyzed in 1890, in which 9.5 per cent. of the dry matter was fat and 29.1 per cent. protein. Previously to this, a high fat was always compensated for by a low protein, or vice versa, and, in general, the composition of grains, both wet and dry, corresponded closely to the lower figures here given. This higher composition is undoubtedly due to a difference of process in the brewery, or an admixture of other grain than barley-possibly corn.

It certainly is not due to any difference in the drying processes of the different manufacturers, since samples of both high and low composition were received from the same drying plant; nor can any process be accused of producing a variable product through its own defects, for a product just as variable was produced by the process of 
the laboratory, which, it is believed, had no defects. The variations in the composition of the dried grains would seem, therefore, to be due only to variations in the raw material, and therefore, as an argument against them, would apply to the wet grains as well as the dry.

The chemist of this Station visited three of the plants preparing the dried samples analyzed in this bulletin, and through the courtesy of those in charge was allowed to inspect the processes employed. With the data at hand, the lack of uniformity which has been shown to exist in the raw material, precludes any comparison of their efficiency. The methods employed were in general to conduct a current of hot air over or through the material in thin layers, properly agitated to expose fresh drying surfaces. In some cases a large part of the water was first removed by mechanical means; in others previous treatment was omitted. The use of centrifugals, presses and similar devices has been believed to be accompanied by a loss of soluble nutrients, which would remain in the dried product if the water were removed by evaporation alone. In order to learn the extent and character of this loss, a separate sample was taken of each of the wet grains whose analysis has been already given. These were pressed by hand in a small but comparatively powerful hand-press, and it is believed, on account of the care taken and the small quantity pressed at a time, that the results with this press were not widely different from those of more powerful machinery, working with less care upon larger amounts of wet material.

The amounts of liquor and residue secured by this method from 100 pounds of wet grains, and the actual weights of dry matter and water in each, may be learned from the following table: 
FROM ONE HUNDRED POUNDS OF WET GRAINS.

\begin{tabular}{|c|c|c|c|c|c|c|c|}
\hline \multirow{2}{*}{ 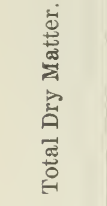 } & \multirow[b]{2}{*}{ 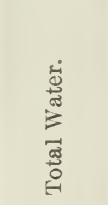 } & \multicolumn{3}{|c|}{ Residue. } & \multicolumn{3}{|c|}{ Liquor. } \\
\hline & & 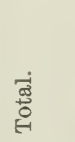 & 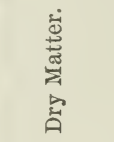 & 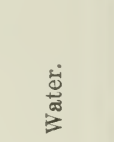 & 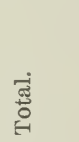 & 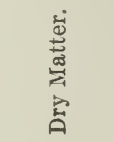 & $\frac{\stackrel{8}{0}}{\underset{\sigma}{0}}$ \\
\hline $\begin{array}{l}\text { lbs. } \\
27.02\end{array}$ & $\begin{array}{l}\text { lbs. } \\
72.98\end{array}$ & $\begin{array}{l}\text { lbs. } \\
60.63\end{array}$ & $\begin{array}{l}\text { Ibs. } \\
24.56\end{array}$ & $\begin{array}{l}\text { lbs. } \\
36.07\end{array}$ & $\begin{array}{l}\text { lbs. } \\
39.37\end{array}$ & $\begin{array}{l}\text { lbs. } \\
2.46\end{array}$ & $\begin{array}{l}\text { lbs. } \\
36.91\end{array}$ \\
\hline 25.25 & 74.75 & 54.45 & 23.70 & 30.75 & 45.55 & 1.55 & 44.00 \\
\hline 23.97 & 76.03 & 65.30 & 23.37 & 41.93 & 34.70 & 0.60 & 34.10 \\
\hline 23.20 & 76.80 & 53.25 & 22.30 & 30.95 & 46.75 & 0.90 & 45.85 \\
\hline 24.50 & 75.50 & 51.35 & 23.61 & 27.74 & 48.65 & 0.89 & 47.76 \\
\hline 24.79 & 75.21 & 57.00 & 23.51 & 33.49 & 43.00 & 1.28 & 41.72 \\
\hline $\begin{array}{c}\text { per cent. } \\
100.0\end{array}$ & $\begin{array}{c}\text { per cent. } \\
100.0\end{array}$ & $\begin{array}{l}\ldots \ldots \ldots \ldots \\
\ldots \ldots \ldots \ldots\end{array}$ & $\begin{array}{c}\text { per cent. } \\
95.0\end{array}$ & $\begin{array}{c}\text { per cent. } \\
44.5\end{array}$ & ......... & $\begin{array}{c}\text { per cent. } \\
5.0\end{array}$ & $\begin{array}{c}\text { per cent. } \\
55.5\end{array}$ \\
\hline
\end{tabular}

By the operation of pressing, 100 pounds of wet grains, containing on the average 24.79 pounds of solid matter and 75.21 pounds of water, was reduced to 57 pounds, consisting of 23.51 pounds of solid matter and but 33.49 pounds of water; or, in other words, in the pomace was contained 95 per cent. of the total dry matter, associated with less than one-half ( 44.5 per cent.) of the water originally in the grains. The liquor, therefore, contained the losses, consisting of 1.28 pounds of matter dissolved or suspended in 41.72 pounds of water.

In order to learn the effect of this loss upon the composition of dried grains prepared by such a process, the pomace and liquor were in each case prepared for analysis by evaporation of the water, the one at $130^{\circ} \mathrm{F}$. and the other at $212^{\circ} \mathrm{F}$. The results of the analysis of the dry matter are given in detail upon page 25 . 


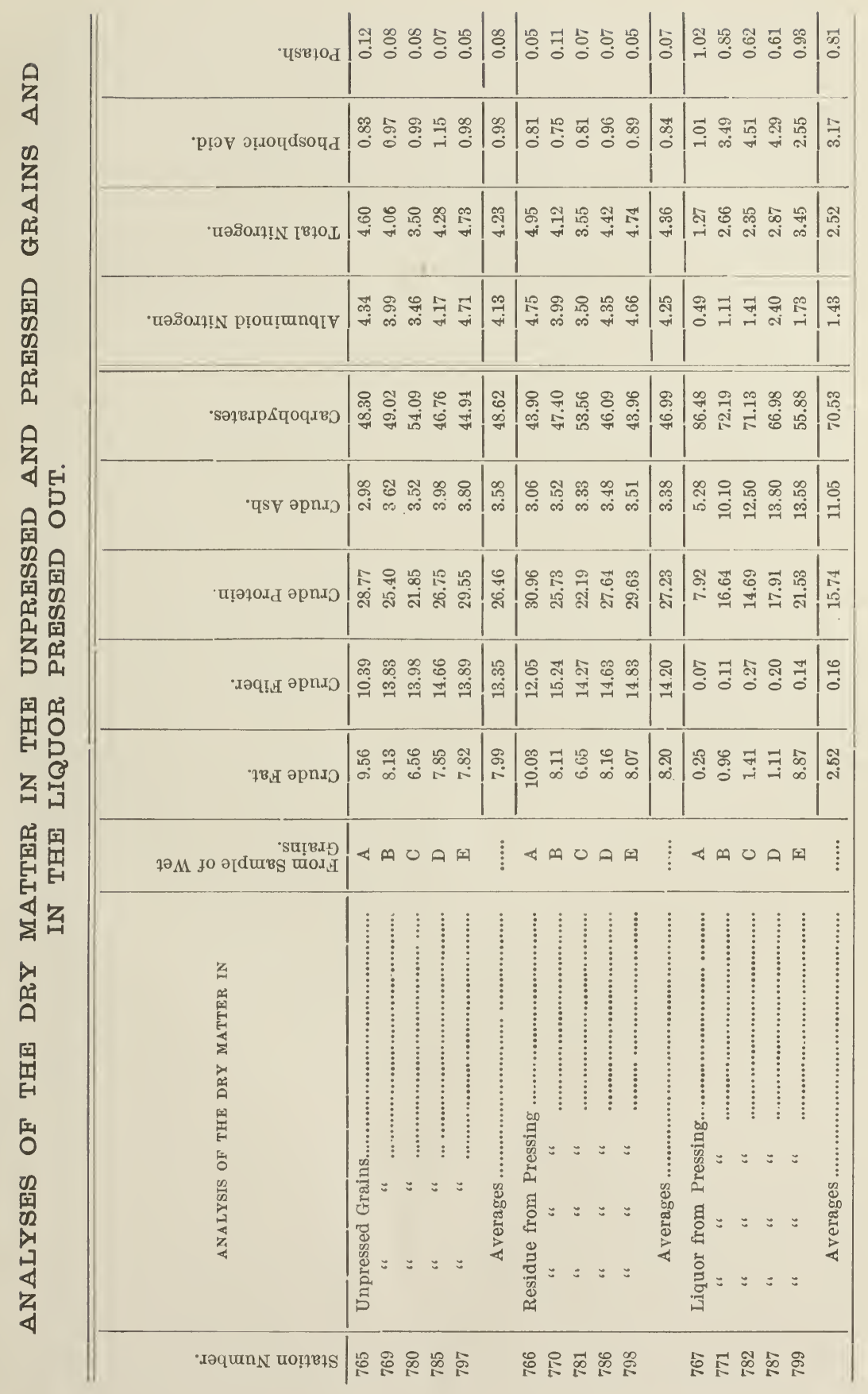


By an examination of the analysis of the dry matter in the liquor it is seen that it drew upon the constituents of the original grain disproportionately. Those soluble in water or easily suspended therein suffered the greater loss. Its composition is consequently entirely different from that of dried grains, being richer in carbohydrates, crude protein and crude ash, especially their soluble portions-sugar, non-albuminoids and potash-the accumulation of which, from a mere trace in the original grain, amounts to relatively considerable. Of the fiber, on the other hand, but a trace appears; while the amount of the fat in most instances is also small, the average being raised by the abnormal content of sample No. 799 .

The total amount of this loss, as before stated, is equal to 1.28 pounds from 100 pounds of wet grains of 75 per cent. water content, or 5 pounds from a normal output of 100 pounds of dried grains. In a consideration from the consumer's standpoint of the effect of this loss upon the dried grains thus prepared, account is to be taken of the nutrients contained not in the residual 95 pounds, but in 100 pounds of such a product. The results of the removal of 5 pounds of substance having the composition of the dry matter in the liquor, and the addition of 5 pounds of material like the residue after that removal, may be shown as follows:

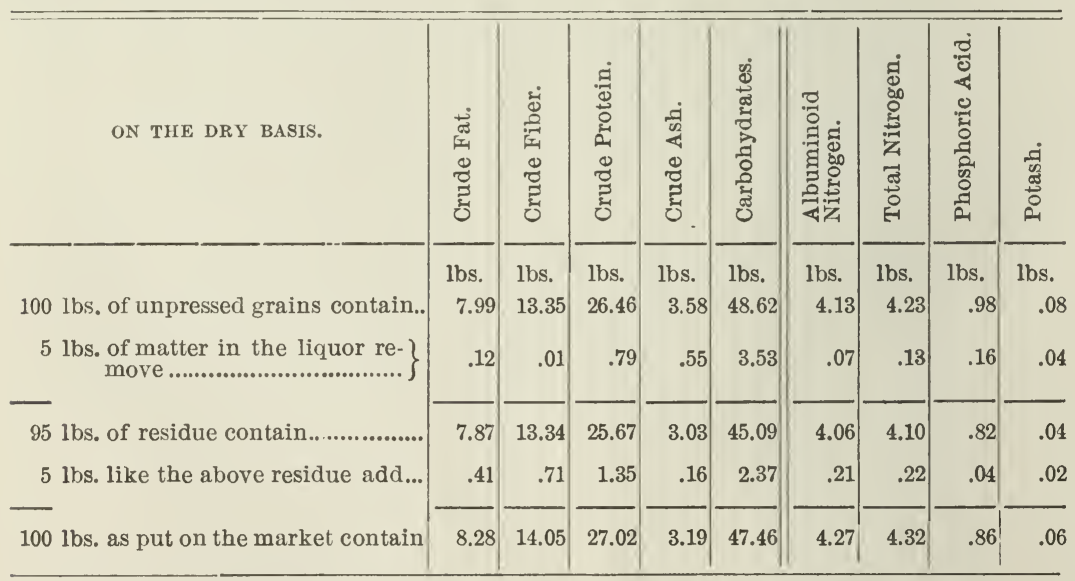

It will be noticed that this calculated analysis of the dry matter of the pressed grains, as they would be put on the market, is slightly different from that given in the table, the one having been calculated from the analyses of the unpressed grains, and of the loss in the liquor, while the other is the direct analysis of the residue. Such 
differences as these are to be expected when separate samples of the same material are taken for analysis, especially when each undergoes a decidedly different manipulation.

Taking either set of figures as a guide, it is seen that the carbohydrates and ash are not fully replaced; but as their loss is compensated for by a corresponding increase in the amounts of protein and fat, the previous pressing of the material does not, from the consumer's standpoint, furnish an inferior product. The loss which occurs falls entirely upon the manufacturer, since he produces but 95 pounds of dried grains instead of 100 ; it concerns him alone whether it is more economical to lose the 5 pounds of product or evaporate 167 pounds of water. To the consumer the method of manufacture is of little practical account, since the variations in the composition of dried brewers' grains, due to a difference of process, are trivial in comparison with those due to lack of uniformity in the raw material.

\section{6.}

\section{Estimated Output of Dried Browers' Grains.}

There are at present four different plants engaged in drying the grains of Eastern breweries, viz.: The Empire Dairy Feed Company, of New York City; The Long Island Drying Company, of Brooklyn, N. Y.; The National Feed Company, of Philadelphia, Pa., and The Hill Drying Company, of Newark, N. J. These all employ different processes, though, as has been shown, the resultant products do not differ widely in chemical composition.

The total calculated capacity of these plants aggregates about 15,000 tons annually. Their actual production for the past year, however, has been very much less, probably not more than 6,000 tons, owing to the fact that one of them has just fairly begun to produce the grains in commercial quantities, and that another, whose claimed capacity is the largest, is in operation mainly through the summer season.

The production of the dried grains is likely to be very largely increased in the near future, since the parties interested in the present methods are now enlarging and extending their works, while parties representing another process are also engaged in the erection of a plant with a claimed capacity of 20,000 tons annually, making a total estimated output, when all are in operation, of 100,000 tons annually, thus utilizing a large portion of the wet grains produced by the breweries in the vicinity of New York and Philadelphia. The 
production of wet grains is not less than 600,000 tons annually, and used almost entirely for milk dairies located within shipping distance of these cities. Plants are also in operation in Milwaukee, St. Louis and Chicago, the product of the latter of which has been used by farmers in this State. The future supply of dried brewers' grains seems, therefore, to be well assured. According to leading authorities, the drying of all the grains depends upon two points : (1) An economical process of drying, and (2) a proper understanding of the nutritive values of the wet and dry product on the part of the consumers.

The first difficulty seems to have been overcome; the second will require more time, because of the difficulty of directly reaching individual consumers in such a way as to overcome acquired prejudice in favor of the wet product for dairy cows, and to encourage the nse of the dried grains for horses and other farm stock.

This study of the food requirements of work-horses and of the preparation of rations suggests :

1. That at the present time too little attention is paid to the preparation of rations for work-horses. Rational feeding is quite as important for horses as for dairy cows.

2. That the kind and quality of specific nutrients contained in feeds, and not their names, should guide in the preparation of rations.

3. That while oats are an excellent horse feed, it it not alone because they are oats, but because of the amounts and proportions of the more valuable nutrients, fat and protein, contained in them.

4. That dried brewers' grains are a wholesome, nutritious and palatable horse feed, and, at present prices, they may be substituted for oats, and a decided saving made in the cost of the ration.

5. Timothy hay and oats, at present prices, are expensive feeds. It does not follow, because a farmer raises these crops, that he should feed them, when other products, equally useful, may be purchased at a less cost per pound of actual nutrients.

6. The condition of the markets in this State furnishes abundant evidence that the selling price of fine feeds and farm products is not a correct basis for estimating actual feeding value.

7. A farmer who intelligently exchanges farm products for commercial feeds, even at the same prices per ton, may secure not only an increase in feeding value, but also a gain in fertility. Market conditions do not recognize differences in the fertilizing constituents of feeds.

JAMES NEILSON, Acting Director.

New Brunswrck, N. J., February 1st, 1893. 
Dec. 15,1895-

ANALYSES AND STUDY OF HOME-MIXED FERTILIZERS AND FERTILIZING MATERIALS.

\title{
NEW JERSEY
}

\author{
AGRICULTURAL
}

\section{Experiment Station.}

93 



\title{
NEW JERSEY
}

\section{Agricultural EXPERIMENT STATION.}

\section{BULLETIN 93.}

JULY 1, 1893.

\section{Analyses and Study of Home-Mixed Fertilizers and Fertilizing Materials.}

\author{
BY LOUIS A. VOORHEES, CHEMIST. \\ JOHN P. STREET, CHEMIST.
}

I. The consumption of fertilizers in the State.

II. The preparation of formulas.

III. Home mixtures; their mechanical condition, composition and valuation.

IV. Comparison of methods of buying fertilizers.

V. Trade values of fertilizing ingredients for 1893.

VI. Average cost per pound of plant-food constituents.

VII. Methods of buying raw materials; chemical analyses.

I.

The Consumption of Fertilizers in the State.

Each year witnesses an increased use of commercial fertilizers by the farmers of the State, consisting both of the mixtures prepared by manufacturers and of raw fertilizing materials. Statistics gathered by the Station show that the use of mixed fertilizers has more than doubled in the last ten years, while the use of raw or unmixed materials, not including ground and dissolved bone, has increased about 40 per cent. The figures are as follows : 


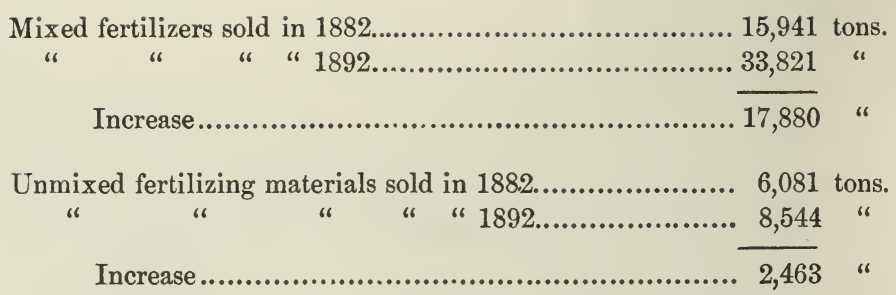

The total value of all reported sales in 1882 was $\$ 1,070,113$ and in $1892, \$ 1,509,921$, an increase in 1892 over 1882 of $\$ 439,808$.

It is observed that the value of the sales made in 1892 is proportionately much less than in 1882. The decrease in cost is due in large part to three causes-first, to the increased supply of raw materials, particularly the nitrogenous salts and phosphates; second, to improved methods in the handling and manufacture of raw materials, and, third, to a better knowledge of fertilizing materials and their proper use, both on the part of the manufacturer and the consumer. The fact still remains, however, that the cost of fertilizers is a very considerable item in the expenditures of the farmer; it is, therefore, of great importance, in order to make economical purchases, that he should have very definite knowledge as to what constitutes value in a fertilizer and of his own particular needs.

II.

The Preparation of Formulas.

While it is now pretty generally understood that the value of a fertilizer depends upon the amount and kind of nitrogen, phosphoric acid and potash contained in it, on the whole the value of definite proportions of these elements, for the different crops, is not so clear. The evidence given by the manufacturers themselves indicates that even they do not agree as to what constitutes perfect proportions, since, in nearly all cases, their special formulas for the various crops are radically different, yet they uniformly insist that their own formula-for potatoes, for instance-is perfect for all conditions of soil and season, and will work equally well everywhere. Such claims have no foundation in fact.

For general farming it is evident that it is more frequently a question of amount of plant-food applied, rather than the proportions in which the different elements exist in a mixture. Still there are many 
good reasons for the preparation of special formulas for the different crops, special not only in amount but in kind of plant-food furnished. Our own experiments have shown this repeatedly. For instance, it has been shown that early tomatoes require, for the best results, not only an abundance of nitrogen, but that the nitrogen shall be in quickly-available forms. A formula, therefore, which contained a high percentage of nitrogen, derived from slowly-available organic forms, would not be likely to give as good results as one which contained a lower percentage, existing in the form of nitrates.

Plants have also been classified as to their special needs for plantfood, and it is a useful classification, yet it seems that there should be a still further subdivision, since it frequently happens that the element which is specifically useful when the object is the largest mature plant, is not the one that is most useful when the object is a rapid, early growth rather than maturity. Furthermore, the kind of soil is an important factor, soils of equal quality in respect to contained plant-food not responding uniformly to equal applications of the same forms of fertilizer constituents. In the preparation of formulas, therefore, regard should be had to the character of soil, whether rich or poor, heavy or light, dry or wet; the method of the growth, whether for quick and partial, or slow and full development. The character of the farming, too, should be regarded. It is obvious that heavy applications of quickly-available and relatively costly forms of plant-food would be less likely to prove profitable in general or extensive farming than in specific and intensive, though in all methods of farm practice there is some one crop regarded as more profitable than another. In such cases, frequent applications of different fertilizers may be avoided, if, by heavy applications of good materials, the more profitable crop is made as large as conditions of season and climate will permit, trusting to the residues of plant-food left by it to bring forward the others in a rotation to a maximum.

The duplication of formulas may be avoided, too, by the preparation of what may be termed a basic formula; that is, one rich in all the fertilizer constituents, without particular reference to any single element, this being applied heavily upon some one crop in the rotation, the other crops being furnished with such specific elements as they may require. Assuming, for instance, that the rotation is the common one, of corn, potatoes, wheat and hay, a rational fertilization, and one which would be likely to be quite as useful as any, would be 
as follows: For corn, 300 pounds per acre of a mixture made up of 200 pounds of S. C. rock superphosphate and 100 pounds of muriate of potash, and such barnyard manure as may be available, all applied broadcast.

For potatoes, apply as a minimum one-half ton per acre of a mixture made up as follows :

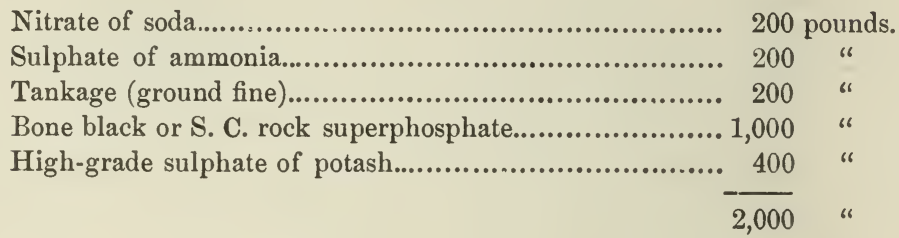

At least two-thirds of this mixture should be applied broadcast, the remainder evenly over the row at time of planting. For wheat and timothy, apply, in early spring, a dressing of from 100 to 200 pounds per acre of nitrate of soda.

By this method of fertilization, the potatoes, frequently the bestpaying crop, would be supplied with sufficient plant-food of all kinds to insure a maximum growth, under normal conditions of season and average conditions of soil, and would leave a considerable residue, particularly of mineral constituents, available for the wheat and hay; the total amount of fertilizer constituents, added in the rotation, would also be more than sufficient to supply the maximum needs of all the crops, thus insuring a gradual increase in fertility. This system may also be adopted where more intensive methods are practiced, such crops as tomatoes, onions, beets, turnips, cabbage, etc., receiving the constituents particularly useful in forcing early growth, the others being supplied by heavy applications of the basic formula.

For fruit trees, vines and similar slow growths, the basic formula may consist of a mixture made up of two parts of ground bone and one of muriate or sulphate of potash. Nitrate of soda should supply the extra nitrogen required, which experience has found to be necessary after the bearing period has begun.

One of the best-producing peach orchards in the State, now 10 years old, and still healthy and vigorous, has received a yearly application of 1,000 pounds per acre of this mixture and 200 pounds per acre of nitrate of soda during the period of bearing. 
FORMULAS USED IN MAKING THE MIXTURES.

No. 5036. John S. Collins.

200 lbs. of Nitrate of Soda.

200 " "Sulphate of Ammonia.

400 " " Peter Cooper's Bone.

400 " "Bone-Black Superphosphate.

600 “" "S. C. Rock Superphosphate,

200 " " Muriate of Potash.

$\cdot \frac{2000}{20}$

No. 5090. Runyon Field.

200 lbs. of Nitrate of Soda.

400 " "Tankage.

1000 " " Dissolved Bone.

400 “ " Muriate of Potash.

$\overline{2060}$

No.5166. M. S. Crane.

150 lbs. of Nitrate of Soda.

200 " "Sulphate of Ammonia.

300 " " "Ground Bone,

900 " "Bone-Black Superphosphate.

450 " " High-Grade Sulphate of Potash.

$\overline{2000}$

No. 5254. Monmouth Co. Grange. $200 \mathrm{lbs}$. of Nitrate of Soda.

200 " "Sulphate of Ammonia.

800 " "Bone-Black Superphosphate.

400 “" " S. C. Rock Superphosphate.

200 " " Muriate of Potash.

200 " "High-Grade Sulphate of Potash.

$\overline{2000}$

No. 5253. J. H. Denise.

200 lbs. of Nitrate of Soda.

150 " " Sulphate of Ammonia.

50 “" Cotton-Seed Meal.

400 " " Dissolved Bone.

400 " "Bone-Black Superphosphate.

400 “ " S. C. Rock Superphosphate.

200 " "High-Grade Sulphate of Potash.

200 “ " Muriate of Potash.

$\overline{2000}$

Home Mixtures: Their Mechanical Condition, Composition and Valuation.

With one exception the home mixtures here reported were made up from high-grade materials, and may be regarded rather as basic in the sense already stated than as mixtures for special crops, though in many cases the formulas were adopted after a study of the requirements of soil and crop in the section in which they are used. Chemical analyses were made of all the materials used in the mixtures and are all reported in this bulletin.
No.514\%. Swedesboro Grange. 200 lbs. of Nitrate of Soda.

200 " " Sulphate of Ammonia.

400 " "Bone-Black Superphosphate.

600 “ " " S. C. Rock Superphosphate.

200 " "Muriate of Potash.

No. 5176. Charles Tindall.

$300 \mathrm{lbs}$. of Nitrate of Soda.

800 " " Ground Bone.

500 “ "Bone-Black Superphosphate.

400 " " Muriate of Potash.

2000

300 lbs. of Nitrate of Soda.

700 " " King Crab.

500 " " Bone-Black Superphosphate.

200 " " Muriate of Potash.

$\overline{2000}$

$2 \mathrm{co}$ lbs. of Nitrate of Soda.

200 " " Sulphate of Ammonia.

200 " " Ground Bone.

1000 “ " Bone-Black Superphosphate.

200 " " Muriate of Potash.

200 “ "High-Grade Sulphate of Potash.

$\overline{2000}$

$200 \mathrm{lbs}$. of Nitrate of Soda.

1000 " " Dissolved Bone.

200 " " Muriate of Potash.

600 " "Hen Manure.

2000 


\section{The Fineness of the Mixtures.}

It has been stated in our previous reports that the samples of home mixtures, as well as manufactured brands, were, on the whole, fine, dry and of good mechanical condition. It is claimed by manufacturers and dealers, however, that a farmer with his ordinary farm appliances cannot get that degree of fineness in his mixtures which is so essential for ease of handling and the best distribution of the material.

Mechanical condition, though of unquestionable value, is a relative term; that is, fineness in a mixture which has been made from materials containing the fertilizer constituents in relatively insoluble forms, is evidently of greater importance than fineness in a mixture which has been made from materials containing easily-soluble and readily-available constituents.

In our studies this year this point was made a matter of actual investigation. All the samples of home mixtures examined, 10 in number, were subjected to a meehanical analysis, and as a means of comparison 12 samples representing the leading brands of different manufacturers were also included. The standard of fineness or perfect mechanical composition was made one twenty-fifth of an inch in diameter; that is, the condition was regarded as perfect if all of the material passed through a sieve, the holes of which were one twenty-fifth of an. inch in diameter. The fineness of the samples examined is given in the following table:

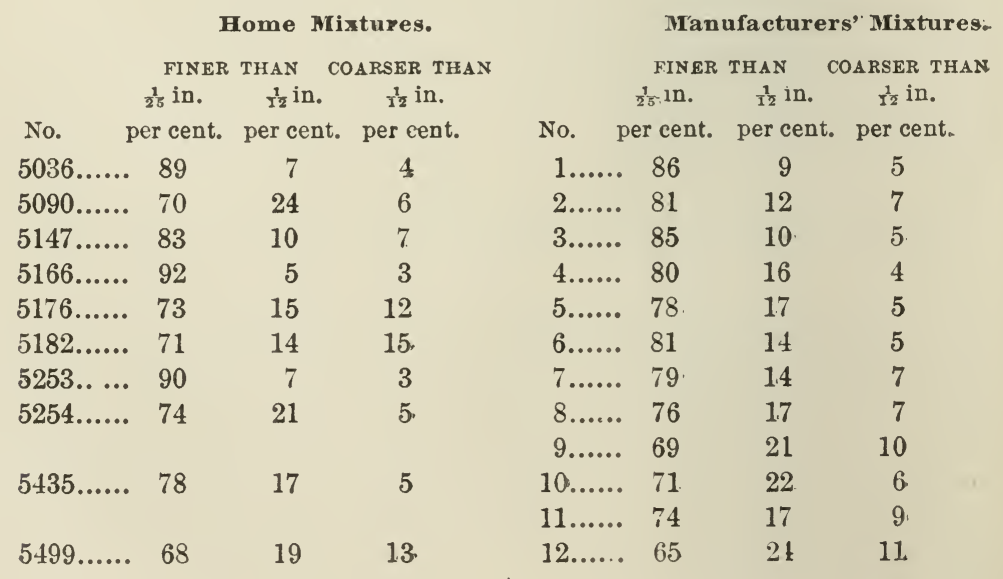


Of the home mixtures it is observed that in two cases only did the samples approach closely to perfection, 90 per cent. and over in each case being finer than one twenty-fifth of an inch in diameter; in one wase the fineness fell below 70 per cent.

In the manufacturers' mixtures the greatest fineness reached was 86 per cent. ; though on the whole the samples were very uniform, in two cases the fineness fell below 70 per cent. The average fineness of the whole number of samples in each lot is as follows:

Home Mixtures.

$\begin{array}{ccc}\text { FINER THAN } & \text { COARSER THAN } \\ \frac{1}{25} \text { in. } & \frac{1}{12} \text { in. } & \frac{1}{12} \text { in. } \\ \text { iper cent. per cent. } & \text { per cent. }\end{array}$

79

14

7

The statement heretofore made in reference to the condition of both 'home mixtures and manufacturers' mixtures seems from this study to have been well founded, though it is further shown that farmers using the ordinary appliances of the farm do make from the supplies of raw materials regularly on sale in the markets better mixtures than the manufacturers.

The superior mechanical condition of the manufacturers' mixtures, so strongly urged by interested parties, is not sustained by this investigation.

The study of the composition of these mixtures, as bearing upon this matter of condition, is also instructive. The State law requires that only the potash soluble in water shall be determined in commercial fertilizers; hence, on the same basis of mechanical condition, home mixtures and manufacturers' mixtures are equal in respect to the availability of potash. In the case of nitrogen and phosphoric :acid, however, both the soluble and insoluble forms are taken into consideration. The soluble nitrogen, for instance, in all cases consists largely of nitrates and ammonia salts, while the organic or insoluble nitrogen may be derived from a whole series of products, ranging from dried blood to ground horn and hoof; the distribution and availability of the former being practically but little influenced by fineness, while the availability of the latter is in direct ratio to the fineness. In the case of phosphoric acid the mechanical condition determines to a certain extent the possible availability of that shown by analysis to be insoluble.

Of the total nitrogen in the home mixtures examined, 72 per cent. 
consists of nitrates and ammonia salts, and of the total phosphoric acid 80 per cent. is available. Of the total nitrogen in the manufacturers' mixtures, but 28 per cent. consists of nitrates and ammonia salts, while 75 per cent. of the total phosphoric acid is available.

It is evident that mechanical condition, so far as it has a bearing on availability, particularly of nitrogen, may be far more important in one mixture than in another. Fineness affects but 28 per cent. of the nitrogenous materials contained in the home mixtures, while in the manufacturers' mixtures it affects 72 per cent.

The claim that farmers cannot secure good mechanical condition in their mixtures must therefore have reference to the use of low-grade materials, rather than to those used in the home mixtures reported. It is admitted that low-grade materials do require the use of machinery for grinding and manipulation in order to secure the requisite fineness.

\section{Composition of Home Mixtures.}

The actual analyses of the different mixtures are given in the following table. The cost of the materials used in making them is also. compared with the estimated commercial value of the mixture at Station's valuation :

TABLE OF ANALYSES

\begin{tabular}{|c|c|c|c|c|c|c|c|c|c|c|c|}
\hline \multirow[b]{2}{*}{ 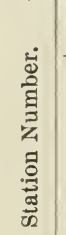 } & \multicolumn{3}{|c|}{ NITROGEN. } & \multicolumn{4}{|c|}{ PHOSPHORIC ACID. } & \multirow[b]{2}{*}{ 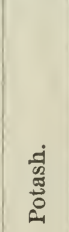 } & \multirow[b]{2}{*}{ 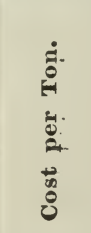 } & \multirow{2}{*}{ 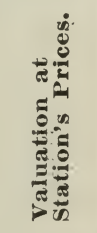 } & \multirow[b]{2}{*}{ 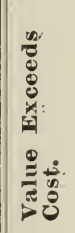 } \\
\hline & 总苛 & 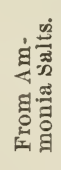 & 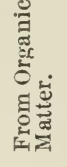 & 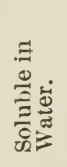 & 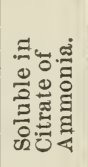 & 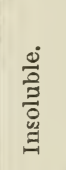 & 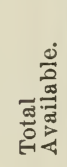 & & & & \\
\hline 36 & 1.86 & 1.92 & 0.42 & 8.80 & 2.16 & 2.31 & 10.96 & 4.96 & $\$ 30.00$ & $\$ 33.42$ & $\$ 3.42$ \\
\hline 5090 & 1.38 & 0.18 & 2.16 & 4.28 & 4.10 & 1.83 & 8.38 & 10.69 & 30.70 & 33.69 & 2.99 \\
\hline 5147 & 1.59 & 1.85 & 0.51 & 8.28 & 2.11 & 2.61 & 10.39 & 5.45 & 27.29 & 32.56 & 5.27 \\
\hline 5166 & 0.81 & 2.18 & 1.12 & 7.56 & 1.76 & 1.44 & 9.56 & 11.78 & 35.83 & 39.76 & 3.93 \\
\hline 5176 & 2.56 & 0.11 & 1.41 & 3.22 & 4.33 & 6.24 & 7.55 & 9.22 & 30.47 & $33.8 \%$ & 3.40 \\
\hline 5182 & 2.42 & 0.25 & 2.61 & 3.34 & 4.04 & 2.31 & 7.38 & 7.13 & 31.02 & 34.42 & 3.40 \\
\hline 5253 & 138 & 1.44 & 0.68 & 626 & $0: 5 t$ & 0.93 & 6.77 & 13.68 & 28.21 & 33.06 & 4.85 \\
\hline 5254 & 1.21 & 1.73 & 0.45 & 8.86 & 0.16 & 0.25 & 9.02 & 10.44 & 29.40 & 33.20 & 3.80 \\
\hline 5435 & 1.46 & 2.09 & 0.93 & 8.86 & 0.91 & 0.26 & 9.77 & 961 & 32.15 & 37.04 & 4.89 \\
\hline 5499 & 2.34 & 0.12 & 0.91 & 3.50 & 1.05 & 1.77 & 4.55 & 10.60 & 21.90 & 27.12 & $5.2 \%$ \\
\hline
\end{tabular}


The chemical analyses of these mixtures compare very favorably with their theoretical composition, calculated from the analyses of the raw materials, and from the weights used in the formulas, and thus verify the claim that farmers, using the ordinary tools of the farm, do make even mixtures of fertilizing materials.

It will be observed that with the one exception where hen manure was used as a base, all of these mixtures are high grade, the average composition being higher than the average of the same number of brands, selected as the highest from the whole number of different manufactured brands now on the market. This matter of concentration is too little appreciated by the farmers, and the relatively low grade of manufactured brands is due in no small degree to a demand on their part for goods at a low cost per ton.

Ton prices alone are not a safe guide in the purchase of mixed fertilizers.

The average composition of all the complete fertilizers or manufacturers' mixtures, examined by the Station last year, and the average of the home mixtures of this year, are as follows:

\begin{tabular}{|c|c|c|c|}
\hline & $\begin{array}{l}\text { Nitrogen. } \\
\text { per cent. }\end{array}$ & $\begin{array}{c}\text { Available } \\
\text { Phosphoric Acid. } \\
\text { per cent. }\end{array}$ & $\begin{array}{l}\text { Potash. } \\
\text { per cent. }\end{array}$ \\
\hline Manufacturers' Mixtures................................. & .. $\quad 2.74$ & 7.70 & 450 \\
\hline 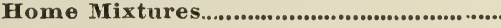 & 4.02 & $\mathbf{8 . 4 4}$ & 9.36 \\
\hline
\end{tabular}

Assuming that the proportions of plant-food are as good in one case as in the other, and that there were as many tons of high-grade as of low-grade brands sold, we can get some idea of the financial importance of concentration.

There were sold in $1892,33,821$ tons of complete fertilizer; each ton contained on the average 299 pounds of actual available nitrogen, phosphoric acid and potash; each ton of the home mixtures contains on the average 436 pounds of actual available plant-food. If, therefore, manufacturers' mixtures had contained as much actual food as the home mixtures, the total amount sold last year would have been contained in 23,172 tons, instead of 33,821 tons, or a difference of 10,649 tons; that is, the 10,649 tons of material mixed, bagged, freighted and sold as part of the various brands, contained no plantfood whatever, and was, therefore, entirely useless. It was shown in Bulletin 89, of this Station, that the charges of the manufacturers 
for mixing, bagging, shipping and other expenses were $\$ 8.53$ per ton. Since it costs no more to mix, bag, freight and sell a high-grade mixture than a low-grade, the cost to the farmers for handling this worthless material amounted in 1892 to $\$ 90,835$. It has been shown by the work of this Station, that the average composition of mixed fertilizers and the fixed charges of the manufacturers have not materially changed in the last ten years. The total sales reported during this time were 247,000 tons, containing, on the same basis of comparison, 77,000 tons of worthless material, which cost farmers over $\$ 656,000$, and from which they could expect no returns whatever. The manufacturers are not altogether to blame for this state of affairs; they aim to supply the demands of their trade, which are too often for cheap goods.

Concentration or highness of grade is also important from the standpoint of quality of plant-food; fertilizers of a low composition must be made either from high-grade materials to which make-weight has been added, or from low-grade materials. This may be illustrated by the average quality of the complete fertilizers on the market. If made from high-grade materials the following quantities would furnish the actual plant-food present, the nitrogen drawn equally from the three forms, nitrates, ammonia salts and organic matter:

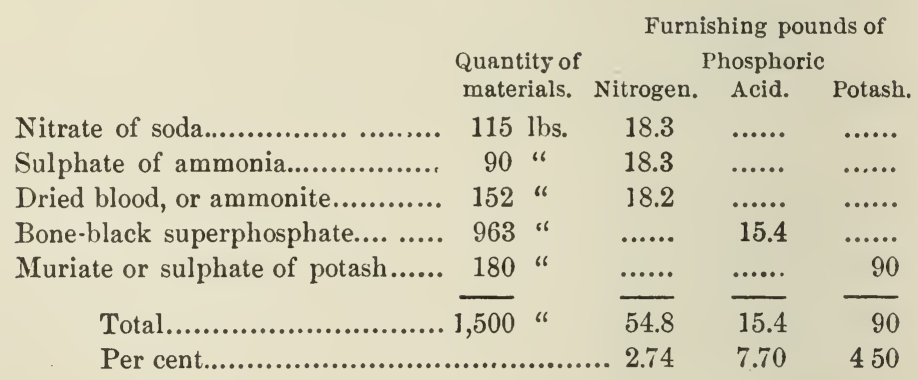

It is observed from this statement that it would be necessary to add 500 pounds of make-weight to each ton. That the materials used in making the complete fertilizers are nut all high grade is evidenced by the fact that less than one-half of the brands contain more than one form of nitrogen, viz., organic, and that nearly all of them contain a very considerable percentage of insoluble phosphoric acid. 


\section{Cost of Home Mixtures.}

These home mixtures represent the purchase of about 700 tons; the average cost is $\$ 29.70$, and the valuation $\$ 33.81$, or a gain of $\$ 4.11$ over Station's prices, which are intended to represent the retail cash cost of fertilizer constituents in the raw materials at factory. The cost of these mixtures may perhaps be better represented by showing the actual cost per pound of the different constituents. Using the average composition of the mixtures and the Station's schedule of prices as factors, the result is as follows:

Nitrogen, 14.9 cents; available phosphoric acid, 5.7 cents, and potash, 4 cents per pound. By this same method of calculation the average cost per pound of the constituents in complete fertilizers sold in 1892 is shown to be :

Nitrogen, 24.8 cents; available phosphoric acid, 9.4 cents, and potash, 6.7 cents per pound. If the constituents in the average home mixture this year had been bought at these figures the cost per ton would have been $\$ 49.27$. This not only illustrates the impossibility of getting at true values by comparison on the ton basis alone, but shows the economy in buying raw fertilizing materials in the open market, and for cash. The difference of $\$ 19.50$ per ton, applied to the 700 tons represented, makes a total of $\$ 13,699$. This is certainly a good return for cash payments instead of credit, for selecting materials suited to the needs of the soil and plant, instead of buying hit or miss, and for using the regular labor of the farm in mixing, instead of paying others who do the work no better.

\section{IV.}

\section{Comparison of Methods of Buying Fertilizers.}

This Station does not maintain that it is always better to buy raw materials and mix at home than to buy the manufacturers' brands, though the studies made here give strong evidence that by so doing money can be saved. This method presupposes in all cases a definite knowledge on the part of the buyer of the sources of supply, of market conditions and of his own particular needs. With such knowledge at command farmers can buy mixtures very much cheaper on the whole than they are now secured. There may be, and doubtless are, too, many cases in which it is preferable, even at a higher 
cost, to buy manufacturers' brands instead of raw materials. A great many farmers object to mixing at home, others to the bother of buying at a distance, and nearly all to paying cash, and to avoid one or all of these inconveniences, and at the same time to do business in a more business-like way, they buy direct from the manufacturer mixtures prepared to their order. Three samples, representing goods bought by this method by the Coopertown Farmers' Club, were received by the Station this year. Their examination furnishes interesting data in reference to methods of buying. The mechanical condition of two samples was good, the third was wet and pasty, the average condition of the three being much lower than that shown by the home mixtures or manufactured brands. The average content of soluble nitrogen is greater than that contained in the manufactured brands, and less than that in the home mixtures, being 56 per cent. as against 28 per cent. in the manufactured brands, and 72 per cent. in the home mixtures.

Mechanical Analyses.

\begin{tabular}{|c|c|c|c|}
\hline \multirow[b]{2}{*}{ No. } & \multicolumn{2}{|c|}{ FINER THAN } & \multirow{2}{*}{$\begin{array}{c}\text { COARSER THAN } \\
\frac{1}{12} \text { in. } \\
\text { per cent. }\end{array}$} \\
\hline & $\begin{array}{l}\frac{1}{25} \text { in. } \\
\text { per cent. }\end{array}$ & $\begin{array}{l}\frac{1}{12} \text { in. } \\
\text { per cent. }\end{array}$ & \\
\hline 5061 ........................... & 74 & 17 & 9 \\
\hline $5062 \ldots \ldots \ldots \ldots \ldots \ldots \ldots \ldots \ldots \ldots . . . . . . . . . . . . .$. & . 82 & 10 & 8 \\
\hline 5063 & . 45 & 43 & 12 \\
\hline Average..................... & 67 & 23 & 10 \\
\hline
\end{tabular}

The average composition of these brands is much lower for all the constituents than the average of the home mixtures, and lower in nitrogen than the average of the mixed fertilizers, sold in 1892 ; with the possible exception of the organic nitrogen, the quality of the materials used was good.

TABLE OF ANALYSES.

\begin{tabular}{|c|c|c|c|c|c|c|c|c|c|c|c|}
\hline \multirow{2}{*}{ 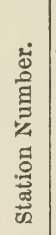 } & \multicolumn{3}{|c|}{ NITROGEN. } & \multicolumn{4}{|c|}{ PHOSPHORIC ACID. } & \multirow[b]{2}{*}{$\begin{array}{l}\frac{1}{1} \\
\text { ฐूँ } \\
0 \\
\text { क }\end{array}$} & \multirow{2}{*}{ 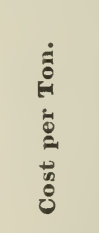 } & \multirow{2}{*}{ 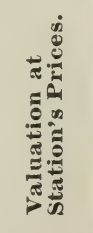 } & \multirow{2}{*}{ 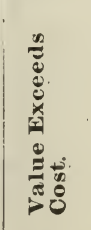 } \\
\hline & 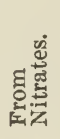 & 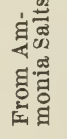 & 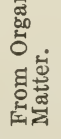 & 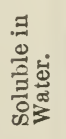 & 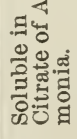 & $\begin{array}{l}\stackrel{0}{0} \\
\stackrel{3}{3} \\
0 \\
0 \\
0\end{array}$ & 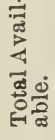 & & & & \\
\hline 5061 & 1.48 & 0.28 & 1.76 & 7.04 & 0.77 & 1.50 & 7.81 & 7.39 & $\$ \mathbf{3 2 . 0 0}$ & $\$ 29.10$ & $-\$ 2.90$ \\
\hline 5062 & 0.78 & 0.11 & 1.03 & 7.36 & 1.21 & 1.61 & 8.57 & 3.18 & 20.00 & 21.04 & $+\mathbf{1 . 0 4}$ \\
\hline 5063 & 1.18 & 0.16 & 0.33 & 6.92 & 0.65 & 1.36 & 7.57 & 9.27 & 28.00 & 24.09 & -3.91 \\
\hline
\end{tabular}


The average cost per ton is $\$ 26.66$, and the average valuation $\$ 24.74$, or a cost $\$ 1.92$ per ton higher than the Station's valuation. The average cost per pound of the constituents is 18.5 cents for nitrogen, 7 cents for available phosphoric acid, and 5 cents for potash. If the average cost per pound of the elements contained in the home mixtures were applied, the cost would be $\$ 22.02$ per ton, or $\$ 4.64$ less than was actually paid; that is, these farmers paid the manufacturers $\$ 4.64$ per ton for mixing an average-grade fertilizer. If the amount of plant-food contained in one ton of a mixture of this brand had been bought in the usual manner, through local dealers, and on credit, the cost would have been $\$ 35.57$, or $\$ 8.91$ greater than was. actually paid. This method of buying, while it is shown to be less desirable than the buying of materials and mixing at home, since the mechanical condition is poorer, the composition lower, and the price higher, is a great improvement on the general method now commonly practiced.

\section{v.}

\section{Trade Values of Fertilizing Ingredients for 1893.}

At a meeting of Stations' Directors and Chemists, the following schedule was arranged for use in Connecticut, Massachusetts, Rhode Island and New Jersey during the season of 1893 :

\section{Schedule of Trade Values Adopted by Experiment Stations for 1893 .}

Cts. per pound.

Nitrogen in Ammonia Salts 17

" "Nitrates.....................................................

and in mixed fertilizers.................. $17 \frac{1}{2}$

$\begin{array}{llll}\text { " } & \text { " } & \text { " castor pomace and cotton-seed meal............ } & 16 \frac{1}{2} \\ \text { " } & \text { " } & \text { " fine ground bone tankage....................... } & 15 \\ \text { " } & \text { " } & \text { " } \text { " medium bone and tankage..................... } & 9 \\ \text { " } & \text { " coarser hone and tankage........................ } & 7 \\ \text { " } & \text { " horn shavings, hair and coarse fish scrap...... } & 7\end{array}$

Phosphoric Acid, soluble in water............................... $6 \frac{1}{2}$
"6
"
" ammonium citrate*.
$6 \frac{1}{2}$

* The solubility of phosphates, in ammonium citrate solutions, is seriously affected by heat. An Act of the Legislature (see Laws of New Jersey, 1874, page 90) provides that in this determination the temperature used shall not exceed $100^{\circ} \mathrm{Fah}$; in Connecticut, Rhode Island and Massachusetts $150^{\circ} \mathrm{Fah}$. has been adopted. The higher the temperature the larger will be the percentage of phosphoric acid dissolved by ammonium citrate solutions, and the larger the amount of this so-called "reverted" phosphoric acid in a ton of superphosphate the lower will: be the price per pound of said acid. Consequently the Station's valuations of phosphoric acid, soluble ln ammonium citrate, have been fixed at six cents per pound for Connecticut, Massachusetts and Rhode Island, and at six and one-half cents per pound for New Jersey. 
Cts. per pound.

Phosphoric Acid, insoluble, in fine bone and tankage................ 6

$\begin{array}{ccccc}\text { " } & \text { " } & \text { " } & \text { " fine-medium bone and tankage...... } & 5 \\ \text { " } & \text { " } & \text { " } & \text { " coarser bone and tankage.............. } & 3 \\ \text { " } & \text { " } & \text { " } \text { mixed fertilizers...................... } & 2 \\ & & & \text { castor pomace and wood ashes.... } & 5\end{array}$

Potash as High-Grade Sulphate, and in forms free from Muriates

(or Chlorides)........................................ $5 \frac{1}{2}$

، " Muriate.... ................................................ $4 \frac{1}{2}$

Valuation of Fertilizing Ingredients in Fine Ground Feeds.

Organic Nitrogen........................................................ 16 $16 \frac{1}{2}$

Phosphoric Acid......................................................... 5

Potash.............................................................................. $5 \frac{1}{2}$

'The Station's prices for nitrogen in ammonia salts and for available phosphoric acid were slightly reduced this year, owing to the lower wholesale quotations which ruled for materials containing them during the six months preceding the adoption of the schedule. For similar reasons the prices for nitrogen in nitrates and organic forms increased. No changes were made in the prices of the various potash salts.

VI.

The Average Cost Per Pound of Plant-Food Constituents.

The average cost per pound of the nitrogen, phosphoric acid and potash, as secured from the tables of analyses, may be fairly assumed to represent the manufacturers' retail prices at factory, and admit of a comparison with the Station's schedule of valuations, which are intended to represent the retail cash cost per pound of the fertilizing ingredients contained in the raw materials before they are mixed to form complete fertilizers.

A study of the following table shows that the Station's schedule agrees closely with the manufacturers' averages for nitrogen and potash, while the Station's prices for available phosphoric acid are 11 per cent. greater than the prices at which farmers have bought direct from the manufacturers. The average cost per pound of the nitrogen and phosphoric acid, in the different grades of bone and tankage, is also compared with the Station's schedule, and is shown to agree very closely : 
COMPARISON BETWEEN STATION'S SCHEDULE AND MANUFACTURERS' AVERAGE: RETAIL PRICES OF PLANT-FOOD IN FERTILIZER SUPPLIES.

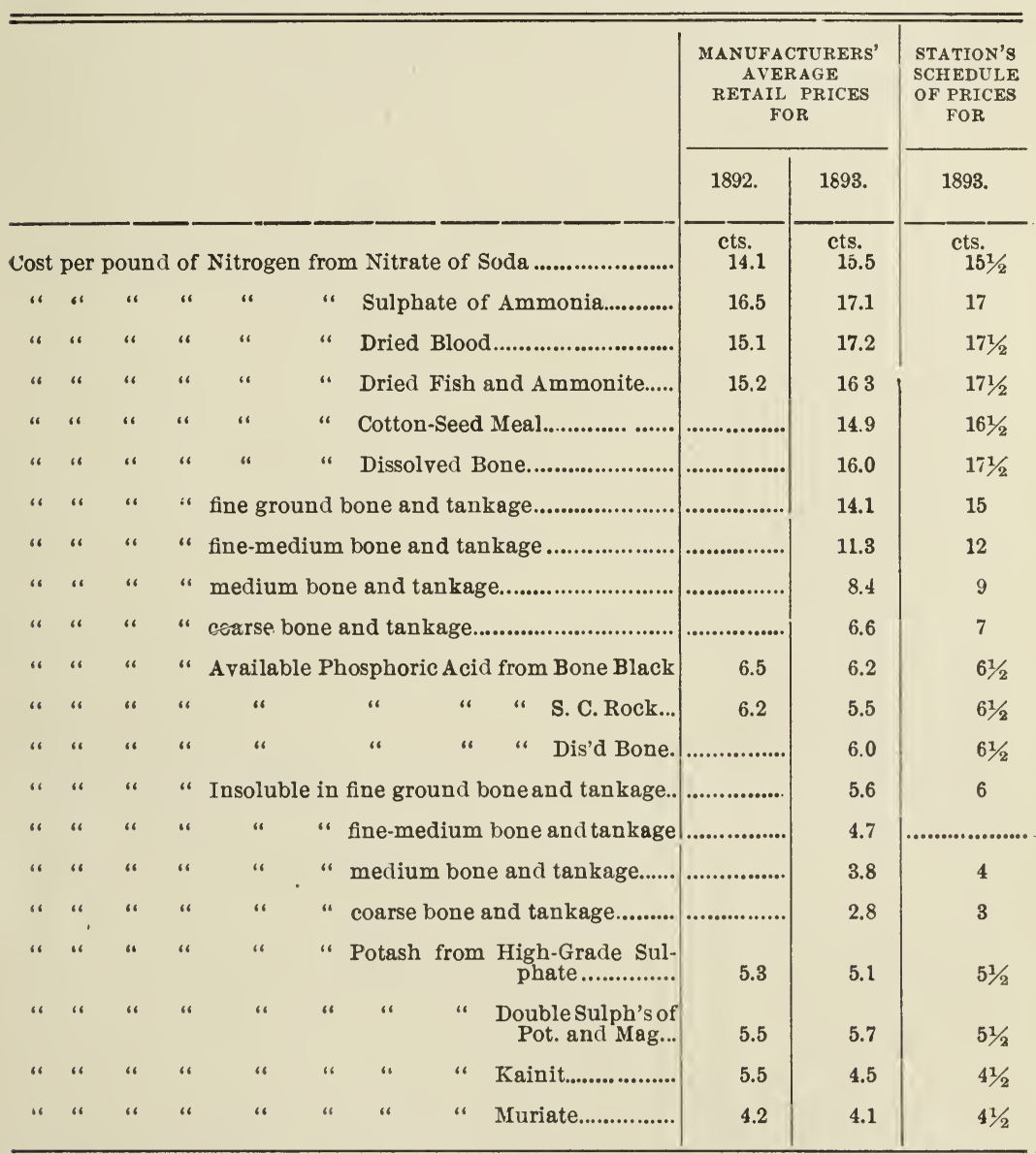

\section{VII.}

Mothods of Buying Raw Materials; Chemical Analyses.

The samples analyzed represent materials bought by farmers' clubs or individuals direct from the manufacturers of complete fertilizers, or from large dealers in fertilizer supplies. A full list of these firms with their business addresses is always published in the annual reportsof this Station. 
The nitrogen salts, with the exception of No. 5169, the superphosphates and the potash salts, were found by analysis to reach their guarantees, to be of good quality and reasonably uniform in composition; the variations in cost per ton being, as a rule, accompanied by corresponding changes in the cost per pound of the fertilizing elements. In standard goods, when average composition is assumed, the price per ton has, as in the past, proved a safe guide as to the actual cost per pound of the element contained. The safest and most satisfactory method of buying is, however, that which makes guaranteed composition or the unit system the basis of contracts.

The variations in cost of materials were chiefly due to the time of buying and the quantity bought. Quotations made on goods bought early in the year, particularly nitrogenous materials, were very much lower than those ruling when the season's work had fully begun and the demand for materials had become more pressing. Prices for car lots of the different materials were from 5 to 10 per cent. lower than when ton lots were purchased.

As a rule, quotations were based upon ton lots. Special rates proved to be no lower than when such claims were not made.

These facts emphasize the importance of a knowledge of the quality of the various materials, the sources of supply and the market conditions.

\section{Summary of Practical Conclusions.}

1. That the use of fertilizers in the State is increasing, and that the present annual expenditure of over $\$ 1,500,000$ may be very materially reduced by a definite knowledge of what and how to buy.

2. That in the preparation of formulas the quality of plant food is of prime importance, and that the proportion of the different elements, as well as the amount of the application, should be determined by the object of their use.

3. That farmers can make mixtures which are equal to the best manufactured brands and superior to the average-first, in mechanical condition; second, in concentration; third, in quality, and, fourth, in point of cost.

4. That in buying manvfacturers' mixtures distinct advantages in quality and cost are secured when bought direct from the manufacturers instead of from local agents. 
5. That the trade values of fertilizing ingredients adopted by the Station are a fair basis for estimating commercial values of manufacturers' mixtures.

6. That sources of supply, time of buying and quantity bought, are the main conditions influencing cost per pound of plant-food in standard fertilizing materials.

\section{FORMS OF NITROGEN}

Readily and Completely Soluble in Water.

NITRATE OF SODA

Furnishing Nitrogen in Form of Nitrates.

\begin{tabular}{|c|c|c|c|c|}
\hline 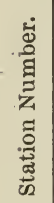 & FROM WHOM RECEIVED. & 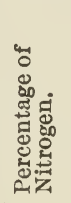 & 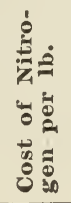 & 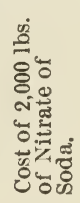 \\
\hline 5028 & Moorestown Grange & 15.90 & $\begin{array}{l}\text { cts. } \\
\mathbf{1 4 . 5}\end{array}$ & $\$ 1600$ \\
\hline 5113 & 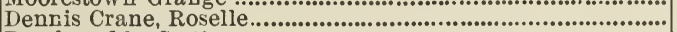 & 16.18 & 18.5 & $\approx 6000$ \\
\hline 5076 & 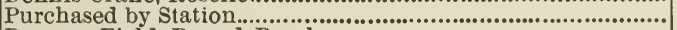 & 15.75 & 15.9 & 5000 \\
\hline 5086 & 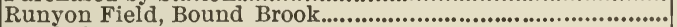 & 16.17 & 14.5 & 4700 \\
\hline 5139 & Swedesboro Grange.. & 15.45 & 14.9 & 4600 \\
\hline 5150 & 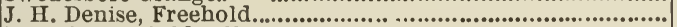 & 15.87 & 14.5 & 4600 \\
\hline 5161 & 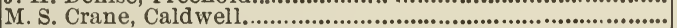 & 15.96 & 16.3 & 5200 \\
\hline 5167 & 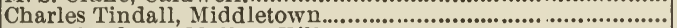 & 15.75 & 15.9 & 5000 \\
\hline 5177 & 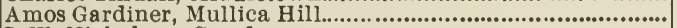 & 15.92 & 17.3 & 5500 \\
\hline $518:$ & 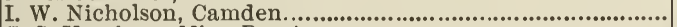 & 15.93 & 17.5 & *56 00 \\
\hline 520 & 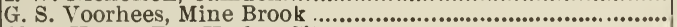 & 16.03 & 15.4 & 4950 \\
\hline 5290 & Chas. Kraus, Egg Harbor City.............................................. & 15.84 & 17.4 & $* 5400$ \\
\hline $51 \ddot{6} 6$ & 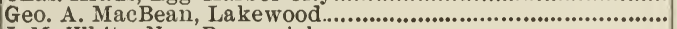 & 16.18 & $\mathbf{1 5 . 5}$ & 5000 \\
\hline 5466 & 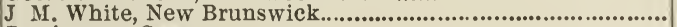 & 15.97 & 15.7 & 5000 \\
\hline 5467 & Parsippany Grange & 15.81 & 14.9 & 4700 \\
\hline & 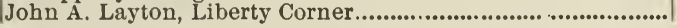 & 15.81 & 16.4 & 5200 \\
\hline & ore Cot Pitroren in vitrot & & 15.5 & \\
\hline
\end{tabular}

* Retail price at point of consumption.

SULPHATE OF AMMONIA.

Furnishing Nitrogen in Form of Ammonia.

\begin{tabular}{|c|c|c|c|c|}
\hline 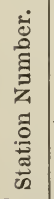 & FROM WHOM RECEIVED. & 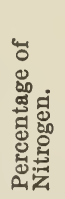 & 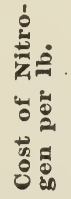 & 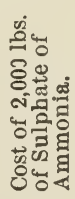 \\
\hline $\begin{array}{l}5029 \\
5140 \\
5151 \\
5162 \\
5168 \\
5169\end{array}$ & 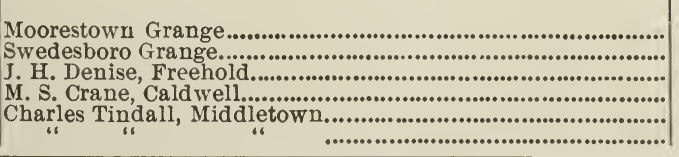 & $\begin{array}{l}20.30 \\
20.22 \\
20.16 \\
19.77 \\
19.98 \\
17.95\end{array}$ & $\begin{array}{l}\text { cts. } \\
16.5 \\
16.6 \\
15.6 \\
18.3 \\
16.8 \\
18.7\end{array}$ & $\begin{array}{rr}\$ 67 & 10 \\
67 & 10 \\
63 & 00 \\
72 & 50 \\
67 & 00 \\
67 & 00\end{array}$ \\
\hline Ave & rage Cost per Pound of Nitrogen in Sulphate of An & & $1 \% .1$ & \\
\hline
\end{tabular}




\section{FORMS OF NITROGEN INSOLUBLE IN WATER}

Furnishing Nitrogen in Form of Organic Matter.

DRIED BLOOD.

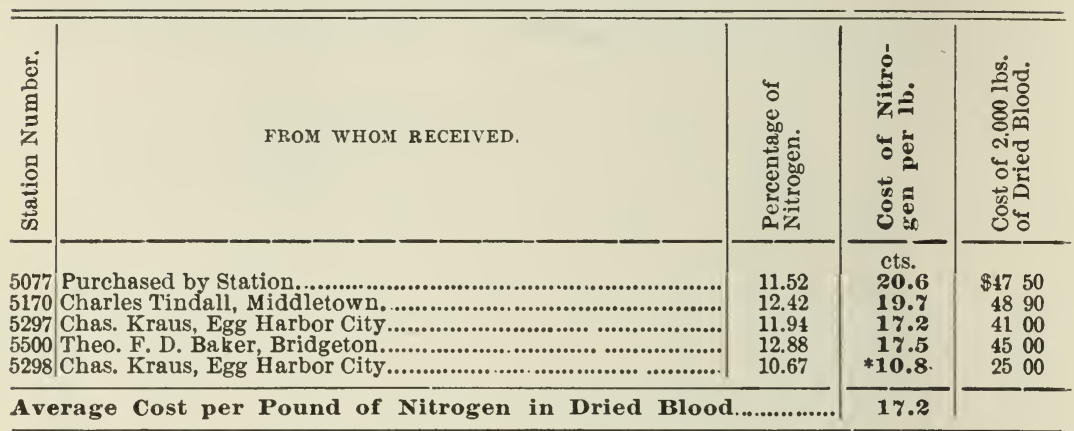

* Contains 1.91 per cent. phosphoric acid.

DRIED AND GROUND FISH.

\begin{tabular}{|c|c|c|c|c|c|c|}
\hline \multirow{2}{*}{ 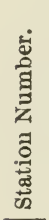 } & \multirow[b]{2}{*}{ FROM WHOM RECEIVED. } & \multicolumn{2}{|c|}{ Percentage. } & \multicolumn{2}{|c|}{$\begin{array}{c}\text { Cost } \\
\text { Per Pound. }\end{array}$} & \multirow{2}{*}{ 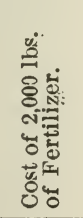 } \\
\hline & & 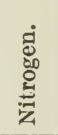 & 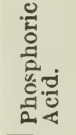 & 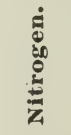 & 员 & \\
\hline $\begin{array}{l}5179 \\
5291 \\
5292 \\
5293 \\
5311 \\
5501\end{array}$ & 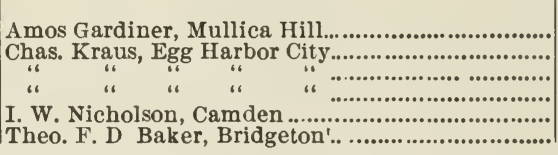 & $\begin{array}{l}9.48 \\
8.72 \\
7.46 \\
5.73 \\
5.43 \\
7.01\end{array}$ & $\begin{array}{r}1.06 \\
7.77 \\
7.61 \\
10.14 \\
9.43 \\
858\end{array}$ & $\begin{array}{l}\text { cts } \\
14.9 \\
17.3 \\
20.4 \\
19.9 \\
15.3 \\
18.8\end{array}$ & $\begin{array}{l}\text { cts. } \\
50 \\
5.0 \\
5.0 \\
5.0 \\
5.0 \\
5.0\end{array}$ & $\begin{array}{r}+\$ 2950 \\
+3800 \\
+3800 \\
+3300 \\
2600 \\
3500\end{array}$ \\
\hline \multicolumn{4}{|c|}{ Average Cost per Pound of Nitrogen in Dried and Ground Fish. } & 16.3 & & \\
\hline
\end{tabular}

* King Crab.

$\dagger$ Retail price at point of consumption.

COTTON-SEED MEAL.

\begin{tabular}{|c|c|c|c|c|c|c|c|c|}
\hline \multirow{2}{*}{ 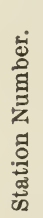 } & \multirow[b]{2}{*}{ FROM WHOM RECEIVED. } & \multicolumn{3}{|c|}{ Percentage. } & \multicolumn{3}{|c|}{ Per Pound. } & \multirow{2}{*}{ 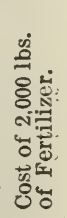 } \\
\hline & & 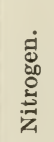 & 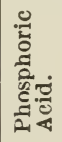 & 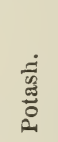 & 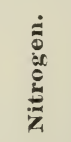 & 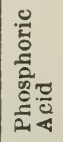 & 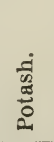 & \\
\hline & D. D. Denise, Freehold & 6.72 & 3.74 & 199 & $\begin{array}{c}\text { cts } \\
\mathbf{1 4 . 9}\end{array}$ & $\begin{array}{l}\text { cts: } \\
5,0\end{array}$ & $\begin{array}{l}\text { ets. } \\
5.5\end{array}$ & $\$ 2600$ \\
\hline
\end{tabular}


GROUND BONE AND TANKAGE.

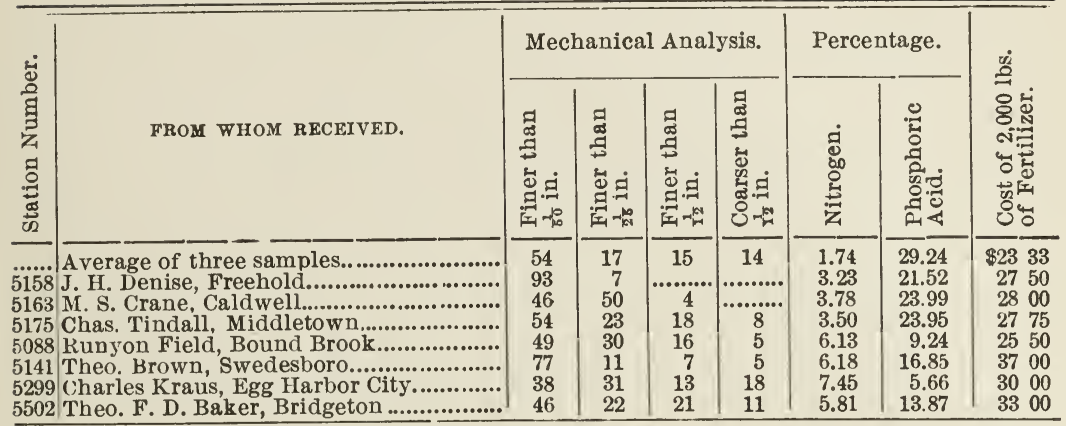

GROUND BONE AND TANKAGE.

\begin{tabular}{|c|c|c|c|c|c|c|c|c|c|c|}
\hline \multirow[b]{2}{*}{ 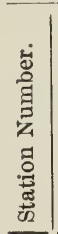 } & & & \multicolumn{4}{|c|}{$\begin{array}{l}\text { Cost of Nitrogen } \\
\text { per lb. 1n- }\end{array}$} & \multicolumn{4}{|c|}{$\begin{array}{c}\text { Cost of Phosphoric Acid } \\
\text { per lb. in- }\end{array}$} \\
\hline & & & 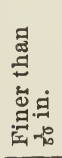 & 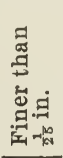 & 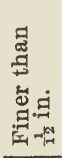 & 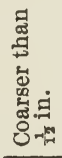 & 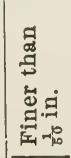 & 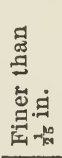 & 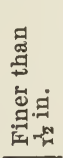 & 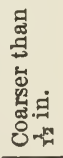 \\
\hline & & & cts. & cts. & ets. & cts. & cts. & cts. & cts. & cts. \\
\hline & Groun & Bone (Peter Cooper's)............... & 10.0 & 8.0 & 6.0 & 4.7 & 4.0 & 3.3 & 2.7 & 2.0 \\
\hline 5158 & " & 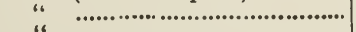 & 11.5 & 9.2 & 6.9 & 5.4 & 4.6 & 3.8 & 3.1 & 2.3 \\
\hline 5163 & “ & 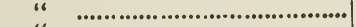 & 11.5 & 9.2 & 6.9 & 5.4 & 46 & 3.8 & 3.1 & 2.3 \\
\hline 5175 & “ & " & 12.2 & 9.8 & 7.3 & 5. & 4.9 & 4.1 & 3.2 & 2.4 \\
\hline 5088 & Tanka & 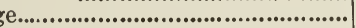 & 15.0 & 12.0 & 9.0 & 7.0 & 6.0 & 5.0 & 4.0 & 3.0 \\
\hline 5141 & & 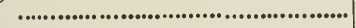 & 15.5 & 12.4 & 9.3 & 7.2 & 6.2 & 5.1 & 4.1 & 3.1 \\
\hline 5299 & “ & 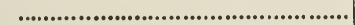 & 19.5 & 15.6 & 11.7 & 9.1 & 7.8 & 6.5 & 5.2 & 3.9 \\
\hline 5502 & “ & 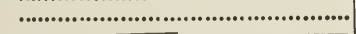 & 17.5 & 14.0 & 10.5 & 8.2 & 7.0 & 5.8 & 4.7 & \\
\hline Ave & grage & Cost per Pound........................ & 14.1 & 11.3 & 8.4 & 6.6 & 5.6 & 4.7 & 3.8 & 2.8 \\
\hline
\end{tabular}

DISSOLVED BONE AND NITROGENOUS SUPERPHOSPHATES.

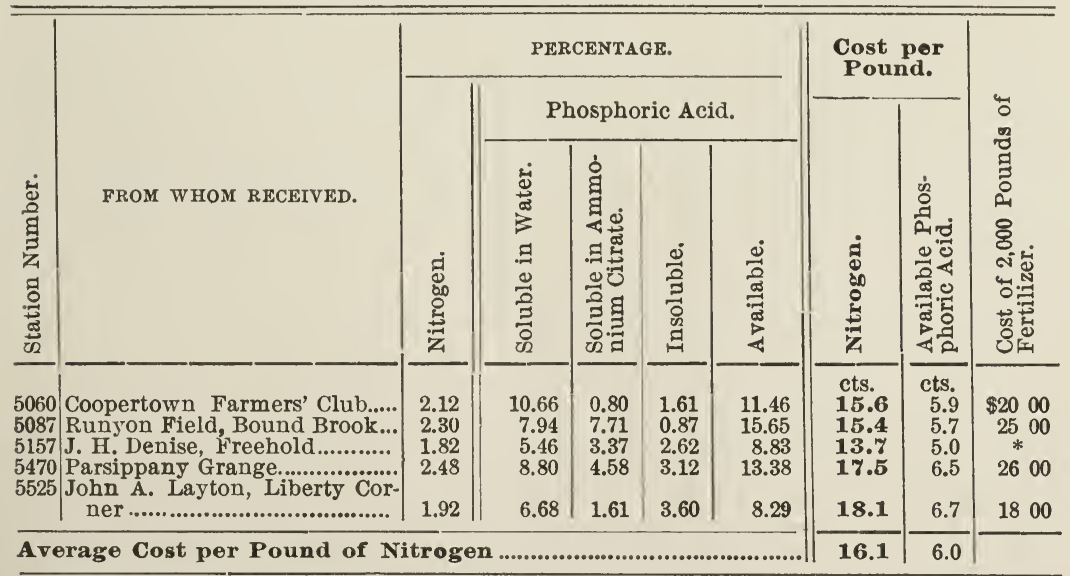

- Ammonia, \$2.25 per unit; Available Phosphoric Acid, \$1 per unit. 


\section{PLAIN SUPERPHOSPHATES}

Furnishing Soluble, Reverted and Insoluble Phosphoric Acid, MANUFACTURED FROM

BONE BLACK, BONE ASH, ETC., ETC.

\begin{tabular}{|c|c|c|c|c|c|c|c|}
\hline \multirow{2}{*}{ 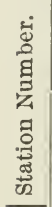 } & \multirow[b]{2}{*}{ FROM WHOM RECEIVED. } & \multicolumn{4}{|c|}{ Phosphoric Acid. } & \multirow[b]{2}{*}{ 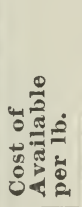 } & \multirow{2}{*}{ 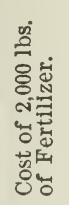 } \\
\hline & & 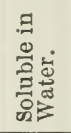 & 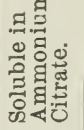 & 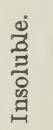 & 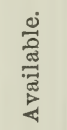 & & \\
\hline 5031 & Moorestown Grange................ & 13.80 & & 0.04 & 13.80 & $\begin{array}{l}\text { ets. } \\
\mathbf{5 . 8}\end{array}$ & \\
\hline 5081 & $\begin{array}{l}\text { Purchased by Station.................... } \\
\text { Swedesboro Grange }\end{array}$ & 15.28 & 0.53 & 0.43 & 15.81 & 6.3 & $\$ 2000$ \\
\hline 5148 & J. M. White, New Brunswick..................... & $\begin{array}{l}13.12 \\
13.18\end{array}$ & 0.55 & $\begin{array}{ll}0.18 \\
1.11\end{array}$ & $\begin{array}{l}13.72 \\
13.73\end{array}$ & 6.6 & 1825 \\
\hline 5152 & J. H. Denise, Freehold .............................. & 14.92 & 0.07 & 0.19 & 14.99 & 6.3 & 190 \\
\hline 5164 & M. S. Crane, Cald well................................ & 15.46 & & 0.20 & 15.46 & 7.3 & 2250 \\
\hline 5171 & Chas. Tindall, Middletown....................... & 13.00 & 0.64 & 0.79 & 13.64 & 5.6 & 1540 \\
\hline 518 & Amos Gardiner, Mullica Hill..................... & 12.42 & 4.95 & 0.40 & 17.37 & 5.8 & 2000 \\
\hline & Chas. Kraus, Egg Harbor City.................. & 14.30 & 0.39 & 1.83 & 14.69 & 8.7 & +2400 \\
\hline & Parsippany Grange..................... & 16.74 & 0.15 & 0.13 & 16.89 & 5.9 & 2000 \\
\hline & Theo. F. D. Baker, Bridgeton ................. & 16.60 & 0.15 & 0.08 & 16.75 & 6.9 & 2300 \\
\hline \multicolumn{6}{|c|}{ Average Cost per Pound of Phosphoric Acid............... } & 6.2 & \\
\hline
\end{tabular}

* \$1.15 per unit of Available Phosphoric Acid.

† Retail price at point of consumption.

SOUTH CAROLINA ROCK AND OTHER MINERAL PHOSPHATES.

\begin{tabular}{|c|c|c|c|c|c|c|c|}
\hline \multirow{2}{*}{ 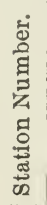 } & \multirow[b]{2}{*}{ FROM WHOM RECEIVED. } & \multicolumn{4}{|c|}{ Phosphoric Acid. } & \multirow[b]{2}{*}{ 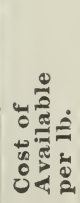 } & \multirow{2}{*}{ 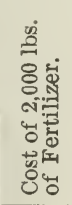 } \\
\hline & & 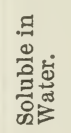 & 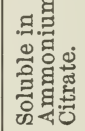 & 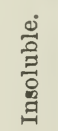 & 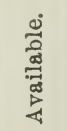 & & \\
\hline \multirow{9}{*}{\multicolumn{2}{|c|}{ 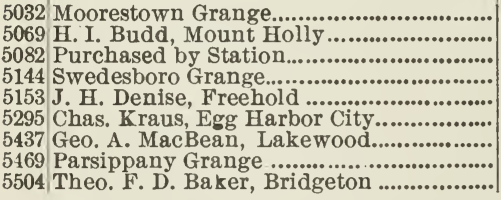 }} & 14.06 & 1.76 & 1.30 & 15.82 & $\begin{array}{l}\text { cts. } \\
\mathbf{4 . 9}\end{array}$ & $*$ \\
\hline & & 10.88 & 1.9 & 1.78 & 12.87 & 6.8 & $\$ 1750$ \\
\hline & & 11.96 & 2.08 & 1.41 & 14.04 & 4.3 & 1200 \\
\hline & & 12.04 & 1.2 & 2.17 & 13. & 4.9 & \\
\hline & & 12.92 & 0.12 & 1.36 & 13.04 & 4.4 & 1150 \\
\hline & & 9.70 & 1.7 & 4.02 & 11. & 9.6 & +22 \\
\hline & & 10.96 & 1.6 & 2.27 & 12. & 6.7 & 1700 \\
\hline & & 10.54 & 1.73 & 1.51 & 12.27 & 5.3 & 1300 \\
\hline & & 9.98 & 1.70 & 4.03 & 11.68 & 6.8 & \\
\hline \multicolumn{6}{|c|}{ Average Cost per Pound of Phosphoric Acid....................................... } & 5.5 & \\
\hline
\end{tabular}

*\$0.98 per unit of Available Phosphoric Acid.

$\dagger$ Retail price at point of consumption. 


\section{GERMAN POTASH SALTS}

Readily Solublo in Distilled Water. MURIATE OF POTASH.

\begin{tabular}{|c|c|c|c|c|}
\hline 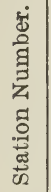 & FROM WHOM RECEIVED. & 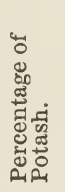 & 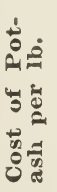 & 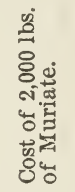 \\
\hline 5035 & 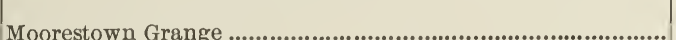 & 48.25 & $\begin{array}{l}\text { cts. } \\
\mathbf{4} .2\end{array}$ & $\$ 4100$ \\
\hline 5084 & Purchased by Station............................................. & 49.98 & 4.3 & 4250 \\
\hline 5089 & Runyon Field, Bound Brook................................................. & 51.47 & 4.1 & 4200 \\
\hline 5145 & Swedesboro Grange............................................................. & 48.84 & $4 . \overline{2}$ & 4100 \\
\hline 5155 & J. H. Denise, Freehold..................................................... & 52.65 & 3.8 & 4000 \\
\hline 5172 & Charles Tindall, Middletown.............................................. & 48.46 & 4.1 & 4000 \\
\hline 5181 & Amos Gardiner, Mullica Hill............................................. & 50.20 & 4.0 & 4000 \\
\hline 5184 & I. W. Nicholson, Camden.................................................... & 50.76 & 43 & $* 4400$ \\
\hline 5185 & " & 48.53 & 5.2 & $* 5000$ \\
\hline 5296 & 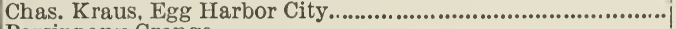 & 51.90 & 4.5 & *4650 \\
\hline 5471 & Parsippany Grange .................................................................... & 49.89 & 4.0 & 4000 \\
\hline 5526 & John A. Layton, Liberty Corner.......................................... & 51.52 & 4.3 & 4450 \\
\hline & tasl in Mruxiate & & 4.1 & \\
\hline
\end{tabular}

* Retail price at point of consumption.

KAINIT.

\begin{tabular}{|c|c|c|c|c|}
\hline 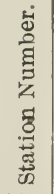 & FROM WHOM RECEIVED. & 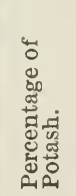 & 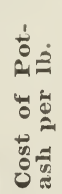 & 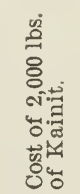 \\
\hline \begin{tabular}{l|}
5018 \\
5085 \\
5146 \\
5149 \\
5156 \\
5186 \\
5208
\end{tabular} & 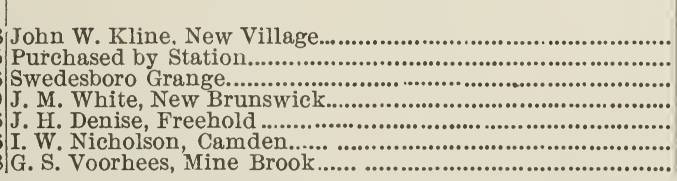 & $\begin{array}{l}13.67 \\
12.70 \\
12.66 \\
12.46 \\
11.25 \\
12.40 \\
11.70\end{array}$ & $\begin{array}{l}\text { cts. } \\
\mathbf{3 . 7} \\
\mathbf{4 . 3} \\
\mathbf{4 . 9} \\
\mathbf{4 . 4} \\
\mathbf{6 . 7} \\
\mathbf{5 . 2} \\
\mathbf{5 . 3}\end{array}$ & $\begin{array}{rr}\$ 1025 \\
1100 \\
1241 \\
1100 \\
* 1500 \\
* 1300 \\
1250\end{array}$ \\
\hline & erage Cost per Pound of Potash in Kainit... & & 4.5 & \\
\hline
\end{tabular}

* Retail price at' point of consumption.

DoUbLe SUlphate OF POTASH AND MAgNesia.

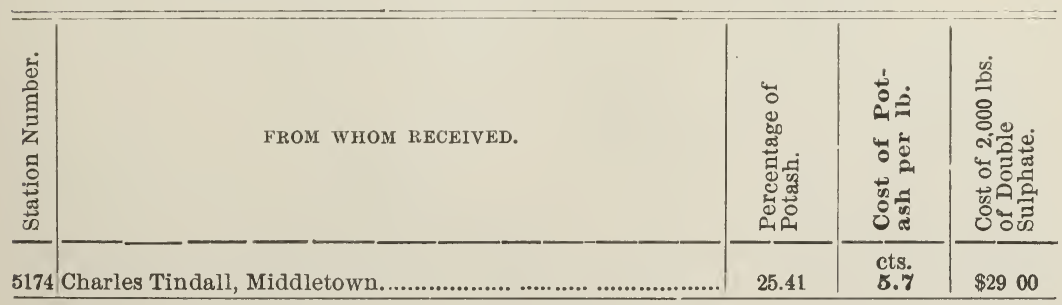


GERMAN POTASH SALTS

Readily Soluble in Distilled Water.

HIGH-GRADE SULPhATE OF POTASH.

\begin{tabular}{|c|c|c|c|c|}
\hline 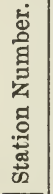 & FROM WHOM RECEIVED. & 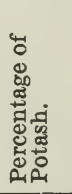 & 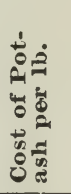 & 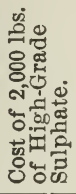 \\
\hline $\begin{array}{l}5033 \\
5083 \\
5165 \\
5173 \\
5154 \\
5527 \\
5528\end{array}$ & 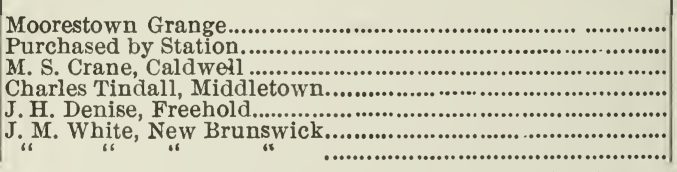 & $\begin{array}{l}49.19 \\
48.29 \\
50.00 \\
50.49 \\
50.85 \\
45.88 \\
48.06\end{array}$ & $\begin{array}{l}\mathbf{c t s} . \\
\mathbf{5 . 2} \\
\mathbf{5 . 7} \\
\mathbf{4 . 6} \\
\mathbf{5 . 0} \\
\mathbf{4 . 5} \\
\mathbf{5 . 4} \\
\mathbf{5 . 2}\end{array}$ & $\begin{array}{r}\$ 51 \\
550 \\
4600 \\
5000 \\
4600 \\
5000 \\
5000\end{array}$ \\
\hline \multicolumn{3}{|c|}{ Average Cost per Pound of Potash in High-Grade Sulphate....... } & 5.1 & \\
\hline
\end{tabular}

\section{EDWARD B. VOORHEES,}

Director.

New Brunswick, N. J., July 1st, 1893. 


\title{
$\tan , 8,1895^{\circ}$
}

INSECTS INJURIOUS TO CUCURBS.

(MELONS, SQUASHES, PUMPKINS, CUCUMBERS, ETC.)

\section{NEW JERSEY}

\author{
Agricultural College
}

\section{Experiment Station.}

$$
94
$$


NEW JERSEY AGRICULTURAL COLLEGE EXPERIMENT STATION.

\section{BOARD OF CONTROL.}

The Board of Trustees of Rutgers College in New Jersey.

\section{EXECUTIVE COMMITTEE OF THE BOARD.}

AUSTIN SCOTT, PH.D., LL.D., President of Rutgers College, Chairman. HoN. GEORGE C. LUDLOW, HENRY R. BALDWIN, M.D.; HoN. HENRY W. BOOKSTAVER, LL.D., JAMES NEILSON, EsQ.

\section{- STAFF OF THE STATION.}

AUSTIN SCOTT, Ph.D., LL.D., Director.

Prof. JULIUS NELSON, Ph.D., Biologist.

Prof. BYRON D. HALSTED, Sc.D., Botanist and Horticulturist.

Prof. JOHN B. SMITH, Sc.D., Entomologist.

ELISHA A. JONES, B.S., Superintendent of College Farm.

IRVING S. UPSON, A.MI, Disbursing Clerk and Librarian.

LEONORA E. BURWELL, Clerk to the Director. 


\title{
NEW JERSEY
}

\section{Agricultural College Experiment Station.}

\section{BULLETIN 94.}

JULY 2, 1893.

\section{Insects Injurious to Cucurbs.}

\author{
(Melons, squashes, pumpkins, cucumbers, etc.)
}

BY JOHN B. SMITH, ENTOMOLOGIST.

Cucurbs are raised in all parts of the State; if not always in fields, for market, at least in the garden, for family use. Cucumbers flourish everywhere, and so do squashes and pumpkins. Watermelons are raised in considerable numbers in the southern counties, while in several districts there are great tracts of cantaloupe or "citron melons," as they are popularly known in South Jersey.

All these plants are more or less subject to attack from a number of species of insects, which always exact a heavy tribute, and not infrequently appropriate the entire crop. In the report for $1890 \mathrm{I}$ gave a brief description of the principal species known to attack these plants; in part from personal experience and observation, in part based upon reports or letters from farmers or upon published material.

In 1890 and 1891 I made a series of experiments on the squash borer, the results of which were published in the reports for those years, and which indicated the possibility of a method of preventing injury from this insect that would be at once cheap and practical.

The melon louse in 1891 did very serious and widespread injury; 
but I could not in that year add to the account published in Bulletin 72 of the College Station.

For 1892 the study of the insect enemies of these cucurbs was made the leading line of investigation; and while by a peculiar dispensation of fate, the Aphids, which were so excessively abundant in 1891, were so scarce as to make it impossible for me to complete their life history, yet the results of the work as a whole may be considered quite satisfactory.

It may be well to note here that under the general term "melon" I intend cantaloupes, muskmelons or citron melons; never watermelons, which are always mentioned as such. "Citron," or "citron melons," are South Jersey terms for muskmelons or cantaloupes, while the term "melon" alone is usually interpreted watermelon.

Among the minor pests is

\section{The Boreal Lady-bird.}

(Epilachne borealis, Fabr.)

This insect is the single exception, in our State, to the rule that the lady-birds are carnivorous, feeding largely on plant lice, and therefore distinctly beneficial. In all its stages it feeds on the leaves of
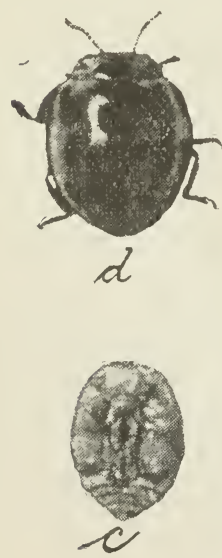

Fig. 1.
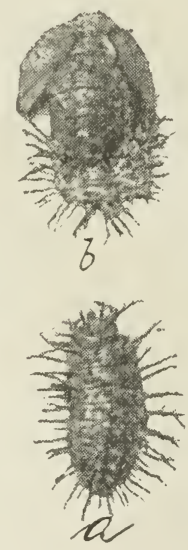
side ; $d$, beetle. Enlarged two diameters. (From a photo.) the cucurbs, manifesting, however, a very decided preference for the squashes and pumpkins. For several years past it has steadily increased in number in our State, and though it can scarcely be called a really injurious insect even yet, the damage actually done could not be carried much further without affecting the vine. Indeed, in sending specimens of the larvæ, August 3d, Mr. Charles T. Adams, Blackwood, N. J., speaks of them as the "worms that kill our watermelon vines;" so that, locally, they are already destructive.

The imagos or adult beetles are about three-eighths of an inch in length, very convex, indeed almost hemispherical; dull yellow in 
color, with four black spots on the thorax and seven on each wing case. Of the latter, two are situated on the suture, or margin where the elytra or wing covers join, so that twelve spots only are counted on the two wings. The appearance of the insect is fairly shown at Figure 1, $d$.

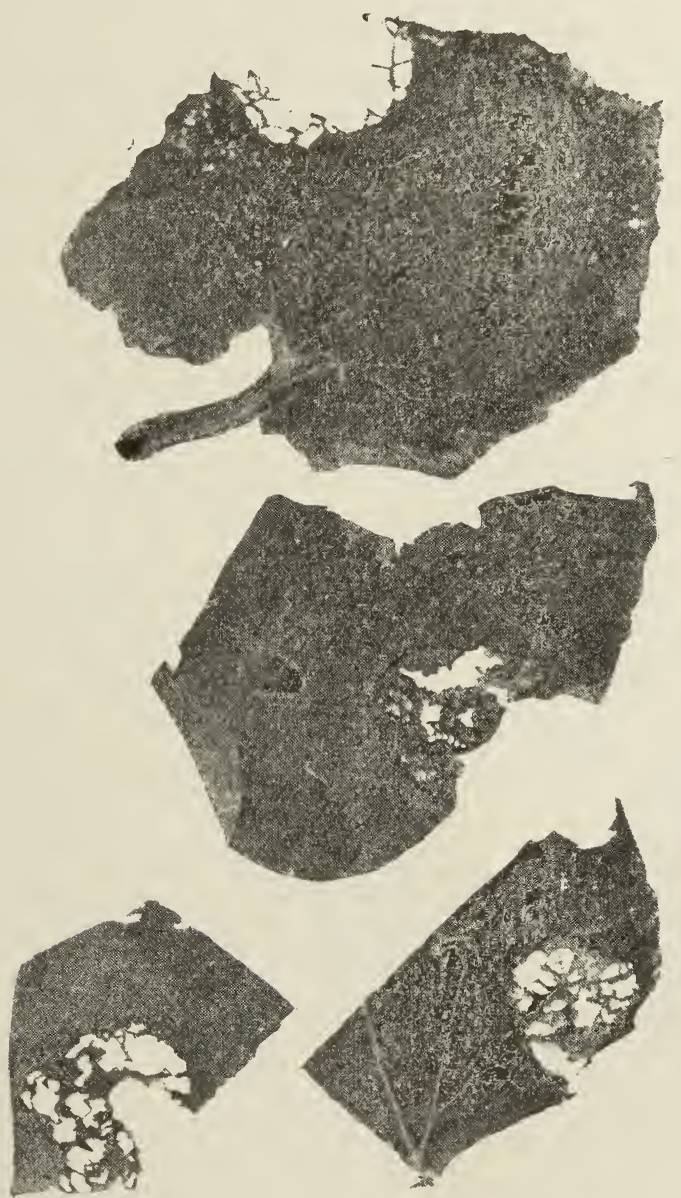

Fig. 2.

Leaves of squash, eaten by the boreal lady-bird, Epilachne borealis. Three-quarters natural size. (From a photo.)

The earliest date at which I have seen the beetles on the vines is June 13th, when I found a single specimen on melons at Swedesboro. After that time they increased in numbers rapidly, and on June 27th I found, at Port Monmouth, numerous specimens eating the leaves of 
melons and cucumbers. The eating done by this insect is unique and quite characteristic: a semicircular space, from three-quarters to one inch in diameter, is marked out at the edge of the leaf, and the beetle then begins its work, feeding on the upper surface. As a rule, the tissue is eaten rather irregularly, and a more or less complete network remains, when another semicircle is started. The tissue dries so rapidly, however, that in a day or two the semicircles usually appear completely eaten out. On a large leaf there may be several of these feeding-places, depending entirely upon the abundance of the beetles.

June 27th I found one (the first) batch of eggs, laid on the under side of the leaf.

July 5th there was a great abundance of these insects at Port Monmouth, very much more numerous, however, on squash than on melon

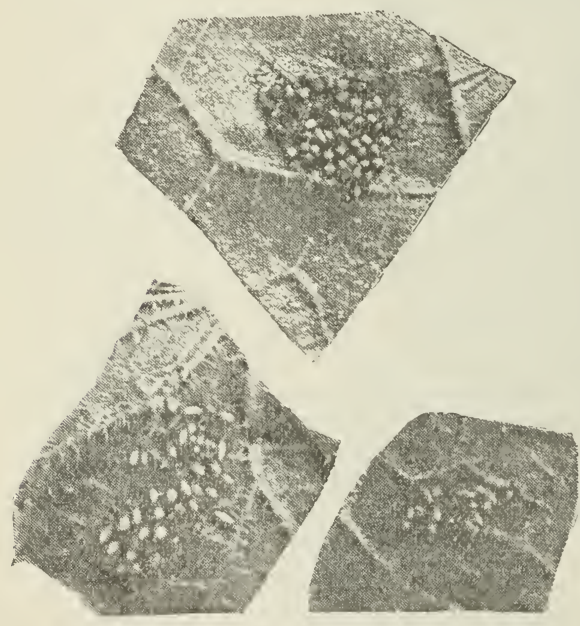

Fig. 3.

Egg clusters of Epilachne borealis. Natural size. (From a photo.) vines; and now I found egg masses in considerable number, each with from fifteen to fifty eggs. These latter are bright yellow in color, elongate oval in shape, and set on end in loose clusters on the under side of the leaf. Figure 3 shows the appearance of the egg clusters and of individual eggs as well. I noticed here and there a specimen of Coccinella 9-notata, the nine-spotted lady-bird, busily engaged in feeding on the eggs of its degenerate relative.

We have in these two species, the boreal and nine-spotted lady-birds, two closely-related forms with entirely different food habits, and a study of the mouth parts, which usually emphasize quite strongly any difference in feeding habits, may prove interesting.

In Epilachne borealis the mandibles are quite well developed and pointed at the tip, with two teeth on the inner side; a mandible belonging to a carnivorous rather than an herbivorous insect. There is a distinct though small prostheca. The maxilla is also well devel- 
oped, the lacinia and galea both stout and prominent, the divisions between the pieces not well marked. The labium, or lower lip, is conic, ending in a point, and is set with a fine, dense pubescence and a few longer, tactile hairs. The labrum, or upper lip, is rather densely clothed on the under side with long, stout hair, set in distinct foveæ.

In Coccinella 9-notata the structure is essentially different. The mandible, in character, would suggest rather a pollen-feeding insect, with its small apical teeth, prominent prostheca and distinct molar. The maxilla is quite different from that of $E$. borealis; all the parts

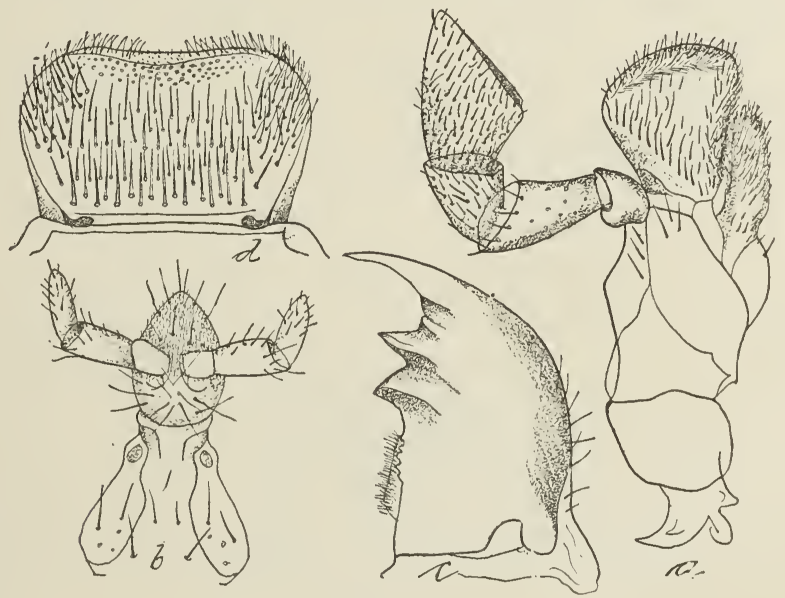

Fig. 4.

Mouth parts of Epilachne borealis: $a$, the maxilla; $b$, labium ; $c$, mandible; $d$, undor side of labrum, or upper lip. Enlarged. (Original.)

are well defined, and the lacinia and galea are both more or less excavated or hood-like. The labium is truncate at the tip, and the surface there is velvety. The labrum is furnished on the under side with a few tactile hairs only; but it has a series of little sensory foveæ or pits not found in the other species.

July 13th I found, at Swedesboro, eggs just beginning to hatch, and on July 15 th they had begun to hatch in numbers and to feed freely.

July 17 th, at Jamaica, Long Island, I found a few larvæ hatched from egg clusters, and noticed, in one case, that the first larva hatched ate into and destroyed a large proportion of the other tggs of the cluster. This explained an appearance that I had noted elsewhere, 
but had attributed to other causes. It seems quite probable that this is far from being an exceptional habit in the young larvæ, and that the excessive increase of the species is thus checked, to some extent, by its own cannibalistic tendencies. Though there was an abundance of eggs, there were, as yet, few larvæ here.

July 22d, at Port Monmouth, found plenty of larvæ, varying from just hatched to fully half grown. There are yet a great many unhatched egg masses and a few beetles; no signs of pupation, however.

August $3 \mathrm{~d}$, at the same place, many larvæ were full grown and were getting ready to pupate, though there were yet a great many broods half grown or less. There seem to be no more unhatched

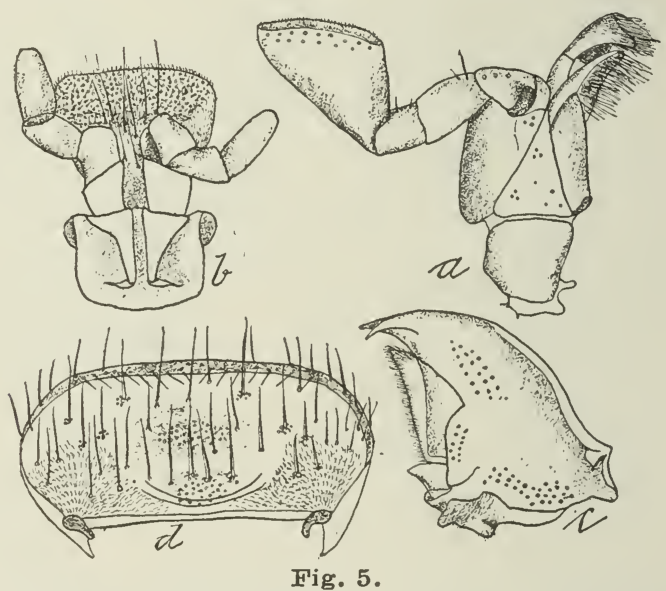

Mouth parts of Coccinella 9-notata: $a$, maxilla; $b$, labium; $c$, mandible; $d$, under side of labrum, or upper lip. Enlarged. (Original.)

eggs. Of a lot of specimens carried to the laboratory, the greaternumber pupated within thirty-six hours, and in less than one week thereafter imagos had emerged. The larvæ are bright yellow in color, with prominent, black, branched spines. Figure 1 shows the appearance of the larvæ, while at Figure $6, e$, is an enlarged figure of one of its spines. It will be noted that the main process or trunk has branches from all sides, and that these branches are themselves jointed, an accessory little spine being set on the basal segment. Its mouth parts are also shown at Figure $6, a$ to $c$.

The larva feeds, unlike the adult, on the under side of the leaf, and does not eat the entire tissue, but shaves off only the surface and central layer of cells, leaving the skin of the upper side intact. 
August 6th, at Cold Springs, Long Island, found a pupa on the wild cucumber; and on the same day found, at Jamaica, eggs, larvæ, pupæ and imagos, some of the latter in copulation. The egg patches were, apparently, new, while the larvæ were of all sizes. What I could not determine was whether the beetles that mated at this time were of those that had appeared in the spring, or whether they were newly-hatched specimens; nor could I find whether the eggs were of the spring brood or from the recently-matured beetles. Those bred

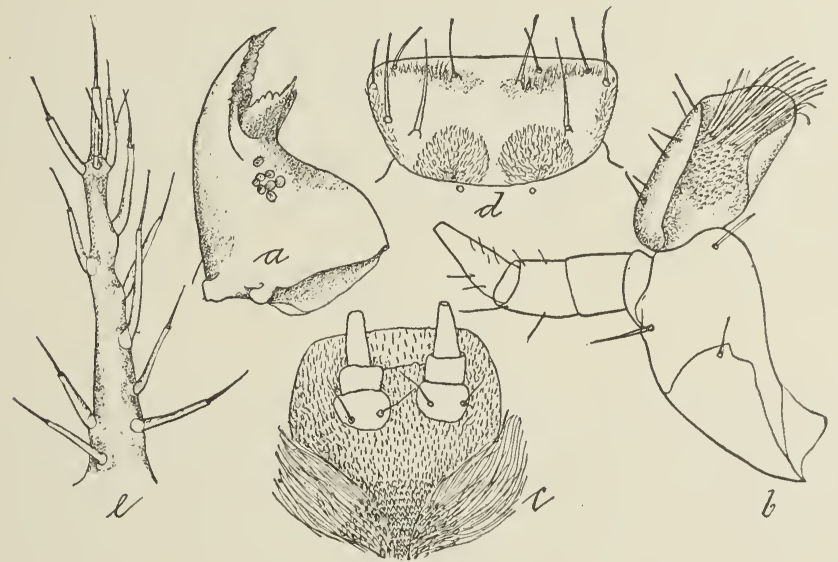

Fig. 6.

Epilachne borealis, larva : $a$, mandible ; $b$, maxilla ; $c$, labium ; $d$, labrum, under side; $e$, one of the spines or processes of the larva. Enlarged. (Original.)

in my laboratory did not attempt to mate, nor did I observe the process elsewhere after this date. In pupating, the larva attaches itself by the tail, and the spiny skin is gradually shed and worked to this point, forming an irregular mass, as shown at Figure $1, b$, where the pupa is seen from the back. A front view is shown at $1, c$.

August 31st, at Port Monmouth, there were to be found only a few scattering larvæ and an occasional pupa. No imagos were seen at this time nor thereafter, nor were either eggs or young larvæ to be found.

\section{Life History.}

From the above observations the following life cycle can be condensed: The beetles come out of winter quarters, beginning about the middle of June. They become more numerous until July 5th, and 
continue, in gradually diminishing numbers, until the beginning of August. Eggs are laid, beginning toward the end of June, and added to constantly until all the beetles have disappeared. I did not try to ascertain how many eggs were laid by a single female. The duration of the egg state is about twelve days, and about the middle of July larvæ appear in some numbers, continually increasing until early in August, when pupation begins. Imagos emerge about six days later, and apparently seek hibernating shelter at once, doing little, it any, feeding. Exceptionally, specimens matured early in August may mate and oviposit; but such cases are rare, I believe. By the beginning of September all trace of the species has disappeared from the fields. For hibernating quarters any shelter answers. They sometimes swarm into barns, sheds or outbuildings of all kinds; but are equally content with a bit of loose bark, or a crevice in a fence-post, or a heap of rubbish.

\section{Remedies.}

As the beetle feeds openly, on the upper side of the leaf, it is easily within the reach of insecticides. Of these, the arsenites are much the most effective, and should be sprayed on the plants when the beetles are first making their appearance. Killing off these adults early will prevent egg-laying and, consequently, the production of larvæ. So the season's brood may be easily destroyed by a timely application of the insecticides. The poisons may be used safely at the rate of 1 pound in 150 gallons of water, lime being added as directed in Bulletin 86 of the Station.

\section{The Striped Cucumber Beetle.}

(Diabrotica vittata, Fabr.)

This is one of the best known of the insects injurious to the cucurbs, and in some States is the most destructive. It has never been as troublesome in New Jersey as it has been in Ohio, Iowa, and in some other of the Western States; but yet it does considerable injury each year without causing special complaint. It is one of those insects to which farmers have become accustomed to pay toll, and, unless the exactions are unusual, no complaint is made. 
May 30th, at Swedesboro, I found that melons were well up in most patches, and were putting forth the middle leaf. Many of the striped beetles were about, and copulation was quite general. The seed-leaves were considerably eaten on the under side, and here and there the stems were scarred; but this injury was as nothing compared to the destruction caused by the "damping off," a disease which attacks the plant at the surface and kills it in short order.

June 13th the beetles had increased in number; but the plants were now generally well able to take care of themselves.

June 27th the beetles were plentiful at Port Monmouth. They had eaten the seed-leaves badly, and had eaten into the stem in some cases; but had done no permanent injury.

July 15 th I found the beetles very abundant on melons at Esopus, N. Y., and they were said to have been yet more plentiful early in the season. At this time they frequent the blossoms of the squash, and a great many can be found each morning in the closed flowers of the preceding day.

July 17 th the beetles were plentiful at Jamaica, Long Island, especially on late plantings of squashes, and were busily eating the seed-leaves and into the stem. I made here a diligent search for larvæ in the roots, but found none, the roots of all the plants examined being free from all trace of injury of any sort; though there had been insects enough on the plants, as the eaten leaves testified.

July 21st I found the beetles plentiful at Metuchen. In looking for other species I sliced up several squash vines, and found no trace of the larvæ of this insect on the roots anywhere; nor did I find either larvæ or pupæ in the soil about the roots. I did find, however, a specimen of the beetle which had been killed by a dipterous parasite. The larva had, evidently, fed in the body cavity of the beetle, and in pupating had burst the abdominal walls. The beetle was attached by its claws to the under side of a leaf, apparently having fixed itself firmly in place when the internal convulsions approached. Though I searched carefully then and later, at Metuchen and elsewhere, I never found another specimen so parasitized, and the single example taken I failed to breed. It is not likely, therefore, that we have here an active ally in the task of controlling the Diabrotica.

July $22 \mathrm{~d}$, found one larva on the root of a squash vine at Port Monmouth. It was lying in a channel which it had eaten through 
the bark, and there were other similar channels or irregular grooves on other parts of the root; though I could find no other specimens. The larva is white, very slender, with a horny, brown head and obtuse tail, very well shown in Figure 7.

August 3d I again searched very thor-

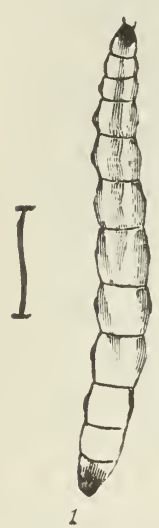

Fig. 7.

Larva of striped beetle: 1 , from above; 2, from sicie. Enlarged. oughly in the same squash-field at Port Monmouth. The crop had been gathered, many of the vines were infested by borers, and the patch had been left to run to (weed) seed. I dealt very freely with the plants under the circumstances, and dug or pulled up and closely examined a large number. The striped beetles were very abundant, and were mating freely; but no trace of a larva was discoverable on any of the plants-not even an eating on the roots to indicate that any had ever been present.

August 6th. Found the beetles very abundant and mating in the squash fields at Jamaica, Long Island, and here also I failed to find larvæ.

August 31st I made another attempt to find larvæ in a melon field at Port Monmouth; but, though there were beetles enough, the roots were clean and sound, showing no trace either of borings or of surfaceeatings other than such as were near the crown and were due to the beetles.

October 17th, at Esopus, N. Y., I found the melon vines all off the ground and the field plowed. Rosettes of wild cruciferæ, mustards and other allied forms were rather abundant, and beneath these I found a considerable number of the striped beetles, feeding freely on the under side of the leaves. I saw no mating, and on the roots of the mustards pulled up I found neither larvæ nor signs of their presence.

The foregoing record, though it adds nothing to our knowledge of the life history of the insect, is not without interest. It does not even confirm, nor does it really contradict what has been previously written concerning it. It proves that there is no reason to fear injury from the larvæ in New Jersey, and that even where the beetles are 
abundant the cucurbs will run away from or outgrow damage once they get a fair start. We can condense the life history of the insect as follows:

\section{Life History.}

The beetles appear in May, before the vines are up, and are found on plants of divers kinds. When cucurbs of any sort appear they abandon everything else to attack them. They first eat the seedleaves, preferably from the under side, hiding quite generally in midday in the soil around the plants, and often eating into the stem at or near the surface. Eggs are said to be laid on the roots, and the larvæ are said to feed on or in them. Some do so, certainly; but whether there is not also some other larval food-plant is perhaps a question. Beetles are in the fields and on the plants continuously throughout the summer, and there are probably three or more broods during the season, beetles appearing as late as the last week in October. Hibernation is probably quite general in the imago stage, perhaps also in the pupa.

\section{Remedies.}

The only time when the plants are in serious danger from the striped beetle is very early in their life, before they have started running; afterward the injury is insignificant and easily borne.

In Ohio and Iowa the beetles appear so numerously early in the season that the plants never get an opportunity to come to the surface at all, the beetles burrowing down to meet them. In those States protection by means of screens and nettings, to keep the beetles off the young plants, is resorted to, and is, of course, effective. A very much better plan is to start the plants under glass, in good soil, in baskets, and set them out when they have begun to grow well and the ground outside is thoroughly warm. This method is not new, but is practiced by growers who are anxious to get the earliest markets, and is more intended by them to get high-priced fruit than to circumvent the beetles. It is very effective for the latter purpose, however, and exposes to them an established plant, instead of a new and tender sprout. Where the beetles are not too numerous, or there is an objection to starting under glass, practical exemption can be obtained by planting a larger number of seeds in each hill. This will so distribute the attack that little real injury will be done, and when the plants are 
firmly established and out of danger it is easy to thin them out as much as is desired. This is probably all that would be needed in New Jersey, where the insects always give the plants a chance to get above ground at least.

In this State, after the plants have started, the beetles sometimes appear rather suddenly, in large numbers, and considerable injury is caused before the danger is appreciated by the growers. The practice in several districts is to "drive" the insects by using plaster, working with the wind. The beetles dislike this and fly before it. When it is noticed that one farmer has begun to "drive" his beetles, his leeward neighbors take up the work when their land is reached and the "drive" is continued, until some field is reached whose owner is not in attendance, and there the beetles remain, for a time at least. Instead of plaster alone, plaster and Paris green or London purple is sometimes used, always with good effect. The arsenites applied in a spray are yet more satisfactory, for with the underspray nozzle the plant can be thoroughly poisoned, and the under side of the seed-leaves, of which the beetles are most fond, are thus effectively reached.

In the report for 1890 I cited cases where the arsenites had been used successfully, and these need not be more particularly referred to. One pound in 150 gallons of water should be used, and lime should be added as before recommended.

The kerosene emulsion has been successfully used (as a repellant?) by Mr. C. L. Riker, Esopus, N. Y. He writes, under date of June 7th, 1892: "We had a little experience yesterday and to-day with the striped beetle which may be of interest to you. Some days ago I prepared my kerosene emulsion. $* * *$ This emulsion we applied to our melon vines (thirty acres) yesterday afternoon, when many of the beetles had suddenly appeared. This morning, although very warm, and we had expected a circus, very few presented themselves, except on plants which had not been suhject to the emulsion, where they were very thick. A sprinkling of the London purple this afternoon, in addition to the kerosene emulsion, seems to have completely annihilated them." I found, later, that there had been no further serious attack on the plant, and though there were a great number of the beetles about when I saw the field in July, the vines were then well out of their way. It was at this time that Mr. Riker was killing off a great many of the insects by gathering, late in the evening or early in the morning, the recently-closed flowers of the squash, in 
which these insects like to hide. There were from two to ten or more beetles in each blossom, and the number collected and destroyed in this way was considerable.

The persistent use of tobacco has also been found efficient in keeping vines free from the attacks of the striped beetles.

We can summarize thus as to remedies:

1. Plant under glass, in baskets, and set out after the vines are well started; or,

2. Plant an excess of seeds, so as to distribute insect-attack, and thin out when the danger is over.

3. When plants are established and the beetles appear in dangerous numbers, spray with the arsenites, or dust with the arsenites and plaster or dry-slaked lime.

Essentials under 3 are a prompt resort to the remedy when the beetles are first noticed, and its thorough application, especially on the ander side of the seed-leaves and on the stem of the plant.

\section{The Squash-bug.}

(Anasa tristis, De Geer.)

The squash-bug is one of the oldest insects known as injurious to the cucurbs, and has been so often written about that there is little left to say concerning it. In our State it does not rank as a very troublesome insect where the cucurbs are grown on a large scale; but it is sometimes decidedly destructive in gardens where only a small number of vincs are annually raised. The injury done by this insect is decidedly different in character from that caused by the species heretofore treated. In those cases there was an eating of the tissue; here there is a puncturing of the vine and a sucking of the sap. The mouth structure is entirely different, the mandibles, maxillæ and labium being replaced by a rigid beak, in which are four slender lancets. By means of these the stem, leaf-stalk or other part of the plant is punctured, and through it the sap is pumped into the stomach of the insect. The structure of the beak is in all essentials the same as that of the melon louse, which is figured in the next article. The mere puncturing and the extracting of a little sap would not in itself suffice to affect the plant, for that is very hardy, and readily recovers 
from even severe cutting and slashing; but the insect injects into the wound a little drop of saliva, which seems to be of so poisonous a character that it causes the death of the tissue around the puncture, and a consequent interruption in the flow of sap. Where the insects are at all numerous, and the stem of a young plant is wounded in several places, it sometimes causes the death of the vine.

The insect itself is rather obscurely represented at Figure $8, a$ and $b$, and is of a dull, smoky-brown color. Its general appearance is sufficiently well shown in the picture to make it unnecessary to
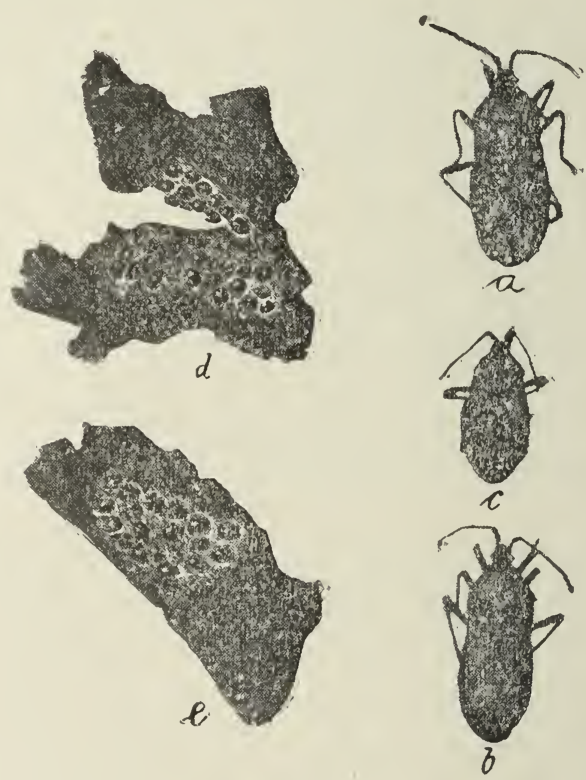

Fig. 8.

The squash-bug: $a, b$, adult bugs; $c$, pupa ; $d, e$, egg clusters. Natural size. (From a photo.)

waste words in description. When handled it imparts to the fingers a peculiar, sickening odor, which is supposed to protect it from the attack of enemies; and surely it must be a curious creature that would relish a squash-bug! The insect makes its appearance on the plants in June, usually not until well along toward the middle of the month, when the vines are already well started. It hides on the under side of the leaves or in the soil, and is little seen during the day. I found them on melons at Swedesboro, in some numbers, July 13th, and there were then also a few egg clusters. 
July 15th, at Esopus, N. Y., I found a somewhat greater number of the bugs and more egg patches. These egg masses are shown at Figure $8, d$ and $e$, and are of a rich light golden-brown color, very handsome and conspicuous. They are laid on the under side of the leaves, in clusters of from twenty to fifty, and are quite securely fastened.

July 17 th I found the squash-bugs very abundant at Jamaica, Long Island, and saw a great many egg masses. Some of these had hatched, and one brood of the young bugs was almost ready for its second moult. The young are odd-looking creatures, with small head and prothorax, and a large, prominent, oval, green abdomen, which is carried elevated high in air.

Three weeks later, August $6 \mathrm{th}$, some of the old bugs were yet on the vines laying eggs, and continued there until after the middle of the month. At this date (August 6th) many of the larvæ were well advanced, and a few had transformed to pupæ. The latter begin to resemble the adults rather more closely; they are like them in color, and have the rudiments of wings well developed. Figure 8 , c, gives a very poor representation of this stage.

September $2 \mathrm{~d}$ I found, at Esopus, N. Y., a few egg masses, a considerable number of larvæ and a very large number of pupæ and recently-transformed imagos. The recent imagos, or new squashbugs, differed from those found in the spring in their lighter gray color and much softer texture, the outer skin appearing to harden very slowly. The number of new bugs continued to increase on the vines until October 17 th, when only a very small proportion of pupæ remained, and no larvæ at all were seen. The imagos seek shelter wherever they can find it, and live through the winter in that stage. The mortality among them during that season must be excessive, for out of hundreds seen in late fall only single specimens survive; these are the solid, brown, hardened sinners who will live on to midsummer or later. In tilled fields there is, or should be, little shelter to serve as winter quarters for these insects. In gardens, or near them, there is usually an abundance. They get into crevices in boards, in fences, into attics, barns or stables, under or in rubbish heaps or wood-piles, in the mulch on plants, among the straw with which others are covered, and in fact anywhere, so that a space large enough to admit them is found. This explains the relatively greater number of insects appearing in gardens in spring. 


\section{Remedies.}

Insecticides, as applied to these insects, have been failures, as a rule; and no smell disagreeable enough to annoy them and act as a repellant has yet been discovered; in fact their own odor is so vile that if they can endure themselves they can surely endure anything else. They can be checked in large fields by raking out, carting off and destroying the vines as soon as the crop is off. Plowing under answers as welk or better. The object is to destroy all the eggs and young then on the vines, and to force the adults, new or old, to other localities for food or shelter. In a large field, plowed early in September, a very small proportion would escape to go into hibernation.

Nothing that may afford a shelter should be left in the field or around it, so that the insects will be forced to travel some distance for winter quarters. The further they are compelled to travel, the less the danger of their finding the way back next spring.

The earlier the plowing can be done, the greater the resulting destruction of the insects, since only the adult or winged forms can escape. Nothing more than this seems necessary in our State to avoid injury to large plantations from these bugs.

In gardens the case is somewhat different; but here also the plants should be taken out and destroyed just as soon as all the desired crop is taken off. Plants left for seed can be easily looked over when the others are removed, and the insects on them can be collected and destroyed. All the adults seen in spring should be collected and killed, and the egg clusters should be systematically collected and burnt. The eggs do not hatch very quickly and are easily seen, so that twice a week would be often enough to collect and destroy them. The result of care and thoroughness in this process will be more evident the year following, in the very much smaller number of bugs making their appearance in spring.

\section{The Melon Louse.}

(Aphis cucumeris, Forbes)

In this State no single insect has caused as much serious injury to some of the cucurbs as the melon louse. Cucumber and melon, cantaloupe or citron vines are the most severely affected; but watermelons also are sometimes considerably injured. Pumpkins and 
squashes are not much troubled, as a rule, though the insect is to be found on them in small numbers.

I had a few letters complaining of this insect in 1889, and quite general though not very severe injury was caused. In 1890, when plant lice in general were abundant, this species became yet more destructive, and was one of those treated in Bulletin 72 of the College Station. In 1891 the injury caused was serious and widespread. In Monmouth, Burlington, Gloucester, Salem and Camden counties the destruction was almost complete; acres of melons were plowed out; other acres were abandoned, and a few fields only managed to revive and to produce a late, ill-paying crop.

It was not until late in June and well along in July, when the aphids had already overrun everything, that requests for remedies, or for methods of repairing the injury done, began to come in-long after the insects had gotten beyond all ordinary methods of control. On July 13th I visited the Swedesboro region, and on July 17 th the Port Monmouth district, finding injury severe in both localities; later, near Merchantville, I found matters worst of all. I made no personal observations except on the dates above named, and then the fields were quite uniformly infested; wingless viviparous individuals being much the most common, though winged forms were scattered about generally. Mr. Edward Burrough, at Merchantville; Mr. H. W. Ridgway, at Swedesboro, and Mr. J. S. Carter, at Port Monmouth, were good enough to show me over the infested districts in their respective localities, and I found everywhere a uniformity of testimony on one important point: the insects are not noticed in the fields until the vines have started running, and always on scattered hills here and there; sometimes only on one or two in a large field. These act as centers of infection, and the lice spread from them with startling rapidity. There was a general tendency in 1891 to charge the plant lice with all the injury observed on the cucurbs; but in many a melon field examined by me, though aphids were abundant enough, they had by no means caused the general dying off among the vines, which was rather to be attributed to a bacterial disease attacking them at or a little below the surface of the ground. I found, at Port Monmouth, that parasites and other insect enemies of the lice were increasing at such a rapid rate that I felt justified in saying that the worst of the attack was over, and that there would be little further spread. My prediction was verified, for Mr. Carter 
wrote me September 1st: "Very singular, they did not spread out on new vines after about the time you were here [July 17th]. By the first of August they were disappearing quite rapidly, and by the middle of August were about gone, leaving a shed skin on the leaves. There are but very few to be found now." September 9th Mr. Carter again wrote, in answer to a request for specimens: "I am unable to send you any melon lice for the reason that there are none to be found ; all gone." I attribute this cessation of injury entirely to the hosts of parasites, lady-birds and syrphus-fly larvæ, which were all busily engaged in their work of destroying the aphids. In the Delaware counties these insect friends were very much less abundant, and, though a factor in checking injury, at no time got the upper hand, so as to really stop the steady increase of the lice.

Attempts to destroy the aphids had been made by some growers, whale-oil soap and kerosene emulsion being used; and while both were found effective, the complaint was of the difficulty of reaching the lice on the under side of the leaves.

In Bulletin 72 of the College Station I hazarded the conjecture that the species might have an alternate food plant, and also mentioned Prof. Forbes' suggestion that it might winter in the ground. Both of these theories I resolved to put to the test in 1892, and concluded, also, that it would be better not to rely upon being notified of the first appearance of the lice by growers.

\section{Field Record.}

Field work began May 21st by a visit to Swedesboro. There were very few melons up as yet, and no signs of aphids on them. Mr. Weatherby, a large grower, said that the lice are first on the roots, and that he has frequently seen them there; that they are attended by ants, and that he has seen the ants carry the lice from the roots to the leaves. Mr. Rulon confirmed the statement that lice are to be found on the roots before they are on the leaves, but confined it to watermelons. I met with this same statement later in so many other localities, usually as to watermelons, that I cannot well doubt its accuracy, though it is probably a very different species from that under consideration here.

May 30th, at Swedesboro, melons were well up almost everywhere, and were putting forth the middle leaf. No trace of aphids was 
found anywhere. Ants were abundant in the fields on all the plants; more plentiful, however, in sweet potato than in melon plantations. Pulled or dug up a great many plants near ant-hills, and found no trace of aphids of any kind on the roots; nor was the investigation of ants' nests more fruitful in results. I failed utterly to find any trace of lice anywhere in the melon-fields, whether in vines for the first or second year, or in sweet potato fields that had been in melons the year before.

June 13th. I found here and there on the melons winged specimens of Siphonophora cucurbito, a much larger species of louse, more usually confined to the squash, and which had never caused any trouble; but saw nothing of the little $A$. cucumeris.

June 27th I visited Port Monmouth, and here found, in Mr. Carter's field, which had been in melons in 1891 as well, isolated winged specimens of the melon louse. Altogether, on over 100 hills examined in all parts of the field, I found about half a dozen specimens; and of these, one only had given birth to a single young. Evidently they could have been on the plants a very short time only. On no plant was there more than a single louse. Vines were about one foot long. Mr. Carter thought he had noticed specimens a week ago; but none were found where he thought he had seen them. Pulled up a considerable number of "extra" plants, among them some of the infested ones, without finding any trace of lice on the roots. The specimens have come on from the outside, without much doubt. In neighboring fields I found much the same conditions.

On Mr. W. S. Roberts' farm a different state of affairs obtained. Here some plants on a small patch of cucumber vines were already badly infested. One hill, at one corner of the patch, had evidently been the center of infection, and every leaf was set with specimens, none of them winged. A few surrounding hills were less infested, also with wingless forms only; and one on the opposite side of the patch carried a few specimens. The insects were noticed a week ago, and Mr. Roberts said there were then winged forms amongst them. The aphids on the less-infested plants were rather scattered; usually there was one large specimen, surrounded by a little group of smaller individuals, evidently its progeny. On some leaves there were little groups of three or four, all very much of a size, obviously deposited there by some parent that had disappeared. I sent Mr. Roberts some whale-oil soap, to test its killing power on the aphids. 
June 28th I found the vines at Swedesboro looking well, and almost the same state of affairs existing, as to plant lice, that I found at Port Monmouth the day before. In most of the fields there were a few plants on which a winged louse was found, and others on which one or two leaves were set with wingless, viviparous females. Wherever this occurred the winged forms had disappeared.

There seems little doubt that from somewhere a few winged lice appear some time in June. These get into the fields and bring forth a few living young. Sometimes they remain on one leaf, but perhaps. more usually they migrate again, to start another colony elsewhere. From the colonies thus started the insects spread.

July 5th, at Port Monmouth, all the aphids had disappeared from the melon and cucumber vines in all the fields examined. Not a single specimen in any stage could be found anywhere. Since my visit of June $27 \mathrm{th}$ there had been a series of cyclonic storms and cold rains, which had whipped the vines about rather freely, and now not an aphid remained. Exactly how much of this state of affairs was to. be attributed to the weather I cannot say. Mr. Roberts informed me that he had received and used the whale-oil soap, and that with it he had checked the spread of the insects on his cucumbers. The general disappearance of the insects elsewhere made this evidence less valuable than it might have been otherwise.

July 13th found the fields at Swedesboro equally free from plant lice. Not a single specimen, nor any indication of any, could be found. Mr. Ridgway had not heard of injury being done anywhere, and had seen nothing of any himself.

July 15th, at Esopus, N. Y., no lice were seen on that portion of a thirty-acre field examined by me.

July 17 th found at Jamaica, Long Island, a few specimens of the Siphonophora on squash, but no trace of the melon louse. My chances for learning anything of the insects that season looked rather slim.

Nothing was found at Port Monmouth July 22d, on fields which a year ago were swarming with lice, and exemption from aphid-attack still continued August 3d.

August 24th Mr. C. L. Riker wrote me from Esopus as follows: "The lice have suddenly appeared on our melons in such numbers that, if we do not succeed in checking them within a few days, they are going to completely ruin our crop, even blackening the melons and the ground beneath the vine." 
As soon as was possible-August 31st-I went to Port Monmouth, to see if perchance the insects had appeared there; but I found no trace of them in any form. Melons were a short crop and were ripening; the best of the early crop perhaps already shipped.

September $2 \mathrm{~d}$ went to Esopus. I found that on the thirty-acre field the lice had started on the northwest corner, which I had not reached on my previous visit, and for a week or ten days after they were noticed had moved slowly. Then the effect of the injury caused by them became apparent, and the leaves dried up and became brown and lifeless. These plants were then abandoned by the lice, and almost the entire field became infested in a few days. At this date there were few of the aphids where the start was made, and most of the plants were dead or nearly so; so far gone, at any rate, that no more fruit would be matured. Elsewhere in the field there were aphids in abundance; winged forms were most plentiful in the portions last attacked, while in the places to which they first spread pupæ were most numerous. Wingless, viviparous forms were the most abundant everywhere, and there were, of course, any quantity of young or larval forms. In small numbers the insects were found on the leaves of squashes, mostly in the winged form, though a few had begun to breed. I found also a considerable number of specimens, largely winged, on the wild cruciferæ, mostly mustards, that were abundant all over the field. Some of these were breeding, and I found all stages, from the smallest larva to the pupa and winged form. It was apparent that the species is quite able to support life on these weeds. Of parasites there were only a few; but there were considerable numbers of "lady-birds," with their larvæ, busily engaged in feeding on the lice. Of these I collected Coccinella novemnotata, Cycloneda sanguinea, Hippodamia convergens, $H$ parenthesis and H. 13-punctata. H. convergens was much the most common, while $H$. 13-punctata was the least abundant of the species. They were, however, far behind the van of the plant lice, and could not, under ordinary circumstances, so increase as to be of any real useas a check until late in the season.

I found, also, Siphonophora cucurbitce on the squashes in some numbers, yet not in anywise injurious. They also were on the wild mustards in all stages, but none were on melons.

As I had no facilities at New Brunswick for raising melon or cucumber vines upon which to observe the insects continuously, I 
arranged with Mr. Riker to send me infested leaves at frequent intervals, in the hope that the first appearance of the sexes might thus be noted, and that I might then make an attempt to follow the specimens into their winter quarters. Three or four lots of leaves were received, all containing the usual summer forms, and then no more arrived.

September 7th I found at Anglesea, N. J., some watermelon vines on which were a considerable number of these insects, mostly pupæ and viviparous, winged forms. Again I was compelled from lack of proper laboratory facilities to miss an opportunity for securing material to complete the life history of the insect. This find proved, however, that the conditions causing the destruction of the insects near Port Monmouth did not extend to all parts of the State.

October 17th made another trip to Esopus. I found that, owing to the cholera scare, then at its height in New York City, melons had become almost unsalable, and on this account, and because the lice still continued their injury, Mr. Riker had raked out all the vines and had plowed the field. The vines were all piled for composting, and nothing in the way of aphids remained on them. The cruciferous rosettes starting all over the field were carefully examined, and a large number of the aphids found on them were collected and, later on, examined in the laboratory. No specimens of the melon louse were among them. On a large squash vine under glass, at some distance from the melon-fields, I found a considerable number of the species of which I was in search, and carried with me two badlyinfested leaves, as well as specimens of all the forms found on the plant. All these proved to be only the ordinary summer types; neither males nor oviparous females were among them.

October 25th I collected over an old melon-patch at Metuchen, and on the wild mustards then starting I found a few specimens of the winged lice. Nearly all were the ordinary viviparous forms; but two specimens may possibly prove to be males of this species when more material is secured. No oviparous females were seen, nor did I find any such later.

The work of the season is inconclusive, therefore, and yet not entirely without result. It gives us the following 


\section{Brief History.}

Winged, viviparous forms appear in the fields in small numbers about the middle of June, starting colonies by bringing forth living young; sometimes on one leaf only, sometimes on several. These mature rapidly, and reproduce, in turn, at such a rate that by the end of the month a considerable spread has been made. If unchecked, they will soon spread over a very large territory, and injury is proportioned to their number. All during the summer and until well along in September, or even later, reproduction continues. In midsummer comparatively few specimens become winged, but later pupæ and winged forms become more numerous. Sexed forms have not appeared by the middle of October. Their history between October 15 th and June 15th following is yet unknown. I am very strongly inclined to believe that the late winged forms migrate to some common weed, probably cruciferous, on the winter rosettes of which eggs are laid, that will carry the species through the winter. These eggs probably hatch quite early in spring, and several generations may be produced before the insects are ready to return to the melons or cucumbers.

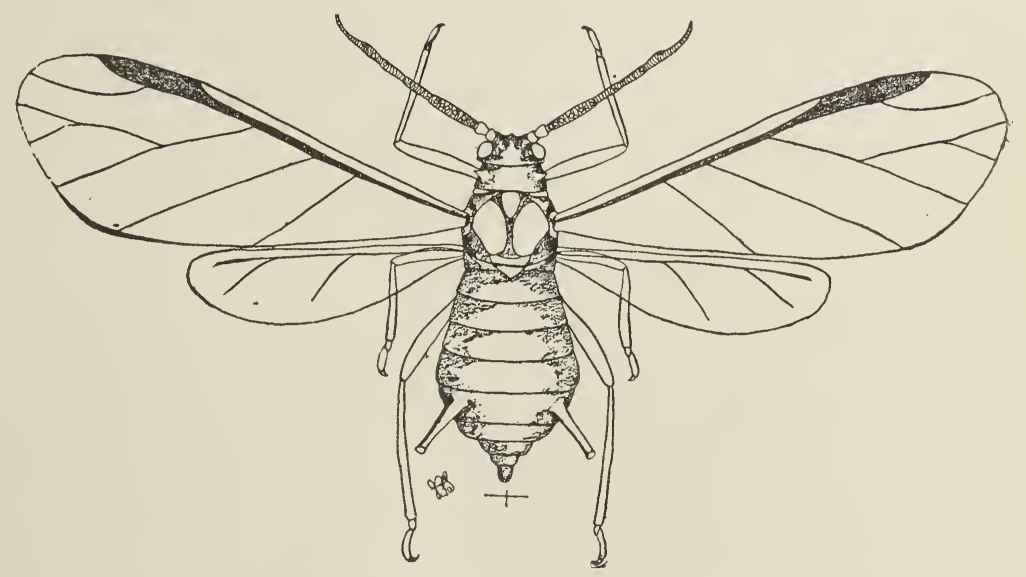

Fig. 9.

Melon louse: Winged, viviparous female. (Original.)

Figure 9 shows the general appearance of the winged louse, with which melon and citron-growers are, as a rule, sufficiently familiar. In color it is deep brown, the abdomen often lighter, or even decid- 
edly green. The young are brought forth alive, and are green or yellowish of varying shades, but darkening as they grow older. The wingless, viviparous forms vary in color from dark green to light brown.

\section{Injury Caused.}

The injury by this insect is similar to that caused by the squashbug, and is done in much the same way. The plant tissue is pierced

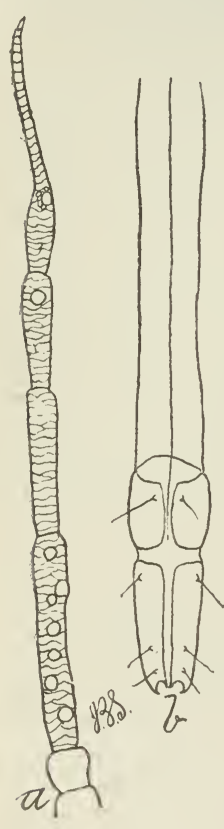

Fig. 10.

Melon louse : $a$, antenna; $b$, beak of winged form. (Original) by a stout beak, in which are four slender lancets, and through this apparatus the plant juices are pumped. At Figure $10, b$, is a representation of the beak as it appears in this species, while at 10 , $a$, is shown the peculiar pitting of the antenna of the winged form. A single specimen could not cause appreciable injury to a plant; but when hundreds, and even thousands, are at work continually, it is unable to bear the strain and succumbs. Did the insects seek only to satisfy hunger, there might yet be a chance for the vine; but whenever they are fully gorged they elevate the abdomen and fject from its anal extremity a stream of clear "honey dew," and continue anew their work of pumping sap, only to excrete it again in the same way a short time after. During a plant-louse attack, therefore, there is a continual pumping of the juices from thousands of points, and it is not at all surprising that the plant dies. It is this "honey dew," or rather a fungus which develops on it, that causes the blackening of the leaves, of the fruit, and even of the ground beneath the vines.

\section{Remedies.}

With a full knowledge of its life history, it may be possible to reach this insect in its winter quarters. At present I can only suggest certain measures to be adopted in the melon-fields. It is fairly certain that there is a migration from some outside point to the melons in June, and there is no evidence that there is any later migration, except from plant to plant within a single field, or to adjacent fields. By checking the spread of the insects at their first appearance, practical 
exemption for the season may be obtained. Fields should be gone over carefully at least twice a week, beginning early in June, and every leaf at all curled or abnormal in appearance should be examined. If aphids are found, the leaf containing them should be destroyed; or, if a vine is at all badly infested, it will be better to pull and bury it, tramping the earth down well above it.

Should the insects be overlooked until they have begun to spread, the plants should be very thoroughly sprayed with the kerosene -emulsion, made as described in Bulletin 86 of the College Station, and diluted with from 12 to 15 parts of water; or whale-oil soap can be used, at the rate of 1 pound in 6 gallons of water; or the fish-oil soap, the formula for which is also to be found in Bulletin 86, can be used, at the rate of 1 pound in 8 gallons of water. In either case a knapsack pump and an underspray nozzle, such as is made by Boekel \& Co., 518 Vine street, Philadelphia, should be used, and the work should be very thoroughly done; extending not only to all vines on which the insects are actually observed, but to all those near by and apparently yet free from attack. Thoroughness at this time may mean complete exemption afterward; while half-way work must certainly be repeated if any benefit is to be derived. The very essence of the fight against this insect is to meet and overcome it while it is weak, and before it gets a start. The difficulty and the uncertainty of complete success increase rapidly for every day of delay. Arsenites, it may be said in passing, are of absolutely no effect as against this insect.

\section{The Squash Borer.}

(Melittia ceto, Westw.)

Of the insects infesting cucurbs, this species is the one most partial to squashes; for although it is occasionally found in all the others, yet only in squashes is it injurious. In these, however, it makes havoc, sometimes rendering it simply impossible to get fruit at all, or only of inferior varieties; for the insect has preferences, and its preferences are for the best. Some growers have never succeeded, despite their utmost efforts, in getting more than half a crop of Hubbards, owing to injury caused by this insect; but even half a crop pays, and planting them continues. Proportionately less damage is usually done where the plants are raised on a large scale than where 
they are raised in the garden or in small patches, for in the latter case all are quite generally destroyed.

In my report for $1890 \mathrm{I}$ gave a brief account of the insect, and made such suggestions concerning remedies as our knowledge at that time indicated, basing my recommendations in large part on the results of the experiments reported in Bulletin 75 of the College Station. It was found, in these experiments, that repellants could not be relied upon to protect, nor could spraying with the arsenites be counted upon to do more than mitigate injury. Cutting out the borers was still the most reliable remedy that could be suggested.

During 1891 I carried on a series of observations and experiments at Metuchen, and the results are given in the report for that year; where, also, the experiences of Mr. D. V. Van Nest afford valuable suggestions. During 1892 I made observations over a very much more extended territory, which, while they modified some of the statements. as to life history, based on the Metuchen results, emphasize the conclusion that the insect can be controlled rather by methods of culture and by mechanical means than by the application of insecticides. In these observations I have had the voluntary assistance of Mr. J. V. D. Walker, of Jamaica, Long Island. Jamaica is a great trucking center, and near it are many acres in squashes. Mr. Walker is a good observer, with a knowledge of insects, and his records and statements. are to be relied upon.

The details of the observations made have not been elsewherereported, and are in place here.

\section{Record for 1892.}

May 28th Mr. C. L. Riker, Esopus, N. Y., wrote, offering his services in making observations and experiments, adding: "I have had considerable experience with the squash borer. In one case a field of squashes, which had cost me about $\$ 500$, had arrived at a stage when the prospect of some mammoth fruit was most excellent, hundreds. weighing more than 100 pounds each, when they were attacked, or the attack became visible, of the borer. I tried many remedies against them. On several hills I almost covered the vines with ground tobacco; upon others used the liquid made by steeping tobacco stems, with the addition of London purple, and had a number of men at work endeavoring to extract the borer. Within ten days after the first appearance of these vagabonds my vines were almost a 
living mass of maggots, from the size of a needle, an eighth of an inch long, to that of a full-sized squash borer, as large as a lead pencil and one and one-quarter inches long. Not one squash on the whole field ripened! We also used kerosene, but in what proportions I am unable just now to state. Also used hellebore and Paris green; and so far as the tobacco was concerned, with me it seemed to attract rather than repel them."

June 27th I found at Port Monmouth one apparently fresh female moth on a cucumber vine. This is later than the insect was observed in 1891, when I already found eggs on the 26th, but I was not trying to fix the date of first appearance. I am satisfied that this covers a considerable period, and that moths may be found at any time after June 1st. In Central Ohio Dr. Kellicott has bred them as early as May; but I do not believe that they appear in the field in New Jersey before the beginning of June.

July 15th, at Esopus, N. Y., found a pair of the moths in copulation about 10 A. M., and saw two other specimens, which I failed to capture. No eggs were found after careful search.

July 16 th, at Jamaica, Long Island, Mr. Walker introduced me to his hunting-grounds, and between 6 P. M. and dark we picked up forty moths; all of them sitting in full view on the upper side of the base of the leaf where it joins the leaf-stalk. They were easy to see, and were so torpid that there was no trouble in capturing them. If clumsily disturbed they made no attempts to fly, but jumped to the ground, where they could be readily picked up.

July 17 th the same fields were visited in the early morning. We found now a number of pupa skins, from which moths had issued that morning, sticking out of the ground, and found, also, two cocoons on the surface, where cultivation had thrown them. Before $11 \mathrm{A.}$. the moths were flying freely and ovipositing. The latter is a very rapid process, and is easily watched. The moth hovers over a plant, selects a spot, and, scarcely stopping the vibration of her wings, deposits an egg, darting off like a shot immediately thereafter. Found the eggs on all parts of the large vines of the summer squashes, on top of the leaves, on the leaf-stalk, on the flower buds, and, in fact, everywhere. On small plants they are on the stem only, near the base. On a small plant with only six leaves I found seven eggs! These eggs are nearly round, very slightly ovate, disc-shaped, the bottom flat with sharp margin, the top somewhat convex with 
round edges. In color they are a light chestnut brown. Under the microscope they show a very finely-shagreened surface, with feeblyraised lines forming hexagonal figures. The shell is thick, chitinous and very brittle.
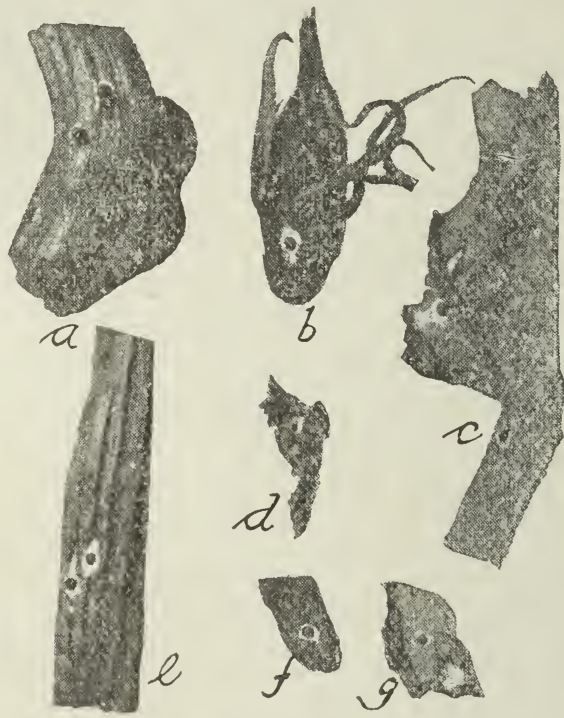

Fig. 11.

Eggs of Melittia ceto: $a$, on stalk ; $b$, on bud; $c$, on leaf; $d$, on tip of runner ; $e$, on leaf-stalk ; $f, g$, on bark of root. Natural size. (From a photo.)

Mr. Hulst, who has also observed the egg-laying habits, says: "The female lays her eggs morning and afternoon, mostly on the stalk of the plant just below the ground. She extends her abdomen into the crack of the ground about the stem of the plant, and the most of the eggs that I have seen were from one-fourth to one-half an inch below the surface. Often, however, they were laid a foot above the ground, and in a few instances, were observed upon the petioles."

Mr. Hulst's statements agree well with what is usually observed on the smaller Hubbards; but on the Crooknecks, or, indeed, on any other varieties that have attained any size, the eggs are laid indifferently on almost all parts of the plants.

The moths are easily recognizable; they are shown at Figure 12, $a$ and $b$, with wings expanded and wings closed. It is in the latter condition that they are to be sought for on the leaves in the early even- 
ing or early morning. In color the anterior wings and the body are brown or blackish brown, with a glistening, olive-greenish tinge. The posterior wings are transparent, glassy, with a broad blackish-brown fringe. The most striking character, however, is found in the prominently-tufted, long hindlegs, which are contrastingly orange colored and thus very easily observed.

July 19th, in separating out the eggs collected on the 17th, found a young larva, evidently three or four days old, in a leaf-stalk, also a very small fellow, only a few hours old at most. Several of the eggs were apparently infertile, and except where they are laid on the stalk, are so slightly attached that they may be dislodged by a mere touch. Mr. Walker informs me that the moths do not copulate on the day

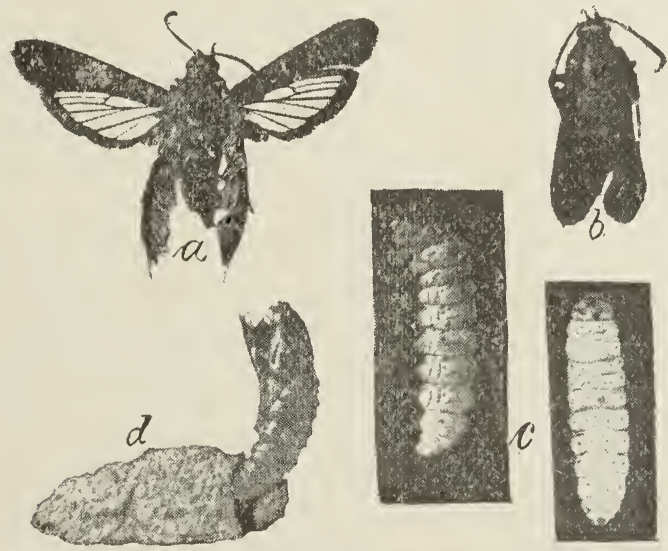

Fig. 12.

Melittia ceto : $a, b$, moth, wings expanded and at rest; $c$, larva, from side and from above; $d$ cocoon, from which pupa skin is extended. Natural size. (From a photo.)

they emerge from the pupa, and do not lay eggs until the third day. This statement he bases in large part on observations made on specimens in confinement, but also on field notes. He has found the cocoons from eight to nine inches under ground, to which depth they had been turned in plowing; normally they lie not more than one or two inches beneath the surface. The pupa is dark chestnut brown, furnished with rings of sharp spines on the abdominal segments and with a sharp, chisel-like projection on the head-case. When the insect is ready to emerge, the pupa braces itself against the inside of the cocoon by means of the abdominal spines and by wriggling about cuts off a circular disc at one end of it with its 
armed head. It then squirms out of the cocoon through the loose soil to the surface and into the air, until only the abdominal segments hold it in the earth.

This usually happens at night, and in the warmth of early morning the moths issue. At Figure 12, $d$, is shown the cocoon from which the empty pupa skin projects. This specimen had been thrown to the surface by cultivating, and the pupa, finding no earthy covering to pierce, maintained its hold on the cocoon as shown in the figure.

July 21st I examined Mr. Marshall's squash-patch at Metuchen, after 5 P. M., but found no trace of moths and no unhatched eggs; found several shells, however, from which larvæ had emerged. Several larvæ were found, ranging in size from one-eighth to onehalf an inch in length, the latter plump and hearty, and evidently two weeks or more old. I cut up one plant completely, and found borers in three joints, one of them three feet from the root. Two larvæ were found in the base of a leaf-stalk, and one egg from which the larva had emerged was found at the base of the leaf itself, just where the moths usually rest at night.

July 22d, in a field of early Hubbards at Port Monmouth, found a short, under-sized crop of squashes ripened, and the vines dying; partly from borer-attack, partly from a bacterial disease. About 20 per cent. of the hills were infested. No moths were seen; but one unhatched egg was found, in which the larva was fully developed and ready to emerge. Egg shells were found in small numbers; larvæ ranged all the way up to those ready for the last moult, but most of them were about two-thirds grown, much as shown in Figure 12, c. Most of the larvæ were at the base of the vine and were well grown; smaller specimens were found in the joints, up to six feet from the root. A few small larvæ were found in the leaf-stalks.

August 3d examined a considerable number of fields near Port Monmouth. North of that point I found a few patches where borers were in the hills near the edges, as if an isolated moth had oviposited here and there. No moths, no eggs, and no young larvæ were here found. In the field at Port Monmouth, from which the crop had been gathered, larvæ were maturing rapidly, and some had apparently left the vines to go underground. South of Port Monmouth I found fields in which there was little or no crop prospect. The vines were badly affected by the bacterial disease, and most of the sound plants were filled with borers, the majority of which were more than half grown. Some vines were infested for their full length; some had 
been abandoned, and the larvæ were then, probably, underground. The borers, apparently, do not care to live in the diseased vines,'for the latter were almost free from them.

August 6th again visited Jamaica, and again Mr. Walker accompanied me to the squash-field. We found quite a number of moths, one pair in copulation; but they were very much less numerous than they were a month ago. They were still most common in the field now in squash for the second year. Eggs were abundant, and larvæ of all sizes were found everywhere. Many full-grown specimens were collected from a row of crooknecks which had been planted as traps, and the appearance of a root-section infested by the larvæ is indicated at Figure 13.

It is easy, though perhaps scarcely necessary, to describe the larva as a fat, white, maggot or grub-like creature, with a black head. At this time the vines of the later plantings were being covered at the joints, to insure rooting. Mr. Walker said (and he was confirmed by the farmers) that squashes will mature from these joints as well as from the main root, even if the latter is eaten off entirely. Mr. Walker also mentioned that he had observed larvæ leaving one vine to attack another on another hill. $\mathrm{He}$ had collected a lot of the larvæ that had matured in July, and these had gone underground in his breeding cages some days since. What their then condition was he could not say. In the fields we noticed that several badly-eaten vines had been abandoned, and there were holes near by, indicating that the larvæ had disappeared beneath the surface.

There is a much larger acreage of squashes near Jamaica than there is in any one locality that $I$ have visited

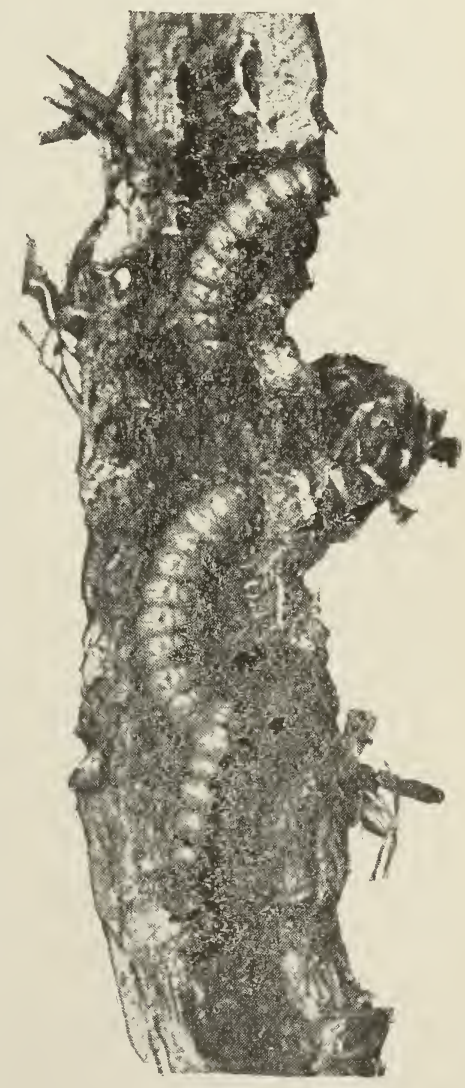

Fig. 13.

Squash borers in main root of squash. Natural size. (From a photo.) 
in New Jersey, and squashes have formed an important staple there for years past; usually making only a fractional crop through injury caused by the borers. The soil is decidedly heavier than it is in those regions where this crop is most grown in New Jersey, and the practice of plowing very deeply turns under a great many cocoons, and retards, though it does not prevent, the development of the moths. I account in this way for the great length of time during which the moths fly at Jamaica. That the moths found now are the eame that were found a month ago is not probable, for they have been persistently collected day after day, and few could have escaped so long a time; besides, the specimens now found are fresh, unrubbed and unfaded.

In the warm, sandy soil of New Jersey the moths emerge earlier and much more nearly together, so that after the middle of July most will have disappeared. It is universally said by our growers that vines planted after July 10th are exempt from borer-attack; which is certainly not the case at Jamaica.

Of the moths collected July 16th six, and of those collected August 6 th four females were dissected to ascertain the number of eggs they contained, and, if possible, whether they matured rapidly or slowly.

The examination of the six specimens collected July 16th resulted as follows:

\begin{tabular}{|c|c|c|c|}
\hline No. & Developed. & Undeveloped. & Total. \\
\hline 1.................................. & ... 50 & 60 & 110 \\
\hline 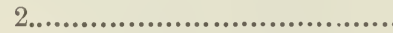 & 94 & 30 & 124 \\
\hline 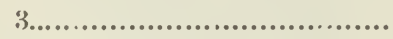 & 10 & 80 & 90 \\
\hline 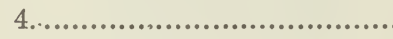 & 20 & 64 & 84 \\
\hline $5 \ldots \ldots \ldots \ldots \ldots \ldots \ldots \ldots \ldots \ldots \ldots \ldots \ldots \ldots \ldots \ldots \ldots \ldots \ldots \ldots$ & ... 4 & 10 & 14 \\
\hline 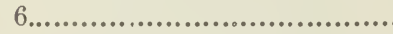 & ... 20 & 64 & 84 \\
\hline
\end{tabular}

The study of the four collected August 6th gave the following:

\begin{tabular}{|c|c|c|c|}
\hline No. & Developed. & Undeveloped. & Total. \\
\hline & ... 124 & 88 & 212 \\
\hline & $\ldots \quad 10$ & 68 & 78 \\
\hline & 20 & 78 & 98 \\
\hline & 74 & 44 & 118 \\
\hline
\end{tabular}

As developed eggs, those were counted that were of full size and of a light-brown color, showing a chitinized shell. Number 1 of the lot of August 6th was taken in copulation, and it may be assumed that no eggs had yet been laid. The very large number of developed ova-124-points to a very rapid oviposition, and this is borne out 
by observations in the field, the female flitting busily from hill to hill, leaving an egg at every point.

Dr. Kellicott had recorded the capture of specimens of the moth late in August, and Mr. Walker claimed to have found them in the field in September; so that it became a question whether there was not a second brood of the insects. I was strongly inclined to doubt it, but published a record made nearly a century ago by Abbot, which I unearthed in the British Museum, proving very conclusively that in Georgia there are two broods. I asked Mr. Walker, therefore, to collect a large quantity of larvæ to test the question for Long Island; and as Dr. Kellicott was making definite experiments in the same line at Columbus, Ohio, I asked him to let me know of his results.

August 25th, the latter wrote me: "On my return home today, I find three examples of Melittia ceto in breeding cages; this absolutely proves a second brood at Columbus."

I at once wrote Mr. Walker, who replied under date of September 1st: "The Ohio cetos must be a more enlightened lot than we have here, as all mine are still in the larval stage. I cut open about a dozen and found them all the same. I caught one fly last Saturday [August 27th] and four the Saturday before. Will look again next Saturday. If you wish, I will mail you some cocoons, as I have about 250 of them. They are very easy to raise by feeding them on squashes, which they bore into and feed upon. I got forty-seven out of one vine in the old row near the barn, and many of them had twenty-five and thirty, which goes to show the utility of planting early rows where you are going to plant later on."

September 9th, Mr. Walker wrote: "I did not find any moths on Saturday [September 5th], and am sure they have all gone. None of mine have pupated, as far as I can see."

September 26th, he again wrote: "The Empire State cetcs must keep up with the Buckeye cetos, for I have two imagos which hatched out yesterday. I cut open a lot of cocoons, but did not find a larva that had pupated, so I think they must hatch out very soon after pupation. The two that have emerged are both males. $* * *$ I think this accounts for my finding them so late last fall, and I think I will look for them in the field next Saturday. I found caterpillars in the vines yesterday week [September 18th], but they were nearly * full grown. In my last letter I told you that I found forty-seven in one vine; so I did, and did not hunt the vine very closely at that, else I am sure I would have found more. The vine was one of the 
row of old vines by the barn, and I took about 600 out of that row, all nearly full grown, and did not keep count of the little ones which I killed. I got all these in three evenings. The farmer's squashes look fine this year, as he lost very few vines. I believe if he had paid more attention to killing the flies, and had planted a few more rows of early squashes in different places, he need hardly have lost a vine."

Again, on November 7th, he writes: "I have been cutting open about a dozen a week of the cocoons of ceto, but have not found any pupa yet. I guess $[$ will give over now until spring and go at them again, for it is not very likely that they will pupate in cold weather.

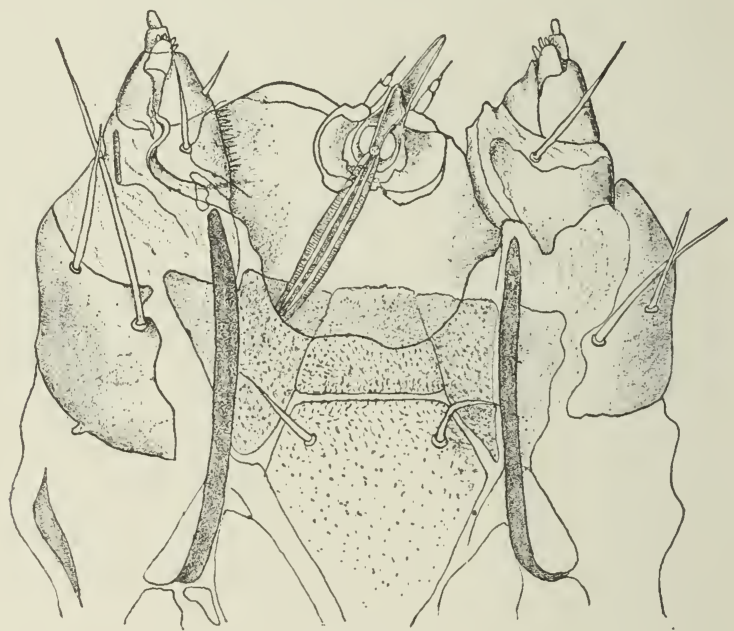

Fig. 14.

Mouth parts of the squash borer. From a camera drawing. Enlarged. (Original.)

Mr. Van Siclen tells me that he has about 2,000 barrels of squashes this year. The growers at Flatlands lost all they had, from the borers."

November 21st, Dr. Kellicott wrote me: "Referring to the squash borer again, I may say that more than a dozen imagos appeared in my cages as a second crop. I continued to make captures in the rield, searching late in the afternoon or early in the morning, until September 16th; larvæ were common in the stems until middle of October. I took one pair in coitu September 6th. While there is no doubt a second brood here (and I suspect there may be in New Jersey or on Long Island) it is not certain that all larvæ of the first. 
imagos change until the next season. In proof, the following facts: In a cage in which were placed August 1st twelve larvæ, out of it issued four or five imagos. A few weeks ago I emptied out the earth and found several cocoons with larvæ, which I expect will transform in the spring."

It seems certain, from these records, that in Georgia and the Southern States the species is double-brooded; in central Ohio about half the larvæ transform, and the others lie over until the spring following; in New York and New Jersey transformation the same season is somewhat exceptional, only two out of about 250 larvæ making imagos. For all practical purposes, the insect can be considered single-brooded in New Jersey.

The head of the larva is small in proportion to the size of the body, and its food is less the tissue of the vine itself than the juices of the plant. Half a dozen larvæ may lie within a section four inches in length, in a mass of fragments and excrement, and they will become full grown, or nearly so, before eating more than a small opening to the outside. They kill the vine by exhausting its vitality, and it rots off, rather than is eaten off, at the surface of the ground. In Figure 14 are shown the fat mouth parts, except the mandibles, which latter are gouge-like structures, shown at Figure 15. The most interesting feature is the spinneret, seen in the center of the mouth structures. The larva, when it goes underground, spins a silken cocoon, in which it rests until ready to change to a pupa. The silk is secreted in two long glands, situated one on each side of the body, coiled irregularly, as shown in Figure 15, which represents that of the right side. The two glands unite into a common duct just inside the mouth structures, and a chitinous tube, shown dark in the center of Figure 14, carries the secretion to the opening of the spinneret.

A consideration of the above record, in connection with the observations made in previous years, gives for New Jersey the following

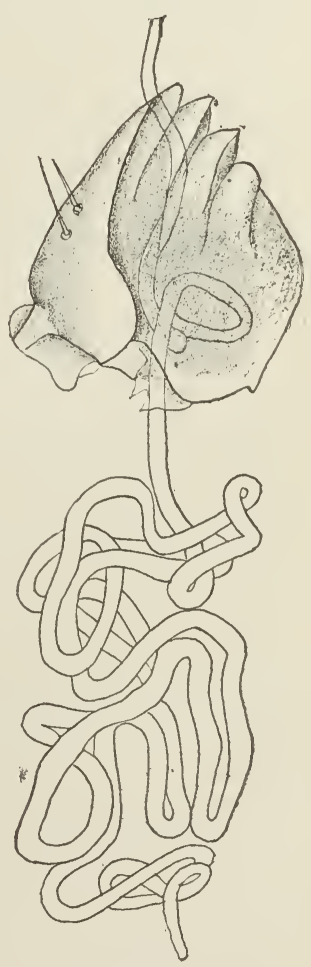

Fig. 15.

Squash borer : Silk gland of right side, the mandible laid over the upper portion. Enlarged. (Original.) 


\section{Life History.}

The moths make their appearance in the fields at or soon after the beginning of June, and continue until the middle of July or thereabouts, ovipositing during that period. Late in June or early in July, from twelve to fifteen days after the eggs are laid, larvæ begin to appear, and attain their growth about four weeks thereafter. The larvæ begin to go underground late in July, and are yet found on the vines well along in September or even later. They bury themselves from one to two inches, and spin a tough cocoon, in which they lie unchanged throughout the winter, transforming to pupæ in spring, shortly before they issue as imagos. In exceptional cases the change is completed the same fall, the moths appearing late in August or in September. The pupa, when ready, cuts its way through the cocoon by means of the chisel-like armature of the head-case, and wriggles its way to the surface during the night, the adult emerging in the early morning. The moths fly only during the day, and are most active during the hottest part of it, becoming sluggish toward the evening, when they settle themselves on the upper side of the leaf at the base, and there remain during the night.

\section{Remedies.}

The claims of the various insecticides have been considered in previous reports, and none have been found reliable. Repellants are simply of no use whatever, since the insect is not confined to any one part of the vine, and it has not been at any time proved that the moths would not dare any but really destructive odors or vapors if no other place to oviposit could be found. Cutting out the larvæ has proved quite effective; but it is a considerable task on large fields, though quite practical and perhaps even the best remedy in gardens or in small patches. In the report for 1891 I recommended rubbing the base of the plants to crush the eggs, and this is a good plan, for it keeps the larvæ from that vital point; but it is not so effective as I was then inclined to believe, because the eggs are much more generally dispersed over the vines than my observations had led me to conclude. The remainder of the recommendations there made have been proved practical and effective, and can be supplemented now by the suggestion first made by Mr. Walker, that the moths be captured and killed. 
I would therefore recommend as good practice when squashes are to be raised for market-

First. Manure or fertilize heavily and evenly ; not in the hills only.

Second. Plant the land to summer squashes, preferably crooknecks, as early in the season as feasible. If the fruit can be marketed to advantage, a full set can be planted; if not, a few rows only will answer as traps.

Third. Plant the Hubbards, marrowfats or other main crop as late as advisable without risking the crop, making the hills between those of the early varieties.

Fourth. Keep a lookout for the moths, and when they are noticed, go over the field every evening during the twilight and kill all that are found sitting on the leaves. A little practice will enable one to cover three rows at one time without missing a specimen, and in less than an hour a large field can be cleared of moths.

Fifth. When the late varieties need the ground, the crooknecks will have made at least a partial crop, even if badly infested by borers, and the vines can be taken out and removed, leaving the ground to the later varieties. This should be done carefully, so that all the borers remain in the vines, and the latter should be thoroughly destroyed in some way that will kill all the contained larvæ.

Sixth. As soon as the late vines begin to run well, they should be covered at the fourth joint, or even beyond it, and the ground should be kept in such condition that they can readily send down suckers from all the joints. This will enable the vine to resist injury and to ripen fruit even if it becomes infested by a few belated borers; but there must be plant-food enough where these joint roots are sent down, for that in the hill may be cut off.

Seventh. When the crop is made, the vines should be at once removed and destroyed, as were those of the summer squashes, so as to prevent the maturing of any borers then in them.

This sounds rather formidable, but is all very much simpler than it reads, and the practice was successfully carried out near Jamaica during the season of 1892 .

In gardens it will be sufficient to keep a watch for the moths and examine the vines once a week for eggs. If, nevertheless, they become infested by borers, the latter will have to be cut out. Layering at the joints should also be done, and, where summer squashes are planted 
with late varieties, the former should be taken out and destroyed as soon as all the crop that is desired has been taken off.

Where an early crop of Hubbards is desired, they should be planted just as early as possible, and should be covered at the joints as soon as it can be done, and at as many places as may be without interfering with the fruit. I have seen vines so treated mature squashes even where badly infested by borers. The moths should be caught off in this as in the other cases, and as soon as the crop is made the vines should be destroyed.

The advantage of the procedure above recommended is that it not only insures a crop for the season in which it is carried out, but, if faithfully done, it destroys, also, the larvæ that would produce next year's moths; and persistently carried on would in a very few years reduce this insect to the rank of a very secondary pest.

There should not be in future any difficulty in controlling this -species. 
THE PERIODICAL CICADA.

(Cicada septendecim, L.)

NEW JERSEY

Agricultural College

\section{Experiment Station.}

95 


\section{NEW JERSEY AGRICULTURAL COLLEGE EXPERIMENT STATION.}

\section{BOARD OF CONTROL.}

The Board of Trustees of Rutgers College in New Jersey.

\section{EXECUTIVE COMMITTEE OF THE BOARD.}

AUSTIN SCOTT, Pr.D., LL.D., President of Rutgers College, Chairman.

Hon. GEORGE C. LUDLOW,

HoN. HENRY W. BOOKSTAVER, LL.D., JAMES NEILSON, EsQ.

\section{STAFF OF THE STATION.}

AUSTIN SCOTT, Ph.D., LL.D., Director.

Prof. JULIUS NELSON, Ph.D., Biologist.

Prof. BYRON D. HALSTED, Sc.D., Botanist and Horticulturist.

Prof. JOHN B. SMITH, Sc.D., Entomologist.

ELISHA A. JONES, B.S., Superintendent of College Farm.

IRVING S. UPSON, A.M., Disbursing Clerk and Librarian.

LEONORA E. BURWELL, Clerk to the Director. 


\title{
NEW JERSEY
}

\section{Agricultural College Experiment Station,}

\author{
BULLETIN 95.
}

SEPTEMBER 11, 1893.

\section{The Periodical Cicada.}

(Cicada septendecim, L.)

BY JOHN B. SMITH, ENTOMOLOGIST.

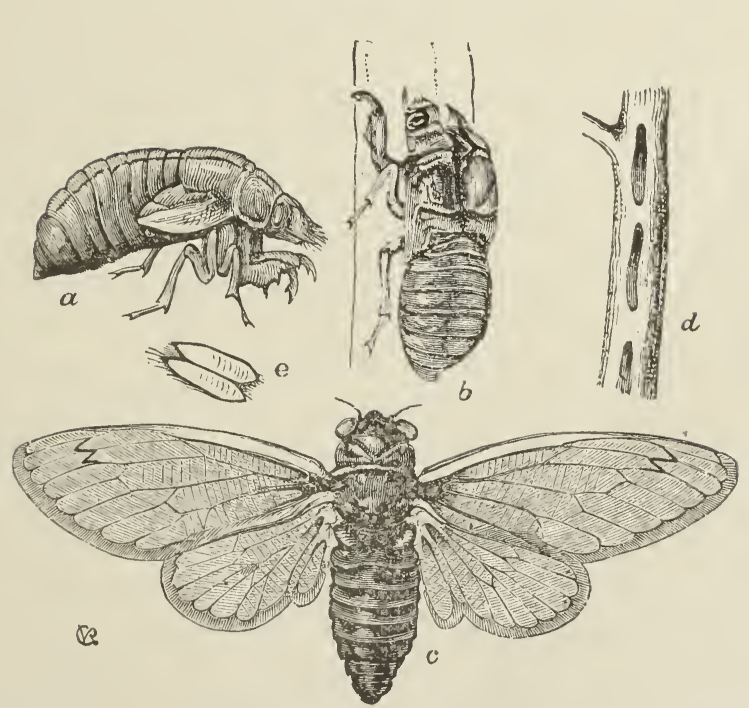

$a$, pupa; $b$, pupa shell from which the imago has emerged; $c$, imago; $d$, punctures in which the eggs are laid; e, eggs, enlarged. (From Riley.)

This insect, under the more commonly-used name of the "Seventeen-year Locust," usually attracts considerable attention when it appears, and generally causes a flood of literature, much of which is 
due to a want of knowledge of the history of the species. The correctness of the popular term is quite frequently disputed by observers who cite a number of years, of irregular interval, at which they claim that this insect appeared. The observations are, in most instances, correct, and the confusion is caused by the fact, not so generally known, that there exist within the limits of the United States no less than twenty-two broods, each of which appears at definite intervals, but counting from different years as a point of beginning. These broods do not all cover the entire United States, nor are they of anything like equal extent. Some of them infest a large territory, while others are confined to one or two States, and in some cases even to parts of one State; that is, the broods are sometimes local. Another confusing feature is, that in the more southern part of our country the period of development of the insect is shortened, and instead of requiring seventeen years to complete its transformations, thirteen years only are necessary. In some of the border States the thirteen and the seventeen-year races overlap, and this produced additional confusion until the limits of each brood were well understood.

This subject has been very thoroughly studied by and under the direction of Dr. C. V. Riley, the United States Entomologist, who gave in Bulletin No. 8 of the Division of Entomology of the United States Department of Agriculture, a full history, with the distribution of all the broods known in the United States. As a result of this work we are now able to foretell, with reasonable certainty, exactly when the appearance of these insects may be expected, and are also able to say whether or not the appearance will be in numbers or whether there will be only a small brood.

In the State of New Jersey, four broods have been recorded, and these are, according to Dr. Riley's enumeration, broods VIII., XII., XVII. and XXII. Not all of these are equally abundant nor equally distributed; in fact, two of them, that is to say, broods VIII. and XVII., appear only in very small numbers, never injuriously, and in very limited districts. Brood XII., which last appeared in 1877, is due again in 1894, and this is one that occurs in almost all portions of the State in very large numbers. Next year, therefore, will be "locust year" in the greater part of New Jersey, and the insects will appear in great abundance, but more numerously north of Monmouth county.

For my present purpose it will not be necessary to go into details 
of structure or the life history of the insect, and its appearance is sufficiently shown in the figures, which illustrate the pupa, the empty pupal skin, the egg and the adult. The insects make their appearance during the last days of May, or early in June, and remain about a month. Very little injury is done in feeding, the food consisting of the sap of trees of many kinds; but there may be quite severe damage when the insects oviposit. The eggs are laid in the twigs and small branches of deciduous trees and shrubs, and fruit trees are especial favorites. When these eggs are laid, deep slits are cut by the females, and the slits are arranged in series, one above the other. After the eggs hatch and the young larvæ drop to the ground, the wounds begin to scar over, and, usually before the end of the season, the twig or small branch withers, dies and is broken off by the winter winds. On well-established or large trees this is seldom a source of serious injury, and means in most cases a severe pruning only. In the case of young trees, and especially with nursery stcck, it means very much more; sometimes the death of the tree, and much more frequently destruction to the shape, because the finest leading shoots are always the first that are attacked. The insects appear in such enormous numbers, so nearly at the same time, and their habits of feeding are of such a character that it is impossible for us to use poisons with a reasonable chance of success. It is, therefore, necessary to use preventive rather than remedial measures, and it is to call the attention of the fruit-growers and farmers generally to the danger that threatens their young trees and shrubs next year that this bulletin is issued.

Since no remedies can be recommended, and there is no practical way to keep the insects from the plants except by actually covering them, it is recommended-

First. That no pruning be done either during the present fall or next spring. This applies as well to shrubs as to trees, for the insects will oviposit in both, and their pruning will probably be severe enough, though perhaps not so well judged as where done by the grower. By offering them a mass of twigs, the damage will be so distributed that the plants will suffer no permanent injury.

Second. Do no budding or grafting either this fall or next spring. The chances are that all young shoots or grafted stock will be severely injured or destroyed by the insects. Sometimes vigorous young fruit 
trees overcome the effects of the punctures the first year, but usually lose the affected branches the year following, destroying the shape or making it necessary to cut back so as to lose a year or two in growth. By adopting the above simple precautions the amount of injury done can be lessened, if not entirely prevented.

These insects have many natural enemies, and chief among these is the English sparrow. It is seldom that one can justly say a good word for these birds, but there is no doubt that they give valuable aid in the destruction of the Cicadas. Wherever sparrows are numerous, the chances are that they will allow few of the insects to propagate their kind.

In a general way, it may be said that the brood occurs all over the State. We have definite information that it occurs in Union, Essex, Morris, Bergen, Hudson, Middlesex, Monmouth, Warren, Sussex and Camden counties, and there the insects will probably be most numerous. They will probably be less troublesome in the southern than in the northern and eastern counties, but it will be well to adopt the measures above suggested in all parts of the State.

Brood XXII., the fourth of those occurring in New Jersey, appeared last in 1885, and will appear again in 1902. It is a wellrecorded brood, and the specimens were numerous and somewhat injurious. This has been recorded from Camden, Mercer, Middlesex, Monmouth, Passaic, Morris, Somerset and Hunterdon counties, and it will be noted that in some of the counties the insects appear in numbers at intervals of less than seventeen years, though each brood has that interval of time between the appearance of the individuals belonging to it. 

CORN STALKS AND STRAW AS HAY SUBSTITUTES.

A BULLETIN OF INFORMATION.

\title{
NEW JERSEY
}

\author{
AGRICULTURAL
}

\section{Experiment Station.}

96 


\section{NEW JERSEY \\ Agricultural Experiment Station.}

BULLETIN 96.

OCTOBER 14, 1893.

\section{Corn Stalks and Straw as Hay Substitutes.}

\section{A Bulletin of Information.}

In many respects the past season has been an unfavorable one; the results are felt now more particularly in those sections where hay has formed a chief money crop, or where the dairy and stock-feeding interests are prominent, though all parts of the State are affected directly or indirectly. The drought of the early summer seriously reduced the hay crop, and the storms of wind and hail in August materially injured the crops of corn fodder and stalks. The conditions now existing give rise to questions something like these :

1. What fodders can be substituted for hay in order that the maximum amount may be sold?

2. How can hay be utilized in order that minimum quantities need be bought?

3. What feeds shall be bought in order to best utilize coarse fodder so as to retain present herds without loss?

These questions are virtually one and the same, though they appear different according to the various conditions of the farmers, and may, perhaps, be stated more concisely as follows: How shall farmers best dispose of their produce?

The problems relating to the feeding of animals are of great importance, and the investigation of certain of them has formed a considerable part of the work of this Station, the results of which 
have been published from time to time, both in bulletin form and in the annual reports. The object of this bulletin is, therefore, not to report the work of recent investigations, but to restate facts and principles already well established; to furnish suggestions in reference to the proper use of farm produce, the buying of feeds and the preparation of rations; in other words, to present a bulletin of information. It is believed that this work will be of value, since farmers are, under the circumstances, as stated, brought face to face with the practical bearings of scientific principles in the matter of feeding.

\section{Object of Feeding.}

Feeds may accomplish two objects-1. Maintenance of life, or 2. Maintenance of life, plus an increase of animal product, the latter of which, according to the kind of animal, may take the form of flesh, fat, milk or work. To accomplish either of these objects the food must possess bulk, palatability and digestible nutritious compounds.

To maintain life, no special attention to these characteristics is required on the part of the feeder; to secure the additional animal product attention to them becomes of the greatest importance. Information that will prove of the most immediate usefulness would seem to be that which concerns-1. Hay substitutes, and 2. The use of these substitutes with feeds in the preparation of rations.

\section{Hay Substitutes.}

Hay possesses those peculiarities of bulk and nutritious compounds which make it particularly useful in accomplishing the first object of feeding, viz., maintenance of life, but lacks in concentration of nutritive matter, and therefore is not the most useful in accomplishing the second object-rapid increase in animal product. This useful characteristic, bulk, is nothing more nor less than indigestible matter, made up largely of the woody part of the hay. The digestible compounds of the hay are identical in kind with those contained in more concentrated products. Hay as hay, then, is not so important, provided we can secure the desired bulk and nutrition from other sources. The question of substitutes for hay, therefore, resolves itself into a question of equivalents; not in the sense that any product may be an exact equivalent in all respects when fed in the same way, but that other products may be used in such a manner as to secure an equivalent result. 
M. Viger, the French Minister of Agriculture, in a circular recently issued, and called forth by the failure of the hay crop, says: "Now that hay has risen to its present price, this commodity can only be obtained by those who keep animals for pleasure. The farmer cannot buy forage at present prices; yet it is an error to. suppose that animals on the farm are condemned to suffer or perish if the hay crop fails, for there are countries where horses and cattle never receive any hay, and these countries are renowned for their cattle." $\mathrm{He}$ also gives equivalents of nutritive materials of various commodities for cattle, compared to 100 pounds of hay, a number of which are as follows: " 100 pounds of hay, of good average quality, can be replaced by either 170 pounds of oat straw, 237 pounds of wheat straw, 150 pounds of husks of oats, 193 pounds of wheat chaff, 150 pounds of fresh leaves (poplar, ash, acacia, mulberry, oak, lime and elm), 80 pounds of dried leaves of the same, gathered when green, 275 pounds of pine leaves, 145 pounds of potatoes, 300 pounds. of forage beet, etc." And in the matter of rations for maintenance, assuming 20 pounds of hay per day as providing the necessary nourishment for a horse of 1,000 pounds live weight, equivalent rations. are: " $a .12$ pounds of hay, 5 pounds of oats; $b .6$ pounds of wheat straw, 8 pounds of oats; c. 16 pounds of green leaves, 2 of straw, 3 of oats and 2 of wheat ; d. 16 pounds of green leaves, 2 of straw, 2 of oats and 2 of barley."

These statements are valuable, not only in giving equivalents. in nutrition, but in showing the wide range of vegetable products that may serve as substitutes for hay. They are actual substitutes. mainly in furnishing the desired bulk, for it must be remembered that while these products in the amounts given may furnish the equivalent of nutrition, it does not follow that they would serve equally well in maintaining life if fed alone; that is, no amount of straw is an exact equivalent of a definite amount of hay, both in the kind and proportion of the nutritive compounds, fat, protein and carbohydrates, because of the differences in chemical composition.

The protein of a feed corresponds to the lean meat of the animal body, and to the casein of the milk, and serves as a direct source of these products in the body; the fat corresponds to the fat of the body, and the butter fat of the milk, and serves as a source of these products, as well as aiding in the maintenance of animal heat and energy; the carbohydrates serve chiefly for the production of animal 
heat and energy, though under certain conditions are capable of conversion into fat.

The protein in straw and other coarse products after digestion is, pound for pound, quite as valuable, and serves its purpose quite as well as that contained in hay; this is also true of the other compounds, fat and carbohydrates, but in the straw the carbohydrates exist in much greater proportion to the others than in the hay, while the fat and protein are in less proportion, and all are combined with a larger amount of the indigestible woody matter in the straw than in the hay, thus rendering the digestion more difficult.

It is interesting, however, to note the extent to which this matter of the utilization of what may be regarded as the least valuable parts of our farm crops or other vegetable products, as substitutes for hay, has been studied, and the value that is now attached to them in those countries where they are used, and profitably converted into valuable animal product. How much more important must be the proper preservation and use of our more valuable farm products, like corn stalks and straw, now so carelessly handled and wastefully used, and which experimental tests have shown to contain almost as much nutriment, ton for ton, as meadow hay. In our own State, therefore, there seems to be no special necessity of giving our attention to the less valuable products until greater care is exercised in the use of corn stalks and straw. These, for us, are the chief substitutes for hay. In the case of straw many farmers insist that although it may possess feeding value, it is more useful as bedding and manure than as feed. Straw has a decided value for these purposes, but if farmers recognized that straw trodden into the mire of an open yard is not good bedding, and that the resultant product is not good manure, there would, in the majority of instances, be a considerable quantity left for feed, after the legitimate uses of bedding were served.

Since two of the characteristics of a feed, bulk and nutriment, are contained in these coarse products, and they are, therefore, hay substitutes, in so far as they aid in accomplishing the first object of feeding-maintenance of life-the real question comes on how to use them in order that they may best aid in the second object-increase in animal product.

\section{Feods to be Used with Hay Substitutes.}

It has already been shown that a feed is a feed because it contains elements or compounds corresponding in kind to those contained in 
the animal body, which the animal organism is capable of converting into materials that sustain life, and thus increase their product. A feed is good when it is eatable, and when it contains a high content of the more valuable constituents, though a good feed is not equally good for all purposes, because of the various products derived from feeding, and because even animals of the same kind differ in their capacities for using feeds. A best feed is one which accomplishes most economically the object in any particular case. It follows, therefore, that the best use of a feed is that which best meets the needs of the animals for any special purpose.

These points have been carefully investigated and have given rise to what are termed feeding standards, or proportions of digestible fat, protein and carbohydrates best adapted to the various purposes of feeding. Feeding standards and their usefulness as guides in the matter of feeding, have been fully discussed in our previous reports, now in the hands of farmers, and are referred to here mainly to indicate the principles which underlie the combinations of fodders and feeds in the rations that may be suggested. It has already been stated that hay, stalks, straw and other coarse fodders consisted largely of carbohydrates, a class of nutrients not calculated to cause a rapid increase in flesh or a large flow of milk. To insure an economical production of these, such farm products must be combined with others, rich or richer in protein and fat, thus approaching a proper balancing of food compounds for specific purposes.

Feeds rich in protein and fat, and thus able to supply the deficiency in this important respect, are, in the order of their content of protein, cotton-seed meal, linseed meal, gluten feed, malt sprouts, buckwheat middlings, dried brewers' grains, wheat middlings and wheat bran. Corn meal should also be mentioned here, for it is one of the best of feeds, although it is not calculated to balance the coarser products of the farm, because of its high content of the same class of nutrients, carbohydrates. The same is also true, though in a less degree, of hominy meal, rice bran, and cerealine feed.

\section{Reliability of Commercial Feods.}

The chemical composition of these feeds may be found in Bulletin 87, which was distributed to the farmers of the State in April, 1892. The samples analyzed and reported in that bulletin were secured from ten local commercial centers, and fully represented the products 
for sale in the State; the results showed that feeds of the same kind, with one exception, were uniform in character, and that all were free from foreign impurities. This is an important fact, since many farmers fear that they cannot tell what they are buying, and that bran and middlings particularly often contain undue proportions of sweepings and dirt from the mills, and hence they hesitate to buy that which may prove injurious to their animals. The evidence gathered by the work of the Station is, that farmers may place reliance upon the uniformity and purity of these products in the hands of reliable dealers, though they should in all cases demand a statement as to the character of those with which they are unfamiliar.

\section{Prices of Feeds.}

The average price per ton for the six months preceding January 1st, 1893, were: Cotton-seed meal, $\$ 28$; linseed meal, $\$ 29$; gluten feed, $\$ 20$; dried brewers' grains, $\$ 19$; malt sprouts, $\$ 18$; buckwheat middlings, $\$ 17.50$; wheat middlings, brown, $\$ 18.75$, and wheat bran, $\$ 18$. These prices, of course, may not exactly represent the facts this year; the main point, however, is that at these prices, or slight variations from them, any one of the feeds will furnish the important constituents, protein and fat, at a less cost per pound than grain which is now so low. Farmers need not hesitate, therefore, to sell their wheat and oats at present prices, for while they are excellent feeds, they are, for the purpose of utilizing coarse farm produce, less desirable and more expensive than the residues resulting from various manufactures.

These concentrated products have been shown to possess a high rate of digestibility, and to give fairly equivalent results if used in not too large amounts in well-balanced rations. Which one of the many to buy is then not so important a question as that of a sufficiency of them, when economy in feeding is alone considered; one feed may be relatively cheaper than another for a specific purpose or in particular cases, yet for general purposes, and in order that animals may have a variety, it is good economy to have a number on hand. Among dairymen this practice is followed, but where small herds are kept, it is not so general as it should be. It is claimed that small lots are expensive, and local dealers do not have a large variety in stock. This claim is true, yet this difficulty may be overcome by a number of farmers combining and ordering large lots. 
Car-load lots may be secured through their dealers at much cheaper rates than ton lots, and a car lot could be easily distributed in a neighborhood.

\section{Fertility in Feods.}

The buying of concentrated feeds should also be studied from the standpoint of fertility. The farmer's capital stock is fertility, the main elements of which are nitrogen, phosphoric acid and potash; these through the agency of plants are converted into products which have a fertilizing value, regardless of market price; that is, if corn, oats, wheat, or hay are returned to the land, they will aid in the growth of other plants by virtue of the manurial elements contained in them. The average amounts of these constituents in the four principal farm crops are shown in,

\begin{tabular}{|c|c|c|c|}
\hline 1 & $\begin{array}{c}\text { Pounds per ton } \\
\text { of } \\
\text { Nitrogen. }\end{array}$ & $\begin{array}{l}\text { Pounds per ton } \\
\text { of } \\
\text { Phosphoric Acid. }\end{array}$ & $\begin{array}{c}\text { Pounds per ton } \\
\text { of } \\
\text { Potash. }\end{array}$ \\
\hline Wheat...................... & 38 & 20 & 11 \\
\hline Oats ........................ & 37 & 15 & 12 \\
\hline Corn ......................... & 33 & 12 & 7 \\
\hline Timothy hay.............. & 20 & 7 & 26 \\
\hline
\end{tabular}

These amounts per ton of fertilizer constituents are removed from the farm when the grain and hay are sold. When feeds are bought it is important to know whether anything is gained in fertility by the exchange, for under equivalent conditions of feeding the same relative amounts of fertilizer constituents are retained in the animal products. Table II. shows the amounts of fertilizer constituents contained in the more concentrated feeds.

TABLE II.

Cotton-seed meal......... Pounds per ton
of
Nitrogen.

Linseed meal..............

139

109

Gluten feed

76

Malt sprouts.............. 88

Buckwheat middlings... $\quad 80$

Dried brewers' grains... $\quad 77$

Wheat middlings......... 56

Wheat bran.

50

$\begin{array}{cc}\begin{array}{c}\text { Pounds per ton } \\ \text { of } \\ \text { Phosphoric Acid. }\end{array} & \begin{array}{c}\text { Pounds per ton } \\ \text { of } \\ \text { Potash. }\end{array} \\ 65 & 38 \\ 42 & 29 \\ 8 & 1 \\ 33 & 37 \\ 43 & 23 \\ 19 & 2 \\ 42 & 21 \\ 60 & 31\end{array}$


It is observed that all of these feeds greatly exceed the grain and hay in nitrogen, and with the exception of gluten feed and dried brewers' grains, the mineral constituents are also in considerable excess. When market prices are such as to make the exchange of farm produce for commercial feeds a judicious proceeding from the feed standpoint, the inevitable result will be a decided gain to the farm in fertility. Farmers of this State spend $\$ 1,500,000$ annually for these identical constituents of fertility in the shape of commercial fertilizers, and many thousands of dollars more for city stable manure. These facts furnish sufficient evidence that an increased fertility is desired. A closer attention to this matter of manurial values in feeds would either materially reduce the expense now incurred in these directions, or secure a greater increase in fertility at the same expense, for market prices of feeds are not influenced by manurial values.

This matter cannot be urged too strongly, particularly where fertility must be imported to the farms in order that maximum crops may be secured. In our exports of linseed meal, and in the bran and middlings contained in the whole wheat exported, farmers in other countries are now given annually an amount of fertility that would cost us, if bought in other forms, not less than $\$ 16,000,000$. This amount of fertility, gathered largely from the rich stores of our Western States, should be retained for the less fertile lands of the East. It will be retained only when farmers have learned to apply more fully those principles which govern the economical use of fodders and feeds, the results of which are a saving of food and of fertility. Finished farm products only should be exported.

\section{Preparation of Rations.}

The first point of importance in the preparation of a ration, bulk and essential nutrients being present, is palatability. The food must be of such a character as to induce a maximum consumption of actual nutrients, because profit in feeding for the production of milk flesh or fat, lies in the excess of feed consumed over that necessary to maintain life. Corn stalks and straw in their original state are not readily and completely eaten by animals. To insure the minimum waste they must be cut, and the coarser and finer portions imtimately mixed, and feeds of known relish added. In England, where great 
progress has been made in feeding methods, the cut hay, straw and other coarse products are mixed with sliced roots, the feeds added, the whole mass thoroughly mixed and allowed to remain some time before feeding. This method doubtless adds to both the palatability and digestibility of the foods, and it is to be recommended where circumstances permit. This matter of preparation, however, gives rise to the question, Will it pay farmers to invest in machinery for this purpose? For dairy farmers, there can be no question as to the advisability of such a course, since in feeding corn stalks, whole, in the usual manner, from one-third to one-half of the food contained in them is wasted. Where few animals are kept, and simple maintenance is desired, if this is ever desirable except in the case of work horses in winter, it becomes a question worthy of some consideration, though an increase of feed equivalent to two or three tons of hay at present prices would pay for a good fodder cutter; one good cutter might serve, too, for several farmers in a neighborhood until the usefulness of the cutter was thoroughly tested.

A few rations are here given which contain the fodders and feeds in good proportions, and which permit of a wide use of corn stalks and straw, as substitutes for timothy hay. These are intended in all cases to be sufficient for a daily feed for one thousand pounds live weight of animal under average conditions, and may serve a useful purpose as guides in the matter of amount and proportion of the nutrients. They are not intended as positive rules; animals must be fed as individuals with peculiarities of appetite, digestion and assimilation, not as fixed machines. The rations given have in all cases, too, the merit of having been tried with entire satisfaction, a number at the College Farm, and others by practical dairymen in the State. Nos. 1 and 2 for horses have been fed in an experiment on horse-feeding at the College Farm since June 1st, and, so far, are giving very gratifying results. A large amount of hay seems unnecessary, and other feeds may substitute oats.

It is not expected that these suggestions will meet all cases, and if those farmers whose conditions are different, or who desire to use smaller quantities, particularly of the concentrated feeds, than is here recommended, will address the Station, giving full details in reference to kind of animals, feeds and fodders obtainable, and object of feeding, their inquiries will receive careful attention. 


\section{Rations for Dairy Cows.}

No. 1.

10 lbs. corn stalks.

3 " corn meal.

3 " hominy meal.

6 "wheat bran.

2 " cotton-seed meal.

8 " roots.

\section{No. 4.}

40 lbs. corn ensilage.

6 " malt sprouts.

4 " wheat middlings.

2 " linseed meal.

$$
\text { No. } 2 \text {. }
$$

6 lbs. clover hay.

8 " oats straw.

4 " corn meal.

4 " malt sprouts.

3 " wheat bran.

3 " linseed meal.

\section{No. 5.}

$6 \mathrm{lbs}$. corn s'alks.

6 " clover hay.

6 " corn meal.

7 " dried brewers' grains. 1 " cotton-seed meal.
No. 7.

8 lbs. corn stalks.

8 " oats straw.

3 " gluten feed.

3 " dried brewers' grains.

5 " buckwheat middlings. 3
No. 8.

6 lbs. clover hay

6 " wheat straw.

5 " corn meal.

3 " malt sprouts.

3 " gluten feed.

3 " linseed meal.
No. 3.

10 lbs. corn stalks.

5 " wheat straw.

4 " dried brewers' grains.

3 " wheat bran.

2 " corn meal.

2 " cotton-seed meal.

No. 6.

10 lbs. corn fodder.

7 " dried brewers' grains.

5 " corn meal.

No. 9.

12 lbs. clover hay.

5 " wheat bran.

5 " ground oats

5 " corn meal.

\section{Rations for Horses.}

No. 1 .

8 lbs. timothy hay.

6 " dried brewers' grains. 6

6 " corn.

No. 4.

No. 5 .

4 lbs. clover hay.

8 " wheat straw.

5 " corn meal.

5 " wheat bran.

2 " linseed meal.
No. 2 .

8 lbs. timothy hay.

"corn.

5 " wheat bran.

$1 \frac{1}{2}$ " linseed meal.
No. 3.

6 lbs. clover hay.

4 " corn stalks.

6 "corn.

4 " wheat bran.

1 " linseed meal.

No. 6.

6 lbs. timothy hay.

8 " oats straw.

3 " wheat bran.

2 " corn meal.

\section{For Fattening Støers.}

\section{No. 1.}

10 lbs. corn stalks.

5 " clover hay.

6 " corn meal.

5 " wheat bran.

3 " cotton-seed meal.
No. 2.

5 lbs. clover hay.

10 " oats straw.

6 "corn meal.

6 " wheat bran.

3 " linseed meal.
No. 3.

10 lbs. corn stalks.

8 " wheat straw.

6 " gluten feed.

5 " corn meal.

3 " cotton-seed meal. 
In these rations four pounds of wet brewers' grains may be substituted for one of dried grains, and ground corn and cob meal may substitute corn meal pound for pound without materially affecting the rations; buckwheat bran free from hulls may also substitute buckwheat middlings. The rations for dairy cows are intended for full flow of milk; for cows approaching the calving period, the feeds should be reduced and coarse fodders increased. Rations 1, 2, 3 and 4 for horses are intended for moderate work, the others for simple maintenance, and perhaps will apply equally well for cattle; both cattle and horses will gain in weight on liberal rations of clover hay. Where stock is kept, clover hay should not be sold from the farm. For young and growing stock, as calves and colts, linseed meal, bran and middlings are the best additions to the rough fodders, stalks and straw, in the way of feeds, as they are rich in the muscle and boneforming constituents; the amounts required should be adjusted by the feeder according to the age of the animals.

Where farmers have not the appliances for making weights at each feed, and prefer to measure, the different materials should be weighed at least once, and the relation between a certain weight and a certain bulk ascertained. The weights of feed for a day's ration for a herd may be mixed together in the proportions given, and in feeding they should be distributed in such a way as to give animals of different live weights and capacities for using food that amount best adapted for them. Where there are a number of dry cows in the dairy, then the mixtures for each lot had best be made separately. For horses the rations for work and maintenance may each be mixed in considerable quantities and placed in separate bins.

Inquiries as to where to buy feeds are frequently received; a list of the dealers in this State, from whom samples were received in 1892, is given in Bulletin 87, to which readers have already been referred for detailed information regarding the character of concentrated feeds.

EDWARD B. VOORHEES,

New Brunswrck, N. J., October 14th, 1893.

Director. 
ANALYSES AND VALUATIONS OF COMPLETE FERTILIZERS, GROUND BONE AND MISCELLANEOUS SAMPLES.

\title{
NEW JERSEY
}

\author{
AGRICULTURAL
}

\section{Experiment Station.}

\author{
97
}




\title{
NEW JERSEY \\ Agricultural Experiment Station.
}

\author{
BULLETIN 97.
}

NOVEMBER 6, 1893.

\section{Analyses and Valuations of Complete Fertilizers, Ground Bone and Miscellaneous Samples.}

\author{
BY EDWARD B. VOORHEES, \\ LOUIS A. VOORHEES, \\ JOHN P. STREET.
}

Bulletin 93, issued in July, contained the analyses of 95 samples of unmixed fertilizing materials, and 10 of home mixtures. This bulletin contains the analyses and commercial valuations of 248 samples of different brands of manufactured complete fertilizers, and 51 of incomplete fertilizers, which include ground bone, dissolved bone, wood ashes and miscellaneous products.

The purpose of Bulletin 93 is to direct attention to the character and composition of standard fertilizer supplies, and to show the actual cost per pound of the constituents contained in them, though it also suggests economical methods of buying plant-food, gives useful formulas, and shows that farmers can make mixtures which, in mechanical condition, concentration and quality, are equal to the best manufactured brands upon the market. It shows how direct savings may be made in the purchase and use of fertilizing materials.

The work of this bulletin has reference almost entirely to products manufactured from the supplies indicated in No. 93. The actual and guaranteed composition of manufactured brands are compared, 
which shows whether the manufacturer fulfills his claims, and how far the guarantee given is a guide as to the actual composition. The application of the schedule of values, adopted for the various kinds and forms of fertilizer constituents, also shows whether the guarantee of a brand warrants the selling price attached, and the commercial value of the different brands studied in connection with their composition, permits of a fair comparison of the charges of the different manufacturers for mixing, bagging and selling their goods.

The value of this work to the intelligent consumer is direct, in furnishing definite information as to the composition and value of the different brands forced upon his attention, and of indirect value to all consumers in that it reduces to a minimum the amount of worthless products offered for sale.

\section{Inspection of Fertilizers.}

It is the aim of the Station to secure a sample of all the different brands and fertilizer products upon the market. It is believed that this aim has been practically attained this year; the number of brands of complete fertilizers is nearly 20 per cent. greater, while the number of those of a miscellaneous character is quite as great as in any previous year. This result is due both to a closer inspection and to the fact that new brands are constantly introduced, the product of both old and new firms. For instance, it is shown that while eleven firms entirely new to the State are represented by one or more brands, one manufacturer is represented by 14 brands, another by 13 , and eight are represented by 8 or more brands.

It is also shown by the results of analyses that in many cases the main difference in a brand is a difference in the selling price attached, the amount and proportion of plant-food constituents apparently being a less important factor to the manufacturer than selling price.

While the multiplication of brands is not on the whole to be commended, a point worthy of consideration is shown, viz., that where dealers have brands made to their order by regular manufacturers the quality is always good and the commercial value is much nearer the selling price than those sold direct by the manufacturer himself.

\section{Commercial Valuation.}

The schedule of values adopted and used in the valuation of complete fertilizers this year as well as that of 1892 , are added. 


\begin{tabular}{|c|c|c|}
\hline & $\begin{array}{l}1892 . \\
\text { cts. }\end{array}$ & $\begin{array}{l}1893 . \\
\text { ets. }\end{array}$ \\
\hline Nitrogen from Nitrates........................................... & 15 & $15 \frac{1}{2}$ \\
\hline Nitrogen from Ammonia Salts.................................. & $17 \frac{1}{2}$ & 17 \\
\hline " $\quad$ " Organic Matter...................................... & 16 & $17 \frac{1}{2}$ \\
\hline Phosphoric Acid, Soluble........................................... & $7 \frac{1}{2}$ & $6 \frac{1}{2}$ \\
\hline 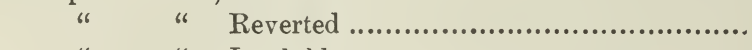 & $7 \frac{1}{2}$ & $6 \frac{1}{2}$ \\
\hline " $\quad$ $\quad$ Insoluble....................................... & 2 & 2 \\
\hline Potash as Muriate..................................................... & $4 \frac{1}{2}$ & $4 \frac{1}{2}$ \\
\hline Potash free from Muriates.......................................... & $5 \frac{1}{2}$ & $5 \frac{1}{2}$ \\
\hline
\end{tabular}

The change in the schedule by the lowering of values for available phosphoric acid, and nitrogen as ammonia, and increasing those of both organic and nitrate nitrogen, makes the valuation per ton on the same basis of analyses slightly lower this year than in 1892 . The work contained in Bulletin 93, however, showed that the schedule was entirely just to the manufacturer.

\section{Composition of Fertilizers.}

The brands examined this year in most cases contain an equivalent of plant-food guaranteed, though many brands show evidences of imperfect mixing or carelessness in fixing the guarantee. A guarantee means nothing to the farmer from the standpoint of proportion and amount of plant-food, unless the analysis corresponds to that guarantee.

In two cases, Nos. 5361 and 5623, the State law, which requires that a guaranteed analysis shall accompany each package of fertilizer for sale, was ignored. Sample No. 5361 is a poudrette, and is of a low-grade character. No. 5623 is of still lower grade, containing six-tenths of one per cent. of nitrogen, about one per cent. of available phosphoric acid, and but a trace of potash, and with a commercial value of only $\$ 3.92$ per ton, though the selling price is $\$ 15$. It may not have been the intention of the manufacturers in either case to defraud consumers, though ignorance of the law or of the constituents that constitute value in fertilizers is no valid excuse for the sale of such products without complying with the law; the actual result is, particularly in case of No. 5623, that farmers who buy the product are cheated. Neither is it any excuse that farmers cheat themselves in the purchase of fertilizers, by a careless comparison or no comparison of guarantee and selling price.

A case of this kind may be illustrated by sample No. 5577. The 
guarantee calls for, even at the best interpretation, but $\$ 8.52$ worth of actual plant-food, while the selling price is $\$ 30$ per ton. The law does not fix the selling price, and purchasers should study the relation of these two factors.

\section{Selling Price.}

As has been the custom in the past, the selling price of the different brands entered in the tables is the price at which they are sold where sampled. These prices do, of course, vary somewhat, though the variation is between reasonably narrow limits. The average price is found in some cases to be lower, and in others to be higher than those given in the table. The average composition, selling price and commercial valuation for 1892 and 1893 are shown in the following tabulation :

\begin{tabular}{|c|c|c|c|c|c|c|c|}
\hline & $\begin{array}{c}\text { Total } \\
\text { Nitrogen. }\end{array}$ & $\begin{array}{l}\text { Total } \\
\text { Phos.Acid. }\end{array}$ & $\begin{array}{l}\text { Available } \\
\text { Phos.Acid. }\end{array}$ & $\begin{array}{l}\text { Insoluble } \\
\text { Phos. Acid. }\end{array}$ & Potash. & $\begin{array}{l}\text { Selling } \\
\text { Price. }\end{array}$ & $\begin{array}{c}\text { Station } \\
\text { Valuation. }\end{array}$ \\
\hline $1892 \ldots \ldots \ldots$ & . 2.74 & 10.38 & 7.70 & 2.67 & 4.50 & $\$ 34.19$ & $\$ 25.66$ \\
\hline $1893 \ldots \ldots . . .$. & 2.69 & 10.23 & 7.54 & 2.69 & 4.58 & 34.11 & 24.41 \\
\hline
\end{tabular}

The average composition and selling price per ton are practically identical with those of last year, while the valuation this year is $\$ 1.25$ less than in 1892, making the difference between valuation and selling price $\$ 9.70$, or the selling price 40 per cent. greater than the valuation, which represents the average charges per ton for mixing, bagging and selling. It is evident that the decrease in the cost of fertilizer supplies has not resulted in a lower selling price per ton for the mixtures made from them by the manufacturers. It is shown, too, from a study of the tables, that the difference between valuation and selling price in nearly half of the brands is above this average, ranging from $\$ 10$ to $\$ 25$ per ton, thus giving a wide opportunity for selection on the part of the purchaser.

\section{Ground Bone.}

The samples of ground bone examined this year are, on the whole, of good character. A criticism made prominent in previous discussions of the analyses of bone products, however, still holds good, namely, that the trade terms, bone meal, pure bone, steamed bone and raw bone, bear no exact relation to the kind of bone, nor do they indicate the method of manufacture. Sample No. 5054 is called a steamed bone. It contains as much nitrogen as the average sample of 
ground bone, but less than half as much phosphoric acid as is contained in a pure bone. The simple steaming of bone would not have a tendency to decrease the amount of phosphoric acid, but rather to increase it. Samples Nos. 5020 and 5071 are also good examples of products that contain much less of both nitrogen and phosphoric acid than would be contained in pure bone, whatever the method of manufacture. That the manufacturers did not regard the samples as pure is evident from the guarantee which accompanied the brands. In all cases, very much less, particularly of the phosphoric acid, was guaranteed than is known to be present in a pure bone.

A guarantee of less than 4 per cent. of ammonia and 20 of phosphoric acid, or its equivalent in bone phosphate of lime, may well create a suspicion that the product is not a pure bone. Samples Nos. 5556 and 5558 contain potash. While a mixture of bone and potash may be a very effective and profitable manure for general farming, the results of the analyses of these samples indicate that farmers would do better to purchase the bone and potash separately rather than together, as in these brands.

\section{Valuations.}

The schedule of prices used in computing values in 1892 and 1893, as well as the average per cent. of fineness of the bone, are added:

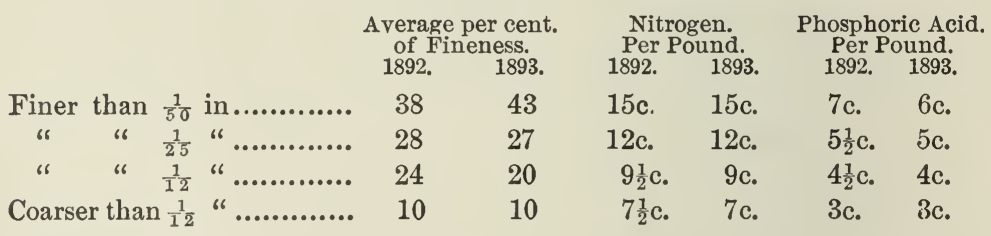

This year the value of the nitrogen in the coarser grades is reduced one-half cent per pound, while the phosphoric acid is reduced in all cases except the coarser grade. The average per cent. of fineness is this year an improvement over that secured in 1892. The average selling price per ton, excluding those samples not comparable, is $\$ 32.50$, and the average valuation $\$ 31.23$ per ton.

\section{Miscollaneous Fertilizing Materials.}

The analyses of samples of dissolved bone contained in the table on page 41 are shown to be of good quality. The commercial valua- 
tions of three out of the five samples bought in the usual manner, by the ton, are within $\$ 3$ of their selling price. Sample No. 5621 was bought on the basis of $\$ 2$ per unit for ammonia and $\$ 1$ per unit for available phosphoric acid. The cost, delivered at consumer's depot, including bags, freight, etc., was 14.3 cents for nitrogen and 5.3 cents for phosphoric acid. These figures for organic nitrogen and available phosphoric acid are 18 per cent. less than the Station's valuations. While the valuation of the other brands is relatively high, the cost per pound of the nitrogen and the phosphoric acid is in every case greater than the Station's valuations. Dissolved bone is an excellent fertilizer for wheat, and at the present low price of this cereal it is of the greatest importance that farmers should take advantage of such opportunities as are afforded by these products to reduce the cost of the crop. Sample No. 5598 is evidently a mixture of ground bone and dissolved S. C. rock superphosphate, and is an expensive product at the selling price given. In sample No. 5060 the superphosphate has been improved by the addition of sulphate of ammonia, and doubtless would serve a good purpose as a wheat fertilizer.

The samples called dissolved bone and potash do not contain dissolved bone, but dissolved S. C. rock to which potash has been added. While good, they are not cheap sources of phosphoric acid and potash. Sample No. 5622 was bought on the unit basis and in car-load lots. The price paid was 85 cents per unit, or $4 \frac{1}{4}$ cents per pound for available phosphoric acid. This is but another illustration of the advantages to be derived from buying fertilizing materials on the unit basis and in large lots for cash.

The samples of wood ashes examined this year were, with two exceptions, below the average quality. The schedule of values adopted for ashes is 5 cents for phosphoric acid and $5 \frac{1}{2}$ for potash. The average cost per pound for potash and phosphoric acid contained in these samples, not including 5562, is 9.7 and 10.7 cents, respectively. While the agricultural value of wood ashes is recognized, it is a question whether farmers do well in purchasing phosphoric acid and potash in this form at the prices named. 
8

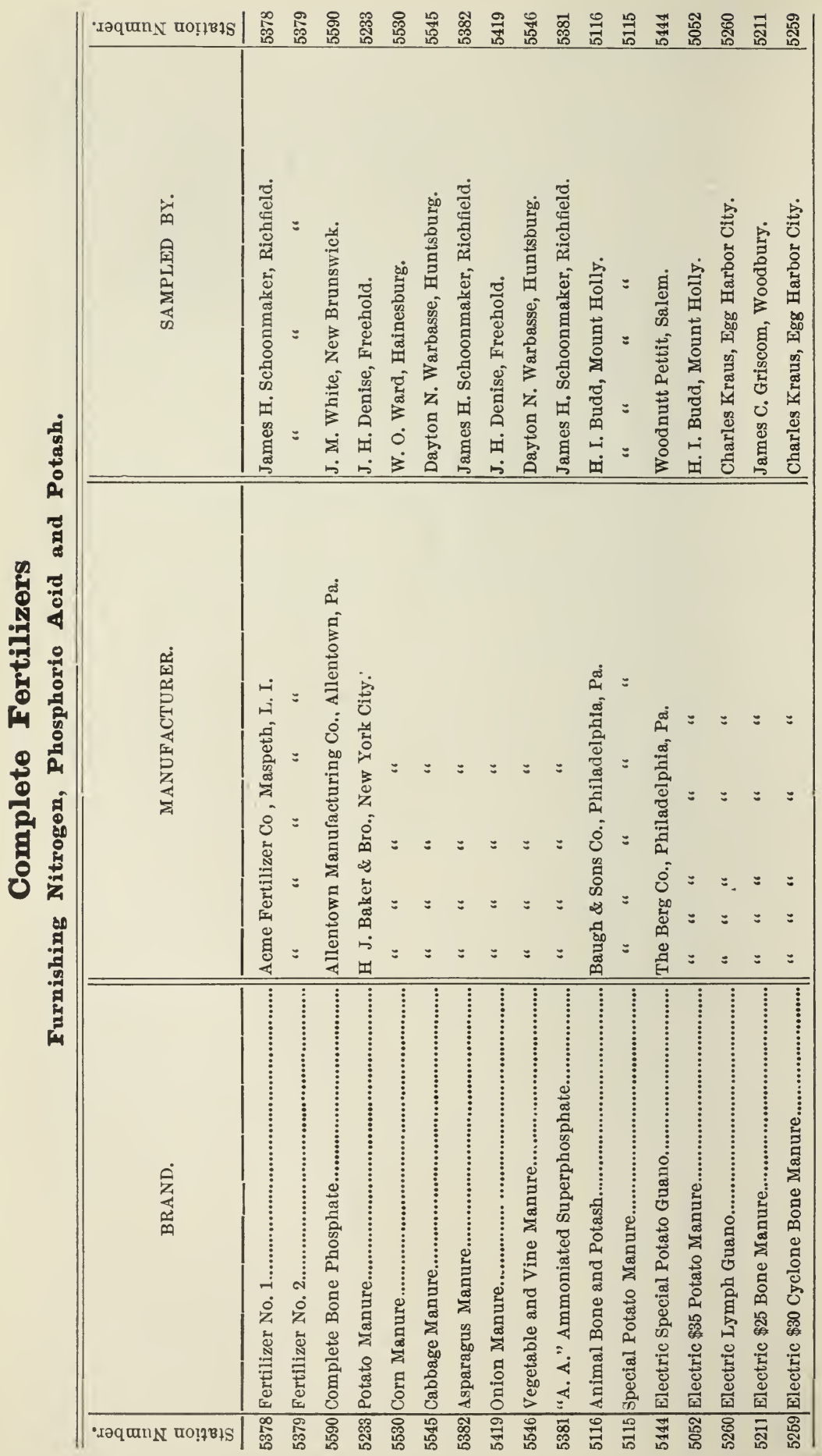




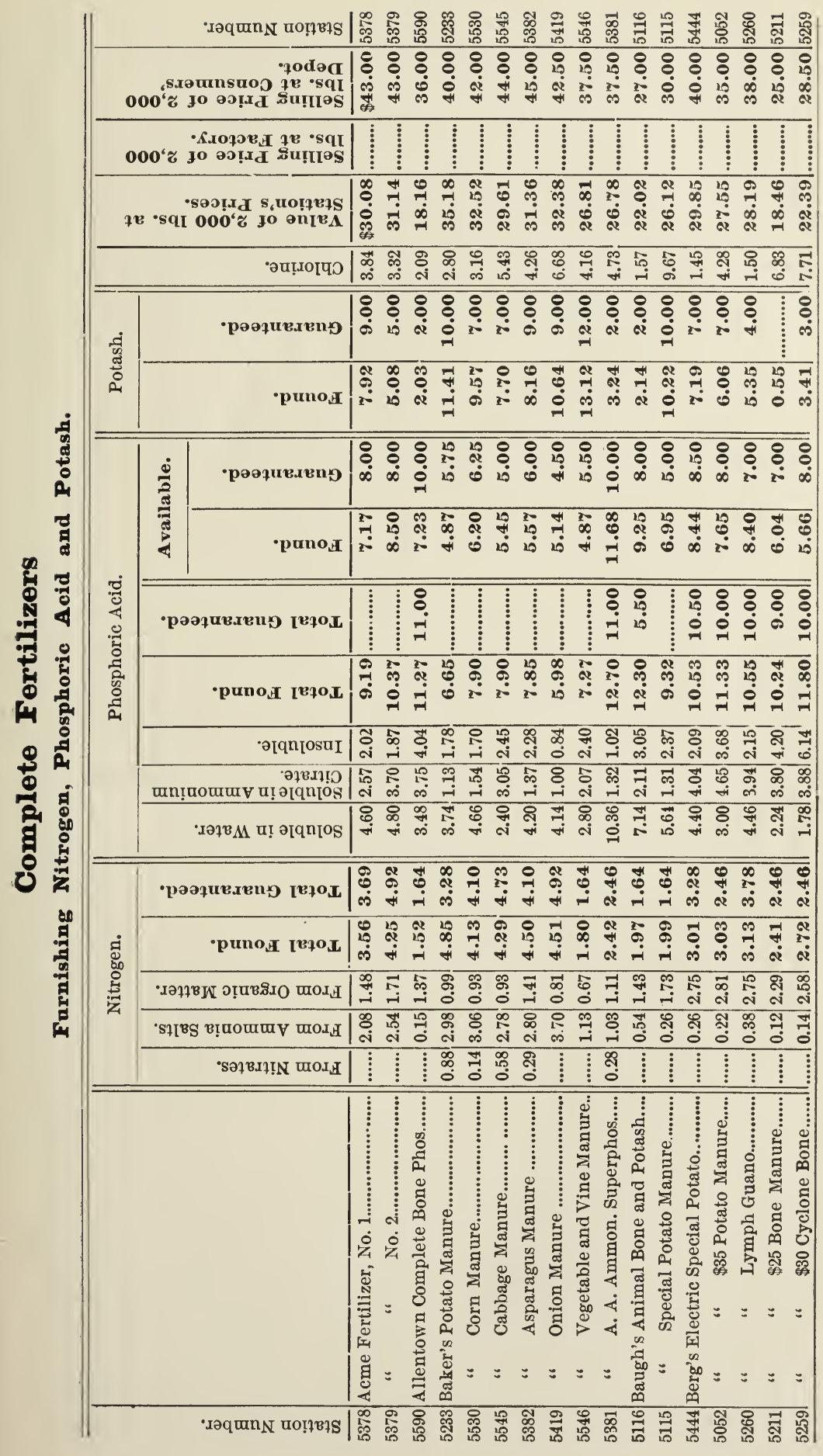




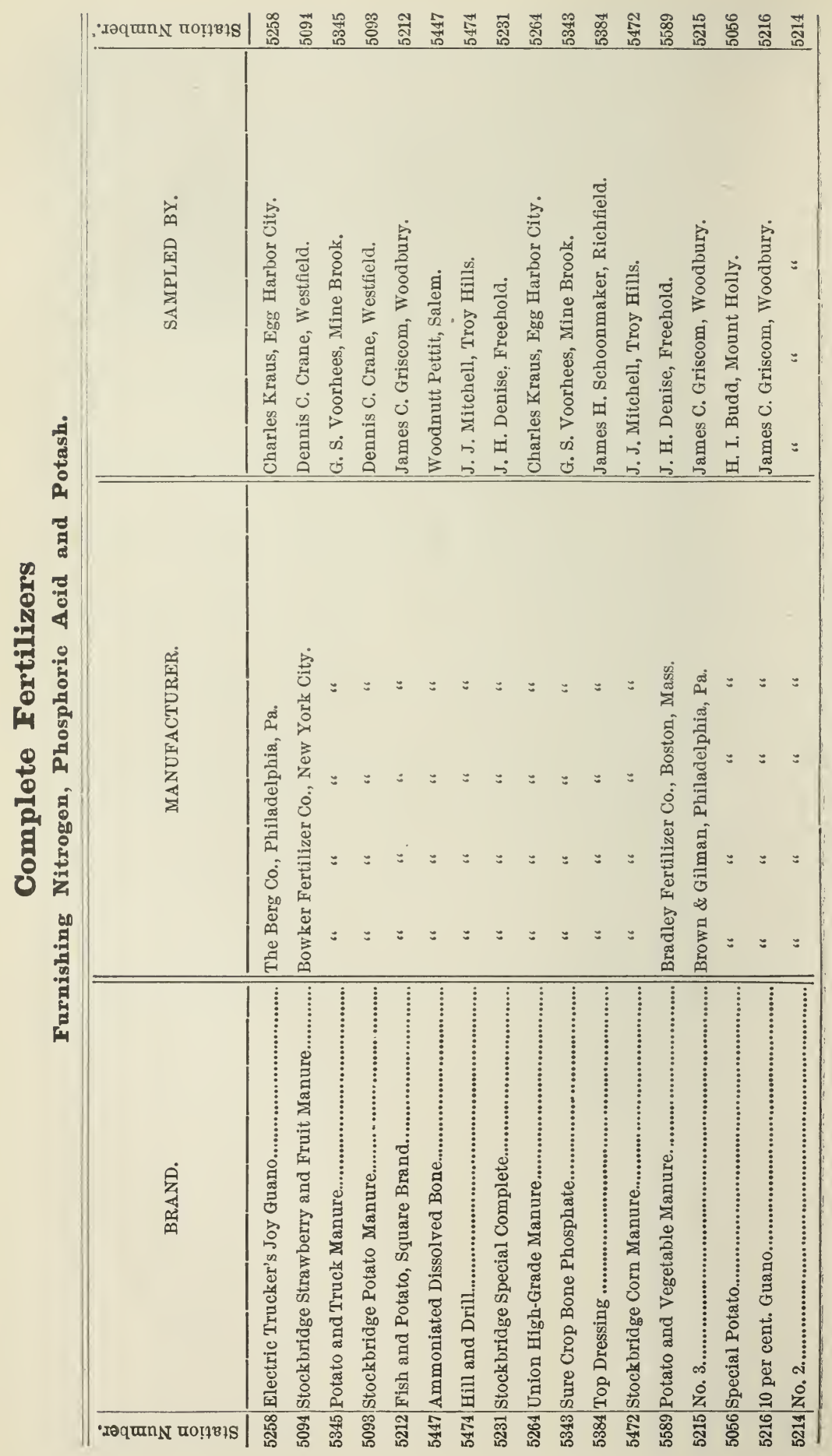




\begin{tabular}{|c|c|c|c|}
\hline & & 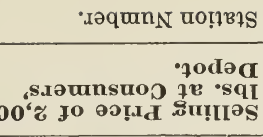 & 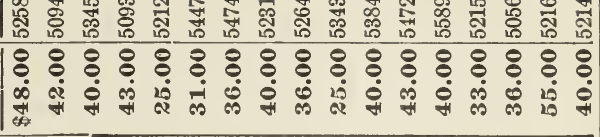 \\
\hline & & 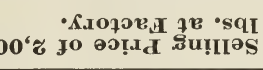 & 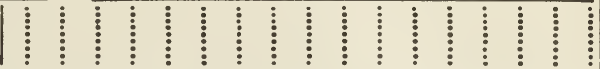 \\
\hline & & 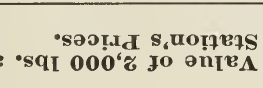 & 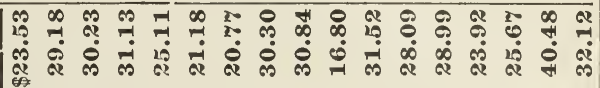 \\
\hline & & 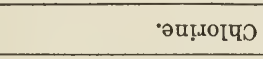 & 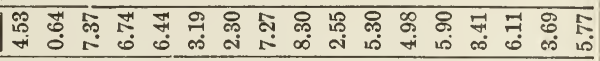 \\
\hline & & •рәәұนеגеnश & 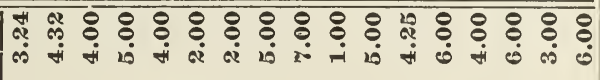 \\
\hline & 昰 & $\cdot$ puno,i & 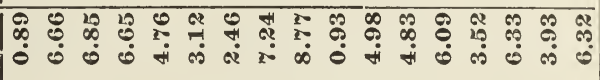 \\
\hline 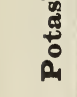 & & -рәәұие.кепю & 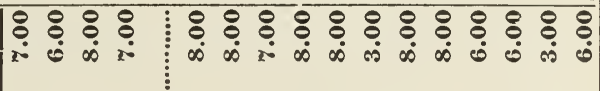 \\
\hline שี & & हैं & 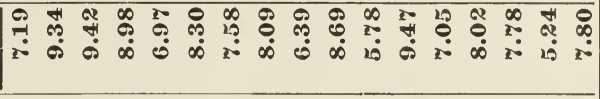 \\
\hline & 芹 & 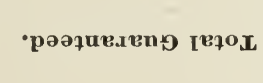 & 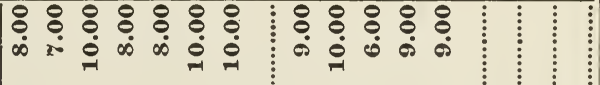 \\
\hline की & 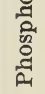 & 'punot I & 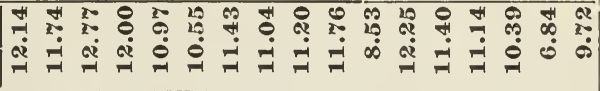 \\
\hline م. & & •ətqnısuI & 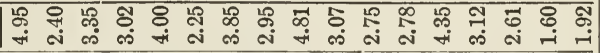 \\
\hline a & & 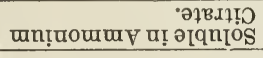 & 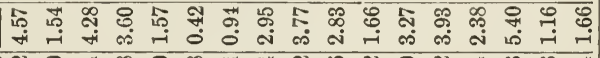 \\
\hline$\overbrace{0}^{2}$ & & 'хәңвМ шा әтпाоS & a \\
\hline 至 & & 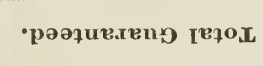 & 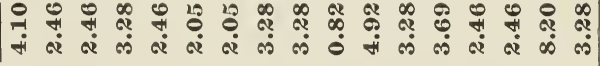 \\
\hline בี & 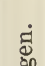 & 'puno, I I eqo $_{\text {L }}$ & 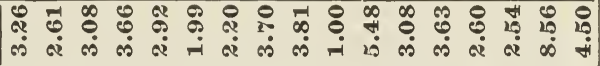 \\
\hline שֶ & 鰙 & 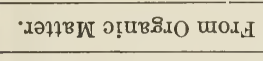 & 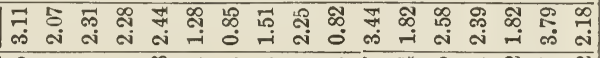 \\
\hline 吾 & & 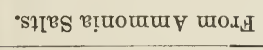 & 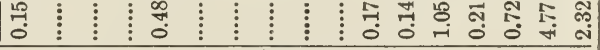 \\
\hline & & 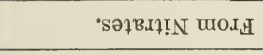 & 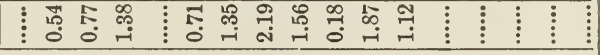 \\
\hline & & & 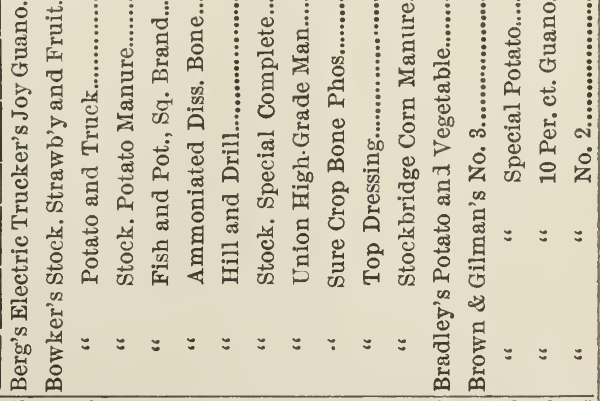 \\
\hline & & & 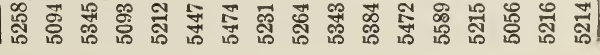 \\
\hline
\end{tabular}




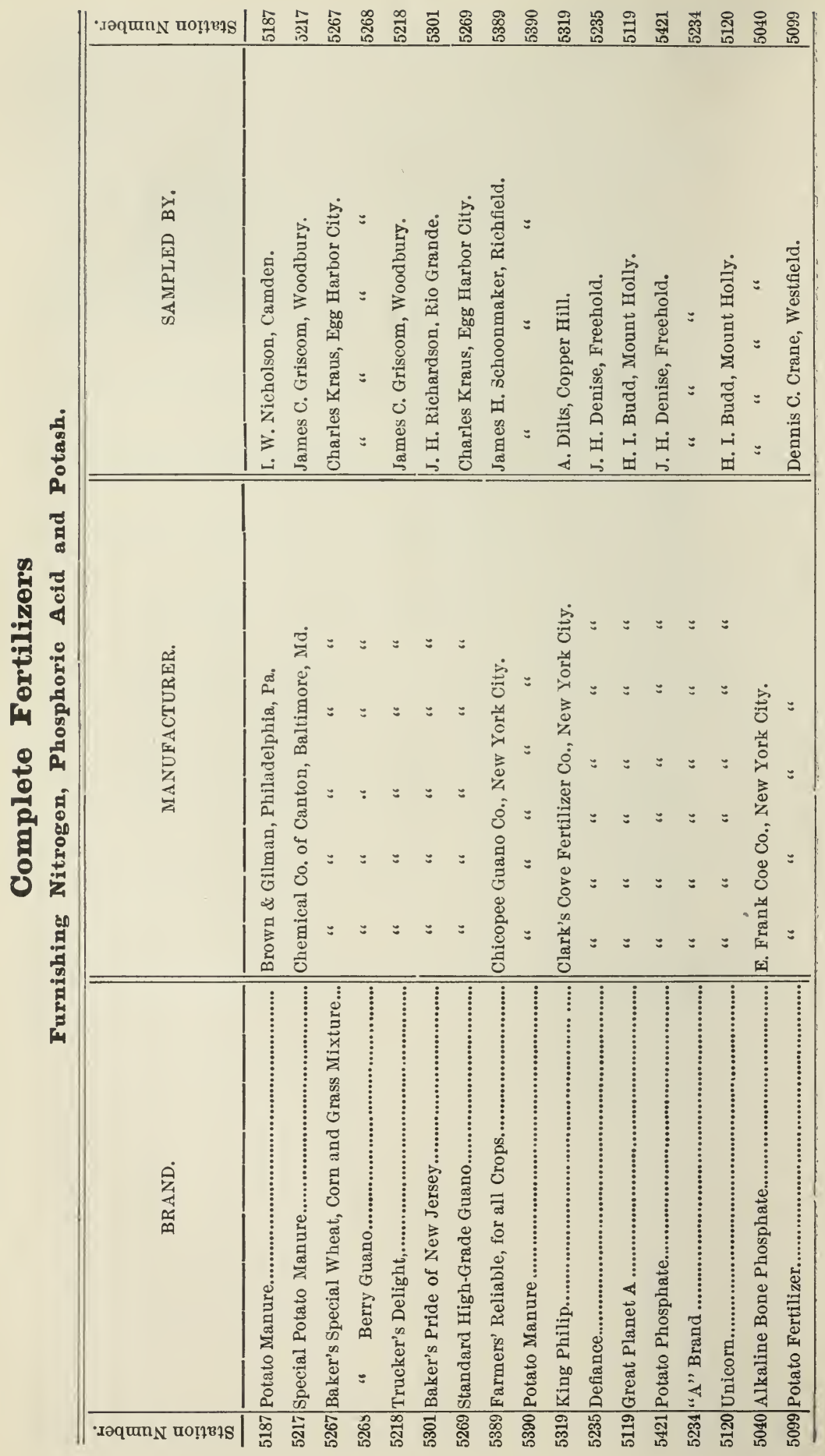




\begin{tabular}{|c|c|c|c|}
\hline & & 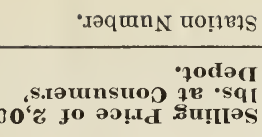 & 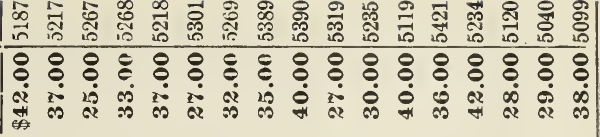 \\
\hline & & 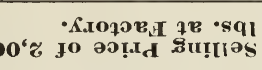 & 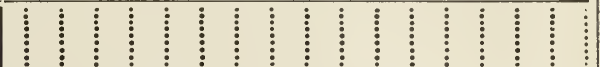 \\
\hline & & 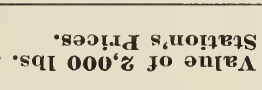 & 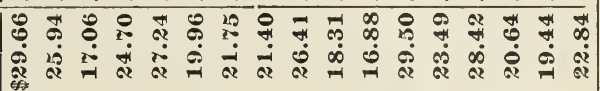 \\
\hline & & 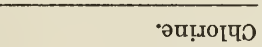 & \% \\
\hline & & 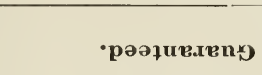 & 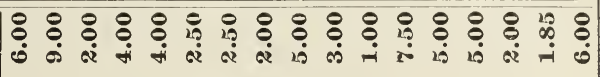 \\
\hline & 贾 & •punos & 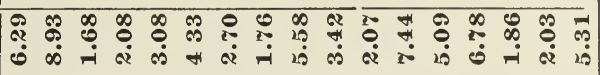 \\
\hline : & & •рәәұиห.xеnђ & 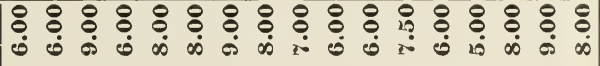 \\
\hline ซี & & -puno & 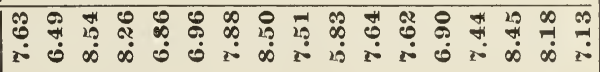 \\
\hline & 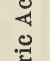 & 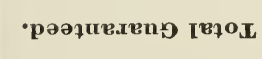 & 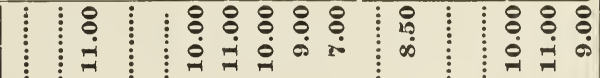 \\
\hline क्ष & $\frac{2}{0}$ & •puno & 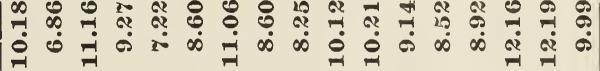 \\
\hline$\frac{1}{10}$ & & •ərqniosuI & 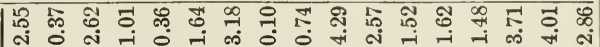 \\
\hline बं & & 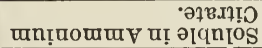 & 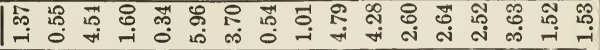 \\
\hline 迹 & & 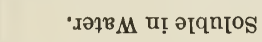 & 管 \\
\hline 证 & & •рәәұนยxยпџ [вұО] & 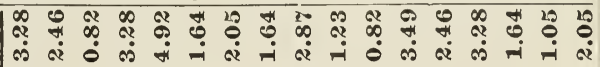 \\
\hline 疍 & घं & 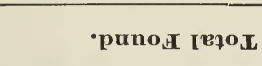 & 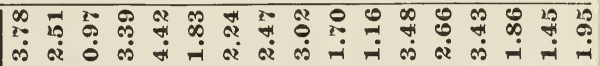 \\
\hline : & 总 & 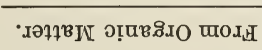 & 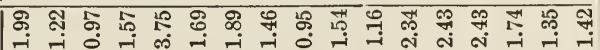 \\
\hline$\underline{m}$ & & 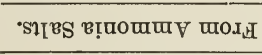 & 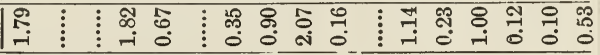 \\
\hline & & 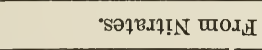 & $\frac{\pi}{0}$ \\
\hline & & & 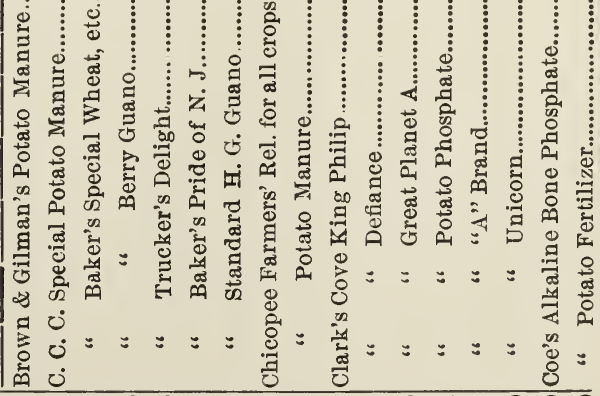 \\
\hline & & & | \\
\hline
\end{tabular}




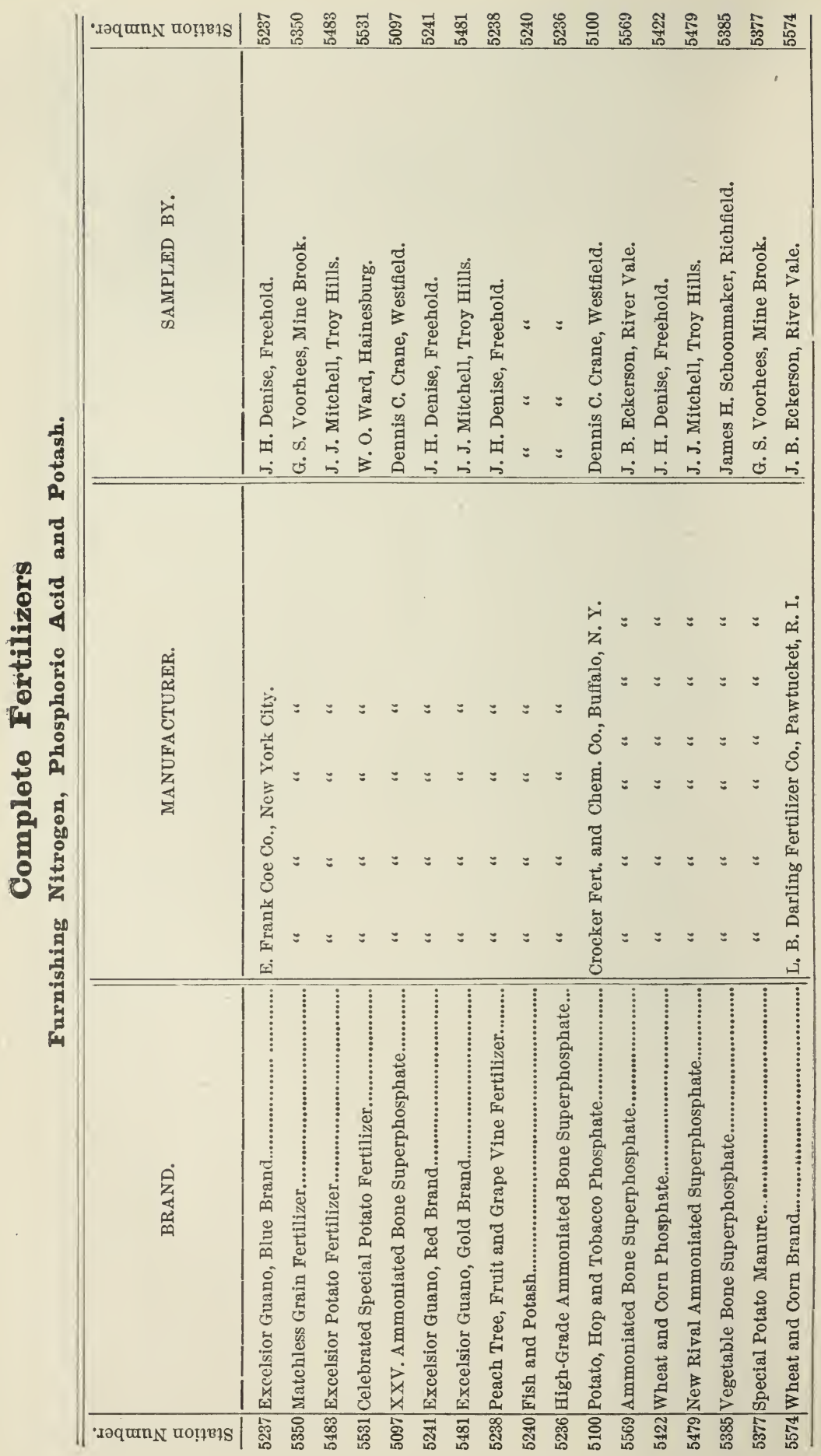




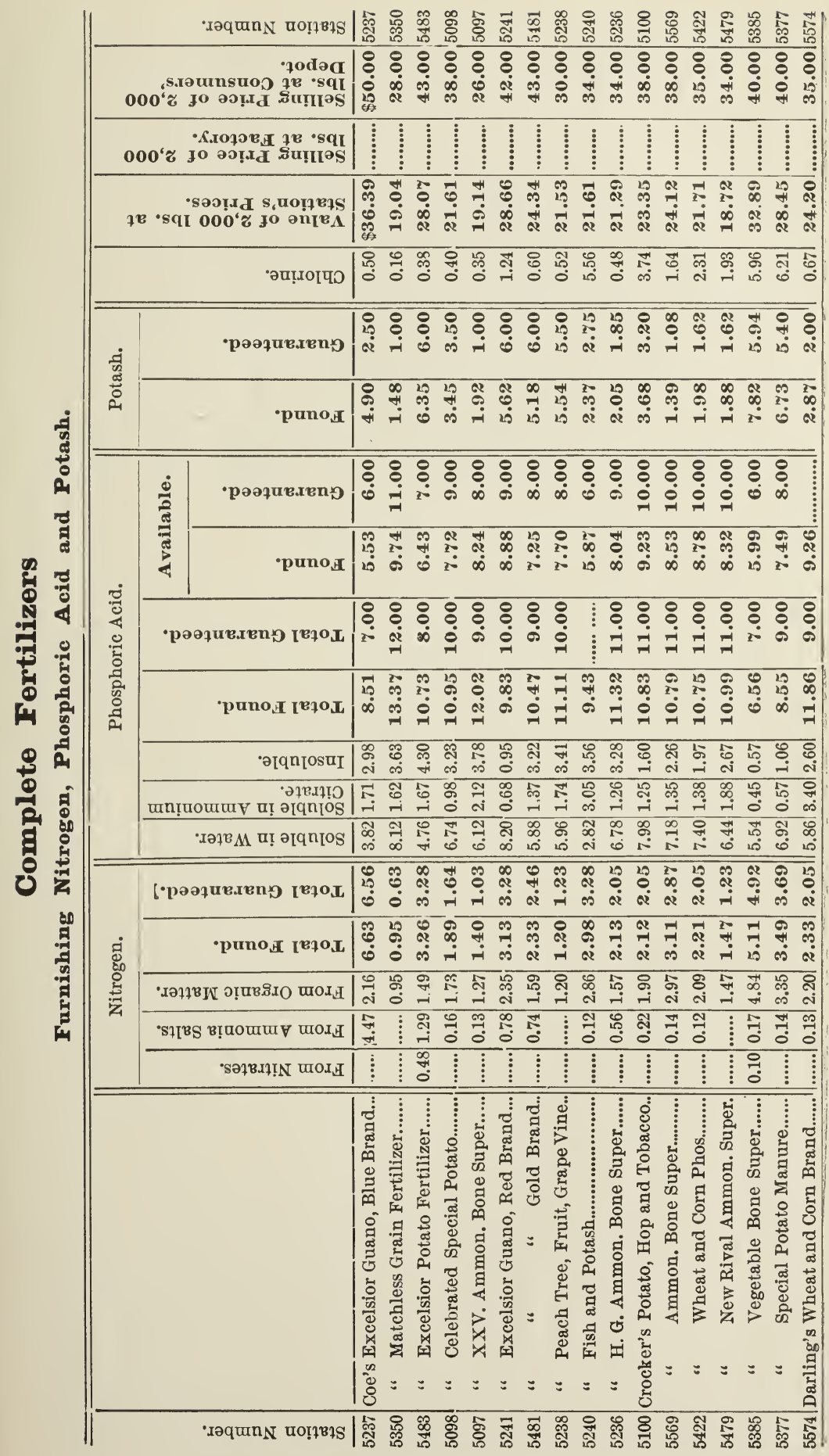




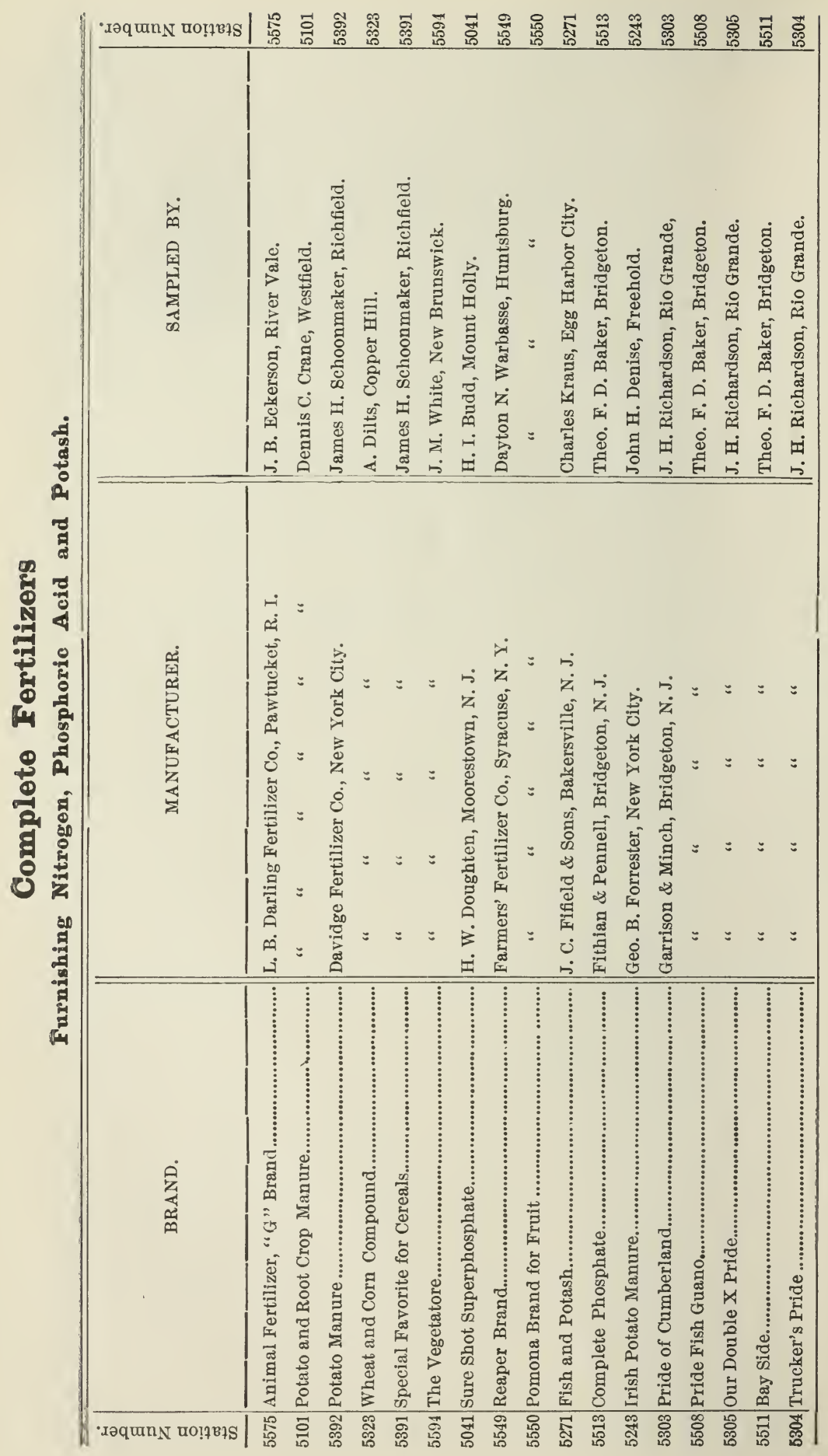




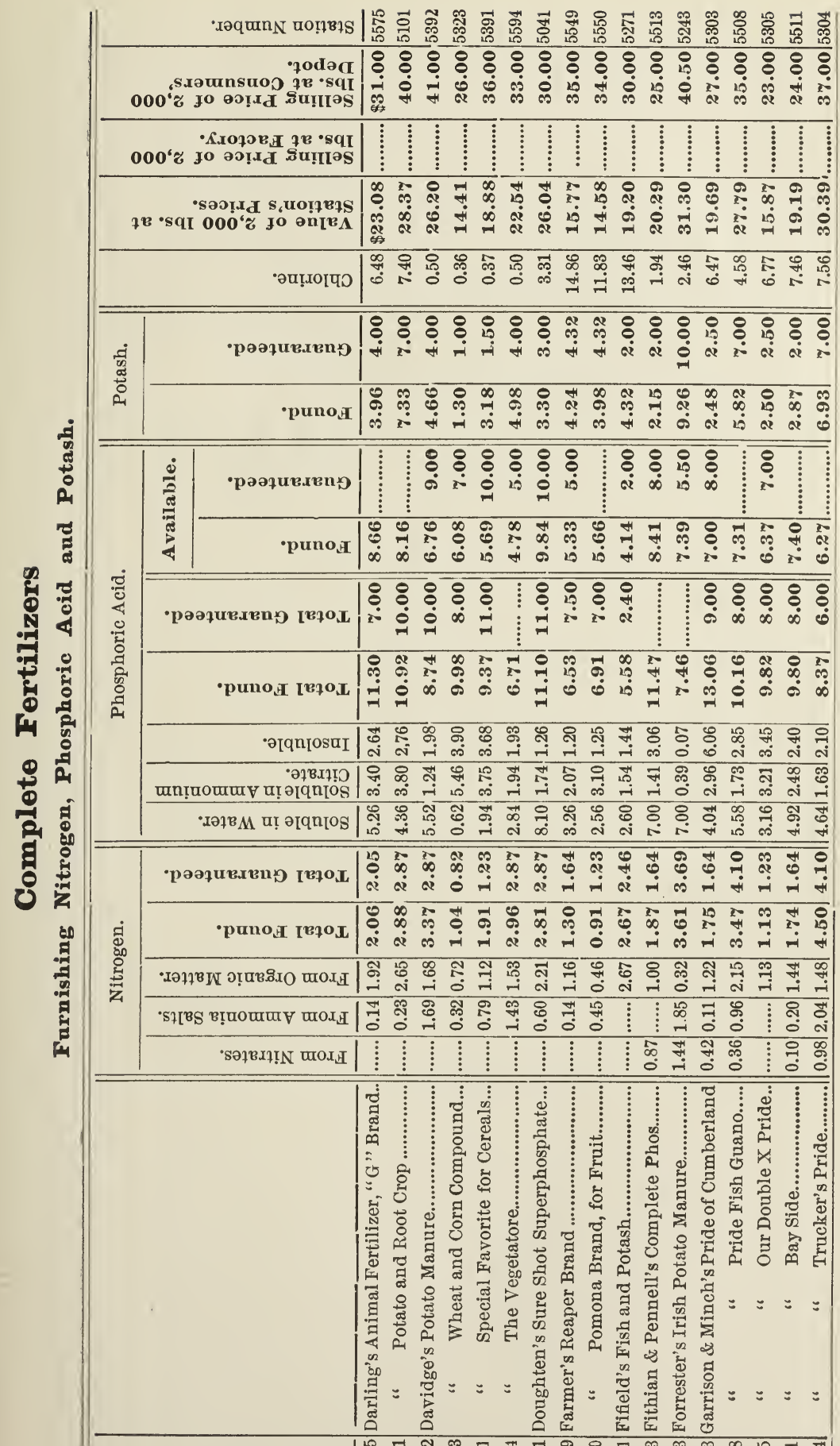

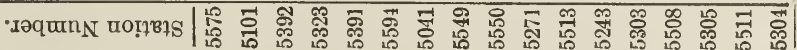




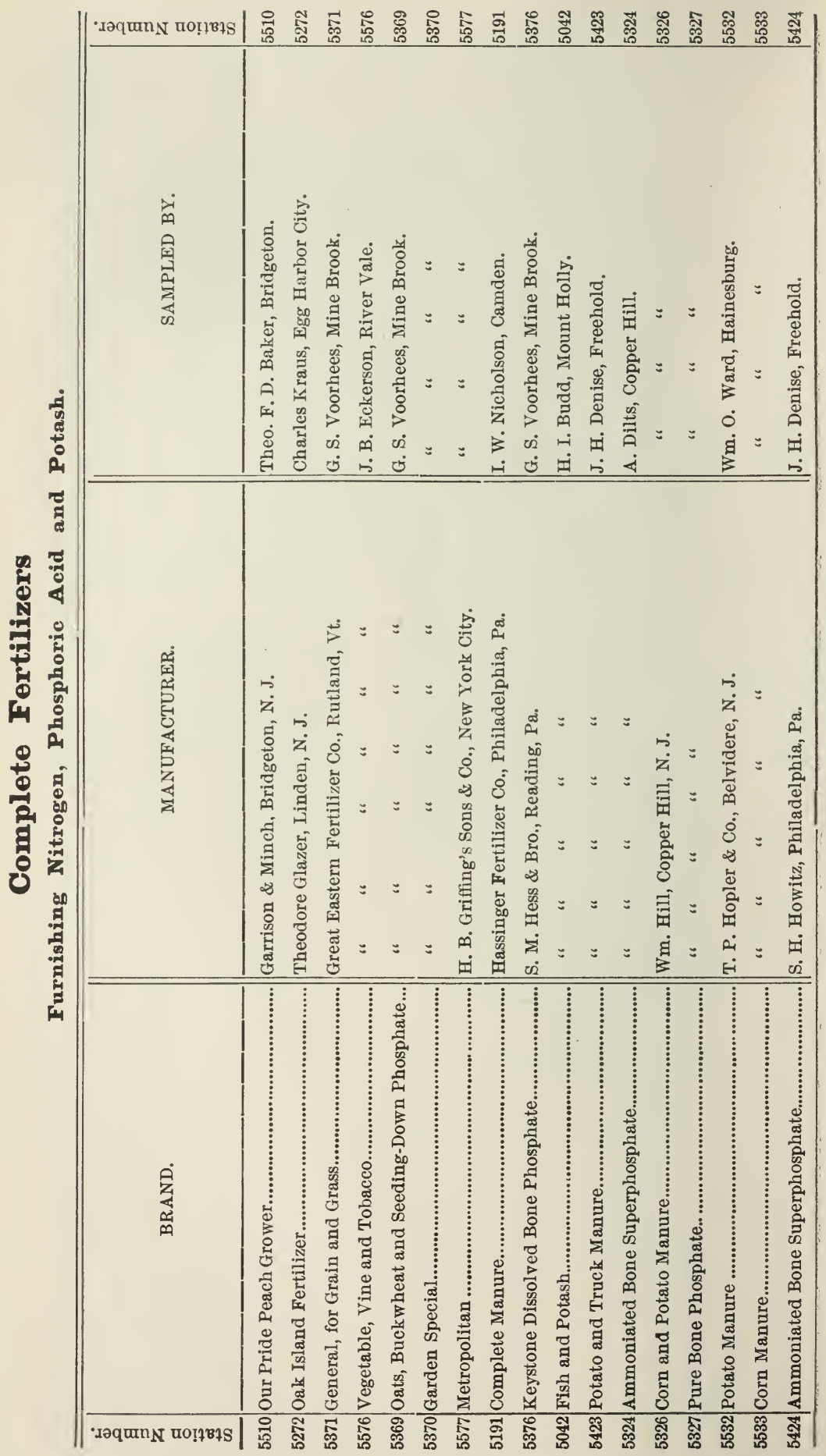




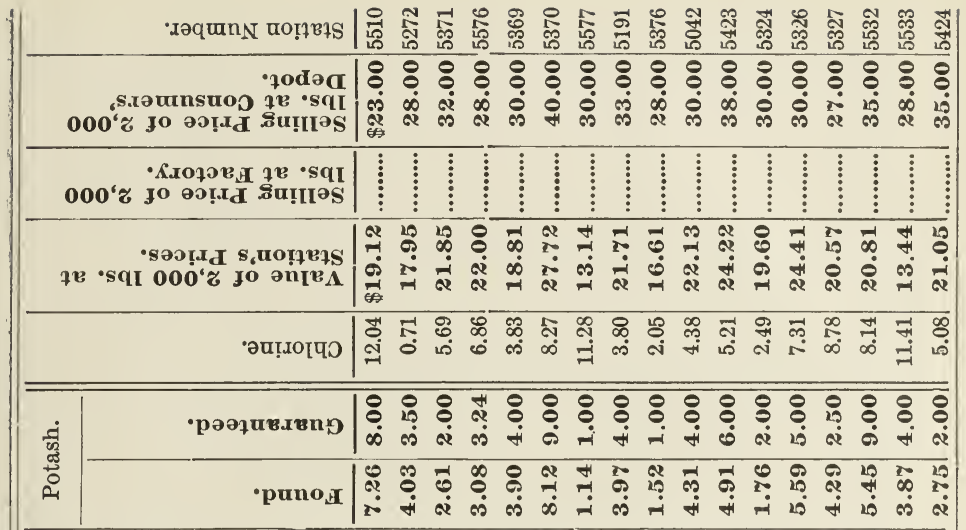

\begin{tabular}{|c|c|c|c|}
\hline & $\stackrel{\square}{\Xi}$ & •рәәұนยגеnџ & 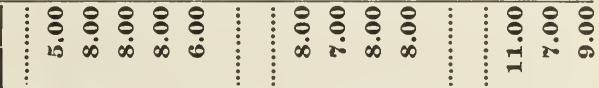 \\
\hline & $\frac{\pi}{4}$ & -puno, & 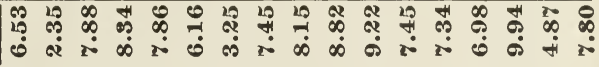 \\
\hline 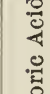 & & 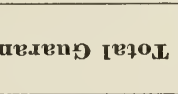 & 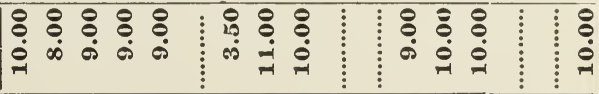 \\
\hline
\end{tabular}

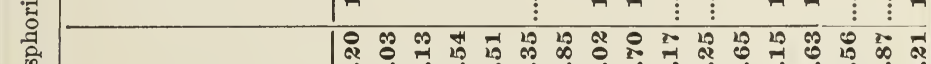
क्व

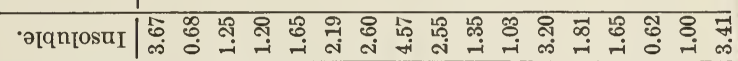

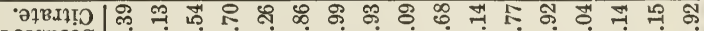

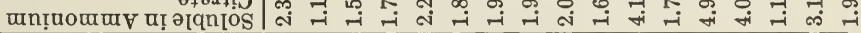

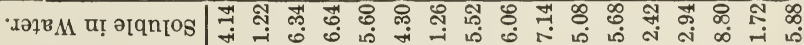

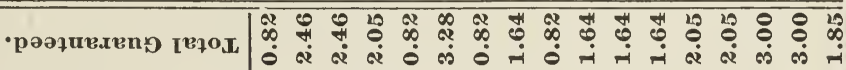

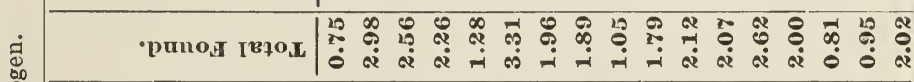

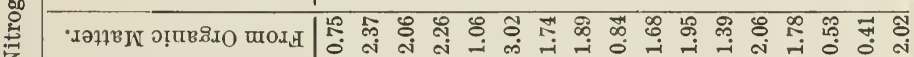

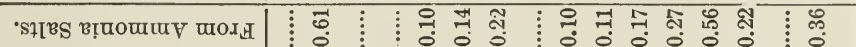

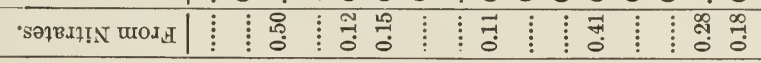

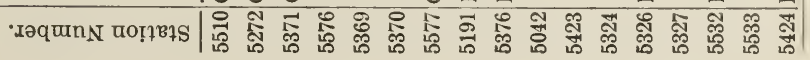




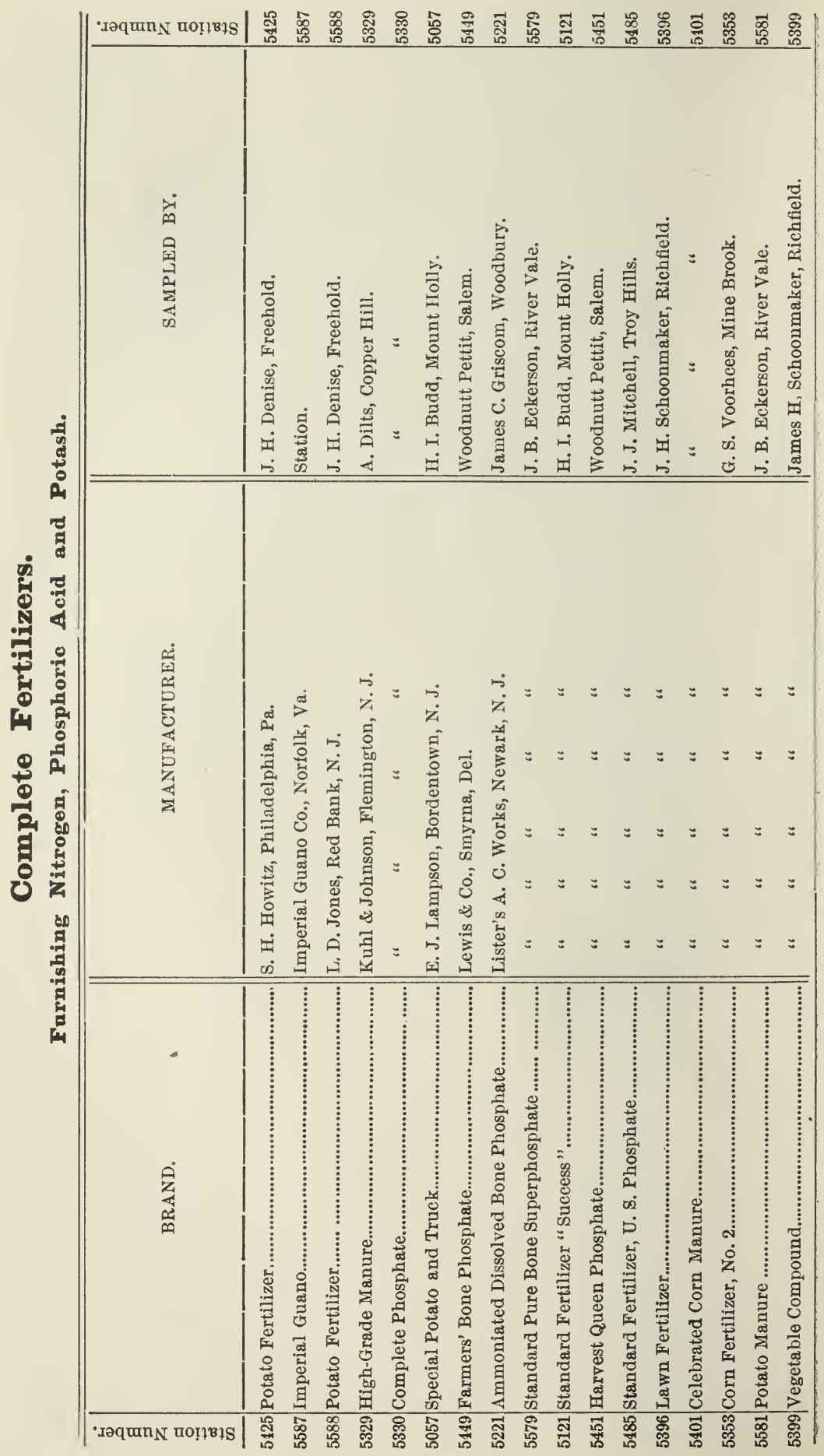




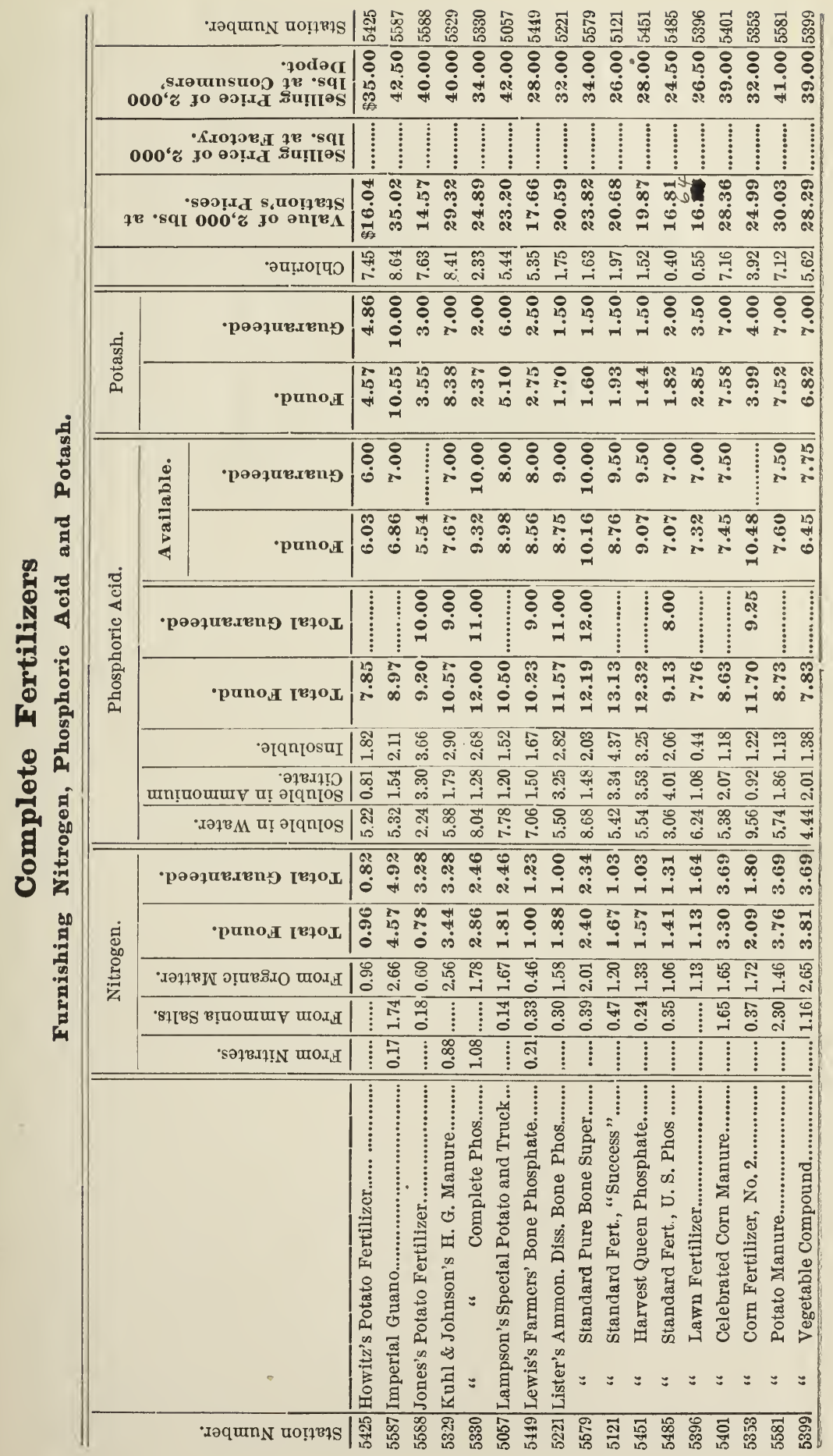




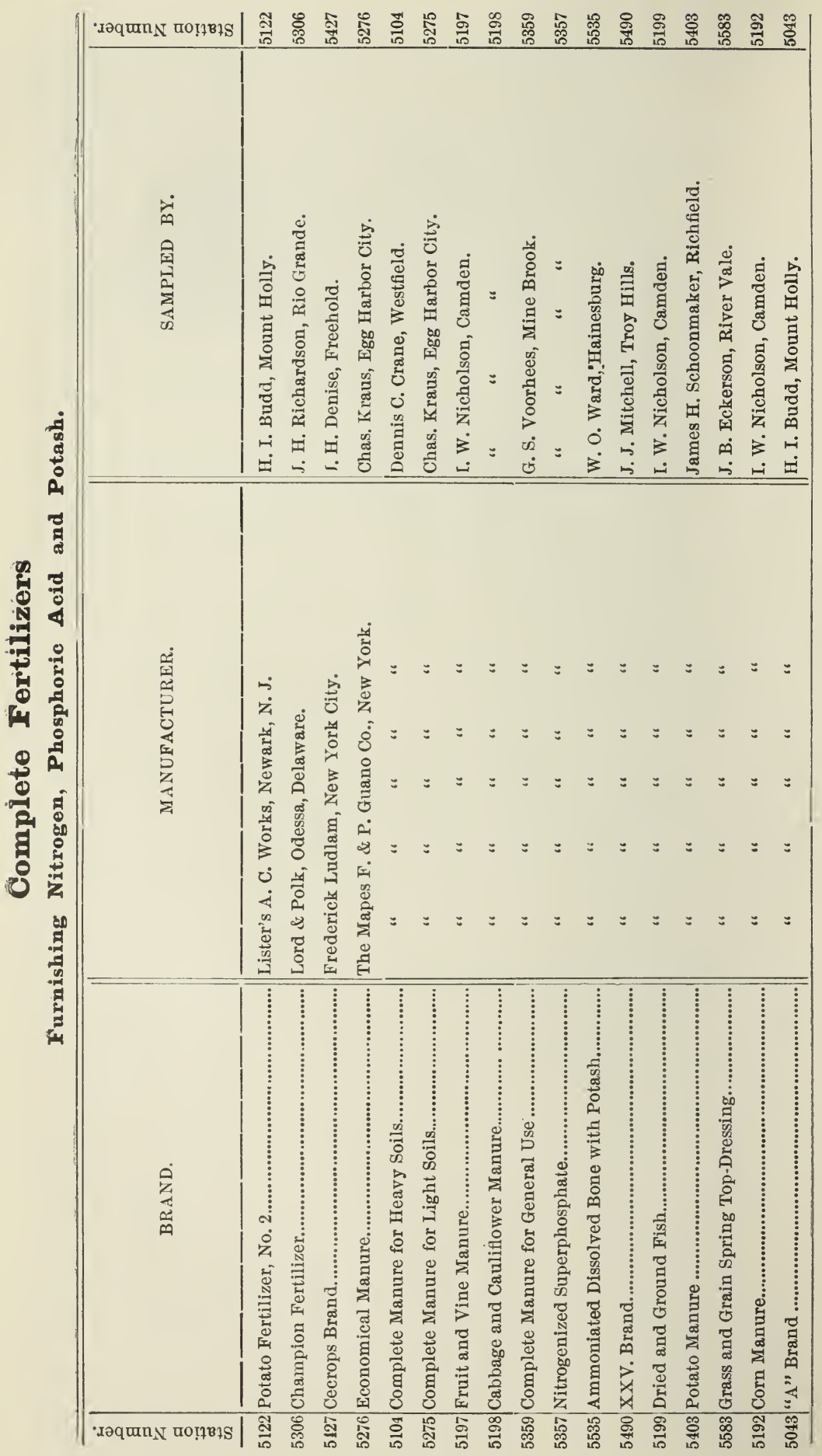




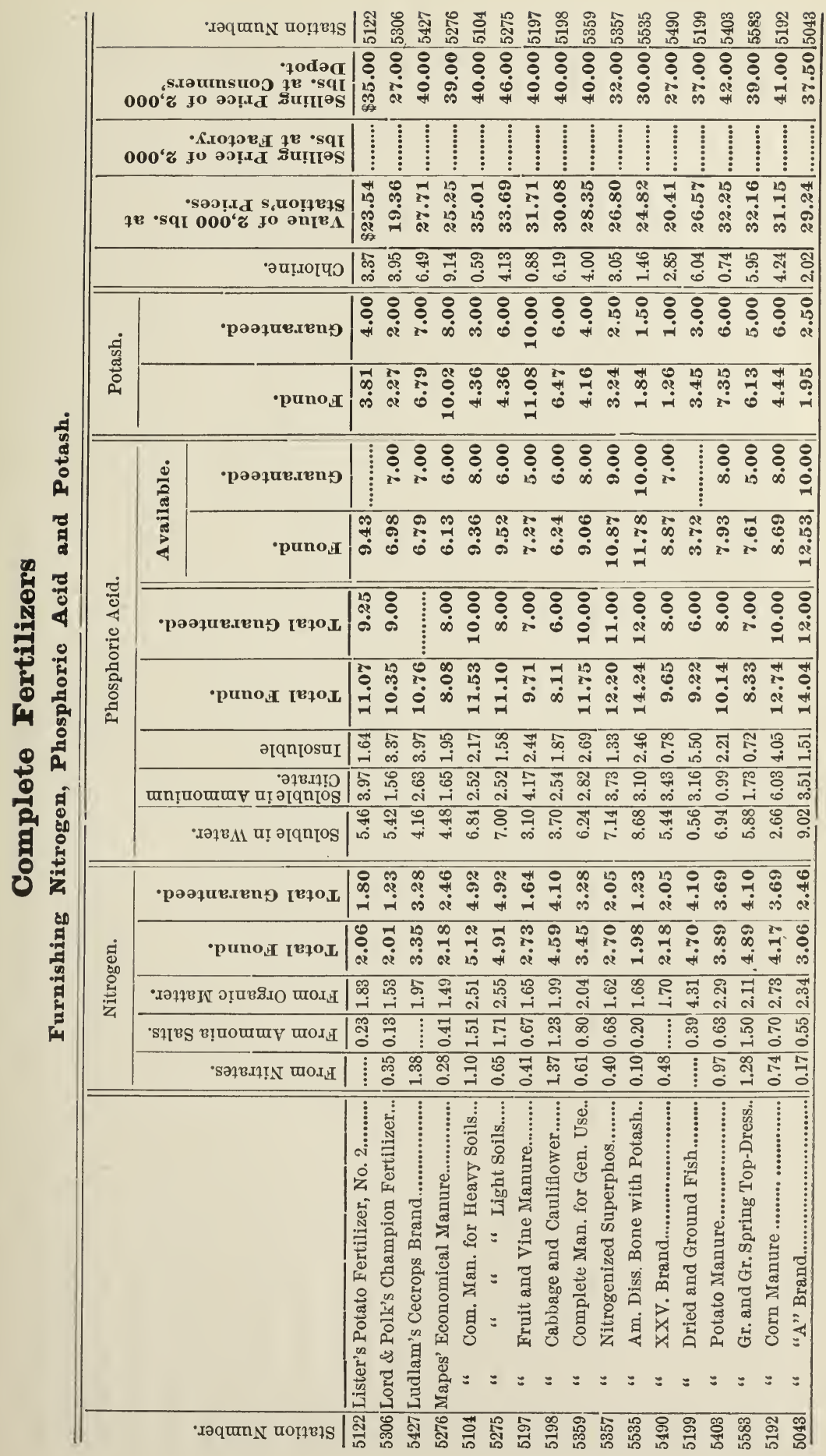




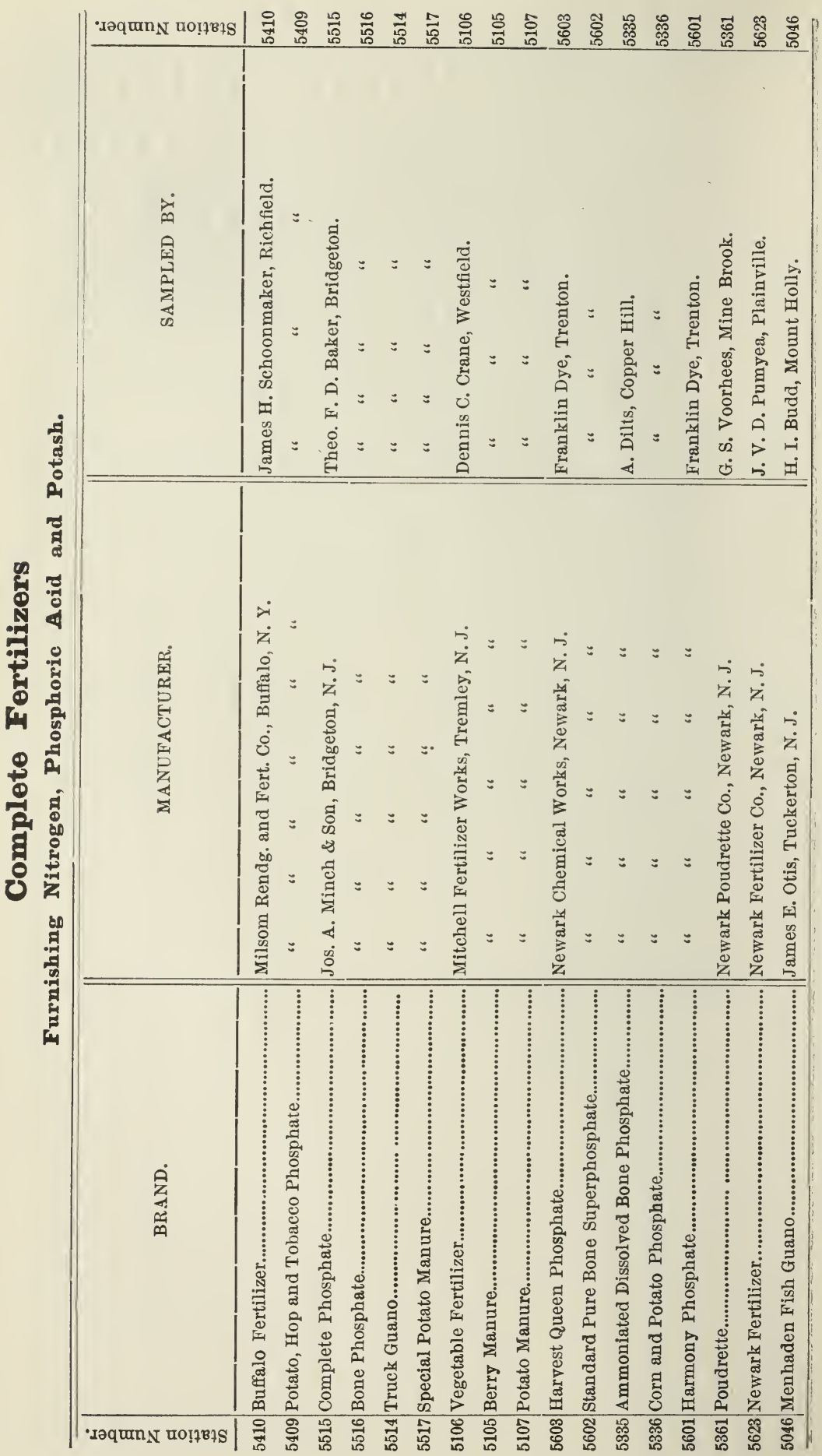




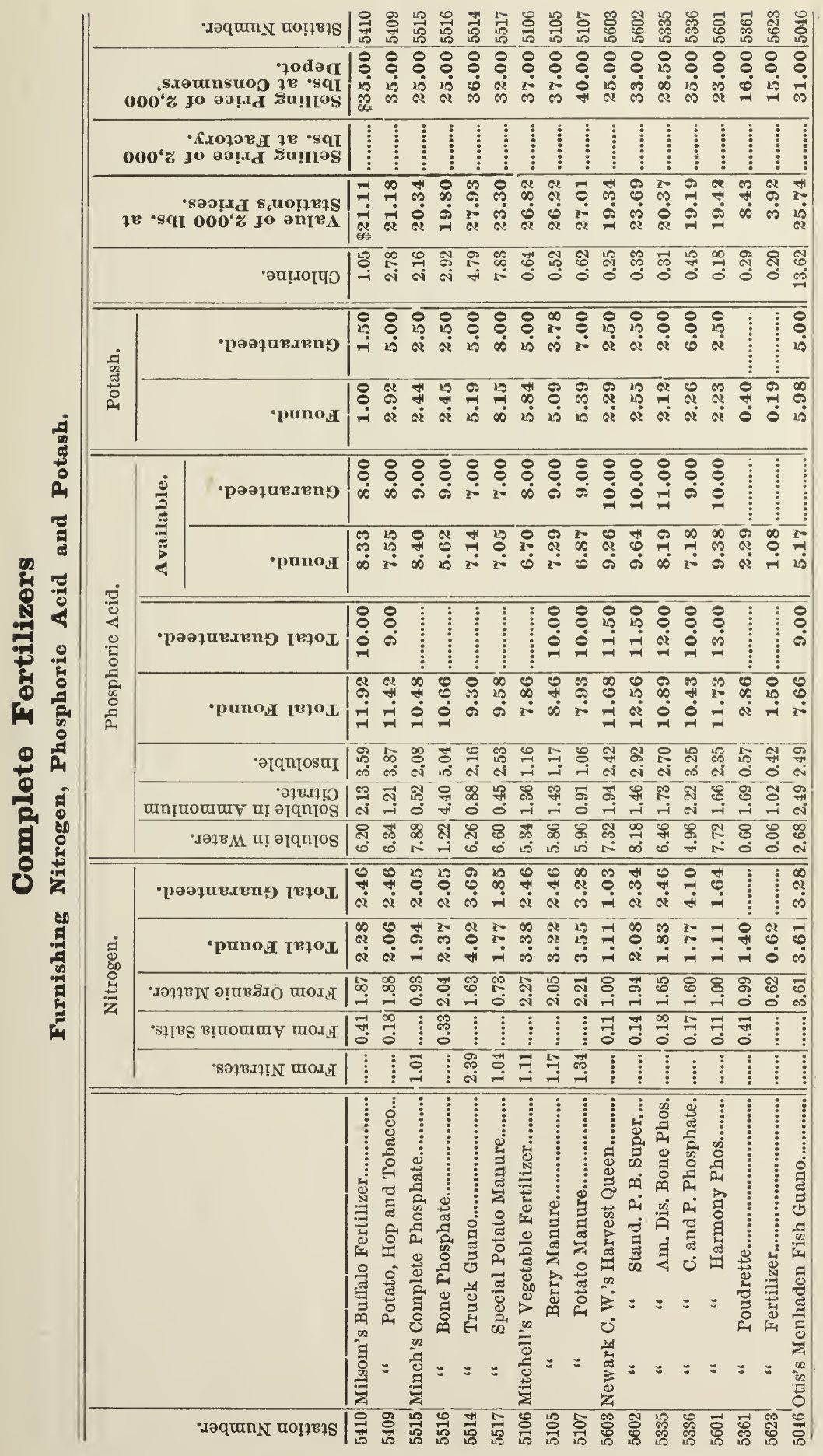




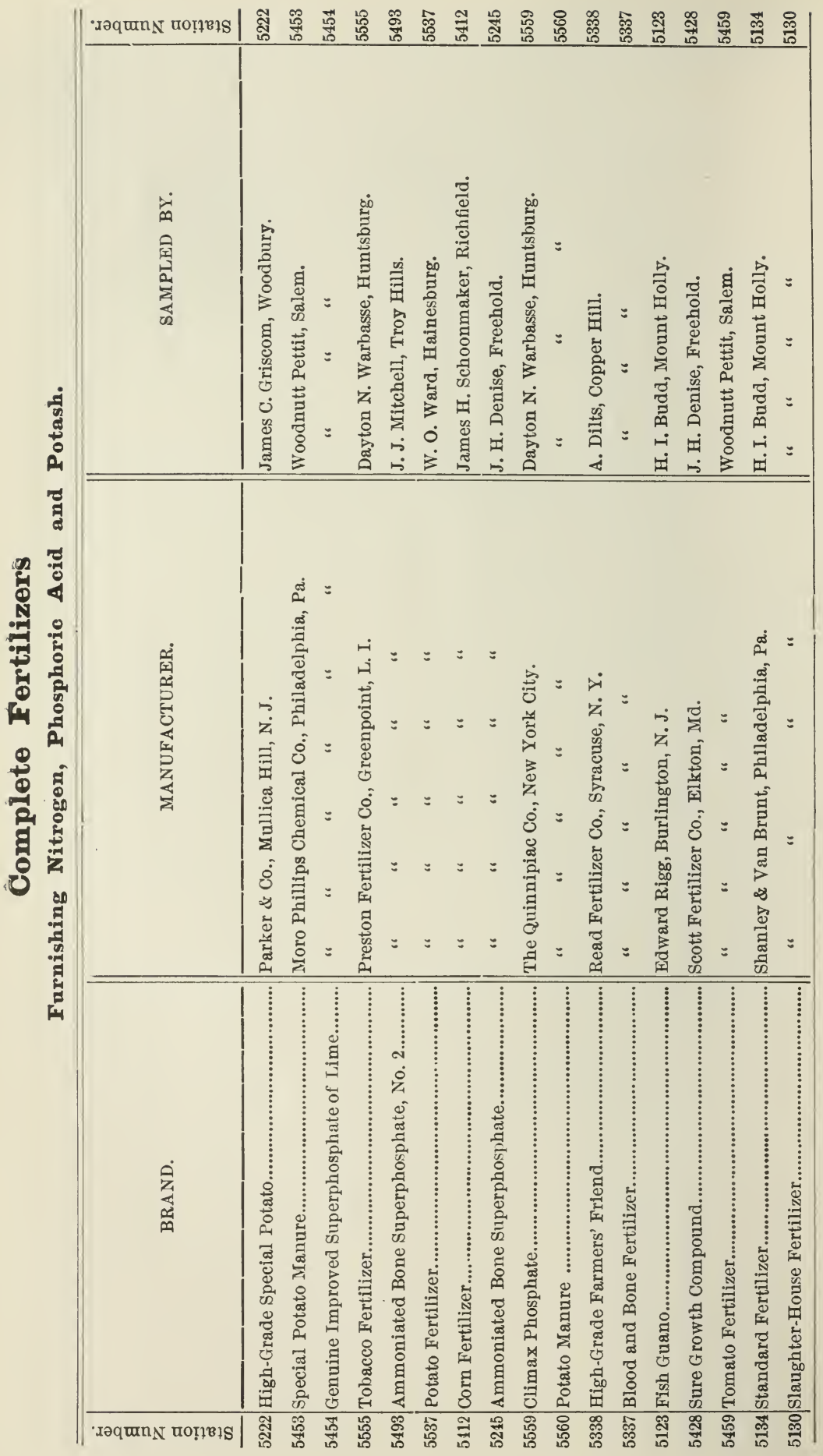




\begin{tabular}{|c|c|c|c|}
\hline & & 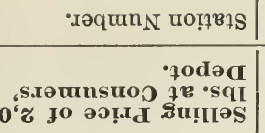 & 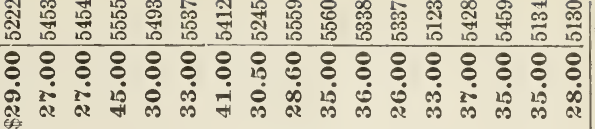 \\
\hline & & 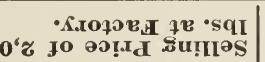 & \\
\hline & & 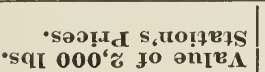 & 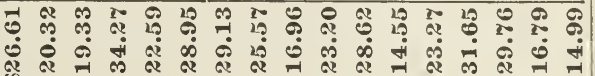 \\
\hline & & 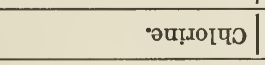 & 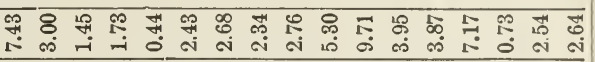 \\
\hline & & •рәәұนеגвn’ & 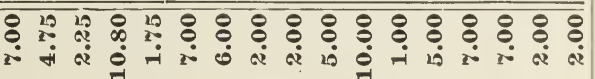 \\
\hline & ثิ & $\cdot$ puno & 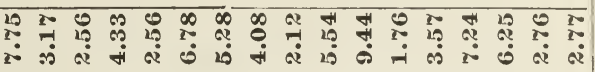 \\
\hline 邪 & & 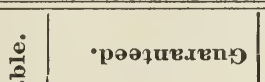 & 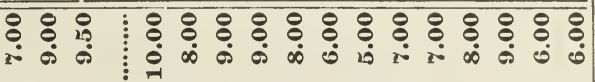 \\
\hline है & & -puno, & 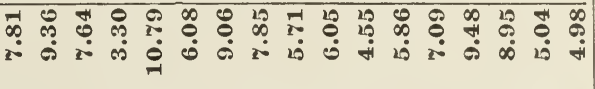 \\
\hline 苞 & 芹 & 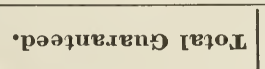 & 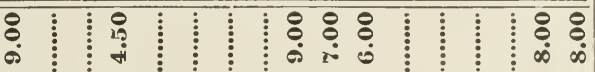 \\
\hline & 究 & 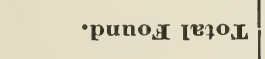 & 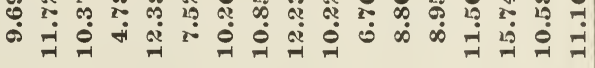 \\
\hline & & •əqniosuI & 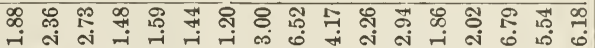 \\
\hline & & 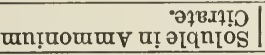 & A \\
\hline & & 'хәғвм पा әтqnios | & 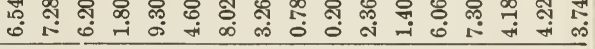 \\
\hline 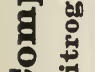 & & 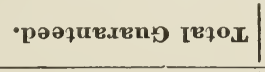 & 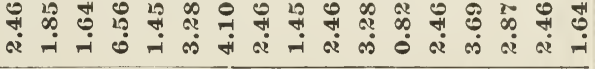 \\
\hline & 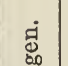 & 'puno:I I I & 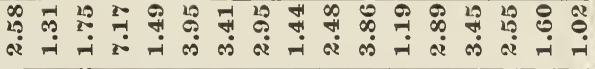 \\
\hline בี & 伞 & 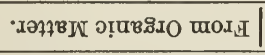 & 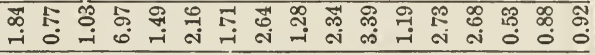 \\
\hline E & & 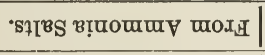 & ! 경 \& \\
\hline & & 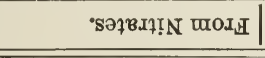 & 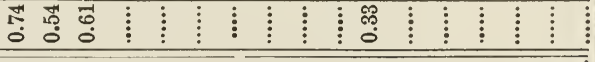 \\
\hline & & & 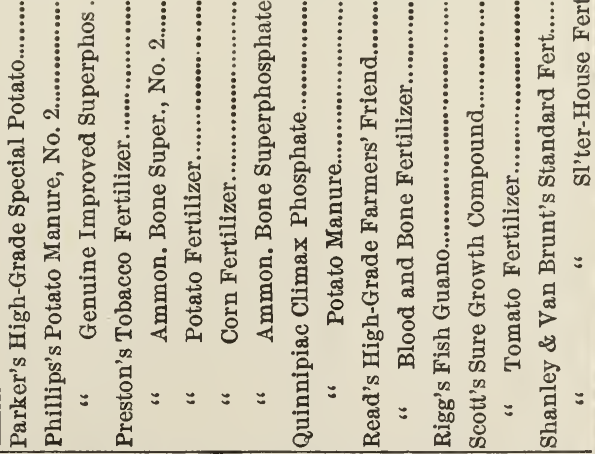 \\
\hline & & & \\
\hline
\end{tabular}




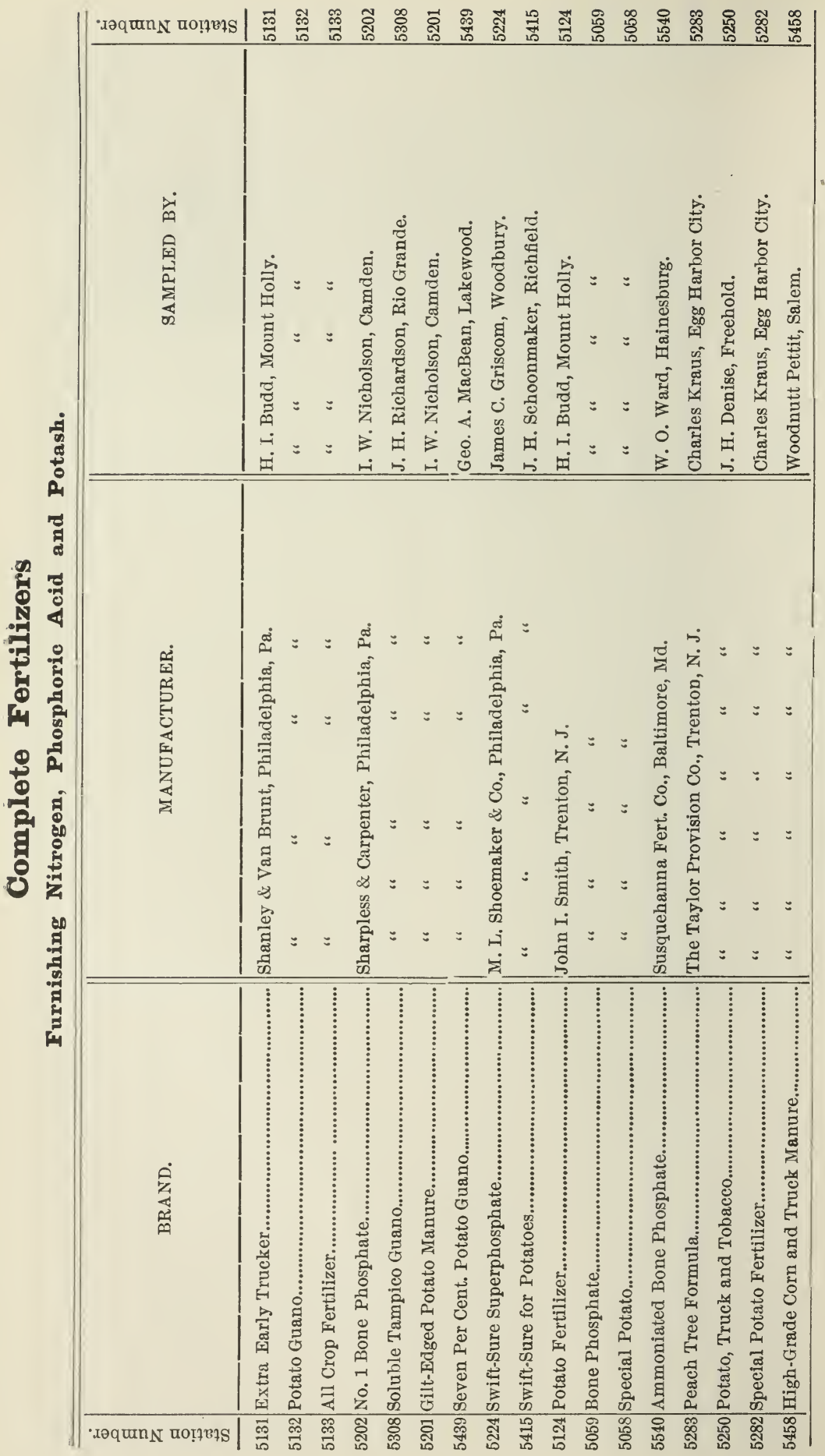




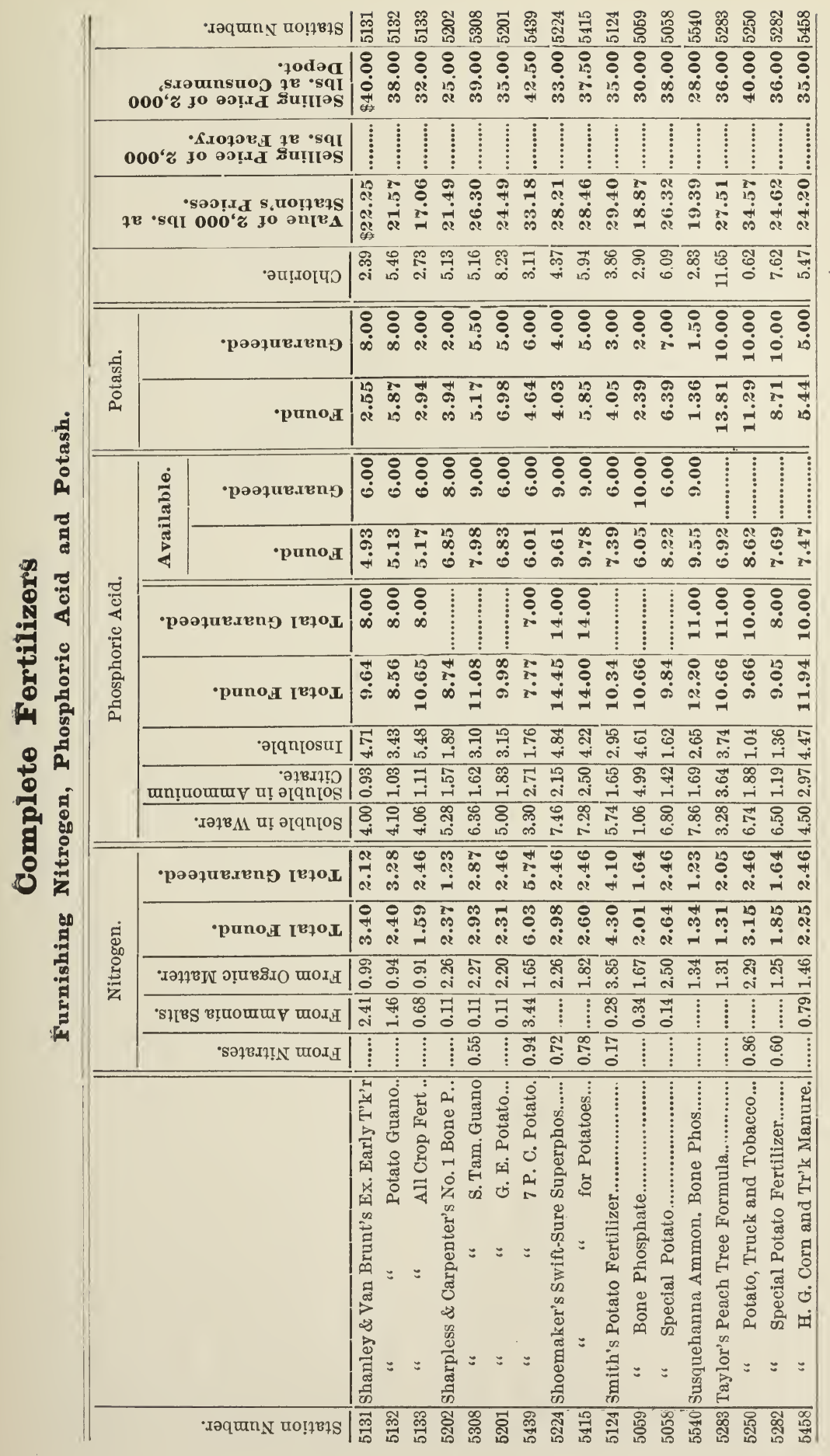




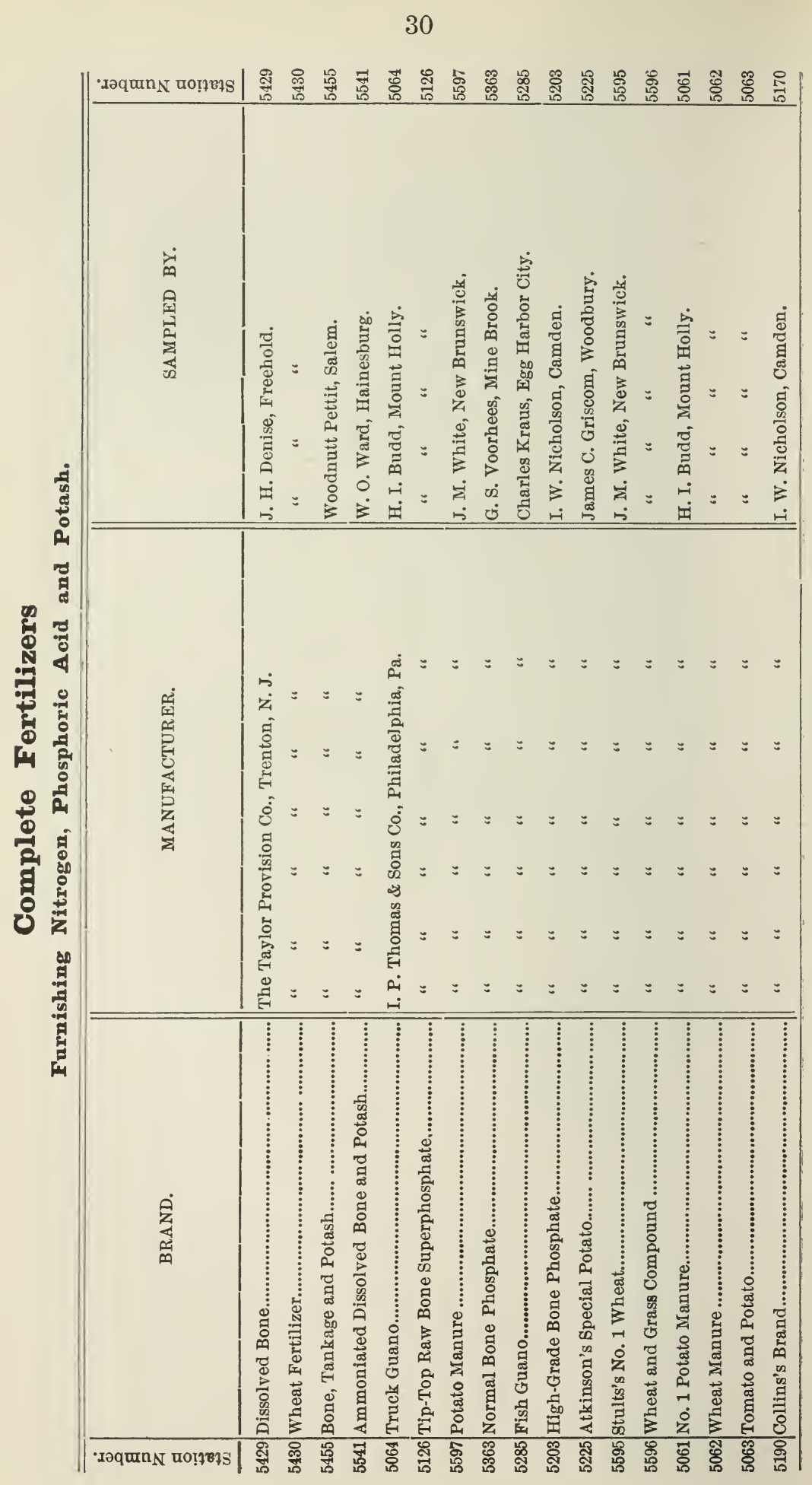




\begin{tabular}{|c|c|c|}
\hline & 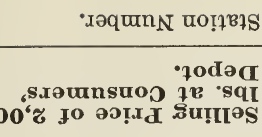 & 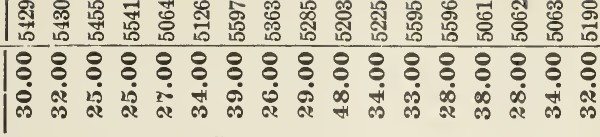 \\
\hline & 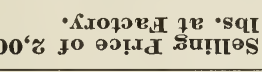 & 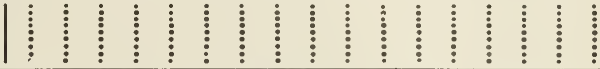 \\
\hline & 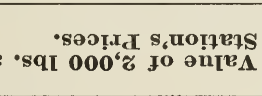 & 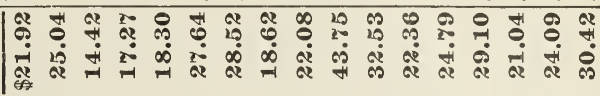 \\
\hline & 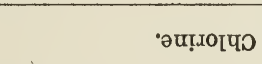 & 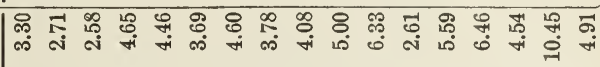 \\
\hline & •рәәрше.кеп, & 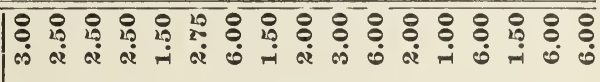 \\
\hline 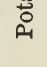 & 'punot & 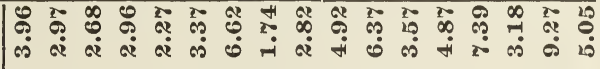 \\
\hline & •рәәұияхвпю & 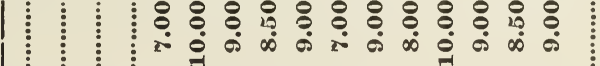 \\
\hline & 'punot & 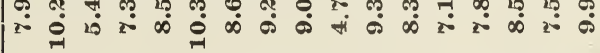 \\
\hline$\stackrel{4}{\circlearrowright}$ & 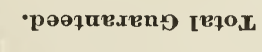 & 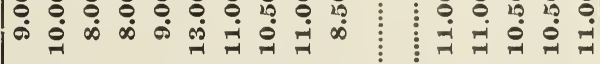 \\
\hline $\begin{array}{l}0_{0}^{2} \\
0 \\
0 \\
0\end{array}$ & 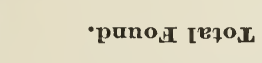 & 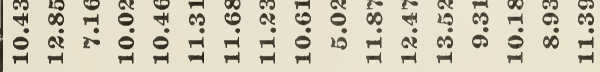 \\
\hline & •əૃqn[osuI & 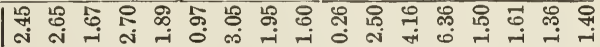 \\
\hline & 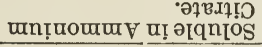 & 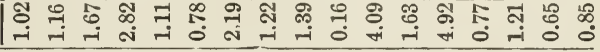 \\
\hline & 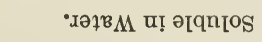 & 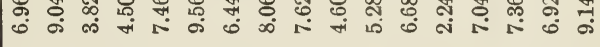 \\
\hline & 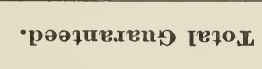 & 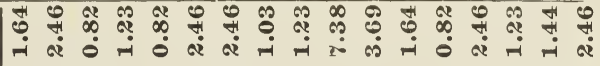 \\
\hline 承 & •punos IEq0, & 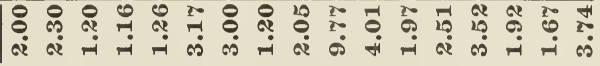 \\
\hline 尝 & 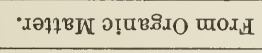 & | \\
\hline & 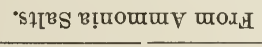 & 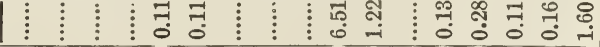 \\
\hline & •sәqBI\}!N modH & 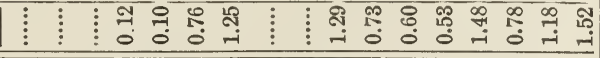 \\
\hline & & 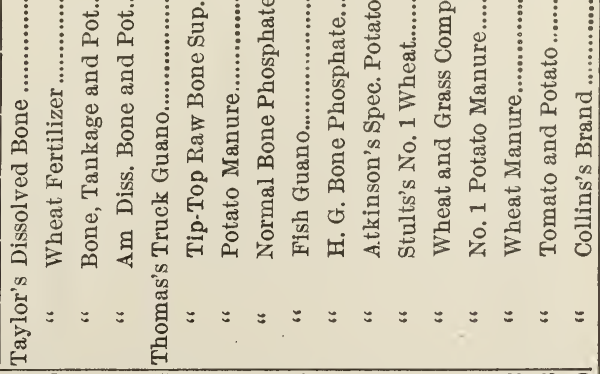 \\
\hline & & 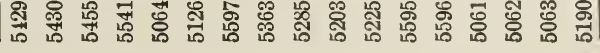 \\
\hline
\end{tabular}




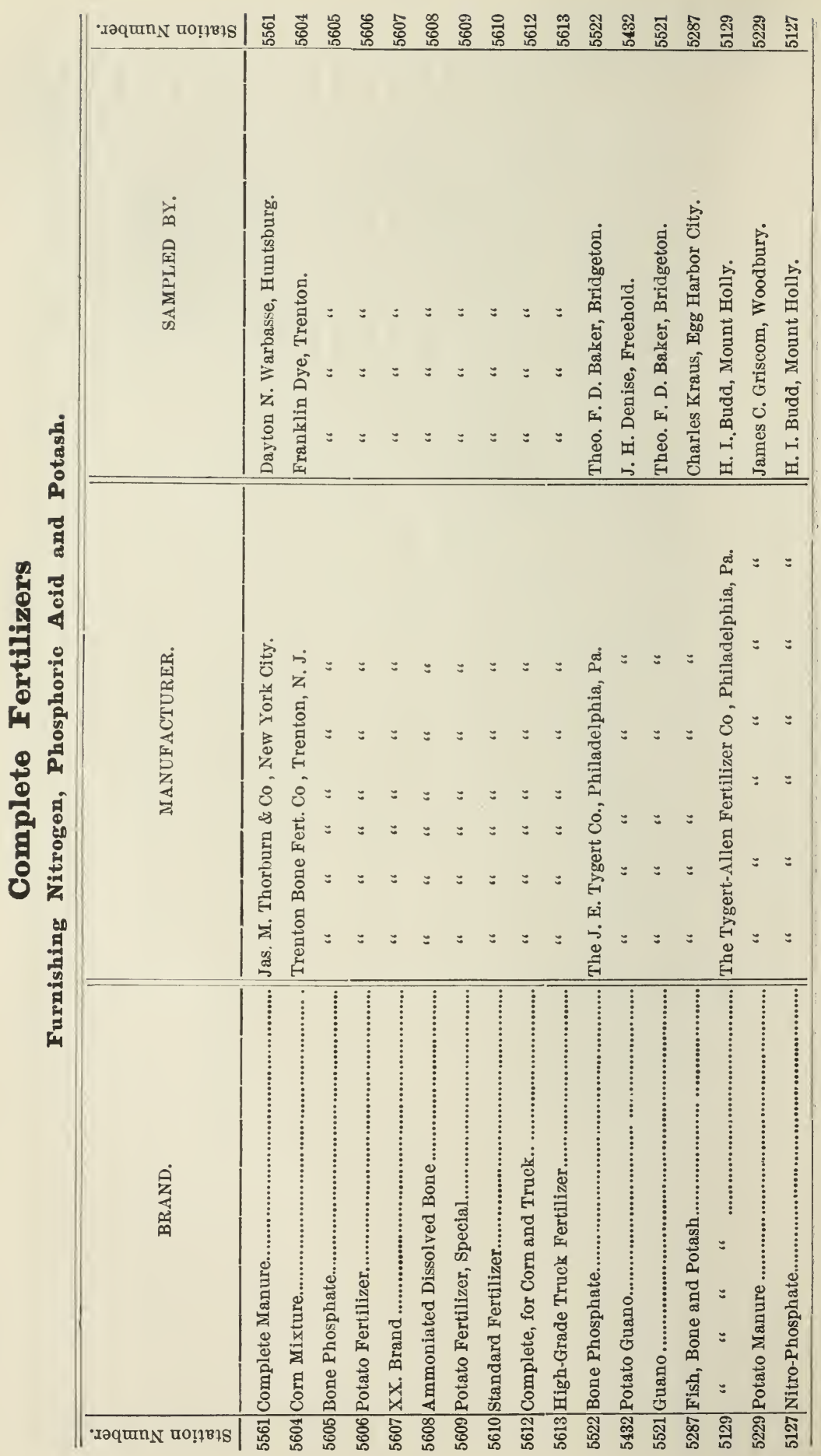




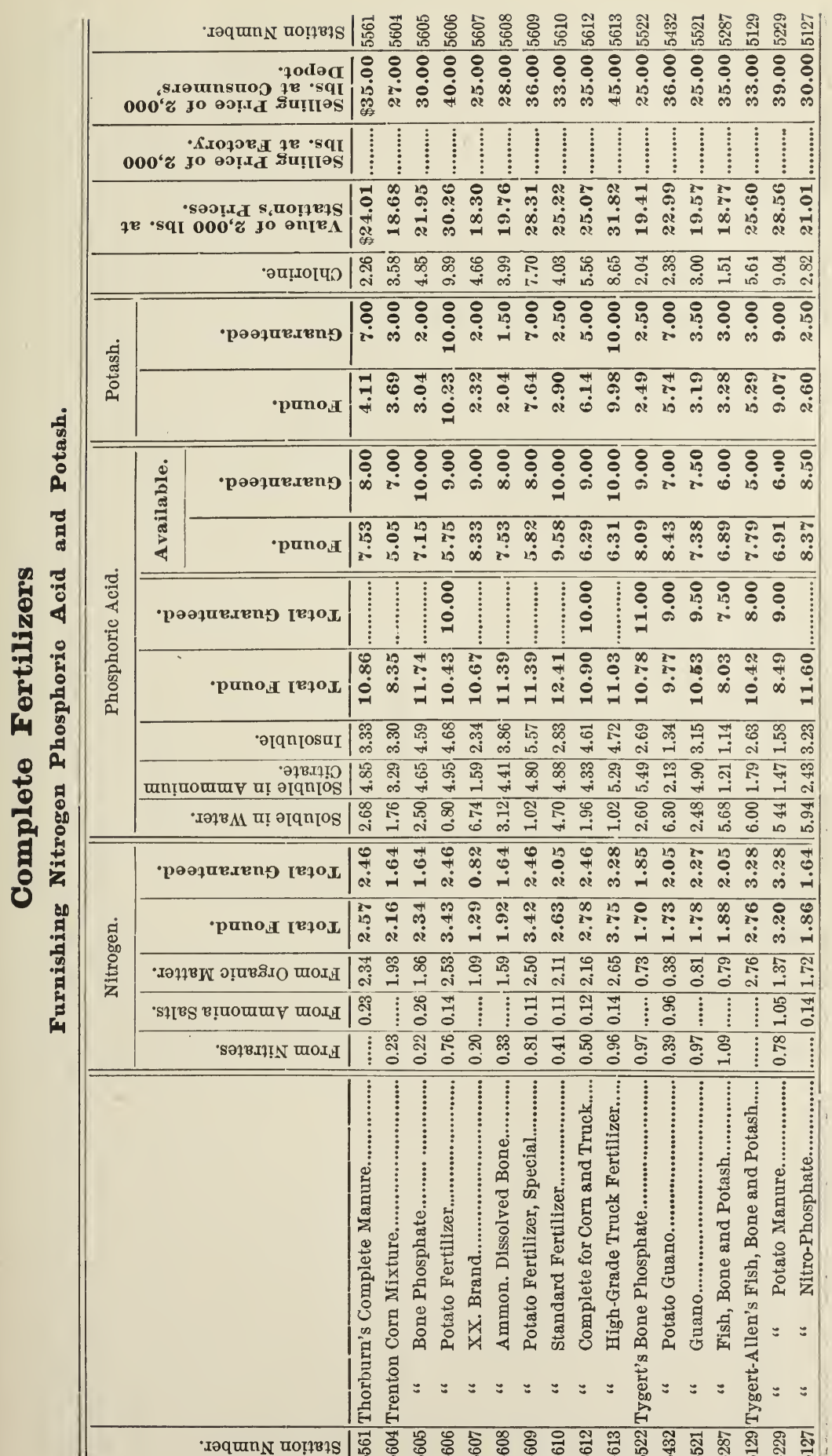




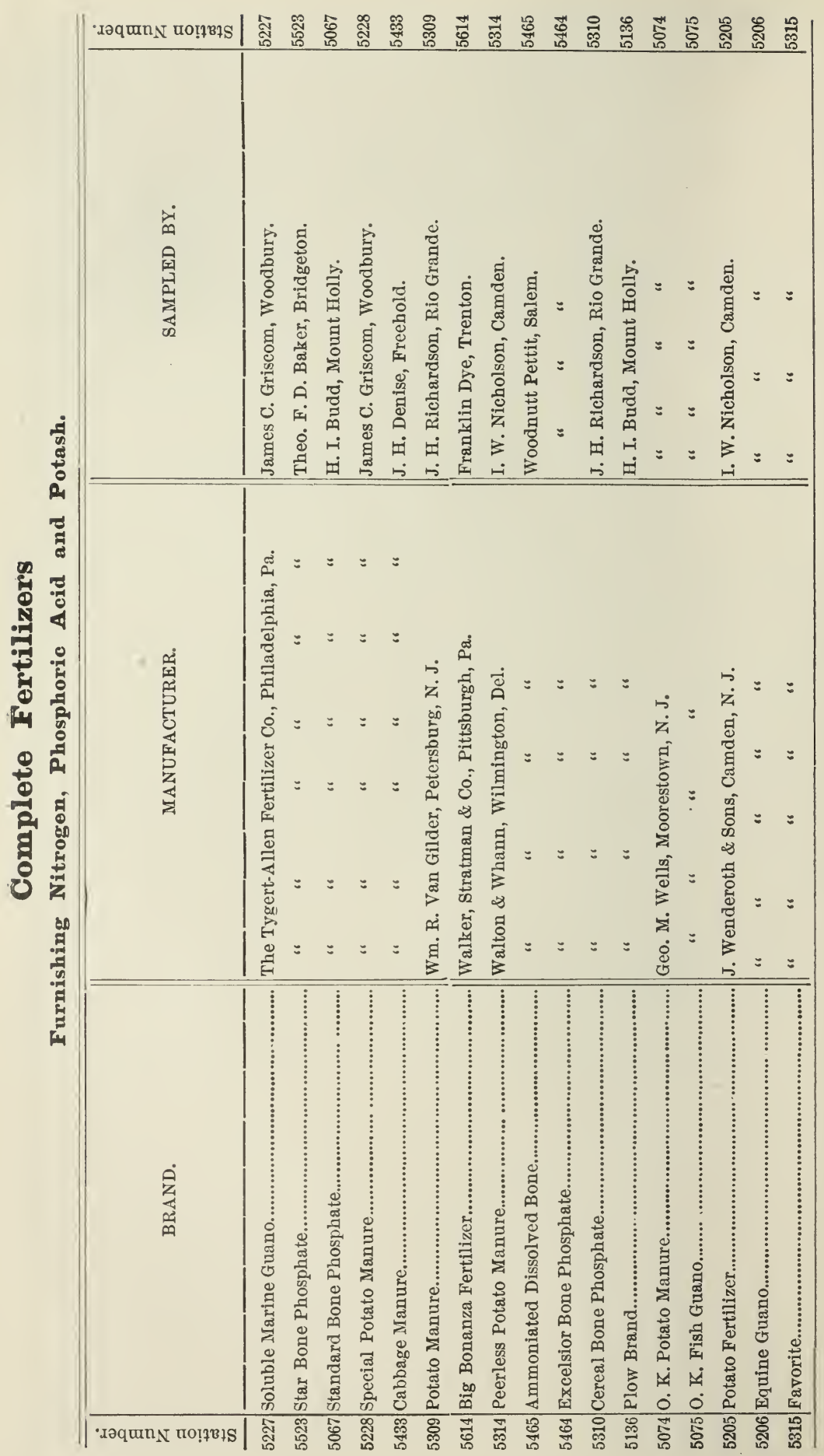




\begin{tabular}{|c|c|c|c|}
\hline & & 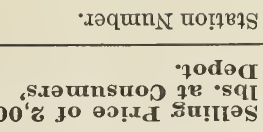 & 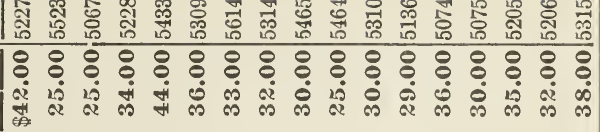 \\
\hline & & 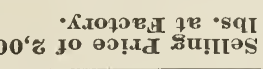 & 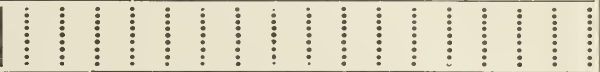 \\
\hline & & 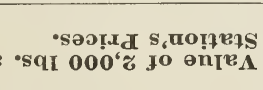 & 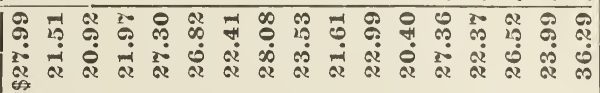 \\
\hline & & 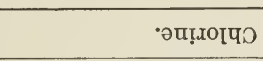 & 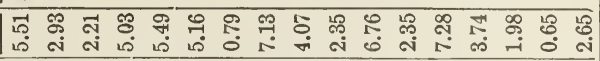 \\
\hline & & 'рәәұие.xвnџ & 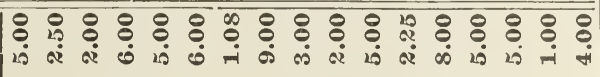 \\
\hline & 苍 & •puno & 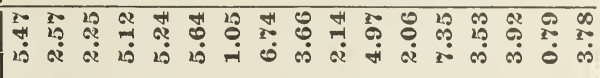 \\
\hline مी & & •рәәұนยлепџ & 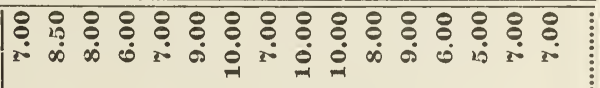 \\
\hline ఊ્ష & & •punoti & 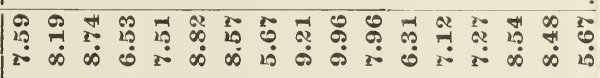 \\
\hline & 品 & 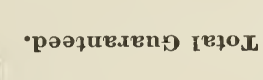 & 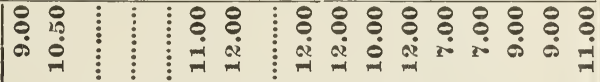 \\
\hline 至 & $\begin{array}{l}\text { की } \\
\text { o: } \\
\text { क्वे }\end{array}$ & -puno:H IеqоL & 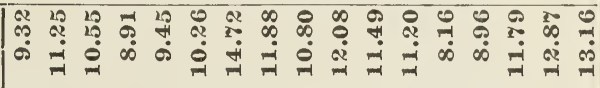 \\
\hline$\stackrel{0}{0}$ & & •əવqnџosuI & 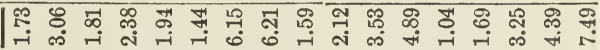 \\
\hline ब्ष & & 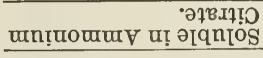 & 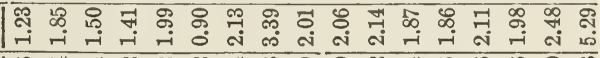 \\
\hline 18 & & •xәңвM u! әIqnโos & 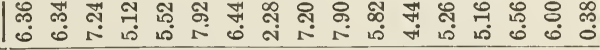 \\
\hline 量 & & 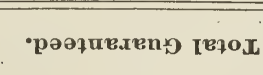 & 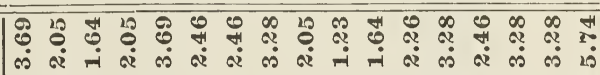 \\
\hline 最 & ฮี & 'puno, I I & 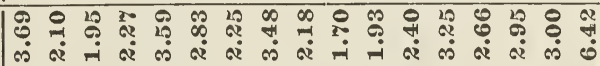 \\
\hline$\frac{\sqrt{n}}{4}$ & 起 & 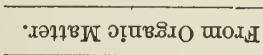 & 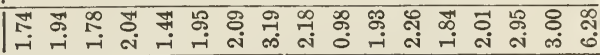 \\
\hline है & & 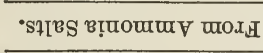 & | \\
\hline & & 'sә78xา!N mox & 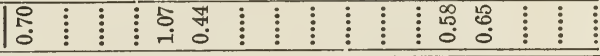 \\
\hline & & & 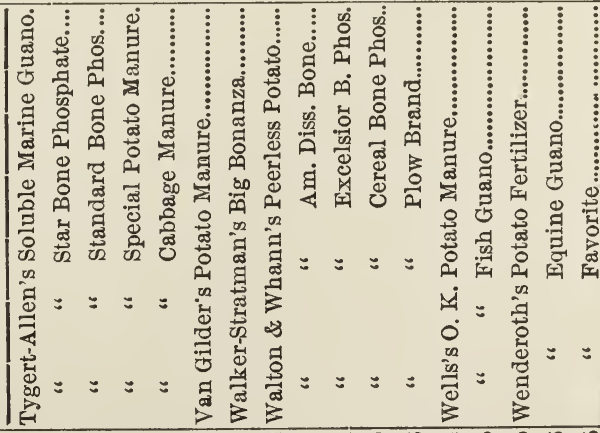 \\
\hline & & & 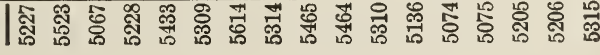 \\
\hline
\end{tabular}




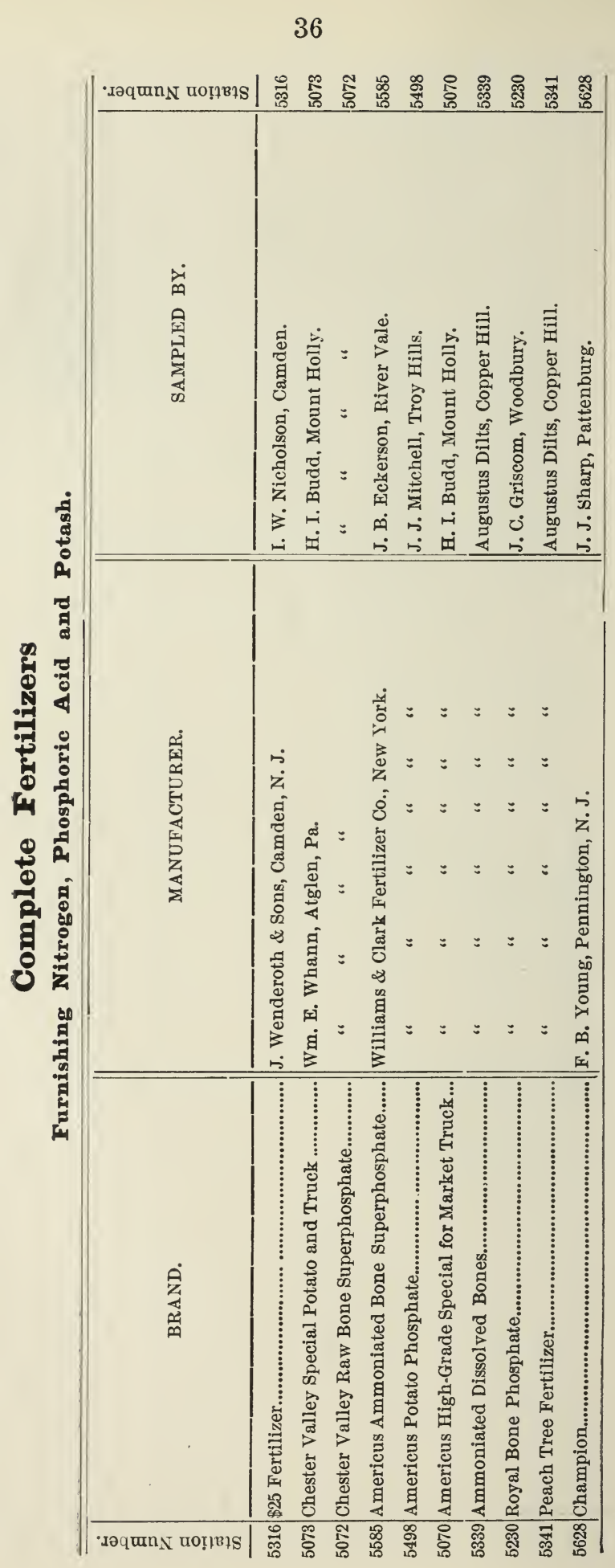




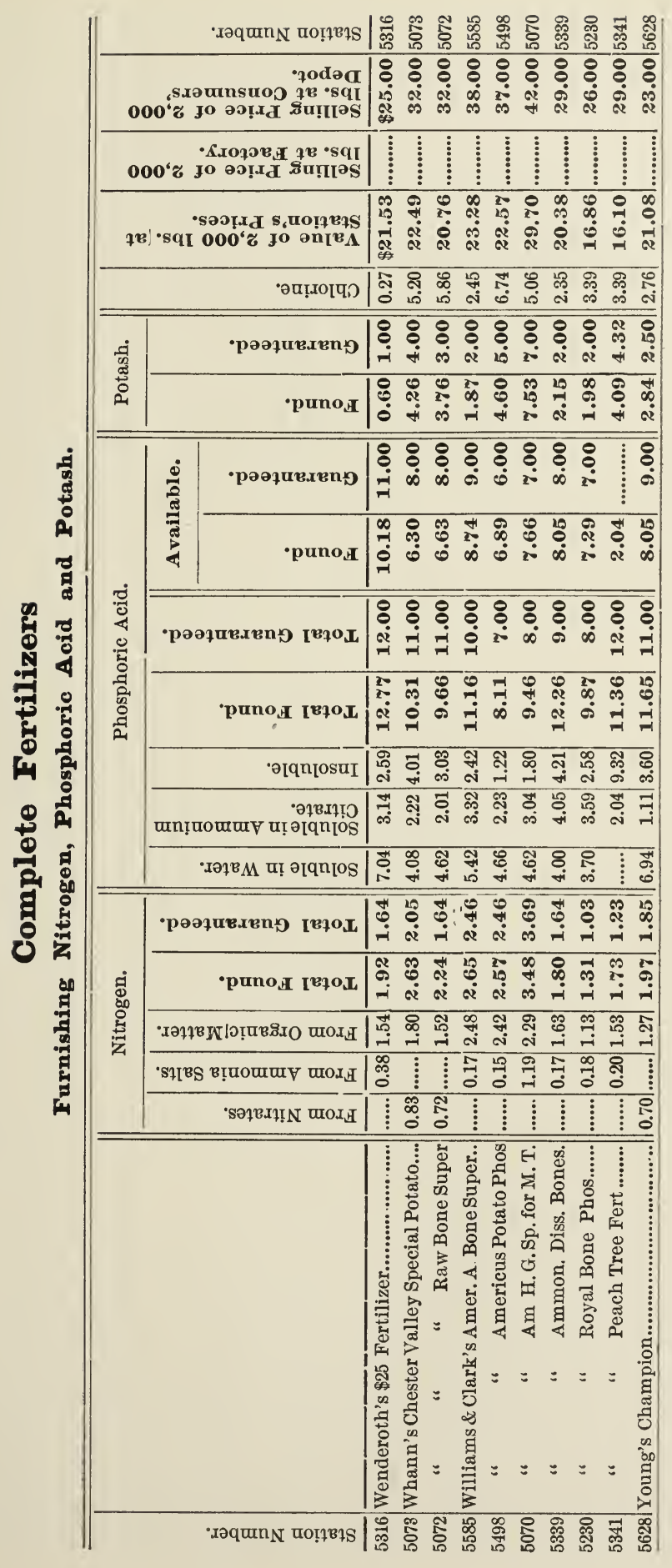




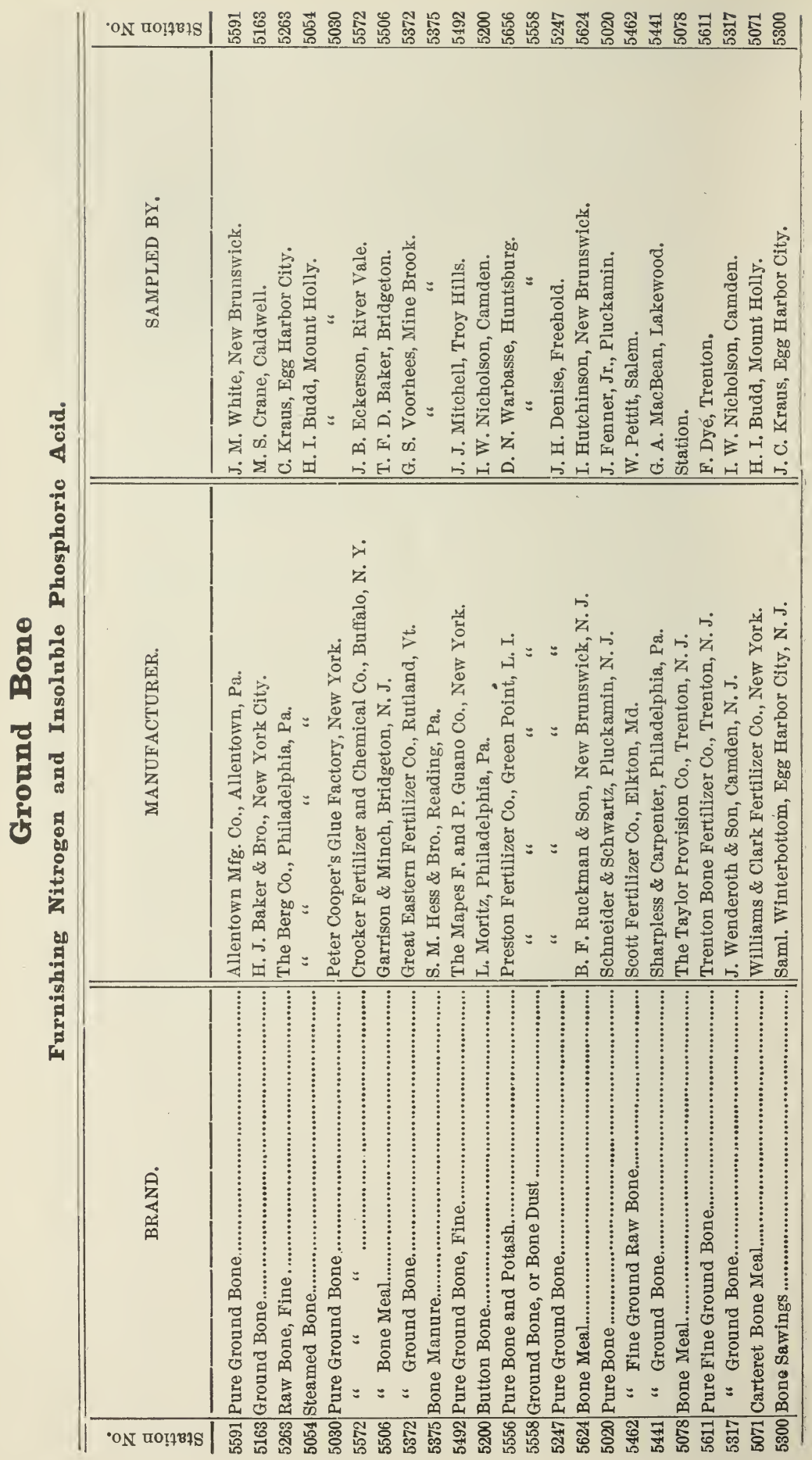




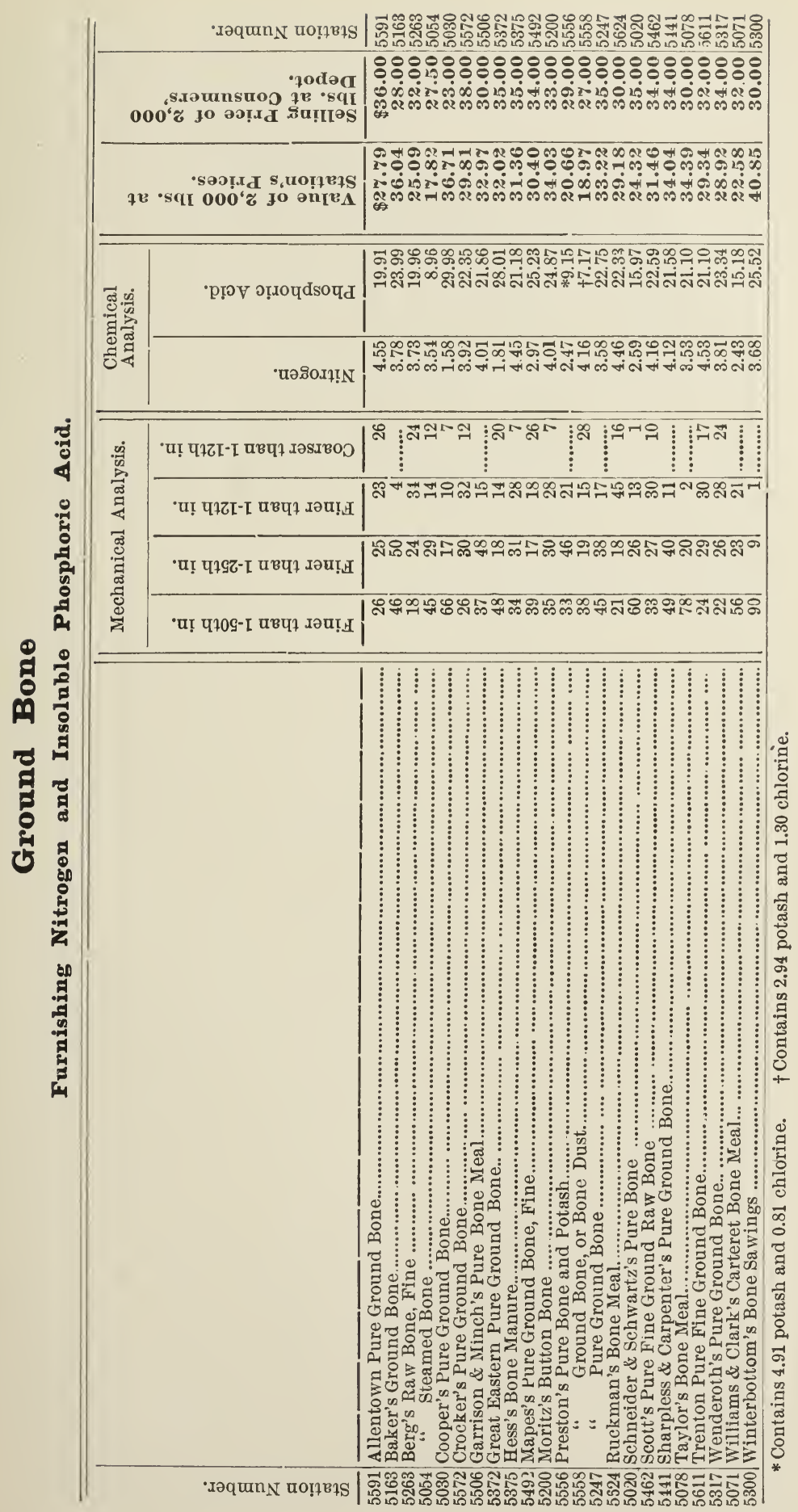




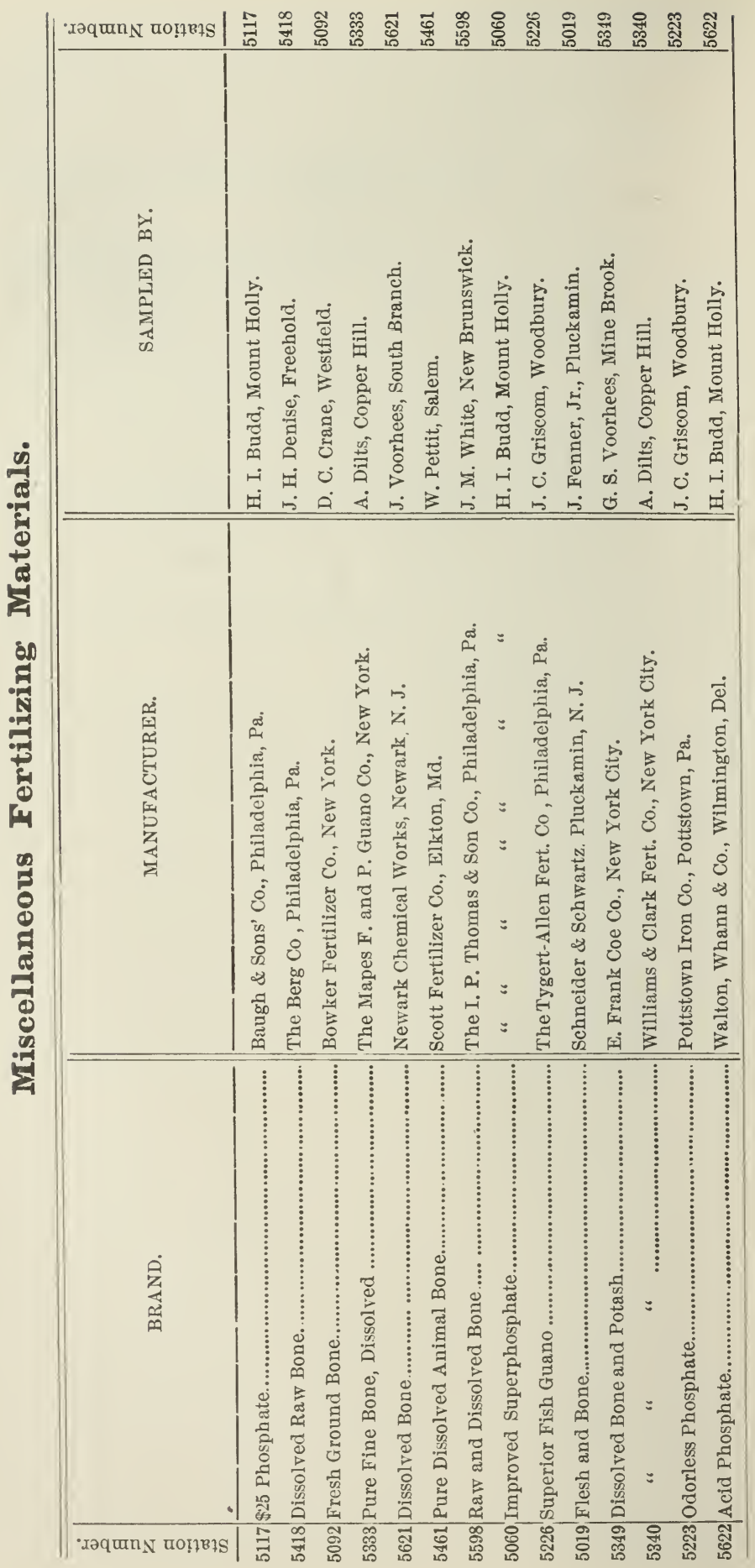




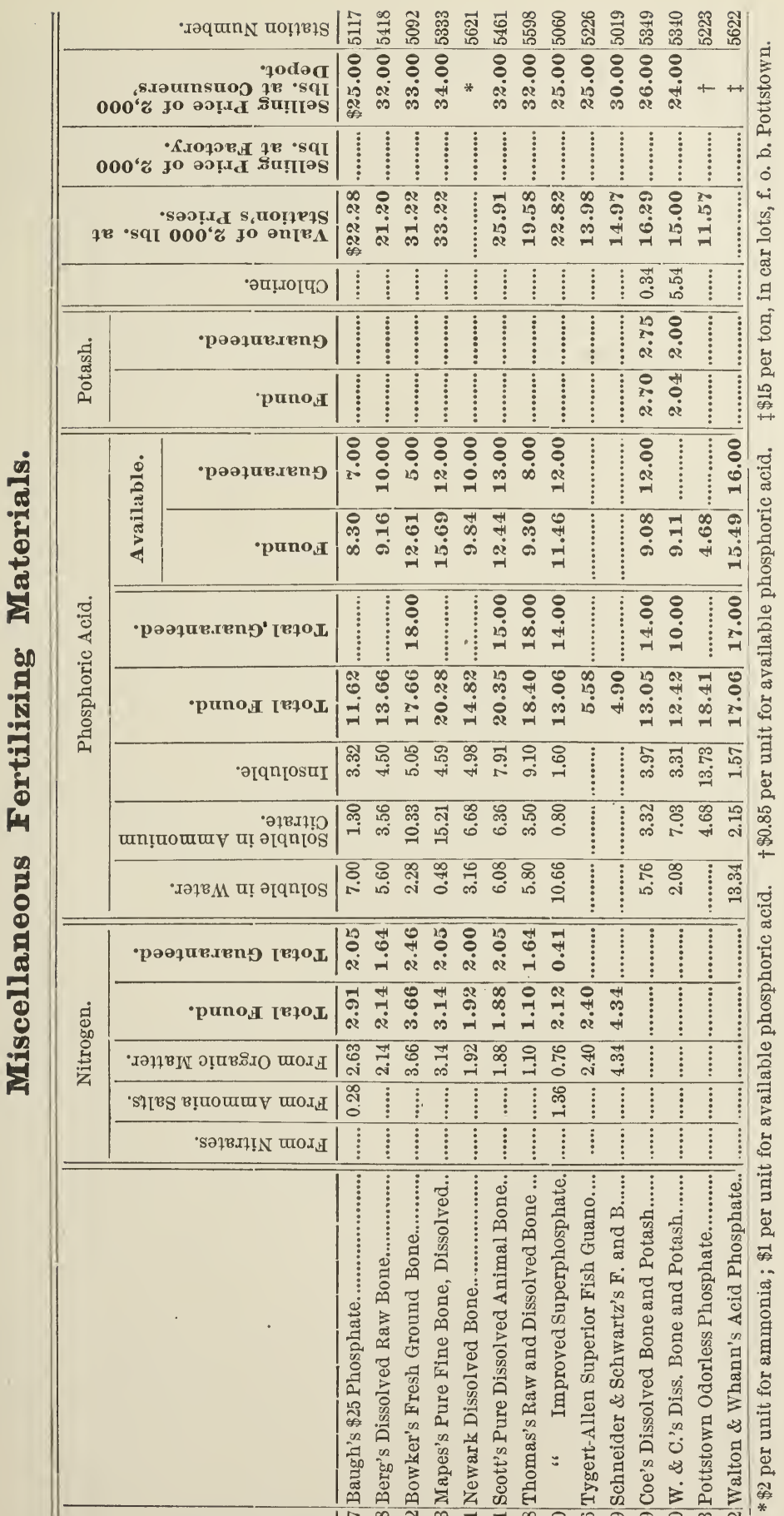


Canada Ashes.

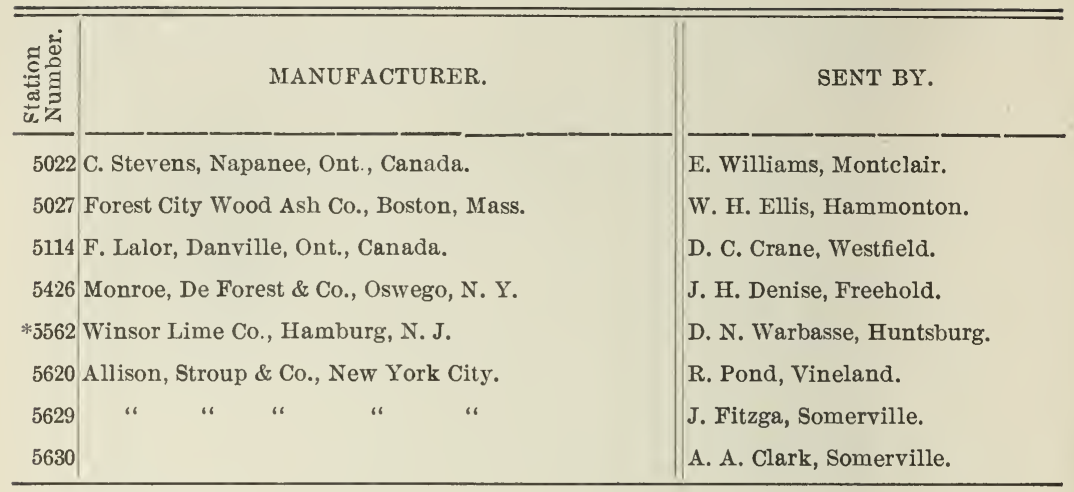

* Lime kiln ashes.

\begin{tabular}{lrrrrrrrr} 
& $\mathbf{5 0 2 2}$ & $\mathbf{5 0 2 7}$ & $\mathbf{5 1 1 4}$ & $\mathbf{5 4 2 6}$ & $\mathbf{5 5 6 2}$ & $\mathbf{5 6 2 0}$ & $\mathbf{5 6 2 9}$ & $\mathbf{5 6 3 0}$ \\
Phosphoric Acid........... & 1.61 & 1.22 & 1.57 & 1.48 & 1.13 & 0.95 & 1.06 & 1.21 \\
Potash.......................... & 5.96 & 5.92 & 4.78 & 4.44 & 0.54 & 3.90 & 4.95 & 3.32 \\
Lime........................... & 34.02 & 31.53 & 36.00 & 26.16 & 37.08 & 45.76 & 35.68 & 34.74 \\
Valuation Per Ton........ & $\$ 8.17$ & $\$ 7.73$ & $\$ 6.83$ & $\$ 6.36$ & $\$ 1.72$ & $\$ 5.24$ & $\$ 6.51$ & 4.86 \\
Selling Price Per Ton... & 12.00 & 12.00 & 13.00 & 15.00 & $\dagger$ & 13.00 & 11.00 & $\$ 11.00$ \\
\hline
\end{tabular}

† Selling price, $12 \frac{1}{2} \mathrm{cts}$. per bushel.

\begin{tabular}{|c|c|c|c|c|c|c|c|c|c|c|}
\hline \multirow{2}{*}{ 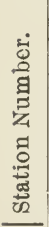 } & \multirow{2}{*}{$\begin{array}{c}\text { From A. H. Hawley, } \\
\text { Vineland, N. J. }\end{array}$} & \multirow[b]{2}{*}{ 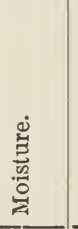 } & \multirow{2}{*}{ 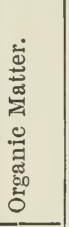 } & \multirow[b]{2}{*}{ 通 } & \multirow[b]{2}{*}{ 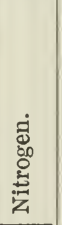 } & \multicolumn{2}{|c|}{$\begin{array}{c}\text { Phosphoric } \\
\text { Acid. }\end{array}$} & \multirow[b]{2}{*}{ 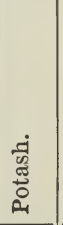 } & \multirow[b]{2}{*}{ 官 } & \multirow{2}{*}{ 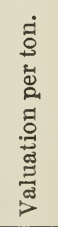 } \\
\hline & & & & & & 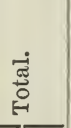 & 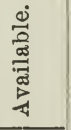 & & & \\
\hline 5024 & Belgian Hare Manure..... & 50.94 & 44.35 & 4.71 & 1.10 & 0.58 & 0.50 & 0.58 & 1.01 & $\$ 5.12$ \\
\hline 5025 & Pigeon Manure................ & 72.66 & 20.68 & 6.66 & 1.34 & 0.82 & 0.73 & 0.43 & 1.67 & 6.13 \\
\hline 5026 & Hen Manure.................... & 73.58 & 16.62 & 9.80 & 1.23 & 1.12 & 1.01 & 0.44 & 2.51 & 6.11 \\
\hline
\end{tabular}

5021. Wool Waste. J. Story, Philadelphia, Pa. Sent by A. McCullough, Folsom. It contains 2.42 nitrogen, 0.50 total phosphoric acid, and 2.10 per cent. potash. Valuation, \$6.41; selling price, $\$ 7$ per ton.

5125. Cotton-Seed Hulls. Tennessee Cotton Oil Co., Memphis, Tenn. Sent by H. I. Budd, Mount Holly. It contains 0.69 nitrogen, 0.56 total phosphoric acid, and 1.08 per cent. potash. Selling price, $\$ 9$ per ton. 
5210. Marl. Sent by C. M. Patterson, Red Bank, N. J. It contains 0.87 total phosphoric acid, 0.11 potash and 0.36 per cent. lime. Selling price, 50 cents per ton.

5629. Dried Swamp Muck. Sent by H. H. Rigge, Hightstown, N. J. It contains 1.24 nitrogen, 0.56 total phosphoric acid, 0.22 potash and 0.50 per cent. lime.

EDWARD B. VOORHEES, Director.

New Brunswick, N. J., November 6th, 1893. 
<smiles>C1C2CC1C2</smiles> 
CLUB-ROOT OF CABBAGE AND ITS ALLIES.

NEW JERSEY

Agricultural College

\section{Experiment Station.}

98 


\section{NEW JERSEY AGRICULTURAL COLLEGE EXPERIMENT STATION.}

\section{BOARD OF CONTROL.}

The Board of Trustees of Rutgers College in New Jersey.

\section{EXECUTIVE COMMITTEE OF THE BOARD.}

AUSTIN SCO'TT, Ph.D., LL.D., President of Rutgers College, Chairman. HoN. GEORGE C. LUDLOW, HENRY R. BALDWIN, M.D., LL.D., HoN. HENRY W. BOOKSTAVER, LL.D., JAMES NEILSON, Esq.

\section{STAFF OF THE STATION.}

AUSTIN SCOTT, Pн.D., LL.D., Director.

Professor JUliUs Nelson, Ph.D., Biologist.

Professor BYRON D. HALSTED, Sc.D., Botanist and Horticulturist.

Professor JOHN B. SMITH, Sc.D., Entomologist.

ELISHA A. JONES, B.S., Superintendent of College Farm.

IRVING S. UPSON, A.M., Disbursing Clerk and Librarian.

CHARLES A. POULSON, Mailing Assistant.

LEONORA E. BURWELL, Clerk to the Director.

AUGUSTA MESKE, Stenographer and Typewriter. 


\section{NEW JERSEY}

\section{Agricultural College Experiment Station.}

\section{BULLETIN 98.}

DECEMBER 9, 1893.

\section{Club-Root of Cabbage and its Allies.}

BY BYRON D. HALSTED, BOTANIST AND HORTICULTURIST.

The Club-root of the cabbage and turnip is an old enemy, having been known in Europe for more than a hundred years, and, being a fatal malady, with peculiar and prominent characteristics, it has received one or more names, often quite descriptive, in several of our leading modern languages. Thus, in Germany it is called "Kohlhernie;" in France, "Maladie digitoire;" in Belgium, "Vingerziekt," and Russia, "Kapoustnaja kila;" in Great Britain it bears the names of "anbury," "hanbury," "finger-and-toes" and other equally expressive terms, while with us, "club-root," "club-foot" and "clumpfoot" are the leading names for this trouble, the process being spoken of as "clubbing."

The injury to the crops attacked may be considerable, sometimes incurring almost a total loss, and in the aggregate the destruction for the whole country is doubtless represented by millions of dollars. It is particularly severe in the eastern portion of the United States, but is not unknown in the West and South, and during the past season (1893) has prevailed extensively in the truck regions around the large cities of New York and Philadelphia. New Jersey cabbage and turnip growers have suffered so heavily of late years as to sug- 
gest the subject as suitable for special consideration by the Experiment Station. Some facts with a practical bearing upon the question of how the club-root lives over from one year to another, have been

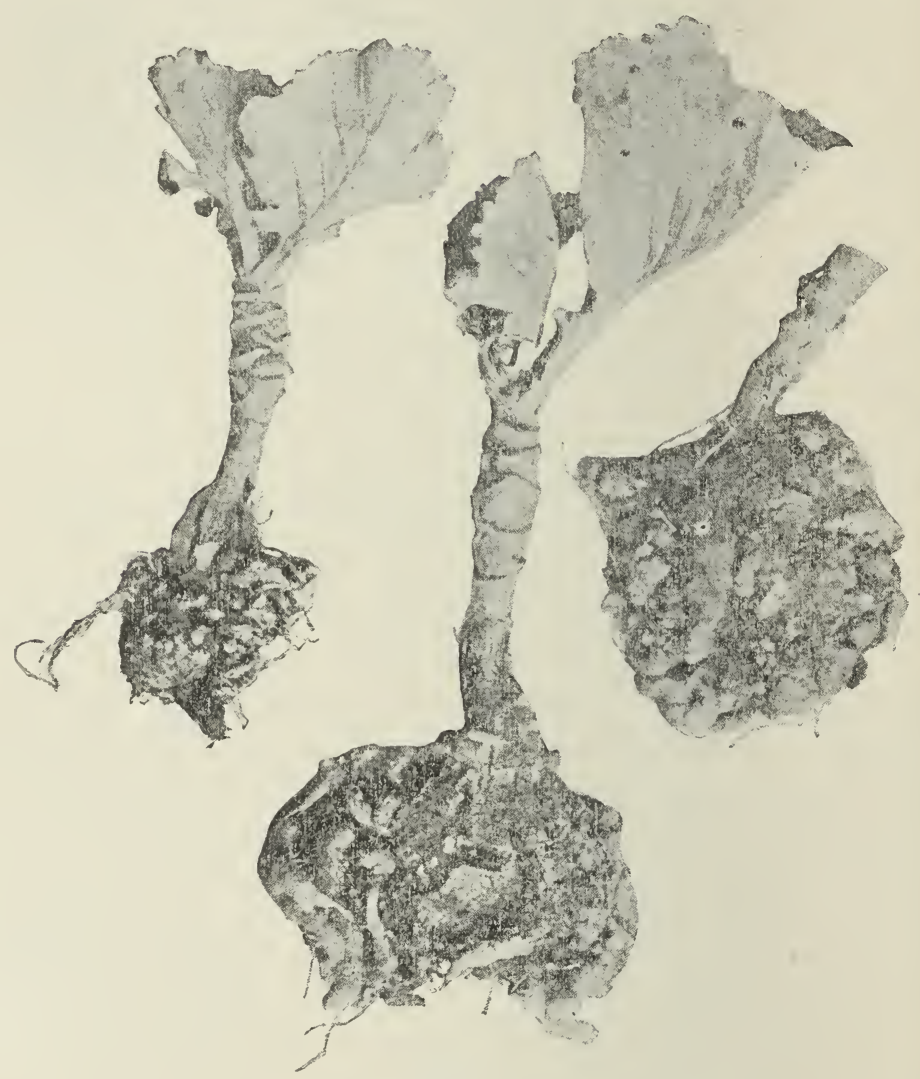

Fig. 1.

Three small cabbage plants badly "clubbed."

literally unearthed, which alone might warrant this publication. The weed plants that harbor this enemy, with engravings showing the pest, will be considered in their proper places later in this bulletin.

\section{The Nature of Club-root.}

In order that the reader may derive the most practical good from any suggestions as to use of preventives and other treatment of the disease, it is best to place before him the facts thus far obtained con- 
cerning club-root. The name of the malady is quite descriptive, for it is an affection of the roots, which become much distorted. The roots may begin to show enlargements while they are quite small and before the plants are more than seedlings. Thus, cabbages while growing in the hot-bed may show unmistakable signs of "clubbing," followed by a loss of vitality throughout the whole plant. The affected parts soon begin to decay, becoming very offensive, and, from places near by, other roots are developed, which, in turn, become swollen and distorted into various shapes.

Figure 1 shows three young cabbage plants taken from a field that was nearly ruined by the club-root. Instead of the numerous long fibrous roots, by means of which the plants are able to obtain the required nourishment from the soil, there is in each an extravagant malformation consisting of a much-knotted and enlarged root-system. The engraving of the three samples is from a photograph, and shows the general appearance so well that further description is unnecessary.

That which is of the most interest in this connection is the cause of the peculiar development and consequent destruction of the infested plants. As in nearly all instances of similar abnormal structures, these root-galls were long ago assigned to insects. A careful study of their development failed, however, to convict any species or group of insects of these depredations, and after much speculation, and no end of articles in the agricultural journals and elsewhere, it was reserved for M. Woronin, a European botanist, after three years (1873-76) of painstaking and exhaustive study, to explain the nature of the subject before us. From his published results* in particular and a recent paper $\dagger$ by Mr. A. C. Eycleshymer, the information as to the microscopic structure is largely obtained.

Instead of any insects being the cause, although such decaying masses usually become the breeding-places for them, Woronin found that a low form of fungus was constantly present in the affected parts. This parasitic organism is only seen with the higher powers of the compound microscope. The family of fungi to which it belongs, namely, the slime moulds, is widely distinct from the mildews, rusts and smuts, and some of Woronin's and Eycleshymer's illustrations, as given in two plates which accompanied the latter author's paper and

* Plasmodiophora Brassicæ. Urheber der Kohlphlanzen Hernie. Prmgs. Jahr. F. Wiss. Bot., Bol. XI., 1878, Plates 6.

$\dagger$ Club-root in the United States; Journal of Mycology, Vol. VII , p. 79, Plates 2. 
Fig.
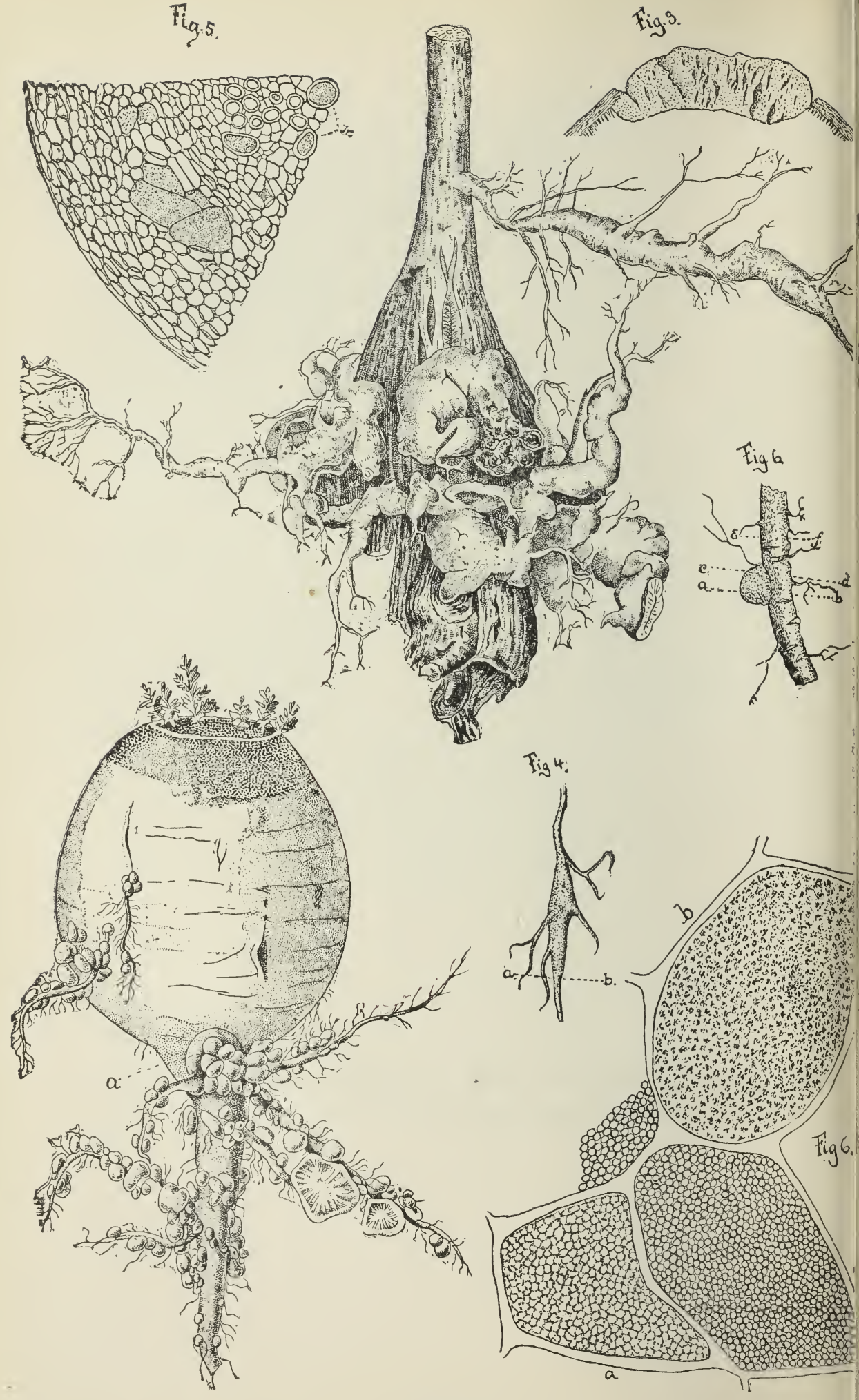

Plate I. 

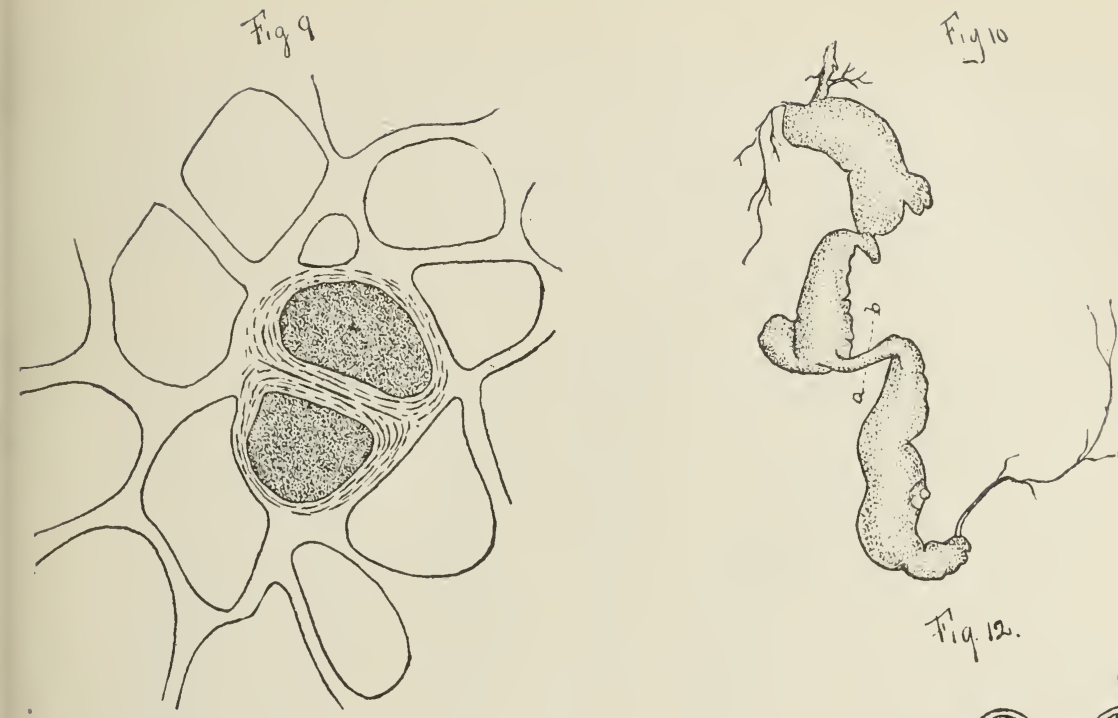

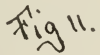

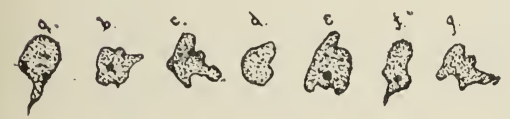
xig13.

(1)

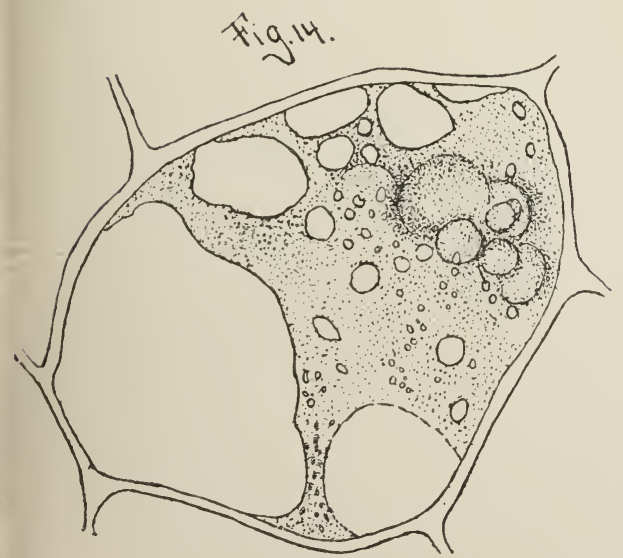

- 0 oto

1
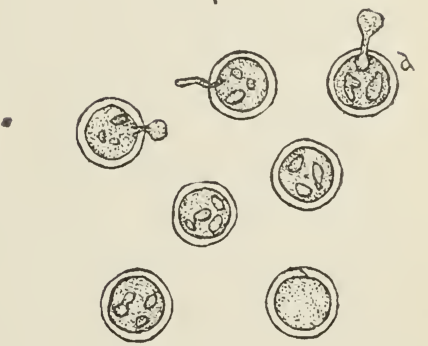

xig 16.
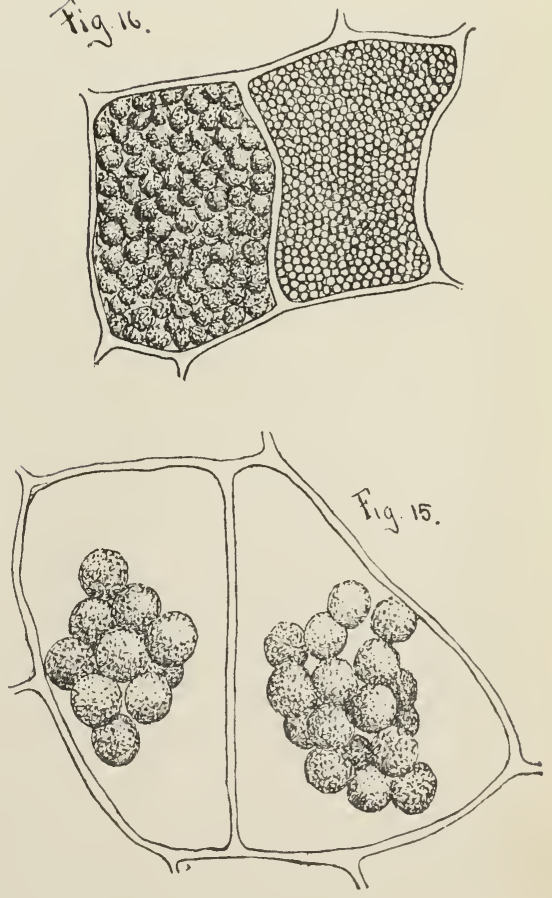

Plate II. 
kindly loaned by Professor Galloway, are here reproduced, to make the nature of the club-root fungus clear. Ordinary fungi, like the grape mildew, corn smut, wheat rust and celery leaf-spot, have long, slender feeding threads which work their way through the tissues of the affected plant. There are no such threads with the cabbage slime fungus.

In Plate I., the first figure shows a specimen of diseased cabbage, natural size, and Figure 2 a "clubbed" turnip. Figure 3 is a portion of a section of a turnip root, and Figure 4 is a rootlet of diseased cabbage, seven weeks after infection. At Figure 5 is shown a muchmagnified view of a section of root (Figure 4) along the line $a, b$. A portion of a turnip root, seven weeks after infection, is shown at Figure 6, natural size, and at $6, a$, are shown cells from the section along the line $a, b$, of Figure 6 , and two hundred times magnified.

In Figure 5, scattered irregularly midway of the center and circumference, are large cells filled with a slimy substance and differing from the other and smaller cells. These are infested with the slime mould, and, on account of the presence of this parasite, the cells undergo remarkable enlargement, and an influence is communicated to the outer neighboring cells so that the root becomes much swollen and even distorted. In its early stages of development the fungus is simply a semi-liquid substance within the cells of the root tissue; but as it reaches maturity the contents of the infested cells become granular and finally they contain a multitude of minute spherical bodies, which are the spores of the mould. In short, this fungus, in the form of a slime or plasma, obtains entrance to the cells of the growing root and there robs the infested tissue of its vital fluids, and, gathering new forces to itself, fills the cells with its own substance. This semifluid material then begins the process of spore formation, which results in the production of millions of minute bodies each of which is capable of a new growth when conditions are favorable.

The three cells, $a, b$ and $c$, in Figure $6, a$, help to show these peculiarities, but the second plate is devoted in particular to the points of development of the fungus. Thus, Figure 9 is a portion of a section of Figure 10 at the line $a, b$, and magnified six hundred times. The two cells shown shaded were completely filled with the plasma or slime of the mould. The spores which form from this semi-fluid substance are spherical, as shown at Figure 12, and in germination their contents come out as seen at $a$, becoming naked bodies capable 
of movement and change in outline, the latter fact being illustrated at Figure 11. These motile bodies may unite with their fellows and form masses of semi-liquid substance, as shown in different forms at Figure 13. A single cell of the cabbage root is shown at Figure 14,

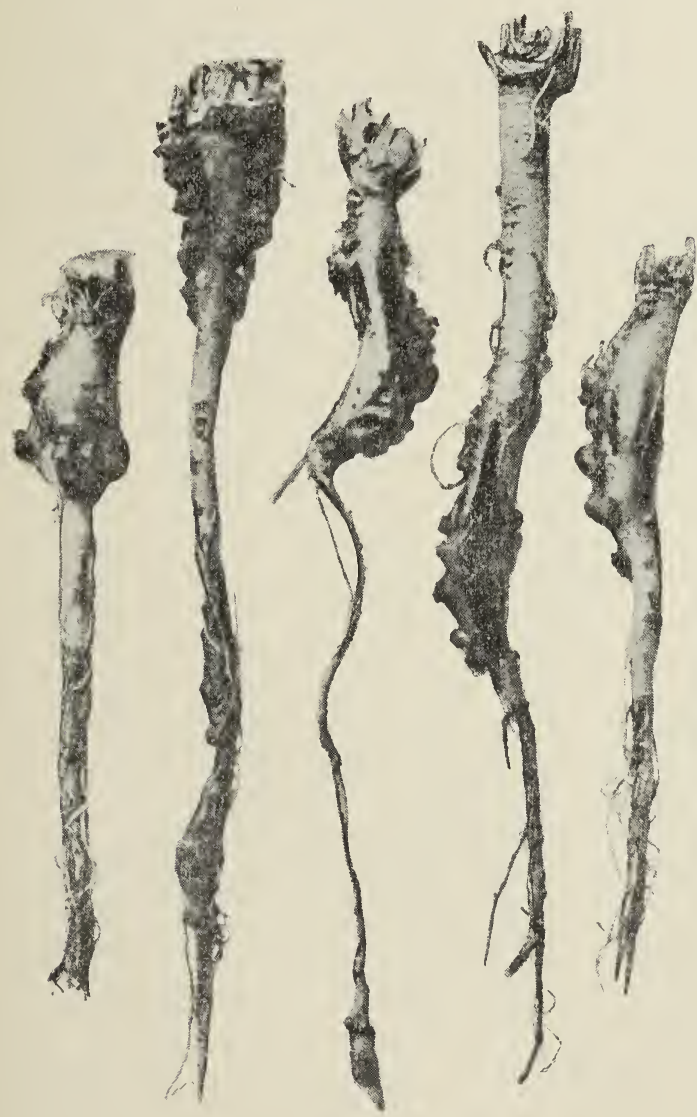

Fig. 4.

Club-root in roots of shepherd's purse. in the early stage of the disease, magnified six hundred times, while at Figure 15 are two cells later in the development and showing the formation of the plasma into spheres. Figures 16 shows the appearance of the fungus two hundred times enlarged.

We have traced above the life of the obscure club-root parasite, from its appearance in the root as a slime in certain cells to the formation of multitudes of spores in these same cells. By the decay of the roots, which takes place rapidly, and with much offensive odor, the spores are set free in the soil. These spores there germinate by producing moving bodies capable of penetrating or being absorbed by the thin walls of the hairs and other superficial cells of the roots. The soil becomes diseased in the sense that the germs, formed in the swellings and other distortions of the roots, are set free and the earth holds them for an indefinite length of time. 


\section{The Club-root in Weeds.}

It is generally known to the students of the club-root fungus that it is not confined to the cabbage and turnip, and this leads to the statement of the botanical name of the parasite we have been con-

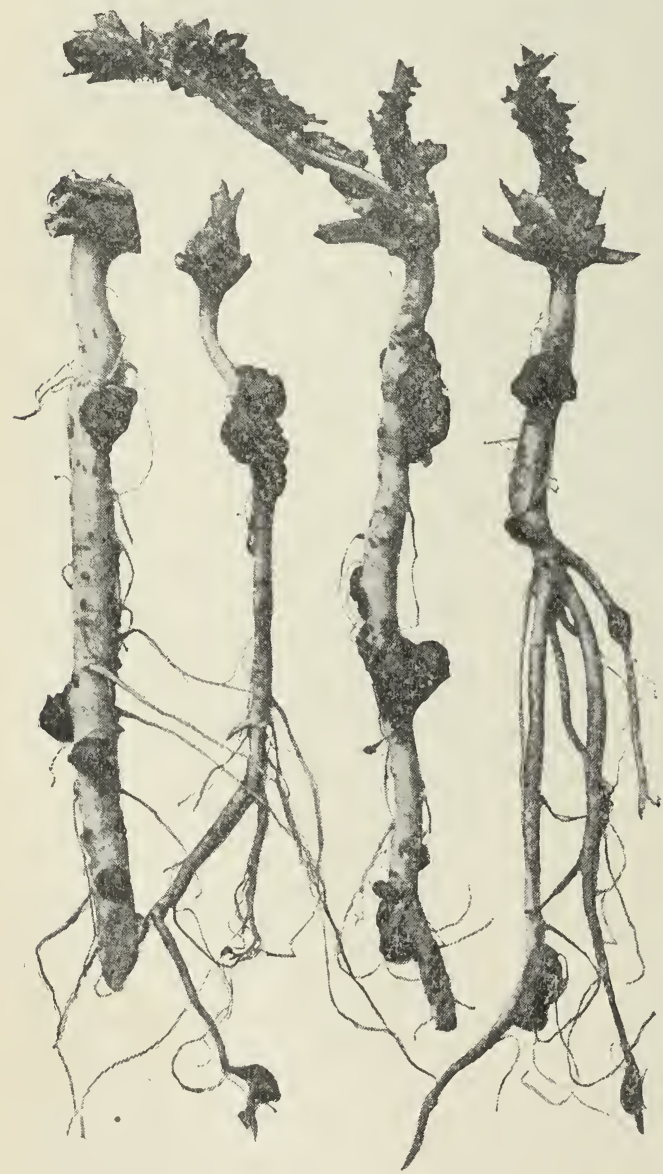

Fig. 5.

Roots of hedge mustard with club-root. sidering. Woronin found it so different from all the other slime moulds as to warrant its being put in a separate genus, which he named Plasmodiophora - that is, the plasma or "slime bearer ;" and, as it infested the cabbage and turnip, both members of the genus Brassica, he made the species Plasmodiophora Brassicce, Wor. Since then two other species of the same genus have been discovered, namely, Plasmodiophora Alni, Wor., upon alder-roots and Plasmodiophora Eloeagni, Schroet., on the roots of Elæagnus. Various works make mention of the club-root being found upon many species of the mustard family, but it is unfortunate that the particular species are not given. Saccardo* states that it is found in several cruciferæ (Brassica, rarely Iberis umbellata). Dr. Zopf $\dagger$ adds to these, "Levkoje" - that is, the Stock (Mathiola incana), also mentioned

* Sylloge Fungorum, Vol. VII., p. 464.

† Die Pilzthiere oder Schleimpilze, p. 129. 
by Woronin. Sorauer* and Frank $\dagger$ simply confirm the above statements. Eycleshymer $\$$ says: "The plants affected are for the greater part confined to the genus Brassica, including the cabbage, cauli-

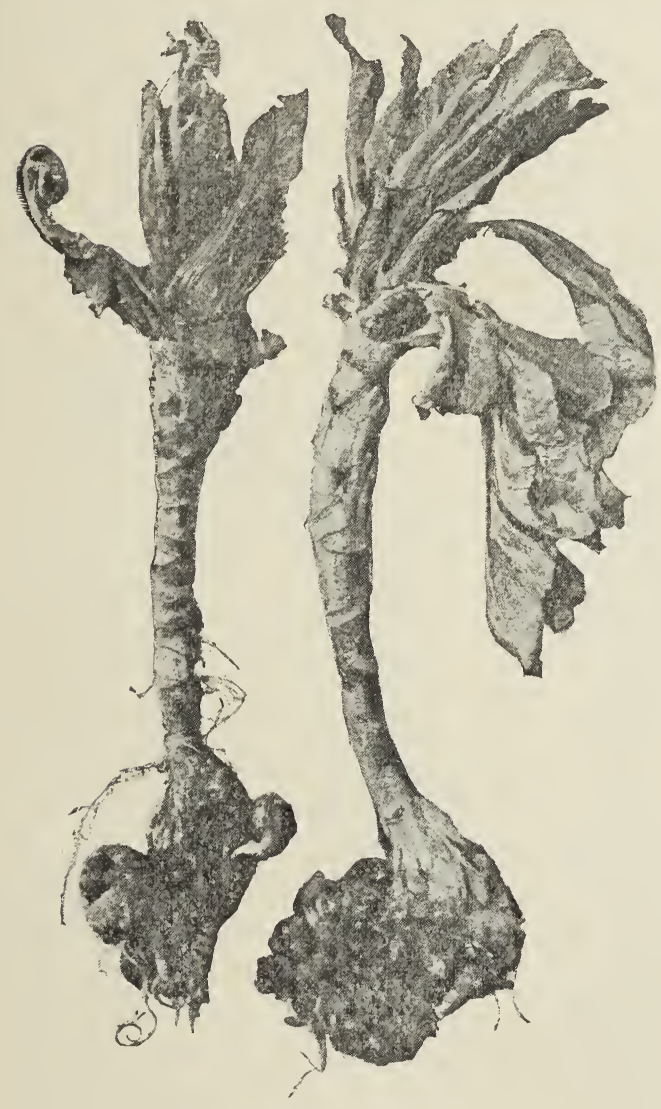

Fig. 6.

Cauliflower with club-root. flower, turnip, ruta-baga. Halsted has recently described it as occurring in the radish. In Russia it effects the genus Mathiola and Iberis."

So far as the actual species of the host of the club-root fungus can be determined from the books at the writer's disposal, the list is Brassica oleracea (varieties), $B$. rapa, Raphanus sativus, Iberis umbellata and Mathiola incana. This is only five species, the last three of which are known to be but rarely affected.

In view of these facts, it is interesting to add to the list two other genera, each with a single species, but both are among our most common weeds, namely, the shepherd's purse (Bursa pastoris, L.) and the hedge mustard (Sisymbrium vulgare, L.).

Figure 4 shows a group of the infested roots of the shepherd's purse. It must be borne in mind that the roots of this prevalent weed are not succulent and the galls are correspondingly small. However, there is no difficulty in distinguishing a diseased from a

* Pflanzen Krankheiten, Part II., p. 69.

$\dagger$ Die Krankheiten der Pflanzen, p. 238.

$\ddagger$ Club-root in the United States; Journal of Mycology, Vol. VII., p. 49. 
healthy plant, even from the appearance of the plant above ground when thoroughly infested, it having a dwarfed and sickly-yellow appearance.

In Figure 5 is seen a similar group of the clubbed roots of the hedge mustard. The general appearance of these galls is quite differ-

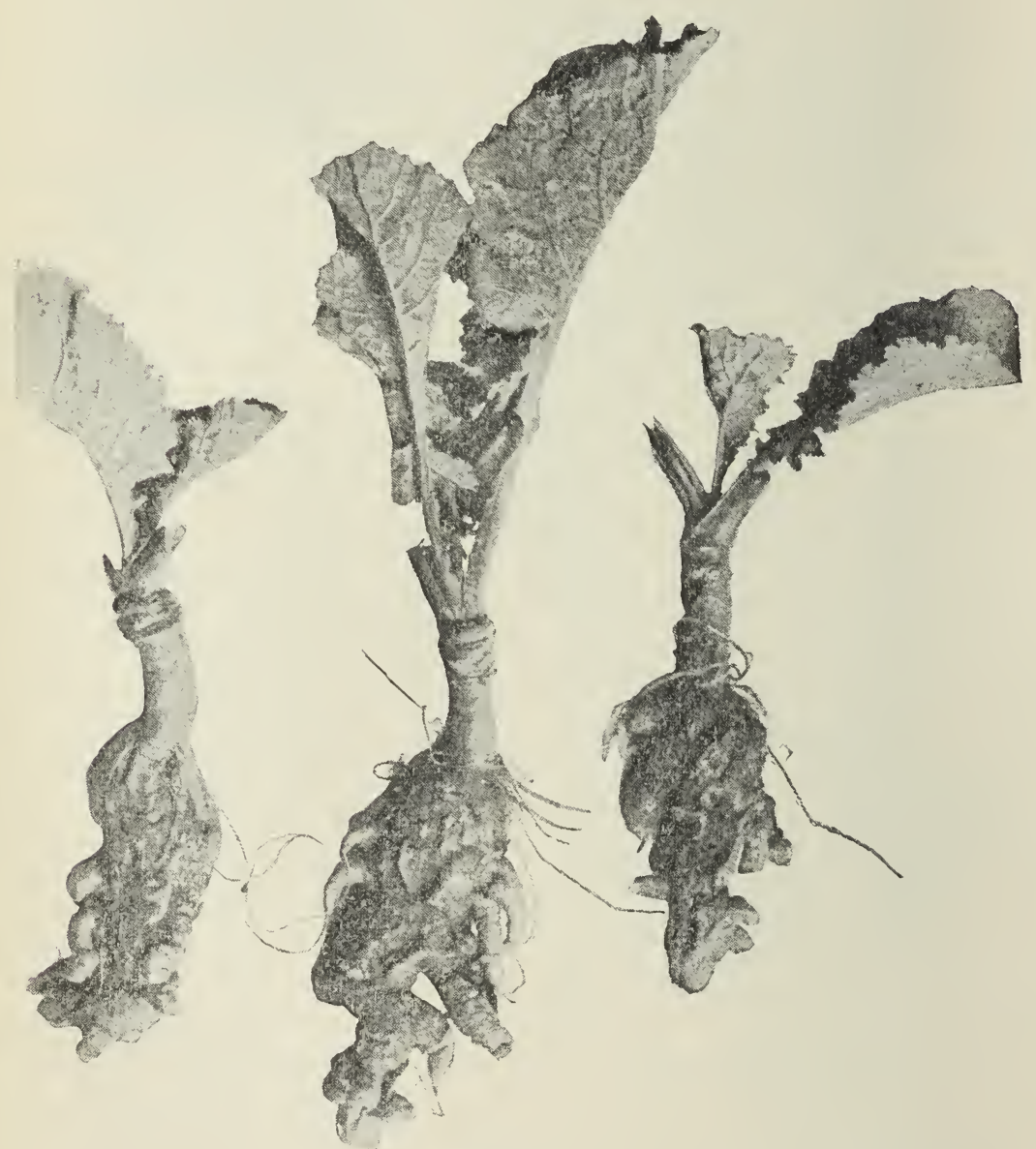

Fig. 7.

Turnips with club-root.

ent from those of the shepherd's purse, being more regular in form, standing out like dark warts from the otherwise well-shaped roots.

In this connection, to add to the information concerning the clubroot upon our crop plants, an engraving each of the cauliflower 
(Fig. 6), turnip (Fig. 7), Brussels sprout (Fig. 8) and kale (Fig. 9) are added. They were all made from photographs by Prof. Smith, of fresh specimens collected by Mr. J. A. Kelsey. The cauliflower and cabbage resemble each other in the general form of the "club" that is produced, and in like manner the kale and turnip galls are somewhat alike. But there is no uniformity in the matter, and the size and shape of the malformations are largely determined by circumstances.

\section{Precautions and Treatment.}

From a consideration of the nature of the club-root fungus and a knowledge of the different kinds of plants infested by it, there may be some suggestions gathered as to preventive measures. When it is understood that the clubroot and all the injury to the crop accompanying it is due to an internal subterranean parasite, it becomes evident that no treatment to which the infested plant may be subjected can give promise of a cure. Preventive measures must be relied upon, and, in the first place, all the refuse of a cabbage, turnip or other infested crop should be removed from the soil and burned. To leave cabbage stumps in the field, feed them to live stock or

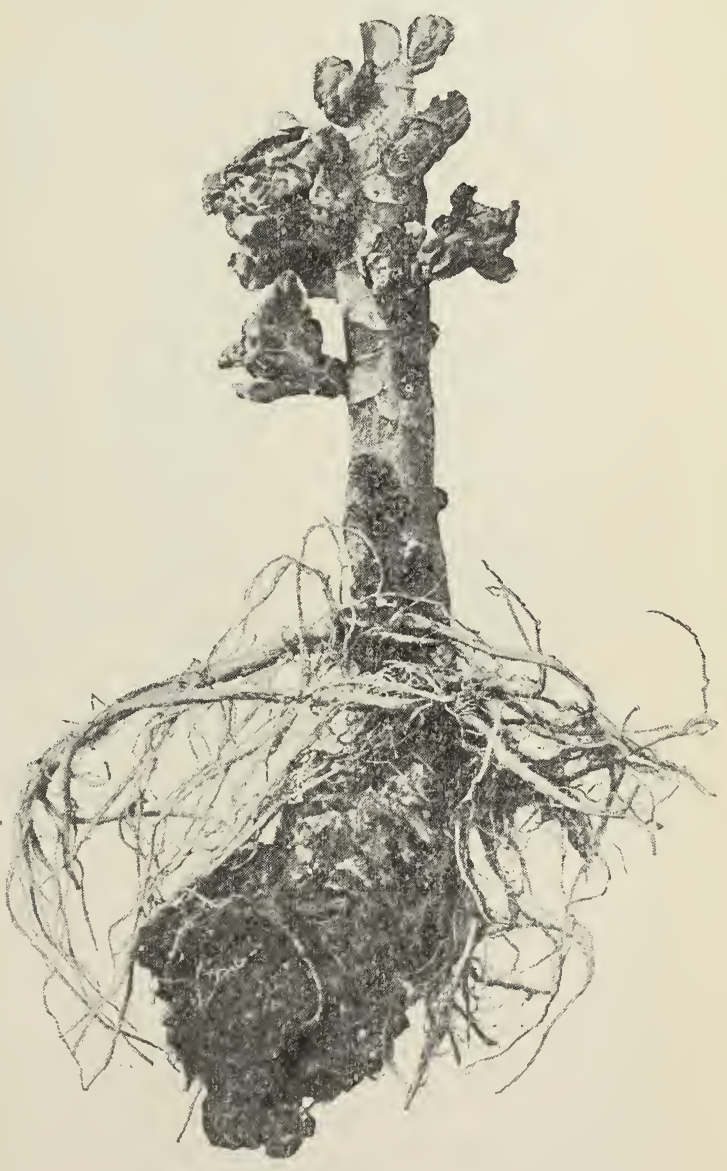

Fig. 8.

Brussels sprout with club-root. 
throw them in the compost heaps, are three of the best methods of propagating and spreading the malady on the farm. It is not enough to destroy the roots, for the Plasmodiophora is found also in the leaves, as Woronin took particular pains to show by means of an engraving in his paper.

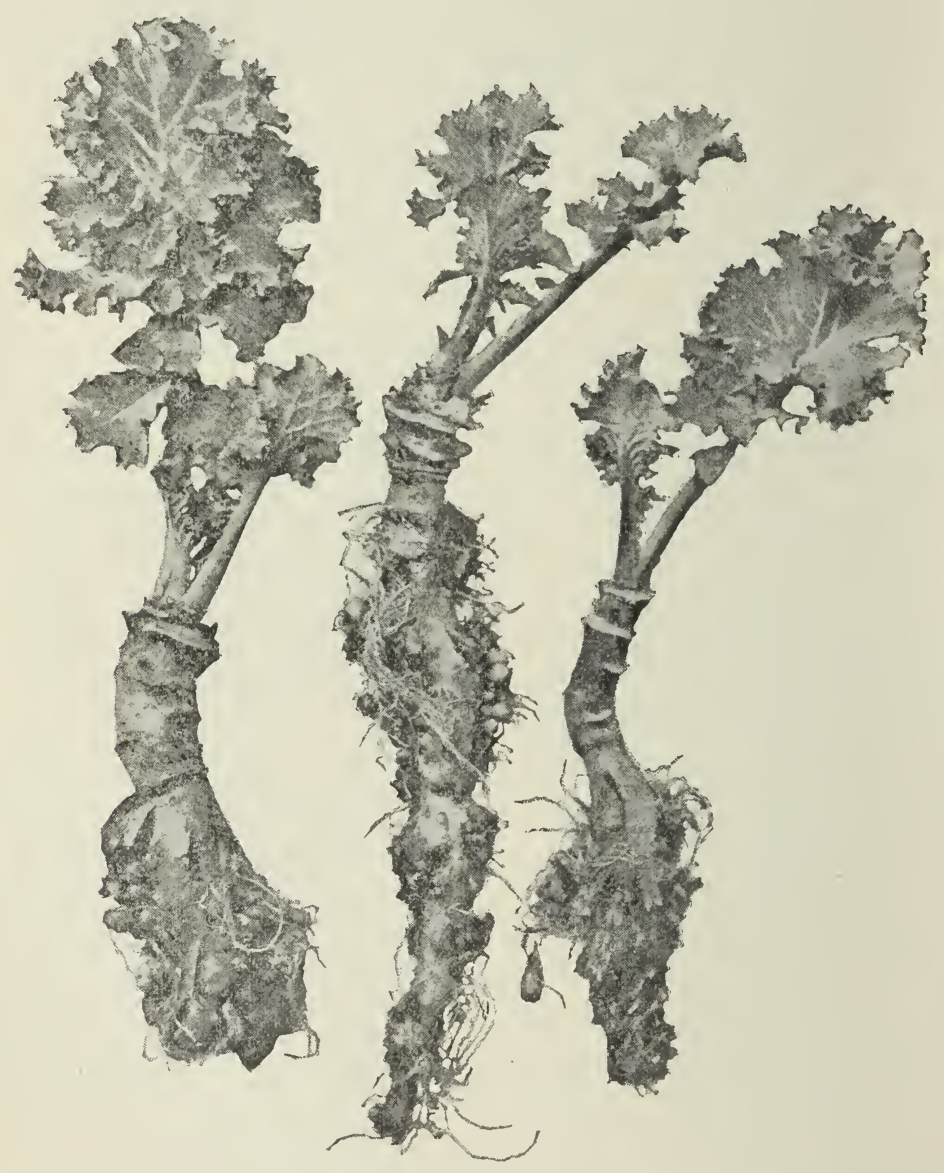

Fig. 9.

Kale with club-root.

Seedlings grown in the hot-bed should be examined carefully, and, if they show signs of the club-root, consigned to the fire. If only a portion of the plants are clubbed, it may be wise to discard the whole lot rather than lose the crop in the field. Start with healthy plants.

In view of the fact that the soil may become more or less impreg- 
nated with the germs during the growth of a crop susceptible to the Plasmodiophora, it is evident that a wise precaution consists in a judicious rotation of crops. Just what that rotation should be is a question for each grower to decide for himself; but, for the best results, cabbages or any allied crop should not be upon the soil oftener than once in three years. Cabbage, kale, Brussels sprouts, kohlrabi, turnips or radishes should not follow each other if club-root is prevalent.

It is possible to get relief by the use of some of the commercial fertilizers; but this needs confirmation through trial. It is a fact that is being acted upon in some of the large truck regions near New York, that lime is an effective preventive of the club-root, and, by its constant use, at the rate of seventy-five bushels or so per acre each year, cabbages have been grown at frequent intervals-almost yearly, upon the same soil. It is likely that a soil naturally abounding in lime may be the best suited for cruciferous crops, so far as club-root is concerned.

Lastly, it has been shown that common weeds harbor the fungous enemy, and, while the farmer may be thankful for the loss of his hedge mustard and shepherd's purse, through "clubbing," this is a case where weeds can be more cheaply destroyed in some other way.

\section{Conclusions.}

Club-root, an old enemy to cabbage and turnip in Europe, has been quite destructive to these crops in New Jersey during the past few years.

The malady is due to a microscopic parasite which infests the cells of the roots, causing them to become swollen and distorted.

The spores of the fungus, upon the decay of the part affected, become scattered through the soil, and from thence the enemy enters the host plant.

Plasmodiophora Brassicce, Wor., infests several plants of the cabbage family, including turnip, kale, radish, stock and candytuft.

Two common weeds, namely, shepherd's purse and hedge mustard, are now to be added to the list of plants infested with club-root.

Preventive measures must be relied upon, for the affected parts of a plant are below ground and not readily reached by any fungicide. 
If the crop is diseased, all refuse at harvest-time of roots, stems and leaves should be burned.

All seedlings from hot-beds with signs of club-root should be destroyed, and, if possible, use only plants from beds in which there is no disease.

Cabbage, kale, Brussels sprouts, kohlrabi, turnip or radishes should not follow each other on the same land if club-root is prevalent.

Lime added to the land, seventy-five bushels per acre, has proved effective. It is possible that some commercial fertilizers may be found to check the trouble.

Keep the land free from shepherd's purse and hedge mustard, and other weeds of the same family, as their roots become "clubbed," and thereby propagate the enemy. 


\title{
fan, 8,1895
}

THE PEAR MIDGE.

(Diplosis pyrivora, Riley.)

\section{NEW JERSEY}

\author{
Agricultural College
}

Experiment Station.

99 
NEW JERSEY AGRICULTURAL COLLEGE EXPERIMENT STATION.

\section{BOARD OF CONTROL.}

The Board of Trustees of Rutgers College in New Jersey.

\section{EXECUTIVE COMMITTEE OF THE BOARD.}

AUSTIN SCOTT, Pн.D., LL.D., President of Rutgers College, Chairman. HoN. GEORGE C. LUDLOW, HENRY R. BALDW IN, M.D., LL.D. HoN. HENRY W.BOOKSTAVER, LL.D., JAMES NEILSON, Esq.

\section{STAFF OF THE STATION.}

AUSTIN SCOTT, Ph.D, LL.D., Director.

Professor JULIUS NELSON, Рн.D., Biologist.

Professor BYRON D. HALSTED, Sc.D., Botanist and Horticulturist.

Professor JOHN B. SMITH, Sc.D., Entomologist.

ELISHA A. JONES, B.S., Superintendent of College Farm.

IRVING S. UPSON, A.M., Disbursing Clerk and Librarian.

CHARLES A. POULSON, Mailing Assistant.

LEONORA E. BURWELL, Clerk to the Director.

AUGUSTA E. MESKE, Stenographer and Typewriter. 


\section{NEW JERSEY}

\section{Agricultural College Experiment Station.}

\section{BULLETIN 99.}

APRIL 4, 1894.

\section{The Pear Midge.}

(Diplosis pyrivora, Riley.)

BY JOHN B. SMITH, ENTOMOLOGIST.

The "Pear Midge" is one of the insects which has been introduced into the United States within recent years, and has, in its spread, developed into the most injurious pest with which the pear-grower has to deal. Its spread has not been extraordinarily rapid, but it has been none the less continuous, and it is annually enlarging the area occupied by it.

The first complaint made came from Connecticut, in 1884, while I was employed by the United States Entomologist, and under the direction of Dr. C. V. Riley I visited the fruit farm of Coe Bros., at Meriden, to investigate. I found that the species had probably been introduced from France in pear stocks imported in 1877, some seven years previously. Two years thereafter, in 1879, the insect was first noticed in the orchard, favoring Lawrence pears, and it increased annually thereafter until in $\mathbf{1 8 8 3}$ it took almost the entire crop. No variety was quite exempt, though the Lawrence remained the favorites. Bartletts came next and all other varieties seemed affected in the order of 
the lateness of blossoming; 1884 was an "off year" for pears, and the Messrs. Coe had resorted to the heroic remedy of picking all the fruit from the trees and destroying it. Unfortunately the work was not completely done before the larvæ matured, and still worse, it had already spread to neighboring orchards, where matters were left to take their course. Yet the insect appeared to be confined to a limited area, so far as observation went, and it could then have been exterminated by concerted action. Such action was recommended in my report on the matter and was strongly urged by Dr. Riley in 1885-without practical result, of course.

Since that time it has continued to spread, as was predicted by Dr. Riley and myself, and in 1891 was reported in destructive numbers from New York and New Jersey. In New York it had extended up the Hudson river valley in force as far as Catskill, and in isolated specimens to Albany; while in New Jersey it was abundant, locally, in Union and Essex counties. It is more than probable that in our own State the insect had been present for at least two years, if not even longer, before it was noticed. I could not learn that there had been any direct importation with plants from Connecticut, and a normal spread is therefore indicated.

My report for 1891 contains an account of the insect, and the report of Dr. J. A. Lintner, the State Entomologist of New York, for the same year, contains a full history of the species. In 1892 the insect was present in destructive numbers at New Brunswick, N. J., and active experiments were made looking to its control. In 1893 it had continued its spread in Middlesex county and had extended into Monmouth county. Experiments and observations made in 1892 were continued in 1893 , and a practical method of controlling the insect has been worked out.

It need not be said that the pear-growing industry is an extremely important one in this State, and that all horticulturists are directly affected by this destructive pest. That it will continue to spread is reasonably certain, and its appearance may be expected in 1894 in many new localities. This bulletin is intended to inform growers of what the insect is like, what injury is done, and what measures for its destruction should be adopted. 


\section{Appearance of the Fly.}

The adult insect or fly much resembles a diminutive mosquito, the expanded wings measuring less than one-fifth of an inch. It is of a pale grayish color with a slender body and very long legs, allied to such pests as the "Hessian fly," "clover-seed midge," "cranberry tip-

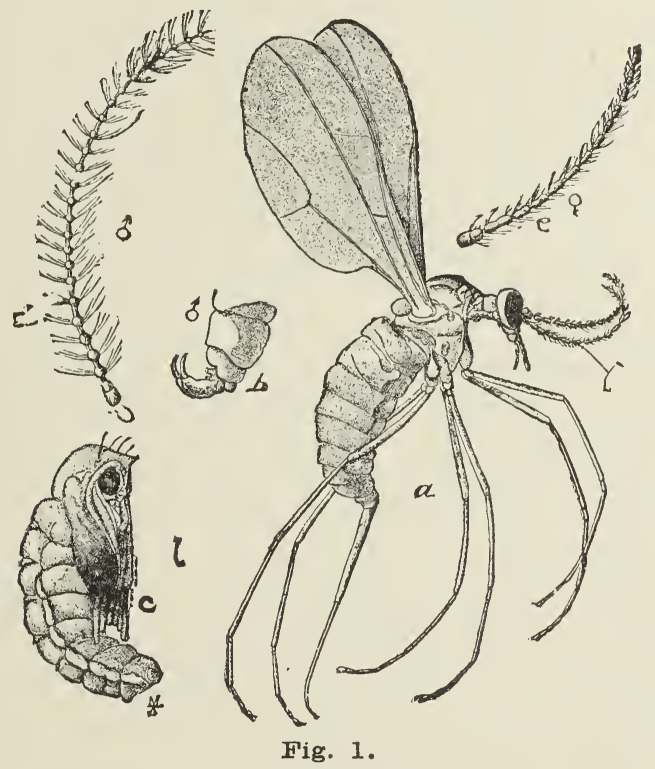

DIPLOSIS PYRIVORA.

The Pear Midge: $a$, the mature fly, female; $b$, tip of abdomen of male; $c$, the pupa; $d$, the male, and $e$, the female antenna. (After Riley.)

worm," \&c. It makes is appearance very early in the season, before the buds of the pear blossoms open, and remains on the wing for a week or at most ten days thereafter. Its appearance is shown in Figure 1, illustrating the female fly from the side.

\section{Egg-Laying Habits.}

The insect has been studied in Europe, and its method of egg-laying has been noted by Schmidberger as far back as 1840. As I have not had the opportunity of observing this process myself I reproduce that already published. 
Schmidberger's account is as follows :

When the blossom-buds of the pear tree were so far developed that in the single blossoms a petal showed itself between the segments of the calyx, I found the first gall-midge in the act of laying it eggs in the blossom; this was on the 12th of April. It had fixed itself almost perpendicularly in the middle of a single blossom, and having pierced the petal through with its long ovipositor, it laid its eggs on the anthers of the still closed blossom. The female was about seven and a half minutes in laying her eggs. When she had flown away, I cut the pierced bud in two, and found the eggs lying in a heap one upon another on the anthers. They were white, longish, on one side pointed and transparent, and ten to twelve in number. I afterwards found several midges engaged in laying their eggs as late as the 18th of April, from which day they ceased to appear in the garden. I also saw a gall-midge on the side of a blossom with its ovipositor inserted in it, so that they do not merely pierce the petals but the calyx also. I even saw one, which having been somewhat long in laying its eggs, could not draw out the ovipositor from the blossom; the cause of which I conceived to be that the wound had begun to close during the operation and the ovipositor was thereby held.

Schmidberger further states that the eggs are quickly hatched in warm weather, for on the fourth day after the deposit he had found the small larvæ on the embryo fruit. They bore into it near the calyx, and before the blossom is expanded they descend to the core, so as not to be exposed to the rays of the sun. They separate at the core and begin to devour on all sides.

In its earliest stages the entrance to the ovary or core of the embryo pear is wide open, and hence no eating or piercing is required of the minute midge larvæ. As the pear sets, the young larvæ develop rapidly, being first white in color and changing to yellow or orange as they become mature.

\section{Appearance of Larva.}

The larva when full grown is of the form shown in Figure 2, $a$ and $b$, about one-sixth of an inch in length, pointed toward each extremity, yellow in color, with a brown, horny "breast bone" on the under side just behind the head. The segments of the body are well marked, and when removed from the infested fruit they 
move about quite rapidly, bending themselves quite double by drawing the tail forward until it touches the head, and then jerking or springing upward and outward several inches at a time.

When they are full grown they remain in the fruit until there comes a rain, which causes a rapid decay and a cracking open of the infested fruit. Through the openings so made they emerge and drop to the ground. In the Lawrence the opening to the core remains quite large for some time after the pear is formed, and many larvæ are able to make their way out at this point; for I have seen a number of pears perfectly sound of surface and yet

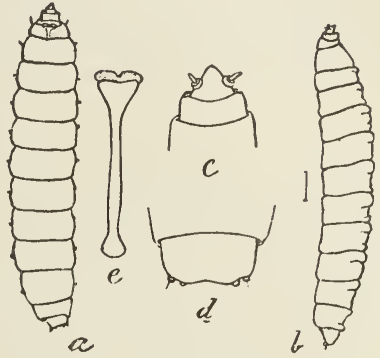

Fig. 2.

Pear-midge larva: $a$, from above; $b$, from side; $c$, head; $d$, anal end of larva; $e$, the breast bone. (After Riley.) abandoned by the larva. The opening through the blossom end in such cases was so prominent that it seems to me certain that they made their way out there.

\section{Pupation.}

As soon as the larvæ leave the infested pears, which is usually early in June, they drop to the ground and at once make their way beneath the surface, varying somewhat with the condition of the soil, from one-half to two inches, and there they lie for some time unchanged. About midsummer the larvæ make oval cocoons of silk covered with grains of sand, and in these they lie unchanged until early spring. It is probable that there is some difference in the date of forming cocoons and in pupation, for Dr. Lintner records his specimens as forming cocoons as early as June 15th, while of the large number confined by me none had formed such on August 3d, and some were still naked early in October. It is worthy of notice, too, that different seasons may make quite a difference in the date at which the flies appear or the larvæ mature. According to Dr. Lintner's report, larvæ emerged from the pears before the end of May in New York State, and on June 10th most of the infested pears had fallen from the trees. On June 10th, 1892, larvæ in Middlesex county, N. J., were not yet mature and none had left the pears. None of my 
specimens had changed to pupæ in October, when my experiments were concluded; but some time during the winter the flies matured and escaped. It is probable that in nature the pupa is not formed until early spring, and that the flies emerge soon afterward, depending upon the character of the season. The pupa is shown at Figure 1, c.

\section{The Injury Done.}

The character of the injury done has been already indicated. The midge larvæ, numbering from ten to thirty or even more, live on the substance of the pear tissue around the core, destroying the seed and checking the growth of the fruit, which in all cases decays and drops in early summer.
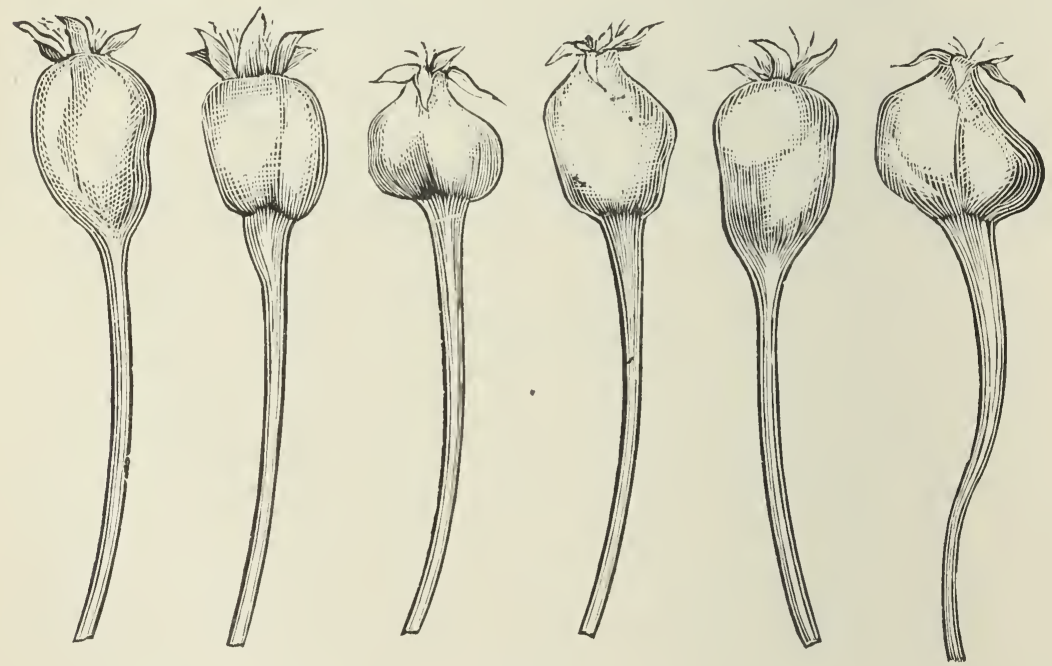

Fig. 3.

Young pears deformed by the pear-midge larvæ-natural size. (After Lintner.)

Infested pears can be readily recognized by a peculiar, irregular or knobby appearance, well shown in the series of outlines under Figures 3 and 4, and this irregularity appears in the fruit almost as soon as it has set.

On cutting open an infested pear, a large central cavity is seen within it, occupying most of its interior, quite irregular in form and often made up of smaller cavities separated by thin walls or by the remains of the core. Among these the larvæ are distributed. No fruit once infested can be saved. 


\section{Experiment Record.}

It will be at once noted from the above life history that there is no period at which this insect is within reach of ordinary insecticide applications. The eggs are laid in the bud before it opens and the young larvæ get into the heart of the fruit before it is fully formed. The adult fly does not feed and is hence beyond our reach. It is only after the injury is done that the insect goes underground and within reach of destructive agencies. Such destructive agencies may be either mechanical as by cultivation, or chemical, using a substance killing by contact.

I had seen reason during past seasons to believe that certain commercial fertilizers were effective in keeping down various underground species, and determined to test these by both field and laboratory tests.

In 1892 the midges appeared in some numbers in the orchard of Mr. J. M. White, near New Brunswick, and in one close adjoining a considerable proportion of the fruit was infested. On Mr. White's land the Lawrence was the main sufferer, a very small proportion of Bartletts only being infested; while in the

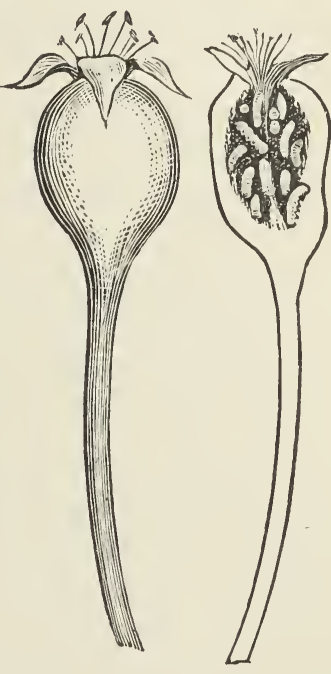

Fig. 4.

Section of a pear containing the larvæ, and a sound one for comparison of form. (After Lintner.) neglected land a large percentage of Bartletts was also destroyed. At my request $\mathrm{Mr}$. White applied a very heavy top-dressing of kainit to his entire pear orchard in late summer, and under the infested trees it was applied at the rate of over half a ton to the acre. In all other respects the orchard was treated as in previous years.

The result in 1893 was remarkable. Late in May I carefully examined the entire orchard-finding just one pear that was infested, though a few others were later found at the edges. The contrast on the other side of the line was striking. I failed to find even one Lawrence pear that was not midged, and of the Bartletts more than 50 per cent. were destroyed. I attributed the exemption enjoyed by Mr. White entirely to the use of the kainit, which killed the larvæ 
under the soil ; but in order to verify my belief the following laboratory experiments were made :

On June 10th, the larvæ being then nearly mature, I gathered between 200 and 300 specimens of infested pears. A portion of them were placed in a breeding-jar for future use and for such experiments as might be required, while the balance was divided among eight one-quart jars, half filled with sand. The pears were distributed among these jars with the idea of getting a nearly equal number of larvæ into each, and a rather careful selection was made of the specimens to that end. These jars were left undisturbed, except that the sand was occasionally moistened with water and the abandoned pears were picked out, until August 3d. At this time the jars were all carefully examined, and it was found that from almost all of the pears the larvæ had made their way, and had burrowed underground a short distance, although none had, at that time, formed cocoons. A small number of the pears, however, had not yet either decayed nor cracked open, and on cutting into these the larvæ were found inside, apparently in good condition. All such pears were cut open and replaced in the jars, the abandoned specimens being thrown away. It might be said that a small brood of plum curculios was bred out of these same pears soon after the midge larvæ went underground. Two jars were selected as checks and set aside, receiving no application of any kind. In two other of the jars a small quantity of nitrate of soda was spread dry upon the surface of the ground, to represent, in the one case, a fair top-dressing under ordinary field conditions, and in the other a heavy dressing; the quantity in the second jar being exactly double that in the first. The amounts were not weighed, as they were too small. Two other jars received muriate of potash, about the same in quantity as in the case of the nitrate, and here also one jar received exactly double the quantity placed in the other. A third lot of two jars was treated with kainit, the amount of kainit applied in jar No. 1 being about the same as the amount of muriate applied in jar No. 2; while in the second kainit jar twice as much was applied as was contained in the first. These eight jars received at intervals small amounts of water, sufficient to keep them moist, until October 6th. On that day all the jars, except one of the checks, were examined.

The check-jar which was first examined showed numerous specimens of the larvæ in the sand, which had not yet formed cocoons, 
and all of these were alive and apparently quite healthy. There were also a very large number of cocoons containing unchanged larvæ, and these all seemed to be healthy and in condition to transform in due time. In none of the other jars examined were there any living larvæ lying free in the soil, although here and there a few dried and shriveled specimens could be found; and in none of the other jars was there anything like the number of cocoons found in the one first examined.

Jar No. 1, muriate of potash, found no free larvæ, but quite a number of cocoons-in bulk perhaps four-fifths as many as were found in the check lot; but of these, nearly one-half of the larvæ examined were dead.

Jar No. 2, containing muriate double in quantity to that contained in No. 1, showed no free larvæ, and of cocoons about as many as in the first lot; but of the larvæ within the cocoons about three-fourths were dead.

Jar No. 3, containing nitrate of soda, a small quantity, had no free larvæ, and of cocoons in bulk about two-thirds as many as in the check lot; but in the cocoons so far as they were examined, not 10 per cent. of the larvæ were alive and the very great bulk of them were dried and shriveled.

Jar No. 4, containing nitrate of soda, double the quantity, had nearly as many cocoons as in the preceding; but certainly not more than 5 per cent. of the larvæ within these cocoons were alive.

Jar No. 5, containing kainit, a small quantity, had no free larvæ, and of cocoons about two-thirds of the check lot, or about the same as in the case of the nitrate; but of living larvæ there were less than 3 per cent. within the cocoons.

Jar No. 6, containing kainit, double in quantity to that in the preceding jar, had cocoons in bulk equal to less than one-third of the check lot, and I found not a single living larva in the cocoons examined by me. That is to say, not one-third of the larvæ in the jar ever formed cocoons, and those that did seemed all of them to be dead.

It may be said that the examination of the jars was made as follows : The entire contents were dumped into a large pan and water added. The pan was then shaken carefully, the dirty water with the loose material floating in it was poured off, and more water was added until it remained clear. The sand was then gradually washed out, 
and there remained only the insect larvæ and their cocoons. These were then transferred to narrow vials of exactly the same size, in order that a comparison might be readily made and then a considerable number of specimens of each lot were examined in order to ascertain the proportion of living larvæ within the cocoons. The balance of the material remaining in each vial was preserved in alcohol for any further or future examination that might be deemed desirable. During the winter the second check-jar received little attention, and the rubber band holding the cheese-cloth cover rotted and broke, giving the maturing midges a chance to escape. Early in April I found only a lot of empty cocoons and pupa skins and a few dry and shriveled larvæ.

Earlier in the season a small portion of the pears set aside for general purposes were selected out, in order to test the effectiveness of chloride of magnesium. The larvæ were placed in a dish containing sand, which was thoroughly moistened with the solution of one-fourth of an ounce of the chloride in sixteen ounces of water; twenty-four hours afterward the insects had burrowed to the bottom of the dish and were showing no signs of injury. As the sand was dry, clean water was added, and yet, in twenty-four hours thereafter, the insects were alive and apparently healthy. Again the sand was moistened with the solution and again it proved ineffective. A sprinkle of kainit was put on the surface and left to be dissolved by the moisture already in the sand, and twelve hours thereafter all the insects were dead or dying.

From Mr. White's experience and from the results of the experiments above detailed, I feel justified in concluding that we have, in kainit, used rather heavily, in fertilizing quantity, an efficient remedy for this insect.

\section{Remedies.}

Under previous heads I have already indicated a line of action. We cannot save the fruit after it has been attacked by the midge larvæ, nor can we prevent the midges from laying their eggs in the blossoms. It has been suggested that we could by the use of arsenites blast the blossoms after the midges had laid their eggs and thus destroy the entire brood by sacrificing the fruit. Where the midges are sufficiently abundant to destroy the crop this may be a good plan; but it will be better if possible to prevent their increase to that extent. 
In the first place keep a close watch on all Lawrence trecs, and have a few Lawrence trees in the orchard to attract such midges as may come. In this way the first appeatanse of the insects vill be readily noticed.

2. When infested pears are found-and they sucuid bo cxamined soon after they are well set-if the trees are not too large, pick off every infested or suspected pear and destroy completely. A very little practice enables any one to recognize an infested pear at sight. This is important to prevent increase on your own land.

3. If the trees are too large to be picked over, the soil beneath those infest d should be cultivated and then well rolled to compact it, not later than the last week in May, and about the middle of June kainit at the rate of 1,000 pounds to the acre should be applied as a top-dressing over the full extent of ground covered by the branches of the infested tree. 'The natural moisture of the soil will dissolve the kainit and will bring a concentrated solution into contact with the naked midge larræ to their destruction.

4. Instead of kainit on limited areas the kerosene emulsion diluted ten times may be usel, wetting the soil thoroughly so far as the branches extend. If this is applied before a rain it will be washed down deeply enough to reach all larvæ to their destruction.

5. If an orchard is generally infested, the following practice is recommended: Cultivate as usual, or, if the orchard is in grass or clover, plow under after June 15th as soon as may be. Top-dress with kainit 1,000 pounds to the acre, to benefit trees as well as to kill insects. As soon as proper, say early in August, sow crimson clover. This will use up the potash not required by the fruit trees, and will store nitrogen, as well as occupy the ground. Early in the following spring turn this sod under as deeply as may be proper. It should be done before the pear buds are developed, in order to head off and destroy any midges then in the pupa state near the surface of the soil.

I need hardly say that this practice is, at the same time, the best for the benefit of the orchard.

If none of the methods advised are adopted, frequent cultivation or a late, rather deep plowing may be effective to some extent.

The practical benefit to be derived from the suggestions above made will be in proportion to the generality with which they are acted upon. If the first and second and third or fourth suggestions are universally carried out, the fifth will not become necessary; but 
it must te 1ementered that one neglected orchard will stock an entire district", arid" that "there is no way of keeping off the midges on the

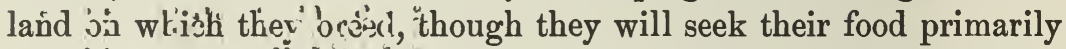
where they first hatch and will usually increase in one orchard until it no loner sciaire them before wandering to another.

Taking "out Laiwrence trees will not help matters, for though they are favorites, yet, lacking them, other varieties are taken. In fact, by concentrating the attack, Lawrence trees are positively advantageous, and it may often be possible by destroying the entire fruit-set of a few Lawrence trees to protect the balance of the orchard. 
CRIMSON OR SCARLET CLOVER.

ITS GROWTH, COMPOSITION, AND USEFULNESS.

NEW JERSEY

AGRICULTURAL

\section{Experiment Station}

100 



\title{
NEW JERSEY
}

\section{Agricultural Experiment Station.}

\section{BULLETIN 100.}

\author{
JUNE 11, 1894.
}

\section{Crimson or Scarlet Clover.}

Trifolium Incarnatum.

BY EDWARD B. VOORHEES.

This clover is known under the name of "Crimson Clover," "Scarlet Clover," and "Italian or German Clover." The color of the blossom is decidedly crimson, hence the name "Crimson Clover" is usually given the preference and should be used exclusively, to avoid confusion.

In this State this clover has been successfully and extensively grown by a gradually increasing number of farmers for the past five seasons, though it is yet a new plant in the sense that its adaptability and usefulness under the varying conditions of climate, season and farm practice have not been thoroughly tested.

Experiments that have been previously conducted here, chiefly to test its hardiness, and the results of the experience of practical farmers have established for it the following points :

1. That it will grow in any part of New Jersey, and that it is quite as hardy as the common red variety.

2. That when seeded between July 15 th and September 15th it will mature from three to four weeks earlier than red clover. 
3. That since it is an annual plant, and differs from other clovers in its time of growth and development, it cannot be regarded as a substitute for them.

4. That the quality of the fodder and hay is superior to that of red clover.

These studies have also indicated that this plant possesses characteristics which make it particularly valuable for a variety of purposes in our State, not now fulfilled by any other plant. To test these points was the purpose of the experiments here reported.

\section{Plan of the Experiments.}

The experiments were planned to further study: The adaptability of this clover to different conditions of soil; and the composition of the whole plant at different stages of growth, in order to determine its value as a green manure, as pasture, or as a soiling crop, when used at different seasons. Samples which would represent the tops, stubble, and roots, the latter plow-deep, or about eight inches, were to be taken at four stages of growth: first, in the latter part of April ; second, in early May; third, when the plant was in bloom; and fourth, after the plant was fully matured. These dates corresponding to pericds when it might be desirable to use the crop in different parts of the State; for instance, in southern portions of the State, spring plowing for corn and sweet potatoes is usually finished the last week in April, while in the central and northern portions, particularly for corn, plowing may be, and frequently is, delayed until the second week in May or later. The first samples taken show the accumulation of food and fertilizer constituents by the whole crop and its parts, when it is desirable to utilize it as green manure, or as pasture, while the samples taken later have reference to the utilization of the plant both as a green manure and as a fodder-crop, when at its best for both purposes.

\section{Location of Experiments and Description of Soils.}

The plots were one acre in area and located as follows :

Plot No. A. Theo. Brown, Swedesboro, Gloucester county.

" " 1 . J. M. White, New Brunswick, Middlesex county.

" "2. College Farm, New Brunswick, Middlesex county. 
In the original plan, one plot was located on the farm of $\mathrm{Hal}$ Allaire, Allaire, Monmouth county, on very light land, which had not been previously cropped. Though a fair catch was secured, the growth was too light to warrant a continuation of the work, and plot A was selected in its stead. All plots were seeded with 16 pounds per acre.

No. A. The land is a sandy loam, with a porous, sandy subsoil ; it is in a fair state of fertility and produces good crops of red clover. The clover was seeded in corn August 1st, and lightly barrowed in one way of the row; a fair catch was secured, very thick between the corn rows and thinner upon the ridges. It made a rapid growth, averaging five inches in height at the beginning of winter, which it survived without loss.

No. 1 was seeded in an eight-year-old peach orchard. The plot included four rows of trees across the orchard. Part of the land is very sandy with sandy subsoil ; the remainder is a sandy loam with clayey subsoil. The land, though not naturally rich, has been well fertilized with the mineral constituents, phosphoric acid and potash. The plot was seeded July 2 5th and the seed covered with a "Breed's Weeder." An even catch was secured which grew rapidly in the fall, and apparently survived the winter without the loss of a plant.

On No. 2 the land is a rather heavy, gravelly clay loam, with tight clay subsoil and in a good state of fertility, though not well adapted for clover. It was seeded September 1st, after a potato crop, which had been dressed with yard manure at the rate of 12 tons per acre. The weather was very dry at time of seeding and continued hot and dry, which resulted in an uneven catch, thick in parts of the land and thin in others. The plants made a rapid growth before winter, where a good stand was secured-an almost solid mat about five inches high. A part of the plot was located on a ridge higher than the surrounding land, and on portions unprotected by snow a number of plants were frozen.

\section{Methods of Sampling.}

The original samples were taken in the fullowing manner:

An area representing a full stand was selected and one square foot marked off; the soil was removed to the requisite depth, and the block lifted out entire. The whole mass was then placed in a box and taken to the laboratory, where the earth and foreign matter were 
carefully removed. The fibrous roots which became separated from the main root in removing the soil were collected in a fine sieve.

The samples taken April 24th were separated into tops and roots. In those taken May 12th, and subsequently, the tops were removed before separating the earth, and the remainder of the plant divided into stubble and roots, the proportion of stubble representing, as near as possible, field conditions. These samples fairly represented the whole plant, though it was impossible to prevent slight losses of the finer roots.

Yield.

Although accurate weights were made of the yield of the whole plant, and of the different portions, per square foot, the object of this was rather to determine the relation by weight of the different parts of the plant at different stages of growth, rather than as a basis for calculating the amount of food or fertilizer constituents in the crop.

In order to arrive at a fair estimate of the yield on a field basis a square rod, representing full stand in experiments Nos. 1 and 2, was carefully cut and weighed on May 24th, when the plants were full grown and before there was any danger of mechanical losses. It was found that the average yield thus secured was 60.34 per cent. of that secured from the calculations upon the square-foot basis. This factor was, therefore, applied to all yields on the square-foot basis, which converted them into what is believed to be a fair field basis for a comparative study. Table 1 gives detailed information in reference to the different samples taken : 
Table 1.

\begin{tabular}{|c|c|c|c|c|c|c|c|}
\hline \multirow{2}{*}{ 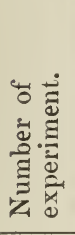 } & \multirow[b]{2}{*}{ 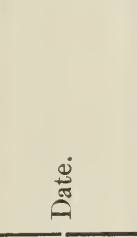 } & \multirow{2}{*}{ 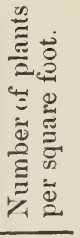 } & \multirow{2}{*}{ 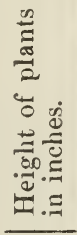 } & \multirow{2}{*}{ 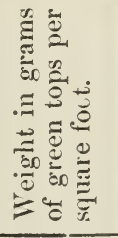 } & \multicolumn{3}{|c|}{$\begin{array}{l}\text { GRAMS OF AIR-DRY SUBSTANCE } \\
\text { PER SQUARE FOOT IN }\end{array}$} \\
\hline & & & & & $\stackrel{\tilde{D}^{\circ}}{E}$ & $\frac{\frac{0}{0}}{\frac{\Xi}{\Xi}}$ & $\begin{array}{l}\dot{p} \\
\overrightarrow{0} \\
\stackrel{0}{0} \\
\dot{\imath}\end{array}$ \\
\hline A & & 86 & 7 & & 53.3 & & 27 \\
\hline 1 & April 24. & 18 & 6 & & 34.0 & & 20 \\
\hline 2 & & 66 & 5 & & 38.0 & & 15 \\
\hline \multicolumn{2}{|c|}{ Average............... } & 57 & 6 & & 41.8 & & 21 \\
\hline 1 & May 12. & 19 & 12 & 453 & 62 & 11 & 18 \\
\hline 2 & & 50 & 14 & 658 & 72 & 13 & 25 \\
\hline \multicolumn{2}{|c|}{ A verage............... } & 35 & 13 & 556 & 67 & 12 & 22 \\
\hline 1 & May 24. & 19 & 22 & 516 & 87 & 12 & 14 \\
\hline 2 & & 37 & 28 & 570 & 105 & 11 & 29 \\
\hline \multicolumn{2}{|c|}{ A verage.............. } & 28 & 25 & 543 & 96 & 12 & 22 \\
\hline 2 & May 31. & 35 & 28 & 658 & 124 & 9 & 18 \\
\hline
\end{tabular}

The particularly noticeable features in this table are, first, the very wide variation in the number of plants per square foot, though in all cases the samples represented what was regarded as a full stand for the field, and second, that the yield of green tops, or air-dry matter, is not in proportion to the number of plants. The tendency of the plant to overcome the disadvantages of thin secding or a poor catch by stooling largely is, therefore, apparent, though this peculiarity would doubtless be less marked on poorer soils than those here represented. Owing to the variations due to differences in locality, kind of soil, evenness of stand, etc., the samples taken on the same date are averaged and this average yield used in subsequent calculations rather than the data from individual samples. 


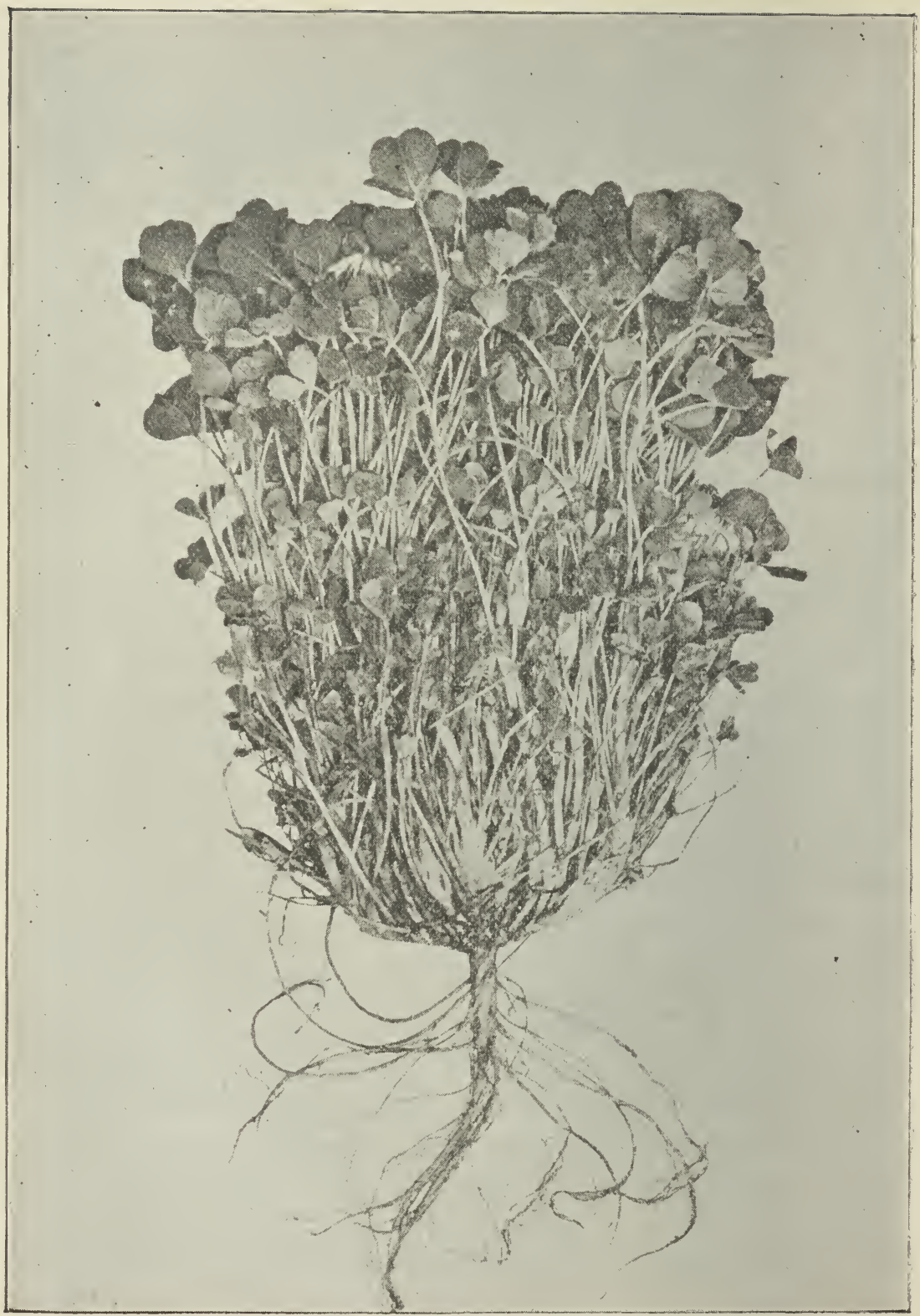

Plate I.

Plate No. I. is a photograph taken April 24th of the present year; its main purpose is to illustrate the stooling capacity of the plant, and to show the size and number of the main roots.

This single stool has eighty-six branches; the height to the tips of the leaves is twelve inches: as it stood in the field it covered more than one square foot. 


\section{How the Crops Were Used.}

The crop on experiment No. A was turned under April 28th and the field planted with sorn, without manure. It was not possible to make a comparative study of the growth of corn with and without manure (the green manure), though the crop made a very rapid early growth and, notwithstanding a severe drouth in July, produced a good yield.

The crop on No. 1 was plowed under May 28th, and while the early growth of the peach trees was apparently somewhat retarded by the crop of clover, they gained rapidly after it was plowed in, and both the growth and fruitage were more satisfactory than on the. remainder of the orchard, where an application of two pounds of nitrate of soda was applied to each tree, the manuring in otherrespects being the same. The crop on the whole orchard was good. The trees this spring are healthy and vigorous and set full of fruit. Mr. White was so well pieased with the results of the experiment that both his peach and pear orchards, in all about thirty acres, were seeded last fall. A good crop was secured and used as green manure this spring.

The clover on plot No. 2 was used as a soiling crop for dairy cattle. Cutting began on May 15th and continued until June 2d. It proved an excellent forage; the animals consumed it with relish and increased perceptibly in the flow of milk. The large yields secured on the: three plots differing radically in character and fertility of soil, and in methods and time of seeding, indicate a wide adaptability of the plant to varying conditions. 
Table 2.

\begin{tabular}{|c|c|c|c|c|c|c|c|c|c|}
\hline \multirow{2}{*}{ 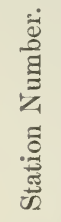 } & \multirow{2}{*}{ 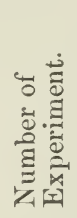 } & \multirow[b]{2}{*}{ 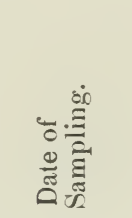 } & \multicolumn{4}{|c|}{$\begin{array}{l}\text { GRAMS DRY MATTER CON- } \\
\text { TAINED IN ONE SQUARE FOOT. }\end{array}$} & \multicolumn{3}{|c|}{$\begin{array}{l}\text { PER CENT. OF DRY } \\
\text { MATTER IN }\end{array}$} \\
\hline & & & స్ & & $\frac{\stackrel{0}{3}}{\stackrel{3}{\pi}}$ & 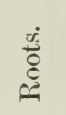 & $\stackrel{\dot{0}}{0}$ & $\frac{\frac{0}{0}}{\frac{0}{\Xi}}$ & 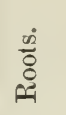 \\
\hline 821 & $\mathbf{A}$ & April 24. & 66.8 & 45.7 & ....... & 21.1 & 68.4 & ..... . . & 31.6 \\
\hline 817 & 1 & " & 45.5 & 28.8 & & 16.7 & 63.2 & & 36.8 \\
\hline 819 & 2 & “ & 44.6 & 32.4 & ..... & 12.2 & 70.3 & & 29.7 \\
\hline \multicolumn{3}{|c|}{ Average..................... } & 52.3 & 35.6 & & 16.7 & 67.3 & ........ & 32.7 \\
\hline 828 & 1 & May 12. & 78.0 & 54.0 & 8.8 & 15.2 & 69.2 & 11.4 & 19.4 \\
\hline 827 & 2 & " & 94.3 & 63.8 & 9.9 & 20.6 & 67.6 & 10.5 & 21.9 \\
\hline \multicolumn{3}{|c|}{ Average.................... } & 86.1 & 58.9 & 9.4 & 17.9 & 68.4 & 11.0 & 20.7 \\
\hline 831 & 1 & May 24. & 99.6 & 78.5 & 9.3 & 11.8 & 78.8 & 9.4 & 11.8 \\
\hline 834 & 2 & " & 125.4 & 92.5 & 9.1 & 23.8 & 73.7 & 7.3 & 19.0 \\
\hline \multicolumn{3}{|c|}{ Average.................... } & 112.5 & 85.5 & 9.2 & 17.3 & 76.3 & 8.3 & 15.4 \\
\hline 837 & 2 & May 31. & 132.8 & 109.8 & 8.0 & 15.0 & 82.6 & 6.1 & 11.3 \\
\hline
\end{tabular}

The data in Table 2 are derived from Table 1, and show the total dry matter as well as the dry matter contained per square foot in tops, roots and stubble, for the different samples. The per cent. of dry matter in the various parts of the plant is also shown.

The important point brought out by a study of this table is that the amount of dry matter contained in the roots is practically uniform for the different dates; the weight of roots in a given area is quite as great on April 24th, when the tops are six inches high, as upon May 31st, when the plant is full grown.

In other words, it is shown that the accumulation of dry matter after the first date of sampling-over 150 per cent.-was found almost entirely in the tops and stubble. 
The Composition of the Dry Matter.

Tables $3 \mathrm{~A}, 3 \mathrm{~B}$ and $3 \mathrm{C}$ show the composition of the dry matter of the tops, stubble and roots. In $3 \mathrm{~A}$ and $3 \mathrm{~B}$ both the food and fertilizer analyses are given, while in $3 \mathrm{C}$ the fertilizer analysis only is given. The percentage of crude ash does not include the sand and insoluble matter mechanically adhering to the samples.

Table 3 A.

\begin{tabular}{|c|c|c|c|c|c|c|c|c|c|c|c|}
\hline \multirow{3}{*}{ 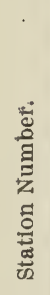 } & \multirow{3}{*}{ 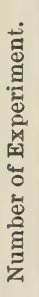 } & \multirow{3}{*}{ 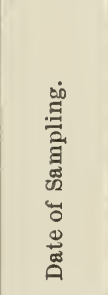 } & \multicolumn{9}{|c|}{ COMPOSITION OF TOPS. } \\
\hline & & & \multicolumn{9}{|c|}{ POUNDS CONTAINED IN 100 LBS. Of DRY MATTER OF } \\
\hline & & & 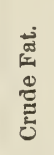 & 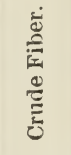 & 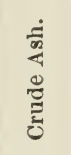 & & 这焉 & 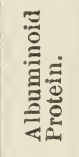 & 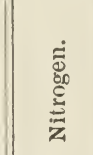 & 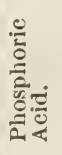 & $\begin{array}{l}\frac{d}{\varpi 2} \\
\frac{\tilde{\sigma}}{0} \\
2\end{array}$ \\
\hline 821 & A & April 24. & 3.31 & 1633 & 12.73 & 22.19 & 45.44 & 16.30 & 3.55 & 0.61 & 3.75 \\
\hline 817 & 1 & “ & 4.26 & 14.81 & 10.79 & 22.03 & 48.08 & 18.73 & 3.52 & 1.00 & 2.76 \\
\hline 819 & 2 & “ & 4.11 & 15.19 & 9.97 & 24.41 & 46.32 & 20.21 & 3.91 & 0.93 & 2.51 \\
\hline \multicolumn{3}{|c|}{ Average...................... } & 3.89 & 15.45 & 11.16 & 22.88 & 46.61 & 18.42 & 3.66 & 0.85 & 3.01 \\
\hline 828 & 1 & May 12. & 3.89 & 16.36 & 11.91 & 23.86 & 43.98 & 16.76 & 3.82 & 1.22 & 3.19 \\
\hline 827 & 2 & “ & 3.88 & 16.51 & 10.18 & 22.73 & 46.70 & 16.37 & 3.64 & 0.81 & 3.14 \\
\hline \multicolumn{3}{|c|}{ Average..................... } & 3.89 & 16.44 & 11.01 & 23.30 & 45.34 & 16.57 & 3.73 & 1.02 & 3.17 \\
\hline 831 & 1 & May 24. & 3.38 & 28.92 & 7.92 & 1856 & 41.22 & 13.07 & 2.97 & 0.68 & 1.93 \\
\hline 831 & 2 & " & 3.39 & 26.51 & 8.61 & 19.50 & 41.99 & 13.37 & 3.12 & 0.75 & 1.88 \\
\hline \multicolumn{3}{|c|}{ Average..................... } & 3.39 & $2 \pi .72$ & 8.27 & 19.03 & 41.61 & 13.22 & 3.05 & 0.72 & 1.91 \\
\hline 837 & 2 & May 31. & 3.16 & 28.53 & 8.80 & 17.65 & 41.86 & 12.72 & 2.92 & 0.67 & 2.54 \\
\hline
\end{tabular}


Table 3 B.

\begin{tabular}{|c|c|c|c|c|c|c|c|c|c|c|c|}
\hline \multirow{3}{*}{ 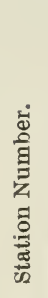 } & \multirow{3}{*}{$\begin{array}{l}\text { 苛 } \\
\text { : } \\
\text { : }\end{array}$} & \multirow{3}{*}{ 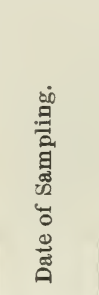 } & \multicolumn{9}{|c|}{ COMPOSITION OF STUBBLE. } \\
\hline & & & \multicolumn{9}{|c|}{ POUNDS CONTAINED IN 100 LBS. OF DRY MATTER OF } \\
\hline & & & 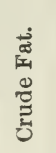 & 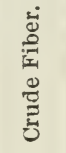 & 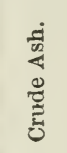 & 胥递 & 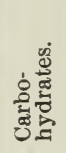 & 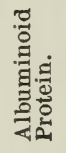 & 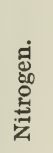 & 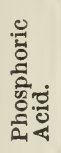 & 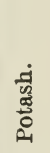 \\
\hline 830 & 1 & May 12. & 2.71 & 22.66 & 10.98 & 13.04 & 50.61 & 10.71 & 2.09 & 0.96 & 2.28 \\
\hline 826 & 2 & “ & 1.85 & 23.36 & 13.60 & 12.34 & 48.85 & 10.26 & 1.97 & 0.55 & 3.03 \\
\hline \multicolumn{3}{|c|}{ A verage..................... } & 2.28 & 23.01 & 12.29 & 1269 & 49.73 & 10.49 & 2.03 & 0.76 & 2.66 \\
\hline 832 & 1 & May 24. & 2.31 & 28.44 & 9.34 & 11.25 & 48.66 & 8.85 & 1.82 & 0.56 & 1.22 \\
\hline 836 & 2 & “ & 2.06 & 31.04 & 8.80 & 12.85 & 45.25 & 11.06 & 2.06 & 0.42 & 1.04 \\
\hline \multicolumn{3}{|c|}{ Average. ................... } & 2.19 & 29.74 & 9.07 & 12.05 & 46.96 & 9.96 & 1.94 & 0.49 & 1.13 \\
\hline 838 & 2 & May 31. & 1.64 & 31.78 & 9.67 & 12.21 & 44.70 & 10.36 & 1.95 & 0.52 & 2.88 \\
\hline
\end{tabular}

The analyses of the samples of stubble, in addition to their value in connection with the analyses of tops and roots in showing the composition of the whole plant, are interesting in indicating a high feeding value for this part of the plant.

The dry matter is nearly 50 per cent. richer in protein than the dry matter of timothy hay, and nearly as rich in carbohydrates and fat. This is accounted for by the lower content of crude fiber in the clover.

The stems of this plant are less woody than those of timothy or red clover, thus materially increasing the relative digestibility of the whole plant. 
Table $3 \mathbf{C .}$

\begin{tabular}{|c|c|c|c|c|c|c|}
\hline \multirow{3}{*}{ 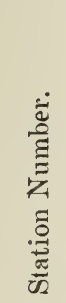 } & \multirow{3}{*}{ 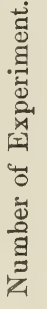 } & \multirow{3}{*}{ 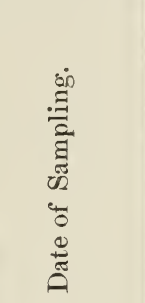 } & \multicolumn{4}{|c|}{ COMPOSITION OF ROOTS. } \\
\hline & & & \multicolumn{3}{|c|}{ CONTAINED IN 100 LBS. OF DRY } & MATTER. \\
\hline & & & $\begin{array}{c}\text { Crude } \\
\text { Ash. }\end{array}$ & Nitrogen. & $\begin{array}{c}\text { Phosphoric } \\
\text { Acid. }\end{array}$ & Potash. \\
\hline 822 & $d$ & April 24. & 15.24 & 2.71 & 0.56 & 2.61 \\
\hline 818 & 1 & " & 9.94 & 3.08 & 1.17 & 1.62 \\
\hline 820 & 2 & “ & 9.87 & 3.04 & 0.89 & 1.20 \\
\hline \multicolumn{3}{|c|}{ Average........................... } & 11.68 & 2.61 & 0.87 & 1.81 \\
\hline 829 & 1 & May 12. & 10.32 & 3.10 & 1.29 & 1.23 \\
\hline 825 & 2 & " & 9.87 & 2.72 & 0.68 & 1.12 \\
\hline \multicolumn{3}{|c|}{ Average.... } & 10.10 & 2.91 & 0.99 & 1.18 \\
\hline 833 & 1 & May 24. & 9.44 & 2.83 & 0.88 & 0.90 \\
\hline 835 & 2 & “ & 9.67 & 2.65 & 0.63 & 0.73 \\
\hline \multicolumn{3}{|c|}{ 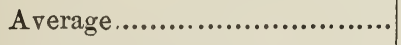 } & 9.56 & 2.74 & 0.76 & 0.82 \\
\hline 839 & 2 & May 31. & 10.73 & 2.73 & 0.81 & 1.45 \\
\hline
\end{tabular}

It will be observed that considerable variations occur in the composition of samples secured on the same date from different localities; this is particularly noticeable in the ash content and in the percentage of fertilizer constituents, the sample in Experiment A, April 24th, showing very much less phosphoric acid and much more potash than either of the other two.

The composition in reference to food constituents is not widely different upon April 24th and May 12th, though on the former date the whole top was included, while on the latter the stubble is separated. The composition after May 12th shows mainly a decided increase 
in crude fiber and consequent decrease of the other constituents, as was to be expected in the development of the plant. The percentage of the ash constituents on May 24th and May 31st, particularly in the case of potash, differs widely and is not in accordance with what was to be expected, though it is uniform throughout for tops, stubble and roots. The chemical analyses were repeated in every particular and found correct. Samples will be taken again this year at as nearly as possible the same stage of growth in order to further study this point, though this part of the analysis does not have any particular bearing upon a study of the value of the plant from a practical standpoint.

Another point of interest is shown in reference to the proportion of true protein; the highest percentage-80.5-is shown in the immature plant on April 24th; on the later dates the percentage is much lower and practically uniform, ranging from 69.4 to 72 per cent.

The composition of the stubble and roots shows no marked change other than those indicated from a study of the tops.

\section{Practical Application of the Results.}

The results secured permit of a discussion of the usefulness of the plant from three standpoints :
1. As a Green Manure.
2. As a Pasture.
3. As a Soiling Crop.

1.

\section{AS A GREEN MANURE.}

Agricultural writers have for a long time advocated what is termed "green manuring," that is, the growing of crops for the sole purpose of turning under in order to improve the soil, particularly in its physical character and in its content of nitrogen. This system of manuring, in the strictest sense, is not, however, widely practiced in this State, first, because there is a well-rooted prejudice against turning under a matured crop which contains good food; second, because this method does not permit of the continuous use of the land for money crops, and third, because of a rather indefinite idea of the true advantages of such a practice when properly conducted. 
Conditions that Warrant Green Manuring.

It is a wasteful practice to plow under a matured crop, though there are special conditions of farming which warrant it, viz, where the soils are only well adapted for small fruits and vegetables, or are naturally poor or worn out, upon which the addition of organic or vegetable matter is essential.

In this State there are just such lands as the former, which receive annually heavy dressings of yard or city manure, and one of the chief purposes of which is to supply the requisite organic matter. This practice is expensive both of money and labor, and the introduction of systematic methods of green manuring here is well worthy of consideration. In the second case the improvement by means of city manure is, in proportion to the returns, still more expensive and not to be recommended as a general practice.

\section{The Advantage of Catch Crops.}

The loss of use of the land for a season is a serious consideration in any case, but more so where high farming is practiced, yet a proper selection of catch crops, $i$. e. those which do not materially interfere with regular rotations, will obviate in a large degree this objection.

As a catch crop for green manuring this clover possesses many advantages, chief among which is that it takes well without cover crop in growing corn, tomatoes, orchards, berry patches, etc.; it also thrives in late summer and fall after other crops have ceased growing, and it makes a rapid growth in the early season, furnishing a considerable crop before ordinary spring plowing begins.

\section{Why Legumes Should be Used.}

The results secured from green manuring are often disappointing, because the crops used for the purpose derive their essential fertilizing constituents, nitrogen, phosphoric acid and potash, entirely from the soil; buckwheat and rye, frequently used for the purpose, belong to this class of plants, and the only advantageous accumulation in the soil from their use consists in the carbon, hydrogen and oxygen, from their organic structure. Green manuring with these crops, while perhaps of value, is much less so than when those are used which possess the power of gathering nitrogen from the air; a fact now well established for plants of the legume family, as clover, peas, beans, lupins, 
etc.; these plants enrich the soil in the expensive element nitrogen derived from the air, while the others mentioned only return to the soil the nitrogen previously existing in it.

Table 4.

\begin{tabular}{|c|c|c|c|c|c|c|c|c|}
\hline \multirow{2}{*}{ 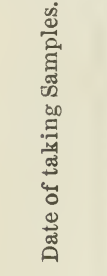 } & \multicolumn{8}{|c|}{ YIEID IN POUNDS PER ACRE OF } \\
\hline & In & 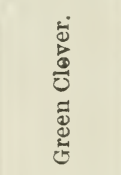 & 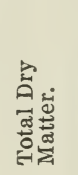 & 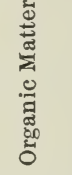 & प्रु & 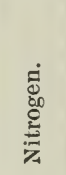 & 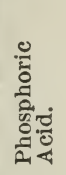 & 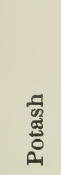 \\
\hline \multirow[t]{4}{*}{ April 24.} & Tops................. & 21,048 & 2,040 & 1,812 & 228 & 74.6 & 17.2 & 61.4 \\
\hline & Roots............... & 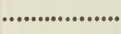 & 992 & 875 & 116 & 29.1 & 8.6 & 18.0 \\
\hline & Total........ & (................... & 3,032 & 2,687 & 344 & 103.7 & 25.8 & 79.4 \\
\hline & Tops.............. & 31,526 & 3,415 & 3,038 & 377 & 127.3 & 34.6 & 108.1 \\
\hline \multirow[t]{4}{*}{ May 12.} & Stubble........ & 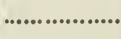 & 547 & 479 & 67 & 11.0 & 1.3 & 13.9 \\
\hline & Roots........... & 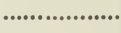 & 1,031 & 927 & 104 & 30.0 & 10.1 & 12.1 \\
\hline & Total....... & (................... & 4,992 & 4,444 & 548 & 168.3 & 46.0 & 134.1 \\
\hline & Tops............. & 31,498 & 4,967 & 4,557 & 411 & 151.7 & 35.5 & 91.6 \\
\hline \multirow[t]{4}{*}{ May 24.} & Stubble........ & …....................... & 548 & 498 & 50 & 10.4 & 2.6 & 6.1 \\
\hline & Roots............ & . & 1,004 & 908 & 96 & 27.5 & 7.5 & 8.1 \\
\hline & Total........ & 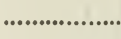 & 6,519 & 5,963 & 557 & 189.6 & 45.6 & 108.8 \\
\hline & Tops................. & 37,976 & 6,356 & 5,797 & 559 & 179.2 & 42.5 & 160.4 \\
\hline \multirow[t]{3}{*}{ May 31.} & Stubble....... & . & 469 & 424 & 45 & 9.1 & 2.4 & 13.5 \\
\hline & Roots............ & 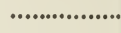 & 870 & 776 & 93 & 23.7 & 7.0 & 12.6 \\
\hline & Total...... & 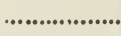 & 7,695 & 6,997 & 698 & 212.0 & 51.9 & 186.5 \\
\hline
\end{tabular}

The object of Table 4 is to show the calculated yield of green clover, and the amount of organic matter and fertilizer constituents contained per acre, calculated from the data secured and which may be regarded as good crops, at the different stages of growth. The height in inches, as shown in a previous table, is a better guide as to the period of growth than the date of cutting, since in an earlier season cuttings on April 24th and May 12th would have shown much larger yields. 


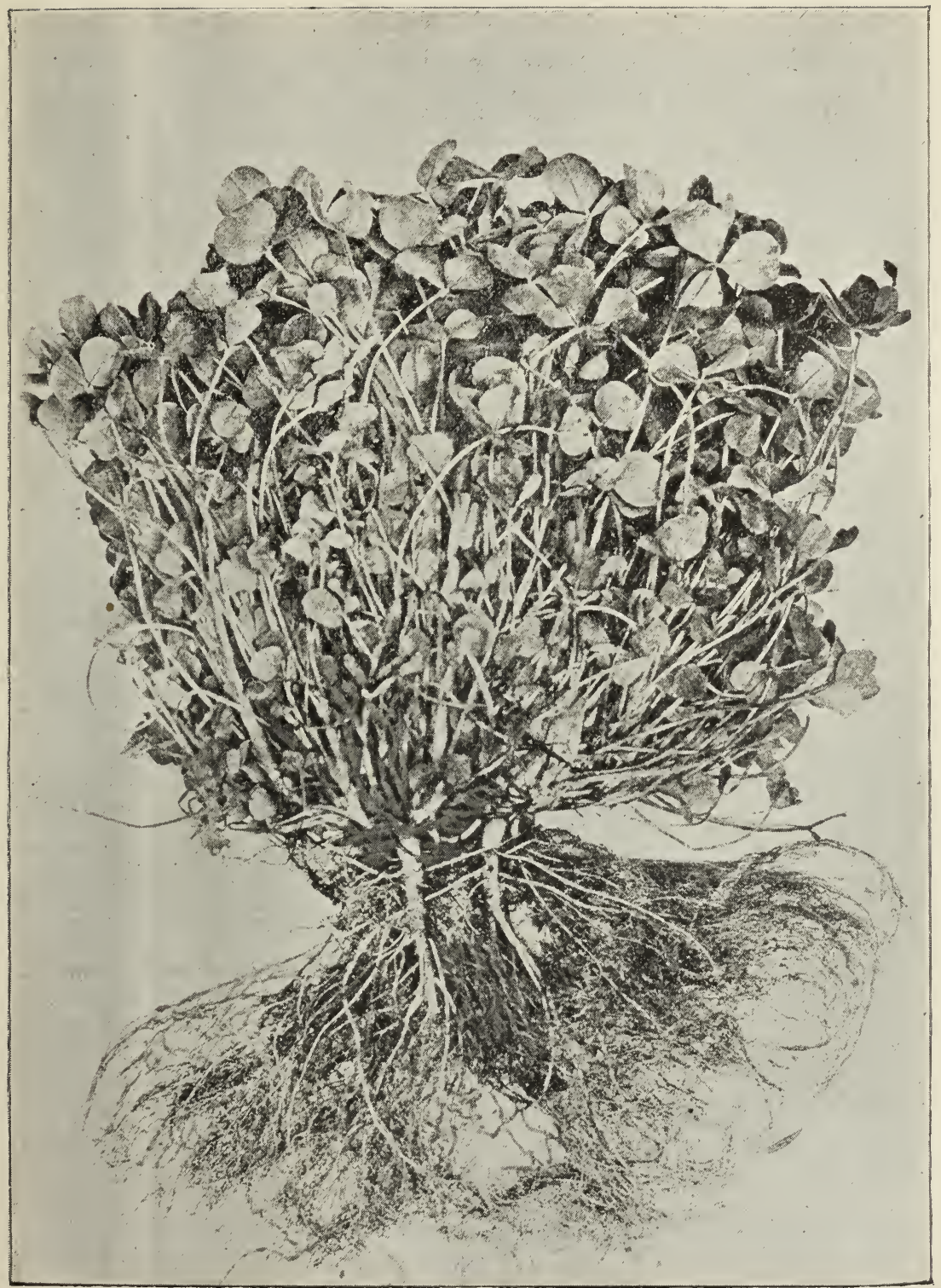

Plate II.

Plate No. II. shows the size of the clover on April 24th this year; on the same date in 1893 it was six inches high, this year it was ten inches high. The five plants here shown were not separated from each other, thus representing the vigor of the growth from a comparative!y thick seeding.

The mrss of fibrous roots also indicates a wonderful feeding capacity and explains its rapid early growth. These plants were taken from a field of four acres upon the College farm. The seed was sown in corn July $26 \mathrm{th}$, and though the weather for nearly a month after seeding was very unfavorable, a good catch was secured, which withstood the winter perfectly. 
The yield of green clover in the whole top on April 24th is shown to be practically $10 \frac{1}{2}$ tons; on May 12th and 24th the yields are nearly identical at 15.75 tons, while on May 31 st the yield is nearly 19 tons per acre. It is observed, however, that as the plant increased in growth the proportion of dry matter relative to total product also gradually increased; the yield of green clover is almost identical upon May 12th and upon May 24th, while the yield of dry matter is over 45 per cent. greater on the 24 th than on the 12 th. The proportion of dry matter increases as the plant matures.

\section{The Relation of Tops to Roots.}

The table also shows that by far the largest amount of organic matter and plant-food is contained in the tops, even at the first cutting, when the plants were six inches high, and that there is practically no increase in the organic matter and fertilizer constituents contained in the roots after that time. The roots had then reached their full development in this respect, and the amount of constituents contained in them at different periods afterwards remained practically constant.

The gain of organic matter and fertilizer constituents in the tops, including stubble, constantly increased until maturity. On April $24 \mathrm{th}$, roughly, two-thirds of the total plant-food was contained in the tops; on May 12th the proportion had increased to five-sixths, on May 24th to seven-eighths, and on May 31st to nine-tenths.

These points are important in showing, first, that no good grounds exist for the statements so frequently heard, that there is as much fertilizing value in the roots of a clover crop as in the tops, and, second, that as a green manure this plant increases in value up to the time of maturity.

\section{Its Value in Early Stages of Growth.}

The advantages to be derived from the use of this plant as a green manure in its early stages of growth are, however, considerable, and in this State it doubtless will find its widest application for this purpose then, rather than at maturity. It has already been observed that the gain to the soil from green manuring with leguminous plants, consists in the addition of organic vegetable matter or humus-forming materials, the gradual decay of which improves the physical character 
of the soil, by rendering it more retentive of moisture and plant-food, and the chemical character by adding to it nitrogen, an element useful to those plants whose entire source of which is the soil. The mineral constituents contained in the crop are derived entirely from the soil, and hence represent no addition to it, though their change of location and concentration in the surface soil in a product which rapidly decays, contribute in no small degree to the good results derived from green manuring.

The amounts of phosphoric acid and potash contained in the crop as early as April 24th, are more than sufficient for an average crop of white potatoes, sweet potatoes, tomatoes or the cereals, or equivalent in phosphoric acid to 200 pounds of S. C. rock superphosphate, and in potash to over 600 pounds of kainit. These facts are interesting in showing the demands of the plant for these constituents, and suggest that on lands of low fertility they should be supplied in order to insure a crop. Assuming that the entire amount of nitrogen contained in the whole crop represents a distinct gain to the soil, the crop harvested on April 24th added 103.7 pounds, an amount of nitrogen equivalent to that contained in 648 pounds of nitrate of soda, which would cost, at present prices, in quantity, $\$ 15$, or to the amount contained in 10 tons of average-quality manure. City manure costs this year $\$ 2.25$ per ton delivered at consumer's depot; reckoning phosphoric acid at 4 cents per pound, at which price "available" can be bought in S. C. rock superphosphate, and actual potash at $4 \frac{1}{2}$ cents per pound, at which price it can be bought in the form of muriate, the cost of the nitrogen in the manure is $\$ 15$, or the same as the nitrate of soda.

\section{City Manure vs. Clover as a Source of Nitrogen.}

The cost of the nitrogen in the clover is represented by the cost of seed and labor of sowing, which need not exceed $\$ 2$ per acre. This is balanced by a charge of 20 cents per ton for the labor of hauling and applying the manure, or about one-half of the usual estimated cost; the crop, therefore, represents an accumulation of nitrogen worth $\$ 15$, free of cost to the farmer.

The amount of organic matter contained in the clover-2,687 pounds-is also equivalent to that contained in ten tons of manure, hence the physical improvement of the soil may be fairly assumed to be quite as great from the clover as from the manure. 
Late white potatoes, sweet potatoes, early tomatoes, melons, citrons and corn are not, as a rule, planted or set until early in May, and the growth of clover indicated in the table may be easily attained without seriously delaying the planting of these crops, upon which city manure is extensively used.

\section{Are Nitrogen and Organic Matter Necossary?}

Statistics gathered by the Station showed that last year New York horse manure to the amount of 85,000 tons was shipped into sections of four counties in southern New Jersey, where these crops are largely grown; the nitrogen in this amount of manure cost the farmers $\$ 127,500$, which sum probably does not represent one-third of the total expenditure for nitrogen in the manure bought in those counties, since large quantities are carted and boated direct from Philadelphia and Camden.

That nitrogen with the accompanying organic matter is believed to be needed is, therefore, sufficiently evident, since immense sums of hard cash are paid for it; the nitrogen in the clover is just as good, and can be had in the clover at a nominal expense of cash and labor, both very important items.

It may be argued that this nitrogen will not in all cases answer as well as that contained in the manure, and that it may not be possible to get sufficient amounts by means of green manures under the system of farming practiced.

These are legitimate arguments but should not have sufficient influence to prevent the farmer from securing all that he can in this way and supplementing by the more soluble forms. It may be, too, that the present system of farming is not the best; farmers' profits in the future, as at present, must come largely through reducing the cost of production, which in many cases necessitates changes in practice.

The facts are that nitrogen is needed for these crops, and that it is the most expensive of the essential fertilizing elements, in whatever form purchased. No other one question is more important to the farmers of these sections than the question of a cheap source of nitrogen; it will pay to give it careful consideration. 


\section{Its Value in Mixed Farming.}

The crop cut May 12th shows a decided gain of nitrogen, or a total equivalent to that contained in 17 tons of manure, and worth $\$ 25.50$ per acre. On this date the crop as a green manure perhaps finds its best application farther north in the State for field-corn, potatoes, orchards, etc.

Where mixed farming on the extensive plan is practiced, few farmers find that they have what they regard as a sufficient amount of manure for their purpose, even when proper care is exercised in saving and using their home product. They also find that buying city manure under these circumstances is too expensive, and unless fertility in some shape is imported the productiveness of the soil is not increased.

To grow under the present conditions of farming only such crops as the natural conditions of soil and season and ordinary methods of culture will permit is frequently unprofitable, and is certainly unprogressive.

Crimson clover sown in corn takes well under average seasonal conditions; it keeps the land occupied during fall and winter, and will, as is shown, secure large quantities of nitrogen before the middle of May, or in time for a corn or potato crop. Upon land of good natural fertility the gain from green manuring alone is often more marked than upon the poorer soils.

\section{Its Value in Soil Improvement.}

The use of the matured crop as a green manure is especially applicable on lands naturally very poor or run down, where the primary object is really to assist in making soils; here the larger the amount of organic vegetable matter added the more rapid will be the improvement, though in such cases mineral manures should be liberally used in order to get the first crop. The average of the matured crops on May 24th and 31st contained per acre 200 pounds of nitrogen and 6,500 pounds of organic matter, or equivalent to that contained in 20 tons of city manure, which would cost in that form $\$ 30$.

An admirable illustration of the advantages of this method of manuring, both in improving the physical character of soil and in 
furnishing nitrogen, is shown in an experiment now in progress by the Station.

A light sandy soil not previously cropped, poor, both in physical and chemical character, was last spring dressed liberally with potash and phosphoric acid only, and seeded with the cow-pea, a leguminous plant; the crop grew well without the addition of nitrogen or organic matter, producting $7 \frac{1}{2}$ tons of green material per acre. The crop was turned under in September and the land seeded to rye, without the addition of manure of any kind. The rye this spring is a fine crop, thick, vigorous and strong in growth, better even than on adjoining land in a good state of fertility, dressed heavily on the preceding crop of potatoes with a high-grade fertilizer and top-dressed with well-rotted manure.

The land was not only improved in its physical character, holding together and making a solid seed-bed, but was also chemically improved by the nitrogen collected from the atmosphere by the crop of cow-peas, since the nitrogen contained in it was the only source of this element available for the rye.

\section{Sources of the Mineral Constituents.}

In this discussion the chemical improvement of the soil is claimed in reference to nitrogen only; this gives rise to the question as to the cheapest source of the mineral constituents, phosphoric acid and potash, both for growing the leguminous plants and for other crops, since in most cases those elements are also required for both classes of crops.

At the present price of city manure, phosphoric acid and potash cost as much as in the best concentrated products containing them, viz., superphosphates and potash salts. The phosphoric acid is certainly less available in manure than in superphosphates, because in the former the organic matter must decay before the plant can secure it. The potash is largely soluble in tha manure, but a uniform distribution of it is more difficult, and the expense of applying is much greater than when contained in the concentrated soluble forms. Where the required nitrogen and organic matter are secured from green manures, phosphoric acid and potash can be more economically secured in these concentrated forms than in city manures. Where green manures are used for soil-making, liberal dressings of both 
phosphoric acid and potash are recommended. The application of lime is also advisable, particularly when a heavy crop is turned under, both because of the lime, and because it is believed to prevent injury to the land consequent upon a too rapid decay of vegetable matter.

2.

\section{AS A PASTURE.}

The keeping of live stock is an important feature of the farming of this State; in this practice whether the stock consists of dairy animals, young stock, sheep or hogs, the importance of a full supply of food, in order to maintain a continuous growth, is recognized. In many cases food-supplies run low in early spring, and food must be bought or the animals suffer; too often the latter is the case. Crimson clover is much earlier than red clover or the grasses, and furnishes an excellent early pasture for all kinds of stock, and its use as a pasture permits of the advantages that are derived when used entirely as a green manure, though in a less degree. The vegetable matter and nitrogen contained in the roots are quite as much a direct gain to the soil in humus-forming materials when used as pasture as when used as manure.

\section{The Composition of Clover Pasture.}

The analysis of the plant at this time shows it to contain a high content of water, in this respect resembling mangel-wurzels, beets, turnips, or cabbage, though the proportions of the food compounds in it are such as to make it better adapted as a sole diet than these crops.

The average composition on A pril 24th, on the basis of 90 per cent. water, is as follows:

\begin{tabular}{cccccccc}
\multicolumn{8}{c}{ POUNDS PER HUNDRED OF } \\
Water. & Dry & Crude & Crude & Carbo- & Crude & Albuminoid \\
90.00 & 10.00 & Fat. & Fiber. & Ash. & hydrates. & Protein. & Proteiu. \\
& 0.39 & 1.54 & 1.12 & 2.29 & 4.66 & 1.84
\end{tabular}

The use of the crop as a pasture is to be recommended, particularly on dairy farms, only when it is desirable to use the land for corn or other early spring crops, since protein, the most valuable of the food compounds derived entirely from the air, and therefore free of expense, increases very rapidly as the plant matures, and since its use as a soiling crop, or as hay, is much more economical of food than pasturage. 
Table 5.

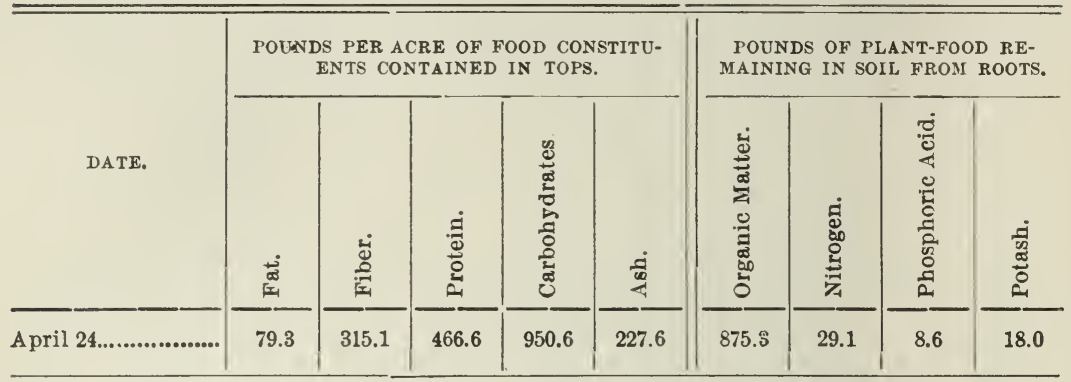

Table 5 shows the average amounts of food constituents contained per acre in the crops used in the experiment, as well as the plant-food remaining in the roots. The whole top is included here, since in pasturing the stubble is an insignificant item and also because it was. impossible at this stage of growth to draw the line sharply between stubble and tops.

\section{Its Value as Early Pasture.}

There is no satisfactory method of valuing exactly food constituents in products of this kind, and no attempt will be made to do so; this, however, does not prevent the drawing of fair comparisons as to the value of the crop.

In applying the digestion co-efficients of pasture grass we find the following amounts of digestible food per acre, viz., fat, 50 pounds; protein, 327 pounds, and carbohydrates, including fiber, 933 pounds, a total of 1,310 pounds.

The proportion of the different food eompounds is good so far as nutrition is concerned, though its use exclusively as pasture may not be the most economical; so used, however, we find that this amount will be sufficient to maintain 12 dairy cows in full flow of milk at least for one week.

A dairy farmer who this year used the crop as an early pasture reports that he is highly pleased with the practical results secured, and that he regards the plant as very valuable for this purpose in dairy districts. He began using it April 15th and the effect was immediately apparent in an increased flow of milk.

Farmers must determine for themselves what the amount of food 
here shown means for them, whether used by cows, sheep, horses or pigs, at a season when there is frequently a shortage of food.

Food furnished by the farm at this time has a greater value than at other seasons, because it is the exception rather than the rule for farmers who are not exclusively in the dairy business to buy feeds. Moreover, early pasture as is thus affurded will diminish the injury to regular pastures from too early use, which is frequently serious, owing to a lack of other food. Farmers should remember, too, that protein, the basis of which is nitrogen, is the most expensive constituent of feeds, and the one which is most liable to be deficient in the ration, and must, therefore, be purchased. In the clover it is furnished free of charge.

The residue contained in the roots only of the crop is shown to be 875.3 pounds of organic matter, containing 29 pounds of nitrogen, or an equivalent of 3 tons of city manure. At least 75 per cent. of the nitrogen contained in the clover eaten should be found in the manure. If this is all returned to the land, it is equivalent in nitrogen to that contained in $5 \frac{1}{2}$ tons of average manure, a total of $8 \frac{1}{2}$ tons, or quite sufficient nitrogen for a corn crop. Thus, even when used as an early pasture, this crop represents a very considerable gain to the land in the expensive element, nitrogen.

3.

AS A SOILING CROP.

The analyses of the different samples of green clover are shown in Table 6

Table 6.

\begin{tabular}{|c|c|c|c|c|c|c|c|c|c|}
\hline \multirow[b]{2}{*}{ 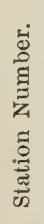 } & \multirow[b]{2}{*}{ DATE OF SAMPLING. } & \multicolumn{8}{|c|}{ POUNDS PER HUNDRED OF } \\
\hline & & 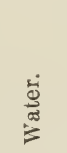 & 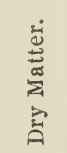 & 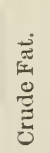 & 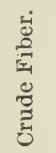 & 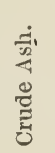 & 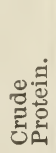 & 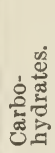 & 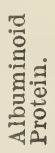 \\
\hline 827 & May $12 \ldots \ldots \ldots$ & 90.31 & 9.69 & 0.38 & 1.60 & 0.99 & 2.20 & 4.53 & 1.59 \\
\hline 828 & 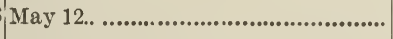 & 88.03 & 11.97 & 0.47 & 1.96 & 1.42 & 2.86 & 5.26 & 2.01 \\
\hline & 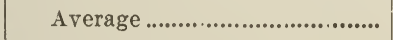 & 89.17 & 10.83 & 0.43 & 1.78 & 1.21 & 2.53 & 4.90 & 1.80 \\
\hline 831 & May $24 \ldots \ldots$ & 84.76 & 15.24 & 0.51 & 4.41 & 1.21 & 2.82 & 6.29 & 1.99 \\
\hline 831 & 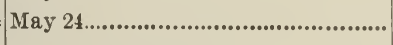 & 83.70 & 16.30 & 0.55 & 4.32 & 1.40 & 3.18 & 6.85 & 2.18 \\
\hline & 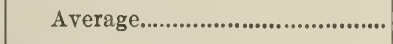 & 84.23 & 15.77 & 0.53 & 4.37 & 1.31 & 3.00 & 6.57 & 2.09 \\
\hline 837 & May $31 . . . . . . . . . . . . . . . . . . . . . . . . . . . . . . . . . . .$. & 83.26 & 16.74 & 0.53 & 478 & $\overline{1.47}$ & 2.95 & 7.01 & 2.13 \\
\hline
\end{tabular}


The samples taken on May 12 th still show a high content of water, in composition not differing widely in any respect from those samples taken April 24th.

The samples representing full bloom on May 24th, and the fully matured plant on May 31st, show a much higher content of dry matter, though still much less than is contained in other green forage crops. The samples at this time also show a much higher percentage of crude fiber than on the earlier dates.

Table 7 shows the amount of food constituents, both total and digestible, contained in the crops obtained from one acre, as well as the residue of plant-food contained in roots and stubble.

Table 7.

\begin{tabular}{|c|c|c|c|c|c|c|c|c|c|}
\hline \multirow[b]{2}{*}{ DATE. } & \multicolumn{5}{|c|}{ POUNDS OF FOOD PER ACRE. } & \multicolumn{4}{|c|}{$\begin{array}{l}\text { POUNDS OF PLANT-FOOD } \\
\text { REMAINING FROM STUBBLE } \\
\text { AND ROOTS. }\end{array}$} \\
\hline & 茜 & 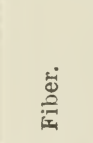 & 离 & 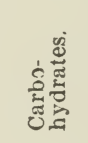 & $\frac{\frac{0}{0}}{4}$ & 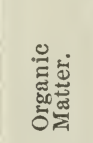 & 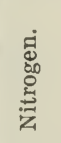 & 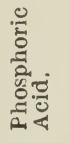 & 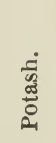 \\
\hline May $12, \ldots . . . . . .$. & 132.8 & 561.3 & 795.6 & $1,518.1$ & 377.0 & $1,406.2$ & 41.1 & 11.4 & 25.9 \\
\hline May $24 \ldots \ldots . . . . .$. & 1684 & $1,376.4$ & 945.3 & $2,066.4$ & 410.8 & $1,406.2$ & 37.9 & 10.1 & 14.2 \\
\hline May $31 . . . . . . . . .$. & 200.9 & $1,874.5$ & $1,121.9$ & $2,660.7$ & 558.9 & $1,200.2$ & 32.8 & 9.4 & 26.1 \\
\hline Average...... & 167.4 & $1,270.8$ & 915.2 & $2,091.7$ & 448.9 & $1,337.5$ & 37.3 & 10.3 & 22.1 \\
\hline $\begin{array}{l}\text { Digestible } \\
\text { food per acre. }\end{array}$ & 80.0 & 610.0 & 6580 & $1,486.0$ & & & & & \\
\hline
\end{tabular}

In the use of forage crops, cutting begins as early as a good yield can be secured, and continues as long as the crop is suitable for the purpose; in studying the yields, therefore, the average of the throe cuttings will be taken as the basis for calculations.

The digestion co-efficients determined for crimson clover hay at the North Carolina Experiment Station, and reported in their Bulletin $87 \mathrm{~d}$, were used to obtain the amounts of digestible food shown in the table. The clover in the earlier stages of growth, as represented by the samples, is too watery to give the best satisfaction as an exclusive feed, though in actual practice the forage would be much drier 
than is indicated by the analysis. In the sampling no loss of water occurred between field and laboratory, in practice a considerable drying is unavoidable, even when fed as soon as possible after cutting.

\section{Its Economical Use.}

The highly-nitrogenous character of the dry matter also indicates that it could be more economically used with cornmeal, which, in composition, is the reverse of the clover, viz., highly carbonaceous. Still excellent results, as in the case of pasturage, have been derived when it forms the entire ration. If so used the average amount of digestible food obtained per acre, on the basis of 15.4 pounds of digestible organic matter per 1,000 pounds live weight, is sufficient to feed 10 cows in full flow of milk for 20 days, the time during which, in average seasons, the product is suitable for the purpose.

If not used exclusively, it should be the aim of the farmer to make the clover furnish the bulk of the protein, and a ration made up of from 50 to 75 pounds of clover, depending upon its content of water, and 8 pounds of cornmeal, is suggested. On this basis the number of animals that could be fed for the given time would be nearly doubled, because the carbohydrates furnished by the cornmeal permits a more economical use of the clover.

\section{Its Value.}

As stated in reference to pasturage, it is a difficult matter to fix. a value on products of this kind in dollars and cents that would be applicable in all cases. It is, however, entirely legitimate in investigations of this kind to give as correct an idea as possible of the probable value.

Farmers do have very positive knowledge as to the value of wellcured red clover hay; they know that it is an excellent feed; it is so because of the kind and proportion of the digestible constituents contained in it.

The analyses of crimson clover hay made at this Station, and published on page 142 of the Annual Report for 1892, showed that a ton contained 83.6 pounds more of digestible matter than red clover, and that over 66 per cent. of this increase consisted of the most valuable 
compound, protein. On the same basis of water content, the yield per acre of dry matter here indicated is equivalent to 266 tons of hay.

The increased labor involved in using the clover as a soiling crop is somewhat greater than would be the case if the crop were made into hay, though this increased cost of food is probably balanced by the better quality of the product, the dry matter of the green forage showing a higher percentage of protein and lower percentage of crude fiber than the hay.

At present prices of feeds a good crop of mature crimson clover should be worth for forage at least $\$ 25$ per acre. In order to provide an unbroken succession of forage crops for the dairy, crimson clover fits in nicely between rye and red clover, two or three acres being sufficient for a medium-sized dairy. If more is grown than is needed for forage, it is suitable for preserving as ensilage, and it also makes an excellent hay, the chief objection here being that it matures too early for good hay weather.

That this clover is appreciated as a soiling crop is well illustrated by the following letter to the Director, dated May 17th, 1894, from Mr. I. W. Nicholson, a prominent and successful dairyman of Camden county :

"As you are interested in the introduction of crimson clover, I would like you to see a piece I am now soiling to my stock. You would see what the possibilities are on a rather light soil, without any extra labor.

"I am prepared to say I think very highly of this clover for soiling. It is an early crop, which is eaten by the stock with great avidity. I had a neighbor who sowed it with corn the last time of tilling, and had upon 7 acres about four weeks' pasture for a herd of 25 cows this spring, before plowing and planting in corn."

\section{The Value of the Manure and Residue in Roots.}

When used as a soiling crop the organic matter and nitrogen remaining in the soil from stubble and roots are equivalent to the amounts furnished by about four tons of city manure, or but little in. excess of that remaining when the crop is used as a pasture. The amount remaining in the manure from the crop fed on the assumption that 25 per cent. of the nitrogen is utilized by the animals, is much greater, or equivalent to $11 \frac{1}{2}$ tons of city manure, a total of $15 \frac{1}{2}$ tons for the whole crop. 
The nitrogen assumed to be utilized by the animals when the tops are used as feed, is 35 pounds, or equivalent to that contained in $3 \frac{1}{2}$ tons of manure, which would cost $\$ 5.25$, hence, when the manure is properly saved and applied, the manurial value of the crop is not materially reduced. Used as a manure only, the average crop per acre is worth $\$ 25.50$; when used as a feed the value is increased to $\$ 4525$.

This illustrates very clearly the wastefulness of using the matured crop solely as a green manure, wherever it is possible to use it as a feed.

These experiments emphasize the points stated in the beginning as already well established for crimson clover, and also suggest further important advantages from its proper management and use. These are summarized as follows:

\section{Summary.}

I. Crimson clover is an annual plant, hardy for the whole State; it has been successfully grown in every county from Cape May to Sussex. It is adapted for a wide variety of conditions, both in reference to character of soil, and method and time of seeding, though not as a substitute for red clover.

II. Its best use is probably derived when seeded in the summer or fall for an early spring crop, either for pasture forage or green manure. The time of seeding may extend from July 15 th to September 15th, depending upon the character of the season and the seed-bed; good results have been secured when seeded later than September 15 th.

The value of a spring seeding for a summer crop, either upon raw ground or with oats, has not been thoroughly tested in the State; experiments are now in progress here to study this point.

It is the experience of growers that the seed takes better when lightly covered. Failures to secure a good stand from good seed are reported as due chiefly to hot, dry weather after the sprouting of the seed, and to heavy rains immediately after seeding.

III. Crimson clover may be seeded in orchards, berry patches, corn, tomatoes, etc., and upon raw ground following after potatoes, tomatoes, melons or other crops harvested before September. It is not adapted for seeding with wheat or rye. 
The amount of seed may range within wide limits -8 to 16 pounds per acre; larger amounts are usually required when sown with other crops, and smaller amounts when sown upon raw ground or in orchards. Twelve pounds per acre will doubtless, be found to be sufficient.

No failures to stand the winter have been reported when good, American-grown seed was used. It is more hardy than red clover. Foreign seed has not proved satisfactory. It contains as impurities. weed seed and less hardy varieties of this clover. The seed is not as yet produced in any considerable quantity in this State. That used in our experiments was raised in Delaware, where the business of seedgrowing is assuming considerable proportions and is reported to be profitable.

IV. This crop, in common with all other farm crops, requires good soils for its best development, though it is well adapted for light lands, catching readily and growing well where red clover will not thrive, and also making use of the mineral constituents not available to the cereals.

The average yield secured from a full stand on May 24th, and representing soils of a different character, was 15.75 tons of green clover per acre, or equivalent to 2.7 tons of dry hay. It is believed that this fairly represents the yield that may be secured under favorable conditions, though very much larger yields have been reported.

V. Regarded as a green manure, particularly as furnishing nitrogen derived from the air, this crop possesses many advantages due to its time of growth and development.

A crop six inches high April 24th, showed an accumulation of nitrogen in the whole plant at the rate of 104 pounds per acre, an amount equivalent to that contained in ten tons of city manure or 648 pounds of nitrate of soda, costing $\$ 15$.

The crop secured at this date may be utilized for early vegetables, potatoes, melons, etc., crops usually benefited by liberal applications of nitrogenous manures.

On May 12th, a crop averaging 13 inches high, which in many sections can be utilized as a manure for late potatoes, corn, and orchards, contained nitrogen at the rate of 168 pounds per acre, worth $\$ 25.50$. The plant at maturity showed nitrogen at the rate of 200 . 
pounds per acre, or an amount equivalent to that contained in 20 tons of city manure, which would cost in that form $\$ 30$.

Good crops of this clover can be obtained on naturally-poor or worn-out lands when fertilized with the mineral constituents only; these soils are rapidly improved by the addition of the nitrogen and accompanying organic matter contained in the crop.

VI. This plant provides a good pasture before other crops are available. An early pasture is not only valuable for the food contained in it, but also because it helps to insure proper feeding and to. prevent too early use of other and later pastures. It was pastured this year in central New Jersey as early as April 10th. The crop when six inches high contained over 1,300 pounds of digestible food per acre, sufficient to properly nourish twelve cows for one week.

The fertilizing value per acre of the residue in the roots, is equivalent in nitrogen and organic matter to that contained in three tons of city manure.

VII. Crimson clover in average seasons provides a soiling crop excellent both in yield and quality of product; it is satisfactory for the purpose for about twenty days, and at a time when other forage crops are not abundant.

On the basis of the yield of digestible food secured in the experiments-2,934 pounds per acre-it will provide sufficient for ten cows in full flow of milk for twenty days, worth at present prices of feed, at least, $\$ 25$ per acre.

The composition and digestibility of this plant show it to be superior to red clover, and when seasons are favorable for early haymaking, the product thus secured is not excelled by any of our farm crops as a feed for all purposes.

The advantages derived from the crop when used solely as a green manure are but slightly reduced when the crop is used for food, provided the resulting manure is properly saved and applied.

EDWARD B. VOORHEES,

Director.

New Bronswick, N. J., June 11th, 1894. 

THE USE OF KOCH'S LYMPH IN THE DIAGNOSIS OF TUBERCULOSIS OF CATTLE.

\title{
NEW JERSEY
}

\author{
Agricultural COLlege
}

\section{Experiment Station}

101 


\section{NEW JERSEY AGRICULTURAL COLLEGE EXPERIMENT STATION.}

\section{BOARD OF CONTROL.}

The Board of Trustees of Rutgers College in New Jersey.

\section{EXECUTIVE COMMITTEE OF THE BOARD.}

AUSTIN SCOTT, Pн.D., LL.D., President of Rutgers College, Chairman. HoN. GEORGE C. LUDLOW, HENRY R. BALDWIN, M.D., LL.D. HoN. HENRY W.BOOKSTA VER, LL.D., JAMES NEILSON, Esq.

\section{STAFF OF THE STATION.}

AUSTIN SCOTT, Ph.D., LL.D., Director.

Professor JULIUS NELSON, Ph.D., Biologist.

Professor BYRON D. HALSTED, Sc.D., Botanist and Horticulturist.

Professor JOHN B. SMITH, Sc.D., Entomologist.

ELISHA A. JONES, B.S., Superintendent of College Farm. IRVING S. UPSON, A.M., Disbursing Clerk and Librarian. CHARLES A. POULSON, Mailing Assistant.

LEONORA E. BURWELL, Clerk to the Director.

AUGUSTA E. MESKE, Stenographer and Typewriter. 


\section{NEW JERSEY}

\section{Agricultural College Experiment Station.}

\section{BULLETIN 101.}

JULY 2, 1894.

\section{The Use of Koch's Lymph in the Diagnosis of Tuberculosis of Cattle.}

BY JULIUS NELSON, BIOLOGIST.

\section{§ 1. Brief Record of Operations at the College Farm.}

Early in June, 1893, I was asked to examine, with the microscope, the milk of a Holstein cow, Tryntje von Hollingen by name, a member of the College farm herd. This cow had been suspected of being tuberculous, although at this time she was in fair condition, coughed only occasionally, but was somewhat languid and the right hind quarter of her udder presented the symptoms of garget-being hard and swollen.

A thorough and extended microscopical study of her milk by numerous methods failed to give me any evidence of the presence of the germ of tuberculosis. The milk was of excellent quality.

Finally it was decided to test her by the Koch test, which consists in the hypodermic injection of a 10 per cent. solution of Koch's lymph (or tuberculin) in a 1 per cent. solution of carbolic acid. Experience had abundantly proven to previous observers that if this is done on a healthy cow no change of her temperature results, but if she have tuberculosis in the slightest degree there is a fever reaction, the temperature rises in from six to twelve hours after injection and remains up for a number of hours before falling back again to the normal. 
It is well known to veterinarians that the normal temperature of a cow in the early morning is lowest, so that if the injection be made in the evening the reaction, if any, will occur when the temperature should be lower than the initial temperature observed in the experiment. When it is found that the morning temperature, after inoculation with tuberculin in the evening, is higher than the evening temperature, a reaction is at once predicated and this reaction is all the more certain in proportion to the absolute rise. So certain is it that a cow which shows a reaction is tuberculous that the State would risk little if any money, should it promise to pay for every cow showing reaction which on being killed failed to show the presence of tuberculosis.

Accordingly, on the evening of July 24th Tryntje was injected with 80 minims of tuberculin solution-a large dose, determined by the large size of the cow. The temperature record observed was as follows :

$\begin{array}{cccccccc}\text { 8:00 } & 10: 00 & 12: 30 & 3: 00 & 5: 00 & 7: 15 & 10: 00 & 11: 30 \\ \text { p. m. } & \text { p. m. } & \text { a. m. } & \text { a. m. } & \text { a. m. } & \text { a.m. } & \text { a. m. } & \text { a. m. } \\ 10335^{\circ} \text { F. } & 103.1 & 103.2 & 102.2 & 102.2 & 101.2 & 101.5 & 102\end{array}$

It is plain that the above record is not a reaction, and I so reported ; but in the light of subsequent experiments, it now seems possible that a reaction took place.

August 11th. A cow from the farm, on being slaughtered, showed abscesses in lungs and near kidneys, which, on microscopic examination, showed the presence of the germs of tuberculosis. At this date the milk from the gargety quarter of Tryntje's udder suddenly changed for the worse; it became watery, coagulated and had little fat or cream content. Microscopic examination showed it to be full of decomposing cells and various bacteria, among which the tubercle germ was found to be present. The cow was then isolated from the other members of the herd, and a continued observation made of her milk, which was thrown away so far as it was not used in experiments.

October 29th a normal, apparently healthy, calf was born to Tryntje. This was isolated and fed by milk from the three teats which produced milk of good quality. The cow had been dry for several weeks before calving. The right hind teat continued to give a small amount of abnormal milk. November 9 th the calf was killed and specimens taken of its different organs for microscopic examination and the rest of the carcass was buried, although to the eye it presented a wholesome appearance. At this time it was noticed 
that the milk of the right front quarter of Tryntje's udder was also becoming abnormal. Experiments were continued, and I was greatly interested in studying certain physico chemical reactions which I supposed might possibly be used in determining whether the milk of a cow is affected by tubercle bacilli or not, when the news came, November 30th, that Tryntje was dead.

The autopsy was held that afternoon, in a field distant from the barn, and it showed clearly that death was the result of tuberculosis. The muscles seemed to be the only tissues not yet converted into tuberculous masses, so extreme was the invasion of this mysterious and irresistible disease. After the birth of the calf, the failure of health of the mother was rapid; the change during the last week was so great that whereas a few days before, the cow seemed likely to live for many months, after death (I meanwhile had not seen her) she presented an appearance of emaciation which, had I scen before, would have determined her immediate slaughter.

Meanwhile, the farm management had called in Dr. E. L. Loblein, veterinary surgeon, to examine the herd. Two cows presented unmistakable signs of tuberculosis, and it was determined to test Koch's lymph again. November 8th, Tryntje's calf was injected with 20 minims tuberculin, and Maria Starr, a Holstein, received 50 minims, the temperature record being as follows for the calf:

$\begin{array}{lrrrrrr}\text { 6:00 } & \varepsilon: 15 & 2: 00 & 5: 00 & 7: 15 & 12: 00 & 4: 00 \\ \text { p. m. } & \text { p. m. } & \text { a. m. } & \text { a. m. } & \text { a. m. } & \text { m. } & \text { p. m. } \\ \text { 102.6 (before injection). } & 102.8 & 103.2 & 103.2 & 104 & 104.8 & 103.6 \\ 102 \text { (immediately after). } & & & & & & \end{array}$

This appeared like a reaction, although the normal temperature of young calves is much higher than of cows, and is readily disturbed, so there is some doubt. The record for the cow was :

$\begin{array}{ccccccc}\text { 6:30 } & 8: 55 & 2: 15 & 5: 00 & 7: 30 & 12: 00 & 4: 00 \\ \text { p. m. } & \text { p. m. } & \text { a. m. } & \text { a. m. } & \text { a. m. } & \text { m. } & \text { p. } \text {. . } \\ \text { 102.5 (before). } & 103.4 & 106.3 & 106.3 & 105.8 & 103 & 103.3 \\ \text { 102.6 (after). } & & & & & & \end{array}$

This is a decided reaction.

A week later, the other cow, Marion Perkins, a native, was injected with 40 minims and gave this record:

$\begin{array}{ccccccccc}5: 00 & 8: 00 & 2: 00 & 5: 00 & 8: 00 & 12: 00 & 3: 30 & 6: 00 & 8: 00 \\ \text { p. m. } & \text { p. m. } & \text { a. m. } & \text { a. m. } & \text { a. m. } & \text { m. } & \text { p. m. } & \text { p. m. } & \text { p. m. } \\ 102.4 & 103.4 & 105 & 104.4 & 105.8 & 106 & 105 & 105.8 & 105.6\end{array}$


Next morning at 6 A. M., 101.8, or more than two and a half degrees $\left(2.5^{\circ}\right)$ lower than on the previous morning, when the tuberculin was acting; hence, an evident reaction. After the death of Tryntje, the slaughter of these two cows, which had been isolated as soon as the reaction was shown, was decided upon, but the desire to continue certain researches upon the milk of Maria Starr delayed the execution. Her milk was fed to a calf born to Fillpail November 8th (the mother at that time not suspected, but later proved to be tuberculous). This calf was injected with 15 minims lymph December 11th, and gave this record:

$\begin{array}{ccccccccc}\text { 5:30 } & 9: 00 & 2: 03 & 5: 00 & 9: 00 & 12: 00 & 4: 00 & 8: 15 & 10: 00 \\ \text { p. m. } & \text { p. m. } & \text { a. m. } & \text { a. m. } & \text { a. m. } & \text { m. } & \text { p. m. } & \text { p. m. } & \text { a. m. } \\ 103 & 101.8 & 104.2 & 104.6 & 104 & 104.5 & 1036 & 104 & 103.6\end{array}$

While this appeared to be a reaction, the fact of the youth of the creature caused a doubt to remain. Accordingly, on the night of December 15th, Mr. E. A. Jones, the College Farm Superintendent, who had taken the above record, observed, at my request, the temperature of the calf when it was not under the influence of tuberculin, with the following results:

$$
\begin{array}{cccc}
\text { 6:00 p. m. } & 10: 00 \text { p. m. } & 2: 00 \text { a. m. } & \text { 5:30 a. m. } \\
101.8 & 102 & 101.6 & 101.8
\end{array}
$$

A comparison with the corresponding hours of December 11th, after injection, shows an evident reaction. This calf was butchered January 15 th ; it was in prime condition, without a flaw to the eye, nevertheless specimens of various organs were taken and prepared for microscopic examination. December 23d, the two cows whose records we have presented, were killed and autopsied near the grave of Tryntje, with the following results :

In the case of Maria Starr (66), the membrane lining the chest walls was studded with tubercles (pearl disease), the bronchial glands were enlarged with tubercles, the lungs were filled with large cheesy bunches, the liver was covered with similar tubercles, and the caul, mesenteries, and intestines showed small scattered tubercles or pimples, known as miliary tubercles.

In the case of Marion Perkins (73), the left lung was nearly solid and the right partly invaded by tubercles; the bronchial and mediastinal glands were enlarged and converted into a bright-yellow cheesy material. She was evidently not so tuberculous as the former case, 
but leaving Tryntje out of comparison, would be still considered as in an advanced stage of tuberculosis.

The results of these autopsies determined the farm management on a thorough inspection of the herd. Dr. Loblein examined the herd, keeping his results to himself temporarily, and I injected the herd with tuberculin, Mr. Jones taking the temperatures. Sufficient tuberculin (thirty dollars' worth, or 240 minims, equals 15 cubic centimeters) was secured, and on the 29th day of December, nineteen cows, and January $2 \mathrm{~d}$, sixteen others were injected, the records of which will be found in the tables accompanying this report. Two heifers and a bull were left uninjected, the lymph having been exhausted. The bull was killed without injection, but found to be healthy. The two heifers were injected by Dr. Loblein at a later date. (See Tables. Nos. 7-43.)

The general results may be summarized as follows: Nine cows are apparently sound, four are doubtfully sound; two are doubtfully tuberculous, six are probably tuberculous, while eighteen may be safely killed as tuberculous.

The veterinarian's inspection showed fifteen cows as "suspicious" cases, varying from "very suspicious" to "slightly suspicious." When these suspicious cases were compared with the classification under the Koch test it was found that two cases came under the "apparently sound" group, one under the "doubtfully tuberculous" group, two under the "probably tuberculous" group and eight under the "certainly tuberculous" group. The other eight tuberculous animals were pronounced $\mathrm{O} \mathrm{K}$.

The cows were killed in the order of their certainty of reaction, and every member of the certainly-tuberculous and probably-tuberculous groups was seen to be decidedly tuberculous, except two cases in the "probable" class, about which there is doubt until the microscopic evidence is in.

Thus there has been a thorough weeding out of the tuberculous cattle, which, but for the use of the Koch test, would have been impossible. Every new cow now added to the herd is first tested by injection, and she is purchased only when her temperature record is unaffected by the injection. The evidences that such cows are sound are discussed in a later section of this report.

The stables and quarters which the College herd has used have been thoroughly cleaned and disinfected, and the Koch test will be used from time to time in the future to detect any case of tuberculosis 
arising in the herd in its incipiency. In this way the herd can be kept clean and reliable. The reason for all this care and expense will appear evident to one who considers the points presented in the next section.

TABULATION OF RESULTS OF DIAGNOSIS BY KOCH TEST COMPARED WITH DIAGNOSIS BY PHYSICAL EXAMINATION.

Diagnosis by Koch's Lymph.

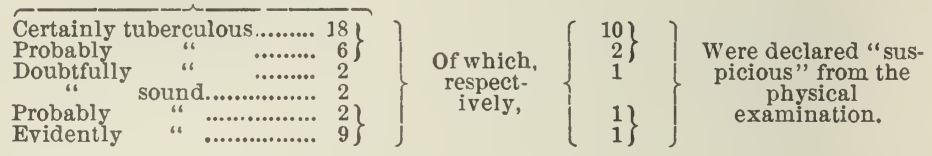

\section{§ 2. What is Known about Tuberculosis.}

Tuberculosis, also known as phthisis, pearl disease or consumption, has hitherto remained incurable; it is the most widely spread scourge that mankind has to deal with. The proportion of adult deaths due to this cause has been placed at a third, while at least a fifth of the infant mortality has been traced to this cause. Some authorities say that about a seventh of the whole population is carried off prematurely by this disease. There are many persons who die of other diseases, and again many whose bodies are not examined, who in all likelihood have developed tubercles to an unknown extent. Then, too, there are other diseases, evidently closely related, but in just what way science has not yet discovered, such as scrofula and lupus; even syphilis and leprosy have been suspected of having relationship here. With all due reserve, the most conservative of physicians admit the prime importance of studies relating to this prince of maladies.

In 1882 Robert Koch definitely settled the question of the cause of tuberculosis by discovering the parasite, the presence of which in the animal tissues causes those degenerations and growths of abnormal tissue known as tubercles. This parasite is a bacterium or bacillus, a rod-like living organism less than one seventy-thousandth of an inch thick and averaging one eight-thousandth of an inch in length. Like other bacteria it grows and multiplies by feeding on the juices of the body and reproduces by continual breaking into halves, each of which is a complete organism from its birth. We can easily calculate the immense numbers that would exist in a short time if the conditions for feeding and reproduction continued favorable. Fortunately our tissues fight these parasites and it is probable that the tuberculous mass results from an attempt on the part of the tissue to imprison 
these marauders, because the blood-supply is cut off from the gland or locality of growth by the formation of fibrous material, so that the internal parts of the tubercle gradually change into cheesy material or undergo other degenerative changes the nature of which is obscure.

Since this discovery by Koch, physicians have separated into three divisions on the question of the cause and nature of consumption.

The first class says, let the germ once invade a healthy man and he will contract the disease; hence the full cause of the disease is the presence of germs; therefore we must combat them, kill them, isolate all consumptive persons and animals, destroy all tuberculous meat and food products; in short, as soon and as thoroughly as possible, eradicate this germ. This group of physicians is giving way, in part, to a second group, now largely increasing in numbers, who believe that an appropriate soil is necessary, a weak condition of constitution, produced by poor feeding, bad habits and especially by poor ventilation. Such a constitution presents appropriate conditions for the invasion of disease germs. Science has considerable to say on this point just now, and it seems likely that the "proper soil" theory will narrow down to this, viz., the body is too weak to combat the entrance of germs or to restrict them after entrance. This is done in various ways, the most usual being the eating (to use a popular expression) of the germs by the white cells of the blood, the lymph corpuscles; also the secretion of special poisons by certain tissues, inimical to the germs, which are thus met by their own weapons, for it is now recognized that bacteria produce disease by means of the poisons they excrete while trying to gain their own subsistence. Scientific investigation will doubtless discover other methods the body has of fighting against these germs, the sum total of which powers constitutes good health.

The third group of theorists is loth to give up the old view of disease, that it is a condition of constitution produced by failure of life forces to keep up a certain "vital force" in face of external changes. Thus it follows that the environment causes disease in the weak, e.g. a cold is produced by exposure. The products of disease, mucous or tubercle or what not, become breeding-grounds for the bacteria which may or may not find their way thither. Certain cases of tubercle, in which investigators failed to find the germs, are brought up in evidence, and the reply of their opponents that the 
bacilli must have been present originally is ridiculed as begging the question.

It seems apparent that the members of the second group hold all that is valuable in the evidence supporting the first and third classes of views, and those who are familiar with disease germs by actual experiment with them belong overwhelmingly to the middle class. Thus the present verdict of authority emphasizes hygienic as well as germicidal and quarantinal methods.

Are all tubercular growths due to a single species of germ ? From what we know by analogy of germ investigations in general, we might expect that the varieties of tubercle and of consumption are due entirely to individual peculiarities of the person reacting on one species of germ. Thus, the germ of quick consumption, when transplanted into another person, need not produce this variety of disease, and similarly, the germ of chronic tubercle, in all likelihood, does not change its nature when transplanted into a person who, as a result, suffers from quick consumption. It is rational to believe that when a person who has suffered for years from the "slow" variety suddenly develops the "quick" variety, that his constitution has finally given up the struggle. We all give up the struggle of life sooner or later, and these germs are only a specific form of the varied forces that cause death universally. The burden of proof lies with those who assert that there are various distinct species of consumption germs. Some tubercles, which are produced apparently without the agency of germs, may be due either to ultra-microscopic spores, or the germs may have disintegrated, possibly forming spores, which we know are difficult, if not practically impossible, to demonstrate in certain cases.

The germ of tuberculosis in animals differs slightly as to size from that thrown up in the sputum of consumptives, yet the characteristic forms of tuberculosis have repeatedly been produced in animals inoculated with tuberculous germs taken from man and from other species of animals at will. Science has, indeed, shown that other germs, as in actinomycosis, for example, do produce forms of tubercle that have been mistaken for tuberculosis, but the same science that demonstrates this specific difference is competent, by means of similar methods, to pronounce upon the question of the unity of the disease tuberculosis. While we admit that the question is not finally closed, we must act on the evidence already in, and that evidence is in favor of such unity. 
To what extent are our domestic cattle affected with tuberculosis? Statistics of slaughter-house and meat inspection in various countries and cities give as an average about 3 per cent., but locally the percentage may rise far higher or may be lower; 16 per cent. and 26 per cent. are some of the figures quoted. One authority has stated that 50 per cent. of the cattle of Holland was infected. The entire College herd of fifty-seven animals of the Maine State Agricultural College was slaughtered and buried as the result of physical examination alone. Our herd has been found tuberculous to the extent of 70 per cent. A herd at Burlington, N. J., injected with tuberculin last autumn, was found affected to the extent of 60 per cent. A herd of high-bred Jerseys at Villa Nova, Pa., was tuberculous to the extent of 50 per cent. The Willard Asylum, N. Y., lost nearly two hundred high-bred Holsteins. And, as inspection goes on, cases of similar great infection are continually being reported. When once tuberculosis has gained foothold in a herd, it rapidly spreads through the entire lot. Our statistics show that by the use of tuberculin twice as many cows were discovered infected as physical examination alone would have revealed. Statistics gathered in the past, based on physical examination alone, are undoubtedly too small. Even those based on meat inspection are probably under the truth. The majority of the cows shown to be tuberculous by our use of the Koch test had tuberculosis in either incipient degree or so slightly that very thorough examination of entrails and the lymphatic structures connected with the lungs became needful in order to diagnose the disease from autopsy. Are we sure that such examination of structures, usually thrown on the refuse pile, though sometimes used in the manufacture of sausages, was absolutely thorough? As regards the carcass, trimmed of these organs, it has been shown that only in the severest cases, and then only to the extent of 10 per cent., is the muscular portion invaded by bacilli, and then only to microscopic extent, requiring inoculation experiments to demonstrate. Most observers have failed utterly to find the bacilli in the meat of tuberculous animals after the most careful work, consisting of inoculation experiments.

How far are other animals affected? The domestic fowl is even more subject to tuberculosis than the cow. Zürn found sixty-two cases in six hundred examinations. More than ten per cent. Cats, dogs and especially swine are susceptible to this contagion, as are, in a 
greater degree, captive animals. Rabbits, guinea pigs and mice are so very susceptible that they are used in all delicate inoculation experiments to test the presence of bacilli.

This disease has been termed both contagious and infectious, but both these terms grow out of the fact that it is due to a germ, and thus the old distinction between these terms is seen to be of secondary, perhaps trivial, value. Certain it is that no matter how susceptible a person or animal may be, if the germs are not introduced into the system no disease of this sort will result. It is this conviction, resting on sure foundations, that is the real animus in the work of physicians as they agitate in favor of methods for stamping out or restricting the disease, on the one hand, by a quarantine of consumptives, with extreme care in dealing with sputa; and on the other, by the destruction of tuberculous animals and care in the disposal of their carcasses.

What conditions favor the state of susceptibility to consumption? First and foremost is bad ventilation. Naturally this weakens the life-forces, and at the same time presents the germs in increased numbers in every breath. While in cultures, and in very susceptible bodies, a single germ can generate millions of offspring, it is found that the question of numbers of these parasites counts for much. There is plenty of evidence to show that tuberculous subjects, whether human or animal, are almost exclusively or at least in great majority produced in ill-ventilated habitations. Next, if not of equal importance, is sunlight. I find this point not sufficiently emphasized in the numerous reports and hygienic recommendations that have been sent out. People, as a rule, are afraid of the light. This is one of the most sinful of unhygienic practices. The shady side of streets receives more visits annually from the physicians than do the sunny side, in spite of numerous sun shutting-out devices. Koch states that a few hours of sunlight acting on a tuberculous germ will destroy it, and a few days of diffused daylight are germicidal. Why neglect this chief of disinfectants? We have bacteria classified as aërobic and anaërobic, according as they thrive with or without access of air. We need to classify bacteria as photic and aphotic. A next fertile source of susceptibility is heredity. I find this word used hardly a single time, by writers, in its proper sense. The transmission of a germ from a mother to a fotus is congenital transmission of disease (or congenital infection) and never is itself true heredity, which word means the sum total of 
the species characteristics as modified by the special environment in which the individual is produced and to which the individuality is due. Thus, if the tissues, by heredity, are strong, the tendency to contract consumption at any period of life, prenatally or postnatally, is slight. But if they are weak, the susceptibility in this regard is strong or certain. This explains why consumption runs in families. Possibly in these cases, many times, the fotus is infected from a consumptive mother during gestation, or even from a father, before conception, but such transmission is simply early infection. The acquiring of consumption by infection in later life is as truly due to hereditary influence as is foetal infection, in such cases. In this sense all cases of consumption are always both hereditary and due to infection; but the special sort of infection termed "hereditary" should always be designated as "congenital" infection or transmission.

Finally, we have to enumerate general unsanitary living, overwork, bad feeding, lack of exercise, dissipation and all bad habits that tend to weaken the organism. It has been stated that a healthy lung cannot be infected with tubercle germs, but there must exist some abrasion or lesion, an inflammation, perhaps, due to the irritation of dust particles. Statistics show that workers in an atmosphere filled with dust of various sorts suffer proportionally more from consumption. Such abrasions and inflammations are less apt to arise in one who takes good care of his health, original hereditary endowment being equal. But we all have our special weaknesses, and at those points the fortress is taken by some germ species or other. The weakest are first weeded out. It is our duty to fight disease germs by scientific methods, as well as by our phagocytes and toxalbumins; thus our energies are available in other lines and last longer. But it must never be forgotten that our present immunity from many of the germs about us, at least for the average lifetime of man, has been purchased at the expense of the weeding out of susceptible ancestors, so that we who remain are the descendants of the strongest.

I point out a danger that may arise could we really succeed in extinguishing this species (which is not probable), viz., the evolution of a weakened race, into which, at some future time, some germ now restricted in its operations, shall suddenly make an incursion as a "scourge of God." We, in fact, aid the beneficent work begun by these bacteria when we hasten the death of the animals which we are responsible for having produced, with their weak constitutions: a 
weakness due to our forcing methods of feeding, with brewers' grains, for example, our overcrowding and, above all, our close inbreeding. Biology teaches us that the great use of crossing is to produce vigor, but in the evolution of our dairy breeds this is, to a large extent, neglected.

We should always emphasize the importance of hygienic methods of life without lessening that fear of the germs which leads to cleanliness. The promotion of aseptic and antiseptic conditions is only a particular branch of hygiene. In what ways do the germs enter the bodyhuman and animal? Some cases are undoubtedly due to congenital infection or transmission. A case has been clearly established in which a foetus was tuberculous, while the mother had tubercle in the lung only. It is presumed that at some period a few bacilli or spores. bad been carried by the blood to the placenta and had been transferred to the foetal circulation. Possibly, certain leucocytes had been the carriers of the germs, for they, by diapedesis, it seems to me, could be the only agents in such a transfer, as these bacilli are not known to possess locomotor powers. That bacilli multiplying in one part of the body may be transferred to distant portions of the body is evident from an inspection of the evidence presented by numerous histories of cases. It is also shown by the experiment of a Greek physician, who inoculated a man in the thigh, and in a few weeks the lungs, hitherto sound, were thoroughly infected. It is a plausible supposition that the intrasomatic distribution of the bacilli is due to the lymphatic circulation, although we have no evidence as yet that the blood does not also aid. Tuberculosis is primarily a lymphatic disease: the lymph glands are the first to show signs of its presence. We must also remember that the serum currents flow from the blood vessels into the lymphatics.

A second method of infection is through abrasions or wounds of the skin and mucous membranes. Of this several cases are recorded. A. third method is through the breathing of air containing the bacilli. In some way due to a lack of proper vigor of the cells lining the bronchial tubes the bacilli are not carried out, but lie and probably breed on the surface before penetrating into the interior. It seems to have been taken for granted that every case of lung consumption has. arisen in some way similar to this. But it may be that the lung is frequently infected through intrasomatic distribution. A fourth point of entrance is through the walls of the alimentary canal. The pres- 
ence of miliary tubercles on the intestine is supposed to point to this conclusion. But we must not forget that intrasomatic distribution may have followed a primary lesion in the lungs which may have gone no further than a localized abrasion or inflammation of the airpassages. If infection through the food be granted, we must assume that the gastric and intestinal juices have failed to destroy the germ. Then we have still to get it through the mucous membrane, and in this instance the possibility of leucocytal infection and diapedesis must likewise be granted. It is plain that the inference of the method of infection from location of tubercular lesions is a complex one. That infection may be produced both by inspiration and by ingestion, has however, been abundantly proven by experiment.

Next as to the method of intersomatic transmission. We know that in the human subject the expectorations are the prime source of contagion. "Millions of bacilli" have been estimated as the daily output from a single patient. The sputum, dried and turned to dust, is in fit condition to contaminate both air and food. The atmosphere in a room occupied by a small-pox patient is no more filled with disease germs than that occupied by a consumptive. But, of course, we have to take many modifying circumstances into account when we calculate the relative amount of "risk" of contagion or infection in the two cases. These circumstances have been discussed in the preceding pages; they are: light, air, cleanliness, vigor, heredity, closeness of contact, length of exposure and many others. Instances of infection introduced by accessions of consumptives to healthy schools could be cited.

A number of cases are on record of pet animals catching consumption from their masters and mistresses. Even hens fed by a consumptive have become infected. On the other hand, what risk is there of transmission from animals to one another and to man? They do not, as a rule, expectorate, still it has been frequently noticed that the introduction of a tuberculous animal in a herd has been followed by the gradual spread of the disease throughout the herd, beginning with the cows nearest to the source of contagion. In such cases it is said that the drinking vessels receive the germs. This presupposes that there is a gradual working up of small quantities of mucus containing the bacilli. The excrement has been examined and is generally free from these bacilli. It has been suggested that the expiratory 
breaths carry out the tuberculous germs, but we certainly need more careful study of these points.

Finally, we have to ask, Does the milk of a tuberculous animal contain tubercle bacilli? This is important because milk is universally used, and is generally taken uncooked. Cooking destroys its digestibility ; four per cent. of the fat of raw milk fails to he assimilated; this rises to six per cent. in the case of boiled milk. The nonassimilable nitrogenous ingredients are similarly raised from seven to eight per cent., and the milk-sugar also undergoes a change. These changes do not take place if the milk be heated for a moment up to $185^{\circ} \mathrm{F}$., a temperature which is germicidal, provided the milk be not allowed to cool too rapidly.

The high percentage of infants showing intestinal tuberculosis has been thought due to the use of contaminated milk. Older persons using the same milk may not become infected. Other things being equal, the number of germs per volume of milk is very important. The subject has been investigated by feeding experiments, by culture experiments, by inoculation of susceptible animals and by microscopic examination. It was for some time believed, on the statement of Koch, that the milk of a tuberculous cow would not contain tubercle bacilli until the udder tissue became the seat of a tuberculous process. But plainly the bacilli must be transferred thither before the udder can become diseased. In the early stages of tuberculosis very few, if any, bacilli are carried to the udder; but in more advanced cases, showing tuberculosis by physical examination, Ernst and Peters have found bacilli in the milk of one-half of the cases (the udders apparently healthy), although other observers have secured less striking, or more often negative, results. Even with inoculation it is found that if milk which is tuberculous be diluted to a considerable extent, forty or fifty to one hundred parts water being added (or less if milk be added), it loses its infectious properties. Mixed milk is therefore safer than the milk from a doubtful cow, provided only one or two cows in a herd are affected.

Feeding experiments with calves and pigs have given positive results with Ernst and Peters and others, and less positive or negative results with still other observers. Microscopical examination, especially of milk, is the least satisfactory of all methods, because the germs must be sufficiently numerous to give at least one germ for each drop of milk, otherwise the chance of finding the germ is so small as to 
increase the tediousness of search beyond practical limits. Ernst and Peters, however, were successful in demonstrating the presence of the germs in one-fourth of the cases.

In the light of these experiments the milk of a tuberculous cow must be regarded with suspicion until proven pure. It is probably easier to sterilize the milk than to have it examined. It is certainly risky to use it for feeding animals without boiling. It may, however, be safely used as a whitewash on the outside of buildings, as when properly salted it makes a valuable paint. The germs have been found equally in the cream and in the milk, so that we are as open to infection through our butter as through our milk. It is the belief of some physicians that if all tuberculous cows were destroyed consumption would disappear from the human family. This is based on the observation that where cows are absent there is no consumption. By the use of Koch's lymph we are now able to detect twice as many tuberculous cattle as was possible by former methods. Should it prove infallible, succeeding in demonstrating every tuberculous animal (when used in connection with physical examination), we have the means wherewith to test the truth of the belief that human consumption is derived from bovine tuberculosis. Nothing but good can be the ultimate result from an attempt to weed out the tuberculous stock in our dairies, and doubtless the breeder and the dairyman will find it to their highest. interest to effect this result as promptly as necessary.

\section{$\S$ 3. Detailed Record of Operations Relative to the Diagnosis of} Bovine Tuberculosis.

This section supplements section 1 , and presents the scientific dats of the experiments and observations which are to be discussed in section 4.

The following order of work was followed as nearly as possible, in the case of each cow in the herd:

(1) Physical examination by a veterinarian.

(2) Temperature per vaginam by means of a self-registering clinical thermometer.

(3) Washing (with warm water and soap) of the right shoulder and rinsing.

(4) Washing with a 4 per cent. solution of creoline, an antiseptic claimed to be superior to carbolic acid. 
(5) Injection, hypodermically, of approximately 50 minims (=3 cc.) of a 10 per cent. solution of tuberculinum Kochii in a 1 per cent. solution of carbolic acid - the puncture swabbed with creoline solution.

(6) Temperature tested approximately every three hours for a period of twenty-four hours.

(7) Examination of the records made by each cow and ascertainment of the amount of reaction, as measured by the highest record compared with the highest normal record. The latter, presumed to be about at evening time, was given by the first two readings taken before the tuberculin had time to act. In some cases a curve of the temperatures was plotted, and in doubtful cases the temperatures were observed again when the animal was not under the influence of the "lymph."

(8) The assignment of each animal to a certain rank, determined by the extent and certitude of the reaction; the order of rank from highest to lowest being taken as determining the order of slaughter. We also determined, in case any doubt remained as to the stopping point, that the occurrence of two successive cases of tuberculous-free autopsies be the signal for stoppage.

(9) Samples of milk were drawn into clean tubes stopped with cotton, the milk being taken from each teat separately.

(10) A portion of the milk was prepared by Thörner's method for determining the presence of tubercle bacilli by microscopic examination, after the use of the centrifugal machine. This method consists in first alkalinizing the sample in a test tube with potash to the extent of 1 per cent., next heating until the milk turns brownish and the fat is partly saponified and the casein rendered soluble in acids, then adding an equal amount of glacial acetic acid and heating until a tolerably clear liquid results. This liquid is then whirled with four thousand revolutions per minute, the sediment, containing tubercle germs in a concentrated or aggregated mass, is washed in hot water, which is again whirled for ten or fifteen minutes, and the new sediment is prepared for microscopic examination. The object is, first, to get rid of the fat globules which always rise in a centrifugal machine and drag at least half the bacteria with them; second, to gather the germs from a relatively large quantity of milk into a small compass, so as to insure their being found under microscopic examination. Our centrifugal machine was a Babcock tester, run by hand-power, capable of giving only one thousand revolutions per minute, and after 
thoroughly testing its ability to separate bacteria, and discovering that even after an hour's whirling no appreciable diminution of germs resulted near the surface, while only the coarser sediment (which, however, dragged down a few bacteria) gathered at the bottom of the tubes, I dropped this link in the series of tests.

(11) A portion of the milk was evaporated on glass slips and slides in an incubator at $104^{\circ} \mathrm{F}$, and some at $70^{\circ}$. All samples thus prepared were inclosed, when dry, in envelopes and stored for future work.

(12) A final portion of the milk was preserved, either by addition of corrosive sublimate or of bichromate of potash, and stored in cotton-plugged tubes for examination.

(13) The animals were next led to execution, killed, skinned and opened by a butcher, under guidance of the observer.

(14) Samples from each quarter of the udder were preserved in a weak alcohol, saturated with corrosive sublimate. To each piece of tissue was pinned a number, and a record was kept of the reference of each number to the proper kind, location, etc., of specimen. The udder was, in each case, split down into the middle of each side to note if any lesions were present. The inguinal glands were also examined. Specimens of tissues other than udder were usually not taken, except they presented either doubtful features, or something peculiar, or possessed typical value.

(15) The trachea, heart, lungs and mediastinal glands were next removed and thoroughly examined. Note was made of the extent to which these structures were tuberculized, and often samples were preserved for microscopic examination.

(16) The liver and intestines and other abdominal organs were next inspected. If tuberculosis was evident in the thorax, as our object was primarily to test the diagnostic value of the lymph and to destroy the diseased animals, we allowed only a superficial examination of the abdominal viscera to pass. We learned, however, soon to look for lesions in certain favored localities, and these were quickly inspected. These regions usually furnished the largest number of specimens preserved for microtomic work.

(17) The uterus was examined, and if any fœtuses were present, if of small size, they were preserved, and if too large for the museum jars, samples of their organs were taken. In the later cases, but, I regret to say, not in the earlier ones, the ovaries were examined and samples preserved. 
We have, therefore, material for study which will throw light on the following points:

(a) What tuberculous lesions can be diagnosed by physical examination, and what cannot?

(b) What peculiarities characterize a tuberculous reaction with Koch's lymph-that is, can we certainly, by this test, select all tuberculous cattle?

(bb) What may be expected as the normal range of temperature of a cow?

(c) To what extent is the milk or udder involved in cases of bovine tuberculosis?

(d) To what extent is congenital transmission or "fotal infection" operative?

$(d d)$ Does the feeding of milk from tuberculous cattle to calves. produce infection?

On all these points we have already more or less evidence, but not so much but that we require more light before any consensus of opinion and legal activity will result. While the primary object has been the removal of tuberculous animals from the College herd, the work has been so done as to enable us to increase our knowledge of this disease, and it is expected that the publication of these results will serve to increase any efforts now made in augmenting scientific knowledge by others who are engaged in a similar work. Science depends on a "multitude of witnesses." The reports we now have, in many instances, give only one or two "supposed" cases, on the strength of which important conclusions are made.

Finally, I must call attention to the fact that this is a report of progress and is partial. The study has not gone far enough to allow of publication of results under the heads of $(b b),(c),(d),(d d)$; special bulletins or reports will appear on these subjects as fast as the work is completed. The main object of the present report is to introducethe subject, to record the outline of work, to test the exact value of Koch's lymph and to indicate the rules for its use and the interpretation of "reactions."

In chronologic order, the work progressed as follows :

June 22d, 1893. First examination of Tryntje's milk.

July 14th. First conference with Dr. Pearson.

July 24th. Injection of Tryntje. See Tables, Case 1. 
August 11th. Milk from right hind quarter of Tryntje's udder gargety ; microscopic examination shows tubercle bacilli.

August 15th-September 15th. During my absence in the West, Mr. Jones - observes milk from each separate teat at each milking of Tryntje, and reports at the close of the month that no change in the quality of the milk had taken place. The milk from the one teat remained uniformly "gargety."

October 7th. Second conference with Dr. Pearson. Doubt having been expressed as to the conclusiveness of the evidence presented by my microscopic preparations, I was asked to send sample of milk for study at the Laboratory of Hygiene, under Dr. A. C. Abbott, University of Pennsylvania.

October 9th. Milk sent to Dr. Abbott. Misunderstanding having arisen as to the use to be made of the sample, explanatory correspondence ensued.

October 18th. Dr. Abbott reported that microscopic examination showed presence of tubercle bacilli in said sample of milk.

October 29th. Tryntje gave birth to heifer calf.

November 8th. Tryntje's calf and cow 66 injected, See Table, Cases 2 and 3.

November 9th. Tryntje's calf killed. Dr. H. R. Baldwin, Dr. A. V. N. Baldwin and Mr. E. A. Jones assisted at the autopsy. Specimens preserved as follows: Lung, base of left lung, apex of right lung, thymus gland, submaxillary salivary gland, spleen, mesenteric glands, Peyer's patches, liver, kidney capsule, kidney, small colon. No microscopic lesions visible.

November 10th. Milk from right front quarter of Tryntje's udder becomes gargety. Recommended that samples of milk from different teats be analyzed chemically.

The chemical analysis was made under direction of Dr. E. B. Voorhees, in the Gtate Laboratory, with the following result, comparison being made with normal milk and cases published by A. W. Blyth :

\begin{tabular}{|c|c|c|c|c|c|c|c|}
\hline & & 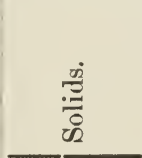 & 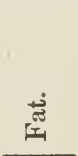 & 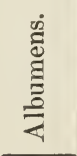 & 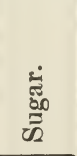 & 这 & \\
\hline $\begin{array}{l}\text { Case } \\
1 .\end{array}$ & 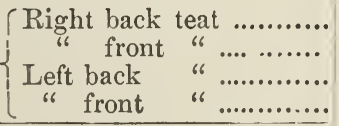 & $\begin{array}{l}621 \\
7.79 \\
8.83 \\
9.79 \\
\end{array}$ & $\begin{array}{l}0.20 \\
1.81 \\
1.93 \\
2.58\end{array}$ & $\begin{array}{l}5.13 \\
4.33 \\
3.92 \\
3.93 \\
\end{array}$ & $\begin{array}{l}0.13 \\
0.60 \\
2.11 \\
2.24\end{array}$ & $\begin{array}{l}0.75 \\
1.05 \\
0.87 \\
1.04\end{array}$ & \\
\hline & Cow 73 , entire bag.......... & 15.88 & 8.11 & 3.34 & 3.69 & 0.74 & \\
\hline $\begin{array}{l}\text { Cow } \\
\text { A. }\end{array}$ & $\left\{\begin{array}{c}\text { Normal milk (Blyth, p. } \\
221) \ldots . .\end{array}\right.$ & $\begin{array}{r}\text { water. } \\
86.87 \\
\end{array}$ & 3.50 & 4.75 & 4.00 & 0.70 & \\
\hline $\begin{array}{l}\text { Cow } \\
\text { B. }\end{array}$ & $\left\{\begin{array}{r}\text { Five-year-old cow, right } \\
\text { l ung t u b e r culous } \\
\text { (Blyth, p. 263)............ }\end{array}\right.$ & $\begin{array}{c}\text { s. gravity. } \\
1.029 \\
1.034 \\
\end{array}$ & $\begin{array}{l}2.77 \\
3.83 \\
\end{array}$ & $\begin{array}{l}4.51 \\
5.76\end{array}$ & $\begin{array}{l}2.82 \\
3.34 \\
\end{array}$ & $\begin{array}{l}0.86 \\
0.77\end{array}$ & $\begin{array}{l}\text { Dates. } \\
\text { Dec., '78. } \\
\text { Feb, '79. }\end{array}$ \\
\hline $\begin{array}{l}\text { Cow } \\
\text { C. }\end{array}$ & $\left\{\begin{array}{r}\text { Two-year-old cow ad- } \\
\text { vanced phthisis }(\text { Blyth, } \\
l . c .) \ldots . . . \ldots \ldots \ldots \ldots \ldots \ldots . . . . . . . .\end{array}\right.$ & $\begin{array}{l}1.033 \\
1.033 \\
\end{array}$ & $\begin{array}{l}2.60 \\
3.28\end{array}$ & $\begin{array}{l}3.00 \\
4.00 \\
\end{array}$ & $\begin{array}{l}2.89 \\
4.10\end{array}$ & $\begin{array}{l}0.91 \\
0.78\end{array}$ & $\begin{array}{l}\text { Jan. } \\
\text { Feb. }\end{array}$ \\
\hline $\begin{array}{l}\text { Cow } \\
\text { D. }\end{array}$ & $\begin{array}{l}\text { Cow with tubercular (?) } \\
\text { gargety udder (Blyth, } \\
\text { l. c.) ....................... }\end{array}$ & $\begin{array}{c}\text { water. } \\
94.64 \\
\text { s. gravity. } \\
1.018\end{array}$ & 0.49 & 3.60 & 0.47 & 0.76 & \\
\hline
\end{tabular}


Remarks on above table: Fat content of tubercular milk is progressively reduced. The albumens vary considerably, the main change being in reduction of casein and increase of "albumen" Sugar is greatly decreased, the ash is nearly unchanged, the specific gravity is also reduced. The carbonaceous constituents suffer most change (reduction).

November 15th. Received letter from chairman of Farm Committee stating that. Dr. Loblein had examined cow 73 and diagnosed tuberculosis, locating the lung deposit behind the left shoulder. The milk of this cow had been used to feed Fillpail's calf (Case No. 5). Isolation and trial of tuberculin on both the cow and the calf was recommended.

November 16th. Cow 73 injected; showed reaction. See Case 4.

November 30 th. Tryntje died this morning. Autopsy held at 3 P. M., at which were present Dr. Austin Scott, Director of the Agricultural College Station; Dr. H. R. Baldwin, Dr. A. V. N. Baldwin, Dr. E. L. Loblein, P. Calydon Cameron and the writer, besides the butcher and farm hands. The following notes were made. Specimens numbered were preserved:

(1) Posterior part right hind quarter of udder, when cut, pus issued from. milk ducts. (2) Middle portion of same quarter. (3) Right fore quarter of udder. (4) Left fore quarter of udder. (5) Left hind quarter of udder. (6) Peritoneal tubercle from left side. (7) Tubercles from pleura. (8) Spleen. (9) Omentum. [caul]. (10) Small colon near ileocolic valve. (11) Tubercle from small colon. (12) Mesenteric gland near small colon. (54) Left lung. (312) Liver. (119) Kidney. (107) Base of right lung. (68) Muscle tissue, subscapular. The lumen of small intestine and small colon practically obliterated by presence of a large sausageshaped tubercle that had grown into it. Thoracic and abdominal viscera adhered to. pleural and peritoneal walls. Tubercles seen on the meninges of the cerebellum. Part of posterior cerebral lobes also preserved. A heavy, peculiar odor arose from the tissues, which had a very depressing effect on the author and was felt for several. days, although he has been accustomed to the dissection of " rank" carcasses.

December 11th. Injected Fillpail's calf, born November 8th, and fed on milk of 66. See Case 5. Calf strong and thrifty.

December 15th. Mr. Jones observed record of calf again without injection. SeeCase $5 a$.

December 23d. Held autopsies of Cases 3 and 4, Dr. H. R. Baldwin and Dr. E. L. Loblein assisting. For general description, see section 1.

Tag 73. (1) Isolated tubercle from left lung. (2) Thymus gland, tuberculous; mediastinal glands breaking down in center. (3) Apparently healthy tissue from. right lung. (4) Right fore quarter of udder. (5) Yellow spot from surface of kidney. (6) Nodules from liver; four montbs' bull foetus present preserved, also theamnion and placenta.

Tag 66. Right pleura studded with tubercles, of which (7) is a specimen; left pleura ditto; both lungs tuberculous throughout; anterior and posterior mediastina: solid with tubercles. (8) Right front quarter udder. (9) Left front ditto. (10) Right hind ditto. (11) Left hind ditto ; liver lead colored, studded with tubercles. and tubercle masses all through ; bile abnormal. (12) Pedunculated tubercle from. liver. (13) Friable tissue of liver. (14) Omental tubercle. (15) Part of smals colon. 
December 28th. Dr. Loblein begins thorough physical examination of herd.

December 29th. Injected cases 7 to 25, inclusive. See table. Time occupied, 6 P. M. to 8 P. M. One assistant washed the right shoulder, followed by second assistant, who applied creoline. Two men held the animal in place by means of rails on both sides. Mr. Jones took the temperature. Amount of dose for each case determined by rough guess at relative size of cow.

January 2d, 1894. Injected cases 26 to 41, inclusive. Time, 6 г. M. to 7 P. м.

January 5th. Received a bottle of milk from cow in herd of George Vandruff, Deckertown, N. J., which differed in no microscopic respect from the "gargety" milk of Tryntje. At this time I was engaged in certain microscopic investigations bearing on the interference of chromatic aberration of bacteria with diagnosis by staining, so did not study this milk microscopically, but determined to visit the herd and test it with tuberculin first. I had hitherto supposed that Tryntje's milk received its characters from the presence of tubercle in her udder, but after investigating this herd I adopted the opinion that the condition of Tryntje's milk was due to garget, and not to tubercle. The correctness of this view would be somewhat shaken should microscopic examination of Tryntje's udder show that tuberculous lesions were present only on the right side. At this date this conclusion was not fully matured, and I expected to find evidence of tuberculosis in the Vandruff herd.

January 6th. Asked Mr. Jones to retake the temperatures of cows 11, 68, 244, 4, 16 and 71 without injection. This was done January 9 th, and repeated January 10 th, making two records for each cow.

January 12th. Held autopsies on cows 15, 13, 39 and 77, being Cases 27, 17, 23 and 15 , respectively, Dr. Loblein directing.

Tag 15, Case 27. Lungs were sound, anterior and posterior mediastinal glands tuberculous, liver friable. (1) Inguinal gland. (2) Right hind quarter of udder.

Tag 13, Case 17. Large tubercles in left lung, bronchi filled, mediastinal glands tuberculous, liver leaden and friable. (6) Left front quarter of udder. (7) Left hind ditto. (9) Right front ditto. (10) Right hind ditto.

Tag 39, Case 23. Posterior lobe of right lung has large tubercle; many small tubercles attached to pleural membrane of lungs, of which (4) is sample. Small tubercles on and in left lung. Mediastinal glands decidedly tuberculous, liver leaden, friable and with its surface covered with small tubercles. Surface of intestine covered with miliary tubercles. (3) Left front quarter of udder. Eight months' fotus present. (40) Thymus of foetus.

Tag 77, Case 15. Miliary tubercles on intestines, liver leaden and friable, mediastinal glands with incipient small tubercles, lungs apparently sound. (35) Inguinal gland. (36) Right front quarter of udder. (37) Left front ditto (38) Right liind ditto. (39) Left hind ditto.

Inspected the Vandruff herd, thirteen animals Six, on physical examination, were supposably sound. Eight were chosen for injection at 9 P. M., each with 50 minims tuberculin. The herd seems to have been invaded by a disease, eitler contagious or due to conditions affecting all, or nearly all, the cattle alike. Swellings had appeared at the joints of the legs, the coat was rough, considerable coughing was heard, one or more of the quarters of the udders had swollen and the milk had become wheyey, with clots. In fact, the symptoms of garget were typically exhibited, together with pneumonic troubles. The disease had come and subsided in some of the cases, and at times re-appeared. The attack had begun with the advent of cold 
weather. One animal, sick in November, had been purged and was found dead nert morning. This was dug up and an examination of its lungs made, January 13th, 3 P. M. These organs were in a highly-inflamed and congested condition, being dark purple in color, but showed no lesions of a tubercular nature. In detail, the animals injected were as follows: Black heifer, sound; range, 2.5 $5^{\circ}$. Jumbo, left front quarter first affected two months before; still somewhat hard, but milk all right again; on auscultation, heard slight murmur; range, $1.2^{\circ}$. Yellow heifer, left hind quarter of udder began to show signs of disease December 22d; the swelling has disappeared from the legs; the left hind quarter of udder is still hard; no especial sounds heard on auscultation; range, $1.4^{\circ}$. Gray heifer, left front and left hind quarters of udder have been affected six weeks; legs had been swollen and bowels loose; slight murmurs heard on right side ; range, $1.6^{\circ}$. Ollie is lean, coughs a good deal, muzzle "sweats ;" entire udder enormously swollen and hard; cow lies down a great deal; legs not 6wollen, hair rough; initial temperature, $103.2^{\circ}$, is highest; range, $1.2^{\circ}$; samples of milk secured; respiratory murmurs very strong; evident lung trouble; record resembles that of Tryntje, and many physical signs seem to point to same conclusion; nevertheless, did not diagnose a case of tuberculosis, owing to the records shown by other cows and the evidence fur garget and pneumonia. I reasoned that probably one affection was present. The absence of tubercular reactions from the other sick members as well as from Ollie, shows that tuberculosis is not present in the herd, for if present, the likelihnod would be that all cows would have it and some reaction would be shown. Hence, the high initial temperature of Ollie points to the presence of a disease other than tuberculosis. Brown cow, whole udder swollen; right hind quarter hard, pressure causes shrinking; left horn is warmer than right; left hock is Ewollen and painful; range, $0.2^{\circ}$. Star cow, right side and left hind quarter of udder swollen and hard; respiratory soughing heard; range, $2.1^{\circ}$; the initial temperature, 102.1, is highest. Brindle, was very bad, but now the milk is coming down; the legs were sore and swollen; now much better; range, $0.8^{\circ}$.

The temperatures of these cows were taken at 9 to 10 in the evening, before injection, again at 6 in the morning, at 9:30 A. M., at 2:30 P. M. and at 4 P. M. (See Table XVI., at close of this report.)

In February, a letter from Mr. Vandruff tells us that there has been slow improvement and only in case there is a decided change for the worse will he consent to have a. cow killed, without compensation, by the National Bureau of Animal Industry, which has become interested in the case through notice given by Dr. Hunt, Secretary of the New Jersey State Board of Health.

January 15th. Held autopsy on cow 6. Case No. 39. Left lung, anterior lobe, has a large tubercle. (1) Small tubercles on ventral lobe of right lung; liver leaden, friable with tubercles on surface and within it. Mediastinal glands greatly enlarged and tuberculous; numerous miliary tubercles on small intestines. (41) Right front quarter of udder. (43) Left front ditto. (44) Right hind ditto. (45) Left hind ditto.

Small intestine.

Fillpail's calf (Case 5) autopsied in the afternoon, shows no macroscopic lesions of tubercle. (11) Glands from ileum near ileo-colic valves. (12) Thymus. (13) Posterior mediastinal gland. (14) Anterior mediastinal gland. (15) Encysted blood clot(?) on stomach. Also a dark lymph gland from liver preserved.

January 16th. Autopsied cows 51, 8, 5 and 71, i. e. Cases 40, 19, 18 and 36. Dr. Loblein, examiner. 
Cow 51, Case 40. Sereral incipicnt tuberc'es fi und on all three lol es of left lung; mediastinal glands apparently sound, liver slightly leaden. (68) White spot on liver. (55) Posterior mediastinal gland. (64) Lung. (56) Mesenteric gland, also (o). (70) Peyer's patch.

Cow 8, Case 19. Left lung wilh incipient tubercles, right, marbled, pneumonic; posterior mediastinal glands tuberculous, yellowish green; liver apparently sound; five months' foetus present. (28) Small intestine. (51) Left front quarter of udder. (59) Left hind ditto. (63) Right hind ditto. (66) Right front ditto.

Cow 5, Case 18. Congested area on right lung, posterior mediastinal glands tuberculous, right side of udder at base, tuberculcus; miliary tubercles on intestine and liver; seven months' fotus present. (71) Inguinal gland. (27) Left hind quarter of udder. (61) Left front ditto. (50) Right hind ditto. (52) Right front ditto. (23) Thymus of foetus.

Cow 71, Case 36. Inflammations and miliary tubercles on pleura of 1 ibs, left side; mediastinal glands ex tremely liypertropliied, with tuberculous deposits; large tubercles on superior part of anterior lobe, right lung, while posterior lobe of same side presents gangrenous and congested condition, with miliary tuberc'es; left lung more tuberculous than the right; pancreas appeared abnormal; liver is tuberculous, and some miliary tubercles present on the intestine; three months' fœus present. (60) Pancreas. (17) Left hind quarter of udder. (58) Left front quarter. (21) Right hind ditto. (19) Right front ditto.

January 20th. Autopsies of cows 9, 12 and 16, Cases Nos. 14, 12 and 28, Dr。 Loblein assisting.

Cow 12, Case 12. Posterior mediastinal glands tuberculous; antelior apparently absent or rudimentary; lungs apparently sound; liver leaden, has large tubercles; ovaries abnormal ; miliary tubercles on intestine. (53) Left ovary. (16) Right hind quarter of udder. (83) Left hind ditto. (88) Right front ditto. (91) Left front ditto. (62) Bronchial gland.

Cow 9, Case 14. Posterior lobe of left lung very tuberculous; liver apparently healthy; miliary tubercles on small intestine; left ovary abnormal; mediastinal glands rudimentary; apparently garget-like condition in left hind quarter of udder. (20) Left hind quarter. (84) Left front ditto. (22) Right front ditto. (87) Right. hind ditto. (26) Left ovary. (25) Small intestine.

Cow 16, Case 28. Posterior mediastinal glands tuberculous, and one broken down in center to fluid condition; spot on lung congested and gangrenous; pimples (miliary tubercles?) on colon; abnormal growth on left ovary. (33) Udder. (86) Broken-down mediastinal gland. (57) Posterior mediastinal gland. (89) Congested part of lung. (18) Lymphatic gland from stomach. (32) Tubercle pimple from colon. (65) Small intestine, with pimples. (69) Colon, with pimples. (54) Left ovary. (29) Upper part of Fallopian tube.

January 22d. Autopsies held on cows 68, 244, 56 and 4, Cases 20, 21, 32 and 25.

Cow 68, Case 20. Lungs sound, bronchial glands tuberculous, miliary tubercles on intestine. (94) Right front quarter of udder. (115) Right hind ditto. (103) Left hind ditto. (82) Left front ditto. (104) Bronchial gland. (24) Left ovary. (98) Right ovary.

Cow 244, Case 21. Posterior cephalic lube of right lung one mass of small tubercles; posterior mediastinal glands tuberculous. (110) Right hind quarter of udder. (92) Right front ditto. (113) Left hind ditto. (106) Left front ditto. (107) Inguinal gland. (96) Left ovary. (85) Right ovary. 
Cow 56, Case 32. Large tubercles on principal lobe of left lung; bronchial and mediastinal glands highly tuberculous; tuberculous (?) papillæ on intestine; left ovary bears papillæ that require investigation; very large tubercle in dorsal mediastinum, near diaphragm. (111) Inguinal gland. (67) Left front quarter of udder. (101) Left hind ditto. (109) Right front ditto. (80) Right hind ditto. (93) Intestinal papilla. (31) Left ovary. (102) Right ovary.

Cow 4, Case 25. Very fat; inguinal glands perhaps abnormal; dorsal mediastinal glands very tuberculous ; right lung a mass of small tubercles ; liver abnormally soft and leaden; miliary tubercles on intestine; twin foetuses present in uterus. (105) Left hind quarter of udder. (114) Left front ditto. (112) Right front ditto. (108) Right hind ditto. (97) Inguinal gland. (81) Intestine. (100) Right ovary. (99) Left ovary.

February 5th. Autopsy of cow 11 (Case 16) imperfect, due to ignorance of butcher, who failed to keep the parts most needed for examination; no responsible parties being present during the slaughter. The butcher reported pleural adhesions of lung walls. A portion of lungs recovered failed to show macroscopic tuberculous lesions. (A) Bronchial gland. (AA) Part of lung.

February 6th. Writer and Mr. Jones present during slaughter of cow 75 (Case 13). Principal lobe of right lung showed large tubercles (size of a fist); mediastinal glands tuberculous, inguinal glands enlarged; no macroscopic tuberculous lesions seen on section. (B) Left hind quarter of udder. (C) Inguinal gland. (D) Small bronchial gland.

February Sth. Lungs and inguinal glands of cow 17 (Case 26) were brought to the laboratory by Mr. E. A. Jones. He reported that he saw no tubercles on the intestines. Examination of material brought showed inguinal glands rather larger than normal, but on section no tuberculous lesions visible; lungs were apparently sound. Samples preserved were marked XVII.

February 15th. Dr. Loblein injected 52 and 53 (Cases 42 and 43), the results plainly showing a reaction with 52 and a doubtful reaction with 53 .

February 24tll. Lungs of 52 (Case 42) and liver and lungs of 2 (Case 8) left by Mr. Jones to be examined at the laboratory; animals killed the day before.

Cow 2 (Case 8 ) showed extreme tuberculosis of the brochial glands; milk taken, but udder was thrown away. Liver congested and with incipient tubercles. (2a) Liver."

Case 42. Mr. Jones reported that the lungs and intestines had been examined by him and no lesions discoverable. Dr. Loblein joined me in examination of these lungs. Near the surface were local areas of superficial inflammation, in which were very small tubercles, with cheesy deposits in their centers. The bronchial glands presented small pus (?) cavities within. (52a) Lung tissue. (52b) Bronchial gland. Samples for desiccation also taken.

February 28th. Mr. Jones brought portions of intestine, udder, liver and lungs of 55 (Case 24) to the laboratory. On posterior part of main lobe of right lung, a spherical tubercle of the size of a hazelnut was found, otherwise the lungs appeared sound; liver was peculiarly pitted, otherwise tuberculous lesions appeared absent; the intestines were well covered with miliary tubercles the size of small peas and caseous in center. Samples preserved. 


\section{§ 4. Summaries of Data, Tables and Discussion of Same.}

Milk has been preserved from the four teats, separately, in the cases of cows 66, 77, [Ollie, yellow heifer, brown heifer and Jumbo, of Vandruff herd], 6, 8, 71, 5, 14, 20, 9, 30, 25, 22, 23, 56, 4, 68, 244, 2 and 55, or more than twenty cases.

Fœtuses have been found in cows 73, 39, 8, 5, 71, 4, and Tryntje and Fillpail also had each a calf that were used in feeding experiments.

Excluding the bull and a cow sold early in the season of experimentation and including the tuberculous cow slaughtered early in August, and the heifers and calves, 43 animals are to be counted as included in this investigation, and of these, 28 animals have been under autopsy, in which two calves and two cows did not show macroscopic tuberculous lesions and are therefore still in doubt; the others were decidedly tuberculous. The temperature records of the calves and the doubtful cows are in themselves not decisive, although running as high as some cases showing decided tuberculosis, but every case of undoubted reaction proved to be undoubtedly tuberculous, whether diagnosed "suspicious" or as "O.K." by physical examination. These and other facts become more strikingly apparent from inspection of the succeeding tables. 


\begin{tabular}{|c|c|c|c|c|c|}
\hline & & 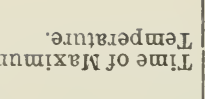 & 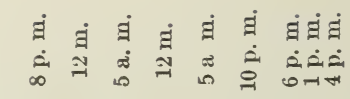 & 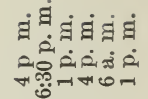 & 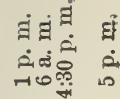 \\
\hline & & 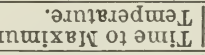 & 가 & สัคณ สฺฺ & 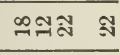 \\
\hline & 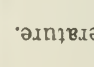 & 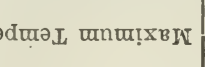 & 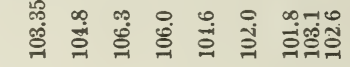 & 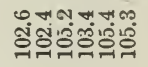 & 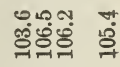 \\
\hline में & & 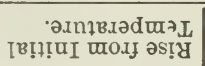 & స్ & 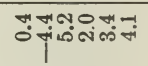 & 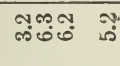 \\
\hline మ & & วஃ̊вч & ન- N & 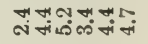 & 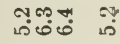 \\
\hline ণิ & 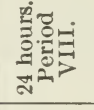 & 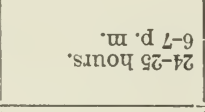 & 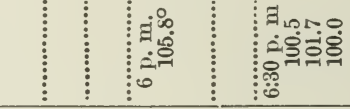 & 我我 & 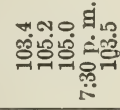 \\
\hline 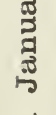 & 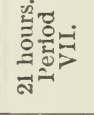 & $\begin{array}{rl}\cdot u \cdot d & t-z \\
\cdot \sin 04 z z-0 z\end{array}$ & 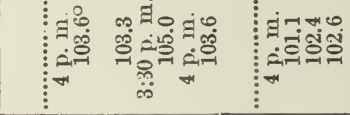 & 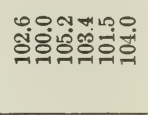 & 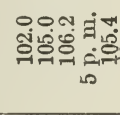 \\
\hline ฌี & 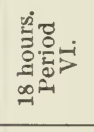 & $\begin{array}{l}\cdot \mathrm{ur} \cdot \mathrm{d} \vec{z}-\mathrm{zI} \\
\cdot \sin 0 \mathrm{t} 6 \mathrm{I}-8 \mathrm{I}\end{array}$ & 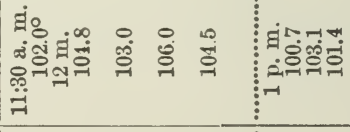 & 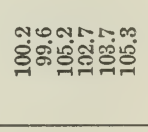 & 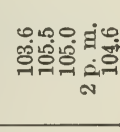 \\
\hline$\frac{\mathscr{0}}{\mathscr{0}}$ & $\sum_{\substack{0 \\
0}}^{\infty}$ & $\begin{array}{c}\cdot \mathrm{cu} \cdot \mathrm{B} I \mathrm{II}-\mathrm{L} \\
\cdot \operatorname{sinoq} 8 \mathrm{I}-\mathrm{gI}\end{array}$ & 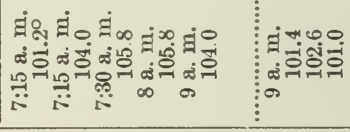 & 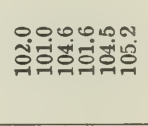 & ํํㅇํำ \\
\hline$\stackrel{\Phi}{\Phi}$ & 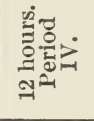 & 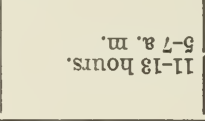 & 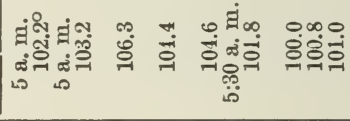 & 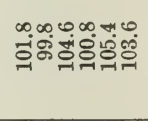 & 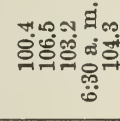 \\
\hline $\begin{array}{l}\stackrel{\oplus}{G} \\
\stackrel{0}{0}\end{array}$ & 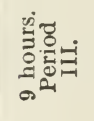 & $\begin{array}{l}\qquad \pi \cdot B \quad t-Z \\
\text { sinoq } I-8\end{array}$ & 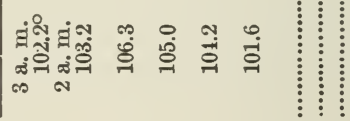 & & \\
\hline 荘 & 官: & $\begin{array}{l}\text { 'U ' B } z-z I \\
\text { sinoy } 8-9\end{array}$ & 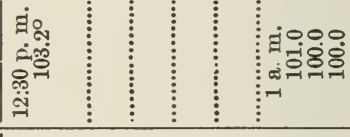 & 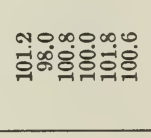 & 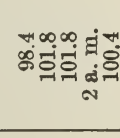 \\
\hline 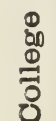 & 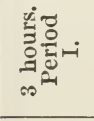 & 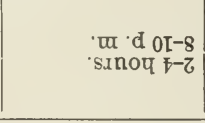 & 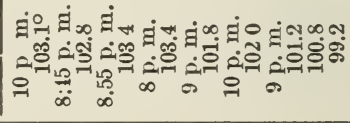 & 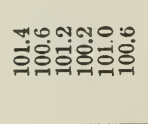 & 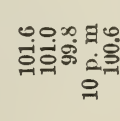 \\
\hline & 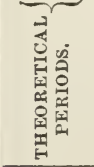 & 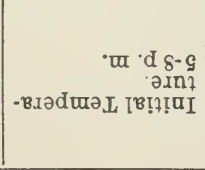 & 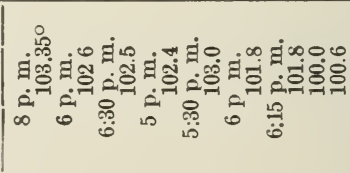 & घं & 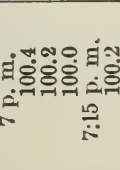 \\
\hline & & suṭu!I-әsod & 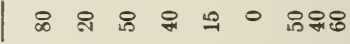 & 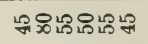 & 800 \\
\hline & & 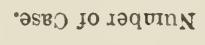 & 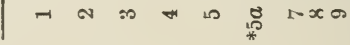 & ミニミュュ゙ロ & 유묙 욕 \\
\hline
\end{tabular}




\begin{tabular}{|c|c|c|c|c|c|c|c|c|c|c|c|}
\hline 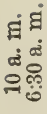 & 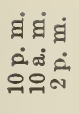 & $\frac{\dot{g}}{\dot{0}}$ & 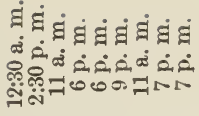 & 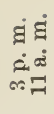 & 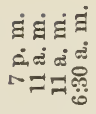 & हn & 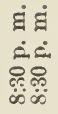 & $\begin{array}{l}\dot{g} \\
\text { के }\end{array}$ & 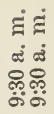 & 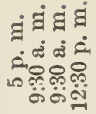 & $\begin{array}{l}\dot{a} \\
\dot{0} \\
\dot{8} \\
\dot{\text { i }}\end{array}$ \\
\hline$\stackrel{2}{2}$ & 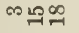 & สี & అ & ఠి & 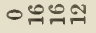 & 0 & $\stackrel{\sim}{\sim}$ & $\stackrel{2}{-1}$ & $\stackrel{m}{-m}$ & 에묘 & 0 \\
\hline 부유 & 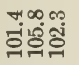 & छ் & 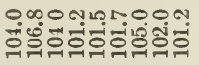 & कํํㅇำ & 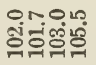 & 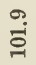 & ํㅜㅇ & $\stackrel{0}{\stackrel{0}{0}}$ & 뭉ำ & 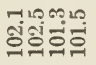 & 욜 \\
\hline $\begin{array}{l}\infty 0 \\
\infty \\
\infty\end{array}$ & ڤேम & $\stackrel{\infty}{\infty}$ & 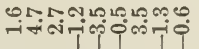 & ஸேन & कृष्त & $\ddot{0}$ & ำ & $\stackrel{0}{0}$ & مُ0 & 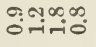 & $\stackrel{?}{0}$ \\
\hline 웅 & $\begin{array}{l}00 \pi \\
\text { Nifi }\end{array}$ & $\infty$ & 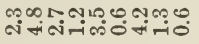 & in & 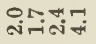 & $\ddot{0}$ & थี & $\stackrel{100}{0}$ & लंख & 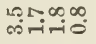 & Fi \\
\hline
\end{tabular}

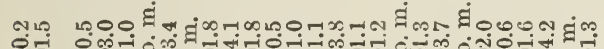

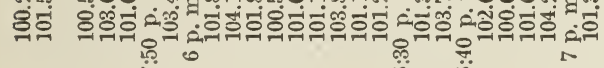
$\ddot{\theta} \ddot{0}$

ఏ घं

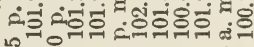
:

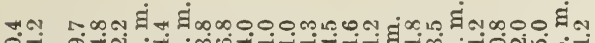
हं०

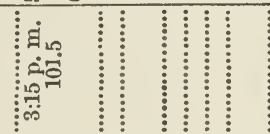

ㅁำ घี : 藏

งฺர் $\dot{0} \ddot{0}$

$\ddot{\sim} \ddot{\theta}$ $\ddot{-1}$

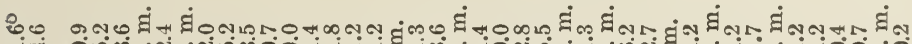

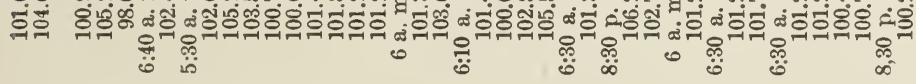

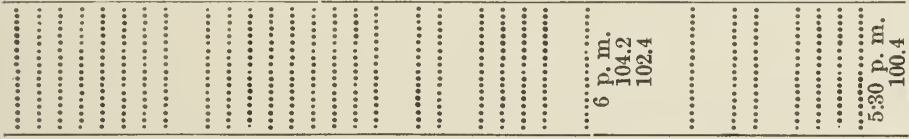

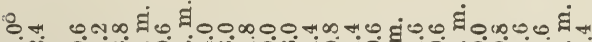

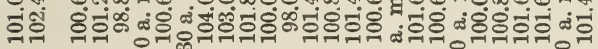
ஸृ

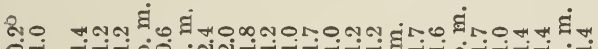

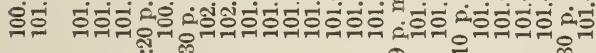

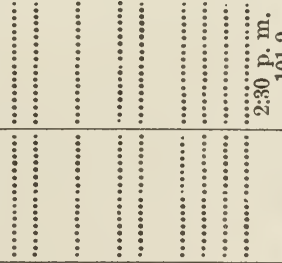

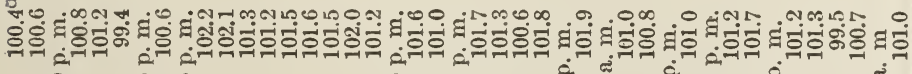

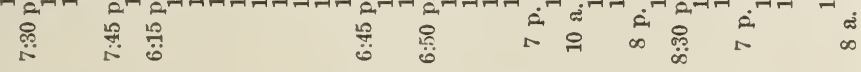

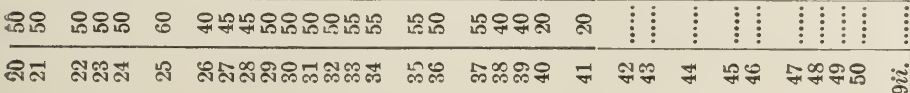


EXPLANATION OF TABLE I.

The eight periods of three hours each cover the night and day, twenty-four hours in all; but, of course, it was impossible to inject and to observe all the cows simultaneously, so that there is some departure from fixed hours. The earlier cases were not observed with the regularity of the later ones. Cases 42 to 50 were injected by Dr. E. L. Loblein, the last eight cases being the new cows added to the herd to date of beginning work on this report. Case $9 i i$ is case 9 injected a second time. Case $5 a$ properly belongs to Table III., but does not fit into its period so well as here. Dotted lines represent absence of observation. The column headed "rise from initial temperature" is the "approximate reaction" as usuaily calculated. When a minus sign precedes a number in this column it represents a fall from initial evening temperature, calculation being made to the lowest record; thus the range and negative reaction are the same. For dates of injection see later tables. 


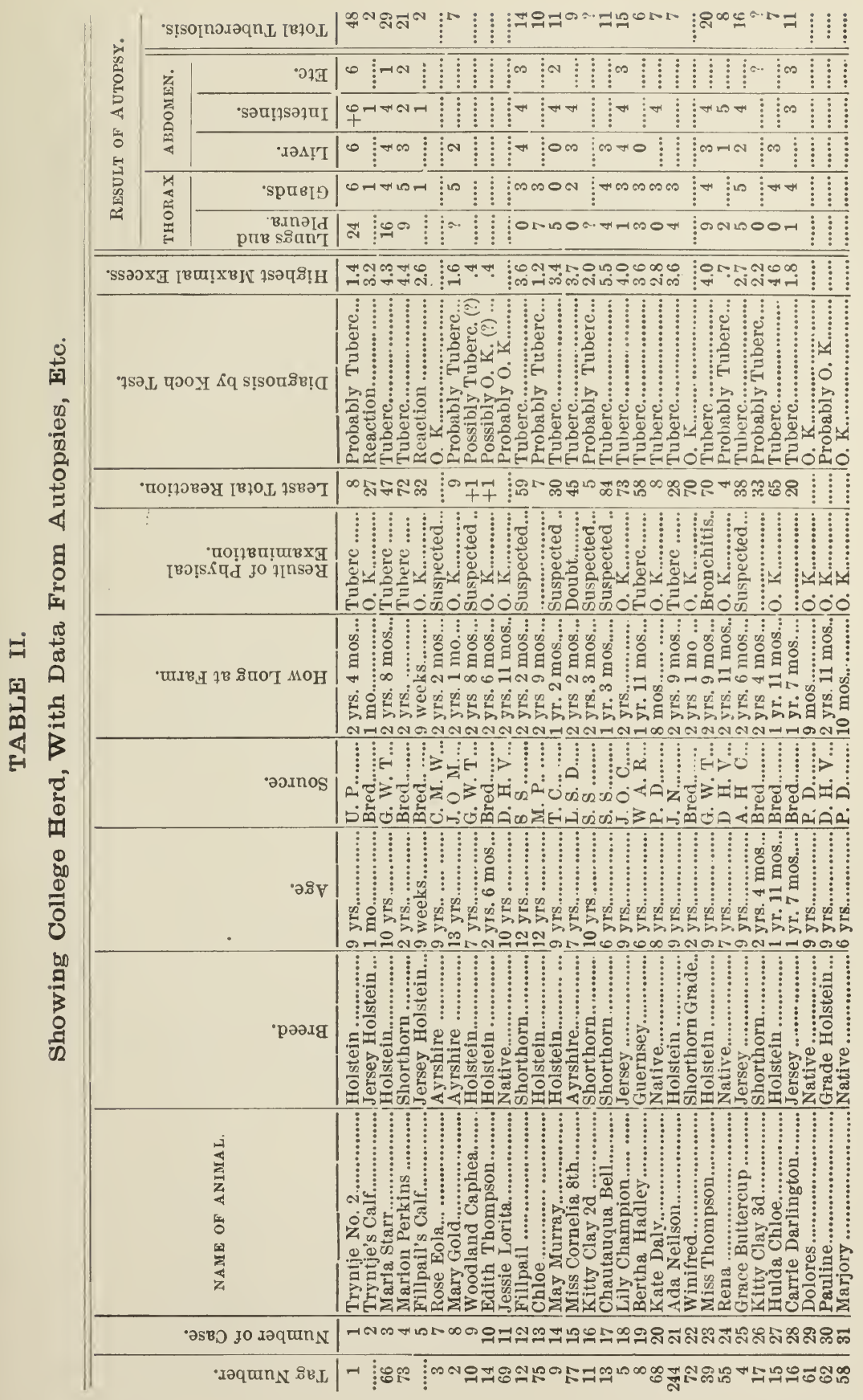




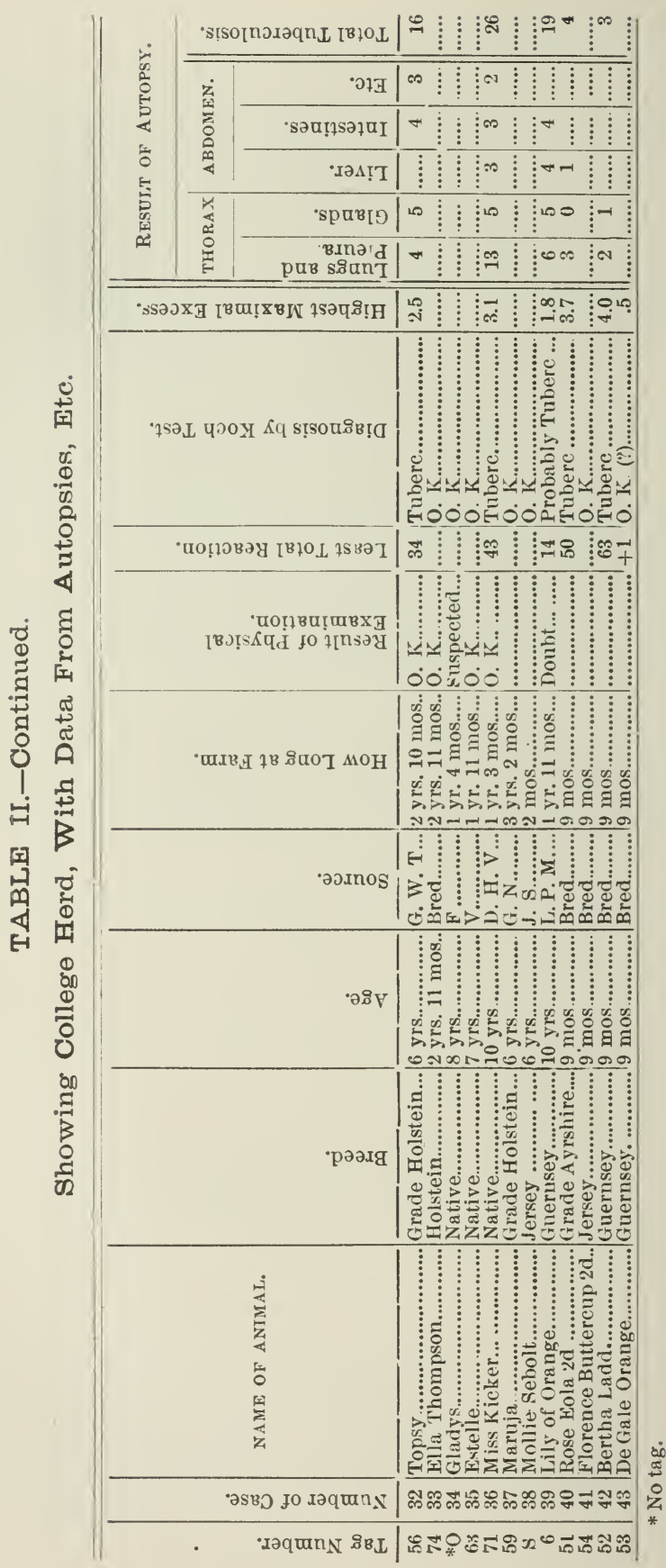


This table gives tag and name, the breed and age of the cows in the herd. The column headed "source" gives the initials of the man from whom the cows were bought, the locality of his residence being reserved for later tables. The next column shows how long the cows have been at the College farm, then follow the results of physical examination.

The succeeding columns were calculated from the temperature figures and the autopsies. The first three columns have been borrowed from tables to be hereafter discussed, and need not now receive further attention; the columns under "result of autopsy" were calculated as follows:

\section{$0=$ no tubercle.}

$1=$ suspected microscopical tuberculosis.

$2=$ incipient tuberculosis.

$3=$ several small or few large tubercles.

$4=$ miliary tuberculosis, many large, or very many small tubercles.

$5=$ thoroughly-advanced tuberculosis of an organ, seriously injuring its functions

$6=$ extreme tuberculosis; on the verge of death.

Each lung and each pleuron counted as a separate organ, the thoracic lymphatic glands, the liver, the intestinal canal and mesenteries, spleen, caul, etc., and finally the ovaries, kidneys, etc., each received counts by itself-judged on the above scale-and the sum is the "total tuberculosis"-necessarily rough, and not so valuable as if we had given the values at the time of autopsy, this evaluation will still help to give indications of a general nature in succeeding studies. 


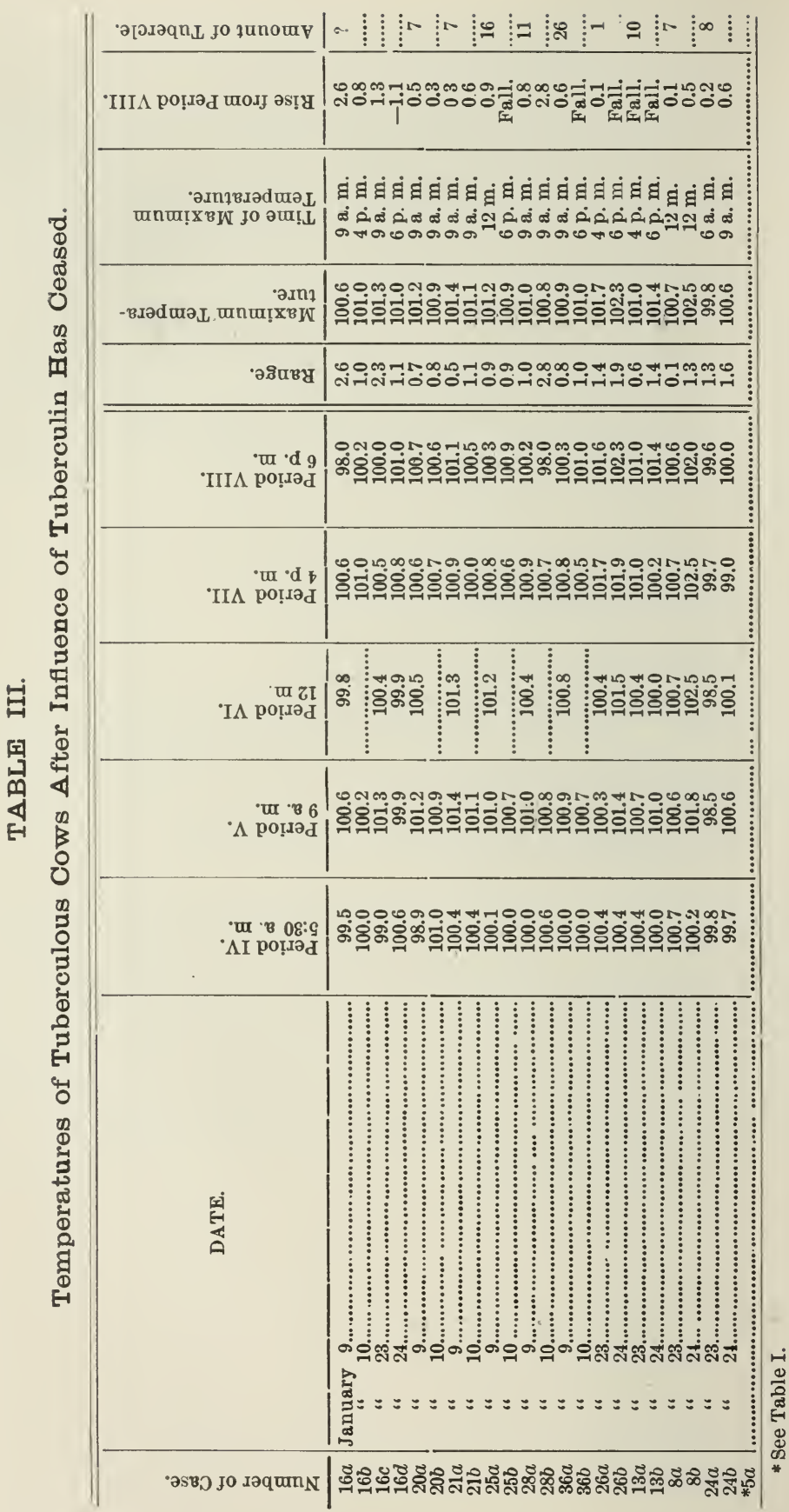




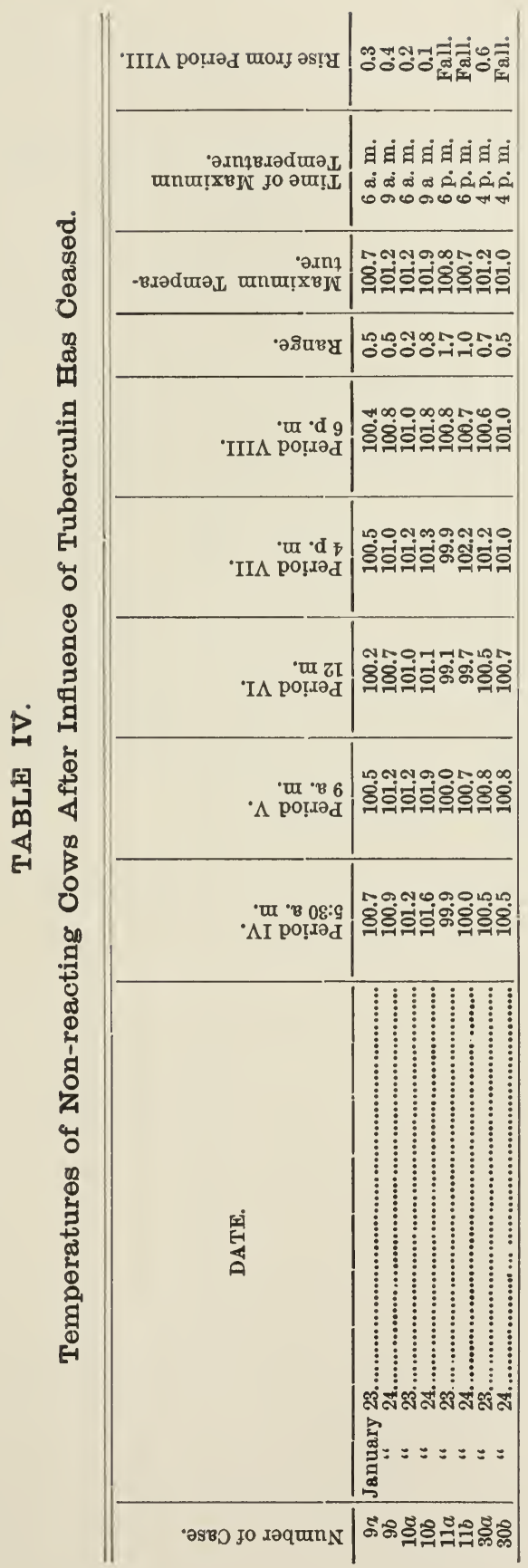


EXPLANATION OF TABLES III. AND IV.

Table III. gives the temperatures of cases at first considered doubtful in their reaction, taken after the influence of the injection has ceased and for two days, the hours chosen being those at which the apparent reaction took place. By comparison with the corresponding. temperatures under Table I., we can gain important information as to the presence of reaction. As will be seen, reaction took place in every case, and the autopsies justify the conclusion. The "approximate reaction" (that is, the difference between initial evening temperature and the maximum, though, of course, no real reaction can be present in absence of injection) could in these cases be calculated from the evening temperature at close of day. Of course, this is just as allowable as to use the temperature of the evening of the previous: day, as is ordinarily done. It could be used in tubercular cases, except that the reaction often lasts over into the night, thus disturbing this temperature; but, as a rule, previous observers have not extended their observations to the second evening. Cases 9 and 10 of Table IV. seem to show small reaction, and have, therefore, been included with reacting cases in subsequent tables. 


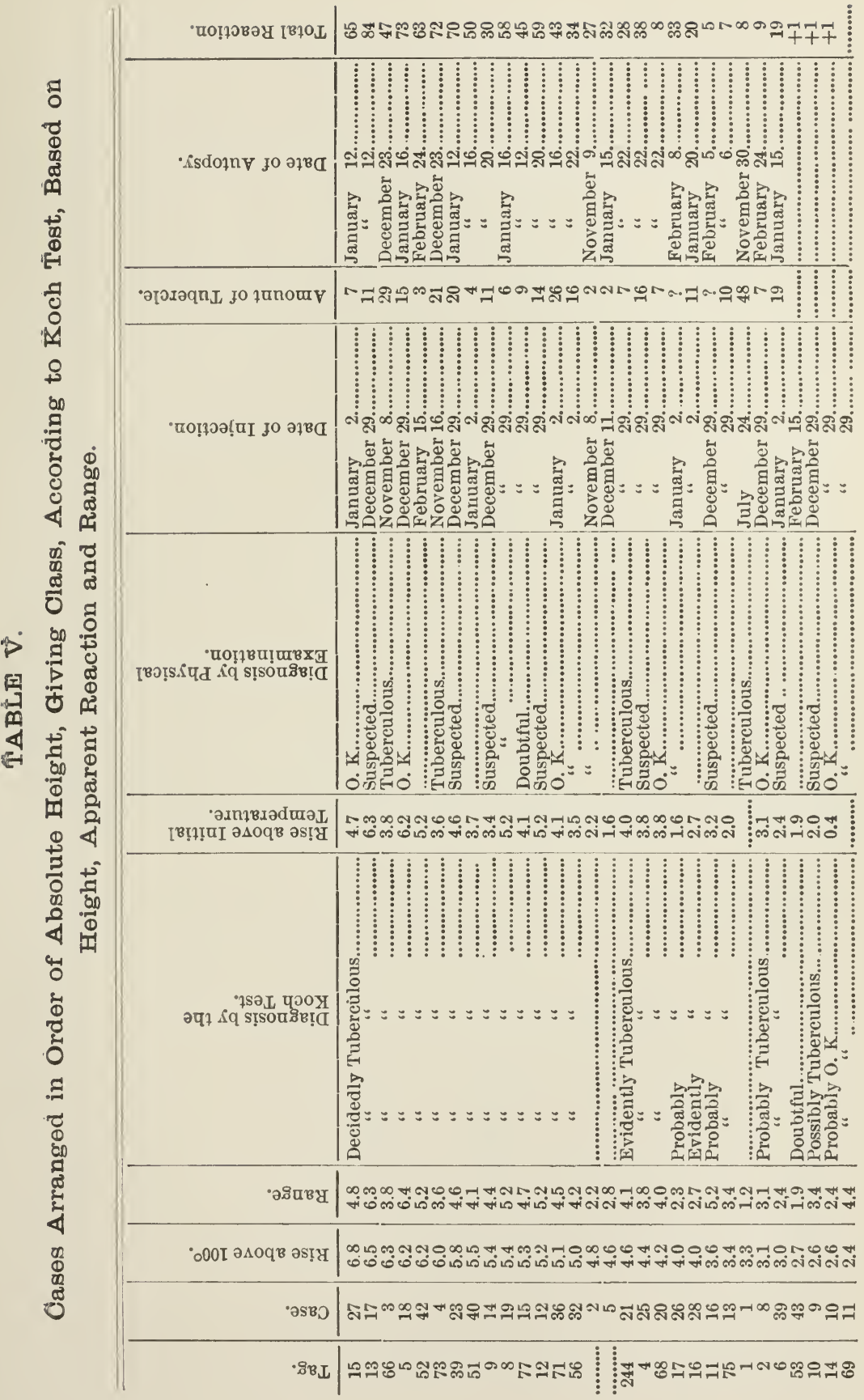




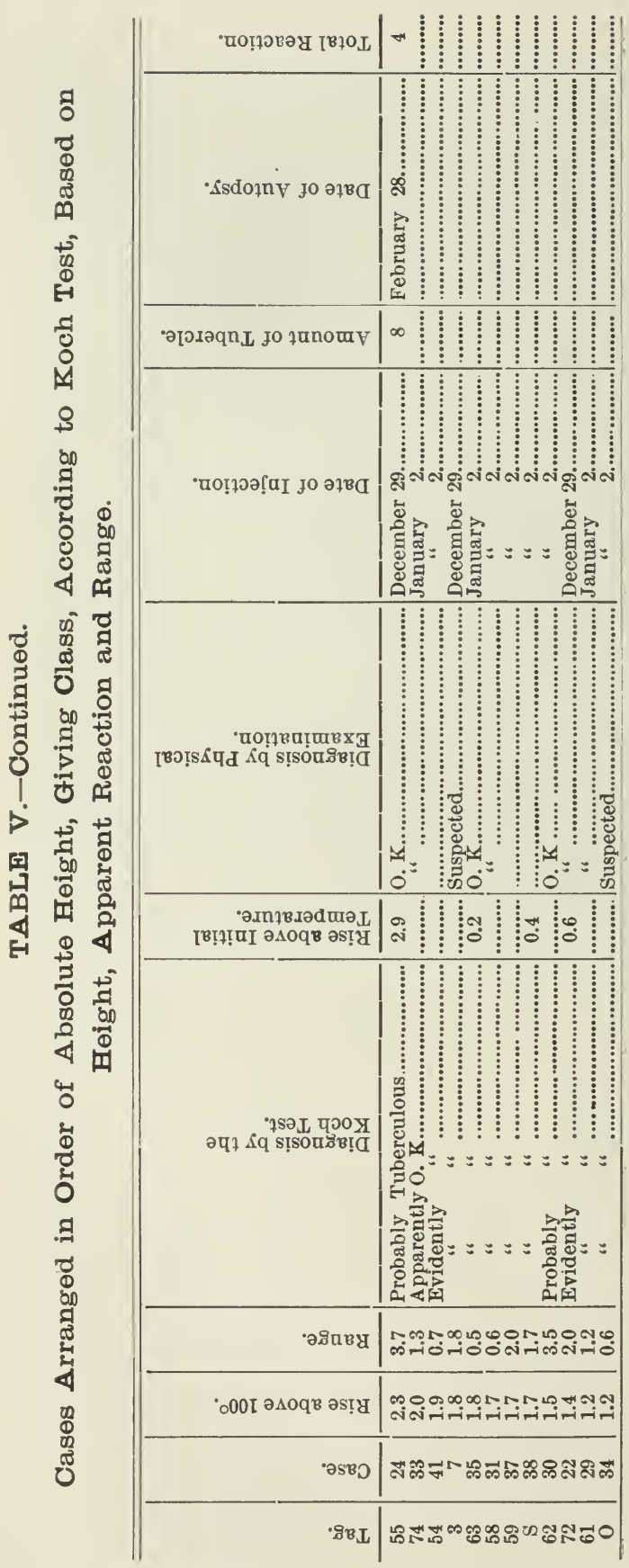


A fter the perceding tables were prepared in the rough, a chart of temperature curves was plotted (Chart I.), from which, by taking the absolute height of the curves as a basis, the cases were arranged as in Table V., in the order of the maxima, by comparing the rise above the initial temperature, and the entire range of the temperatures for maxima between $102^{\circ}$ and $103^{\circ}$ (the chart apparently showing that everthing above $103^{\circ}$ is tuberculous), I could arrange these doubtful cases in sequence, and characterize them as doubtful, probably, or possibly tuberculous or $\mathrm{O}$. K., as the case might be. So little has this order been disturbed by introduction of a more accurate method of determining the reaction that the old table has been introduced here without change, except slight new choice of words, and that the order of maxima has given the succession. The killing has been done in accordance with the column headed "diagnosis by the Koch test," no great effort being made to take up the cows in the order here given, except to keep to the order of the groups, "decidedly," " evidently" and "probably," tag 6 excepted. (The "possibly" and "doubtful" [9 and 43] have at this writing not yet been killed.) This marks the limit, so long as cases 16 and 26 remain doubtful in the autopsy. The last column shows they have a very low total reaction. They will, however, receive further study, and may yet pay the penalty.

It will be noticed that I ignored the ordinary method of calculating the reaction, viz., by taking the difference between the initial temperature and the highest later observed temperature. Such a procedure seemed to me to be extremely inaccurate, but careful studies of my data have shown that this method is not so bad as it at first sight appears. I have, therefore, called it the "approximate reaction." It is easy to see that in some cases it is too great, and in others too small, thus the cases are not treated alike, and it is impossible to grade them in proper order. Fortunately the majority of cases react so markedly that the margin of inaccuracy is more than swallowed up, so that if the operator chooses a sufficiently high reaction as his limit, he has no difficulty in showing that the verdict rendered by the injection of Koch's lymph is infallibly justified by the autopsy. Practice seems to have settled on this limit as $2.5^{\circ}$ above initial evening temperature, experience having shown that to take a smaller limit is apt to include 
some sound animals which result is of course naturally avoided; but experience has equally shown (our own in particular) that tuberculous animals have given a smaller "approximate reaction," and thus we may be certain that Koch's lymph as ordinarily used fails to stamp out tuberculosis, root and branch, from large herds. I believe that evidence sufficient has been accumulated to make any experimenter certain that every reacting animal has tubercle, but the trouble lies in determining what is a reaction in certain exceptional instances. Case 1, the most tuberculous of all our herd, gave no approximate reaction, in fact it resembled the healthy cows in giving the uninfluenced maximal temperature at evening; though to be sure this temperature was relatively high, it was no higher than dozens of normal temperatures recorded in tables by other observers, such as those recorded by Dr. Leonard Pearson, for the Pennsylvania State College herd (Bulletin 21); Dr. E. P. Niles, for the Virginia State Station herd (Bulletin 26); and Dr. Conrow, for the Taylor herd, Burlington N. J. (Vet. Mag., Jan., '94). Case 1 was, however, so advanced as to make error of physical diagnosis impossible; but, unfortunately, there is no absolute relation between amount of reaction and amount of tuberculosis; while some "incipient" cases give an extremely high reaction, others give low and doubtful reactions. It is, therefore, worth while to study into this matter closely, to see if a more equable reaction determination be possible.

Now, what causes the "fever reaction"-the rise of temperature? Evidently an increased oxidation, accompanied by increased activity in the tissue cells, due to increased stimulation. How does Koch's lymph secure this result? The subject is practically a mystery. The best answer yet made runs somewhat as follows: The lymph is an extract of tuberculous tissue, and hence, among other matters, contains the toxines which the tubercle bacilli have produced. A small amount of these toxines is readily excreted from the body before they can produce any serious effect on the tissue cells. This explains why a small dose injected into a healthy animal produces no effect. But if the tubercle germs have been for some time at work, they have manufactured an additional amount of toxine (or ptomaine). If this amount is very great, the small amount added by injection increases this amount by so small an increment as to be unnoticed; but when the ptomaine in the tissues is less, the increment is noticeable. According to this explanation, the healthy cow receives the maximal 
increment, and so we see a fault in the theory. I would offer this amendment, viz., the presence of the bacilli, and of the poisons they excrete, causes an increased activity of the tissues, both in the work of getting rid of the poison by excretion and in the work of secreting toxalbumens inimical to the germ, and we may also include the work of producing tubercle. This increased work is so little, or is distributed over so long a time, as at no period to seriously influence the general temperature until the disease has reached an extreme point. That is, there is always a reaction present in a tuberculous animal, but usually so small as to be unnoticeable. The rate at which the bacilli secrete the toxine is so uniform as not to present any special breaks or accessions that may serve as stimuli, but the injection of a quantity bearing an appreciable relation to that which the tissues are already responding to, is such a sudden increment that the tissues respond by a sudden increase in the work they are already engaged in.

The tissues of a sound animal are not adjusted to take any special notice of a slight and temporary accession of poison. It requires the presence of this slight amount for such protracted periods as the bacilli supply, to develop this sensibility of the cells.

It follows that any observed temperature is a resultant of two sets of forces-first, those that produce the normal temperature, or the temperature that would be present if the injection lymph were absent; second, the sensibility of the tissues to the particular increment of stimulus. Both this sensibility and the magnitude of this increment are unknown quantities, and if injection be made, the normal curve of temperature for all the time the lymph is acting is, of course, also unknown. We possess simply the observed temperature, and no one is competent to declare how much of this temperature is "reaction." That is, the exact amount of reaction in any given case is, on a priori grounds, absolutely unknown now, and perhaps impossible of knowledge to future science.

We may, however, approximate to this quantity by gaining some idea of the probable normal temperature at the particular time the temperature was taken, $i$. e. what would the temperature have been if injection had not been made?

It becomes first and foremost necessary to study the behavior of temperature curves for normal cases. This work we did not at first realize the importance of, so that the data herewith presented are necessarily less full than is desirable. We may include as "normal tem- 
peratures" all those temperatures, of cows under injection, which manifestly have not been disturbed by injection, viz., the initial temperature, and all subsequent observations up to the point where the reaction becomes manifest. As our injection was made on a falling thermometer, such point of reaction is in the majority of instances easily discoverable. There is a latent period after injection, before the lymph produces its effects. As to the law of this latent period we refer to later pages.

Of course, the entire series of observations, for sound cows under injection, becomes available, and also the data collected in Tables III. and IV. 


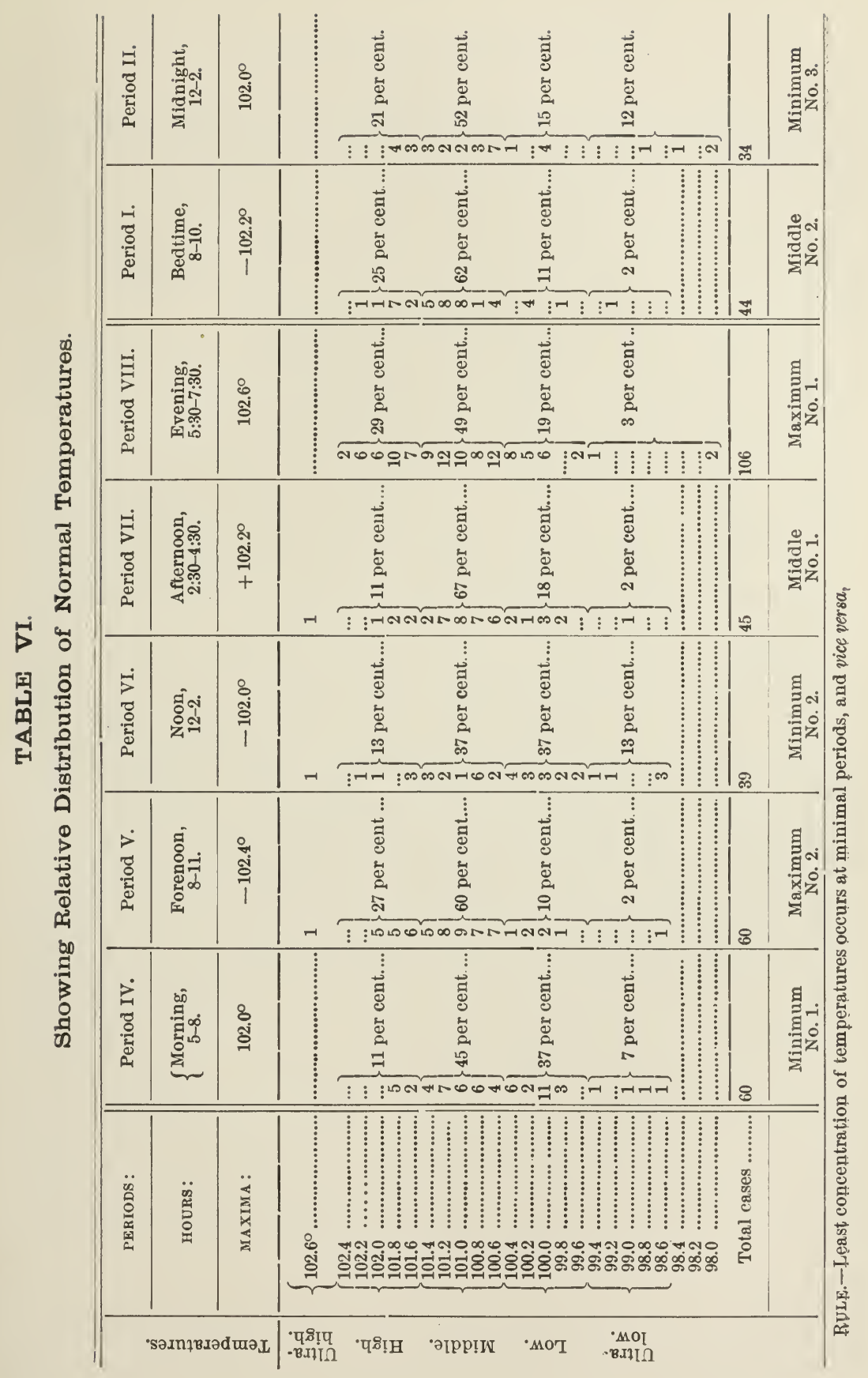


In accordance with the reasoning just presented, these data of normal temperatures were plotted into a table shown in No. VI. The temperatures on each side (above and below) $99^{\circ}$ are grouped as "ultralow," those about $100^{\circ}$ as "low," those about $101^{\circ}$ as "middle," those about $102^{\circ}$ as " high," and those above $102.5^{\circ}$ as "ultra-high." Only the even tenths are presented. All readings falling on odd tenths have been shoved up one-tenth of a degree.

Following these temperatures are the figures representing the number of times this reading was presented in each period. The percentage of cases for each group was calculated, and a study of the table shows that neglecting the period from 2:30 A. M. to 5 A. M., called "foredawn," for which we have scarcely any readings, the other periods present three columns in which the temperatures range lowest, two in which they range highest and two connecting, " middle" periods. The highest maximal and the lowest minimal periods are numbered " 1 " respectively, and fall at evening and at morning respectively. The other maximal period is shortly before noon, which is itself the second minimum (minimum No. 3, coming at midnight). At the top of the columns are the maximal temperatures for normal cases, so that any cow presenting a higher reading at these periods than these maxima, must be considered "suspected." The "minimum" periods are produced by a certain number of cases dropping, some further than others, and the maximal periods by the reverse process, so that viewed from above downwards, the maxima show a much better concentration of the temperatures than do the minima, but all these periods give us a range of four degrees or more within which the temperature of a cow may occur and still be normal.

But this is for the entire herd; no one cow is apt to run the gamut of these four degrees. What may be considered the highest range to be expected of any particular animal? We have data bearing on this point, but unfortunately the number of observations are less extensive than should be required, and future work along this line has been planned. We may, however, present what facts we have as follows: 
TABLE VII.

Showing Highest Variation in Temperature of Same Animal in Each Period.

Calculation of the variation of single animal in evening temperatures, for successive evenings, for thirty cases, gave the maximum variation as $2.2^{\circ}$.

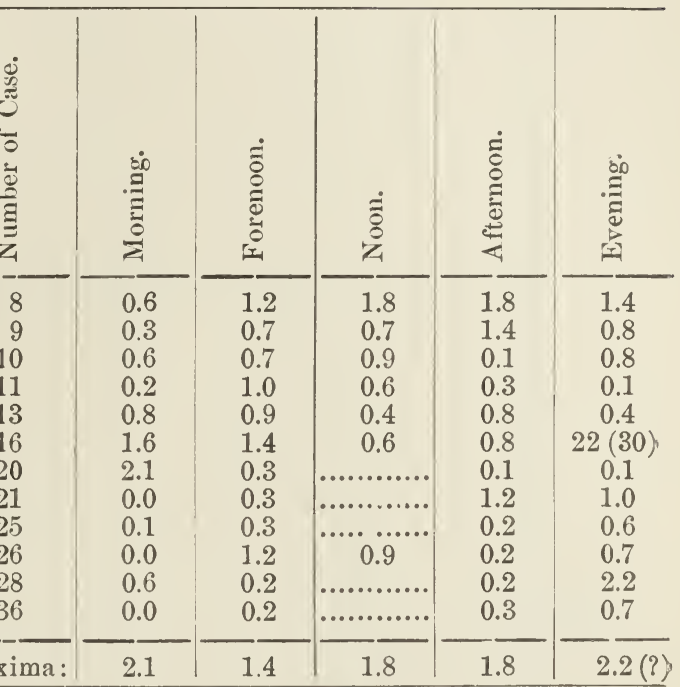

From Table VII. we may conclude that the greatest departure any animal is likely to show from any observed temperature of any day, on any preceding or succeeding day, at the same hour, is in the neighborhood of two degrees for the morning and evening, and less than two degrees during the day. This must guide us in any comparison we may make between a supposed reaction temperature of any period and a known normal temperature for same period twenty-four hours removed therefrom. 


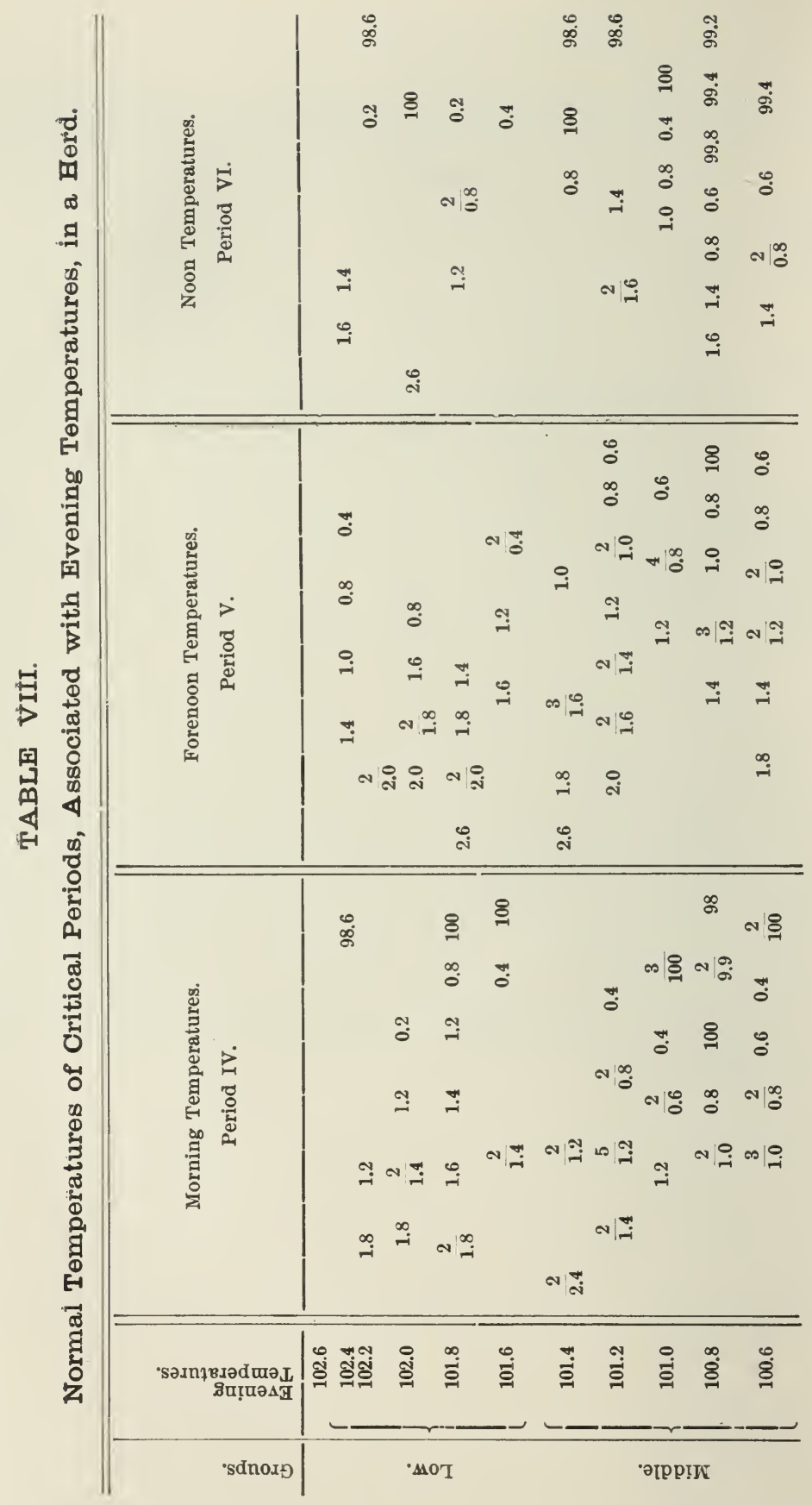




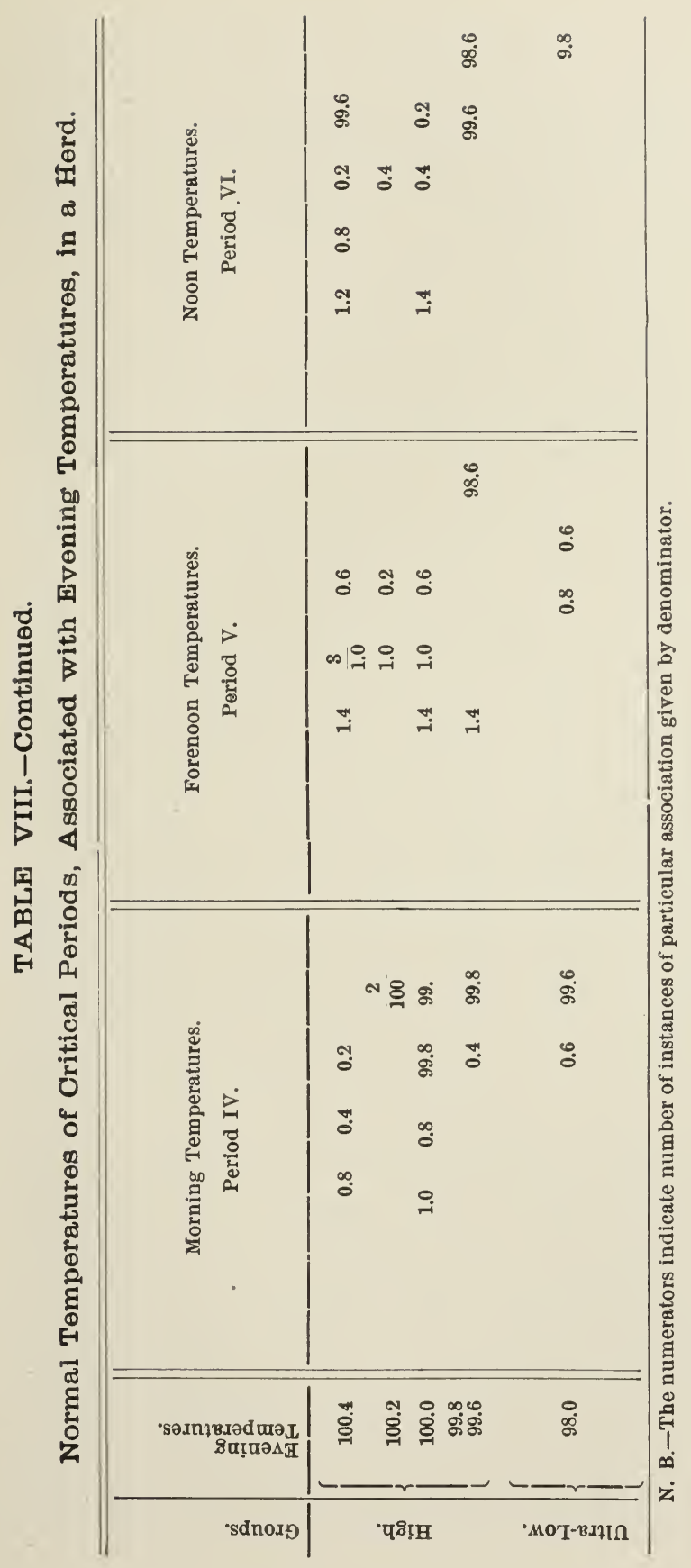


TABLE IX.

Showing the Maximal Departure from Initial Evening Temperature, of Temperatures of Critical Periods.

\begin{tabular}{|c|c|c|c|c|c|c|c|c|}
\hline \multirow{2}{*}{ 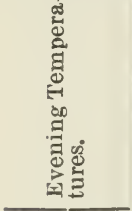 } & \multicolumn{2}{|c|}{$\begin{array}{l}\text { PERIOD IV. } \\
\text { MORNING. }\end{array}$} & \multicolumn{2}{|c|}{$\begin{array}{l}\text { PERIOD V. } \\
\text { FORENOON. }\end{array}$} & \multicolumn{2}{|c|}{$\begin{array}{l}\text { PERIOD VI. } \\
\text { NOON. }\end{array}$} & \multicolumn{2}{|c|}{$\begin{array}{l}\text { Period VIII. } \\
\text { EVEning. }\end{array}$} \\
\hline & : & 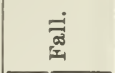 & 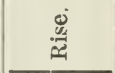 & 西 & 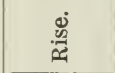 & 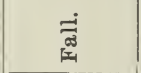 & 总 & चี \\
\hline $\begin{array}{l}102.6^{\circ} \\
102.4 \\
102.2 \\
102.0 \\
101.8 \\
101.6 \\
101.4 \\
101.2 \\
101.0 \\
100.8 \\
100.6 \\
100.4 \\
100.2 \\
100.0 \\
99.8 \\
99.6 \\
994 \\
98.0\end{array}$ & 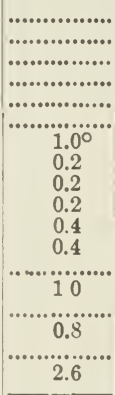 & 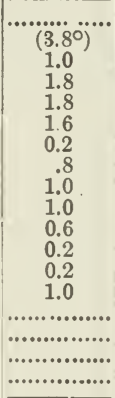 & 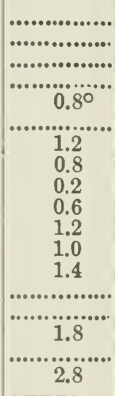 & 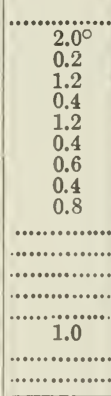 & 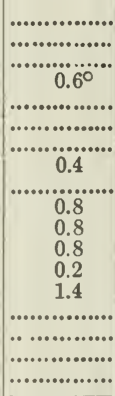 & 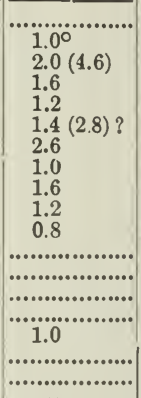 & $\begin{array}{c}\ldots \ldots \ldots \ldots . . . \\
\ldots \ldots \ldots \ldots \ldots . . . \\
0.4^{\circ} \\
0.7 \\
0.5 \\
0.9 \\
0.8 \\
1.6 \\
1.4 \\
0.6 \\
1.6 \\
1.7 \\
\ldots \ldots \ldots . . . \\
0.8 \\
1.6 \\
2.2\end{array}$ & 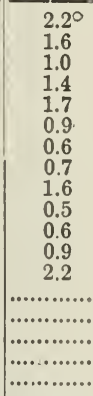 \\
\hline Maxima .... & -2.6 & +18 & -2.8 & -2.0 & 1.4 & $2.8 ?$ & -2.2 & 2.2 \\
\hline \multirow[t]{2}{*}{ 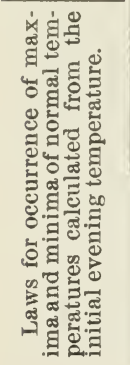 } & 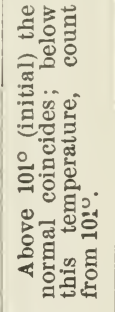 & 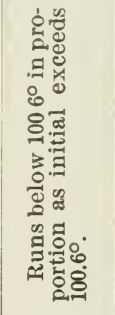 & 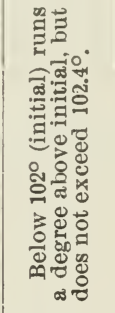 & 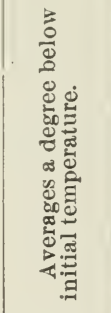 & 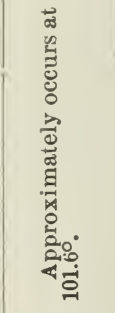 & 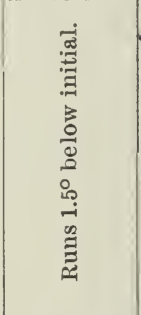 & 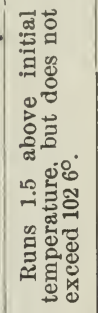 & 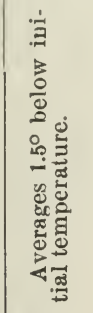 \\
\hline & Max. & Min. & Max. & Min. & Max. & Min. & Max. & Mis. \\
\hline
\end{tabular}

Suppose, however, we have but one series of observations for less. than a twenty-four-hour period. What departure from any initial temperature may be expected in any subsequent period? Our data. must be judged from the initial evening temperatures. Table VIII. shows the temperatures for the critical periods (when reaction is measured) that were associated in the same animal with the evening temperatures shown in the first column. From this table and other data we have prepared Table IX, which shows the greatest amount of departure from the initial temperatures which the various cases. presented, both in an upward and downward direction. From this. 
table we see that we have departures from the initial temperature ranging from $1.4^{\circ}$ to $2.8^{\circ}$ (neglecting one or two very aberrant cases). The general average of these departures is about $2.5^{\circ}$, which has already been independently chosen by operators as the limit of legitimate variation from the initial temperature. An examination of these tables shows further that the general tendency of these associations is to keep within still narrower limits of the initial temperature, so that a degree, or at most two degrees, limit of variation is more nearly approximately the true normal departure. Thus we have now seen the strongest evidence that can be offered in favor of using this method for "approximate" determination of the reaction.

When, however, the initial temperatures are relatively high, it is manifestly wrong to allow any margin in an upward direction. Our data show that in such cases the subsequent temperatures are correspondingly lower than they would be if the initial temperatures were low, and the reverse rule also holds good. Thus it follows that we can use, with equal certainty, a fixed standard of reference, and this was employed in Table V. with marked success. After finding how much the initial temperature was a guide to the subsequent normal, I concluded to calculate the reaction from rules discoverable by inspection of Table IX. These rules combine the advantages of both methods in such a way as to eliminate some of the factors of error present in each. The rules are in place on Table IX., and need not be repeated here. It will be noticed, however, that there is some variation in the rules for the different periods. The difference between the maximal normal, as calculated by these rules, and the actual record may be termed the "supra-maximal excess," or simply "maximal excess," it being understood that no reaction is to be predicated if the recorded temperature falls below the calculated normal. As this maximum is based on data from all the herd, and up to which only a few animals come, there is left a wide zone in which individual cases of normal temperature may occur, clear down to the minimal normals of a herd. That is, the maximal excess is the "least actual reaction," while it is possible that the real reaction may also include this wide zone (greatest downward departure to greatest upward departure). When so included, we have the "possible excess." To determine the probable location of the real reaction between these limits, it is necessary to observe the individual cow for a protracted period, in order to learn the most usual associations with the initial temperature, or to deter- 
mine the usual habit of variation at the hours the reaction occurred. Such a calculation will give the "mean reaction," which, of course, is only the nearest approximation which it is possible for us to make. Unnecessary as it is in the majority of cases to go to all this trouble, it is necessary, if we wish to determine all the cases of reaction. Let the reader emphasize this point. We see just what care must be exercised if we would reduce the present element of uncertainty which all operators realize exists, and which has been well expressed by Dr. Pearson as follows (italics his):

"But we have not yet reached the time when it will be possible to give each animal in a herd the same dose of tuberculin, measure the temperature and blindly declare each animal which reacts, tuberculous and the others healthy."

So far as our experience goes, the above quotation may be revised to read :

"We have not yet sufficient knowledge of the true normal temperature which we may expect of any particular cow so that we can declare what, if any, the reaction in her case is."

I think, however, that we can attain a closer approximation to this knowledge by proceeding according to the rules laid down in this paper. 
TABLE X.

Giving a Comparison Between the Least and the Possible Reactions, as Calculated by General Rules and from Individual Records.

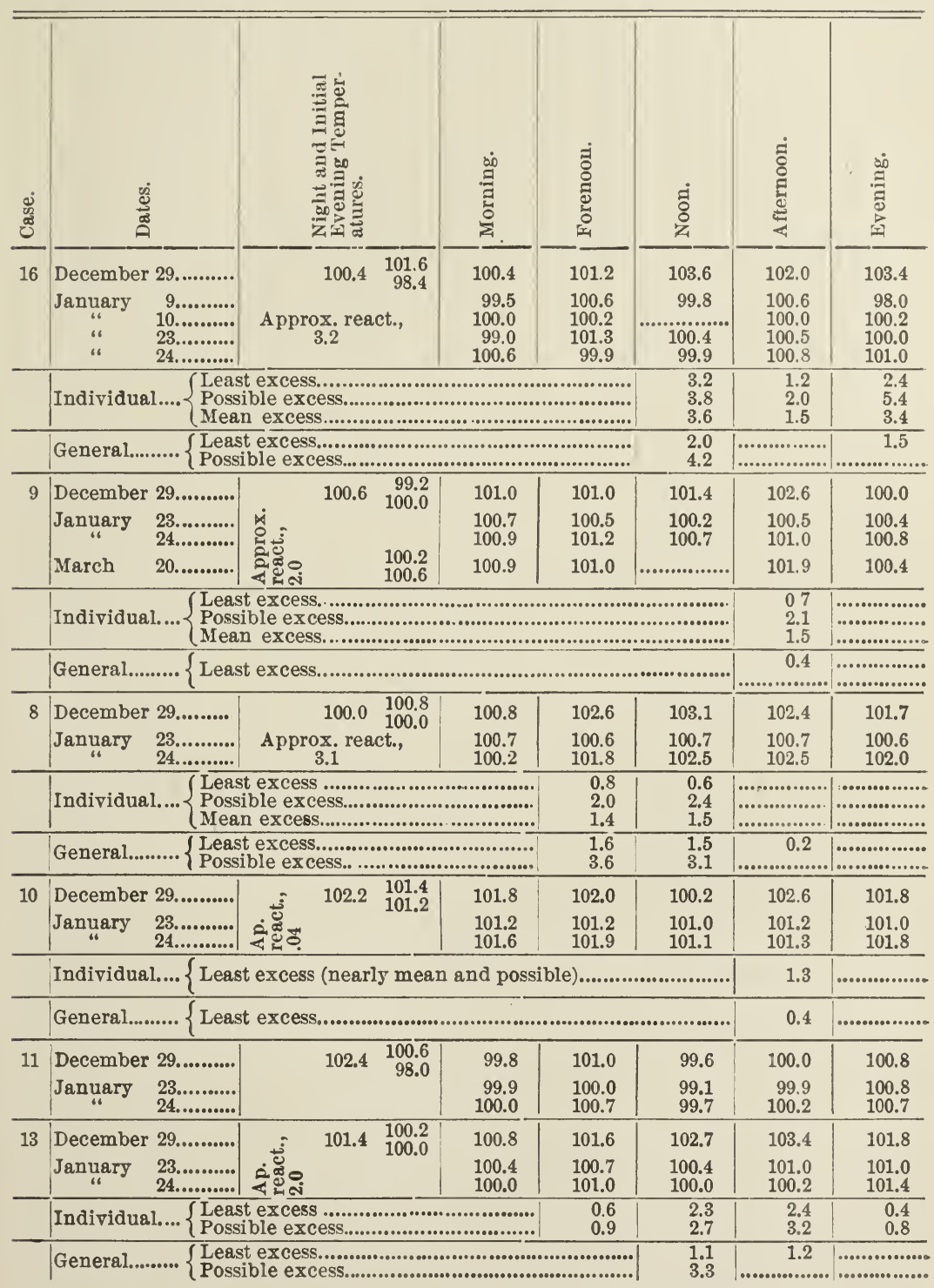


TABLE X.-Continued.

Giving a Comparison Between the Least and the Possible Reactions, as Calculated by General Rules and from Individual Records.

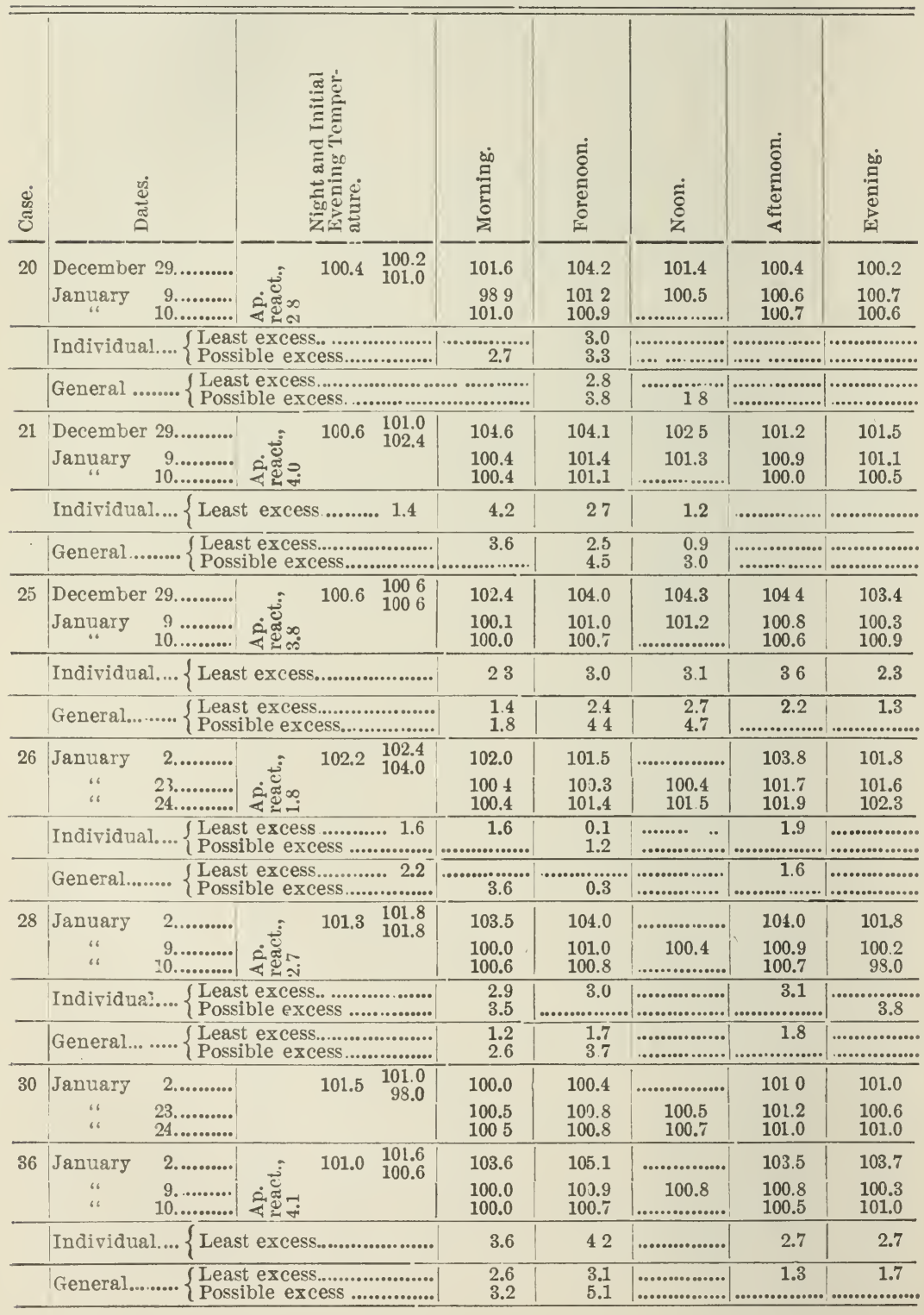


Not any of our cases have been observed long enough to determine the probable reaction. The few records we have on this line we present in Table X., an inspection of which table serves to show how great the difference is in the application of these various methods. The "approximate reaction" compared with these figures shows how, at one time, the coincidence is with the "least excess;" at another, how it falls in with the greatest "possible excess."

However, the best that can be done is to take the "general rules" and to determine the maximal excess, if any, for each period. Of that much reaction we are at least sure, and we are also sure that the figures more equably represent the true state of things than if we had used the approximate reaction. Accordingly we have Table XI. 


\begin{tabular}{|c|c|c|c|}
\hline$\underbrace{\frac{1}{3}}_{\frac{1}{3}}$ & 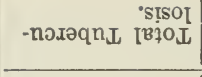 & 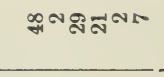 & 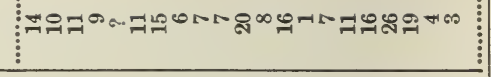 \\
\hline$\frac{\sqrt{2}}{\frac{0}{0}}$ & 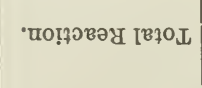 & \multicolumn{2}{|c|}{ 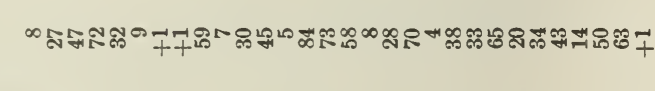 } \\
\hline$\frac{H^{4}}{3}$ & •sรəəx & \multicolumn{2}{|c|}{ 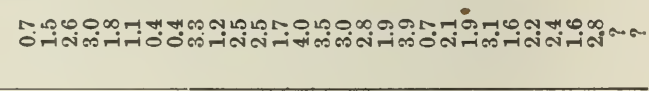 } \\
\hline 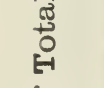 & 'ао!̨в.nत & \multicolumn{2}{|c|}{ 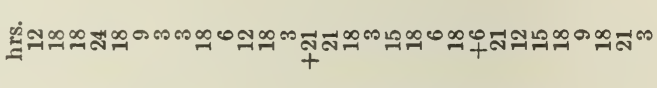 } \\
\hline 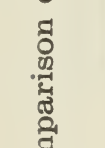 & $\begin{array}{l}\text { •unut } \\
\text {-IXBIT Jo әயu!L }\end{array}$ & \multicolumn{2}{|c|}{ 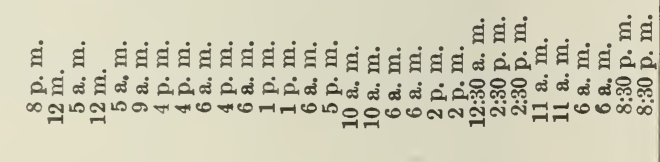 } \\
\hline ర్త్ర & 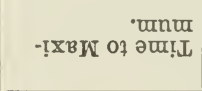 & \multicolumn{2}{|c|}{ 20ㅂำ } \\
\hline in gृ & 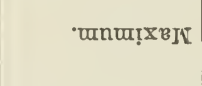 & \multicolumn{2}{|c|}{ 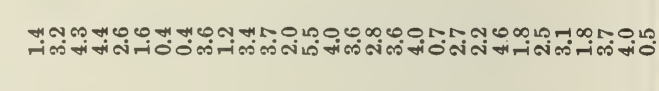 } \\
\hline 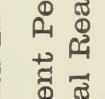 & 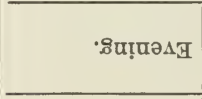 & 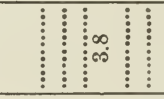 & 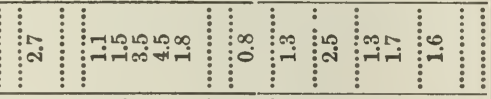 \\
\hline$\stackrel{\oplus}{\oplus} E$ & 'น0оนләभร & \multicolumn{2}{|c|}{ 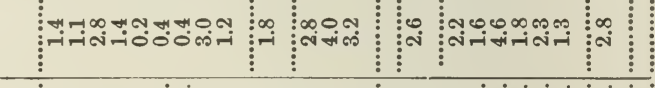 } \\
\hline$\frac{9}{1}$ & $\cdot 400 N$ & \multicolumn{2}{|l|}{ 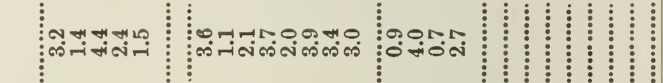 } \\
\hline$\stackrel{\infty}{\infty}$ & ' иоопәлон & 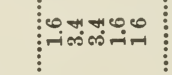 & 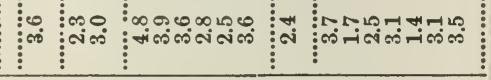 \\
\hline ॠ్రై & 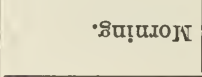 & 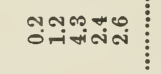 & 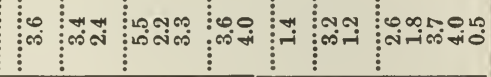 \\
\hline व्व & •имврәлон & \multicolumn{2}{|l|}{ 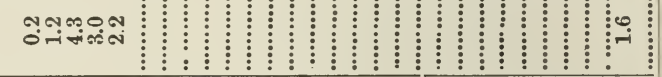 } \\
\hline $\begin{array}{l}0 \\
\text { o } \\
0 \\
0\end{array}$ & 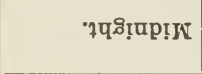 & \multicolumn{2}{|l|}{ 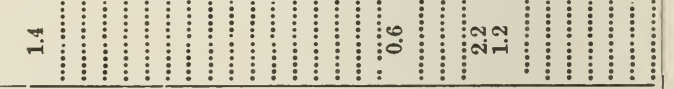 } \\
\hline 齐 & •əuा!ฺpəg & \multicolumn{2}{|l|}{ 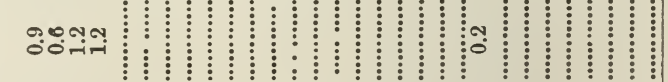 } \\
\hline$\frac{8}{3}$ & 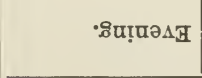 & $\stackrel{\infty}{\infty} \stackrel{0}{0}:$ & $\vdots$ \\
\hline & •əsв & \multicolumn{2}{|c|}{ 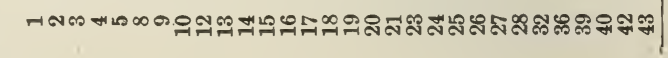 } \\
\hline
\end{tabular}


This table was calculated by the methods just discussed; for bedtime period we added a degree to the initial to get the normal, not to exceed $102.2^{\circ}$; for midnight we chose the maximum $101.8^{\circ}$ as a fixed normal; for afternoon the fixed normal maximum of $102.2^{\circ}$ was chosen.

The first thing that strikes us is that by these rules the period having the highest temperature need not be the one necessarily which gives the highest reaction. Thus we discover that No. 1, which had a continuously falling temperature, shows a decided reaction at midnight. We also learn that the reaction period is one of varying length, and that the highest point in it, is not necessarily at its middle, although there seems to be a general tendency towards a regular curve, whose height increases with the length, but not directly so, the longer curves being much flatter than the shorter ones. In calculating the "duration of a reaction," we have been guided largely by the general nature of the few curves that are complete, as most of the longer ones have both ends disappearing in periods where no observation was taken. Thus the figures on this head are probably rather roughly approximate. The total reaction was calculated by multiplying the average reaction into the "duration." 


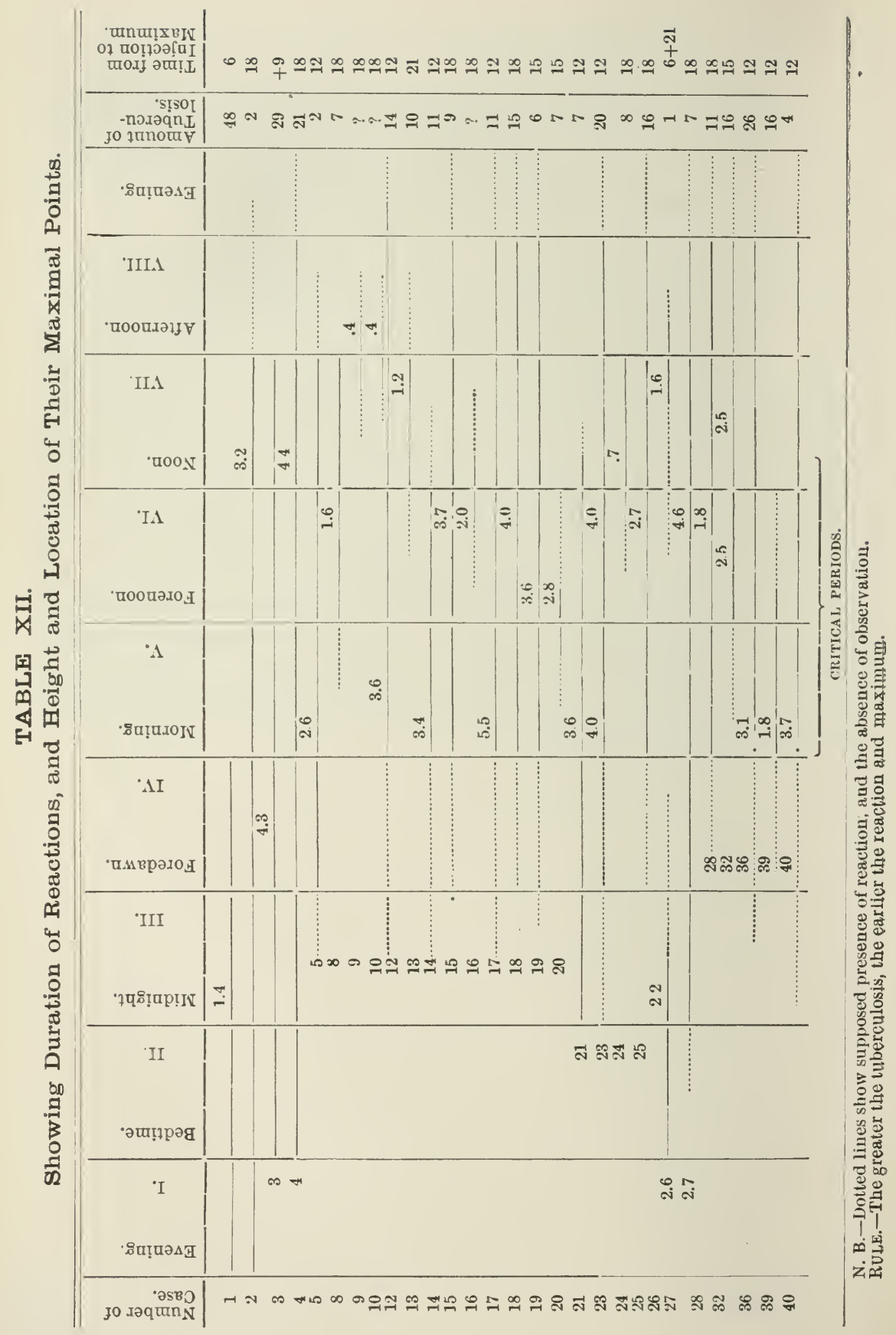


This table is partly also a chart showing by means of lines the length of the reactions, the height of the highest reaction, and the point in the line where this maximum occurs. The main object of the chart is to show that observation at morning, forenoon and noon strikes most (though not all) the reactions at some point where reaction can be determined. These periods are, therefore, the most " critical" in importance; but the midnight and afternoon periods are needed to include all the cases, while if one desires to get a proper idea of the "duration" from which to calculate the total reaction, it becomes needful to observe, not only in all the periods of the first night and day, but indefinitely into the serond night. For practical purposes this is not needful, as the long reactions are easily diagnosed from a single observation, which is likely to strike them anywhere. It is the short reactions that may escape us; these, as can be seen, occur late in the day. Thus in selecting cows for purchase, if on being tested for twelve or fifteen hours, and no reaction occurs, it is not safe to stop at this point, because a reaction may be found at eighteen or twenty-one hours after injection. 
TABLE XIII.

Showing the Co-Variants of H. M. E.

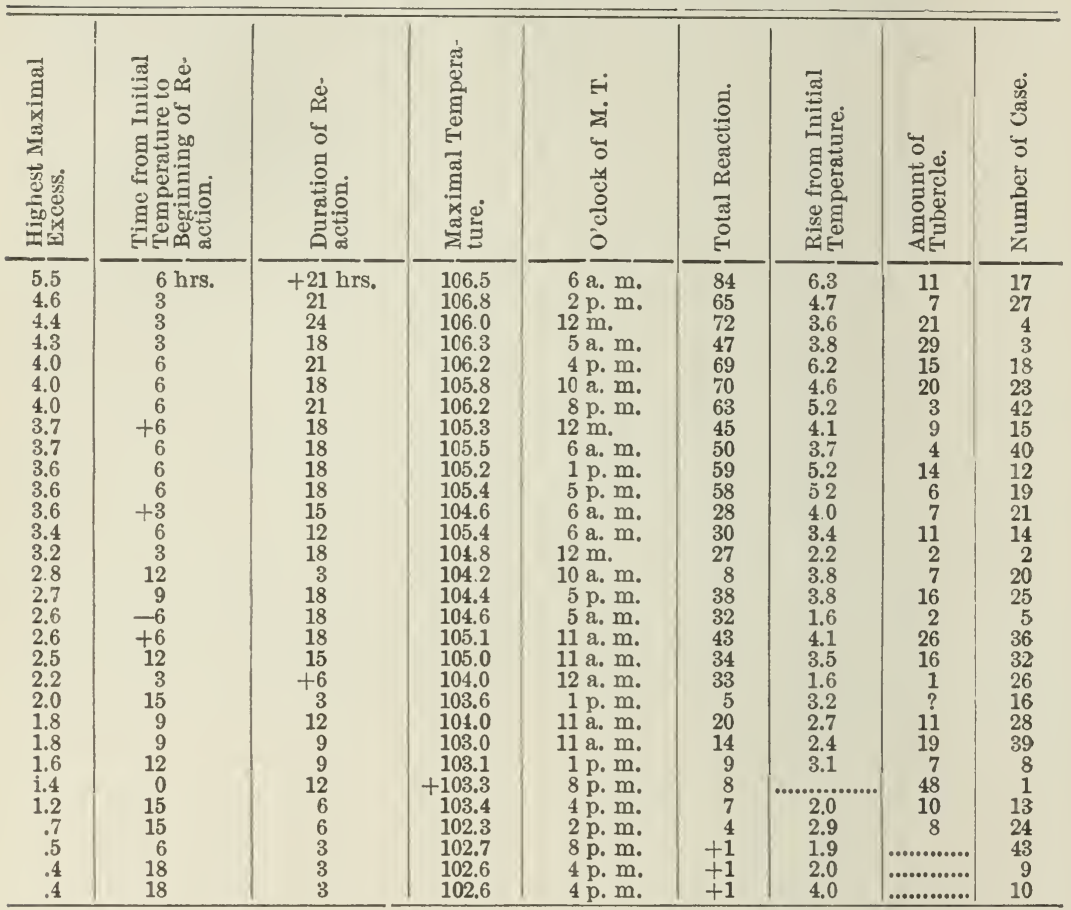

\section{A STUDY OF CO-VARIANTS AND DI-VARIANTS.}

We have now, from direct observation and from calculation, quite a number of facts pertaining to each case, and it behooves us to compare these facts to see how they are related.

\section{DISCUSSION OF TABLE XIII.}

This table has the highest maximal excess figures placed in the order of their magnitude, beginning with the highest. In succeeding columns are placed the facts that are associated with each "H. M. E. number," and from a diligent study of them the following laws appear : 
(1) The higher the reaction the sooner it occurs. Should this law be definitely established, it would show that the calculated reaction for No. 1 gives a greatly too low figure.

(2) The higher the reaction the longer it lasts. Should this law be shown to be absolute, we have but to determine the duration of a reaction to enable us to judge of its probable height.

(3) Naturally, the maximal temperature will directly co-vary with the H. M. E.

(4) Naturally, also, it follows from (1) that the o'clock of the occurrence of the maximal temperature is later in the day, the smaller the H. M. E.

(5) Naturally, the total reaction will vary, but not uniformly, with the H. M. E. If we had a true record of maximal excesses and of "durations," I believe that the "total reaction," as calculated from their product, would be a valuable set of data from a purely physiological standpoint, for this alone would really express the "true reaction."

(6) The next column gives the "approximate reaction," and shows how far this varies from the order of the H. M. E., although a general co-variation is naturally to be expected.

(7) The amount of tuberculosis seems to be thoroughly disvariant with H. M. E., and about everything else in the table. This shows that the reaction is in no wise directly dependent on the amount of tuberculosis. Sometimes the high reaction indicates a small amount, and in other cases a large amount of disease, and vice versa for low reactions. What is to be ascertained is the presence of a reaction. Let no one think that he may allow a few cows to go scot free, as "probably not much affected," because the reaction was "low or doubtful." Herein lies the real reason for emphasizing work of this sort. Let us have all the light we can; let the observations be extended; let the slaughter be extensive until sound animals are sacrificed; let the facts be carefully and fully observed, and with great detail and accuracy, and above all, let them be published. Are we to be treated to the spectacle of men going about injecting herds of cattle, making a few temperature observations, killing the cases most obviously reacting, finding, naturally, that their diagnoses were correct, and then pocketing their data, no one knows what they may be? The scientific world gets only the brief mention, "such and such a herd was injected, so many animals were diagnosed as tuberculous, and have been 
slaughtered, the diagnosis confirmed, and the carcasses have been buried." Will any one dare believe that tuberculosis has been stamped out of these herds? And yet that is what the public are led to think.

\section{TABLE XIV.}

Showing Co-variants of Age.

\begin{tabular}{|c|c|c|c|c|c|c|c|c|c|}
\hline 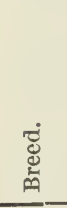 & AGE. & 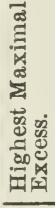 & 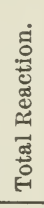 & 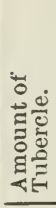 & 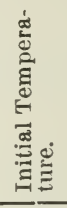 & 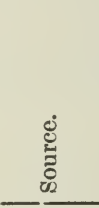 & 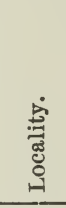 & 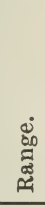 & 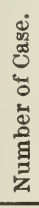 \\
\hline A. & 13 years & 1.6 & & 7 & 100.0 & J. O.M. & N. J. & & \\
\hline S. H. & 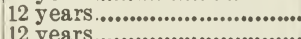 & 3.6 & 59 & 14 & 100.0 & $\mathrm{~S} S \mathrm{~s}$ & N. Y. & 5.2 & 12 \\
\hline$\stackrel{\mathrm{M}}{\mathrm{H}}$ & 10 years & $\begin{array}{l}1.2 \\
4.3\end{array}$ & 44 & 29 & $\begin{array}{l}102.5 \\
102.5\end{array}$ & G.W. W. & $\mathrm{N} . \mathrm{B}$. & $\begin{array}{l}3.4 \\
3.8\end{array} \longrightarrow$ & $\begin{array}{r}15 \\
3\end{array}$ \\
\hline S. H. & 10 years.................................... & 2.0 & 5 & $?$ & 100.4 & $s \mathrm{~s}$ & N. Y & 5.2 & 16 \\
\hline$\stackrel{N}{\mathrm{~N}}$. & 10 years.......................... & 2.6 & $\begin{array}{l}43 \\
14\end{array}$ & $\begin{array}{l}26 \\
19\end{array}$ & $\begin{array}{l}101.0 \\
1006\end{array}$ & D. H. V. & N. B. $\mathrm{Y}$. & $\begin{array}{l}4.5 \\
24\end{array}$ & $\begin{array}{r}36 \\
39\end{array}$ \\
\hline $\mathrm{H}$. & 9 years............. & 1.4 & 8 & 48 & 103.3 & M. P. & N. J. & 1.2 & 1 \\
\hline & 9 ye & 3.4 & 30 & 11 & & T. C. & N. B. & & \\
\hline & $9 \mathrm{ye}$ & 4.0 & 69 & 15 & & J. O. & & & \\
\hline & $9 \mathrm{ye}$ & 3.6 & & 7 & & $\mathrm{~J}_{\mathrm{i}} \mathrm{N}$ & & & \\
\hline & 9 year & 4.0 & 70 & 20 & 101.2 & G. W. T. & N. & & \\
\hline & 9 years.................................... & $\begin{array}{l}2.7 \\
2.8\end{array}$ & $\begin{array}{r}35 \\
8\end{array}$ & $\begin{array}{r}16 \\
7\end{array}$ & 100.4 & $\begin{array}{l}\text { A.H. D. } \\
\text { P. }\end{array}$ & $\begin{array}{l}\text { N. Y. } \\
\text { N. B. }\end{array}$ & 4 & 25 \\
\hline$H$ & 7 years............................ & 0.4 & +1 & & 100.6 & G. W. T. & N. B. & 3 & $\begin{array}{c}20 \\
9\end{array}$ \\
\hline$A$ & 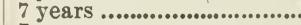 & 3.7 & 45 & 9 & 101.2 & L. S. D. & $\mathrm{Vt}$ & 4. & 15 \\
\hline & 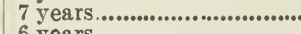 & 0.7 & 4 & 8 & 1094 & D. H. V. & $\mathrm{N} . \mathrm{B}$. & & 24 \\
\hline $\mathrm{H}$ & 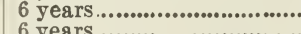 & 5.5 & $\begin{array}{l}84 \\
58\end{array}$ & 11 & $\begin{array}{l}1002 \\
100.2\end{array}$ & W. A. R. & N. Y. & 6.3 & 17 \\
\hline G. H. & 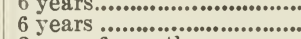 & 2.5 & 34 & 16 & 101.5 & G. W. T. & N. B. & 4.2 & 32 \\
\hline S. H. & 2 years 6 mont & $\begin{array}{l}0.4 \\
22\end{array}$ & $\begin{array}{l}+1 \\
33\end{array}$ & $\cdots$ & $\begin{array}{l}102.2 \\
102.2\end{array}-\mathrm{r}$ & $\begin{array}{l}\text { Bred. } \\
\text { Bred. }\end{array}$ & N. B. & ${ }_{2}^{2}$ & 10 \\
\hline S. H. & 2 years... & 4.4 & 72 & 21 & 102. & Bred. & N. B. & 3. & 4 \\
\hline H. & 2 year & 4.6 & 65 & 7 & 102. & Bred. & N. B. & 4. & 27 \\
\hline G. A. & 19 year 8 mont & $\begin{array}{l}1.8 \\
3.7\end{array}$ & 50 & 4 & 101.8 & $\begin{array}{l}\text { Bred. } \\
\text { Bred. }\end{array}$ & N. B. & 4. & 40 \\
\hline $\mathrm{C}$ & 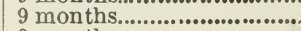 & 4.0 & 63 & 3 & 101 & Bred. & N. & 5. & 42 \\
\hline G. & $9 \mathrm{mon}$ & 05 & +1 & & 100 & Bre & N. & 1. & 43 \\
\hline H. & 1 month & 32 & $\begin{array}{l}52 \\
27\end{array}$ & 2 & 102.6 & $\begin{array}{l}\text { Bred. } \\
\text { Bred. }\end{array}$ & N. B. & 2.2 & \\
\hline
\end{tabular}

STUDY OF TABLE XIV.

This table exhibits the co-variants of the age of the animals. We see first that the different breeds are pretty uniformly represented for the different ages. The highest maximal excess seems also to be distributed without reference to age. The total reaction preponderates in amount with the younger animals. They have a greater power to react. They also have a less amount of tubercle, and this of itself may explain why the reaction is higher; for, while from Table XIII. we saw that the amount of tubercle did not vary per individual with the reaction, on summing up the amount for a number of cases, we 
get indications that a small amount of tuberculosis produces a greatertotal reaction (not necessarily a greater "approximate reaction" or even H. M. E.) than does a more advanced state of the disease. Cows over nine years old have three times as much tuberculosis as those under three years of age. The initial temperature also seems to be higher with young animals, averaging about $102^{\circ}$ for those under three years and $101^{\circ}$ for those above nine years. This fact is easily observed. Almost any temperature chart where the young animals are exhibited by themselves shows this, and, coupled with the fact that they are less tuberculous, no wonder veterinarians are cautious in diagnosing reaction. But age is one factor to be considered in such a judgment.

The next column of this table shows that the older animals have come from other herds, while all the youngest (below three years of age) have been bred on the farm. The column giving locality shows that not only this State but New York and several of the New England States had their representatives in the herd-all tuberculous. Are we to judge that these States are also saturated with tuberculosis? 


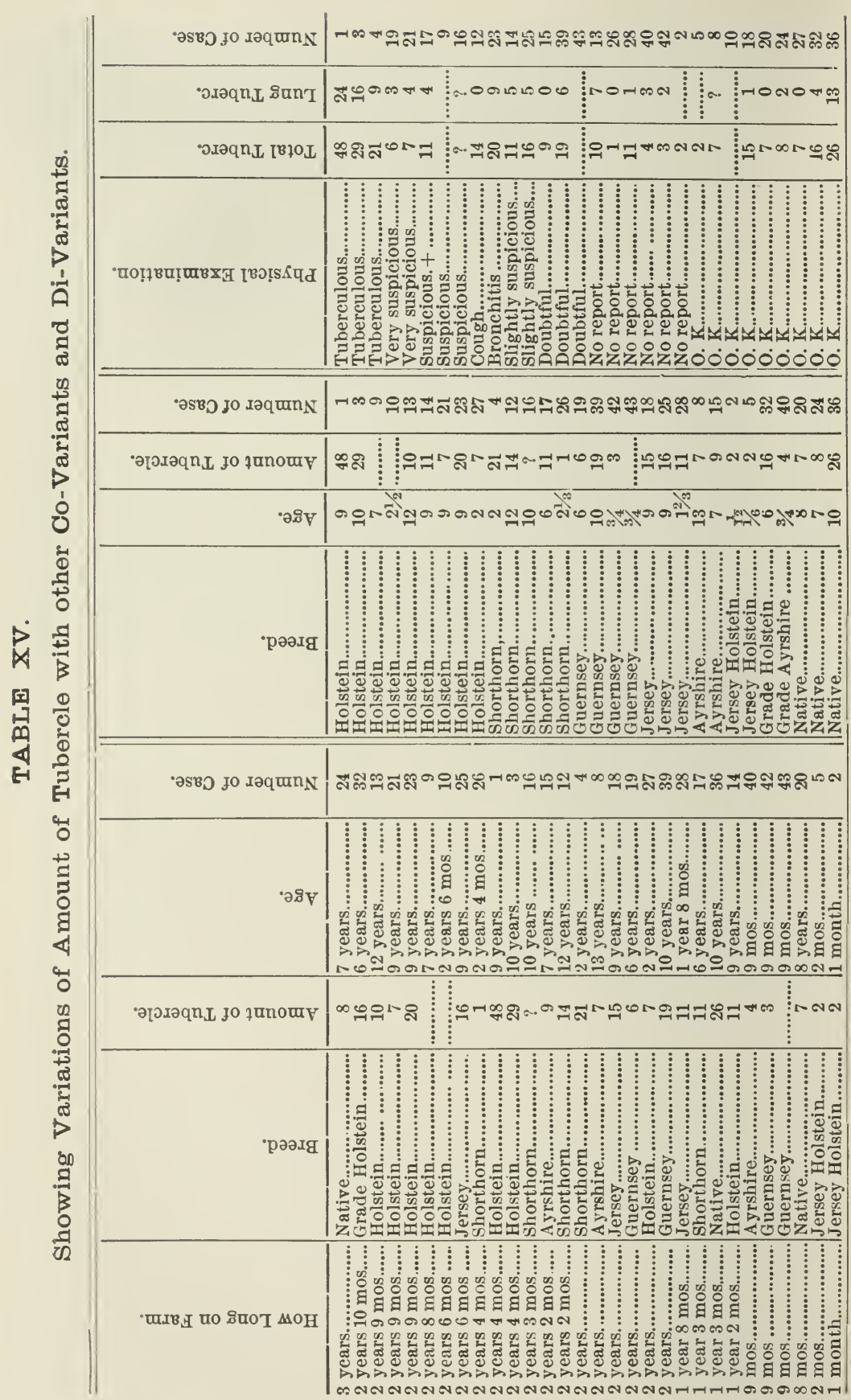


STUDY OF TABLE XV.

First let us ascertain if the length of time the cows have been members of our herd has influenced the amount of tuberculosis.

Cows over two years at the farm, average in tubercle, 19; in age, 8.

Cows two years at the farm, average in tubercle, 12 ; in age, 7.

Cows under two years at the farm, average in tubercle, 10 ; in age, 3.

The age relations show that the tubercle relations should increase no faster than they seem to have done, so that we may conclude that these cattle were infected before coming here.

With reference to the breeds, it is apparent that no one breed has any advantage over the others except the natives. Of course, age must also be taken into consideration. It will be noticed that all the cows added to the herd after being first tested are natives.

The physical examination compared with the amount of tubercle shows, of course, no co-variation. We should expect, however, that the amount of lung tuberculosis would co-vary with the physical diagnosis, and, to a certain extent, this is true. But some individuals remarkably free from lung lesions were "suspected," while others pronounced $\mathrm{O} . \mathrm{K}$. had a very high state of lung tuberculosis. The average amount of lung tubercle in $\mathrm{O} . \mathrm{K}$. cases is 2 ; in "suspected" cases 4 , and in "very suspicious" cases it is 7. There is, however, a marked preponderance of tuberculous cases among the suspected animals.

Unfortunately in this matter, general averages and tendencies and "majorities" count for nothing, so long as the object is to discover individual cases. Each animal has its own strong individuality; it should not be judged by its fellows. I suspect, too, that each herd has its own individuality. 


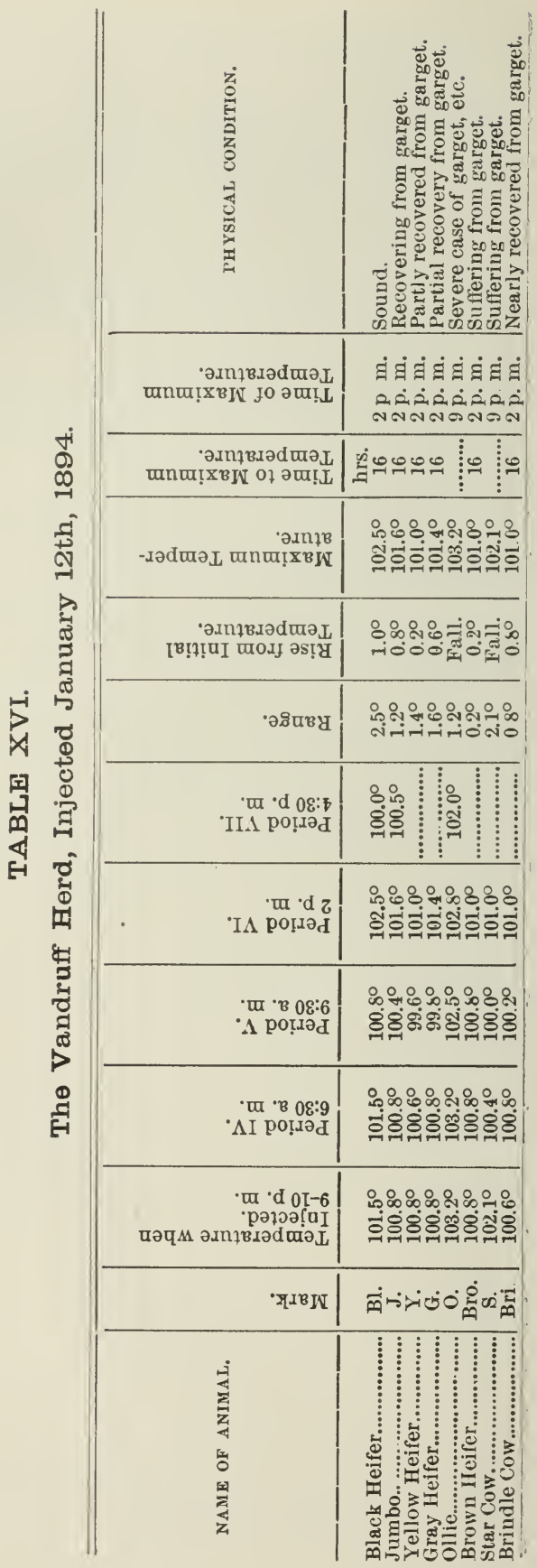




\section{OTHER HERDS.}

Table XVI. shows the data observed on the Vandruff herd, near Deckertown, N.J. This certainly presents a remarkable case in Ollie, who, in many respects, suggested our Case 1. The temperature curve is almost identically similar. No doubt would have remained in my mind of this cow being tuberculous had she been alone. But so many other members of this herd had been sick "like her" and were recovering, and showed no reaction, that I concluded that this herd was free from tuberculosis-pneumonia and mammitis being probably the true diseases present, and accounted for the high temperature of Ollie. Nevertheless, the possibility remains that this one animal may be tuberculous, although from the evidence I had, I was not justified in diagnosing a case of this disease.

I have already referred to the work of other men, and three or more sets of their temperature tables lie before me. Were these temperatures recorded in connection with those presented in my tables, I would be justified in putting the mark of condemnation upon many cases that have been "passed" as sound. But I dare not go so far as to pronounce judgment against these creatures whom, in the first place, I have never studied, and, in the second place, are members of herds with peculiarities different from our own. I merely mention this to emphasize the point that we need to experiment along these lines with greater care than ever.

There should be no unscientific haste. For thousands of years have we battled with these unseen and undreamed-of germs, and now that we know them, let us study them more carefully. If legislation be needed to aid in the stamping out of this disease, let the work be done thoroughly and not superficially. It is not for the experimenter to pronounce on the advisability of certain features of a law on this subject, $e . g$. the matter of pecuniary reimbursement by the public to the loser of tuberculous animals. I would merely suggest that if the matter be brought properly before the public, the people will insist on getting milk from herds that have stood this test. Thus will dairymen be compelled, for their own interests, to call in the veterinarianfirst, to test the herd; secondly, to disinfect the premises; thirdly, to suggest sanitary modifications in the stables, and lastly, to test all newcomers. This work no doubt is expensive, but it will pay. 
I would also suggest that if the State assume control of this business of stamping out tuberculosis, that first of all the temperature record of each cow be published, and that all suspected cases be quarantined until we know about how many cases there are, then it will be easier to judge what strain the treasury will stand. But, seriously, these cows should not be slaughtered until they have been properly studied. We need to know a good deal more about many points; all those studied in connection with our rather meager data should be viewed from a broader standpoint, but especially do we need to know more about the methods of infection and the presence of bacilli in the milk. We ought also to know to what extent it is true that a second injection produces a greatly reduced reaction, as suggested from the work of Dr. Pearson. There should also be a series of analyses made of the meat of tuberculous animals to see to what extent tuberculin may be stored in the tissues, so as to be an element of danger as presupposed by Dr. Low in his recent pamphlet issued from the Cornell Station, N. Y. A pamphlet, by the way, which gives an admirable synopsis of what is known about tuberculosis, in more detail than our section 2 .

\section{SUMMARY OF CONCLUSIONS.}

In summarizing this paper only the last section will receive extended attention. Section 1 outlines the work done in stamping out tuberculosis at the College farm. Forty-one animals were injected with tuberculin; twenty-four showed reaction, and the autopsies revealed tuberculous lesions in all except two doubtful cases. Half, only, of these cases had been "suspected" from physical examination.

Section 2 considers among other things the question of liability to infection, in man, from the milk of tuberculous cows; discussion of the work of other observers on these subjects being presented.

Section 3 is a record or journal of the operations in connection with the autopsies. Samples of milk and of various organs were preserved for microscopic work, to be prosecuted later.

Section 4 presents the tables of data, both those ascertained by direct observation, and those from calculation, together with a detailed comparison of the facts to discover co-variants. The following results are those most clearly indicated: 
(1) A "reaction" consists in the recognition, by the body, of the presence of toxines, to which the previous presence of tubercle bacilli has rendered the tissues sensitive. It is incapable of exact measurement and can best be determined from a calculated normal, the location of which can be approximately fixed from an extended series of temperature observations on the individual whose record is in doubt. It can also be located as being certainly below a fixed maximum determined for the herd, and, finally, the initial temperature gives a clue to it, because the latitude of individual variation is only half that of the herd as a whole, viz., about $2.2^{\circ}$. Furthermore, the associations of normal temperatures with the initial evening record is such that a yet closer approximation may be made. The special rules governing this for the different hours of the day and for various temperatures are presented with Table IX.

(2) Thus, the determination of the reaction reduces itself to a revision of the ordinary method (that, viz., by taking the difference between the initial temperature and the maximum record) by incorporating the principle that the temperature of an animal tends to vibrate about a fixed mean, with fixed maximal limits of oscillation, beyond which any excess must be certainly predicated as a reaction. Furthermore, that this reaction is an extended affair, the true total reaction being the integral of the reaction curve.

- (3) The duration of a reaction is proportional to the greatest height thereof.

(4) The higher the reaction the sooner it occurs.

(5) The height of reaction is no index to the amount of tuberculosis present.

(6) The amount of tuberculosis increases regularly with the age of the victim.

(7) There is little difference between the different breeds of highbred cattle, so far as their susceptibility to tuberculosis goes; but grades, crosses and especially "native" cattle appear somewhat less subject to its development.

(8) The total reaction tends to be greater in cases of slight than in cases of well-developed tubercle.

(9) The normal temperatures of young animals range higher than those of the older ones. 
(10) While the diagnosis of tubercle from physical examination is dependent on the presence of tubercle in the lungs, there is no certainty that even well-advanced cases can be thus discovered, nor does it necessarily follow that all suspected tuberculous animals have lesions of the lungs. In the absence of lung lesions, however, the chance of discovery of advanced cases of this disease by physical means is but slight. It also happens that a number of cows not suffering from tubercle are usually included as "suspected" by this sort of diagnosis. Certainly at least twice as great accuracy in discovering tuberculous cattle results from the use of Koch's lymph as from all other means combined.

(11) Slight cases of reaction may occur later than fifteen hours after injection; and, to be certain that all cases have been given a chance to make a record, the observations following injection should be continued for twenty-four hours at least.

(12) If the object of injection be to eradicate the disease utterly from a herd, the reacting cases should be arranged in the order of the certainty of the reaction (in a few cases it will be needful to continue the temperature observations for several days to gain a knowledge of the probable "normal") and killed seriatim until among the doubtful cases there occur at least two in immediate succession which are adjudged sound after extremely thorough examination of all lymphatic structures and places where connective tissue abounds. Then the premises should be thoroughly cleaned and disinfected, and no new animals admitted until they have passed the "test." Finally, to keep the herd "clean," the animals should be tested annually or biennially.

\section{ACKNOWIJEDGMENTS.}

In conclusion, I desire to acknowledge, with thanks, the various services rendered me by the different persons named below. These services have been of material aid to me and to the securing of the data for this publication. Dr. Leonard T. Pearson, of Philadelphia, Professor in the Veterinary Department of the University of Pennsylvania, for kindly granting me several audiences in which conference was had on my work and valuable directions given as to procedure; Dr. Henry R. Baldwin, for much general direction, counsel 
and interest in the autopsies; Dr. A. V. N. Baldwin, for assistance at several autopsies; Dr. E. L, Loblein, veterinarian, for personal conducting of many of the examinations; last, though not least, Mr. E. A. Jones, who observed nearly all the temperatures-perhaps the most important and arduous portion of the work. 


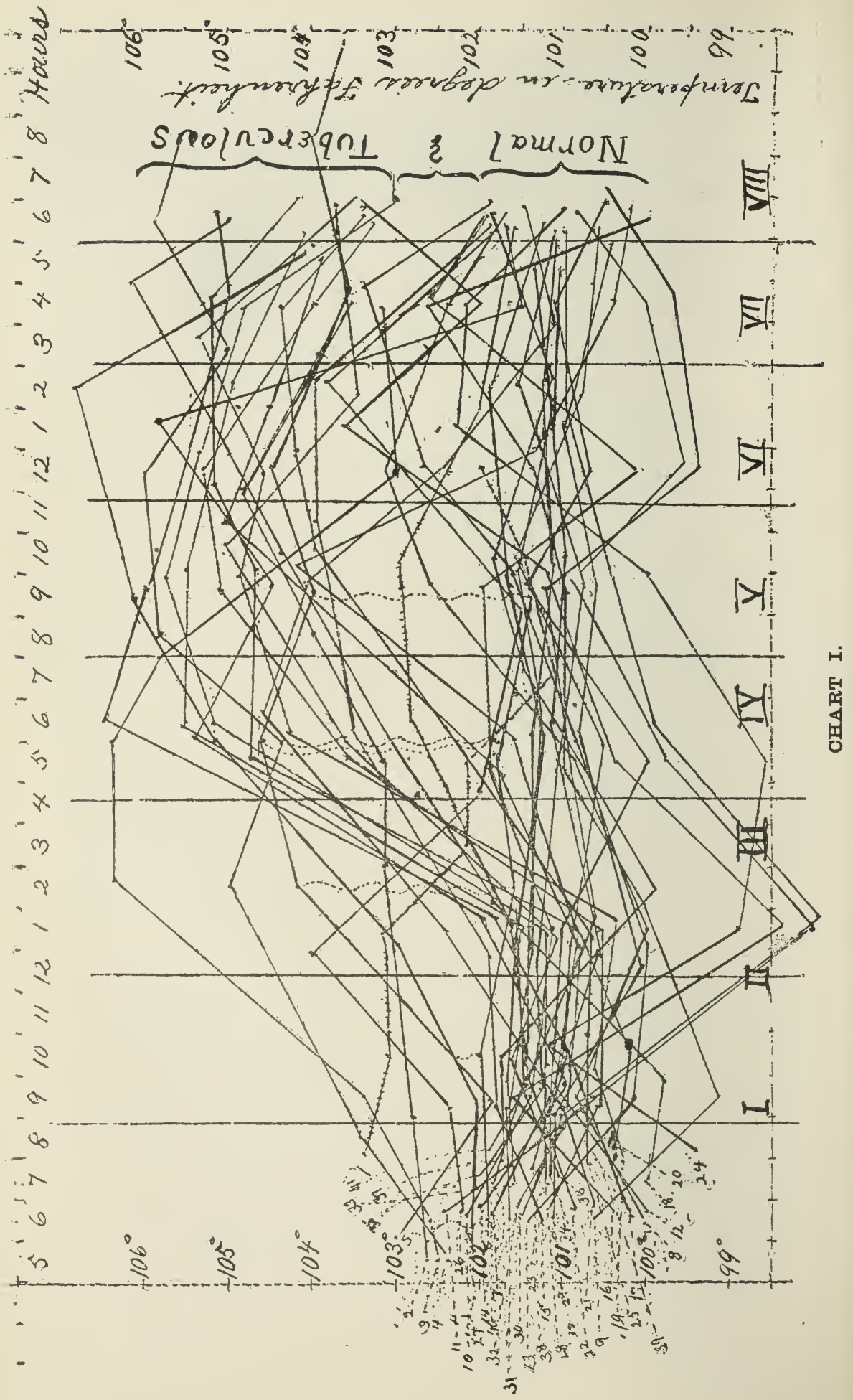




\section{EXPLANATION OF CHART I.}

Chart showing temperature curves for twenty-four hours after injection of the members of the College herd, each curve kept separate from its neighbors.

While two main courses are pursued by these curves, namely, the upward course in Period III. of most of the reacting cases, and the lower course for those not reacting, we find many cases that vary widely from the average, and some cases of late reaction. The numbers at the top of the plate are the hours of the night and the daytime. The degrees of temperature are shown at the sides from $99^{\circ}$ to $106^{\circ}$. 

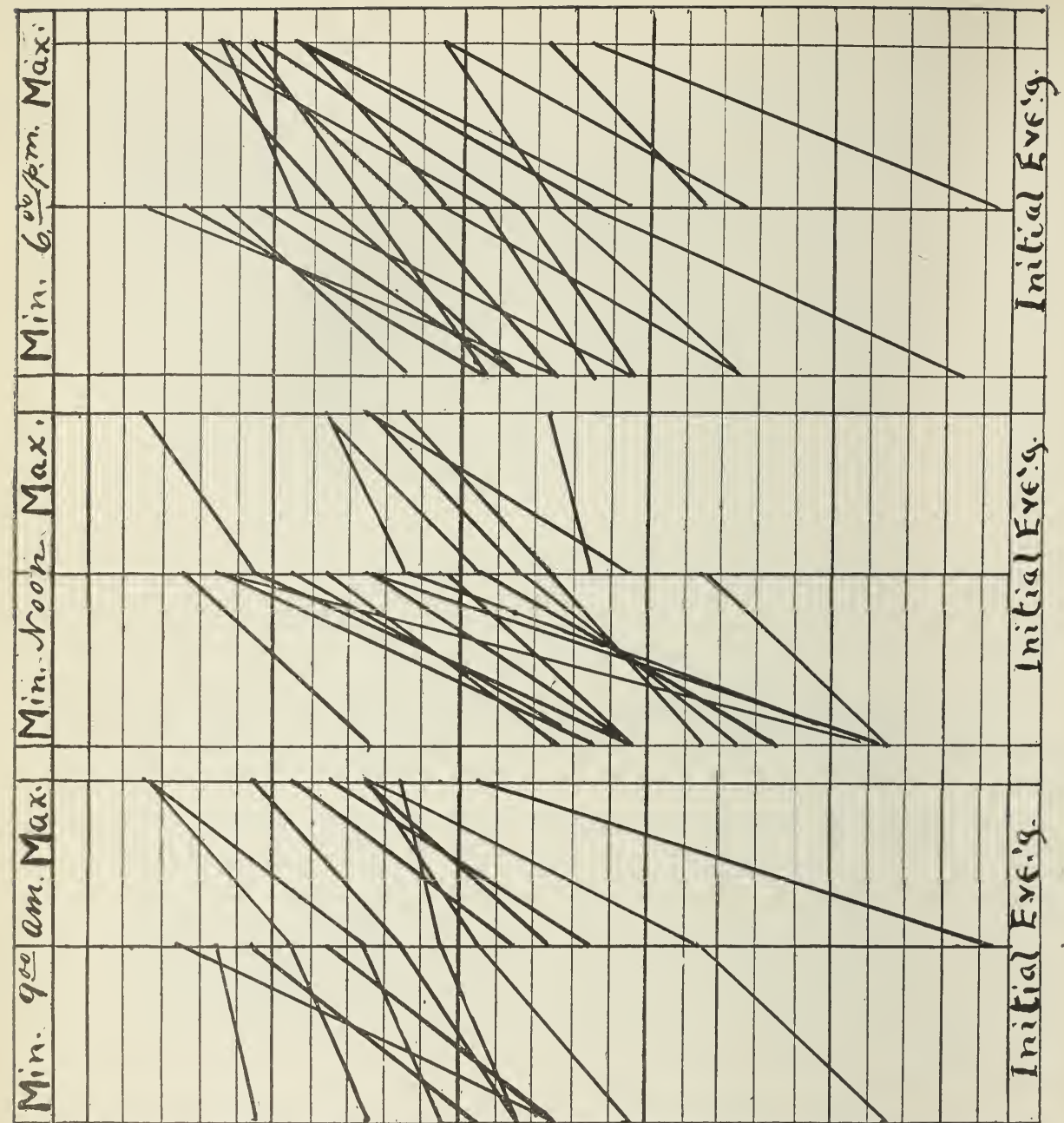

1

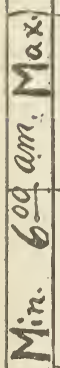

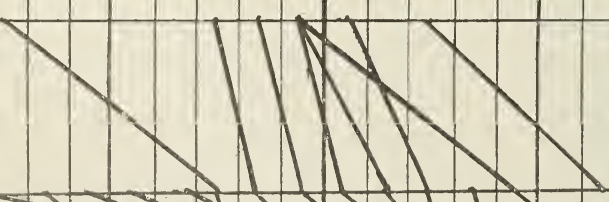

का L

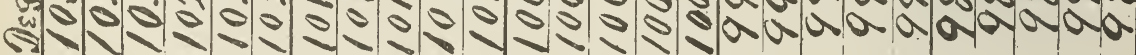




\section{EXPLANATION OF CHART II.}

Chart showing the association of temperatures at critical periods, with initial evening temperature, for non-reacting cases in the College herd. Morning, forenoon, noon and evening, periods are shown.

The central vertical line in each period represents the scale of initial evening temperatures, the degrees of which are shown at the left of the plate. On the right-hand side of each period the rising lines show the highest temperatures associated with the particular evening temperature, and on the left-hand side the lines slanting down from the middle vertical one show the minimal associations.

A general parallelism in these lines suggests the law which for all periods may be stated as follows: The highest expected temperature for any period does not exceed $102.6^{\circ}$, nor fall below $100.2^{\circ}$, and between these points is roughly $1^{\circ}$ above the initial evening temperature. Especially in the morning is a rise of more than a degree above the initial evening temperature (between $100^{\circ}$ and $102.6^{\circ}$ ) to be looked at with suspicion, if injection has taken place. 


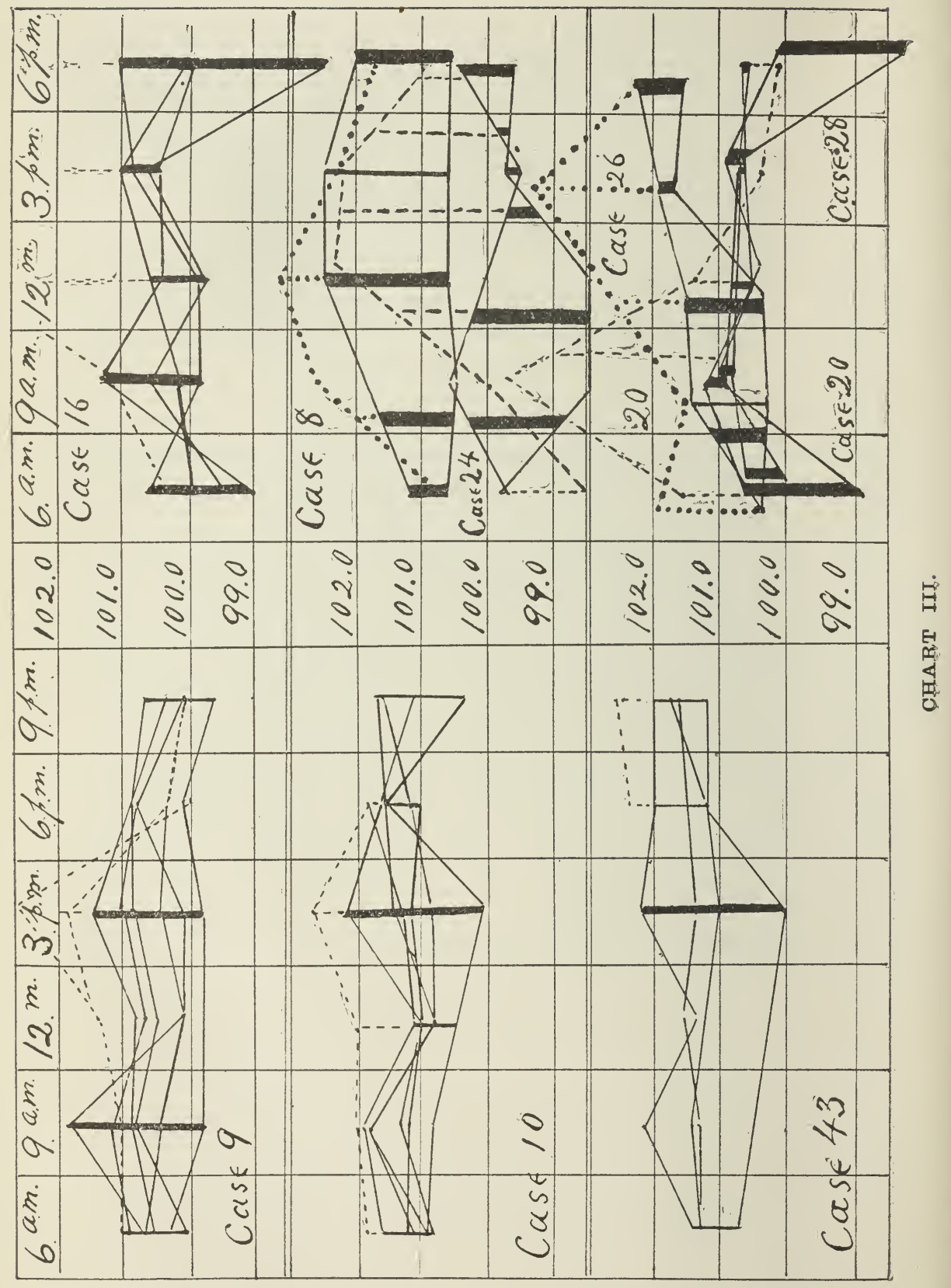




\section{EXPLANATION OF CHART III.}

Chart showing ranges of temperature in individual cases. Six equal scales are drawn. The heavy vertical lines show the ranges, the dotted "curves" represent injection temperatures, the unbroken ones are normal temperatures, the broken vertical lines show the extent of the probable reaction, positive or negative, for the different periods.

In Case 9, the lower dotted line represents the second injection.

In Case 10, the noon reaction is greater than that of the afternoon, even though the temperature was rising.

In Case 43 , the injection occurred in the morning, so that only a small part of the reaction curve coincides with the other curve periods, the record not being begun before $6 \mathrm{P}$. M.

('ase 8, compared with Case 24 (both tuberculous), shows, first, that a true reaction curve may lie below the normal of a different case, and secondly, that a rise of only half a degree above normal, if the latter be already high, indicates a true reaction. In this instance there was a rise of more than two degrees above initial temperature, but a higher initial was possible, and such would have probably had a lower normal at noon, thus tending to increase the "real" reaction while lessening the "calculated" one.

In the sixth scale, three cases $(20,26$ and 28$)$ have been plotted, the reaction curves being shown for two of them (20 and 26). 


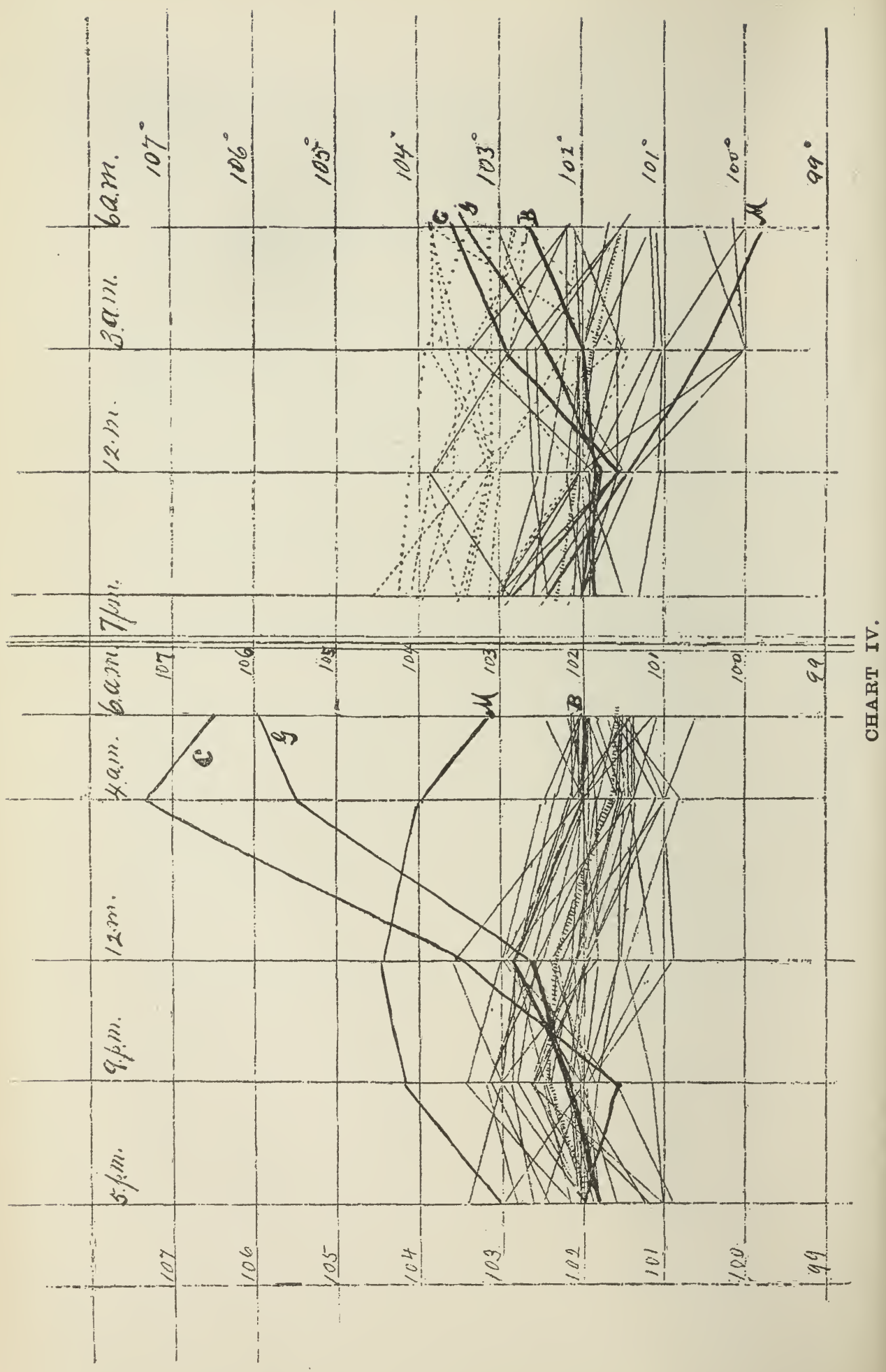




\section{EXPLANATION OF CHART IV.}

Chart showing the temperature curves of Pennsylvania State College herd, injected by Dr. L. F. Pearson. The dotted lines in the right-hand set of curves show the temperatures for calves. The curves C, G, M, B are of cows injected twice. The right-hand set of curves shows the effect of a second injection on these curves.

Only $\mathrm{C}$ and $\mathrm{G}$ were condemned, but according to our formula four or five others besides $\mathbf{M}$ would have been suspected. It is to be noted, however, that all the temperatures average a degree higher than with our herd, possibly due in part to a different method of taking temperature, viz, deeper insertion, for longer time, and to the fact that these were taken in midsummer, ours in midwinter. It also seems likely that a few cases reacted later in the day. These suggestions are with diffidence put forward only as possibilities, and as incentives to increased carefulness for future observers. 


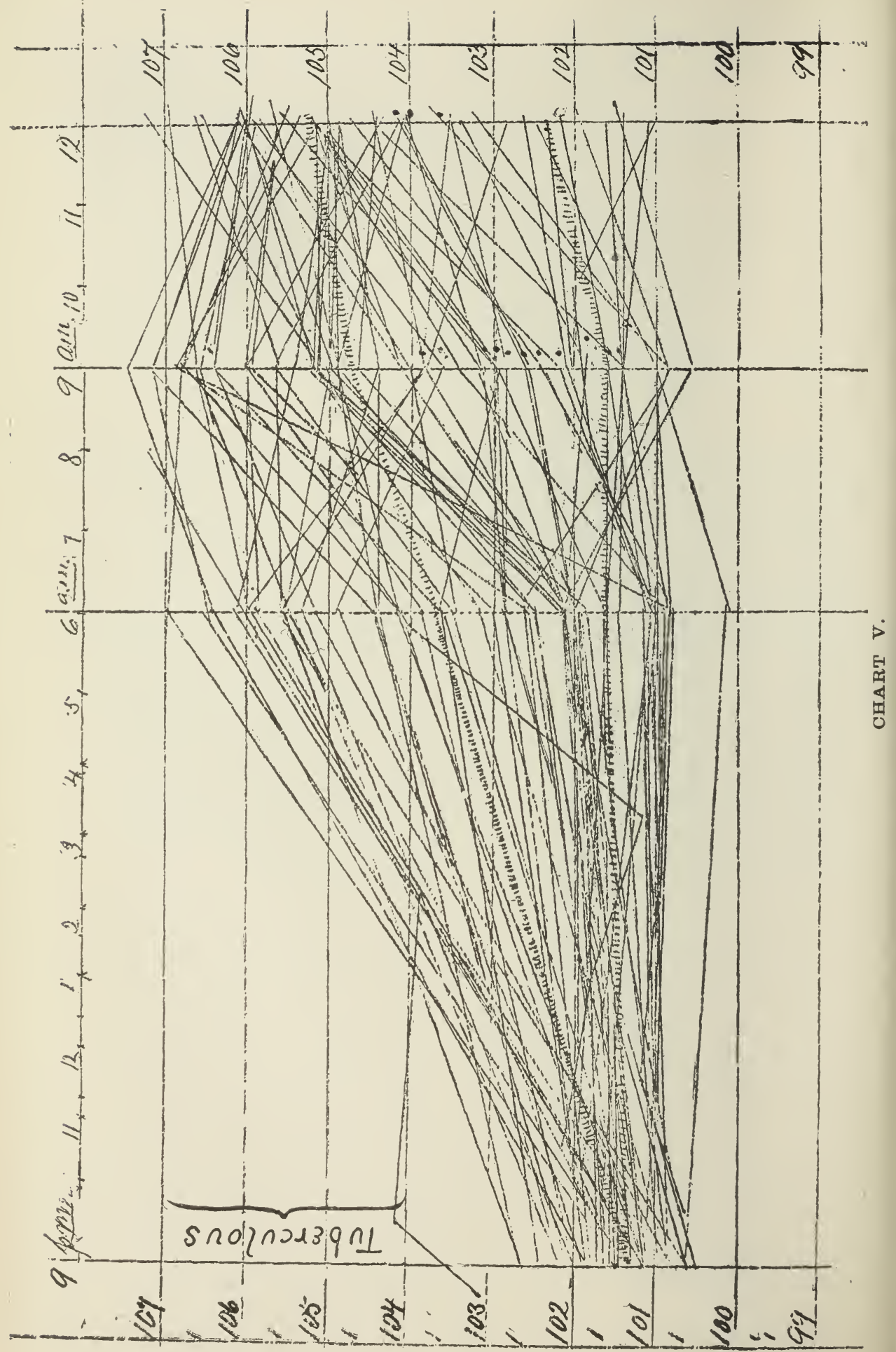




\section{EXPLANATION OF CHART V.}

Chart showing temperature curves of the older members of the Taylor herd, injected by Dr. Conrow. See "Veterinary Magazine," January, 1894.

It will be seen at a glance that the temperature averages higher than in our herd and that a higher limit for condemnation was set. The dots show curves of uncondemned cases, which had they occurred in our herd would have been certainly tuberculous. The general effect of these charts upon the observer is to make it seem a difficult task to draw the line between a normal and a "reacting" case. 

ANALYSES OF FERTILIZING MATERIALS AND HOME MIXTURES.

THE EXPERIENCE OF FARMERS WITH HOME MIXTURES.

\title{
NEW JERSEY
}

\author{
AGRICULTURAL
}

\section{Experiment Station}

\author{
102
}





\title{
NEW JERSEY
}

\section{Agricultural Experiment Station.}

\section{BULLETIN 102.}

JULY 30, 1894.

\section{Analyses of Fertilizing Materials and Home Mixtures.}

\section{The Experience of Farmers with Home Mixtures.}

\author{
LOUIS A. VOORHEES, CHEMIST. \\ JOHN P. STREET, CHEMIST.
}

I. Trade values of fertilizing ingredients for 1894.

II. Average cost per pound of plant-food constituents.

III. Chemical analyses of fertilizing materials.

IV. Home mixtures; Formulas, analyses.

V. Home mixing; The experience of farmers.

I.

Trade Values of Fertilizing Ingredients for 1894.

It is the custom in many States where a fertilizer control is exercised, to affix a commercial valuation per ton to the various brands analyzed. This ton valuation is derived by applying to the various kinds and forms of fertilizer ingredients values previously determined upon for them. These values are fixed from year to year; they vary according to the cost of the standard materials containing them, which are the sources of the constituents contained in mixed fertilizers. 
At a meeting of Stations' Directors and Chemists, the following schedule was arranged for use in Connecticut, Massachusetts, Rhode Island and New Jersey during the season of 1894 :

Schedule of Trade Values Adopted by Experiment Stations for 1894.

Cents per pound.

Nitrogen in Ammonia Salts..................................... 19.0

" "Nitrates............................................... 14. $\frac{1}{2}$

Organic Nitrogen in dried and fine ground fish, meat and blood, and in mixed fertilizers.................... $18 . \frac{1}{2}$

" " " castor pomace and cotton-seed meal............. 15.0

" " " "fine ground bone and tankage.................. 16. $\frac{1}{2}$

" " " fine-medium bone and tankage................. 15.0

" " " " medium bone and tankage...................... 12.0

" " " " $"$ " coarser bone and tankage ....................... 7.0

" " " horn shavings, hair and coarse fish scrap..... 7.0

Phosphoric Acid, soluble in water.................................. 6.0

$\begin{array}{llllll}\text { " } & \text { " } & \text { " } & \text { " amsoluble, in fine bone and tankage............... } & 5 . \frac{1}{2} \\ \text { " } & \text { " } & \text { " } & \text { " fine-medium bone and tankage..... } & 4 . \frac{1}{2} \\ \text { " } & \text { " } & \text { " } & \text { " } & \text { " medium bone and tankage........... } & 3.0 \\ \text { " } & \text { " } & \text { " } & \text { " mixed fertilizers................... } & 2.0 \\ & \text { " } & \text { " castor pomace and wood ashes... } & 5.0\end{array}$

Potash as High-grade Sulphate, and in forms free from Muriates

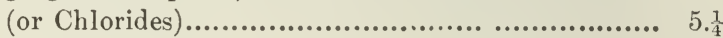

" " Muriate.........................................................

Valuation of Fertilizing Ingredients in Fine Ground Feeds.

Organic Nitrogen .................................................... 15.0

Phosphoric Acid................................................ 5.0

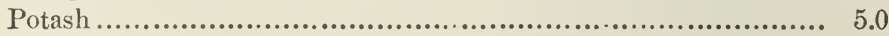

The Stations' value for nitrogen, both in ammonia salts and in most organic forms, including bones, was considerably increased this year, owing to higher wholesale quotations which ruled for the materials containing it during the six months preceding the adoption of the schedule.

\footnotetext{
* The solubility of phosphates, in ammonium citrate solutions, is seriously affected by heat. An Act of the Legislature (see Laws of New Jersey. 1874, page 90) provides that in this determination the temperature used shall not exceed $100^{\circ} \mathrm{Fah}$; in Connecticut, Rhode Island and Massachusetts $150^{\circ} \mathrm{Fah}$, has been adopted. The higher the temperature the larger will be the percentage of phosphoric acid dissoived by ammonium citrate solutions, and the larger the amount of this so-called "reverted" phosphoric acid in a ton of superphosphate the lower will be the price per pound of said acid. Consequently the Station's valuations of phosphoric acid, soluble in ammonium citrate, have been fixed at five and one-half cents per pound for Connecticut, Massachusetts and Rhode Island, and at six cents per pound for New Jersey.
} 
In the case of phosphoric acid, both as "available" in superphosphates, and as insoluble in the form of ground bone, and in the case of potash in the form of sulphate, the Stations' prices are slightly reduced, because of the lower wholesale quotations. No changes were made in the price of potash derived from muriate or kainit.

Owing to the greater relative proportion of phosphoric acid in mixed fertilizers, and in ground bone, these changes in the schedule of prices will doubtless result in slightly lower ton valuations, on the same basis of composition, than last year.

II.

Average Cost Per Pound of Plant-Food Constituents.

The cost per pound of the actual constituents in fertilizing materials is readily derived by dividing the selling price per ton by the number of pounds of the constituents contained in it, as determined by analysis. In the following tables of analyses the prices per ton of the various materials represent actual transactions for cash, the amounts purchased ranging from less than a ton to carload lots. In most cases the prices are for goods free on board cars at factory, though in a number of cases these prices include cost of delivery.

The average cost per pound of the nitrogen, phosphoric acid and potash, as secured from the tables of analyses, may, however, be fairly assumed to represent the manufacturers' retail prices at factory, and admit of a comparison with the Station's schedule of valuations, which is intended to represent the retail cash cost per pound of the fertilizing ingredients contained in the raw materials before they are mixed to form complete fertilizers.

A study of the following table shows that the Station's schedule of prices is, with two exceptions, higher than the manufacturers' average, viz., in the case of "available" phosphoric acid from bone-black superphosphate, and potash in the form of kainit. The application of the schedule prices to the constituents in mixed goods is, therefore, perfectly fair to the manufacturers in showing the relative commercial value of the different brands.

The samples analyzed represent materials bought by farmers' clubs, or individuals, direct from the manufacturers of complete fertilizers, or from large dealers in fertilizer supplies. A full list of these firms, with their business addresses, is always published in the annual reports of this Station. 


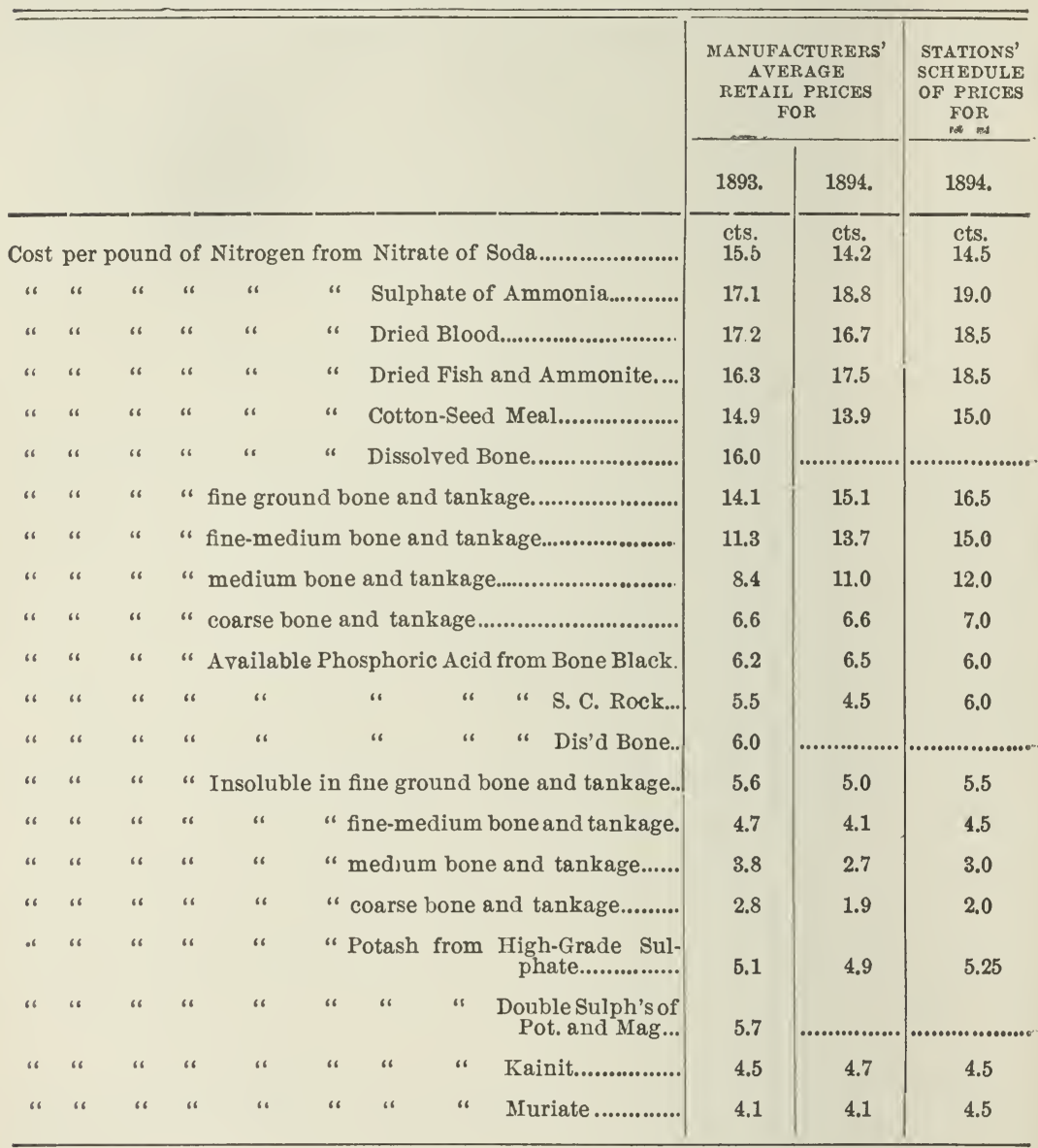

In the purchase of raw materials the advantages of a knowledge of the markets, and method and time of buying, are shown in the variations in the cost per pound of the different constituents. Those who carefully study the sources of supply, and make up their orders early, and purchase considerable quantities, are able to get better quotations than those who buy at the busiest season of the year, in small lots at a time, and of the nearest dealer.

It pays quite as well, proportionately, to use good business methods in the purchase of fertilizer supplies, as in the sale of produce. 
III.

Chemical Analyses of Fertilizing Materials.

\section{FORIS OF NITROGEN}

Readily and Completely Soluble in Water.

NITRATE OF SODA

Furnishing Nitrogen in Form of Nitrates.

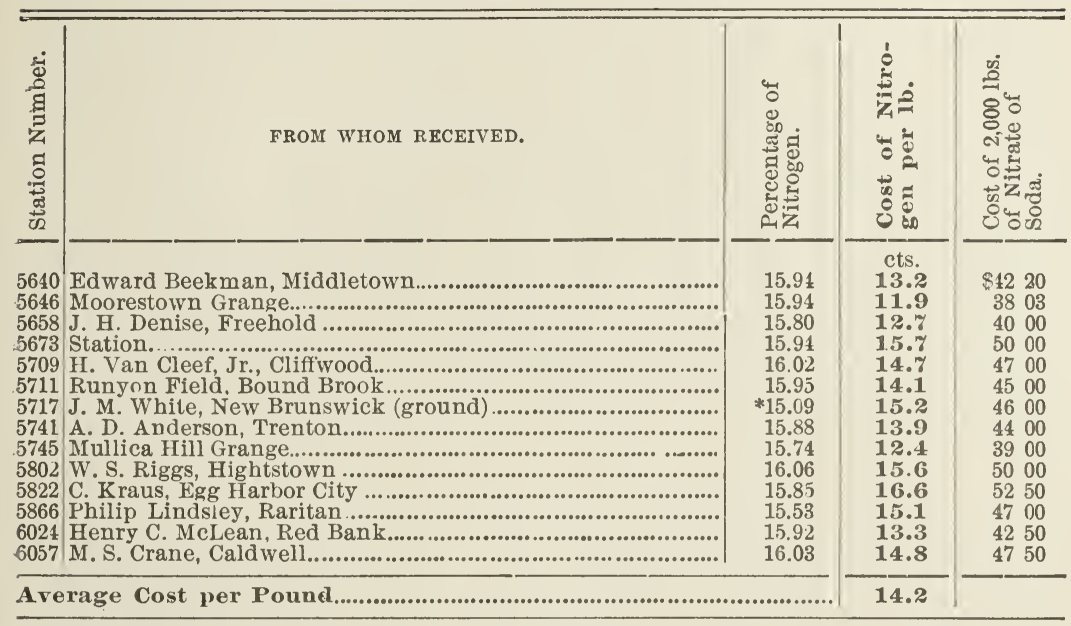

* This sample contained impurities due to grinding.

SULPHATE OF AMMONIA

Furnishing Nitrogen in Form of Ammonia.

\begin{tabular}{|c|c|c|c|c|}
\hline 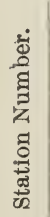 & FROM WHOM RECEIVED. & 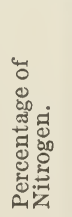 & 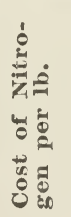 & 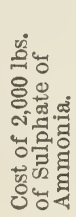 \\
\hline $\begin{array}{l}5672 \\
5746 \\
5808 \\
6058\end{array}$ & 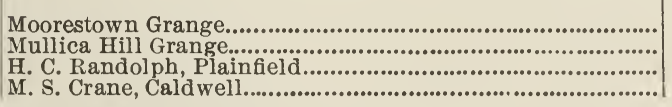 & $\begin{array}{l}20.89 \\
20.70 \\
19.79 \\
19.65\end{array}$ & $\begin{array}{c}\text { cts. } \\
16.9 \\
20.5 \\
18.5 \\
19.1\end{array}$ & 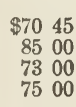 \\
\hline Ave & rage Cost per Pound & & 18.8 & \\
\hline
\end{tabular}




\section{FORMS OF NITROGEN INSOLUBLE IN WATER}

Furnishing Nitrogen in Form of Organic Matter.

DRIED BLOOD.

\begin{tabular}{|c|c|c|c|c|c|}
\hline 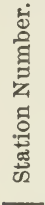 & FROM WHOM RECEIVED. & 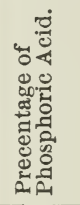 & 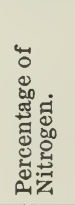 & 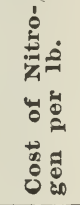 & 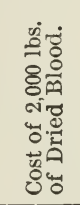 \\
\hline $\begin{array}{l}5641 \\
5651 \\
5659 \\
5674 \\
5712 \\
5747 \\
6025\end{array}$ & 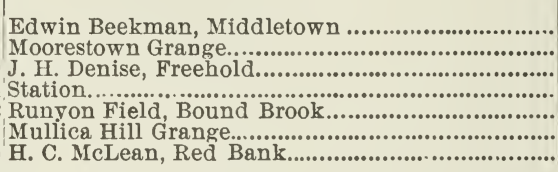 & $\begin{array}{l}0.24 \\
1.24 \\
0.29 \\
1.87 \\
1.23 \\
0.33 \\
2.48\end{array}$ & $\begin{array}{r}13.83 \\
13.19 \\
13.85 \\
8.37 \\
12.39 \\
12.61 \\
11.73\end{array}$ & $\begin{array}{l}\text { cts. } \\
19.8 \\
16.5 \\
16.0 \\
16.8 \\
14.0 \\
16.7 \\
16.8\end{array}$ & $\begin{array}{l}\$ 5500 \\
* \\
4465 \\
3000 \\
3600 \\
4250 \\
4200\end{array}$ \\
\hline & race Cost per Pound & & & +16.7 & \\
\hline
\end{tabular}

*\$2.70 per unit of Ammonia.

†In calculating the cost per pound of Nitrogen the value of the Phosphoric Acid contained: in the samples was regarded.

DRIED AND GROUND FISH.

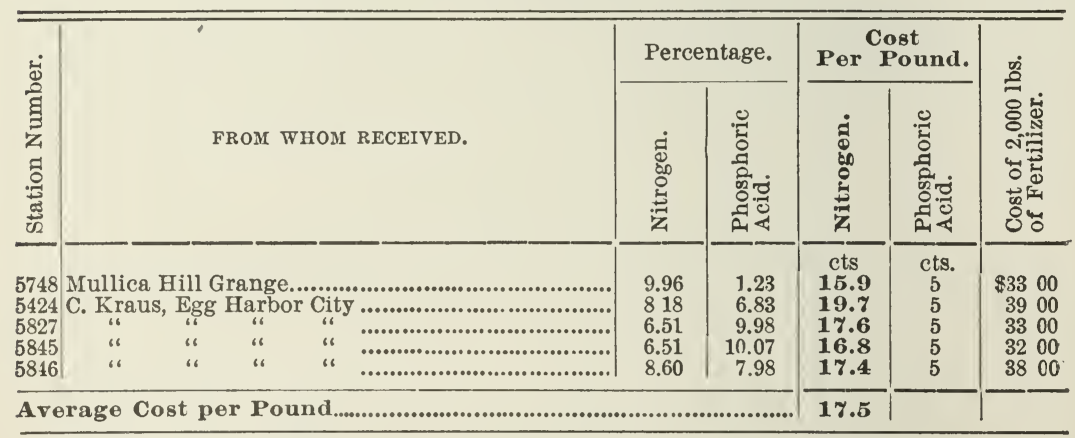

COTTON-SEED MEAL.

\begin{tabular}{|c|c|c|c|c|c|c|c|c|}
\hline \multirow{2}{*}{ 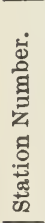 } & \multirow[b]{2}{*}{ FROM WHOM RECEIVED. } & \multicolumn{3}{|c|}{ Percentage. } & \multicolumn{3}{|c|}{ Per Pound. } & \multirow{2}{*}{ 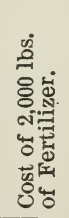 } \\
\hline & & 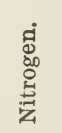 & 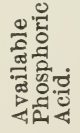 & 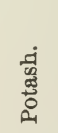 & 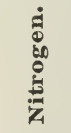 & 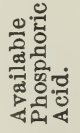 & 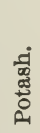 & \\
\hline 5649 & H. I. Budd, Mount Holly........ & 7.45 & 3.15 & 1.44 & 13.9 & 6 & 5 & $\$ 2600$ \\
\hline
\end{tabular}


GROUND BONE AND TANKAGE.

\begin{tabular}{|c|c|c|c|c|c|c|c|c|c|c|c|}
\hline \multirow[b]{2}{*}{ 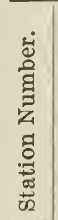 } & & & & \multicolumn{4}{|c|}{$\begin{array}{l}\text { Cost of Nitrogen } \\
\text { per lb. in- }\end{array}$} & \multicolumn{4}{|c|}{$\begin{array}{c}\text { Cost of Phosphoric Acid } \\
\text { per 1b. in- }\end{array}$} \\
\hline & & & & 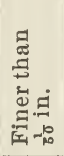 & 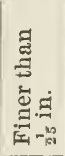 & 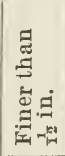 & 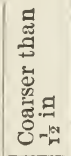 & 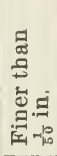 & 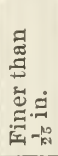 & 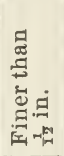 & 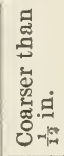 \\
\hline 5714 & \multicolumn{3}{|c|}{4 Tankage............................................ } & $\begin{array}{l}\text { cts. } \\
148.8\end{array}$ & cts & $\begin{array}{l}\text { cts } \\
10.7\end{array}$ & cts. & cts. & cts. & $\begin{array}{l}\text { cts. } \\
2.6\end{array}$ & cts. \\
\hline 5803 & $\operatorname{lam}_{\text {" }}$ & \multirow{2}{*}{\multicolumn{2}{|c|}{ 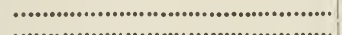 }} & 19.1 & 17.4 & 13.9 & 8.7 & $\begin{array}{l}4.9 \\
6.4\end{array}$ & 5.2 & $\begin{array}{l}2.0 \\
3.5\end{array}$ & $\begin{array}{l}1.0 \\
2.3\end{array}$ \\
\hline 5844 & “ & & & 17.7 & 16.1 & 12.8 & 7.5 & 5.9 & 4.8 & 3.2 & 2.1 \\
\hline 026 & "6 & \multicolumn{2}{|c|}{ 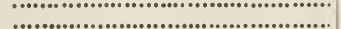 } & 12.6 & 11.5 & 9.2 & ......... & 4.2 & 3.4 & 2.3 & \\
\hline 6032 & “6 & \multicolumn{2}{|c|}{ [.............................................. } & 19.9 & 18.1 & 14.5 & 8.4 & 6.6 & 5. & 3.6 & 2.4 \\
\hline 5638 & Ground & \multicolumn{2}{|c|}{ Bone..................................... } & 14.3 & 13.0 & 10.4 & 6.1 & 4.8 & 3. & 2.6 & 1.7 \\
\hline 941 & 6 & 6 & ...................................... & 19.9 & 18.1 & $14 . \overline{5}$ & 8.4 & 6.6 & 5. & 3.6 & 2.4 \\
\hline 652 & "6 & “6 & [.................................... & 11.1 & 10.1 & 8.1 & 4.7 & 3.7 & 3 & 2.0 & 1.4 \\
\hline 27 & “ & 6 & & 143 & 130 & 10.4 & 6.1 & 4.8 & 3. & 2.6 & 1.7 \\
\hline 660 & “6 & "6 & 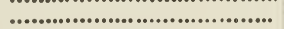 & 11.7 & 10.6 & 8.5 & 4.9 & 3.9 & 3. & 2.0 & 1.4 \\
\hline 559 & “ & “6 & & 138 & 12.6 & 10.0 & & 4.6 & 3.8 & 2.5 & \\
\hline & “6 & “6 & n.................................... & 13.6 & 12.4 & 9.9 & 5.8 & 4.5 & 3.7 & 2.5 & 1.7 \\
\hline & 66 & $\because 6$ & & 15.8 & 14.3 & 11.5 & 6.7 & 5.3 & 4. & 2.9 & 1.9 \\
\hline 5864 & "6 & “ & & 12.8 & 11.6 & 9.3 & 5.4 & 4.3 & 3.5 & 2.3 & 1.6 \\
\hline P & $g e$ & st & r & 15.1 & 13.7 & 11.0 & 6.1 & 5.0 & 4.1 & 2.7 & 1.9 \\
\hline
\end{tabular}

GROUND BONE AND TANKAGE.

\begin{tabular}{|c|c|c|c|c|c|c|c|c|}
\hline \multirow{2}{*}{ 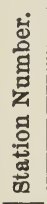 } & \multirow[b]{2}{*}{ FROM WHOM RECEIVED. } & \multicolumn{4}{|c|}{ Mechanical Analysis. } & \multicolumn{2}{|c|}{ Percentage. } & \multirow{2}{*}{ 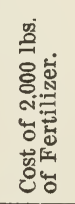 } \\
\hline & & 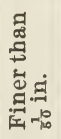 & 点 & 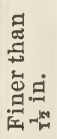 & 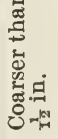 & 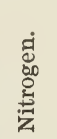 & 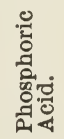 & \\
\hline 5714 & Runyon Field, Bound Brook................... & 48 & 25 & 18 & 9 & 5.95 & 13.14 & $\$ 2600$ \\
\hline 5803 & W. S. Riggs, Hightstown ............... & 14 & 46 & 36 & 4 & 6.92 & 6.25 & 2800 \\
\hline 5844 & C. Kraus, Egg Ḧarbor City.............. & 29 & 41 & 13 & 17 & 7.97 & 7.51 & 3000 \\
\hline 6026 & H. C. McLean, Red Bank...................... & 54 & 41 & 5 & 0 & 5.77 & 12.15 & 2300 \\
\hline 6032 & W. Vreeland, New Brunswick................. & 11 & 18 & 25 & 46 & 5.18 & 15.62 & 2500 \\
\hline 5638 & E. Beekman, Middletown..................... & 32 & 30 & 26 & 12 & 4.04 & 24.60 & 2720 \\
\hline 5941 & H. C. Randolph, Plainfield.................... & 35 & 18 & 19 & 28 & 2.86 & 26.07 & 3300 \\
\hline 5652 & Moorestown Grange.......................... & 64 & 22 & 12 & 2 & 2.63 & 26.91 & 2335 \\
\hline 6027 & H. C. McLean, Red Bank...................... & 56 & 27 & 15 & 2 & 2.11 & 23.42 & 2500 \\
\hline 5660 & J. H. Denise, Freehold ......................... & 43 & 27 & 27 & 3 & 3.02 & 25.68 & 2250 \\
\hline & M. S. Crane, Caldwell............................. & 43 & 39 & 18 & 0 & 4.05 & 22.80 & 2800 \\
\hline & Mullica Hill Grange................................... & 47 & 22 & 17 & 14 & 1.65 & 29.30 & 2498 \\
\hline & W. S. Riggs, Hightstown...................... & 41 & 18 & 19 & 22 & 1.95 & 28.20 & 2700 \\
\hline & Philip Lindsley, Raritan...................... & 58 & 24 & 13 & 5 & 2.73 & 26.44 & 2600 \\
\hline
\end{tabular}




\section{PLAIN SUPERPHOSPHATES}

Furnishing Soluble, Reverted and Insoluble Phosphoric Acid, MANUFACTURED FROM

BONE BLACK, BONE ASH, ETC., ETC.

\begin{tabular}{|c|c|c|c|c|c|c|c|}
\hline \multirow{2}{*}{ 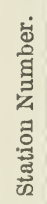 } & \multirow[b]{2}{*}{ FROM WHOM RECEIVED. } & \multicolumn{4}{|c|}{ Phosphoric Acid. } & \multirow[b]{2}{*}{ 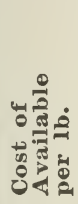 } & \multirow{2}{*}{ 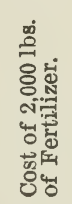 } \\
\hline & & 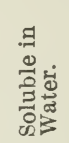 & 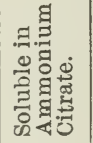 & 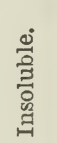 & 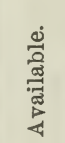 & & \\
\hline $\begin{array}{l}5642 \\
5661 \\
5676 \\
5718 \\
5739 \\
5750 \\
5805 \\
5825 \\
5910 \\
6028 \\
6060\end{array}$ & 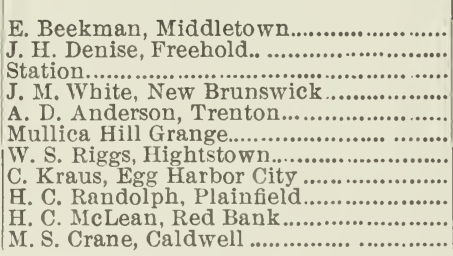 & $\begin{array}{r}17.74 \\
14.28 \\
13.08 \\
15.52 \\
16.21 \\
9.82 \\
16.24 \\
14.88 \\
13.56 \\
13.36 \\
1700\end{array}$ & $\begin{array}{l}0.59 \\
0.81 \\
0.95 \\
1.13 \\
\ldots \ldots \ldots \\
3.20 \\
\cdots \ldots \ldots \\
0.42 \\
0.41 \\
1.99 \\
0.20\end{array}$ & $\begin{array}{l}0.51 \\
0.69 \\
1.19 \\
0.98 \\
0.07 \\
6.40 \\
0.10 \\
2.59 \\
1.61 \\
4.07 \\
0.23\end{array}$ & $\begin{array}{l}18.33 \\
15.09 \\
14.03 \\
16.65 \\
16.24 \\
13.02 \\
16.24 \\
15.30 \\
13.97 \\
15.35 \\
17.20\end{array}$ & $\begin{array}{l}\text { cts. } \\
5.9 \\
5.3 \\
7.1 \\
5.6 \\
7.1 \\
7.1 \\
7.0 \\
8.2 \\
7.1 \\
6.5 \\
6.5\end{array}$ & $\begin{array}{rr}\$ 21 & 45 \\
16 & 00 \\
20 & 00 \\
18 & 75 \\
23 & 00 \\
18 & 40 \\
25 & 00 \\
* 25 & 00 \\
20 & 00 \\
20 & 00 \\
22 & 50\end{array}$ \\
\hline & 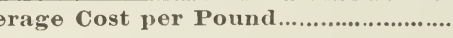 & & & & & 6.5 & \\
\hline
\end{tabular}

* Cost per ton at retail.

SOUTH CAROLINA ROCK AND OTHER MINERAL PHOSPHATES.

\begin{tabular}{|c|c|c|c|c|c|c|c|}
\hline \multirow{2}{*}{ 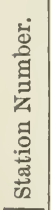 } & \multirow[b]{2}{*}{ FROM WHOM RECEIVED. } & \multicolumn{4}{|c|}{ Phosphoric Acid. } & \multirow[b]{2}{*}{ 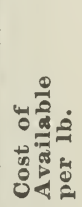 } & \multirow{2}{*}{ 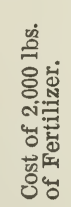 } \\
\hline & & 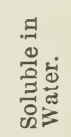 & 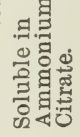 & $\begin{array}{l}\stackrel{0}{0} \\
\frac{3}{\Xi} \\
0 \\
\Xi \\
\Xi\end{array}$ & 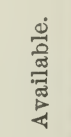 & & \\
\hline $\begin{array}{l}5647 \\
5648 \\
5662 \\
5677 \\
5751 \\
5843 \\
5867 \\
5894 \\
6095\end{array}$ & 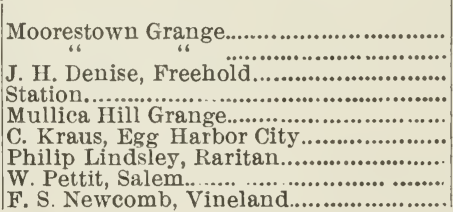 & $\begin{array}{r}10.86 \\
1050 \\
13.84 \\
12.32 \\
11.20 \\
9.64 \\
13.76 \\
11.26 \\
10.44\end{array}$ & $\begin{array}{l}1.45 \\
1.66 \\
1.03 \\
1.36 \\
1.48 \\
2.44 \\
1.01 \\
1.32 \\
1.43\end{array}$ & $\begin{array}{l}2.79 \\
3.46 \\
1.46 \\
2.22 \\
3.24 \\
3.79 \\
1.45 \\
2.97 \\
4.08\end{array}$ & $\begin{array}{l}12.31 \\
12.16 \\
14.87 \\
13.68 \\
12.68 \\
12.08 \\
14.77 \\
12.58 \\
11.87\end{array}$ & $\begin{array}{l}\text { cts. } \\
4.5 \\
4.6 \\
\mathbf{3 . 9} \\
4.8 \\
4.4 \\
8.3 \\
4.4 \\
4.6 \\
5.1\end{array}$ & $\begin{array}{rl}\$ 11 & 10 \\
11 & 10 \\
11 & 60 \\
13 & 00 \\
11 & 10 \\
* 20 & 00 \\
13 & 00 \\
11 & 50 \\
12 & 00\end{array}$ \\
\hline & ner & & & & & 4.5 & \\
\hline
\end{tabular}

* Cost per ton at retail. 
GERMAN POTASH SALTS

Readily Soluble in Distilled Water.

MURIATE OF POTASH.

\begin{tabular}{|c|c|c|c|c|}
\hline 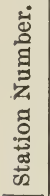 & FROM WHOM RECEIVED & 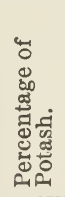 & 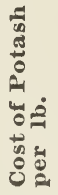 & 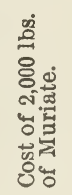 \\
\hline $\begin{array}{l}5639 \\
5645 \\
5679 \\
5682 \\
5684 \\
5715 \\
5742 \\
5752 \\
5806 \\
5826 \\
5868 \\
6096\end{array}$ & 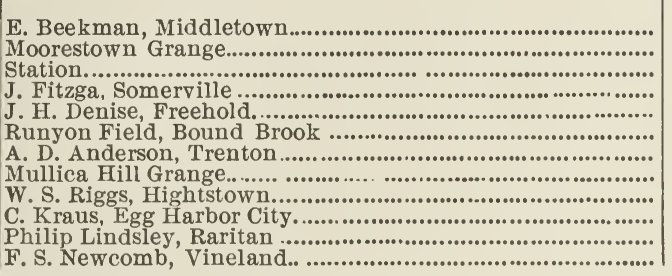 & $\begin{array}{l}50.83 \\
52.27 \\
49.23 \\
54.33 \\
52.90 \\
48.87 \\
52.30 \\
52.16 \\
49.65 \\
47.99 \\
51.57 \\
49.78\end{array}$ & $\begin{array}{l}\text { cts. } \\
4.0 \\
\mathbf{3 . 7} \\
\mathbf{4 . 2} \\
\mathbf{4 . 0} \\
\mathbf{3 . 8} \\
\mathbf{4 . 0} \\
\mathbf{4 . 0} \\
\mathbf{3 . y} \\
\mathbf{4 . 4} \\
\mathbf{4 . 8} \\
\mathbf{4 . 0} \\
\mathbf{4 . 2}\end{array}$ & $\begin{array}{rl}\$ 40 & 20 \\
38 & 25 \\
41 & 00 \\
43 & 50 \\
40 & 00 \\
39 & 00 \\
42 & 00 \\
39 & 00 \\
44 & 00 \\
46 & 50 \\
41 & 00 \\
42 & 00\end{array}$ \\
\hline & rage Cost per Pound & & 4.1 & \\
\hline
\end{tabular}

\section{GERMAN POTASH SALTS}

Readily Soluble in Distilled Water.

HIGH-GRADE SULPHATE OF POTASH.

\begin{tabular}{|c|c|c|c|c|}
\hline 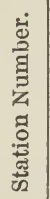 & FROM WHOM RECEIVED. & 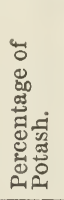 & 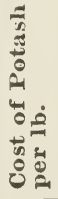 & 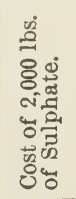 \\
\hline $\begin{array}{l}5643 \\
5650 \\
5663 \\
5681 \\
5716 \\
5719 \\
5865 \\
6061\end{array}$ & 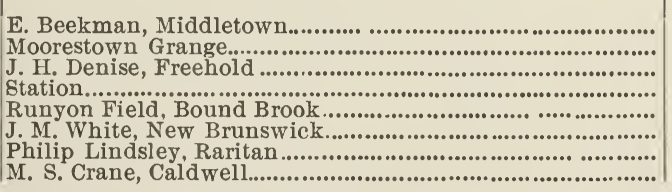 & $\begin{array}{l}48.54 \\
49.35 \\
49.41 \\
48.30 \\
48.18 \\
48.81 \\
49.12 \\
48.62\end{array}$ & $\begin{array}{l}\text { cts. } \\
\mathbf{5 . 2} \\
\mathbf{4 . 4} \\
\mathbf{4 . 4} \\
\mathbf{5 . 2} \\
\mathbf{5 . 0} \\
\mathbf{5 . 0} \\
\mathbf{4 . 9} \\
\mathbf{4 . 7}\end{array}$ & 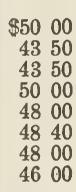 \\
\hline Av & rage Cost per Pound & & 4.9 & \\
\hline
\end{tabular}

\section{KAINIT.}

\begin{tabular}{|c|c|c|c|c|}
\hline 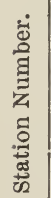 & FROM WHOM RECEIVED. & 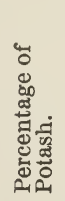 & 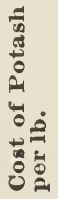 & 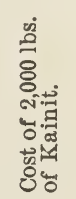 \\
\hline $\begin{array}{l}5680 \\
5708 \\
5811 \\
5893 \\
6137\end{array}$ & 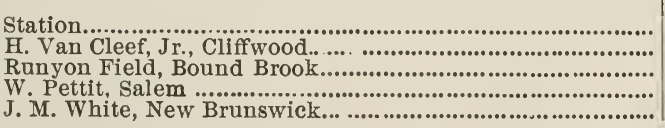 & $\begin{array}{l}11.58 \\
13.50 \\
12.06 \\
12.44 \\
12.45\end{array}$ & $\begin{array}{l}\text { cts. } \\
\mathbf{5} .4 \\
\mathbf{5} .2 \\
\mathbf{4 . 1} \\
\mathbf{4 . 4} \\
\mathbf{4 . 4}\end{array}$ & $\begin{array}{l}\$ 1250 \\
1400 \\
1000 \\
1100 \\
1100\end{array}$ \\
\hline Ave & rage Cost per Pound & & 4.7 & \\
\hline
\end{tabular}


IV.

\section{Home Mixtures; Formulas; Analyses.}

The home mixtures here reported were made up from high-grade materials, the analyses of which appear in the previous tables. The formulas used were in most cases adopted after a study by the farmers. represented of the conditions of soil and the needs of the crop, in the localities in which they are used. A number of the mixtures. prepared according to these formulas have now been used for several years with entire satisfaction. With the exception of No. 5809, which is intended for fruit trees, they are largely used for potatoes and market-garden crops.

\section{FORMULAS USED IN MAKING THE MIXTURES.}

No. 5\%43. A. D. Anderson, Trenton.

200 lbs. Nitrate of Soda.

700 " Dissolved Bone.

700 " Bone-Black Superphosphate.

400 " Muriate of Potash.

$\overline{2000}$

No. $580 \%$. W. S. Riggs, Hightstown.

300 lbs. Nitrate of Soda.

400 " Tankage

400 " Ground Bone.

400 “ Bone-Black Superphosphate.

500 " Muriate of Potash.

$\overline{2000}$

No. 5925. D. D. Denise, Freehold.

200 lbs. Nitrate of Soda.

300 " Dried Blood.

200 " Ground Bone.

900 “ Bone-Black Superphosphate.

200 " Muriate of Potash.

200 " Sulphate of Potash.

$\overline{2000}$

No. 5\%\%. G. W. F. Gaunt, Mullica Hill.

150 lbs. Nitrate of Soda.

100 " Sulphate of A mmonia.

200 “ Dried Blood.

200 "Ground Fish.

500 " Ground Bone.

300 " Bone-Black Superphosphate.

400 “ S. C. Rock Superphosphate.

350 " Muriate of Potash.

2200

No. 5809. H. C. Randolph, Plainfield.

200 lbs. Nitrate of Soda.

800 " Ground Bone.

400 “ Bone-Black Superphosphate.

600 “ Muriate of Potash.

$\overline{2000}$
No. 5812. Runyon Field, Bound Brook.

200 lbs. Nitrate of Soda.

400 " Tankage

1000 “ Dissolved Bone.

400 " Muriate of Potash.

$\overline{2000}$

No. 6094. H. C. Randolph, Plainfield.

$200 \mathrm{lbs}$. Nitrate of Soda.

150 " Sulphate of Ammonia.

250 " Dried Blood.

1100 " Bone-Black Superphosphate.

300 " Muriate of Potash.

$\overline{2000}$

No. 606\%. Mr. S. Crane, Caldwell.

150 lbs. Nitrate of Soda.

200 " Sulphate of Ammonia.

300 " Ground Bone.

900 " Bone-Black Superphosphate.

450 " Sulphate of Potash.

$\overline{2000}$

No. 5926. Monmouth Co. Grange, Freehold.

200 lbs. Nitrate of Soda.

300 " Dried Blood

200 " Ground Bone.

500 " Bone-Black Superphosphate.

400 “ S. C. Rock Superphosphate.

200 " Muriate of Potash.

200 " Sulphate of Potash.

$\overline{2000}$

No. 6039. J. S. Collins, Moorestown.

200 lbs. Nitrate of Soda.

100 " Sulphate of Ammonia.

300 " Cotton-Seed Meal.

500 " Ground Bone.

600 " S. C. Rock Superphosphate.

300 " Muriate of Potash. 
It is claimed by manufacturers of mixed fertilizers and by others who have not given the matter attention, that farmers cannot make mixtures that will compare favorably in mechanical condition with those produced by machinery made expressly for the purpose.

A careful study of this point was made last year and reported in Bulletin No. 93 ; the results obtained showed that the ten home mixtures examined exceeded in fineness and condition the leading brands of the manufacturers themselves. It is not disputed that the manufacturers can make better mixtures; the fact is that, on the whole, they do not.

A mechanical analysis was made of the samples of home mixtures received this year. The standard of fineness or perfect mechanical composition was made one twenty-fifth of an inch in diameter; that is, the condition was regarded as perfect if all of the material passed through a sieve, the holes of which were one twenty-fifth of an inch in diameter.

The average fineness of the home mixtures examined this year is here shown in connection with the results obtained last year:

\begin{tabular}{|c|c|c|c|}
\hline & per cent. & per cent. & per cent. \\
\hline Home Mixtures............................ 1894 & 78 & 17 & 5 \\
\hline ، $\quad$ " $\quad$,............................1893 & 79 & 14 & 7 \\
\hline Manufactured Brands....................... 1893 & 77 & 16 & 7 \\
\hline
\end{tabular}

The fineness of the mixtures examined this year is practically identical with that obtained in 1893, and it is evident that this measure of fineness, in connection with dryness, which all the mixtures possessed, permits of ready and even distribution, the chief consideration when the quality of the mixtures is not regarded. It must be remembered, however, as suggested last year, that fineness or mechanical condition is a relative term; that is, fineness in a mixture which has been made from materials containing the fertilizer constituents in relatively insoluble forms, is evidently of greater importance than fineness in a mixture which has been made from materials containing easily-soluble and readily-available constituents.

\section{Composition of Home Mixtures.}

The actual analyses of the different mixtures are given in the following table. The cost of the materials used in making them is also compared with the estimated commercial value of the mixture at Station's valuation : 
Table of Analyses.

\begin{tabular}{|c|c|c|c|c|c|c|c|c|c|c|c|}
\hline \multirow[b]{2}{*}{ 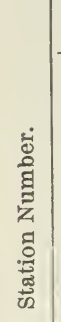 } & \multicolumn{3}{|c|}{ NITROGEN. } & \multicolumn{4}{|c|}{ PHOSPHORIC ACID. } & \multirow[b]{2}{*}{$\begin{array}{l}\text { चี } \\
\text { జूँ } \\
\stackrel{0}{0}\end{array}$} & \multirow[b]{2}{*}{ 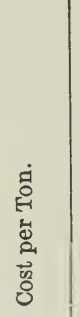 } & \multirow[b]{2}{*}{ 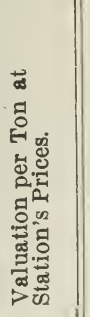 } & \multirow[b]{2}{*}{ 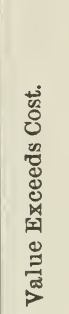 } \\
\hline & 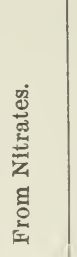 & 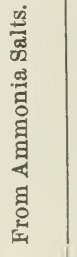 & 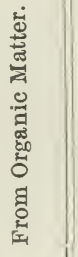 & 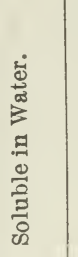 & 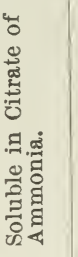 & 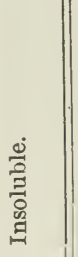 & 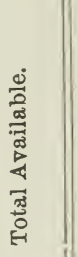 & & & & \\
\hline 5743 & 1.42 & 0.10 & 0.96 & 8.48 & 0.06 & 0.17 & 8.54 & 14.03 & $\$ 3100$ & $\$ 3100$ & $\ldots . . . . . .$. \\
\hline 5777 & 1.10 & 1.25 & 2.36 & 3.38 & 4.47 & 4.13 & 7.85 & 8.16 & 2981 & $\begin{array}{ll}35 & 08\end{array}$ & $\$ 527$ \\
\hline 5807 & 1.69 & $\ldots$ & 2.57 & 3.76 & 4.29 & 2.14 & 8.05 & 11.96 & 3207 & 3569 & 362 \\
\hline 5809 & 0.74 & 0.11 & 1.83 & 1.74 & 5.75 & 9.47 & 7.49 & 11.48 & 3340 & 3243 & -097 \\
\hline 5812 & 1.34 & 0.12 & 2.10 & 5.14 & 3.34 & 1.74 & 848 & 10.84 & 3000 & 3276 & 276 \\
\hline 5925 & 1.37 & 0.14 & 2.97 & 6.68 & 2.47 & 0.81 & 9.15 & 10.41 & 2849 & 3660 & 811 \\
\hline 5926 & 1.61 & 0.12 & 2.14 & 5.84 & 1.88 & 1.32 & 7.72 & 14.23 & 2761 & 3690 & 929 \\
\hline 6062 & 0.92 & 1.90 & 1.41 & 8.52 & 1.04 & 1.57 & 9.56 & 9.74 & 3574 & 3784 & 210 \\
\hline 6039 & 1.82 & 0.93 & 2.20 & 3.42 & 4.10 & 5.72 & 7.52 & 353 & 2900 & $\begin{array}{lll}31 & 44\end{array}$ & 244 \\
\hline 6094 & 1.76 & 1.52 & 1.34 & 6.64 & 0.94 & 1.21 & 7.58 & 7.13 & 3133 & 3184 & 051 \\
\hline
\end{tabular}

The chemical analyses of these mixtures, with two exceptions, compare very favorably with their theoretical composition, calculated from the analyses of the raw materials, and from the weights used in the formulas. The majority of them agree remarkably well with their calculated guarantee. This point of evenness of mixing is important both in home mixtures and manufactured brands, particularly when the needs of the crop are understood, though variations in this respect are not so serious as may be inferred from the labored calculations of certain writers.

In the majority of cases the amounts used per acre are too small to make the variations in composition apparent in the growth of the crop.

In the use of concentrated manures, the first consideration is quality of the constituents; second is quantity applied, and the third is proportion of the constituents.

A study of the manufactured brands shows that wide variations occur between the guaranteed and actual composition, much wider in 
a large number of cases than has ever been shown in the home mixtures examined by this Station.

If farmers in their application of manufactured brands use the guarantee as a guide as to the proportions of plant-food for the various crops, they are, on the whole, led much farther astray than in the use of home mixtures, yet writers who state, without foundation of fact, that farmers cannot mix evenly, and condemn home mixtures on that ground, entirely ignore this point.

\section{Quality of the Mixtures.}

All of the mixtures are high grade ; they contain large amounts of the best forms of plant-food. On the average fifty per cent. of the total nitrogen exists in forms soluble in water, while the organic nitrogen is largely drawn from the best sources. The "insoluble" phosphoric acid, a form of this constituent which varies in "availability" according to its source, is largely drawn from animal bone, a product more highly regarded as a source of this element in its untreated state than mineral phosphate.

The potash is in all cases derived either from high-grade muriate or sulphate of potash.

The question of concentration is also important; in this respect the mixtures this year are fully equal to those previously examined, though slightly differing in the proportion of the plant-food contained in them.

The average composition of all the complete fertilizers or manufacturers' mixtures examined by the Station last year, and the average' of the home mixtures for 1893 and 1894, are as follows:

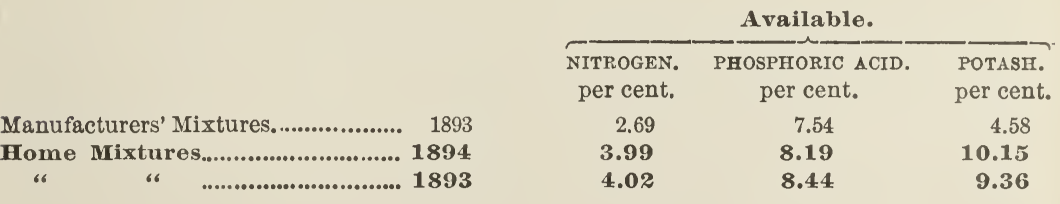

High-grade mixtures cannot be made from low-grade goods. This fact indicates either that a large number of the manufacturers' mixtures must contain low-grade materials or that "make-weight" has been added to the high-grade products used. 
This point has been discussed in former reports, where it was shown that, in the purchase of low-grade and cheap fertilizers, enormous sums are spent annually for mixing, bagging, shipping and selling material that is absolutely worthless. In purchasing high-grade raw materials and mixing at home, high-grade mixtures are the legitimate result, and expenses in this direction are avoided.

The statement of the fact that the value of a fertilizer depends upon the kind, quality and amounts of nitrogen, phosphoric acid and potash contained in it will bear frequent repetition even at this late day. True progress in the use of manures depends largely upon the thorough appreciation of this principle by the consumer.

\section{Cost of Home Mixtures.}

These home mixtures represent the purchase of at least 800 tons; the average cost is $\$ 30.85$ and the average valuation $\$ 34.16$, or a gain of $\$ 3.31$ per ton over Station's valuations, which are intended to, and actually do, fairly represent the retail cash cost of the fertilizer constituents in the raw materials at factory. The cost per ton is 10.7 per cent. less than the valuations; in the manufacturers' mixtures examined in 1893 it was shown that the cost per ton was 40.0 per cent. greater than the valuations.

\section{v.}

\section{Home Mixing; The Experience of Farmers.}

The main object of this study of fertilizing materials by the Station is to furnish farmers with detailed and accurate information in reference to the sources, composition and value of the various products which enter into the manufacture of commercial fertilizers.

In connection with this work, the conditions under which the purchase of raw materials is advisable, either for home-mixing or for direct use unmixed, have in the past been pointed out.

Many farmers have adopted this method of purchasing their supplies, and their experience, particularly in the making and using of home mixtures, which in many cases now covers a series of years, has been reported to the Station in answer to our inquiries. These farmers, numbering sixty, whose replies were received in time to be 
included in this bulletin, and representing ten counties, are making farming their business, and are among the most successful in the State. The questions asked covered in the main the following points:

1. The number of years that home mixtures have been used?

2. The amount used yearly?

3. Whether the quantity of fertilizers used was greater or less than when this method was first adopted?

4. Whether they had any difficulty in getting good mechanical condition?

5. The cost of mixing per ton?

6. Whether the results obtained were satisfactory?

7. Whether it pays to buy raw materials and mix at home?

8. The advantages or disadvantages of this method of purchasing fertilizers?

1. Three report having used home mixtures for 20 years; twelve, from 10 to 12 years; twenty-three, from 5 to 10 years; seventeen, from 2 to 5 years; and five, this as their first year.

2. Seven farmers use over 25 tons per year-one as high as 40 tons; sixteen use 15 tons or more; fourteen use 10 to 15 tons; sixteen use 5 to 10 tons; and six less than 5 tons.

3. Forty-two of the sixty use more now than when they began; five, three to four times as much, and eleven about the same quantity, varying according to the area of the best-paying crop.

4. Fifty-four state that they do not have any difficulty in getting good mixtures; four had some difficulty at first, while one states that his home mixtures excel in mechanical condition any manufactured brand he has ever used.

5. Considerable variation is reported in the cost of mixing; two report an expense of $\$ 1.50$ per ton; fifteen say that it costs $\$ 1$ per ton; sixteen estimate the cost at 75 cents; nineteen at 50 cents; one at 60 cents; two at 25 cents, and two do not regard the mixing as an extra cost. They all report the mixing as being done by the ordinary labor of the farm, when other work is not pressing, and therefore no extra expenditure.

6. Fifty-four farmers report that the results are thoroughly satisfactory, both in regard to the yield and quality of crop. Five report 
this year as their first year, though their crops are looking quite as well as where other brands were used.

7. Fifty-three state that it pays them well to buy raw materials and mix for themselves; five have not yet secured results, and one thinks he can do about as well in buying the regular brands.

8. With two exceptions all agree that the main advantage derived is that the actual constituents cost much less than in the same grade of goods purchased either directly from manufacturers or from dealers. Twenty-six state that the saving is from $\$ 6$ to $\$ 10$ per ton, and that further advantages are-

First, that they know exactly what they are using. Second, that they can use the best forms of plant-food. Third, that the essential constituents can be varied to suit the requirements of various soils and crops.

One farmer reports that the third point alone has been of the greatest service to him, enabling him to make profitable, crops which were formerly considered almost impossible to raise.

But three farmers report any disadvantage. One states that there is considerable loss from handling; another that it is difficult to procure the materials in small quantities at a reasonable price, while a third considers it a disadvantage to pay cash.

The above summary of the practical experience of farmers is, perhaps, sufficient evidence of the value of home-mixing, and the strongest argument that could be presented for the adoption of this method of purchasing supplies.

The main conditions to be observed, and which are necessary, in order to make the method entirely feasible and truly economical, arefirst, that the supplies should be purchased in considerable quantities; second, that they should be purchased early, and prepared before the beginning of the busy season on the farm; third, that contracts should be on a cash basis.

These reports also show indirectly that it pays to use fertilizers, since thirty-seven out of the sixty use more than a carload annually; sixteen use a half carload or more, and nearly all use a great deal more than when they first began.

Such a large and increasing annual expenditure for fertilizing materials, reaching as high as $\$ 1,000$ in a number of cases, could not be continued for any great length of time at a loss. It is a fact that 
those who use the largest amounts are among the most prosperous farmers. They use large amounts because they know it pays to provide sufficient food to insure, as far as possible, maximum production, under the existing conditions of climate and season.

No stronger proof than the above is required to show that in farming, under present conditions, it is of the greatest usefulness to know what constitutes plant-food, the best methods of buying, and how to use to the best advantage.

\section{EDWARD B. VOORHEES,}

Director.

New Brunswick, N. J., July 30th, 1894. 

SOME INSECTS INJURIOUS TO SHADE TREES.

NEW JERSEY

Agricultural COLlege

\section{Experiment Station}

103 


\section{NEW JERSEY AGRICULTURAL COLLEGE EXPERIMENT STATION.}

\section{BOARD OF CONTROL.}

The Board of Trustees of Rutgers College in New Jersey.

\section{EXECUTIVE COMMITTEE OF THE BOARD.}

AUstin SCOTT, Ph.D., LL.D., President of Rutgers College, Chairman. Hon. GEORGE C. LUDLOW, HENRY R. BALDWIN, M.D., LL.D., HoN. HENRY W. BOOKSTA TER, LL.D., JAMES NEILSON, Esq.

\section{STAFF OF THE STATION.}

AUSTIN SCOTT, Pr.D., LL.D., Director.

Professor JUliUs NeLsON, Ph.D., Biologist.

Professor BYRON D. HALSTED, Sc.D, Botanist and Horticulturist.

Professor JOHN B. SMITH, Sc.D., Entomologist.

ELISHA A. JONES, B.S., Superintendent of College Farm.

IRVING S. UPSON, A.M., Disbursing Clerk and Librarian.

CHARLES A. POULSON, Mailing Assistant.

LEONORA E. BURWELL, Clerk to the Director.

AUGUSTA E. MESKE, Stenographer and Typewriter. 


\title{
NEW JERSEY
}

\section{Agricultural College Experiment Station.}

\section{BULLETIN 103.}

OCTOBER 8, 1894.

\section{Some Insects Injurious to Shade Trees.}

\author{
BY JOHN B. SMITH, ENTOMOLOGIST.
}

"A barren, detested vale, you see, it is;

The trees, though summer, yet forlorn and lean"

-Titus Andronicus.

Nothing makes a worse appearance than shade trees injured by disease or insects-trees without or with but ragged foliage, or with leaves that are seared and brown in midsummer. In many of our New Jersey cities, towns and villages, in which shade trees form an important element of beauty, insect injury has been so marked for two or three years last past as to bring me many letters of inquiry. During the season of 1894 matters were so much worse than ever before that even the authorities were aroused in some instances and sufficient general interest developed to make it seem desirable to prepare a brief account of our most troublesome species for general information, and as a guide to methods for their destruction.

Chief among all the troublesome forms is

\section{The Elm-Leaf Beetle.}

(Galeruca xanthomelæna, Schrank.)

This insect makes its appearance early in spring, just as soon as the elms leaf out, and sometimes almost as soon as the buds begin to unfold, in the form of an oblong beetle about one-fourth 
of an inch in length, yellowish in color, and with a black stripe on each wing-cover. This period is usually a little after the middle of May in the latitude of New Brunswick, varying with the season, and about ten days earlier or later at the extreme south or extreme north of the State.

The first indications of their presence are small round holes in

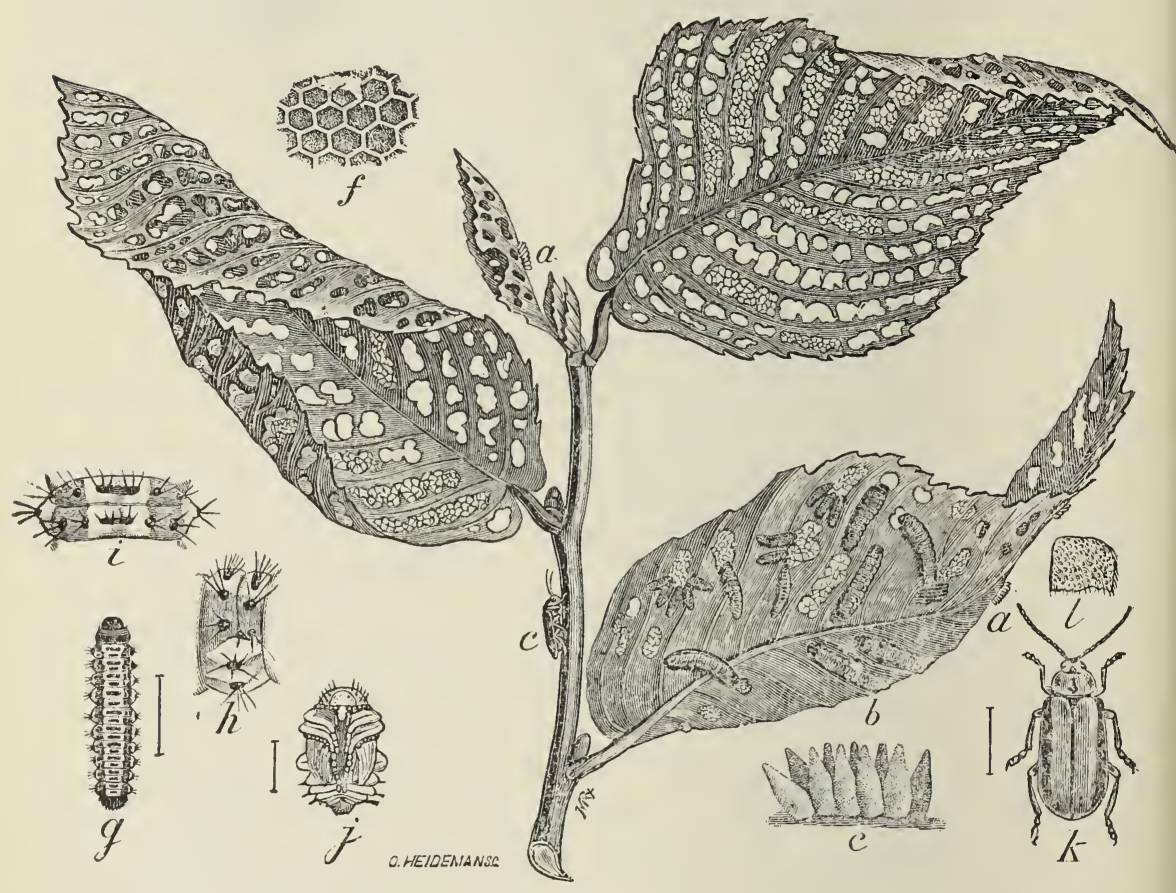

Fig. 1.

Elm-leaf beetle: $a$, eggs; $b$, larvæ; $c$, adult ; $e$, eggs, enlarged; $f$, sculpture of eggs; $g$, larva, enlarged; $h$, side view of greatly-enlarged segment of larva; $i$, dorsal view of same; $j$, pupa, enlarged ; $k$, beetle, enlarged ; $l$, portion of elytron of beetle, greatly enlarged. (After Riley.)

the more mature leaves. These rapidly increase in number as the foliage develops, until the tree looks as if loads of small shot had been fired through it in every direction.

Late in May oviposition begins, and soon thereafter, in early June, patches of little yellow eggs, somewhat bottle-shaped and set on end in a double row, make their appearance on the under side of the leaves in all parts of the trees. They continue to increase in number until after the middle of June, decreasing 
afterward until, before July 1st, very few living eggs remain. At about the same date the beetles that laid the eggs, having accomplished their life work, disappear completely, and are succeeded by their larvæ, which began hatching from the eggs first laid, early in June. These increase in number rapidly, and soon the trees show the effects of their appearance. Unlike their parents, they do not eat the entire leaf tissue, but scrape from either the upper or under surface only the superficial layers of cells. This causes such injury that the eaten spots in the leaf turn brown and die, the foliage eventually becoming dry, burnt by the sun and falling in midsummer.

The larræ causing this injury are small, blackish slugs, soft and a little moist to the touch, yellowish underneath and with six little black legs anteriorly. They are, when full grown, about three-eighths of an inch in length and furnished with little black tubercles, giving rise to tufts of stiff blackish hair. In Figure 1, $b$ and $g$, the larvæ are well and characteristically shown. In from twenty-five to thirty days they become full fed and ready to transform to pupæ. They cease feeding and begin their journey to the surface, crawling down twig to branch, to trunk, and down the trunk to the ground, where, among the grass or whatever rubbish may be handy, they cast their larval skins and appear as soft, bright-yellow pupæ. These pupæ are inactive and helpless, with all the members of the future beetle separately encased and closely tucked in. Thousands of them may be easily found at the base of a very medium-sized elm, and up the trunk, under all loosened bark scales, and in all other crevices, hundreds may be found, representing the ill or weary that become discouraged or otherwise unable to reach the ground. This brings the time to the end of June, and a week later, or about July 7 th, new beetles begin to make their appearance, increasing constantly in number until the end of that month or later, and again eating round holes in such foliage as escaped earlier in the season. Early in August the earliest beetles begin to seek winter quarters and gradually decrease in number; though stragglers will be found throughout September, especially at lights, to which they are readily attracted. Winter quarters are found in lofts and attics, in out-houses, barns or other shelter, in the cracks of posts and fences, or eren of telegraph poles; in fact wherever 
cover is attainable. The College belfry at New Brunswick is a favorite lodging place, quarts of the beetles having been found there in early September.

Further south, at Washington, D. C., there is a second and sometimes even a third brood, but in New Jersey we have only one, and, occasionally, a very partial second brood.

Quite usually, where a tree has been almost or entirely stripped of foliage, a second growth makes its appearance late in August, and this is again riddled by such beetles as remain. They prefer this to the less succulent foliage that has passed the summer, even if entirely uninjured. On such new foliage may be found the few eggs and larvæ of the partial second brood already mentioned. I greatly doubt whether on the mature foliage they could come to full growth.

There is no necessity for any further description of the injury inflicted, which is obvious to all, and we may proceed at once to the question of

\section{Remedies.}

These insects can be controlled, and the trees enitirely preserved by two or three sprayings with either London purple or Paris green, at the rate of one pound of either in one hundred and fifty gallons of water, one pound of stone or shell lime, or two gallons of milk of lime, being added to prevent possible injury to the foliage. Two quarts of glucose or molasses adds greatly to the sticking power of the poison used.

Arsenate of lead is a new material which may, eventually, replace Paris green or London purple for insecticide purposes, as it is absolutely insoluble in water, and may be applied in ahmost any strength without danger of injury to foliage. It is formed by adding four ounces arsenate of soda and eleven ounces acetate of lead to one hundred gallons of water. The chemicals dissolve readily and unite to form a white precipitate which is arsenate of lead and which remains in suspension a long time, settling very slowly, and thus requiring less stirring than either Paris green or London purple. Two quarts of glucose or molasses to one hundred gallons of the mixture will add so greatly to its sticking qualities that even a heavy shower will not wash it off completely. 
If less than one hundred gallons are desired, the mixture can be made in the same proportions, or the material may be dissolver and the precipitate formed in one gallon of water, stirring thoroughly to secure complete combination of the chemicals. This concentrated mixture can then be added in proper proportion to the tank or other vessel from which spraying is done. Care must be taken to have it well stirred before pouring out. If the ehemieals are purchased in quantity, the arsenate of lear will be somewhat cheaper than either Paris green or London purple. Purchased at retail, the cost will be greater.

Spraying should be first done when the beetles are beginning to feed in spring, and when the little round holes, already described, become noticeable. This spraying is intended to reach the adult insects and to kill them off, in large part, before eggs are laid. The second spraying should be done as soon as the larve begin hatching from the eggs, which can be known by direct observation or by the appearance of scraped leaves. This is intended to reach the young larra, which suecumb very readily. As egg-laying and hatching continue through a long period, a third spraying ten days after the second is advisable, especially if it has rained during the interval, and this should be sufficient to protect the trees. The third spraying is not a necessity unless it rains; but is desirable.

On large trees, it will be impossible to reach all points so as to kill all insects, and some will become full grown and will make their way down the trunk to the base of the tree. When this is noticerl, a strong brine, whale-oil soap-suds, kerosene, kerosene emulsion diluter nine times, or even hot water, should be poured on the ground around the base of the trees for a distance of two feet, and this should be repeated at intervals of five days as long as new additions are noticed.

For trees in gardens or on private grounds I would recommend the three sprayings and the destruction of the larve and pupe at the base of the trees. In public parks and for street trees, the two, or, if it rains, three sprayings will be sufficient.

It looks like a great task to spray a large elm, or a large number of trees in a park or town, and yet it is easier than it seems. The elms on the College campus at New Brunswick are probably as large as most of those to be found in the State, and they have 
been, during the past season, sprayed twice and fairly well protected. They have, indeed, been sprayed almost every year since I have been at the Station, with good results, one year only being entirely omitted to give a basis for comparison.

Any good spraying outfit will serve for small trees or where only a few trees are to be protected. For large trees and for protecting street trees there should be a tank, mounted on a wagon, and holding from 100 to 150 gallons of water. To this should be attached a double-acting, brass-cylinder force-pump, with full hose couplings, capable of supplying a good pressure to two lines of hose. Such pumps can be obtained from almost any manufacturer. That in use at the Station is made by the Gould's Pump Company, but others, equally good, are made by other manufacturers. Two lengths of hose are required, sufficient to reach well into large trees, and, in addition, a bamboo pole or other light rod should be used to carry the nozzle into the foliage and away from the person holding it. $\Lambda$ light ladder reaching to the point of branching will complete the equipment except as to nozzles. Spraying can be done by two men from among the branches of one or two trees to the extreme tips of those 75 feet in height, one man at the pump being sufficient.

The nozzle to be used is an important feature. For small trees, the Nixon nozzle, made by the Nixon Nozzle and Machine Company, Dayton, Ohio, or the V'ermorel nozzle, made by most of the makers of insecticide machinery, are entirely satisfactory and most economical. For large or street trees, where a full hose is used, a graduating nozzle, such as is used in lawn sprinkling, is as satisfactory as anything I have found. It is more wasteful than the nozzles above mentioned, but can be changer from a spray to carry a long distance or to throw a solid jet, if desirable, almost at once. It is eapable of making a very fine spray at close quarters and there is no danger of clogging.

\section{Varietios Attacked.}

Not all species of elms are equally susceptible. The insect is an imported one, its original home being in Europe, and, naturally enough, European elms are most troubled, though none are exempt. According to observations made by Prof. C. I. Riley, at Washington, I'lmus compestris is the greatest favorite, 
and next to it come U. suberosa, U. effusa and U. montana. The latter is the least infester of the imported varieties, except U. parvifolia (siberica), on which the larva seem to be unable to live at all. Ulmus americana was only a little attacked, and was found to be the most desirable form so far as its freedom from insect pests is concerned. In setting out elms, therefore, our American varieties should be preferred. The most susceptible are those having thin, smooth leaves.

Next in order, in some localities at least, is

\section{The Wood Leopard Moth, or Imported Elm Borer.}

(Zeuzera Pyrina, L)

This is also an imported insect, and its appearance in the larval and adult condition is well enough shown in the figures

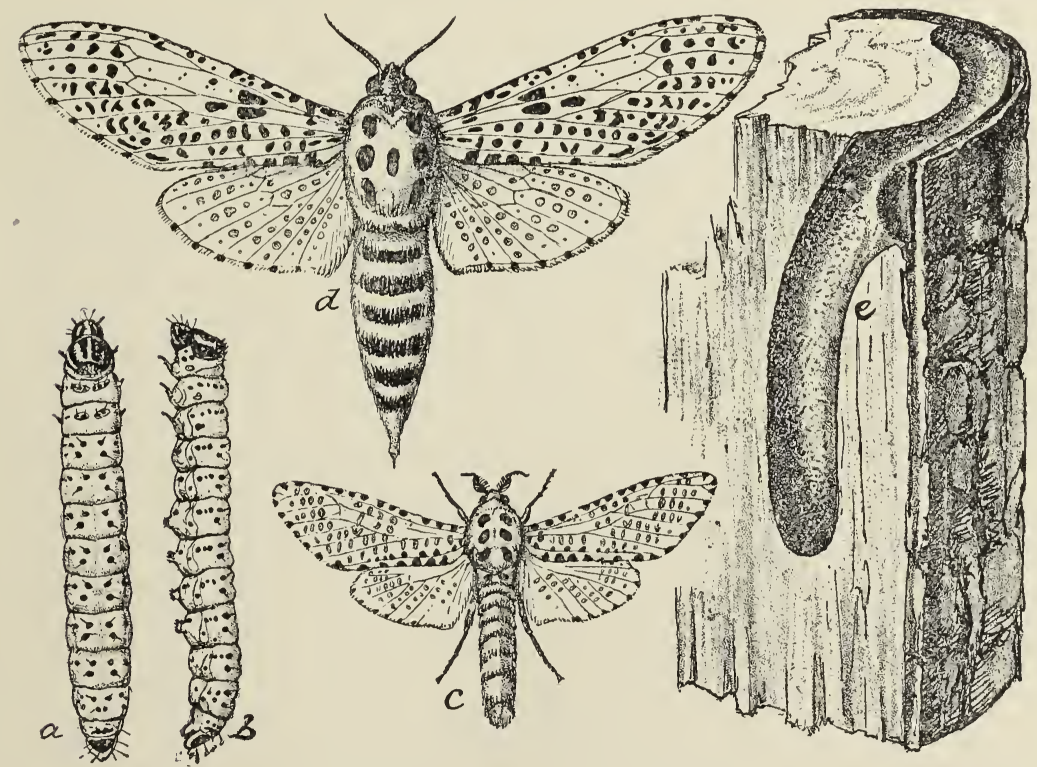

Fig. 2.

The wood leopard moth: $a, b$, larva from above and from side; $c$, male moth; $d$, female moth; $e$, larval burrow. All natural size.

herewith given, which are reproduced from "Insect Life" by the courtesy of the United States Department of Agriculture. It is, so far as my records go, confined at the present time to Jersey 
City, Hoboken and Newark, and to the immediate vicinity of these cities. It occurs as a serious pest in the park and shade trees of New York and Brooklyn, and has caused the death of numerous trees of quite a wide range of species. In the city of Newark, it is distinctly the most serious of the tree pests, attacking all the species of maple and elm and also, less seriously, the sweet gum, tulip tree, the lindens and several others. The horse-chestnut and Ailanthus are not attacked, though the former is also infested in Central Park, New York.

The moths make their appearance in May or June, continuing through July and into August, and are readily attracted to light. It has become the most common species seen around the electric lights in the cities named, and each moth represents a larva that has fed for at least two years in the wood of a neighboring tree, while every female represents the possibility of hundreds of other larvæ to follow the same life history.

The eggs are laid by the female moth on the branches, probably placed just into the bark, and the young larve bore at once into the wood, usually at the crotch of a small branch, or at a node, and work downward; sometimes just under the bark, sometimes in the solid wood. They grow apace and get intò larger branches, still working downward as a whole, but often varying in course; sometimes making it eircular, so as to girdle the stick they feed in. For at least two years they feed, rarely emerging from the burrow, though they do occasionally come out for the purpose of changing their quarters and beginning their destructive work elsewhere. Then they change to somewhat slender, brown pupæ, and these wriggle themselves through the bark in due season, and soon after the moths emerge.

\section{Remedies.}

An insect with the life history above given is beyond the reach of ordinary insecticides. There is no period in its life history when we ean reach it by any application made on the trees. I have already stated that a great many moths are attracted to the electric lights, and there meet death. It is to this, I believe, that we owe the failure to spread more rapidly from Newark and other cities into the surrounding country. 
Active measures are possible in one direction only. Every badly-infested tree should be cut down and burnt, as its death would be a mere matter of time at the best. Trees infested toward the tip only should be cut back hard in winter, and whatever is taken off should be burnt.

Unlike some of the other introduced species, this insect is also a sad pest in its native home. Mr. J. W. Tutt, in a little book recently issued, says: "Then the caterpillar of the wood leopard moth, whose almost transparent wings are covered with bright metallie, greenish-black dots, does immense damage to trees in our London parks. Almost all the branches that come tumbling about our ears during a high wind are snapped, owing to the damage done by this dreadful scourge, whilst it is estimated that one female alone lays above a thousand of her minute salmoncoloured eggs."

Mr. E. B. Southwick, Entomologist to the New York Park Commissioners, says that this is the most troublesome of all the insects infesting the New York City parks. Wagon-loads of twigs and branches are trimmed off in Central Park annually, and the insect seems now to have been somewhat checked. The openings to the burrows made by the larva are easily seen by the trained eye, and where they are in the trunks of valuable trees or shrubs, or in branches that cannot be easily spared, a few drops of bisulphide of carbon are forced into the burrow by means of an ordinary oil can holding half a pint, such as is used by mechanics, and a little dab of putty closes the opening. The vapor of the bisulphide will penetrate the full length of the tunnel, and will kill the larva wherever it may be in it, without injury to the tree.

I would recommend, wherever this borer has gained a footing, cut down and burn all badly-infested trees where the trunk and larger branches are involved. Where the trunks are free and the larger branches are not badly infested, cut back as hard as the tree will easily bear, and burn all the cuttings. The tree should then be carefully examined, and wherever a hole is noticed, bisulphide should be forced into it and the opening should be closed with putty. All this can be done during the winter. During the summer the trees should be kept under 
inspection and wherever signs of borers are noticed, either the infested wood should be cut out or the borer destroyed by means of bisulphide of carbon as above described.

\section{The White-Marked Tussock-Moth.}

(Orgyia leucostigma, S. \& A)

The most abundant caterpillar to be found in our shade trees is that herewith figured, and it attacks a very great variety of species, very few only being exempt. When it is full grown it is a very pretty creature and quite striking in appearance. The head and two little elevated spots on joints nine and ten are bright vermilion-red; the back is velvety and there are three brightyellow lateral lines. The whole body is thinly clothed with long, pale-yellow hairs, originating from small, wart-like elevations. Four cream-colored or white dense brushes of hair are in a row on the back, on the middle of the fourth, fifth, sixth and

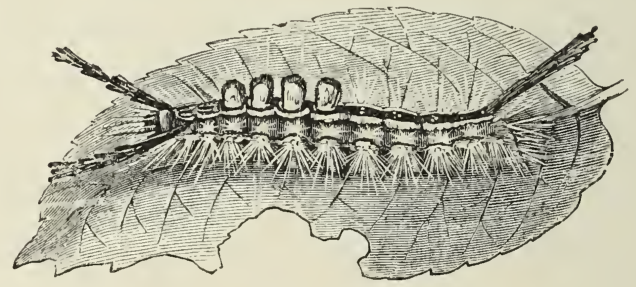

Fig. 3.

Larva of white-marked tussock-moth. (After Riley.)

seventh joints, while from each side of the head arises a long, plume-like tuft of black hair, projecting forward and outward. A similar plume projects upward from the last joint.

These caterpillars are found scattered all over the trees in June, move about freely and, when suddenly disturbed, they drop from their perch, suspending themselves by a silken thread which is attached to the leaf from which they were started. Toward the middle or end of June they become full grown and begin to spin whitish cocoons, intermixed with their own hairs, in all sorts of convenient places. The angles of wooden treeboxes become filled with them, every projection is made use of as a shelter, and on the trunks of trees themselves great numbers 
make use of every crevice. In this cocoon the larvæ change to pupæ, the male much the smaller and showing rudiments of the future wings. Less than two weeks thereafter, the final change takes place, and the adult insects emerge-the sexes strikingly dissimilar in appearance. The male has two pairs of broad, dusty-gray wings, the anterior crossed by narrow black lines and with a white spot toward the hind angle. The feelers or antennæ are broadly feathered and the fore legs are plumed and tufted. The female, on the other hand, is entirely without wings and somewhat slug-like, consisting principally of an abdomen which is enormously distended with eggs. When she emerges from the

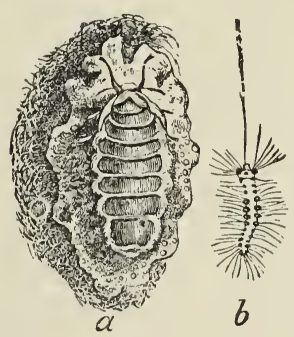

6

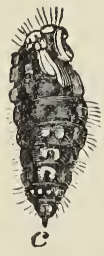

Fig. 4.
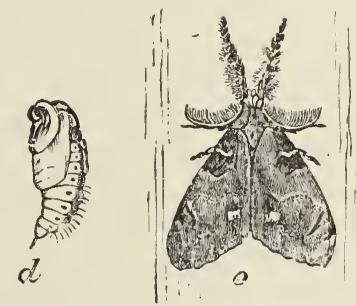

White marked tussock-moth : $a$, female on its egg-mass; $b$, soung larva suspended by its thread; $c$, pupa of female; $d$, pupa of male; $e$, male moth. (After Riley.)

pupa she crawls upon the cocoon, to which she clings for the balance of her life. Egg-laying begins soon after the male has found her, and the eggs are laid upon the old cocoon and covered with a frothy mass, which soon becomes hard and brittle and is snow white. From these eggs a second brood of caterpillars emerges in. July and the same life history is repeated, the adults of the second brood appearing in September. The eggs laid at this time remain on the trees during the winter. White at first, they gradually darken by exposure to dust and rain and before spring resemble their surroundings fairly well.

\section{Remedies.}

We can keep this insect in check with comparatively little trouble. All the egg masses on the trees should be removed early in the winter, while they are prominent on the bare trunks and limbs, and every tree that is thoroughly cleaned will be 
exempt for the season to come, except for such larvæ as may crawl on it from adjoining trees. As the females are incapable of flight, there can be no spread from them, and the wandering habit of the caterpillar just before pupation provides for the spread of the insect. The egg masses, as they are taken off, should be placed in a basket and afterward burnt in a furnace.

A few men employed in cleaning trees during the winter in the cities, towns and villages of our State would perhaps relieve distress in some cases, and would certainly pay well in the improved appearance of the trees during the ensuing summer.

Elms that are sprayed for the beetle need no special treatment for this insect, which will be killed off by the same application which destroys the major pest.

If winter treatment is not resorted to, a spraying with either of the arsenites, as recommended for the elm-leaf beetle, should be made about the middle of June.

\section{General Considerations.}

All trees have their insect enemies, and all parts sustain their own peculiar pests. Some attack them in life; some only when they are weakened by disease, age or other adverse circumstances, hastening death and giving room each year for other species which, erentually, if not interfered with, reduce them to dust. Not all species of trees suffer equally, however, and in many cases trees and insects are so adapted that both live and flourish, while in yet other instances the insects find it difficult to flourish in surroundings in which the trees yet do fairly well.

It should be remembered as a matter of primary importance that, other things equal, healthy trees are least susceptible to insect attack, and the effort should be, in all cases, to have healthy, clean, well-fed trees. All shade trees should be scrubbed each winter with a stiff brush and whale-oil soap-suds, to destroy the numerous insects hibernating in the crevices, and to remove fungous growths, mosses or other parasitic vegetable life. Sickly or infested shoots or branches should always be cut out promptly when noticed, and the cuttings should be, in all cases, burnt to prevent the transformation of any larre that they may contain. 


\section{Classified List of Shade Trees.}

The following list of shade trees, based on that prepared by Mr. B. E. Fernow, Chief of Division of Forestry, U. S. Department of Agriculture, for the Brooklyn Tree Planting and Fountain Society, is arranged in the order of least susceptibility to insect attack, though none are entirely exempt. It is not intended to suggest that they are the best in the order named, except so far as freedom from insect attack in New Jersey is concerned. Dr. Halsted has kindly marked the list for fungous troubles, and the numbers in parenthesis following the names indicate the orter of their freedom from disease, No. (1) indicating the species least affected.

Tree of Heaven. Ailanthus glandulosus. (3)

Ginko, or Maiden-hair Tree. Ginkgo biloba. (1)

Tulip Tree. Liriodendron tulipifera. (6)

Sweet Gum. Liquidamber styraciflua. (2)

American Linden. Tilia americana. (7)

European Linden. Tilia vulgaris. (8)

Small-leafed Linden. Tilia microphylla. (9)

Cottonwood Poplar. Populus monilifera. (19)

Horse-chestnut. Esculus hippocastanum. (18)

Oriental Plane Tree. Platanus orientalis. (20)

American Plane Tree. Platanus occidentalis. (21)

Box Elder. Negundo aceroides. (10)

All Oaks. Quercus Sp. (11)

All Maples. Acer Sp. (12)

All Willows. Salix Sp. (13)

American Elm. Ulmus americana. (17)

Slippery Flm. Ulmus fulva. (16)

Scotch Elm. Ulmus montana. (15)

European Elm. Ulmus campestris. (14)

Black Locust. Robinia pseudacacia. (5)

Honey Locust. Gleditschia triacanthos. (4) 

ANALYSES AND VALUATION OF COMPLETE FERTILIZERS, GROUND BONE AND MISCELLANEOUS SAMPLES.

\title{
NEW JERSEY
}

\author{
AGRICULTURAL
}

\section{Experiment Station}

104 



\title{
NEW JERSEY
}

\section{Agricultural Experiment Station.}

\author{
BULLETIN 104.
}

NOVEMBER 19, 1894.

\section{Analyses and Valuations of Complete Fertilizers, Ground Bone and Miscellaneous Samples.}

\author{
BY EDWARD B. VOORHEES, \\ LOUIS A. VOORHEES, \\ JOHN P. STREET.
}

Two bulletins containing fertilizer analyses are issued by this Station annually, each having a specific purpose. Bulletin No. 102 , issued June 30th, contained the analyses of 90 samples of fertilizing materials and 10 samples of mixtures made from such materials by the farmers themselves. The main object of this work was to show the sources and composition of the materials containing the best forms of nitrogen, phosphoric acid and potash, the cost per pound of the ingredients, and the advantages of making home mixtures.

A large number of these samples were, however, examined for the purpose of determining for the purchaser the number of pounds, or "units," of nitrogen, phosphoric acid or potash contained in the products bought, the purchaser agreeing to pay for the actual amount of plant-food found by the Station. It is obvious that the analyses for this purpose were of direct usefulness in protecting both the dealer and the purchaser, in case of unusual variation in the composition of the products. 
In this bulletin the analyses and valuation of 224 samples of mixed fertilizers, 29 samples of ground bone, 17 samples of miscellaneous products, and 9 samples of wood ashes are reported.

The main object of this work is to show whether the actual composition of the various products corresponds with their guarantee as required by law. It is, therefore, of direct value in detecting fraud and in showing carelessness on the part of the manufacturer in the preparation of the mixtures, though the analyses are sufficiently complete to give definite information as to the kind of materials used in making the different brands, and also in showing whether there is sufficient variation in the composition of the brands now offered to fulfill special soil and crop requirements.

\section{Chemical Composition of Mixed Fertilizers.}

The samples examined this year represent the product of sixtyfour manufacturers and dealers, and were, in most cases, taken by regularly-appointed inspectors, many of whom have performed this work for the Station since 1884.

On the whole the products are of fairly good quality, and as a rule contain as much total plant-food as is guaranteed. In many cases, however, it is not distributed in the proportions stated by the guarantee, which indicates either a lack of skill or of carefulness in their preparation.

In two cases only the consumer receives less of all of the plant-food constituents than is guaranteed. One product, represented by sample. No. 5710, is decidedly fraudulent in character. It shows but fifty-five hundredths of one per cent of nitrogen, and less of phosphoric acid and potash than is contained in good marl, which evidently forms the basis of the mixture. Its commercial value is $\$ 3.68$ per ton, and its selling price is $\$ 25$.

The sample represented a car-load lot bought directly from the manufacturer. The analysis was reported early in the season to the purchaser, with the statement that the product was practically valueless.

\section{Guarantees and Their Uses.}

A careful comparison of the actual composition of the various brands, with their accompanying guarantee, shows that the chief 
difficulty in respect to keeping the guarantee is in the case of phosphoric acid.

Ninety-six of the 224 brands, or 43 per cent., contain less phosphoric acid than is guaranteed; 27 brands contain less potash and 20 less nitrogen. In the case of nitrogen, particularly, the actual amount contained is in many cases greatly in excess of the guarantee.

As already stated, the object of the guarantee is to indicate to the purchaser the amount and proportion of the plant-food constituents contained in the different brands. If the brand contains less of any one constituent than is guaranteed, the consumer may secure damages under the law. The fact that the brand contains the amount guaranteed is, however, of but little importance in itself, since there is no obligation placed upon the manufacturer to guarantee any specified amount. It is useful only in connection with intelligence on the part of the purchaser, who understands the relation that should exist between guarantee and selling price.

The importance of this knowledge may be illustrated in the case of two brands from the same manufacturer, and reported in this bulletin: Brand No. 1 is guaranteed to contain 2 per cent. of ammonia or its equivalent, 1.64 per cent. of nitrogen, 8 per cent. of "available" phosphoric acid and 1.50 per cent. of actual potash, and sells for $\$ 28$ per ton. Brand No. 2 is guaranteed to contain 3 per cent. of ammonia or its equivalent, 2.46 per cent. of nitrogen, 10 per cent. of "available" phosphoric acid and 10 per cent. of actual potash, and sells for $\$ 32$ per ton. The commercial valuation of No. 1 , when reaching its full guarantee, is $\$ 17$ per ton. The valuation of No. 2, on the same basis, is $\$ 30.10$ - a difference of $\$ 13.10$ per ton, though the selling price differs by only $\$ 4$. In other words, though the guarantee is reached in each case, the manufacturer offers in brand No. 2 55 per cent. more plant-food for the same money than in brand No. 1.

The above illustration is not an isolated example of how the keeping of guarantees may mislead those who compare brands only on that basis. It is obvious, therefore, that an inspection which shows that the brands reach their guarantee is limited in 
its usefulness. Consumers must study the relation of guarantee țo selling price.

The importance of a strict conformity of guarantee and composition in reference to proportion of the constituents, is also worthy of notice.

A farmer buys a special fertilizer for potatoes, or other crop, because he believes from experience and experiment that certain proportions of plant-food constituents are better than others. He must trust to the guarantee for guidance in this respect; if the actual composition does not correspond to the guarantee in proportion of the constituents, his results in the field may be quite as disappointing as if he received less plant-food than was offered.

\section{Station's Valuations and Selling Prices.}

The Station's valuation per ton is derived from applying to the different ingredients the schedule of prices published in Bulletin No. 102 ; it is intended to show the retail cash cost of the amounts of nitrogen, phosphoric acid and potash contained in one ton if they were bought at factory in the form of raw materials, unmixed. The difference between selling price and Station's value shows, therefore, the charges that are made for mixing, bagging, shipping and selling the different brands.

The selling price per ton, entered in the tables, is the price at the point where sampled. These prices differ in the various localities of the State, due mainly to differences in freight rates from point of production to consumers' depot, the amount sold and commission charged.

In certain States a definite though arbitrary sum for these charges is fixed by the Station and added to the valuation. This method has not been adopted here, since the only effect is to reduce the difference between valuation and selling price. Farmers know what is a fair charge for freight from shipping points to their localities, and can make such calculations themselves, with the further advantage that they apply to their own conditions.

The average composition, selling price and commercial valuation per ton of all the brands of mixed fertilizers examined in 
1891, 1892, 1893 and 1894, as well as the percentage difference between valuation and selling price, or the charges for mixing, bagging and selling, are shown in the following tabulation:

\begin{tabular}{|c|c|c|c|c|c|c|c|c|}
\hline & $\begin{array}{c}\text { Total } \\
\text { Nitrogen. }\end{array}$ & $\begin{array}{l}\text { Total } \\
\text { Phos. Aci }\end{array}$ & $\begin{array}{l}\text { Available } \\
\text { Phos. Acid }\end{array}$ & $\begin{array}{l}\text { Insoluble } \\
\text { Phos. Acid. }\end{array}$ & Potash. & $\begin{array}{c}\text { Selling } \\
\text { Price. }\end{array}$ & $\begin{array}{c}\text { Station } \\
\text { Valuation. }\end{array}$ & $\begin{array}{l}\text { Percentage } \\
\text { Difference. }\end{array}$ \\
\hline $1891 \ldots .$. & 2.71 & 10.12 & 7.29 & 2.83 & 4.21 & $\$ 34.23$ & $\$ 25.31$ & 35.2 \\
\hline$\ldots$ & 2.74 & 10.38 & 7.70 & 2.67 & 4.50 & 34.19 & 25.66 & 33.2 \\
\hline & 2.69 & 10.23 & 7.54 & 2.69 & 4.58 & 34.11 & 24.41 & 39.7 \\
\hline $94 \ldots$. & 2.87 & 10.40 & 7.37 & 3.03 & 4.94 & 34.17 & 24.83 & 37.6 \\
\hline
\end{tabular}

It will be observed that the average composition for the four years is remarkably uniform, with an apparent tendency toward a higher content of nitrogen and potash, and a decrease in available phosphoric acid. The selling price is also very uniform; the difference between highest and lowest is but 12 cents per ton. The percentage charges for mixing, bagging and selling are, however, much greater in 1893 and 1894 than in 1891 and 1892.

If these charges were sufficient in former years, the selling price now should be reduced, in order to correspond with the decrease in cost of both fertilizing material and other supplies. The purchaser, however, has, even under these conditions of apparent extravagant average charges, an abundant opportunity for selection. In 34 brands the average charge is less than 20 per cent., while in 90 others it does not reach 30 per cent.

It was shown in Bulletin No. 102 that manufacturers were willing to sell the fertilizing ingredients in raw materials at less prices per pound on the average than those used in computing Station's values. If the charges here shown are legitimate, then it appears that in a large number of cases the laborers who mix, bag and handle these goods, the railroads which carry, and the dealers who sell are entitled to greater returns for their labor than the farmer who uses the product. At the average cost per pound of the nitrogen, phosphoric acid and potash in these fertilizers, it would cost the farmer 36 cents to return to the soil the fertilizing ingredients carried off in every bushel of wheat sold, 28 cents to return the amount contained in a bushel of corn, 30 cents to return that contained in a bushel of rye, 18 cents for that contained in a bushel of oats, and $\$ 7.16$ to return the fertilizer constituents removed in a ton of timothy hay. 
Prices for these crops are low, and those, too, which remove relatively less of the expensive fertilizer constituents-potatoes, vegetables and small fruits-and which require for their production a larger expenditure for labor, and proportionately more available plant-food, in order to secure maximum crops, also bring much less now than formerly.

It is clear that at these prices for plant-food a very narrow margin is left to the farmer in the sale of crops for legitimate charges for labor of growing, handling, selling and other expenses.

Farmers cannot completely change their methods of practice if they would, and, furthermore, it is advisable to increase the productive power of their soils to the maximum point. To do this at a profit they must know not only what their soils and crops need in the way of plant-food, but they must get what they need at a much lower cost per pound than is possible in the average mixed fertilizer.

The Station has repeatedly stated that it paid to use fertilizers, and it reiterates that statement now, even under the existing unfavorable conditions of farming, since the opinion is based upon the indisputable testimony of actual facts. The main conditions are, however, economy in their purchase, and rational use both of natural and artificial supplies.

Farmers may accomplish this-I. By reducing the cost per pound of plant-food constituents in mixed fertilizers. II. By limiting the exportation of plant-food from the farm. III. By purchasing less of the expensive element nitrogen.

I. The cost of plant-food in mixed fertilizers may be reduced by purchasing on the "unit" basis. The "unit" means 1 per cent. on the basis of a ton, and is 20 pounds. For example, a unit of "available" phosphoric acid means 20 pounds, and a superphosphate guaranteed to contain 12 units means that it contains 240 pounds per ton.

An illustration of the advantages of this method may be shown by applying it to the brands referred to on page 5 . Brand No. 1 contains-according to guarantee-2 units of ammonia, 8 of "available" phosphoric acid and $1 \frac{1}{2}$ of potash; and No. 2 
contains 3 units of ammonia, 10 of "available" phosphoric acid and 10 of potash. Assuming $\$ 3.50$ per unit for ammonia, $\$ 1.30$ for "available" phosphoric acid and $\$ 1$ for potash-which would be fair prices this year at point of consumption-No. 1 would cost $\$ 18.90$ and No. $2 \$ 33.50$ per ton, as against $\$ 2 S$ for No. 1 and $\$ 32$ for No. 2, the prices now charged under the present system of buying on the ton basis.

That is, agree to pay for what the mixture actually contains at a definite price per pound or "unit" of plant-food constituents contained in it, the number of pounds or "units" to be determined by an analysis at the Experiment Station, as is now done: in the case of unmixed goods.

Where 20 tons or more are purchased, and agreements are made on this basis, the Station will make the analysis free of charge.

A number of the leading manufacturers have signified their willingness to sell on this plan, and it is quite likely that all would do so, since it is eminently fair' to both parties to the transaction, and because manufacturers now buy their supplies. on this basis.

II. The exportation of plant-food, particularly in general farming where stock is kept, may be reduced by a judicious exchange of grain and hay for concentrated feeds, rich in the fertilizing constituents, coupled with careful saving and intelligent application of the manure made.

III. Sixty per cent. of the price of the average fertilizer is now paid for nitrogen. The necessity for purchased nitrogen, particularly in general farming and fruit-growing, may be greatly decreased by sowing larger areas of leguminous crops, which gather nitrogen from the air.

Crimson clover, which does not interfere with regular rotations, and which may be sown under a wide variety of conditions, is a valuable crop for this purpose.

These facts have been pointed out again and again in the Station's reports and bulletins, and are worthy of careful study. Successful farmers do study them and act accordingly. 


\section{Ground Bone.}

The samples of ground bone examined this year, on the whole, reach their guarantee, show a good degree of fineness, and with few exceptions a relatively high valuation. A larger number than usual, however, belong to the class "steamed bone," which is not indicated by the manufacturer in the naming of the brand, and is liable to mislead as to the composition if guarantees are not carefully examined. Steamed bone contains less nitrogen and more phosphoric acid than raw bone.

A number of these samples doubtless represent local products, which are limited in quantity.

\section{Valuations.}

The schedule of prices used in computing values in 1893-4, as well as the arerage per cent. of fineness of the bone, are shown below :

\begin{tabular}{|c|c|c|c|c|c|c|c|}
\hline & \multicolumn{2}{|c|}{$\begin{array}{l}\text { A verage per cent. } \\
\text { of Fineuess. }\end{array}$} & \multicolumn{2}{|c|}{$\begin{array}{l}\text { Nitrogen } \\
\text { Per Pound. }\end{array}$} & \multicolumn{2}{|c|}{$\begin{array}{l}\text { Phosphoric Acid } \\
\text { Per Pound. }\end{array}$} \\
\hline & & 1893. & 1894. & 1893. & 1894. & 1893. & 1894. \\
\hline Finer than & $\frac{1}{50}$ in......... & 43 & 43 & $15 \mathrm{c}$. & $16 \frac{1}{2} \mathrm{c}$. & $6 c$. & $5 \frac{1}{2} \mathrm{c}$. \\
\hline " " & $\frac{1}{25} \quad " \ldots \ldots \ldots \ldots$ & 27 & 27 & $12 \mathrm{c}$. & $13 c$. & $5 c$. & $4 \frac{1}{2} \mathrm{c}$. \\
\hline " $\quad$ " & $\frac{1}{12} " \ldots \ldots \ldots \ldots$ & 20 & 22 & $9 \mathrm{c}$ & $12 \mathrm{c}$. & $4 c$. & $3 c$. \\
\hline Coarser than & $\frac{1}{12} "$ "............ & 10 & 8 & $7 c$. & $7 \mathrm{c}$. & $3 c$. & 2c. \\
\hline
\end{tabular}

The average per cent. of fineness is practically identical with that shown in 1893. The schedule prices of the nitrogen in the three finer grades are considerably higher, while those of phosphoric acid are lower in all the grades this year. This change in the schedule has the effect of relatively increasing the valuation of the pure bone, and of decreasing that of the steamed bone. The Station's average valuation and the selling price per ton are practically identical, showing that on the average the nitrogen and phosphoric acid contained in bone are obtained at the prices per pound indicated in the schedule.

\section{Miscellaneous Products.}

The miscellaneous samples, which on the whole represent good products, require notice particularly in regard to the brand 
names. The name "Improved Superphosphate," for instance, doubtless conveys the idea to many that the superphosphate contained in it is an improvement on other superphosphates, while the obvious intention of the manufacturer in so naming the brand is to signify that it differs from mineral superphosphates, the addition of nitrogenous material making it correspond with dissolved bone in composition. The correct name for such a product is " nitrogenous superphosphate.."

The term "bone phosphate," applied to purely mineral phosphates, is also misleading, since it is liable to give the impression that animal bone has been used in making the product.

\section{Wood Ashes.}

The number of samples of wood ashes examined this year is somewhat larger than usual, and they show the usual wide variation in composition. The valuations are based entirely upon the content of potash and phosphoric acid.

Sample No. 5634 represents a small product sent to the "Fruit Growers' Union," of Hammonton, and guaranteed to be unleached. It was submitted for analysis previous to purchasing, and hence a contemplated large order was not given.

Samples No. 6090 and No. 6148 represent products guaranteed to contain as a minimum 5 per cent. of actual potash and 1 per cent. of phosphoric acid, and the price, delivered, to be $\$ 11$ per ton, on the basis of guarantee. The dealers also agreed that if it did not reach the guaranteed composition, a proportionate price should be paid for such amounts as it did contain. On the basis of guarantee and selling price given, the charge for potash was 9.24 cents per pound, and for phosphoric acid 8.8 cents per pound, or 76 per cent. greater than on the average is charged for the same elements in high-grade sulphate of potash and in superphosphates.

The high prices charged, though the consumer only paid for the actual amounts present, illustrates forcibly the importance of studying the relation existing between the guarantee and selling price. With but one or two exceptions the prices charged for the plant-food constituents contained in the samples of wood ashes rexamined are excessive. 


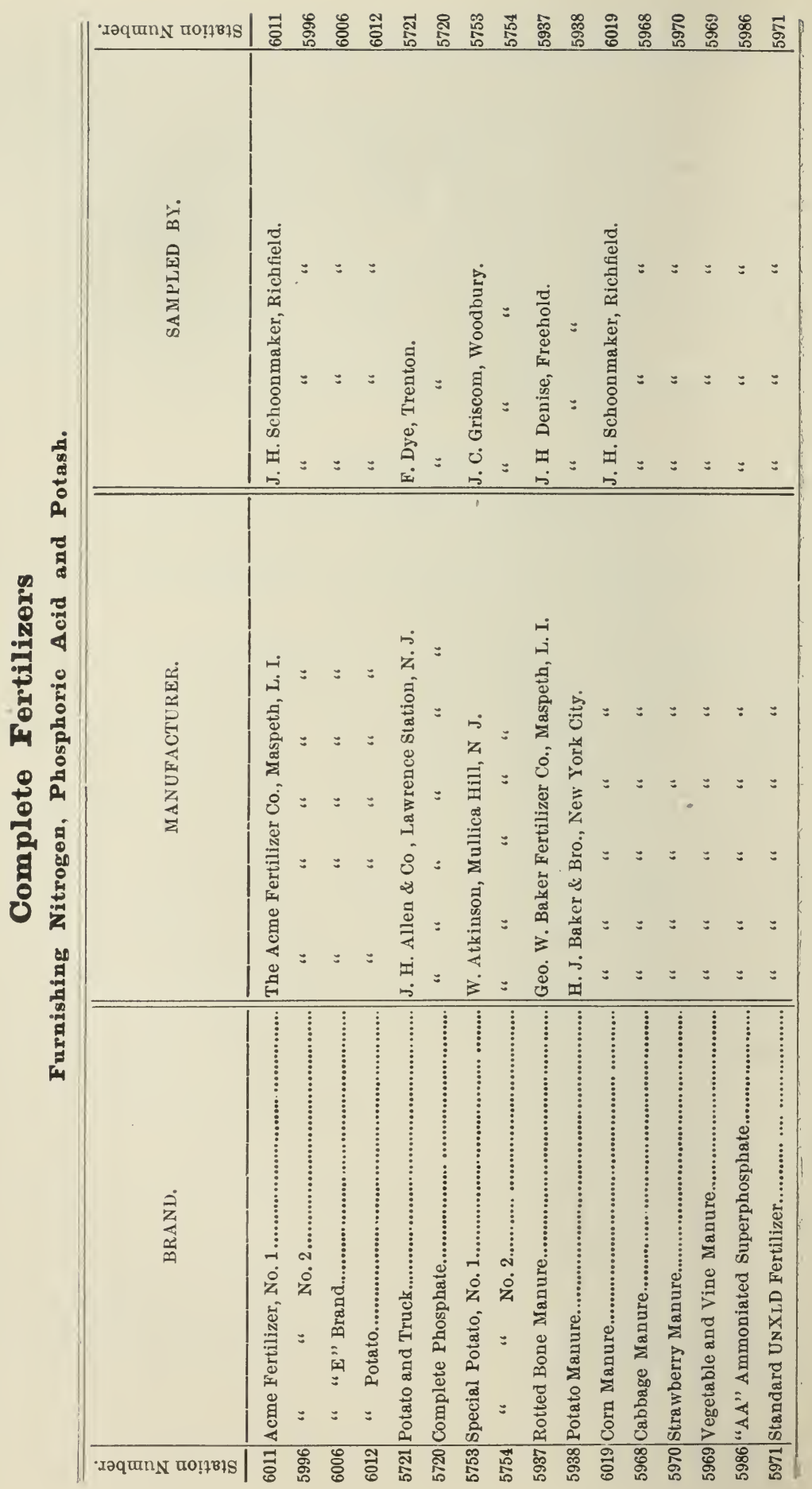




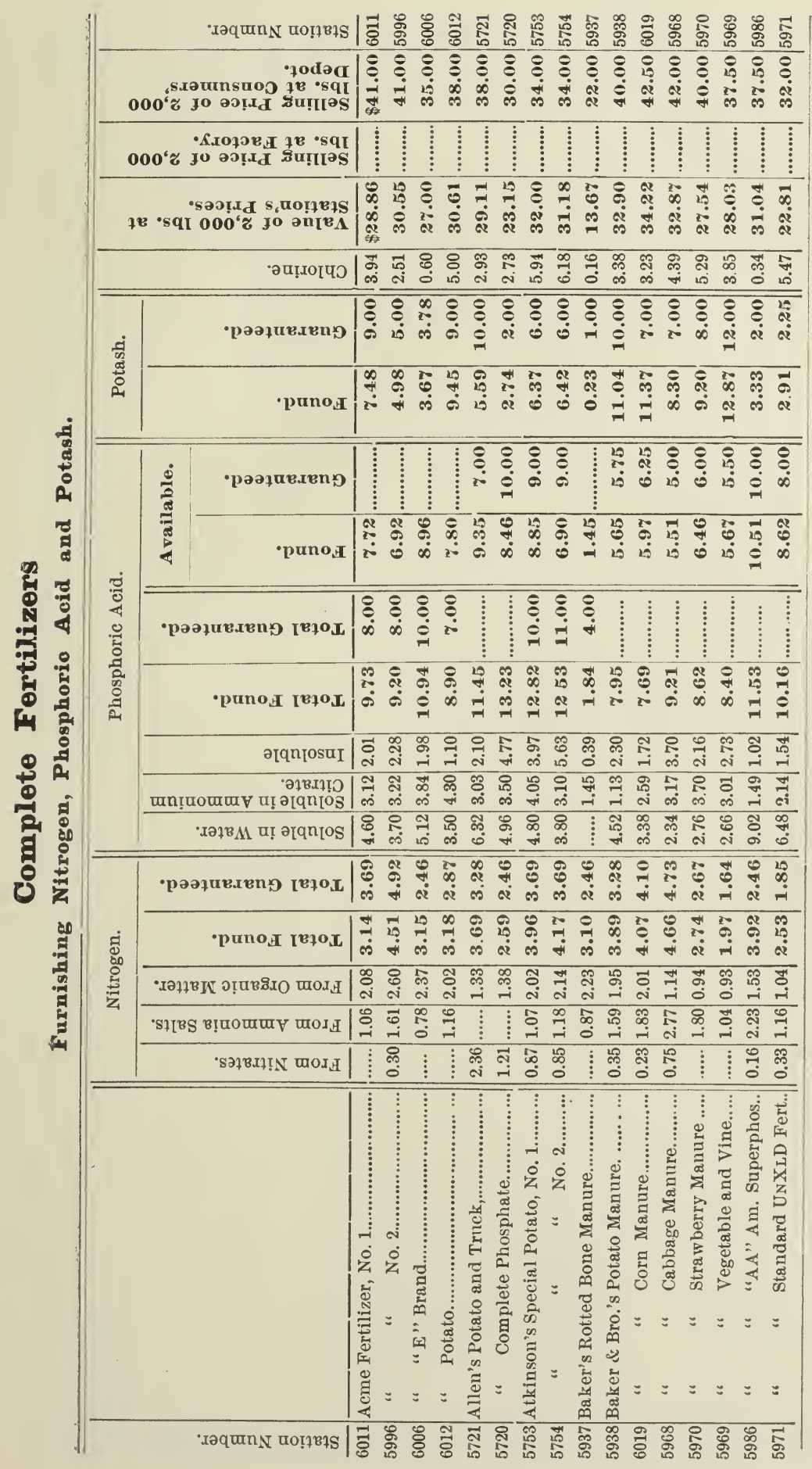




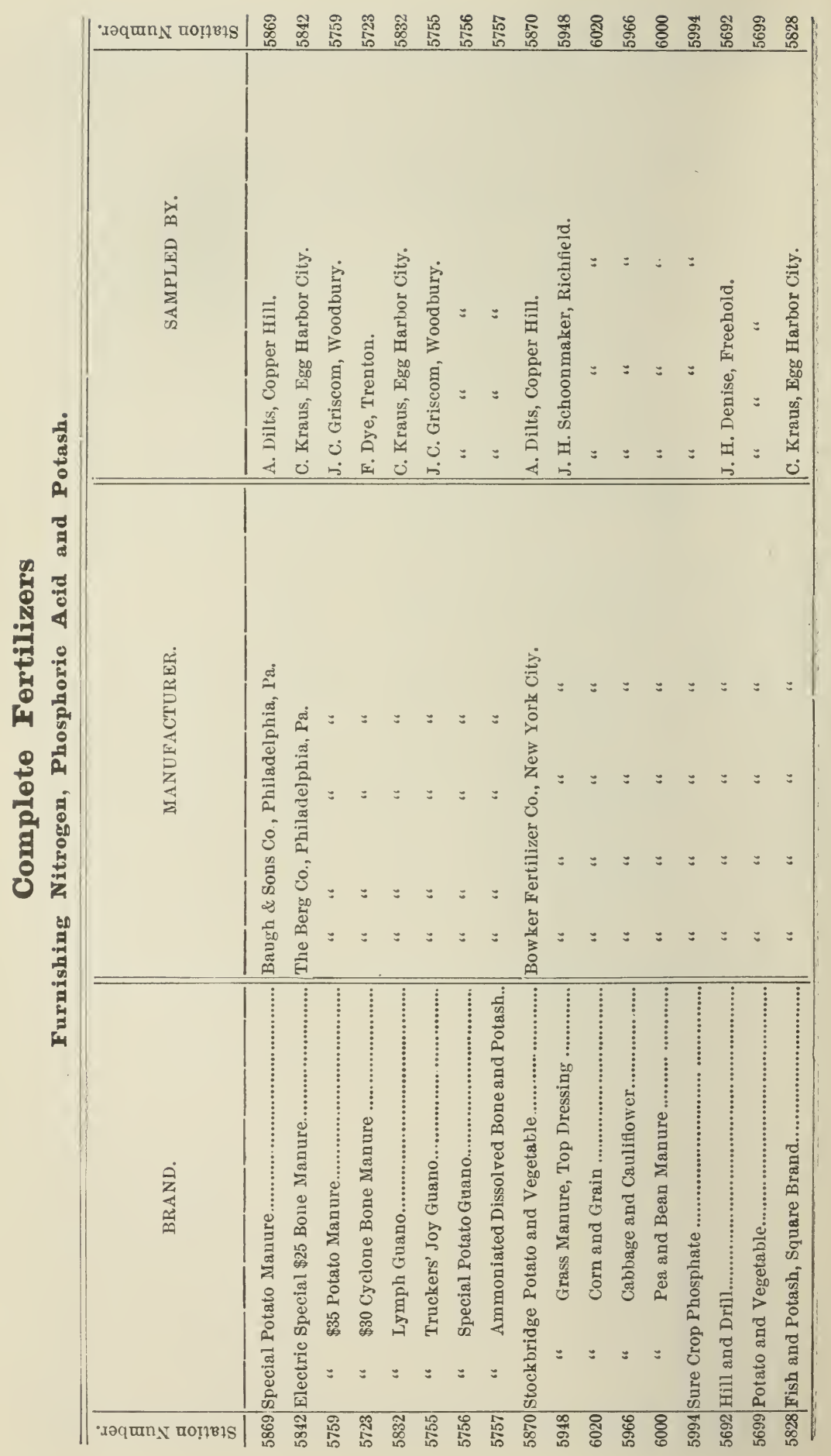




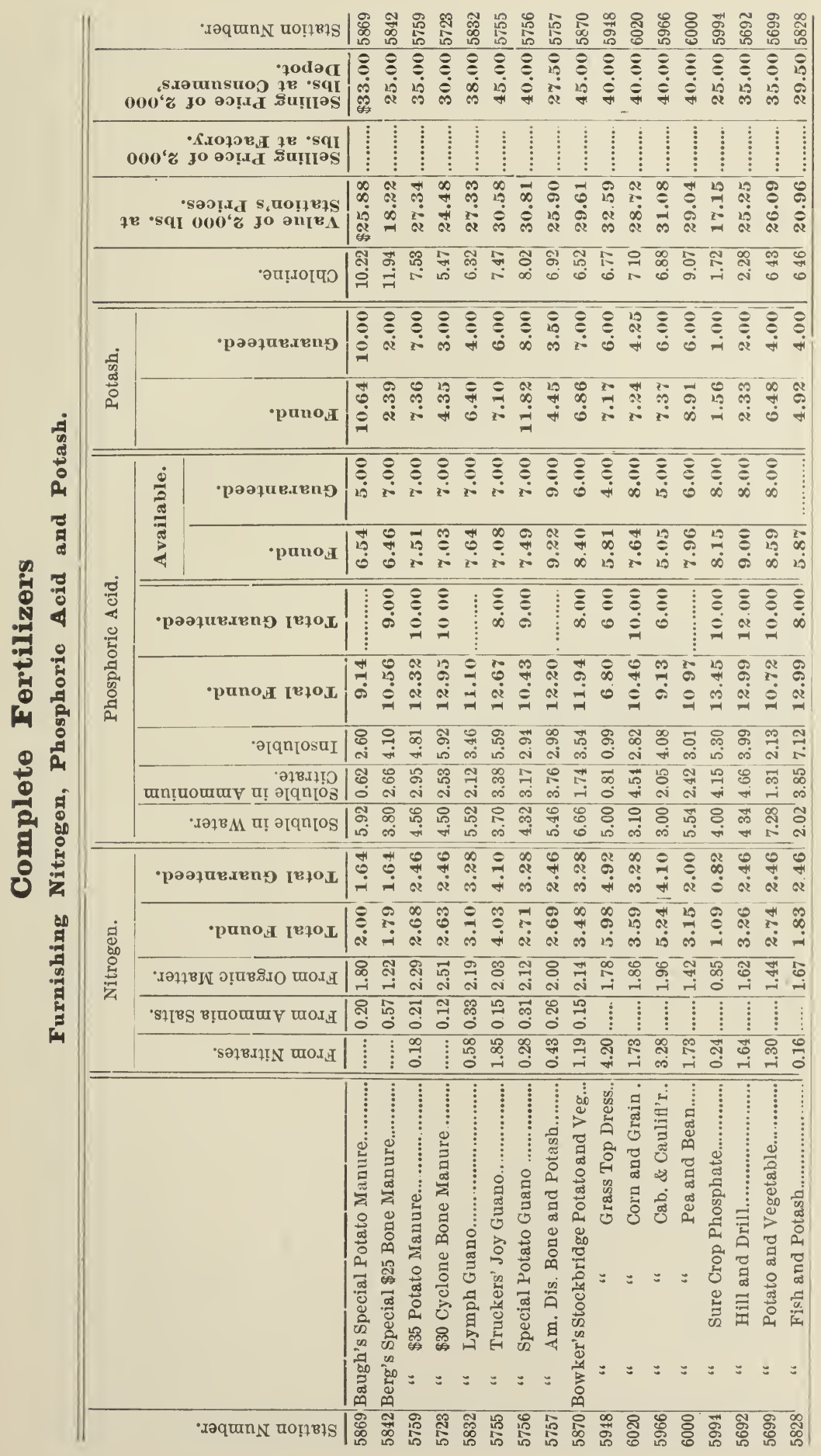




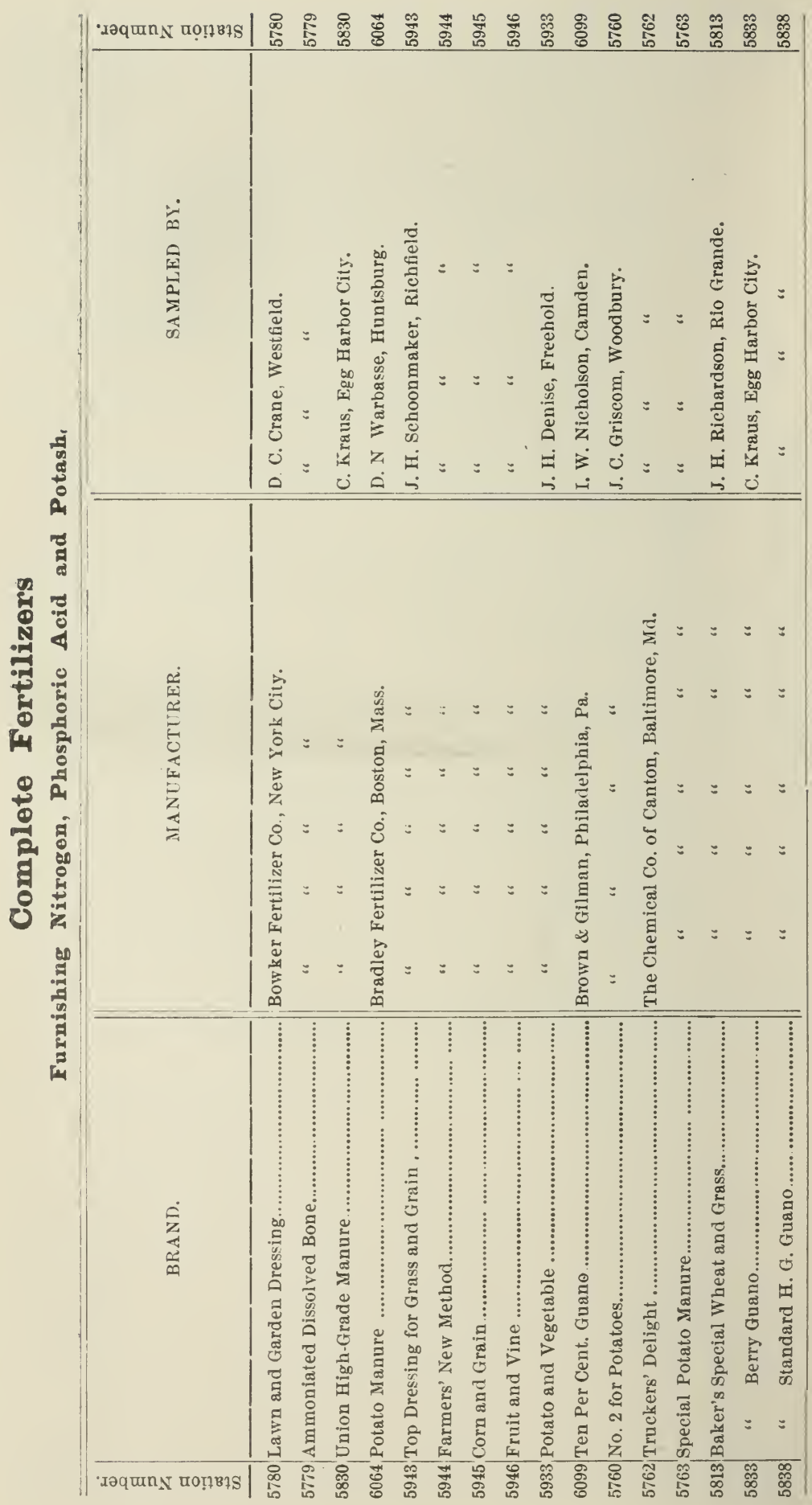




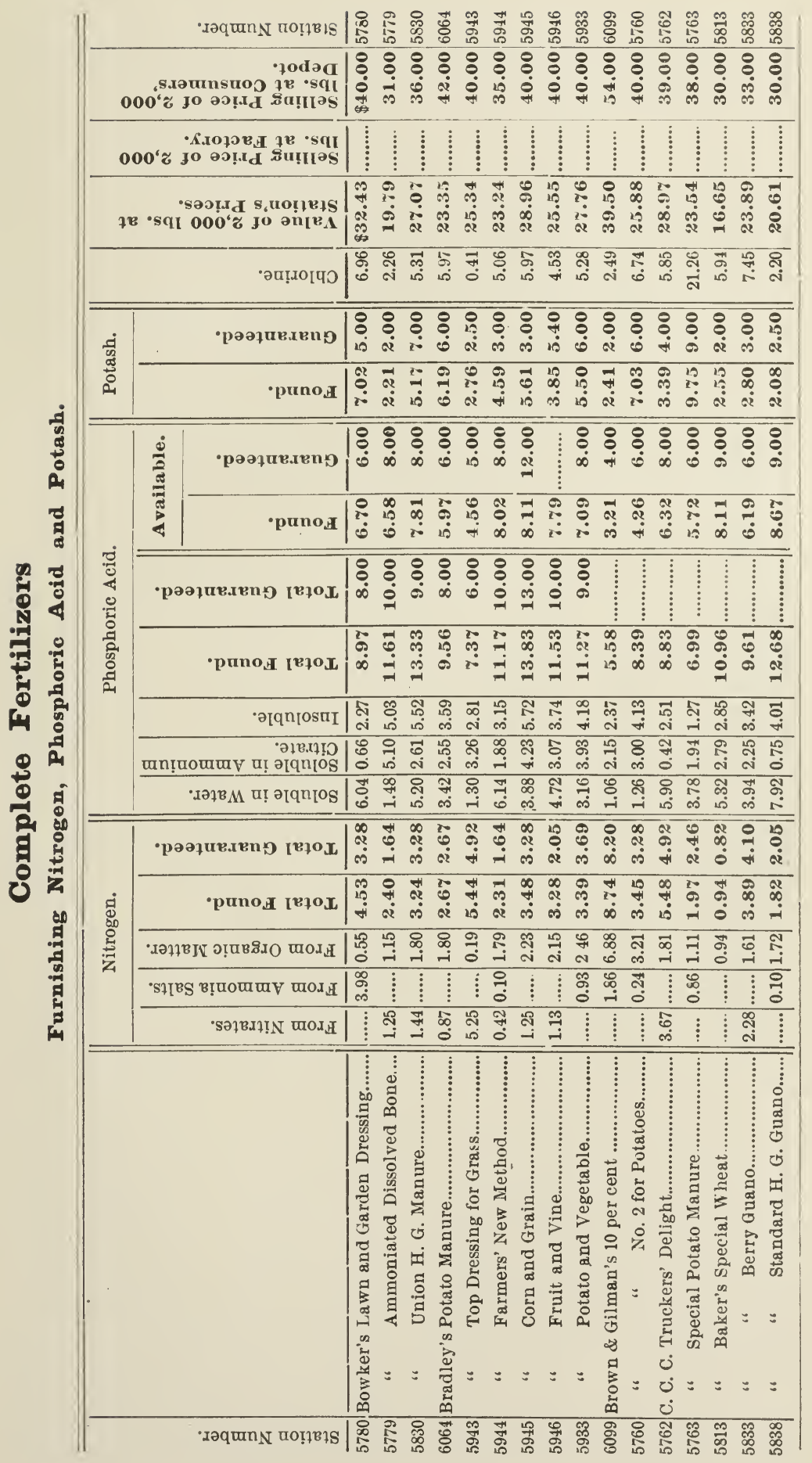




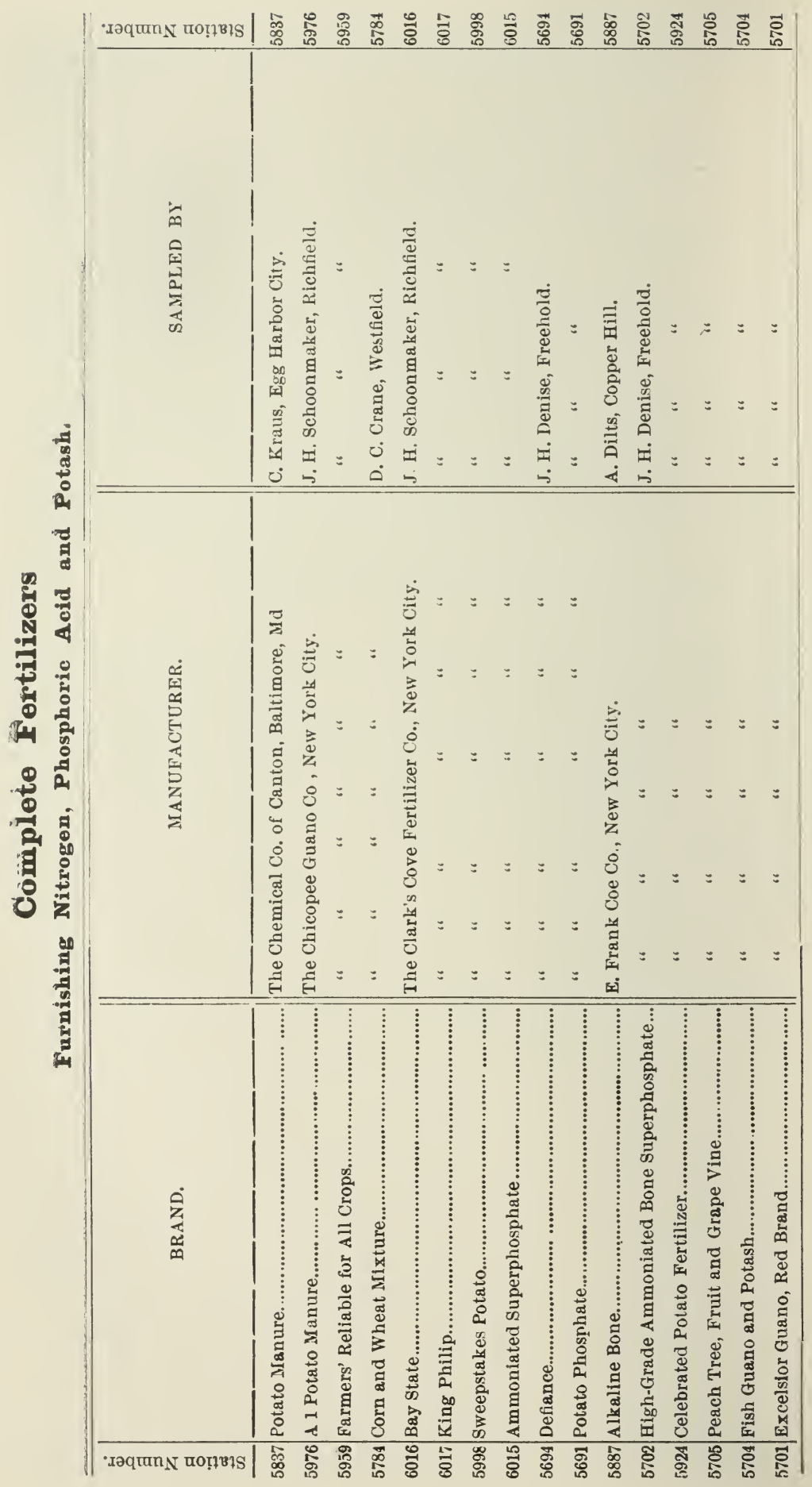




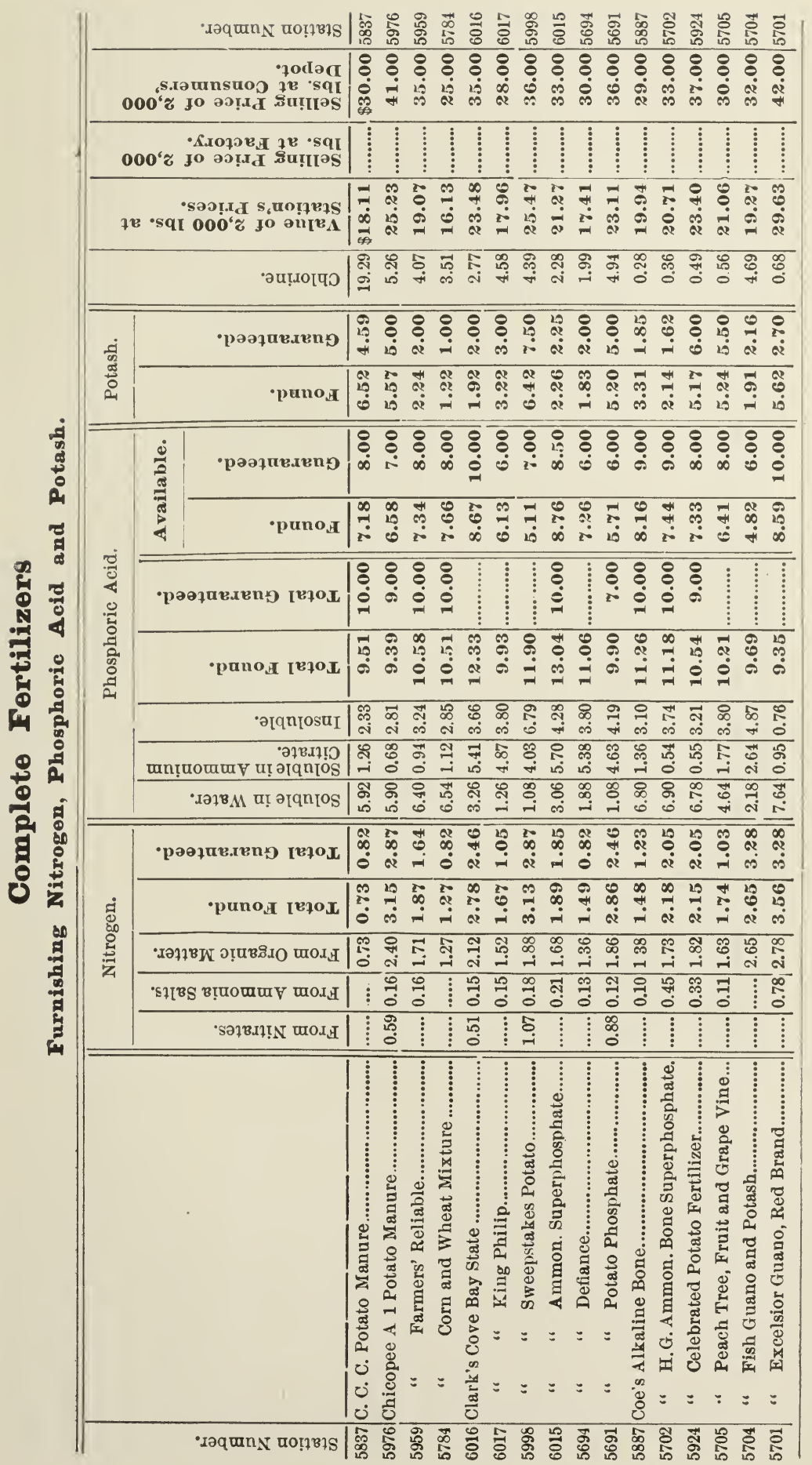




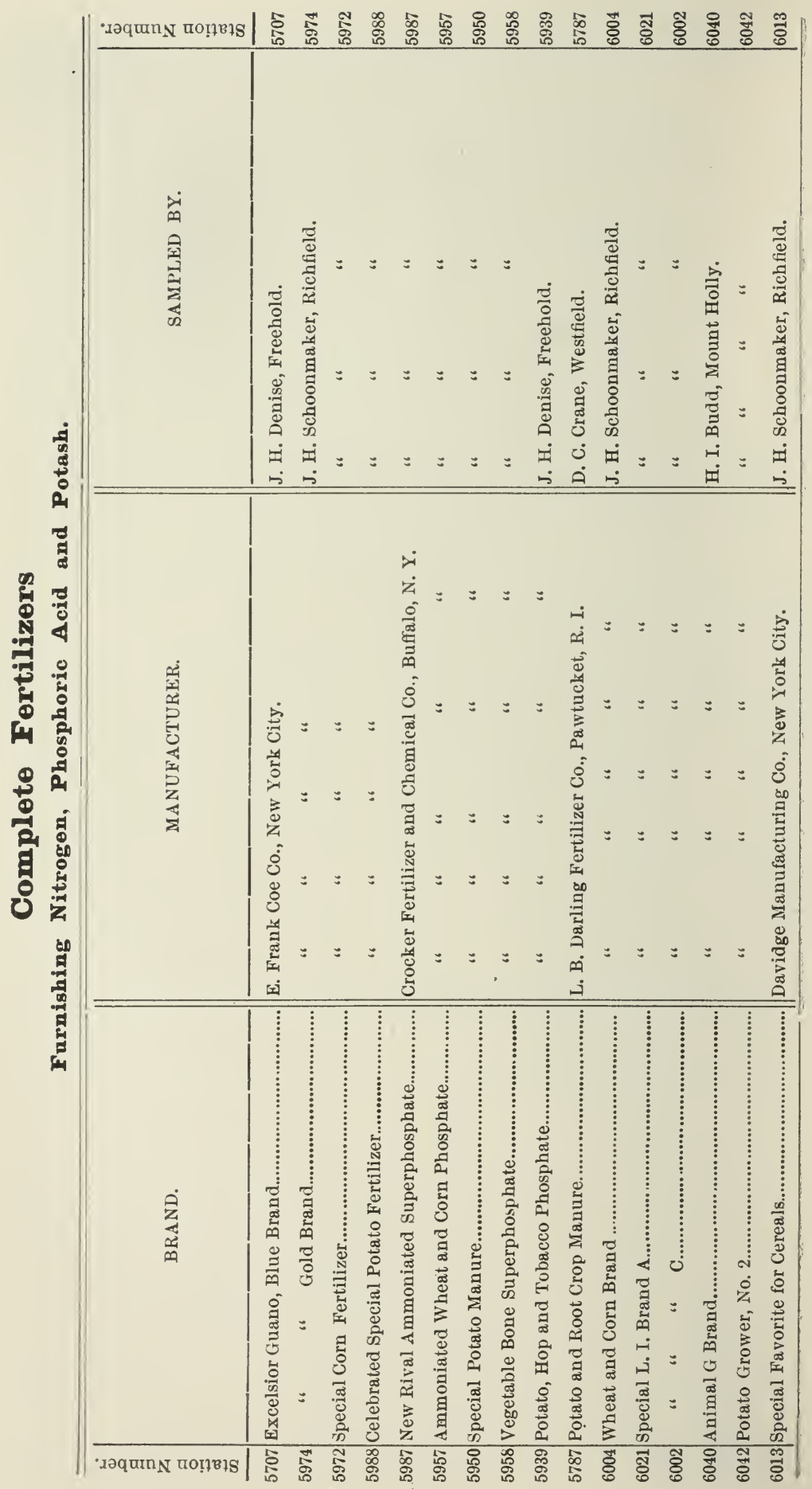




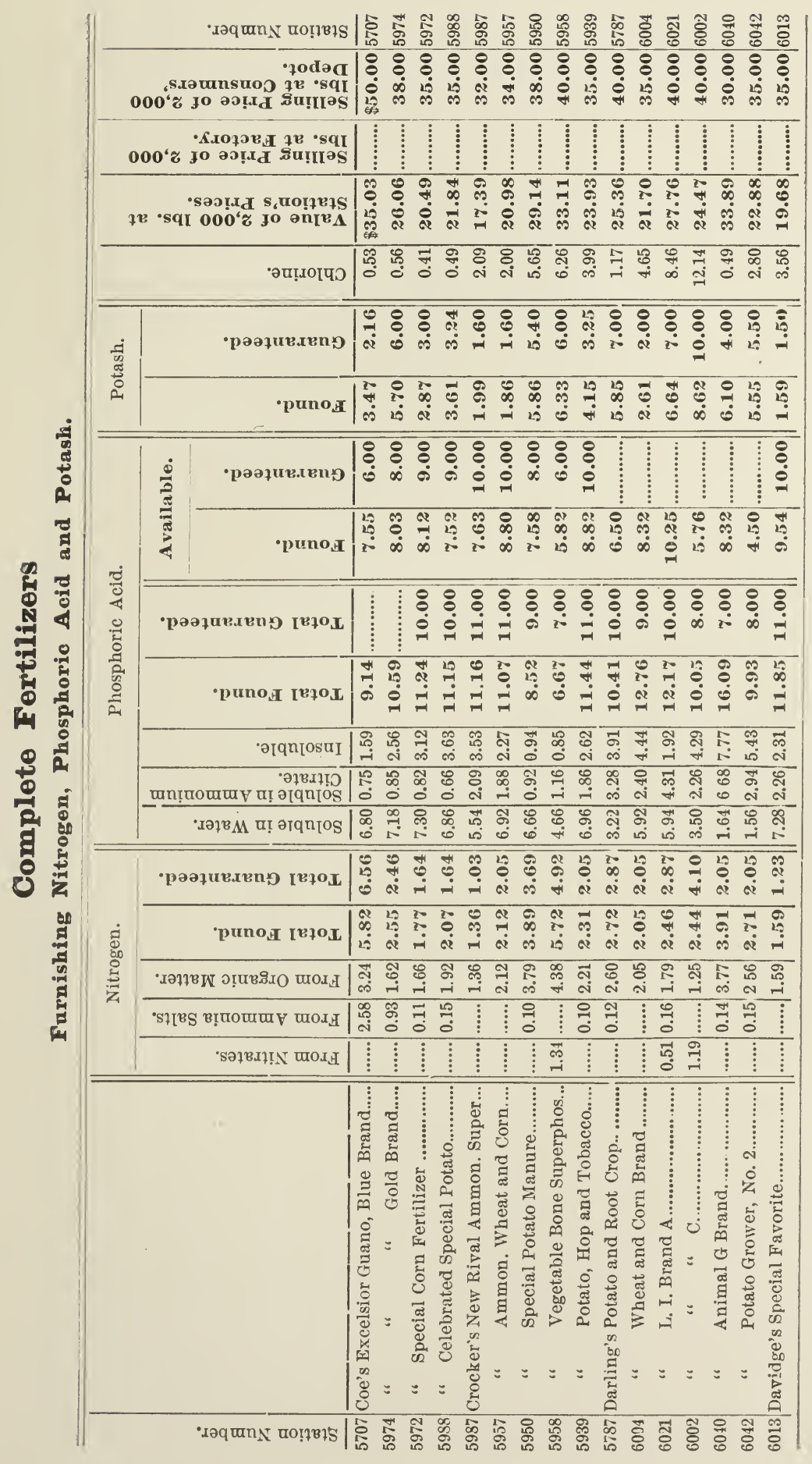




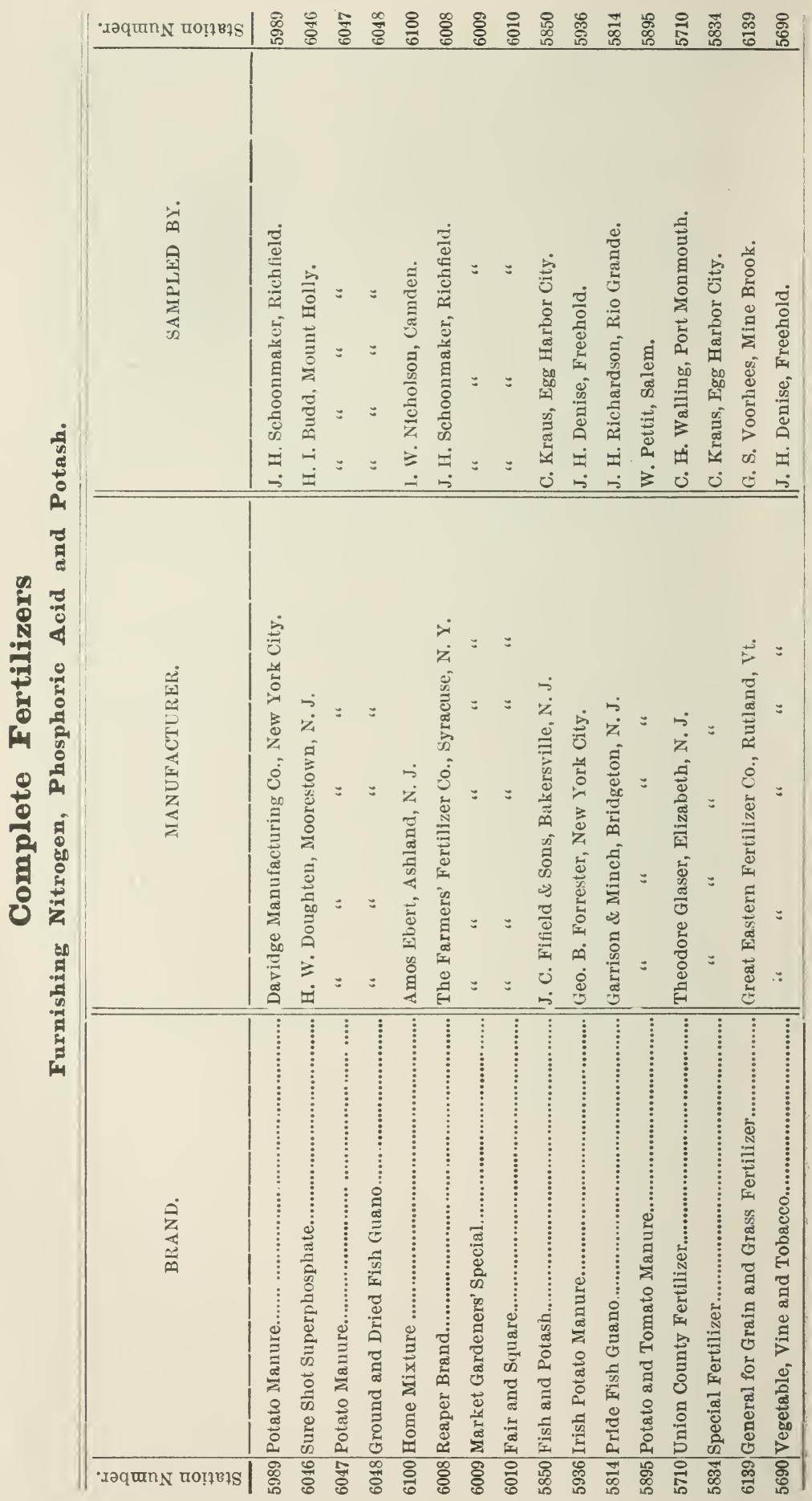




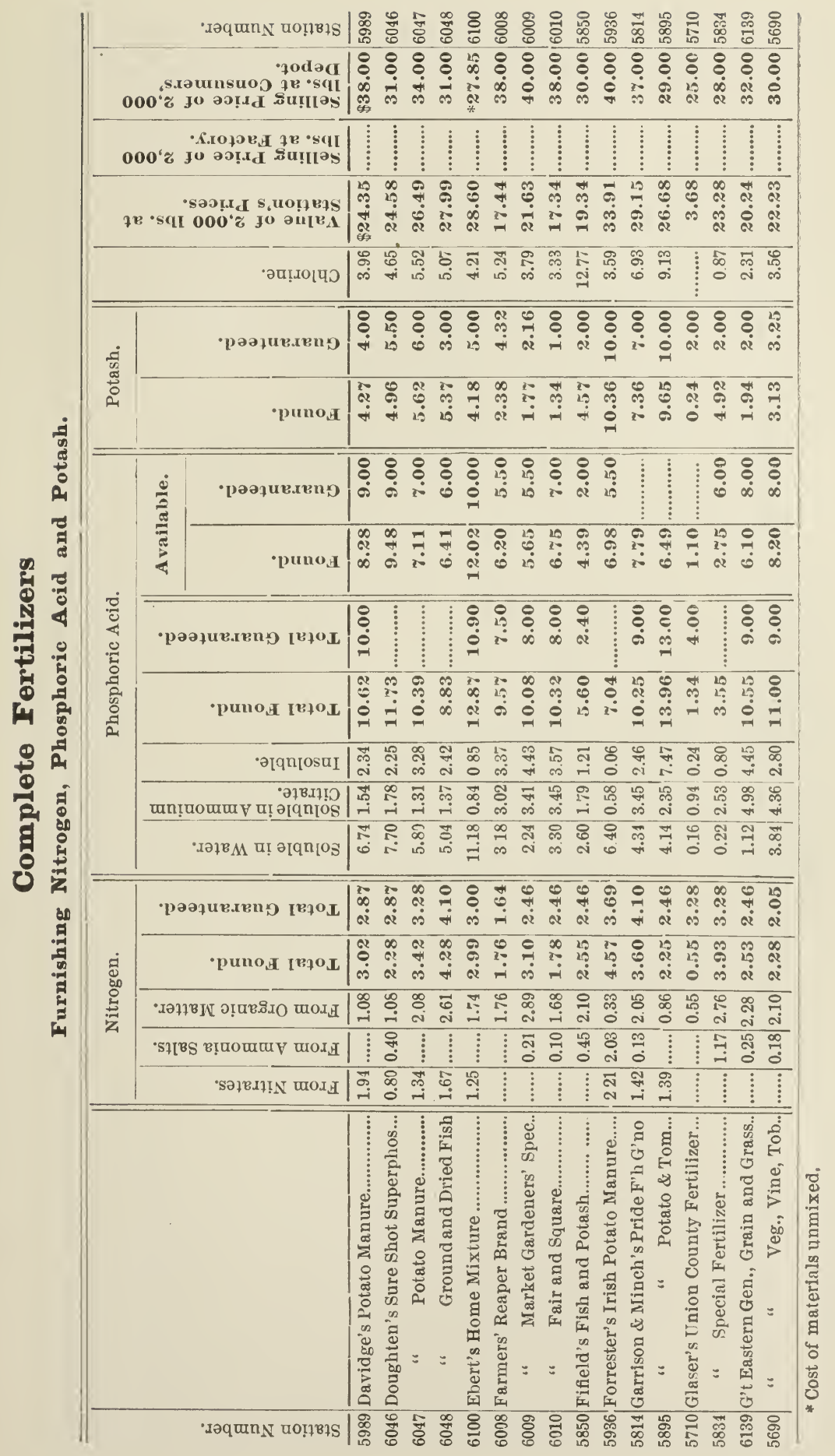




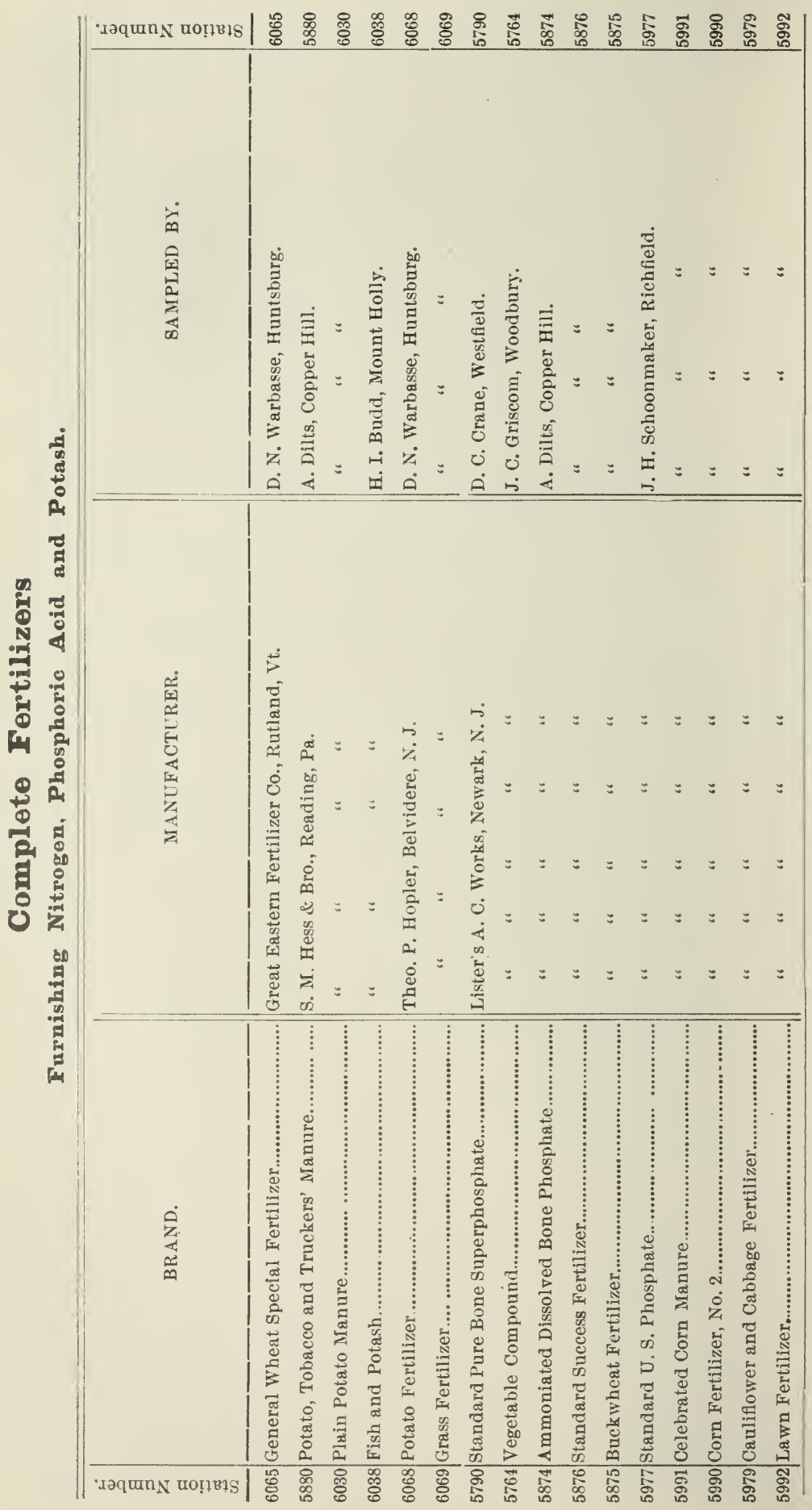




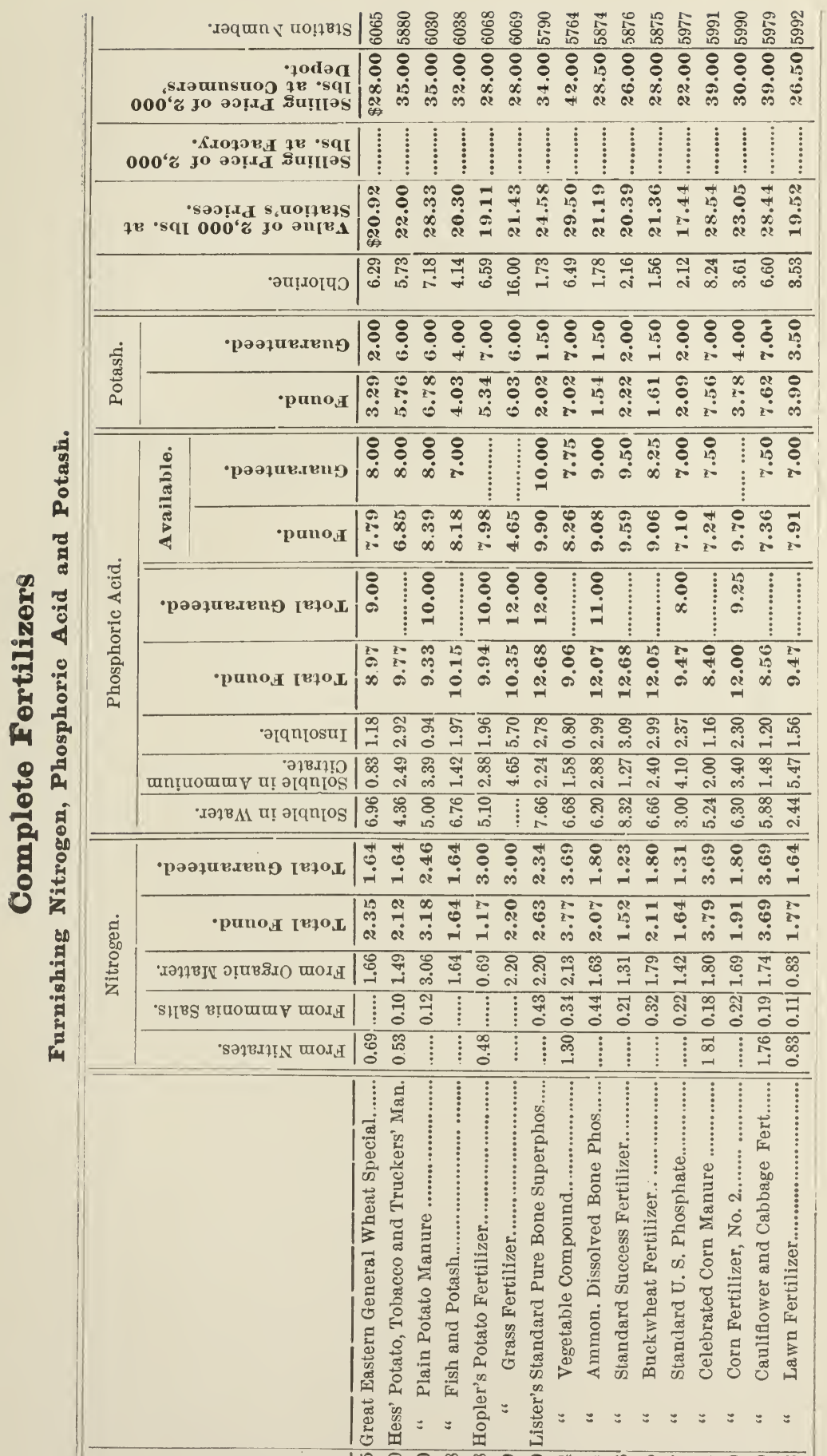

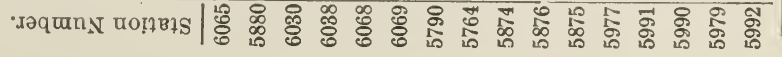




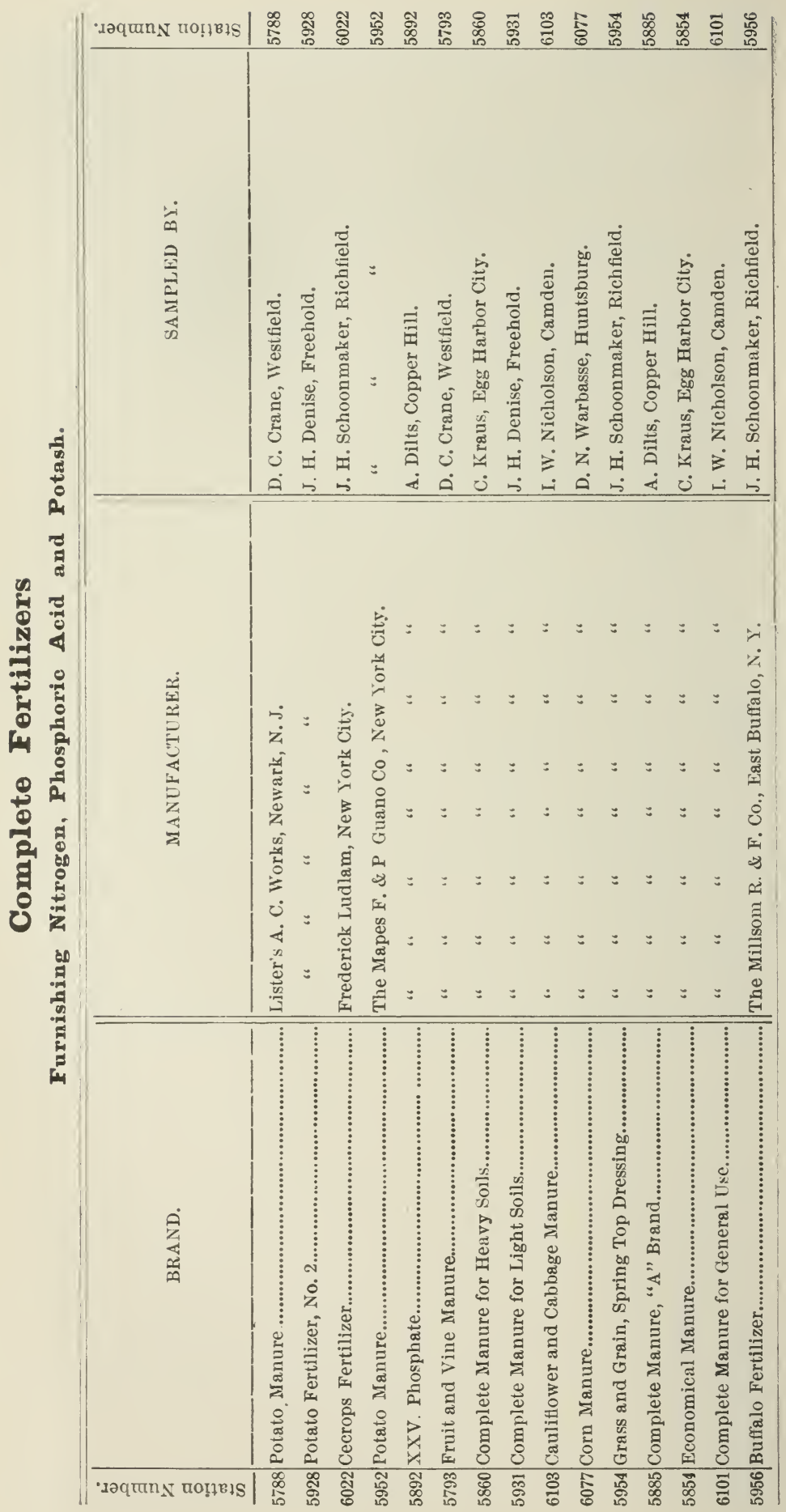




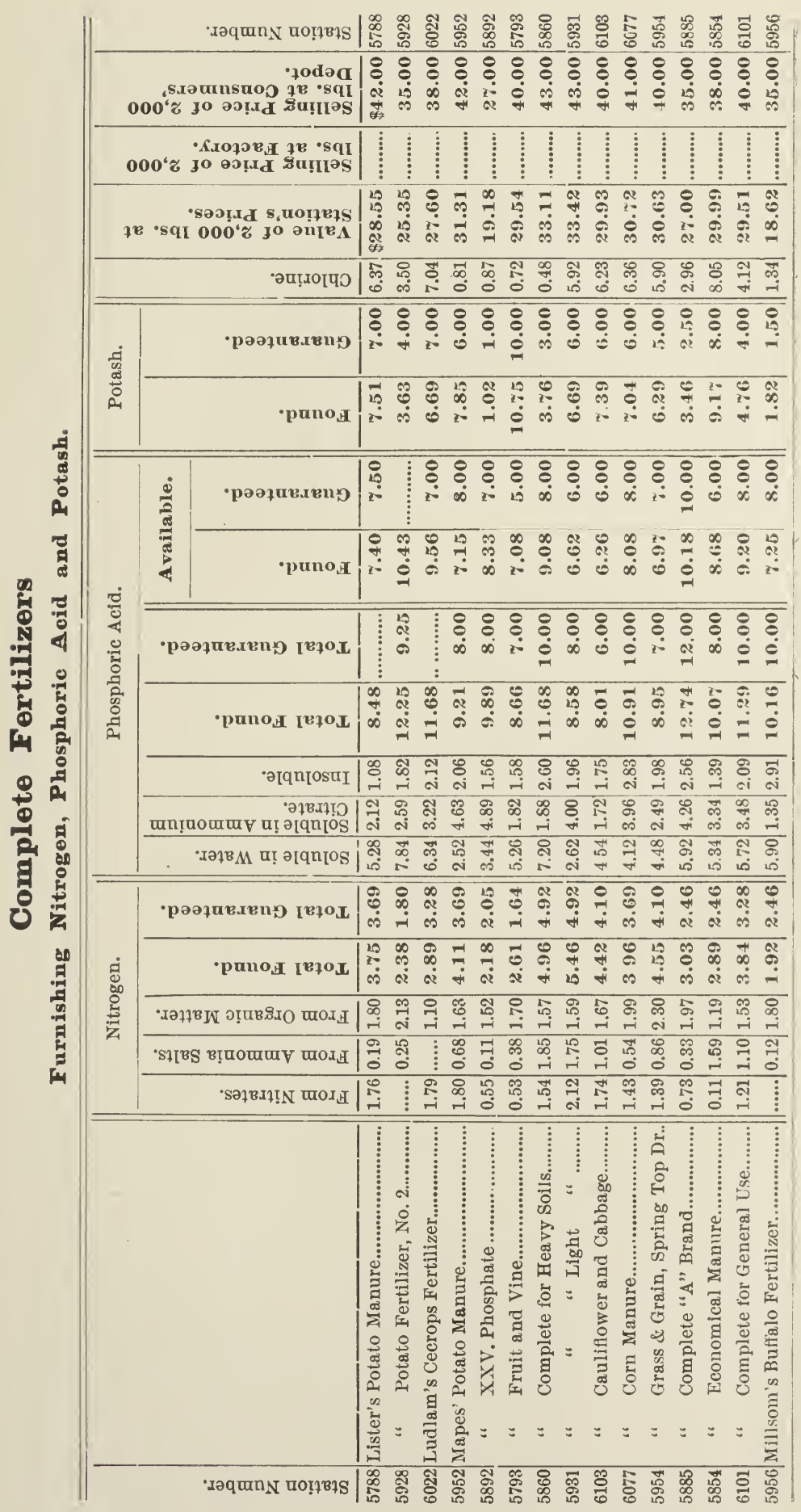




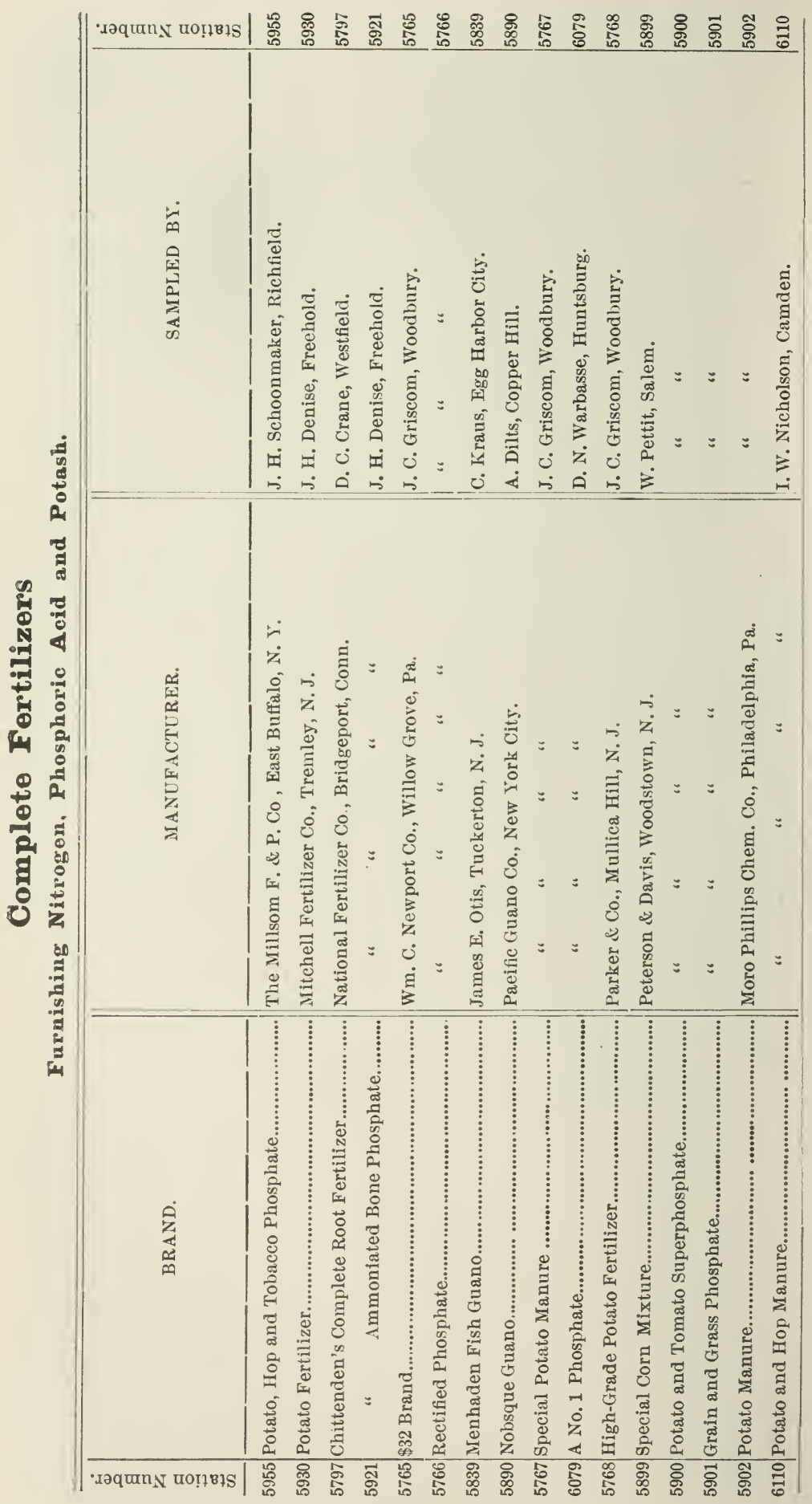




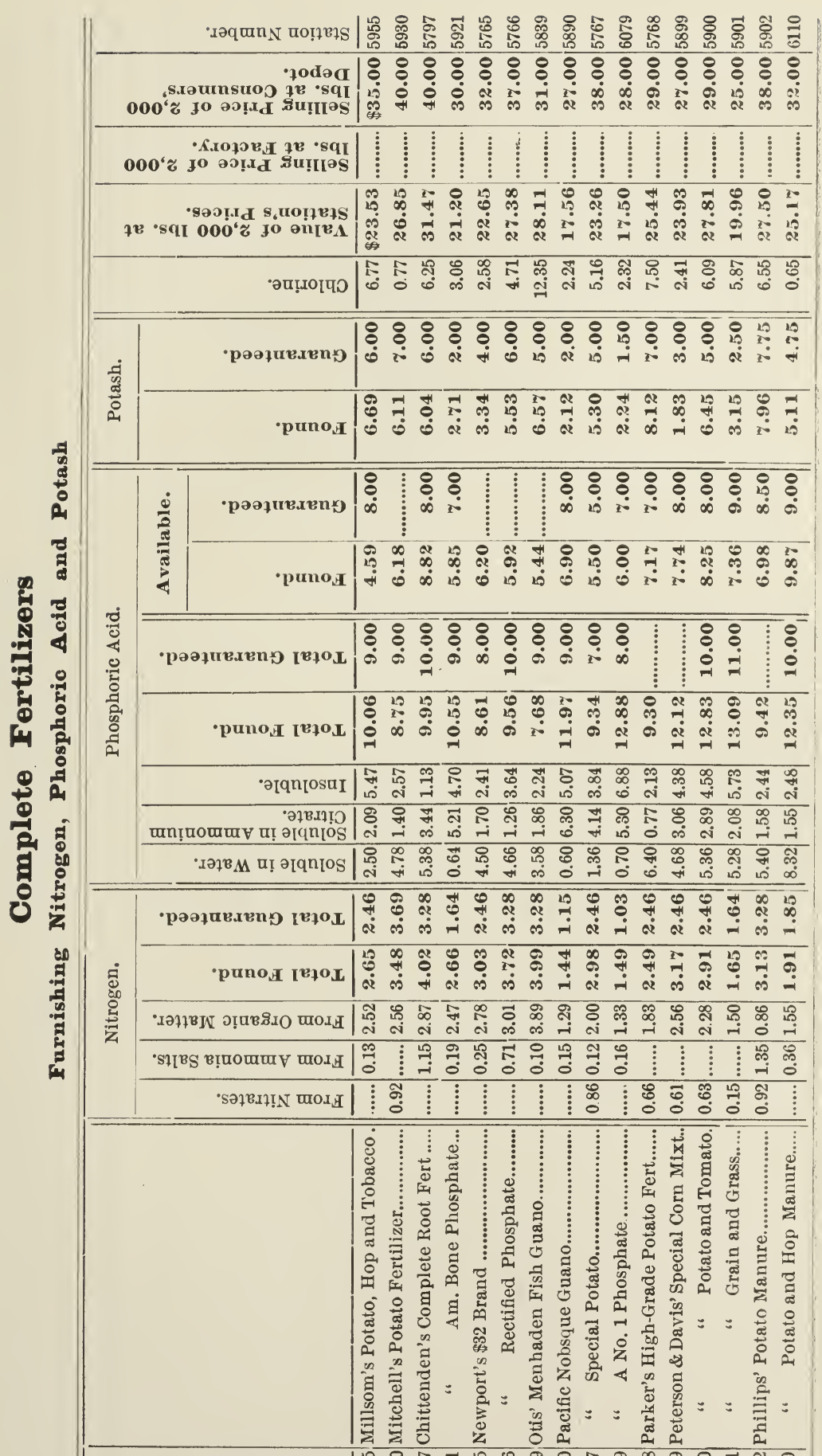

'xəqunN 


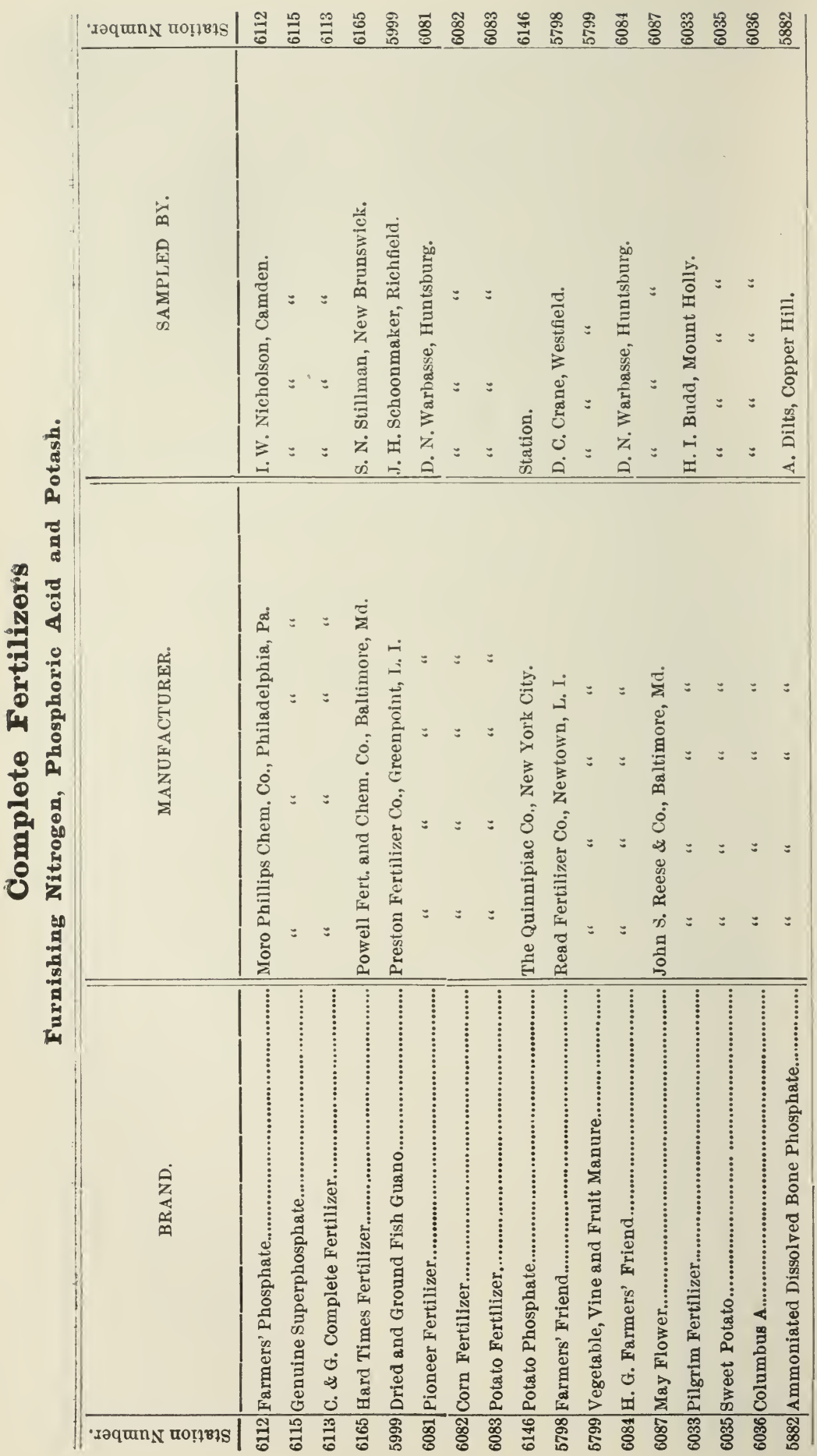




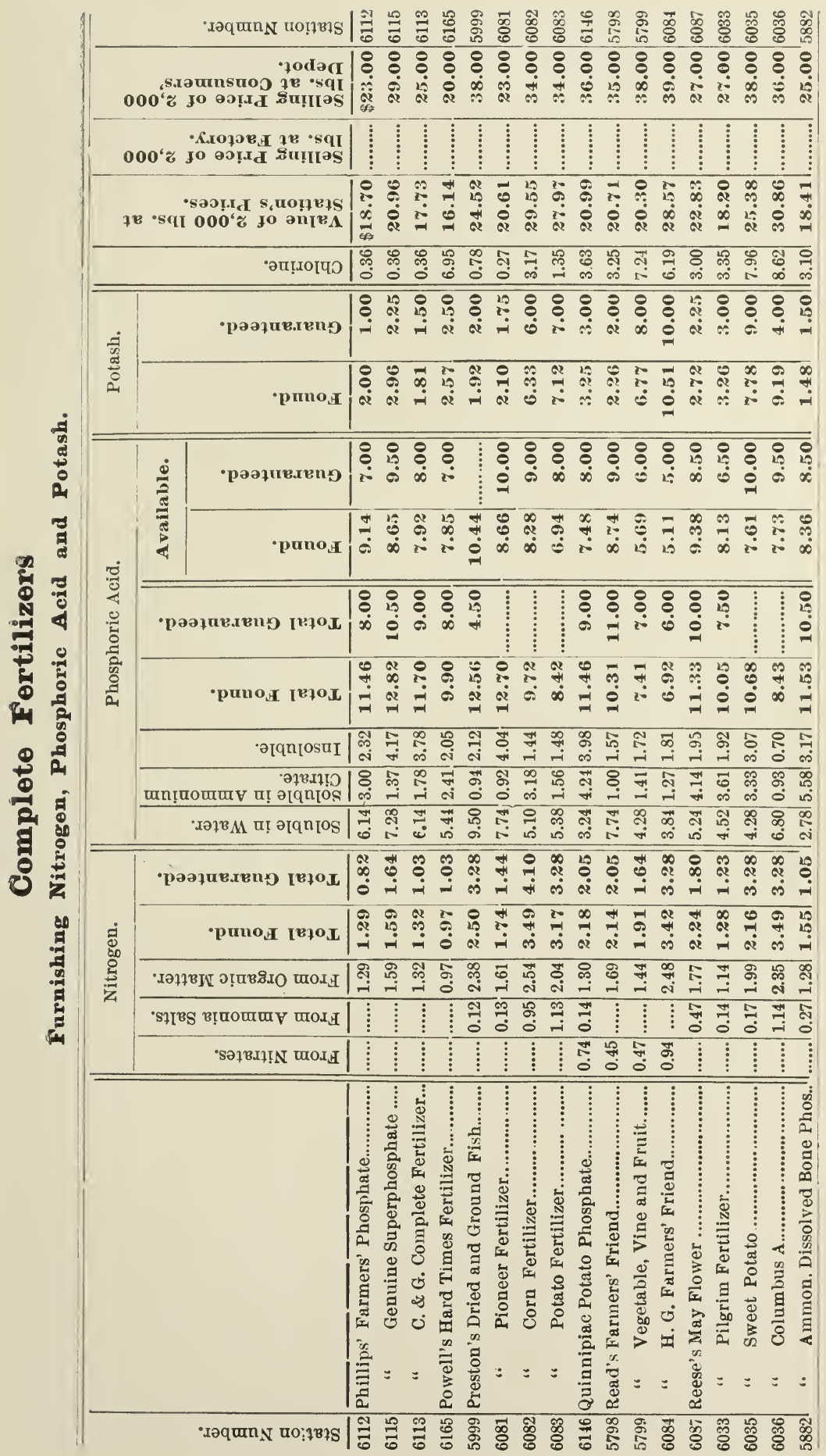




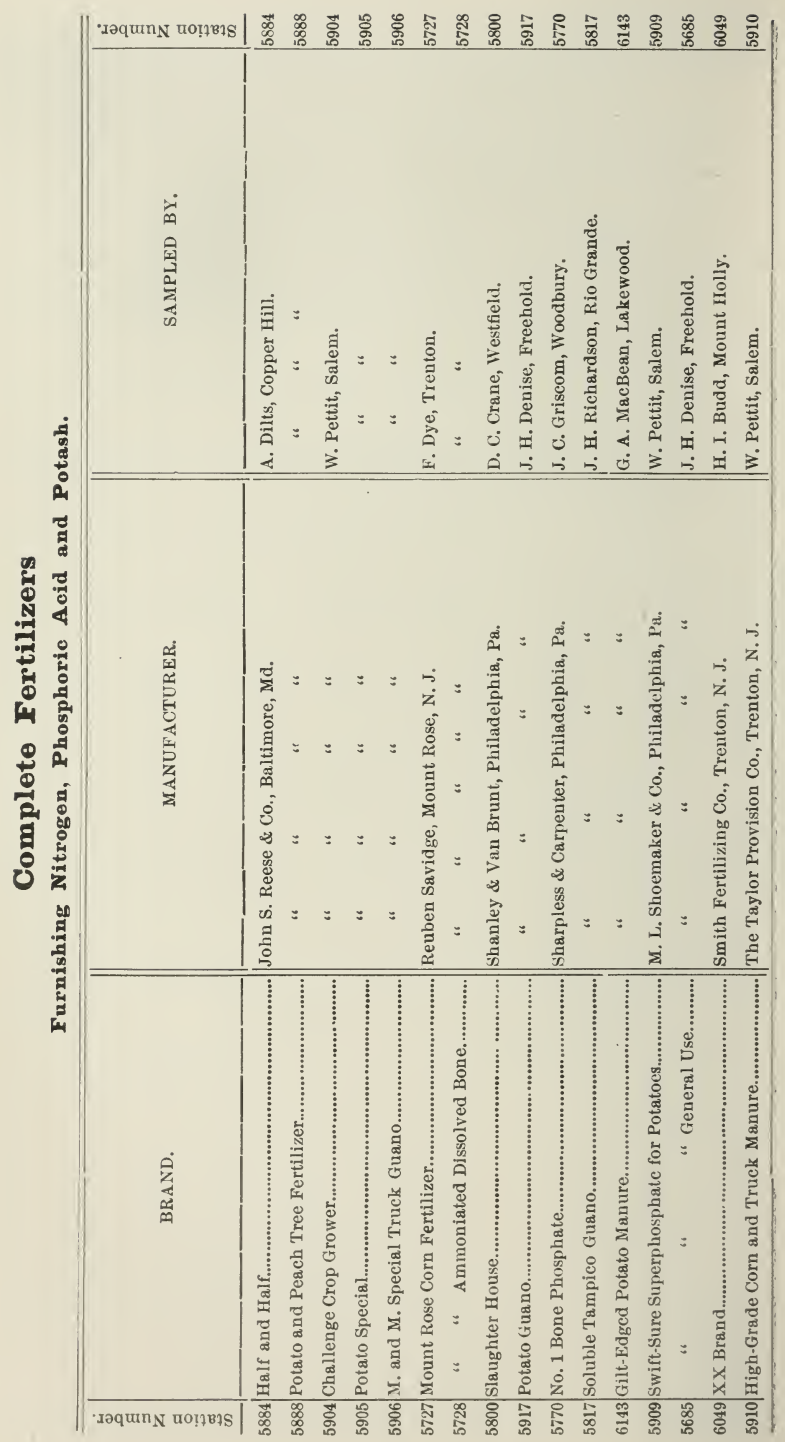




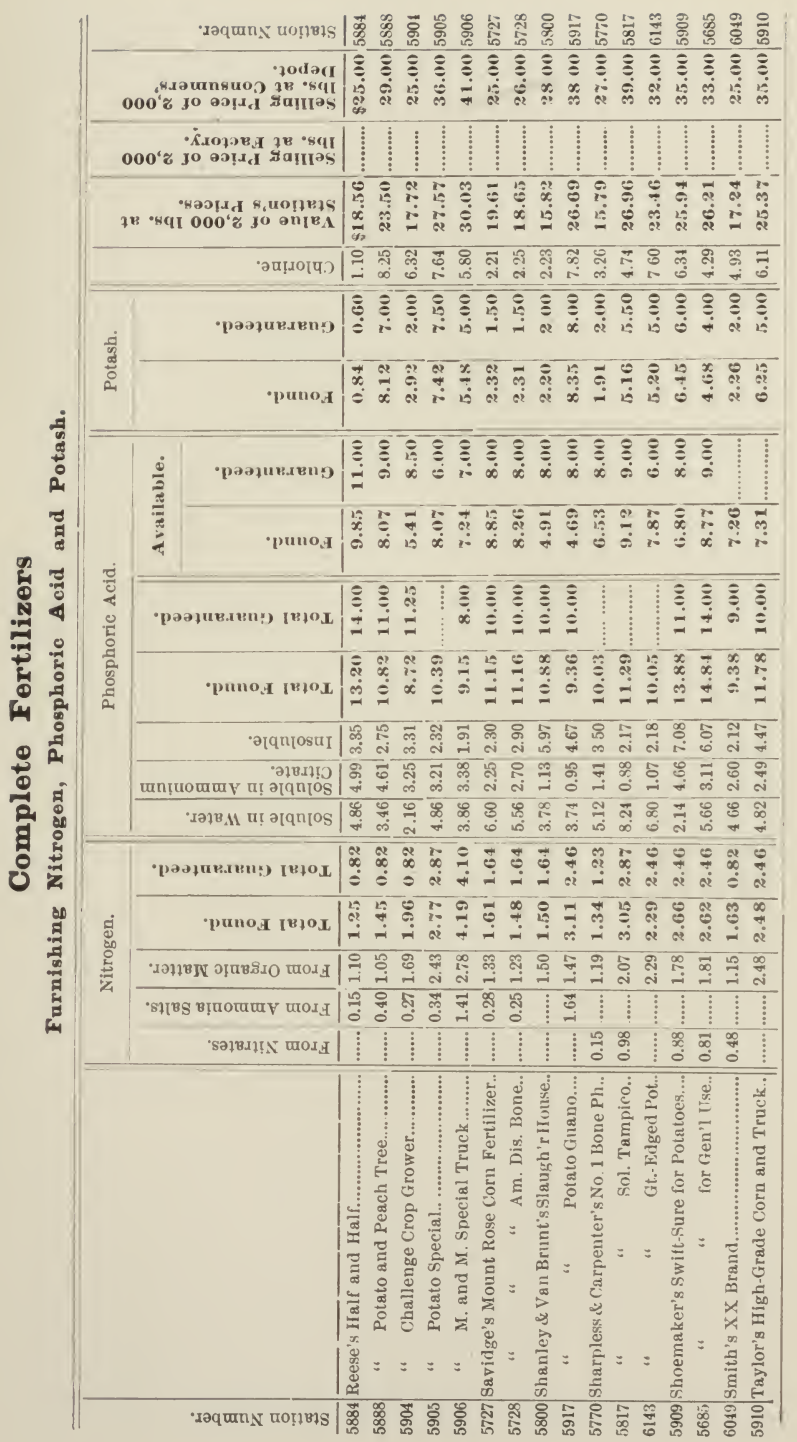




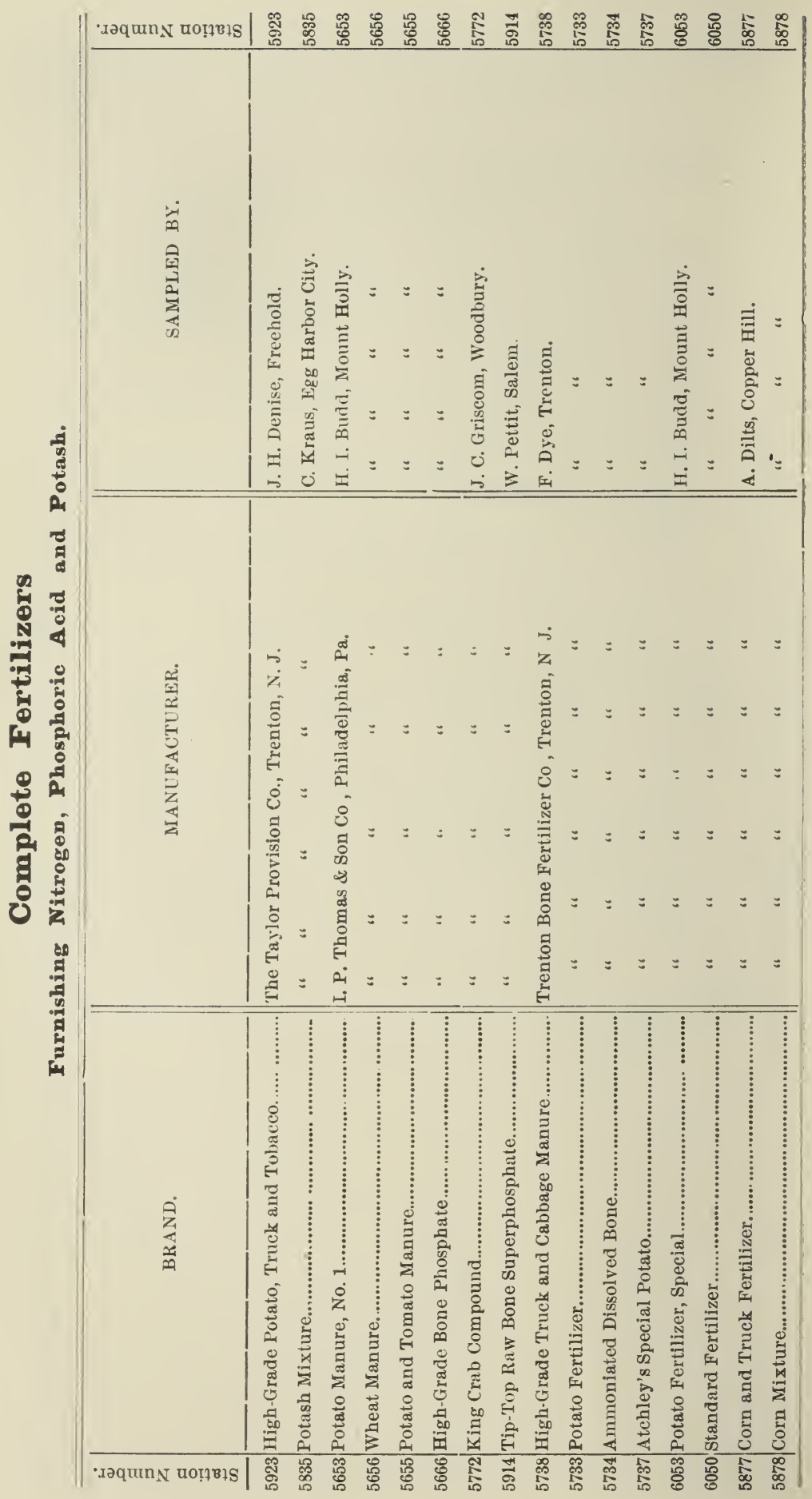




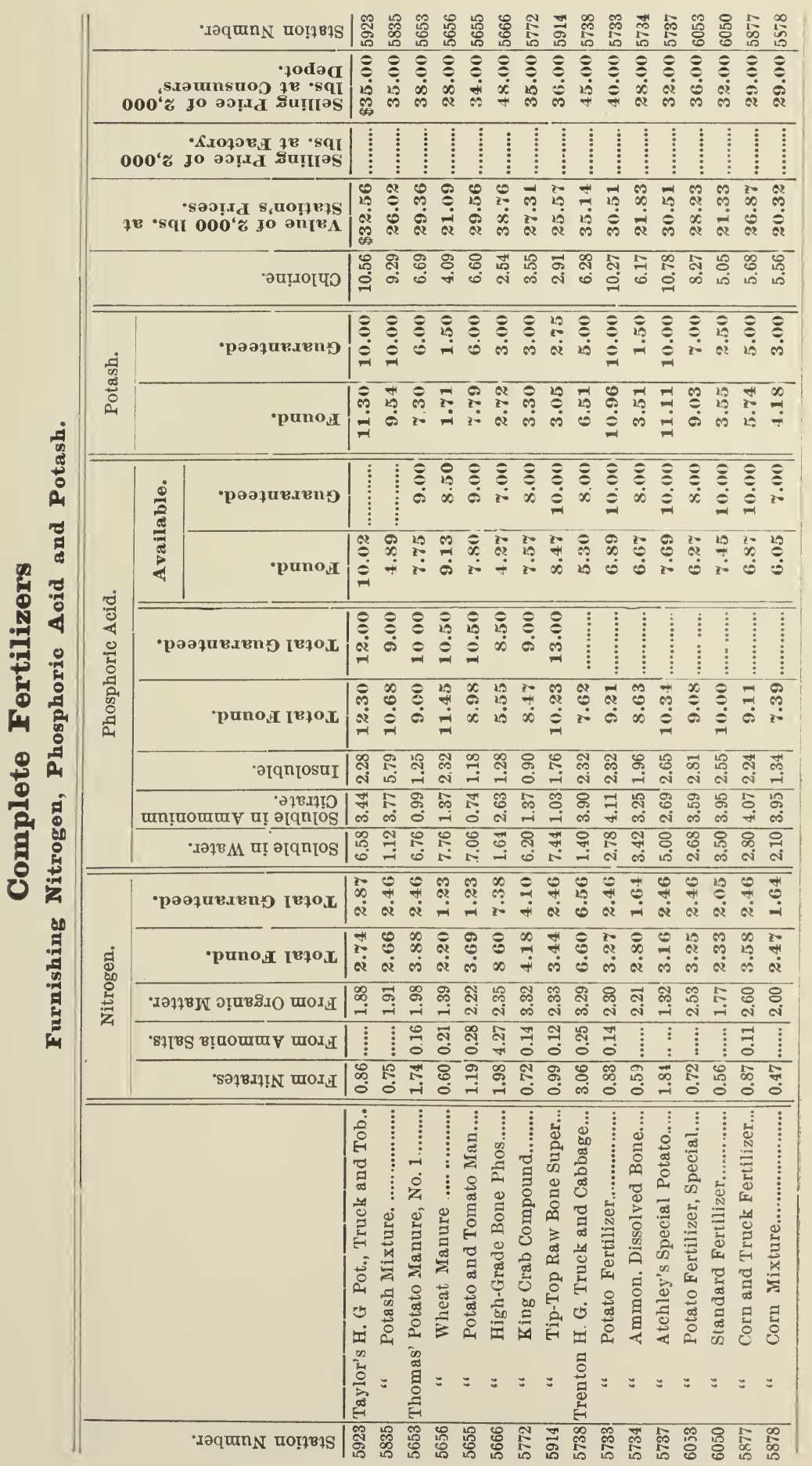




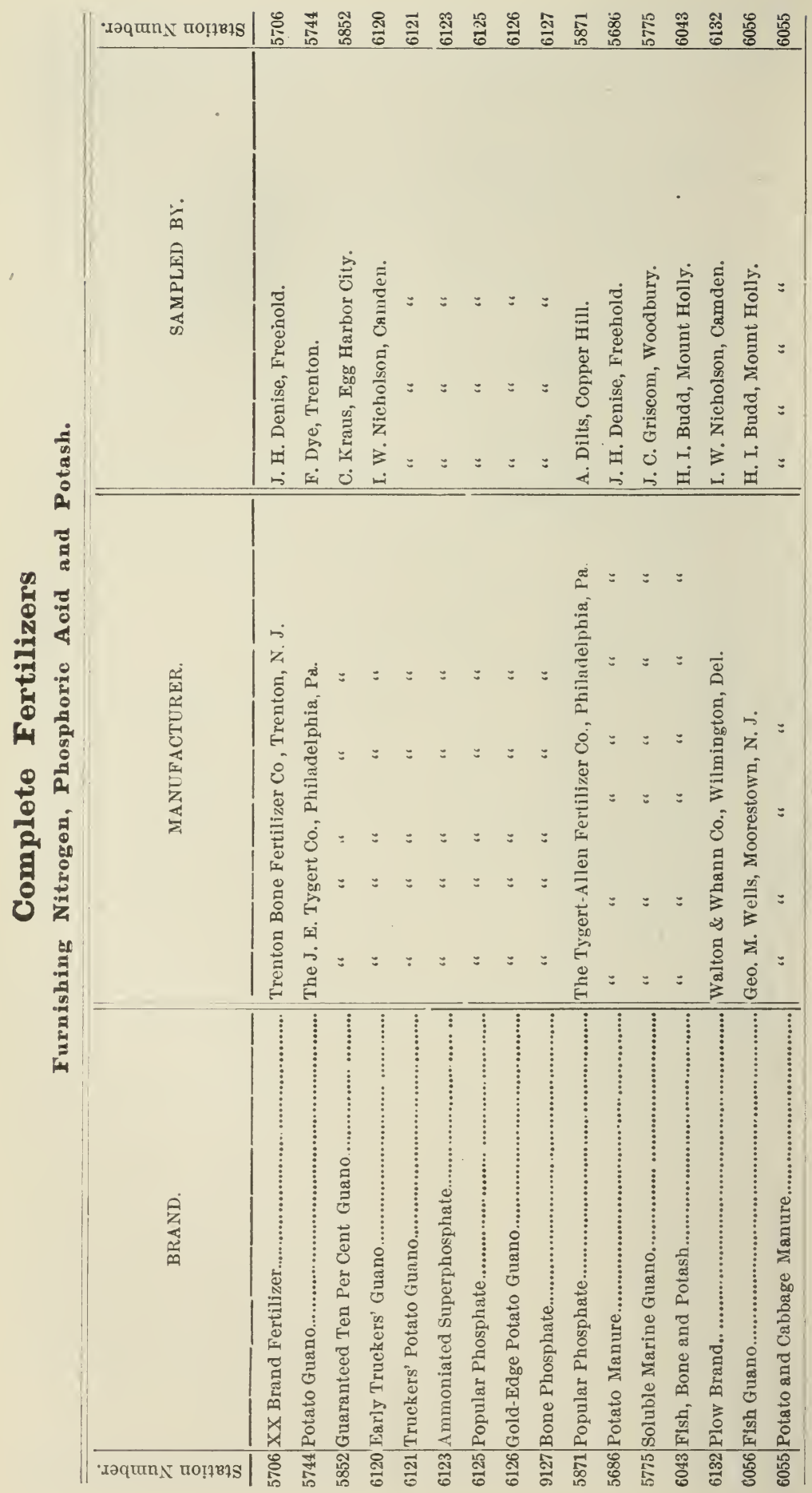




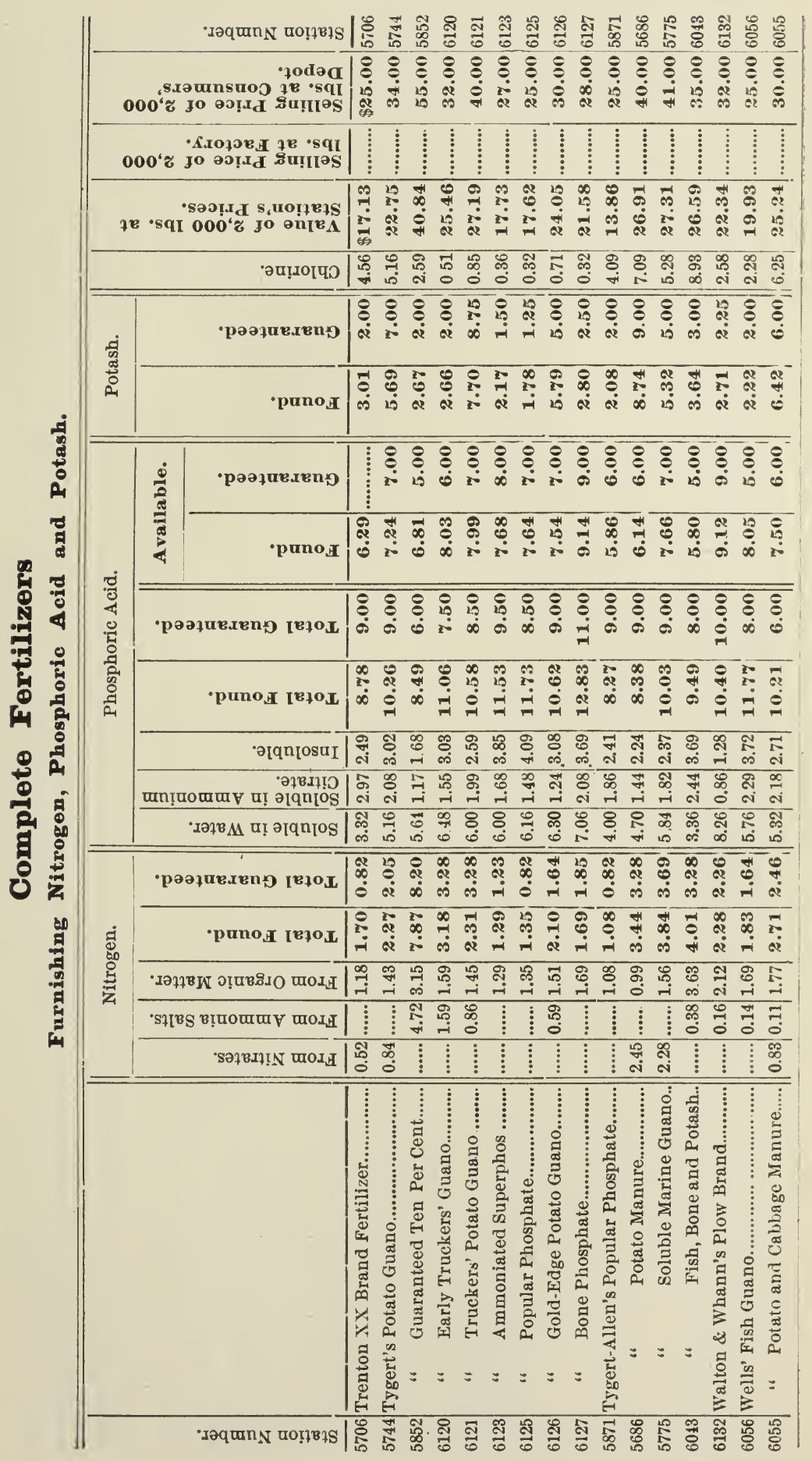


$3 S$

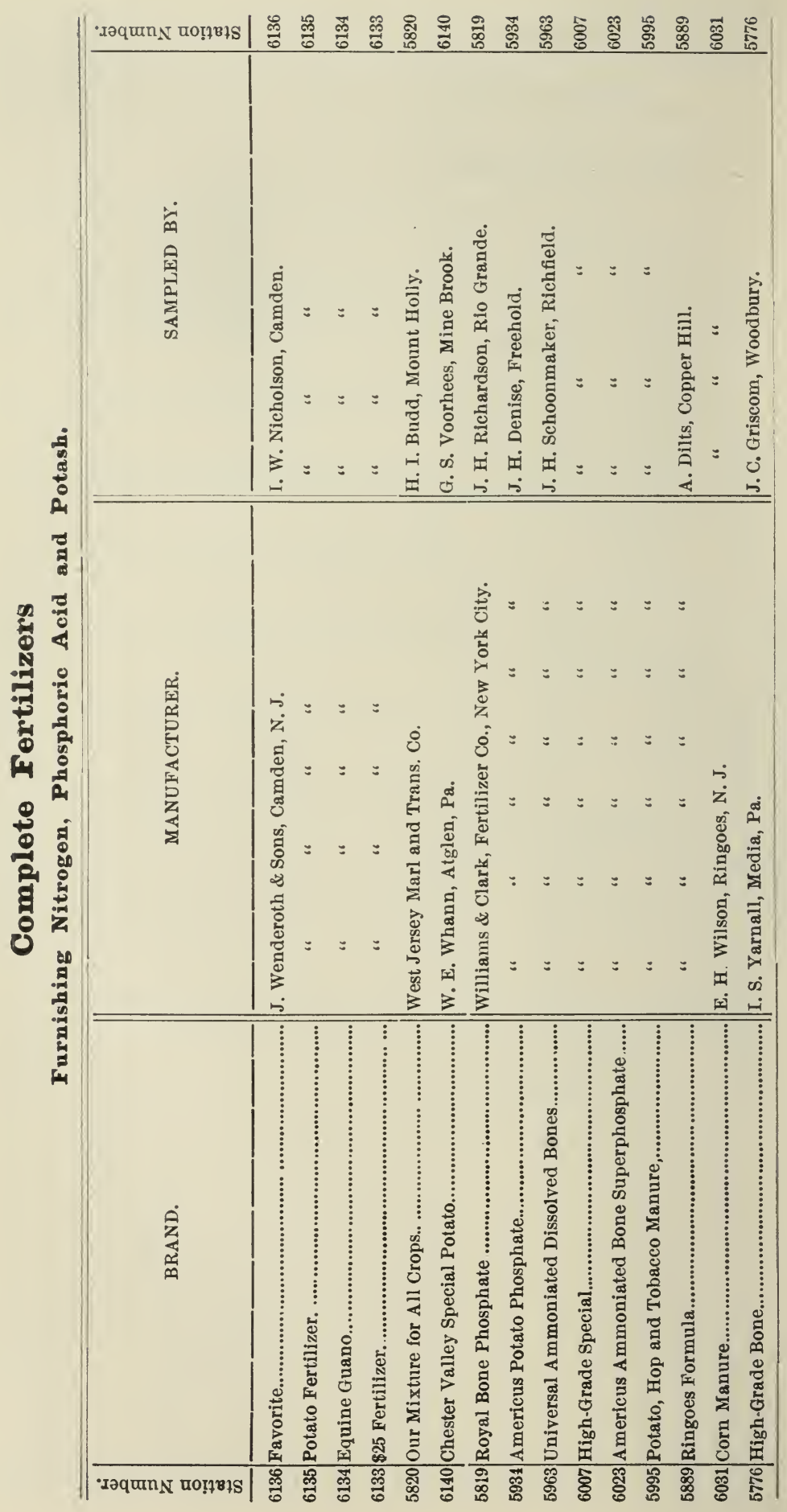




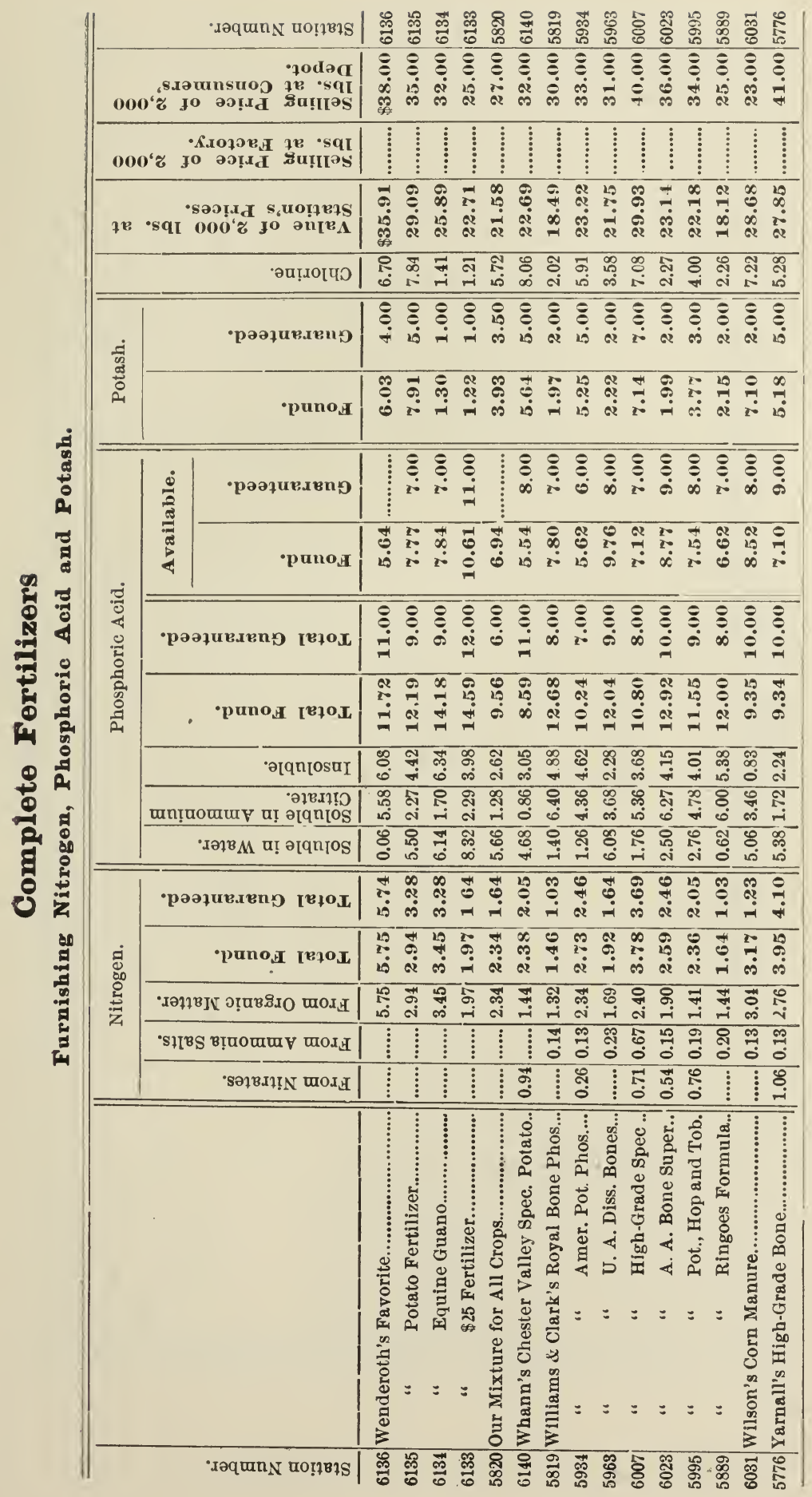




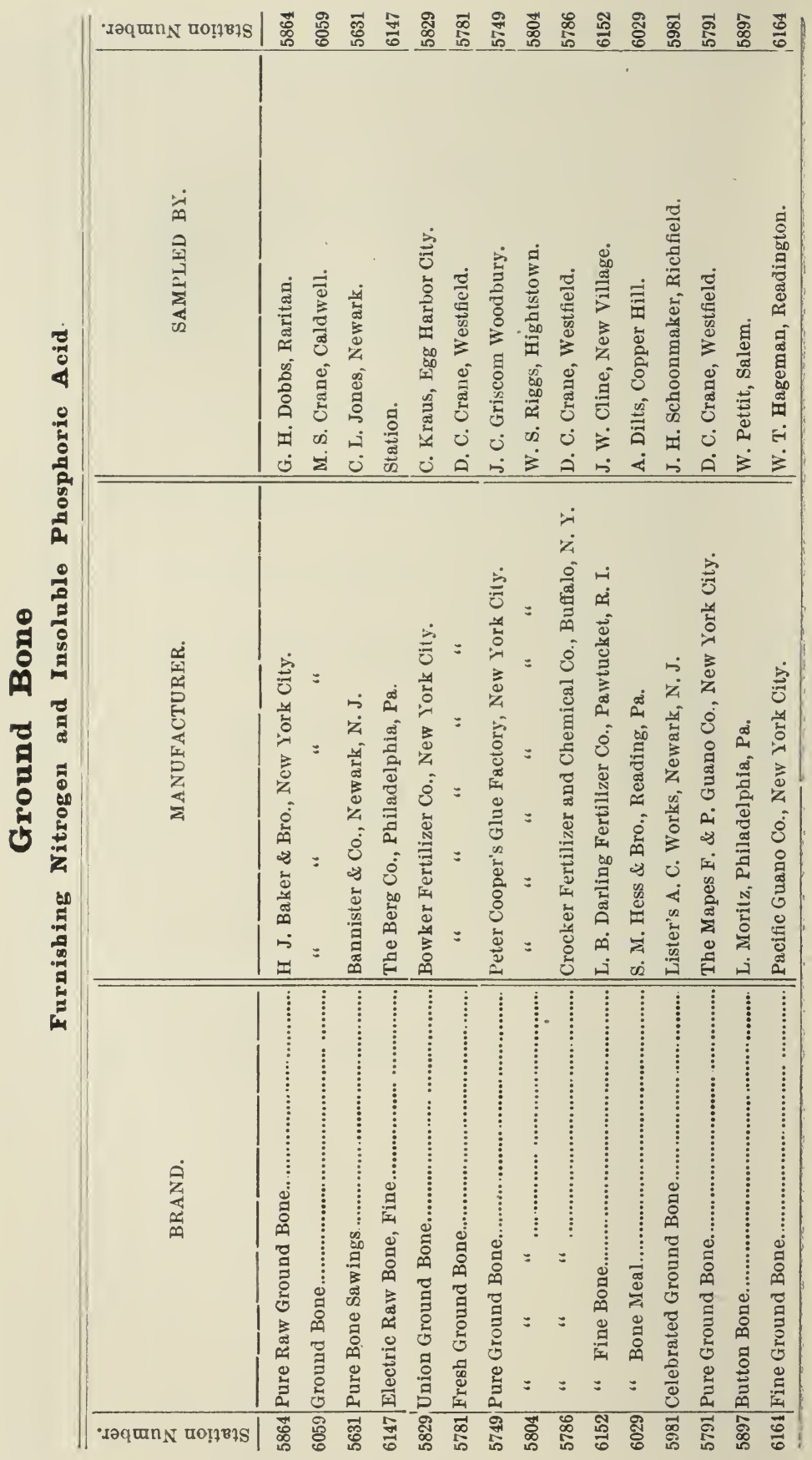




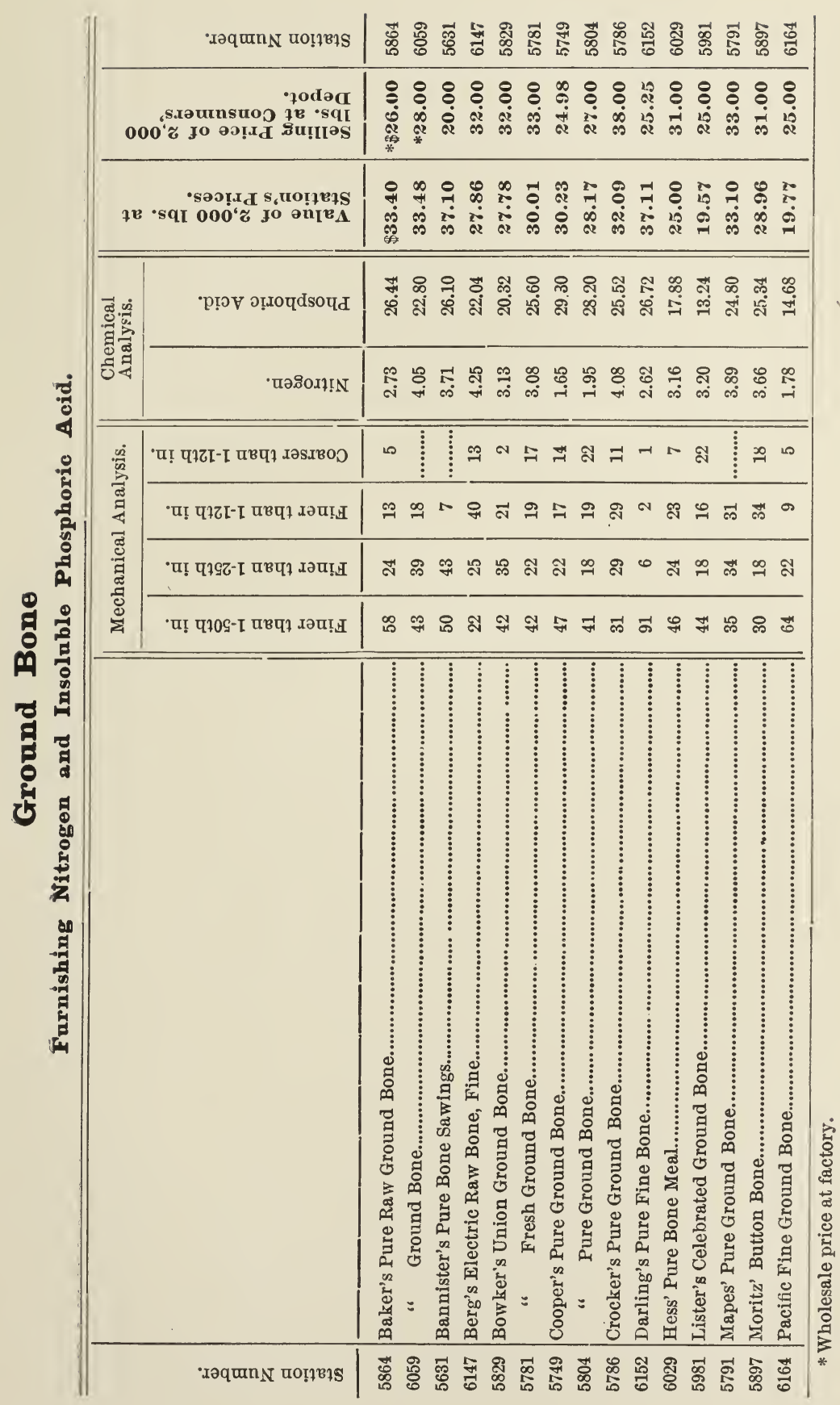




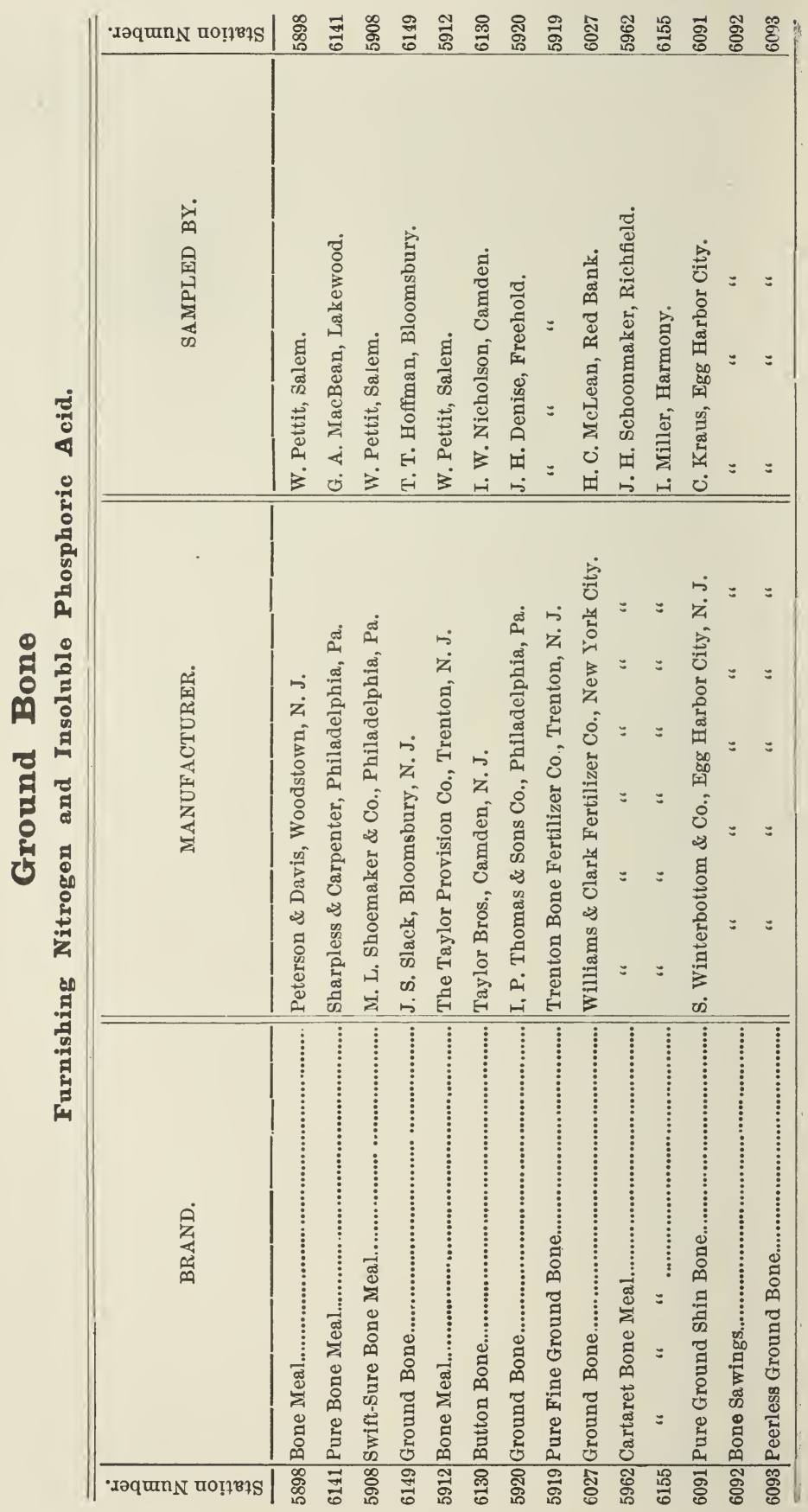




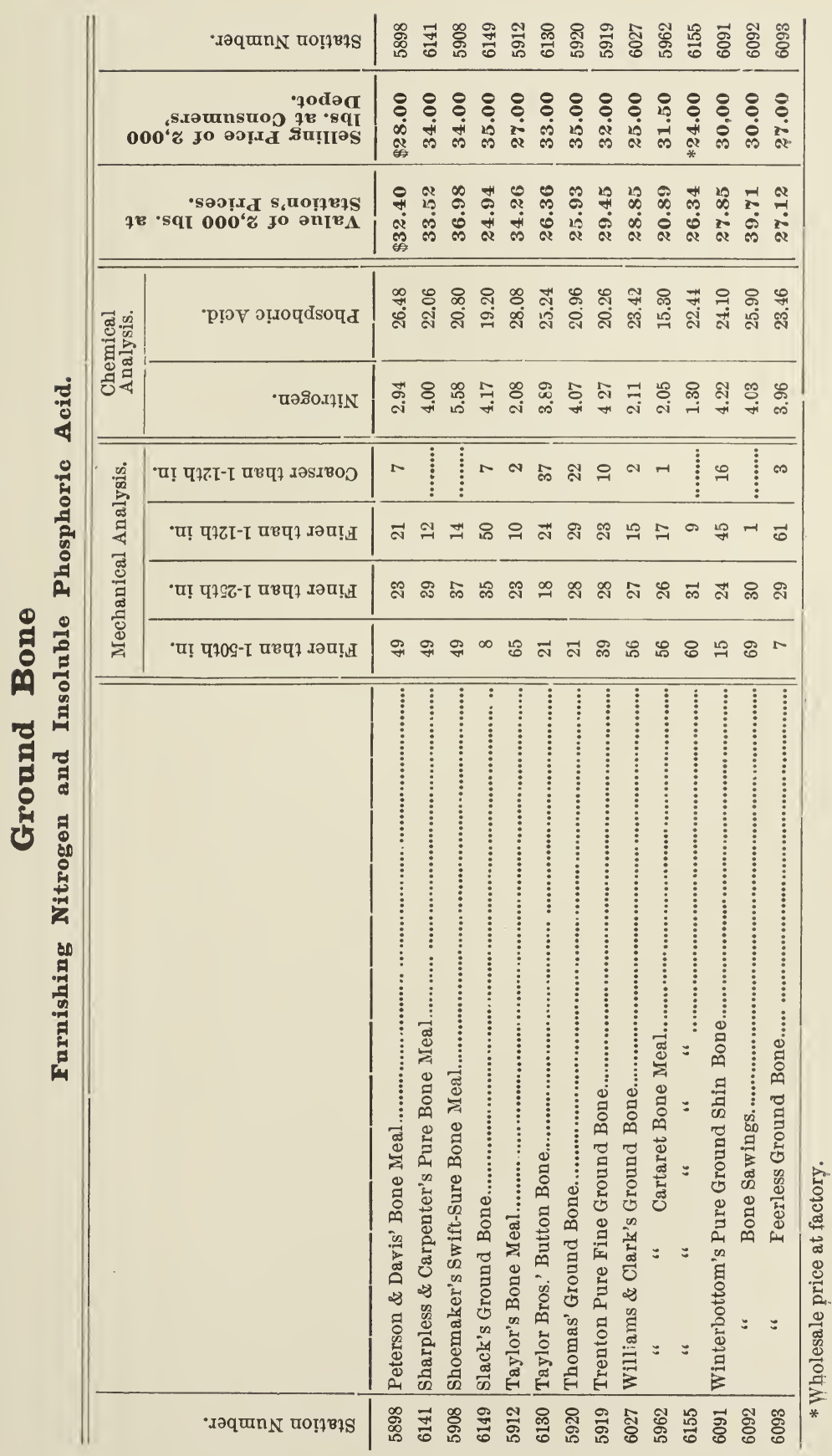




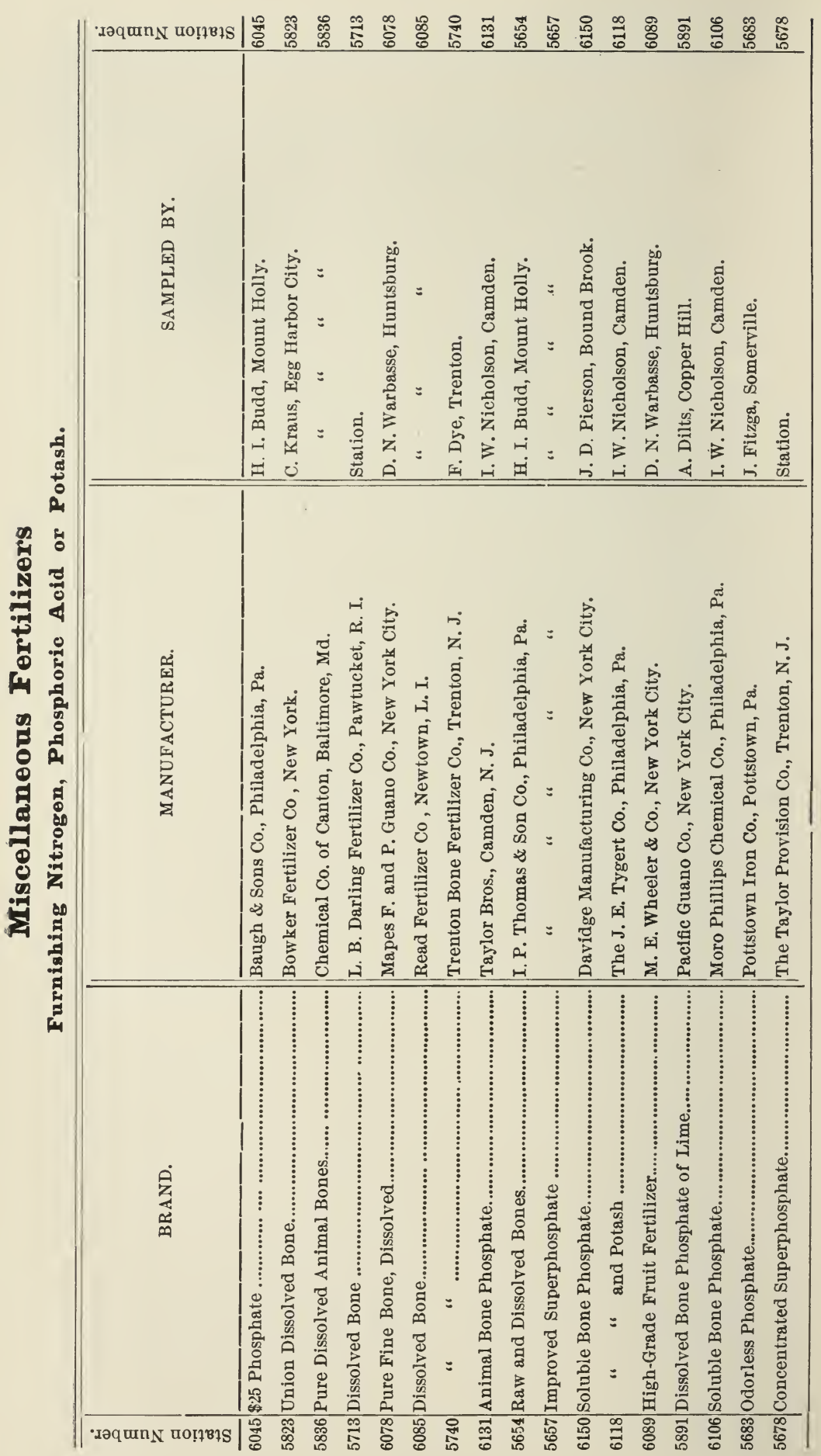




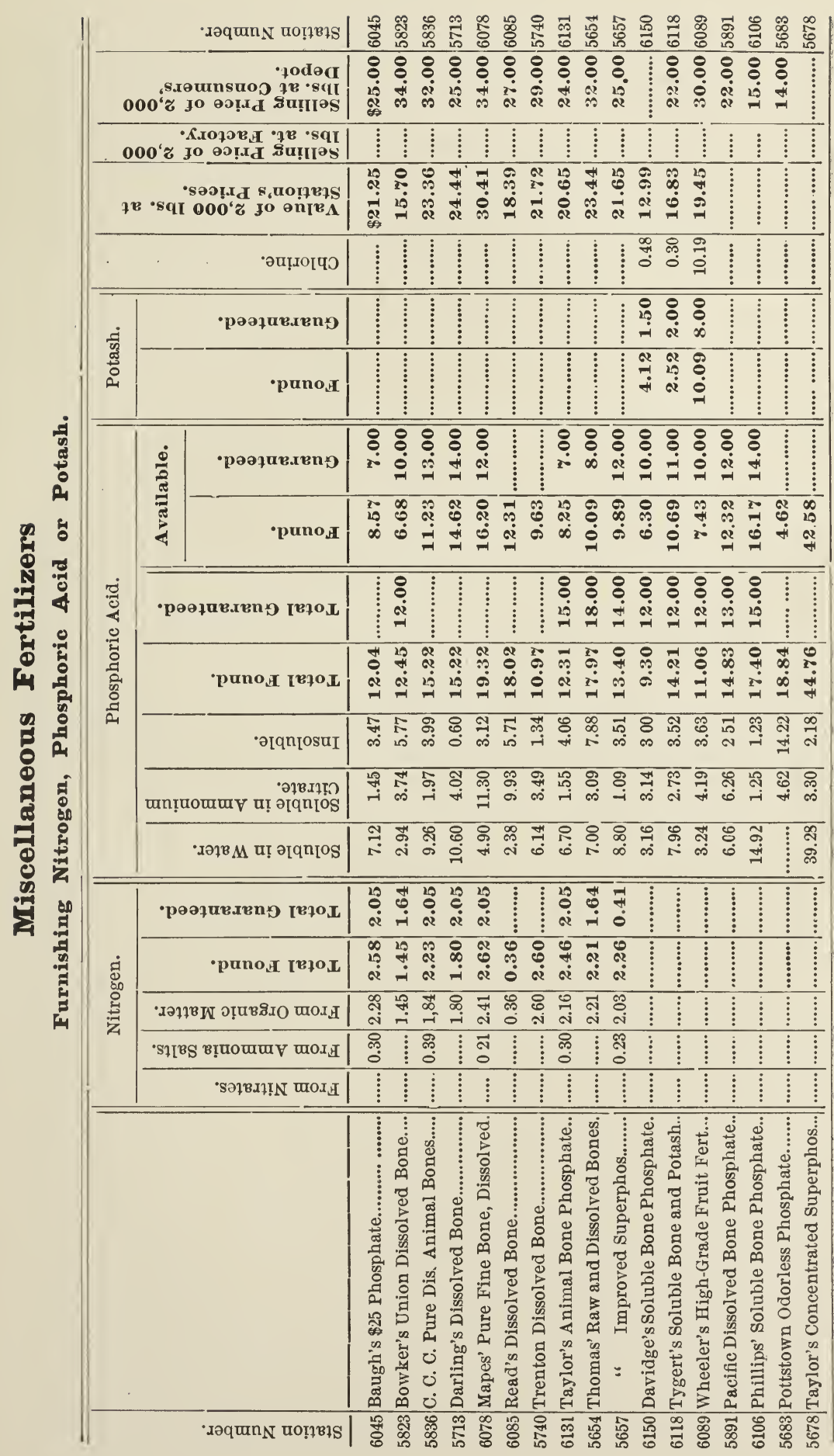




\section{Canada Ashes.}

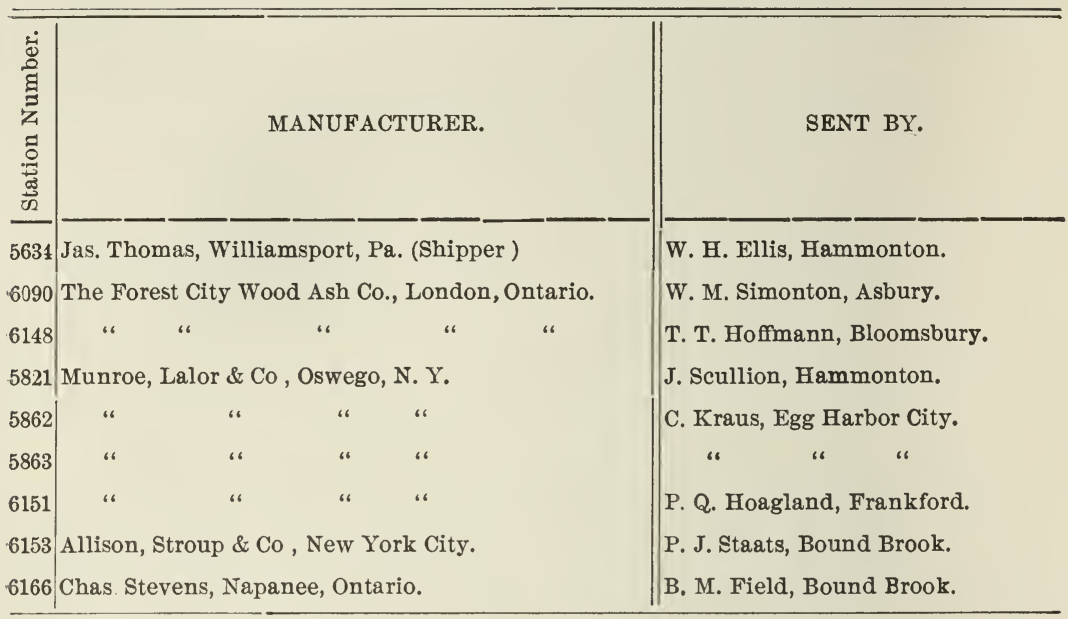

\begin{tabular}{|c|c|c|c|c|c|c|c|c|c|}
\hline & 5634 & 6090 & 6148 & 5821 & 5862 & 5863 & 6151 & 6153 & 6166 \\
\hline Phosphoric Acid..................... & 1.34 & 1.28 & 1.16 & 1.57 & 1.43 & 1.54 & 1.45 & 1.75 & 1.67 \\
\hline Potash.................................... & 0.51 & 4.08 & 3.26 & 3.82 & 6.93 & 4.97 & 8.81 & 4.10 & 4.19 \\
\hline Lime........................................... & . 34.26 & 24.88 & 23.71 & 28.76 & 31.26 & 35.24 & 32.90 & 33.06 & 38.10 \\
\hline Valuation per Ton.................... & . $\$ 1.88$ & $\$ 5.56$ & $\$ 4.58$ & $\$ 5.58$ & $\$ 8.71$ & $\$ 6.76$ & $\$ 10.70$ & $\$ 6.06$ & $\$ 6.07$ \\
\hline Selling Price per Ton................. & 11.00 & 11.00 & 11.00 & 13.00 & 12.50 & 12.00 & 13.00 & 12.00 & 15.00 \\
\hline
\end{tabular}

\section{EDWARD B. VOORHEES,}

Director.

New Brunswick, N. J., November 19th, 1894. 
GLUTEN FEEDS.

THEIR SOURCE, COMPOSITION AND METHODS OF USE.

NEW JERSEY

\author{
AGRICULTURAL
}

Fiperiment Station

105 



\section{NEW JERSEY}

\section{Agricultural Experiment Station.}

\section{BULLETIN 105.}

NOVEMBER 20, 1894.

\section{Gluten Feeds-Their Source, Composition and Methods of Use.}

In recent years there has been a considerable addition to the number of concentrated, or commercial feeds, upon the market; many of these products are extremely valuable, not only because they are concentrated in bulk, but also because their purchase and use serve to make more palatable and economical the feeding of the coarser and more bulky products of the farm; in many cases, too, such a practice diminishes the exportation of plant-food constituents consequent upon a direct sale of grain crops, or of beef, pork or milk.

The better utilization of the coarse products, particularly corn stalks and straw, by means of concentrated feeds, and the economic bearings of such methods of feeding, were discussed at length in Bulletin No. 96, distributed in November, 1893.

Among the list of useful feeds, those which consist of the parts of the cereal grains, as wheat bran, middlings and brewers' grains, with the manufacture of which the farmers are familiar, and into which no foreign or deleterious substances enter, have reached a wide use; their value is well established; while those which result from the manufacture of vegetable products with which they are not familiar, and which in some cases are not strictly food products in their original form, are slowly accepted, and even now sparingly used in many sections of the State. 
Such has been the case, for example, with cotton-seed meal, notwithstanding its very great value, both from food and fertility standpoints.

In other words, a familiarity with the value of the original product as a feed, coupled with a knowledge of the processes by which the by-products have been secured, are factors which largely influence introduction and use.

It is well understood by many, that the removal of a part of the whole grain does not destroy, though it may modify, the value of the residue, but that greater skill may be required in order to obtain satisfactory results in its use, because it may be less perfect, or complete, in itself as a general food than the original product.

Foods one-sided in the sense that one or more of the digestible constituents may be in too great excess, or too deficient, are not necessarily very good or very poor, though such may be the case ; they are, however, less likely to prove valuable as exclusive diets than the entire grains. For instance, oats, wheat bran and linseed meal are all excellent horse feeds, yet of the three, oats is the only one that can be fed exclusively with safety; the total value of the food compounds in one ton of linseed meal is, however, quite as great, if not greater than in the oats; the main fact is that it is not as perfect in its proportions of food compounds, or in its physical character, for the purpose of horsefeeding.

Illustrations of this kind could be multiplied to show that it is physical character, or bulk of the product, and proportion, as well as kind and amount of constituents, that gives value in a complete diet.

\section{Gluten Feods.}

These feeds have been introduced in our Eastern markets recently in large quantities, under the general name of "Gluten Meal" or "Gluten Feed." The fact that they are relatively new, and because the various products differ in their appearance, their feeding value and price per ton, there has arisen frequent inquiries as to their composition and value, particularly from 
those progressive dairymen who closely study economical methods of purchasing and using feeds.

The analyses of certain of these feeds have been published by a number of Experiment Stations, a few have conducted feeding experiments to test their value, and the results secured indicate for them a high position among the concentrated feeds. A difficulty, however, still exists in that the names attached are too indefinite, and do not indicate the true composition of the various products.

The object of this bulletin is, therefore, to publish an analysis of all of these products, to indicate their sources and method of manufacture, and as far as possible, from a study of the analyses, to classify them according to their composition and relative feeding value. In prosecuting this work representative samples were secured both from dealers in the State and directly from the manufacturers. In some instances it was possible to secure a number of samples of the same kind, thus permitting a study of possible variations in composition.

\section{How the Products are Derived.}

These feeds occur as residues in the manufacture either of starch, or of glucose (grape sugar), from maize or Indian corn. It is the aim of the manufacturer to secure from the corn a maximum product of starch or sugar; the whole resultant residue, therefore, is relatively low in starch, and varies in composition according to the excellence of the method of manufacture, and the variation in the composition of the original raw materialcorn.

The average of a large number of analyses shows that one hundred pounds of the dry matter of corn contain :

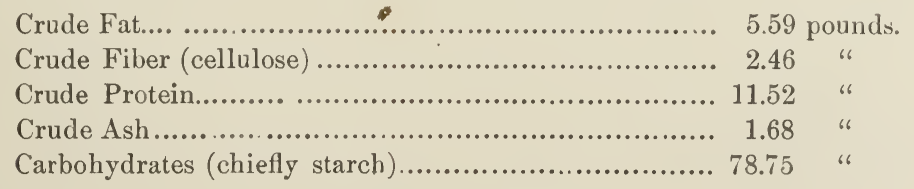

A glance at these figures shows that corn is made up chiefly of the class carbohydrates, or starch; it is evident that the re- 
moval of any part of it must increase the proportion of the other constituents in the residue.

The constituent contained in corn next in amount to carbohydrates is protein-a collective term which includes all of the albuminoids-and to which the name "gluten" is commonly applied; hence, the partial or complete removal of the starch

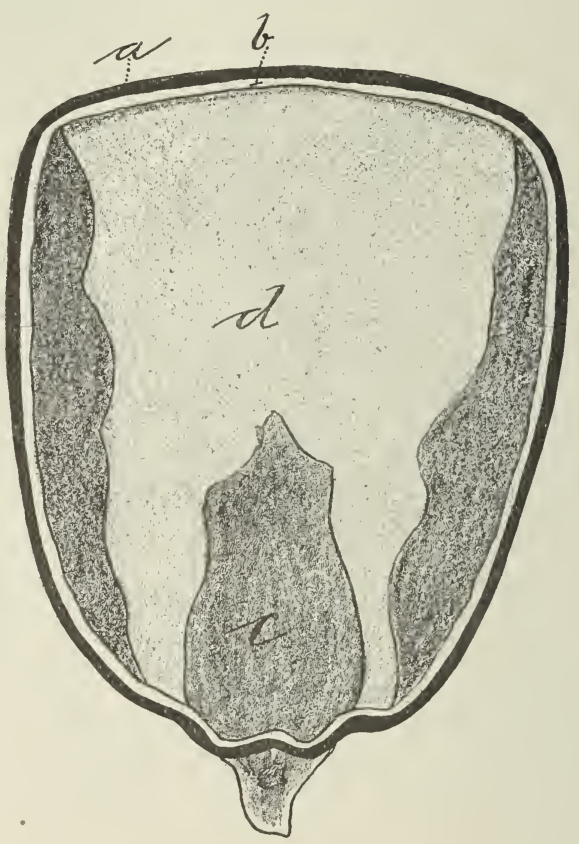

makes this constituent the most prominent, and the general name "gluten" has been applied to the feeds so derived, and in point of amount the protein is the most important constituent in many of the products.

The starch in the class carbohydrates is, however, not entirely separated even under the best methods of manufacture now employed; hence, the total residue still contains a large portion of carbohydrates, often amounting to more than one-half of the total dry matter.

\section{Parts of Corn.}

The accompanying enlarged cut of a corn, or maize, kernel will assist in locating the four distinct parts which are of interest in this study. 
$a$ is the husk, or skin, which covers the whole kernel; it consists of two distinct layers, the outer and inner, which when removed constitute the bran, and contain practically all of the crude fiber of the whole grain.

$b$ is a layer of gluten cells, which lies immediately underneath the husk ; it is yellow in color, and cannot be readily separated from the remainder of the kernel. This part is the richest of any in gluten.

$c$ is the germ, which is readily distinguished by its position and form; it also contains gluten, though it is particularly rich in oil and mineral constituents.

The large portion, $d$, is composed chiefly of starch; the dark color indicates the yellow, flinty part, in which the starch-holding cells are more closely compacted.

A perfect separation of the corn kernel into its parts as described is difficult, if not impossible. It was found possible, however, to partially separate 100 grammes of kernels of new corn, so as to secure for analysis the skin and the germ in a state of comparative purity. To do so it was necessary to leave portions of each attached to the starchy and hard part of the corn. The parts analyzed as follows:

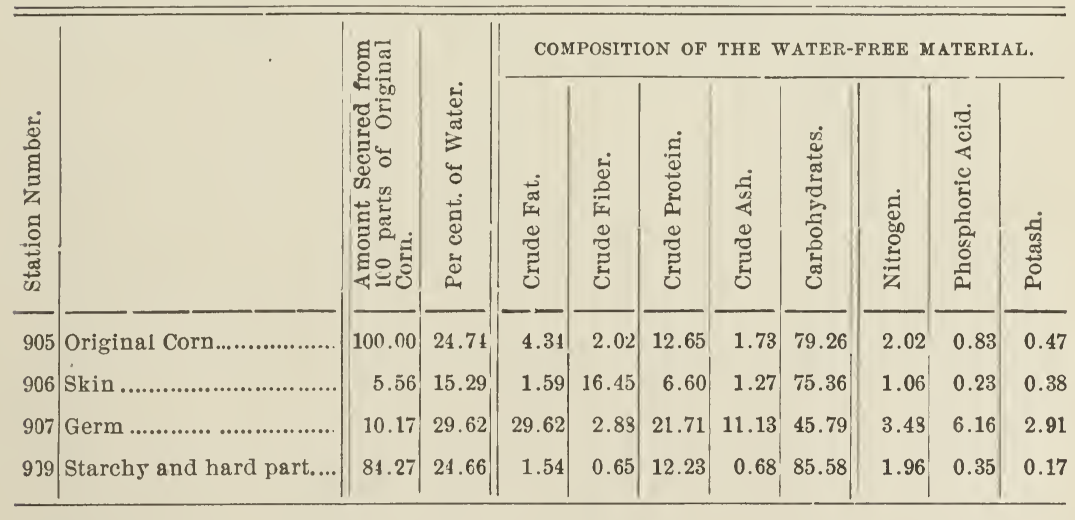

The germ, although only about 10 per cent. of the whole kernel, contains 65 per cent. of the fat, $61 \frac{1}{2}$ per cent. of the mineral matter, 71 per cent. of the phosphoric acid, 60 per cent. of the potash, and $16 \frac{1}{3}$ per cent. of the nitrogen, or protein. The 
remaining portions are characterized, the skin by its content of fiber, 51 per cent. of the whole, and the starchy part by its carbohydrates, of which it contains nearly 90 per cent. of that in the whole grain.

The processes by which the starch is obtained, while perhaps differing somewhat, consist essentially in the separation first of the germ and hull from the stareh and albuminoids contained in the remainder either directly by machinery, or by soaking in warm water, crushing into a coarse powder, and separating by gravity, the hulls floating on the surface, and the germs sinking to the bottom; and second, the final separation of the gluten from the starch, which is effected by allowing the fluid containing them to run slowly through long troughs, the heavier starch settling to the bottom, and the lighter yellow substance, containing the protein and fat, floating off.

The residue in this manufacture may, therefore, consist either of one product, a mixture of the gluten, germ and hulls, or of three, when the gluten, germ and hulls are each separated. In any case, however, the feeds are parts of the original corn, though when dried for market they differ in appearance, in proportion of food constituents, and in physical character.

The entire residue is in color brighter yellow than corn meal, and of a much more bulky character, owing to the presence of a larger proportion of bran; the trade name of this product is "Gluten Feed." The gluten is distingushed by a higher content of both protein and fat, and a bright-yellow color, and is called "Gluten Meal." The germ is more bulky than the meals, shows a high content of crude fat, and is called "Germ Meal" or "Germ Food." The hulls are very bulky, show a high content of crude fiber, and are usually sold as "Corn Bran."

\section{Gluten Feed.}

Table I. shows the composition of the feeds of the various manufacturers, and with one exception they consist of the entire residue.

The samples are arranged in the order of their richness in fat and protein-the two compounds of highest value in foods of 
this class. No. 862 is much less valuable in this respect than the others, though much richer in carbohydrates, which appears to be clue in large part to a less perfect extraction of the stareh.

TABLE I.

Gluten Feeds.

\begin{tabular}{|c|c|c|c|c|c|c|c|}
\hline & \multirow[b]{2}{*}{ NAME AND ADDRESS. } & \multicolumn{6}{|c|}{ POUNDS PER HUNDRED OF } \\
\hline & & 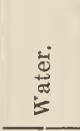 & 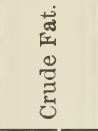 & 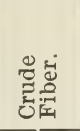 & 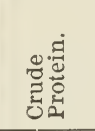 & $\begin{array}{l}\frac{9}{01} \\
\frac{0}{4} \\
0 \\
0 \\
0 \\
0 \\
0\end{array}$ & 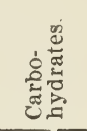 \\
\hline 871 & $\begin{array}{l}\text { Chicago Gluten Feed ..................... } \\
\text { American Glucose Co., } \\
\text { Chicago, Ill. }\end{array}$ & 7.61 & 14.18 & 6.31 & 24.03 & 0.87 & 47.00 \\
\hline 883 & $\begin{array}{c}\text { Peoria Gluten Feed.......................... } \\
\text { Peoria Grape Sugar Co., } \\
\text { Peoria, Ill. }\end{array}$ & 6.91 & 14.84 & 7.11 & 22.61 & 0.97 & 47.50 \\
\hline 903 & $\begin{array}{c}\text { Buffalo Gluten Feed ...................... } \\
\text { American Glucose ro., } \\
\text { Buffalo, N. Y. }\end{array}$ & 10.20 & 13.67 & 7.17 & 22.65 & 0.84 & 45.47 \\
\hline 859 & $\begin{array}{r}\text { Buffalo Gluten Feed....................... } \\
\text { American Glucose (:o., } \\
\text { Buffalo, N. Y. }\end{array}$ & 8.74 & 11.91 & 7.75 & 23.39 & 1.01 & 47.20 \\
\hline 899 & $\begin{array}{r}\begin{array}{l}\text { Buffalo Gluten Feed........................... } \\
\text { American Glucose Co } \\
\text { Buffalo, N. Y. }\end{array}\end{array}$ & 9.82 & 13.41 & 6.98 & 21.38 & 0.82 & 47.56 \\
\hline 813 & $\begin{array}{l}\text { Buffialo Gluten Feed....................... } \\
\text { American Glicose ('o., N. Y. } \\
\text { Buffalo, N. }\end{array}$ & 8.62 & . 12.83 & 7.20 & 19.54 & 0.93 & 50.88 \\
\hline 862 & $\begin{array}{c}\text { Dry Gluten Feed } \\
\text { National Starch Mf..................... } \\
\text { New York City. }\end{array}$ & 6.33 & 8.31 & 5.34 & 17.61 & 0.59 & 61.82 \\
\hline 875 & $\begin{array}{l}\text { Chicago Maize Feed * ................. } \\
\text { ( hicago Sugar Refining Co., } \\
\text { Chicago, Ill. }\end{array}$ & 8.50 & 8.28 & 7.43 & 25.91 & 1.20 & 48.68 \\
\hline & Average ............... & 832 & 12.74 & 684 & 21.61 & 0.86 & 49.63 \\
\hline
\end{tabular}

* Not included in average.

No. S75, "Chicago Maize Feed," is claimed to be a mixture of the hull and yellow portion, without the germ, and is less rich in fat; it is included because in chemical composition it corresponds more nearly with the whole resiclue than with any of the separate parts.

In Table II. the samples have been reduced to the "water-free basis," and the average composition of the dry matter compared with that of the corn kernel of the yellow dent variety, and also with the calculated composition of the total residue from it, 
when 75 per cent. of the class carbohydrates has been removed in the form of starch.

TABLE II.

Composition of Dry Matter.

\begin{tabular}{|c|c|c|c|c|c|c|}
\hline & \multirow[b]{2}{*}{ NAME. } & \multicolumn{5}{|c|}{ POUNDS PER HUNDRED OF } \\
\hline & & 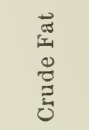 & 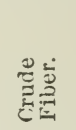 & 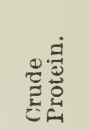 & 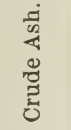 & 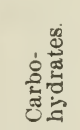 \\
\hline 871 & Chicago Gluten Feed.................................. & 15.35 & 6.83 & 26.01 & 0.94 & 50.87 \\
\hline 883 & 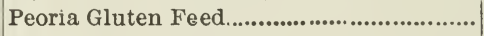 & 15.95 & 7.64 & 24.33 & 1.04 & 51.04 \\
\hline 903 & 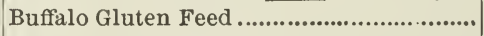 & 15.22 & 7.98 & 25.22 & 0.94 & 50.64 \\
\hline 859 & Buffalo Gluten Feed ................................... & 13.05 & 8.49 & 25.63 & 1.11 & 51.72 \\
\hline 899 & Buffalo Gluten Feed .................................. & 14.90 & 7.71 & 23.71 & 0.91 & 52.74 \\
\hline 843 & 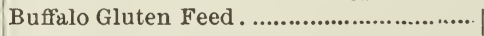 & 14.04 & 7.88 & 21.38 & 1.02 & 55.68 \\
\hline \multirow[t]{4}{*}{862} & 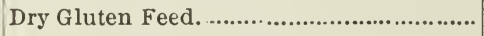 & 8.87 & 5.70 & 18.80 & 0.63 & 66.00 \\
\hline & Gluten Feed, Average Composition... & 13.91 & $7.4 \%$ & 23.58 & $\mathbf{0 . 9 4}$ & 54.10 \\
\hline & Corn, less 75 per cent. Starch.. ........... & 13.66 & 6.01 & 28.15 & 4.10 & 48.08 \\
\hline & Corn, Average Composition................. & 5.59 & 2.46 & 11.52 & 1.68 & 78.75 \\
\hline
\end{tabular}

A study of this table shows that, as compared with corn, the dry matter of the gluten feed contains higher percentages of fat, protein and fiber, and lower percentages of carbohydrates and ash, that is, with the exception of ash, all of the classes of food compounds have been increased by the removal of starch.

Assuming that 75 per cent. of the class carbohydrates contained in the average sample of corn may be rêcovered as starch and that all of the residue can be recovered as feed, the average composition of such residue should be much richer in protein and ash, and poorer in fat, fiber and carbohydrates, than any of the samples examined which are claimed to represent the total residue.

This disagreement in composition is mainly due to the fact that in the methods of manufacture now carried out, in which water is freely used, a large part of the mineral constituents and a portion of the albuminoids are extracted, though, of course, other losses, perhaps largely mechanical, are possible.

From the feeders' standpoint, the extraction of the mineral or 
ash constituents is of some importance as affecting both food and fertility values; for instance, in feeding young stock and dairy cows the ash elements in a food are not only generally useful, but very necessary for the building up of the bone and framework of the body, and in furnishing mineral salts for the animal product-milk; while in the exchange of farm products for concentrated feeds, the fertilizer constituents in the feeds are worthy of consideration. These residues are, however, much richer than the original corn in the more valuable constituents, fat and protein, and the more expensive fertilizer element, nitrogen, and may, therefore, be quite as valuable from the standpoint of both food and fertility, though in a different way.

The next question of importance is: Are the same food constituents in the corn residue-gluten feed-as useful as when contained in the whole corn?

The usefulness of a feed depends chiefly upon the three characteristics, palatability, digestibility, and the proportion of food compounds contained in it, no one of which is sufficient in itself to accomplish the purpose.

In the corn these characteristics are fairly well combined, making it one of the most useful feeds we have. There is a sweetness and a flavor which are attractive to animals, and this palatability is accompanied by a high rate of digestibility. The proportion of the three classes of constituents is such, however, as to make it less valuable as a sole grain ration, even for fattening purposes, than when mixed with products containing a higher content of protein.

The gluten feed, or total residue from the corn, is slightly less palatable than the original product, since in many cases animals do not eat it greedily when first offered to them, though it is in the main readily eaten.

The co-efficients of digestibility of the gluten feed were shown by experiments conducted with ruminants at the Massachusetts Experiment Station to be slightly less for the carbohydrates and fat and greater for the protein than those commonly used for corn meal. They are for crude fat 81 , crude fiber 43 , crude protein 85 , and 81 for carbohydrates. The direct experiments on digestibility are too few to warrant any positive statements in 
reference to this point; nevertheless, since the experience of practical feeders indicates that the actual food compounds in the gluten feed have not suffered any injurious change due to the methods of manufacture, it is believed that these co-efficients may be safely used until further data are secured.

\section{The Use of Gluten Feed.}

The chemical analysis shows that gluten feed should be classed as a nitrogenous, or flesh-forming, rather than a carbonaceous, or fat-forming, food, though much richer in fat than the corn meal; hence, its usefulness lies in an opposite direction. Its best use is accomplished when fed in connection with products deficient in protein, of which meadow hay, corn stalks, straw and corn meal, the general feeds of the farmer, are good examples.

Our reports have pointed out from time to time the results of feeding experiments, which show that the proportion of the digestible constituents in a feed should be varied according to the object of the feeding.

In a ration for simple maintenance the proportion of the fats and carbohydrates together, or fat-formers, may be greatly in excess of the digestible protein, or flesh-formers, while for the production of milk, or of flesh, products rich in albumen and casein, protein, the direct and only source of these compounds, should be increased. The proportion of the one class to the other is called the "nutritive ratio."

If the sum of the digestible carbohydrates and two and onefourth times the digestible fat is divided by the digestible protein in the ration, the quotient gives the nutritive ratio. If the quantities of digestible fat and carbohydrates are large relative to the protein, this number will be large and the ration is called a "wide ration;" if the quantities of digestible fat and carbohydrates are relatively small, the quotient is a small number and the ration is a "narrow" one. A ration where the nutritive ratio is much more than 1 to 6 may be called a "wide ration ;" if much less, it may be called a "narrow ration."

The calculated rations given in this bulletin are intended for dairy cows, and therefore show a narrow nutritive ratio approxi- 
mating 1 to 5.4. The average composition and digestibility of the various feeds used, other than gluten, were obtained from the tables given on pages 174-177 of the Annual Report of the Station for 1893.

The effect of corn meal and gluten feed in influencing the nutritive ratio, or the proportion of protein to fat and carbohydrates in a ration, may be illustrated as follows, the valuable coarse product, crushed corn stalks, serving to furnish the requisite bulk :

1.

Corn Meal Ration.

Corn Stalks

Corn Meal

12

2.

Gluten Feed Ration.

Corn Stalks.

Gluten Feed $15 \mathrm{lbs}$

12
CONTAINS POUNDS OF DIGESTIBLE

Fat. Protein. Carbohydrates. .47

1.45

18.63

Nutritive ratio 1 to 13.6 .

CONTAINS POUNDS OF DIGESTIBLE

Fat. Protein. Carbohydrates.

$\begin{array}{lll}1.41 & 2.72 & 11.60\end{array}$

Nutritive ratio 1 to 5.4 .

The nutritive ratio of No. 1 is shown to be very wide; in other words, there is a defieiency of protein. The substitution of 12 lbs. of gluten meal for 12 lbs. of corn meal changes or narrows it from $1: 13.6$ to $1: 5.4$, corresponding very closely with our standard for milk cows.

The addition of the corn meal to the corn stalks simply results in increasing the proportion of that class of compounds already in excess in the coarse fodder, while the addition of an equal weight of the gluten feed instead adds the constituents that are deficient in the coarse products.

The use of No. 1, which practice has shown can be safely fed, would obviously result in a waste of carbohydrates, while No. 2, which is satisfactory from the standpoint of nutritive ratio, could hardly be recommended either on the ground of entire safety as a steady diet for dairy animals, or as the most useful ration that could be compounded with the gluten feed as an important part. The following is given as a substitute, though it perhaps does not mark the limit in the amount of gluten feed that may be safely used : 
3.

Gluten Feed Ration.

Corn Stalks

Clover Hay.

Buffalo Gluten Feed

Wheat Bran

$\left.\begin{array}{rr}10 & \text { lbs. } \\ 5 & \text { " } \\ 6 & \text { " } \\ 5 & \text { " }\end{array}\right\}$

CONTAINS POUNDS OF DIGESTIBLE

Fat. Protein. Carbohydrates

$$
2.50
$$

12.21

\section{Nutritive ratio 1 to 5.8 .}

The main purpose in the foregoing is to show the influence of the feed in preparing rations which shall show the proper proportion of food compounds, rather than to suggest the best possible use of the feed, though it is believed that the last given will be satisfactory. Where it seems desirable to use a larger number. of feeds the following is suggested:

4.

Gluten Feed Ration.

Corn Stalks

Clover Hay

Wheat Bran

Buffalo Gluten Feed.

Dıied Brewers' Grains.

Cott n-Seed Meal.
CONTAINS POUNDS OF DIGESTIBLE

Fat. Protein. Carbohydrates.

\subsection{3}

11.27

Nutritive ratio 1 to 5.3 .

\section{Gluten Meal.}

The samples of gluten meal examined represent the product of five different firms, and are claimed to consist largely of the gluten of the corn, separated from the germ and hull, as indicated on page 8 . 
TABLE III.

Gluten Meals.

\begin{tabular}{|c|c|c|c|c|c|c|c|}
\hline & \multirow[b]{2}{*}{ NAME AND ADDRESS. } & \multicolumn{6}{|c|}{ POUNDS PER HUNDRED OF } \\
\hline & & 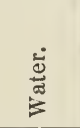 & 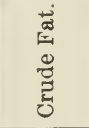 & 总施 & 异芯 & 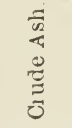 & 官兽 \\
\hline 869 & $\begin{array}{l}\text { Cream Gluten Meal.......................... } \\
\text { Chas. Pope Glucose Co. } \\
\text { Chicago, Ill. }\end{array}$ & 7.37 & 15.64 & 1.45 & 41.76 & 1.58 & 32.20 \\
\hline 885 & $\begin{array}{l}\text { King Gluten Meal................................... } \\
\text { National starch Mfg. Co..ंity. } \\
\text { New York City. }\end{array}$ & 9.36 & 19.77 & 1.47 & 35.09 & 1.90 & 32.41 \\
\hline 872 & $\begin{array}{l}\text { Iowa Golden Gluten Meal............... } \\
\text { Firmenich Mfg. Co., } \\
\text { Marshalltown, Iowa. }\end{array}$ & 7.61 & 12.65 & 3.60 & 30.47 & 1.00 & 41.67 \\
\hline 881 & $\begin{array}{c}\text { Gluten Meal (Flour)..................... } \\
\text { Continental Food Product Co, } \\
\text { Waukegan, Ill. }\end{array}$ & 8.51 & 11.78 & 0.67 & 30.27 & 1.09 & 47.65 \\
\hline \multirow[t]{2}{*}{892} & $\begin{array}{l}\text { Hammond Gluten Meal.................... } \\
\text { Stein, Hirsh \& Co. } \\
\text { Chicago, Ill. }\end{array}$ & 7.85 & 10.48 & 1.12 & 26.56 & 1.00 & 52.99 \\
\hline & Average .............................................. & 8.15 & 14.06 & 1.66 & 32.83 & 1.31 & 41.99 \\
\hline 876 & $\begin{array}{c}\text { Chicago Gluten Meal ...................... } \\
\text { Chicago Sugar Refining Co., } \\
\text { Chicago, Ill. }\end{array}$ & 8.70 & 6.52 & 1.42 & 42.96 & 0.91 & 39.46 \\
\hline 856 & $\begin{array}{l}\text { Chicago Gluten Meal ..................... } \\
\text { Chicago Sugar Refining Co., } \\
\text { Chicago, Ill. }\end{array}$ & 8.95 & 4.98 & 1.15 & 33.70 & 0.83 & 50.19 \\
\hline \multirow[t]{2}{*}{878} & $\begin{array}{c}\text { Chicago Gluten Meal..................... } \\
\text { Chicago Sugar Refining Co., } \\
\text { Chicago, } 111\end{array}$ & 10.82 & 5.18 & 1.64 & 30.71 & 0.81 & $50.8 t$ \\
\hline & 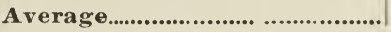 & 9.49 & 5.56 & 1.50 & 35.79 & 0.86 & 46.80 \\
\hline
\end{tabular}

An examination of the chemical composition of these samples. shows considerable variation in the proportion of the nutritive compounds, fat, protein and carbohydrates, though they all agree. with each other in showing much less crude fiber than the gluten feeds, as a result of the more or less complete separation of thehull and germ.

The product of the Chicago Sugar Refining ( $o$. is less rich in fat than any of the others, and therefore belongs to a separateclass, and is distinguished from the other's by adding the name "Chicago." It contains less than half as much fat, and about 60 per cent. more protein than the feeds.

The gluten meals are calculated to serve the same purpose as. 
the feeds in the preparation of rations, though in a still greater degree-i. e., it will require less amounts to accomplish the purpose.

Gluten meal has an attractive appearance and a pleasant flaror, though, as with the gluten feed, animals do not eagerly eat it at first. In case of one meal it was reported that animals refused to eat it altogether; a sample was carefully examined and found to be in good condition, perfectly sweet, and, as far as could be discovered, free from any objectionable qualities.

The co-efficients of digestibility of the meal were shown by experiments conducted at the Maine Experiment Station to be ss for fat, 87 for protein and 91 for carbohydrates, somewhat higher for all of the food compounds than those reported for the gluten feed, and higher for protein than Imerican digestibility experiments have shown for the whole corn.

\section{Use of Gluten Meal.}

Because of its high content of protein and fat, gluten meal requires to be more carefully used than the gluten feed. Its use should be similar to that of old-process oil meal, with which the "Chicago (iluten Meal" compares, or cotton-seed meal, to which the others are similar. In our experience four pounds per day may be used with entire safety.

It is shown by the following tabulated ration that four pounds of gluten meal furnishes practically the same amounts of fat and protein as are furnished hy six pounds of the gluten feed, since with this amount the total digestible nutrients in the ration are nearly identical with those shown in ration No. 3, when the other products are the same in amount and kind:

5.

Gluten Meal Ration.

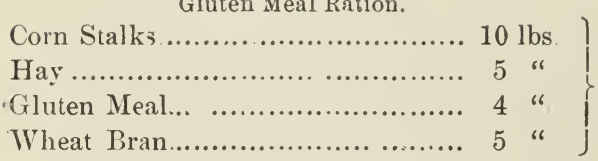

CONTAINS POONDS OF DIGESTIBLE

Fat. Protein. Carbohydrates.

2.55

11.16

Nutritive ratio $1 \mathrm{t}, 5.4$. 
The "Chieago Gluten Meal," containing less fat and more. protein, would show practically the same nutritive ratio if used as follows:

6.

Chicago Gluten Meal Ration.

Corn Stalks

Chicago Gluten Meal

Wheat Bran.
CONTAINS POUNDS C F DIGESTIBLE

Fat. Protein. Carbohydrates.

.55

2.57

12.53

Nutritive ratio 1 to 5.4 .

It is, therefore, observed that in the preparation of rations one pound of gluten meal is as efficient as one and one-half pounds of gluten feed in narrowing the nutritive ratio of a ration, or in furnishing the nutrients deficient in coarse products.

As in the case of the gluten feeds, other rations than these, which are used for the sake of example, may be more desirable, using either larger or smaller amounts of the meal to suit the conditions of the feeder.

\section{Grauo Gluten Feed.}

This feed, while not strictly a corn product, being the residue from the manufacture of alcohol from corn, barley and oats, will answer practically the same purpose as the gluten meal in the preparation of rations.

TABLE IV.

Grano Gluten Feed.

\begin{tabular}{|c|c|c|c|c|c|c|c|}
\hline & \multirow[b]{2}{*}{ NAME AND ADDRESS. } & \multicolumn{6}{|c|}{ POUNDS PER HUNDRED OF } \\
\hline & & $\begin{array}{l}\stackrel{\dot{W}}{\Phi} \\
\dot{3}\end{array}$ & 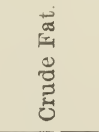 & 急苍 & 窇莒 & 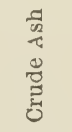 & 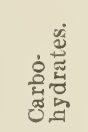 \\
\hline 884 & $\begin{array}{l}\text { Grano Gluten Feed ............................. } \\
\text { H. H. Shufeldt \& Co., } \\
\text { Chicago, Ill. }\end{array}$ & 5.17 & 13.91 & 10.82 & 31.51 & 2.71 & 35.88 \\
\hline 888 & $\begin{array}{l}\text { Grano Gluten Feed......................... } \\
\text { H. H. Shufeldt \& Co, } \\
\text { Chicago, III. }\end{array}$ & 6.86 & 13.72 & 11.49 & 30.38 & 2.58 & 34.97 \\
\hline & Average & 6.01 & 13.82 & 11.15 & 30.95 & 2.65 & 35.42 \\
\hline
\end{tabular}

The two samples examined are practically identical in composition, showing a high content of fat and protein, but less of carbohydrates than the gluten meal, owing to the relatively high percentage of crude fiber. 


\section{Corn Oil Meal and Cake.}

These products consist of the corn germ, from which the oil has been partially extracted by pressing. The samples differ considerably in their composition, owing, doubtless, to the more or less complete extraction of the fat.

TABLE V.

Corn Oil Meal and Corn Oil Cake.

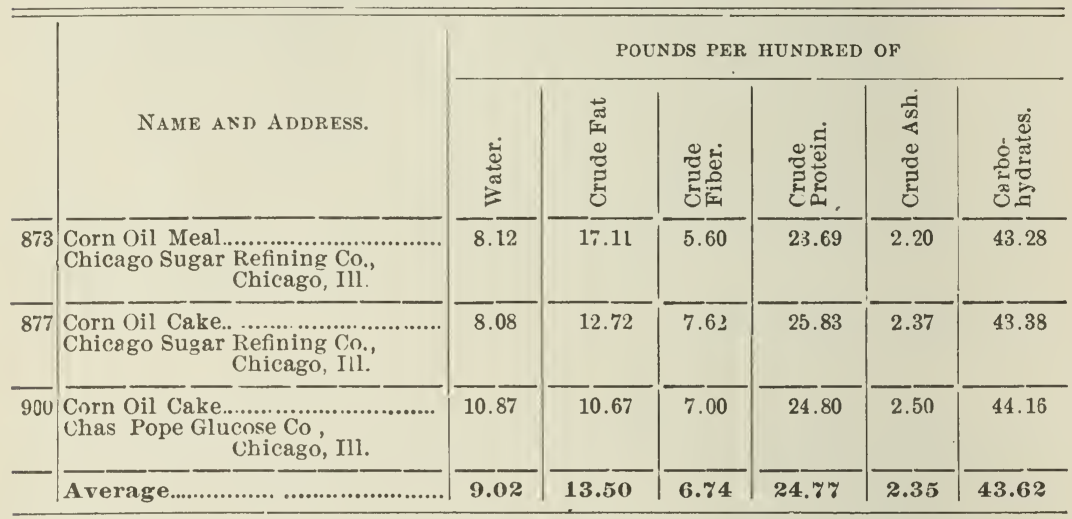

On the arerage these products contain slightly higher percentages of fat and protein, considerably more ash, and less fiber and carbohydrates than the gluten feeds. We have no extended data in reference to the palatability of these products, our experience being limited to feeding one lot of two animals; it was absolutely refused by one, however disguised by mixing, and eagerly eaten by the other. Nothing in the appearance, mechanical condition or taste would lead to the suspicion that these feeds were not quite as palatable as the products already discussed.

As yet no results of digestion experiments have been reported; assuming the same co-efficients of digestibility as those found for the gluten feed, their influence in supplying the constituents fat and protein is shown in the following tabulation:

7.

Corn Oil Meal Ration.

Corn Stalks

Clover Hay.

Corn Oil Meal.

Wheat Bran
CONTAINS POUNDS OF DIGESTIBLE

Fat. Protein. Carbohydrates.

.90

2.46

11.53

Nutritive ratio 1 to 5.6 . 
With the same amounts and kinds of other feeds as in ration No 3, it is shown that five pounds of "Corn Oil Meal" furnish practically the same amounts of fat and protein as six pounds of the "Gluten Feed ;" it is, however, less rich in carbohydrates, thus giving a slightly narrower nutritive ratio.

Since there is some doubt as to the palatability of these feeds, it is perhaps desirable that in the first trials of them small amounts, not more than two pounds per day, be used in connection with products of known palatability. The following is, therefore, recommended as a trial ration:

8.

Carn Oil Meal Ration.

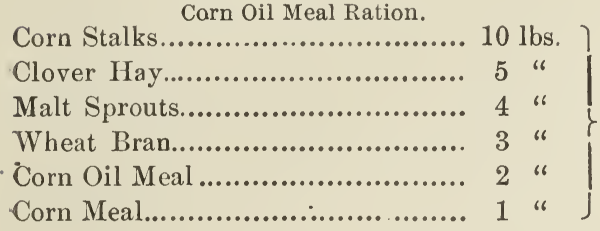

CONTAINS POUNDS OF DIGESTIBLE

Fat. Protein. Carbohydrates.

Nutritive ratio 1 to 5.4 .

\section{Corn-Germ Meal and Corn Bran.}

These products, as their names signify, consist in part, at least, of the germ and hull, or bran, of the corn.

TABLE VI.

Corn-Germ Meal and Corn Bran.

\begin{tabular}{|c|c|c|c|c|c|c|c|}
\hline & \multirow[b]{2}{*}{ NAME AND ADDRESS. } & \multicolumn{6}{|c|}{ POUNDS PER HUNDRED OF } \\
\hline & & 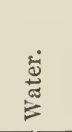 & 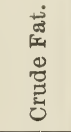 & 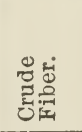 & 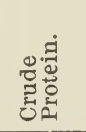 & 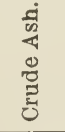 & 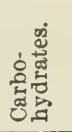 \\
\hline 870 & $\begin{array}{c}\text { Corn-Germ Food......................... } \\
\text { Chas. Pope Glucose Co., } \\
\text { Chicago, Ill. }\end{array}$ & 4.94 & 16.90 & 7.96 & 12.07 & 0.76 & 57.37 \\
\hline 880 & $\begin{array}{l}\text { Germ Meal ................................. } \\
\text { Continental Food Product Co., } \\
\text { Waukegan, Ill. }\end{array}$ & 9.52 & 4.81 & 7.70 & 10.63 & 2.32 & 65.02 \\
\hline 842 & $\begin{array}{l}\text { Corn Bran.................................. } \\
\text { Chicago Sugar Refining Co, } \\
\text { Chicago, Ill. }\end{array}$ & 8.96 & 7.81 & 10.10 & 11.83 & 0.83 & 60.44 \\
\hline 874 & $\begin{array}{l}\text { Corn Bran................................... } \\
\text { Chicago Sugar Refining Co., } \\
\text { Chicago, Ill. }\end{array}$ & 8.07 & 8.32 & 12.90 & 10.92 & 0.79 & 59.00 \\
\hline 879 & $\begin{array}{l}\text { Corn Hulls................................. } \\
\text { Continental Food Product Co., } \\
\text { Waukegan, Ili. }\end{array}$ & 9.15 & 3.75 & 10.88 & 10.16 & 0.93 & 65.13 \\
\hline
\end{tabular}


A study of the table of analyses shows that all of the products examined agree very closely in their content of protein.

Samples Nos. 870 and $\$ 80$ are claimed to be mixtures of the germ and hull; they, however, differ widely in composition, particularly in their content of fat. It is quite evident that 870 contains relatively more germ than bran, and that 880 contains. more bran than germ.

Samples 842 and 874 agree with each other in composition, showing a much higher content of fat than the corn hulls, and a much lower amount than is contained in the "Corn-Germ Food."

Samples Nos. 879 and 880 agree closely in their content of fat, protein and carbohydrates, differing only in their content of crude fiber and ash. It is quite evident, therefore, that the germ. meal consists more largely of hulls than germ.

The manufacturers claim that the corn hulls are separated from the whole corn entirely by machinery, which may account for the difference in composition of the hulls and bran. It is apparent, however, that the common name as applierl to these products does not give definite information as to their composition.

These products, too, while differing in the relative amounts of their constituents, practically correspond with the original product, corn, in the ratio of the flesh-formers to fat-formers; hence, their usefulness in the preparation of rations lies in the same direction, viz., in widening rather than narrowing the nutritive ratio by furnishing chiefly carbohydrates.

In the following table an average analysis of "Corn Bran" is compared with "Hominy Chop" and "Cerealine Feed," products derived in the manufacture of hominy and cerealine from corn, and consisting largely of the germ or hull: 
TABLE VII.

Corn Bran, Hominy Chop and Cerealine Feed.

\begin{tabular}{|c|c|c|c|c|c|c|c|}
\hline & \multirow[b]{2}{*}{ NAME AND ADDRESS. } & \multicolumn{6}{|c|}{ POUNDS PER HUNDRED OF } \\
\hline & & 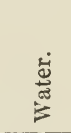 & 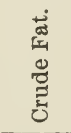 & 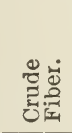 & 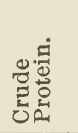 & 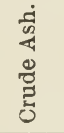 & 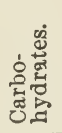 \\
\hline$\cdot$ & Corn Bran (Average Analysis)........... & 8.52 & 8.08 & 11.50 & 11.37 & 0.81 & 59.72 \\
\hline 868 & $\begin{array}{l}\text { Hominy Chop ................................ } \\
\text { Baltimore Pearl Hominy Co. } \\
\text { Baltimore, Md. }\end{array}$ & 11.80 & 11.17 & 2.58 & 11.00 & 2.92 & 60.53 \\
\hline 860 & $\begin{array}{l}\text { Hominy Chop.................................... } \\
\text { Hudnut Co., } \quad \text { Terre Haute, Ind. }\end{array}$ & 8.50 & 8.72 & 3.35 & 11.30 & 2.66 & 65.47 \\
\hline 808 & $\begin{array}{l}\text { Cerealine Feed ....................................... } \\
\text { Cerealine Mfg. Co Indianapolis, Ind }\end{array}$ & 9.39 & 7.82 & 5.01 & 10.12 & 2.50 & 65.16 \\
\hline
\end{tabular}

The composition of these three products, in reference to fat and protein, is very uniform, and for most purposes of feeding will answer the same end in the preparation of rations, though the hominy and cerealine feeds are much superior in that they contain less crude fiber than the corn bran. They may all be male to serve a very valuable purpose as substitutes for corn. The effect of the substitution of any of these products for corn meal is illustrated in the two rations given below, which are well adapted for milk dairies:

9.

Corn Meal Ration.

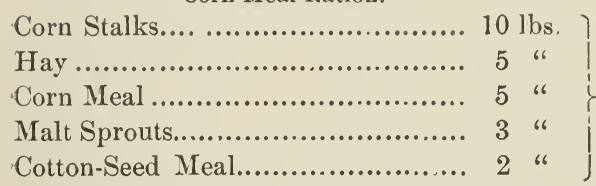

10.

Hominy Meal or Corn Bran Ration.

Corn Stalk

Hay

$10 \mathrm{lbs}$.

Hominy Meal or Corn Bran...

Malt Sprouts.

Cotton-Seed Meal
CONTAINS POUNDS OF DIGESTIBLE

Fat. Protein. Carbohydrates.

.61

2.45

12.46

Nutritive ratio 1 to 5.6 .

CONTAINS POUNDS OF DIGESTIBLE

Fat. Protein. Carbohydrates.

.78

2.47

12.28

Nutritive ratio 1 to 5.6 . 


\section{Suggestions.}

A careful review of the composition and uses of the various products shows that, while all are valuable feeds, there is, in the case of gluten meal, oil cake meal, germ meal and corn bran, $\mathrm{or}^{-}$ hulls, the uncertain factor of variability in composition, and in case of gluten meal and corn oil meal the further disadvantage. for general feeding of too great concentration in fat and protein.

In the gluten feeds, or total residue from the manufacture of starch, these criticisms do not apply, since they are practically uniform in composition, and possess a physical character which permits a generous use for most purposes of feeding.

It would seem, therefore, that unless some good reason exists. from the manufacturers' standpoint for the separation of the various parts of the com that general use would be promoted by making but one product, which should consist of the total residue. It would relieve the purchasers of the uncertainty as to composition, reduce the danger liable to result from the careless feeding of the more highly concentrated parts of the residue, and abolish the necessity of a study of comparative values as. now manufactured.

As before stated, the nutrients contained in the various residues. described are similar in that they have all been derived from the same source. The fat is corn fat, and the protein is corn protein, whatever the name may be that is given to the product. That these nutrients do virtually have practically uniform nutritive effects is shown by the studies of digestibility already made.

\section{The Ash Constituents of Feods.}

In addition to the organic food compounds in feeds, the mineral, or ash, constituents are of considerable importance, though they are seldom taken into consideration, because in most natural food products the amount present is always more than sufficient. to supply the needs of the animal for them.

It has already been noted that in many of the processes of manufacture of starch there is a very considerable extraction of the ash constituents; this is shown by the following tabulation: 


\begin{tabular}{|c|c|c|c|}
\hline \multirow[b]{2}{*}{ Corn ................................................ } & \multicolumn{3}{|c|}{ POUNDS PER HUNDRED OF } \\
\hline & $\begin{array}{l}\text { Ash. } \\
1.50\end{array}$ & $\begin{array}{c}\text { Phosphoric Acid. } \\
0.70\end{array}$ & $\begin{array}{c}\text { Potash. } \\
0.40\end{array}$ \\
\hline Buffalo Gluten Feed......................... & .87 & .31 & .08 \\
\hline Gluten Meal................................... & 1.29 & .56 & .07 \\
\hline Chicago Gluten Meal........................ & .89 & .35 & .06 \\
\hline Corn Oil Meal... .......................... & 2.28 & 1.36 & .14 \\
\hline 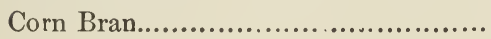 & .81 & .24 & .06 \\
\hline
\end{tabular}

With one exception the original corn contains more total ash, and more phosphoric acid, and in every case more potash than any of the products derived from it as feeds.

The effect of this exhaustion upon the feeding value of the residues might not be noticeable, except when used as a large part of the total ration for milch cows or growing stock; when the products are used in connection with other feeds no trouble is liable to result from this source.

\section{Fertility in Foeds.}

The composition of the ash is of importance, however, when feeds are considered from the standpoint of fertility. In the feed products derived from the manufacture of flour from the cereal grains, wheat and rye, the ash constituents-phosphoric acid and potash-exceed in amount those contained in the original grain. From this standpoint, therefore, they are valuable because of mineral constituents and nitrogen, while the gluten feeds are mainly valuable because of nitrogen alone. The average amount of nitrogen, phosphoric acid and potash contained in one ton of the various grains, the gluten or corn products, and of wheat bran and cotton-seed meal, clearly illustrates this point:

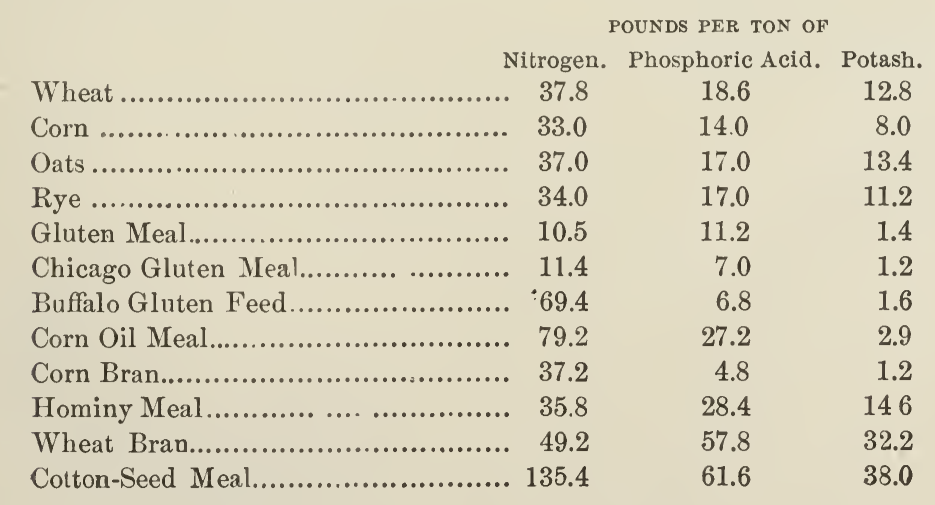


When it is remembered that a pound of any one of the iertilizer constituents contained in these feeds is quite as useful, as far as fertilizer effect or the prevention of soil exhaustion are concerned, as when contained in the original grain, it is apparent that in the exchange of grain for commercial feeds-when the exchange on the basis of food ralues alone is adrisable-a very considerable increase in fertility values may be obtained without any direct expenditure.

A number of these feeds have been used with satisfaction by our farmers; if they are not obtainable from local dealers they may doubtless be secured from the manufacturers, whose addresses are given in the tables of analyses.

In purchasing it should be remembered-

1. That while all are derived from corn, the gluten feed consists of the whole corn less a large part of the starch, and that because of its good physical character and richness in fat and protein, it is well adapted for use with coarse farm products in the preparation of rations either for dairy cows or for fattening stock.

2. That the gluten meal, which does not contain the hull or germ, is still more valuable as a source of fat and protein than the feed, and because of its concentration in bulk and richness in these constituents, should be fed with greater care.

3. That the corn oil meal and cake, which consist of the pressed germ, are very rich in fat and protein, and should not be fed in excessive amounts.

4. That the corn bran and corn germ, which consist chiefly of the hulls and germ, are rich in fat and carbohydrates, and are excellent substitutes for corn meal.

EDWARD B. VOORHEES,

Director.

New Bruxswick, N. J., November 20th, 1894. 
THE SAN JOSE SCALE IN NEW JERSEY.

NEW JERSEY

Agricultural College

\section{Experiment Station}

106 
NEW JERSEY AGRICULTURAL COLLEGE EXPERIMENT STATION.

\section{BOARD OF CONTROL.}

The Board of Trustees of Rutgers College in New Jersey.

\section{EXECUTIVE COMMITTEE OF THE BOARD.}

AUSTIN SCOTT, Ph.D., LL.D., President of Rutgers College, Chairman. HoN. GEORGE C. LUDLOW, HENRY R. BALDWIN, M.D., LL.D., How. HENRY W. BOOKSTAVER, LL.D., JAMES NEILSON, Esq.

\section{STAFF OF THE STATION.}

AUSTIN SCOTT, Pн.D., LL.D., Director.

Professor JULIUS NELSON, Ph.D., Biologist.

Professor BYRON D. HALSTED, Sc.D, Botanist and Horticulturist.

Professor JOHN B. SMITH, Sc.D., Entomologist.

ELISHA A. JONES, B.S., Superintendent of College Farm.

IRVING S. UPSON, A.M., Disbursing Clerk and Librarian.

CHARLES A. POULSON, Mailing Assistant.

LEONORA E. BURWELL, Clerk to the Director.

AUGUSTA E. MESKE, Stenographer and Typewriter. 


\section{NEW JERSEY}

\section{Agricultural College Experiment Station.}

\section{BULLETIN 106.}

NOVEMBER 22, 1894.

\section{The San Jose Scalo in New Jersey.}

BY JOHN B. SMITH, ENTOMOLOGIST.

The above species, Aspidiotus perniciosus, Comstock, is said by its describer to be "the most destructive of the scale-making Coccids." It is supposed to be a native of Chile, or to have been first brought from that country to California about 1870 . It was noticed at San José in 1873, the popular name being derived from this fact, and spread rapidly until 1880, when Prof. J. H. Comstock, then U. S. Entomologist, collected it in Santa Clara county and first gave it a scientific name. The specific name, perniciosus, was intended to express the author's estimate of its character, as he found it swarming in countless numbers in certain orchards, infesting all deciduous fruit trees except the apricot and Black Tartarian cherry. In 1892 the insect had spread through all the fruit-growing regions of California, through Oregon and into the State of Washington. It has caused great pecuniary loss, many crops of fruit have been ruined and thousands of trees have been killed.

The insect enemies of farmers more than a thousand miles off do not greatly interest the agriculturists of New Jersey, who have enough to attend to at home; hence, naturally, no one ever con- 
sidered the San José scale as a creature which it was necessary to know; and this proved unfortunate.

In the summer of 1893, Dr. C. V. Riley, then U. S. Entomologist, announced to the Association of Economic Entomologists, meeting at Madison, Wisconsin, that the insect had been found infesting a small orchard at Charlottesville, Virginia. At that time the source from which the infection came was not known, and an accidental introduction on infested fruit was deemed probable. Radical measures were to be adopted to stamp out what was then supposed to be a solitary plague-spot.

In April, 1894, a circular was issued from the Division of Entomology, U. S. Department of Agriculture, calling the attention of fruit-growers to this scale, stating its history and spread, enumerating the points in the East at which it was known to occur, and closing one paragraph with the words: "The owner stated that the scales were first noticed three years ago, and expressed himself as of the opinion that the insect was brought into this orchard on nursery stock purchased from a New Jersey dealer."

This attracted my attention at once, and I decided to find the offending nursery or nurseries, to check, if possible, further distribution of the pest. Letters were sent to the leading establishments in our State, and I made excursions in rapid succession to those points where horticulture is a leading industry, examining the stock in the hands of dealers, and also many orchards recently set out. I soon located two nurseries, both large and well known, which were infested by the scale, and these, so far as I have been able to ascertain, are the only distributing centers in our State. It is not deemed necessary to name at this time the establishments which have unintentionally introduced the scale into New Jersey and into a number of surrounding States. The gentlemen concerned acted in ignorance and not in bad faith; they are taking active steps to stamp out the insect on their bearing trees, and have adopted measures which will, if faithfully carried out, prevent the shipment of other infested stock. It is also considered advisable to induce farmers to examine all fruit stock carefully before setting it out, and to that end they should be suspicious of all nurseries. 
This is perhaps as good a place as any to say that there are several nurseries on Long Island in which the scale is present; that one at least, in another part of New York State, is suspected, and that in Missouri we know of another which has distributed scaly stock. All material, therefore, whether received from our own or foreign nurseries, should be critically looked over before being set out.

\section{Introduction of the Scale.}

The history of the introduction of the scale is practically the same at both the infested nurseries in our State. In either 1886 or 1857 each imported from California a lot of Kelsey plum trees, the fruit of which was said to be "curculio-proof," and otherwise desirable, and with them other Japanese varieties were also received. In both cases the trees looked bad, were weak, made little growth, and after remaining in the nursery for two years were taken out and destroyed. It was afterward remembered that they seemed scaly; but no especial attention was paid to this at the time, and the nature of the scale was not suspected. It is almost certain that these trees carried this scale in large numbers, and from them the insects spread to the nearest bearing fruit trees, on which they multiplied exceedingly. In one case a row of Bartlett pear trees adjoined the block in which the Kelsey plums were grown, and these I found to be covered from base of trunk to the tip of the twigs ; scarcely a bit of bark being visible. The trees were nearly dead, and were at my suggestion taken out at once and burnt. From this row of trees the scales annually spread to the nursery stock round about, so that in an entire block, containing thousands of young fruit trees, scarcely one could be found without a few scales fixed on it. At all events, in both instances, the scale spread rapidly, and about 1889 or 1890 the first scaly stock was distributed. Since that time every year has continued the distribution of the insects, though it is probable that in the majority of instances they failed to establish themselves in their new homes. There is reason to believe that some Idaho pear stock, received from Western nurseries and shipped without further growth to purchasers, was also infested when set out. 


\section{Spread of the Scale in Now Jersey.}

It was considered important to ascertain just how far the scale had been distributed in our State, and to what extent the insect had spread from the points at which it was introduced. The nurserymen could and did give me willing and efficient assistance here, and furnished lists of names of persons to whom suspicious stock had been sent for five years past. These lists aggregated nearly 1,000 names, and to each individual a letter was written, inclosing a copy of the circular above referred to as published by the U. S. Department of Agriculture. A supply of these circulars was kindly furnished the Station at different times by the Department, through Dr. C. V. Riley and Mr. L. O. Howard, each at the time holding the position of U. S. Entomologist, and these gentlemen have in all ways facilitated my work by suggestions, information and assistance. Replies to my letter were received in considerable number, and I soon located a number of infested orchards and centers of infection. I realized that I could not depend upon correspondence alone in this matter and spent more than twenty days in active field work, examining thousands of trees and visiting a very large number of orchards. My plan was to visit one of the horticulturists on my list, and have him drive me about in his neighborhood; especially to those places where young orchards had been recently set out. Thus, I found a large number of places where the scale was present, and owe thanks to the gentlemen who so willingly gave their time and local knowledge to aid my investigations.

The result has been, on the whole, encouraging. In one case only had the scale spread beyond the trees that were infested when received from the nurseries; and while many of these were so badly infested that I advised taking them out immediately, I believe that in most instances they can be easily cleaned. I found, curiously enough, that all the infested orchards are south of the red shale. This formation crosses the State obliquely from Island View, opposite Staten Island, on the Atlantic Coast, to Trenton, on the Delaware, and extends northward ; clay, marl, loam and sand succeeding it to the south. I do not mean to assert that the scale does not exist on the red shale or northward; 
but simply that I have not found it there, and have not had any information which leads me to suspect its presence. South of the border indicated I have located the insects in every county. It is certain that climate has nothing to do with the absence of the pest in the northern half of our State, because it is known to exist on Long Island and in an orchard in Columbia county, N. Y., and it may be accident, merely, that is responsible for the apparent exemption from attack of the region mentioned. It will not do for farmers to assume that the scale cannot maintain itself in localities thus far uninfested; but, on the contrary, they should be especially cautious not to introduce it where it does not already exist. Nothing will be gained by enumerating the orchards in which this insect occurs, or even the townships in which they are located; there are nearly one hundred of them known to me, and probably there are more in places not visited, and from which I received no replies to my letter. It is probable, also, that the insect exists on fruit trees in some of the gardens in the many towns and villages along the Delaware, and within a short distance south and west from Camden on all the railroads. Its absence should be nowhere assumed.

\section{California Fruit Infested.}

While, so far as we know at present, all the existing scales in New Jersey are traceable to nursery stock, yet there exists a continuous danger from California fruit, and especially pears. I found in the markets of Philadelphia, Newark, New York and Brooklyn any number of pears with this scale conspicuously present, and noticed it on some of the fruit sold on the trains out of Philadelphia and New York. At the meeting of the Association of Economic Entomologists, at Brooklyn, N. Y., during August, 1894, this insect was discussed, and I purchased at the first handy fruit stand half a dozen California pears and exhibited them. Every fruit was infested more or less, male and female scales being equally abundant, and on one fruit the active yellow larvæ were found in some numbers, crawling about and seeking a place to fix. Should a pear of this kind, or the peel- 
ings from it, find lodgment near or on any plant suitable for its existence, there would be nothing to prevent the establishment of a colony.

\section{Life History.}

As the study of this insect is a matter of national importance, it has been taken in hand by the Division of Entomology of the U. S. Department of Agriculture. Indeed, the insect had been

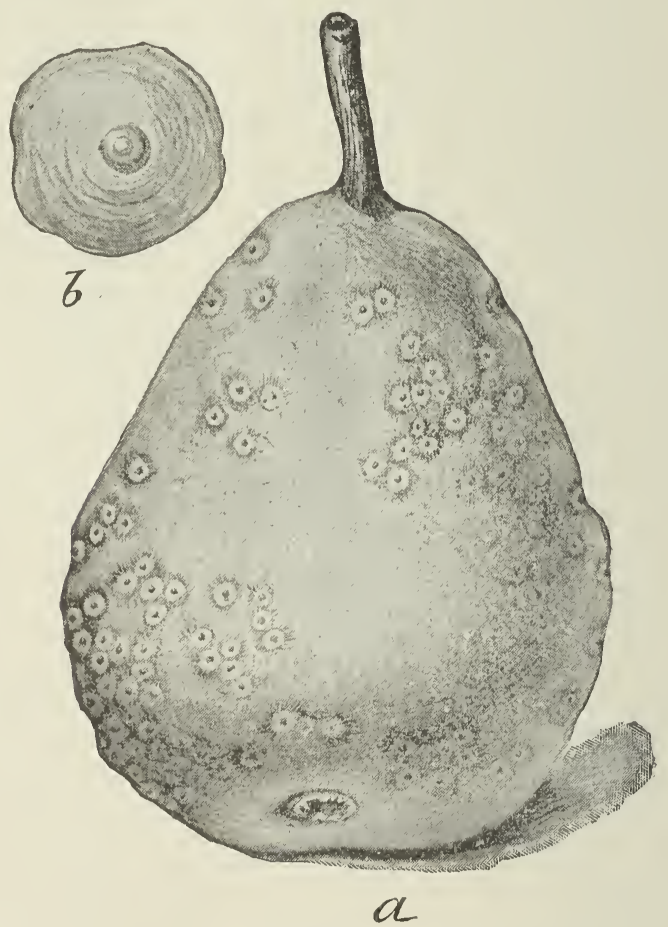

Fig. 1.

SAN JOSE SCALE.

$a$, California pear, moderately infested-natural size; $b$, female scale-en]arged.

studied, and its life history ascertained in California years ago, so we are quite familiar with its general habits and derelopment. I deemed it unnecessary to duplicate work, and have made no attempt at an original study. I have confined myself to observing the development and habits of the insect in our State, and 
to ascertaining those points that are practically important in its treatment. The life history that follows is therefore taken in its essential features from Circular No. 3, Second Series, of the U. S. Department of Agriculture, Division of Entomology, supplemented by my New Jersey observations. The illustrations are also from the above-mentioned circular, electrotypes being procured by the courtesy of the officers of the Department.

The San José scale belongs to the group of armored scale insects to which the common oyster-shell bark-louse of the apple belongs. It differs from that species in that the scale is perfectly round, or at most very slightly elongated and irregular. In these particulars it resembles the "scurfy scale," Chionaspis furfurus, or "Harris louse," as it seems to be quite universally called in this State; but it is deciderlly smaller and more convex than the latter species. Its round shape and small size distinguish it at a glance from all the other species infesting deciduous fruit trees in our State. It is quite flat, a little raised in the center, pressed close to the tree around the edges, resembles the bark of the trigs in color, and when full grown is decidedly less than one-eighth of an inch in diameter. Perhaps the majority of the scales do not equal one-sixteenth of an inch where they are closely crowded together; but where a few only are found on the succulent shoots, or on fruit, they become larger, and the females may in extreme cases reach nearly one-eighth of an inch. The males rarely exceed one-sixteenth

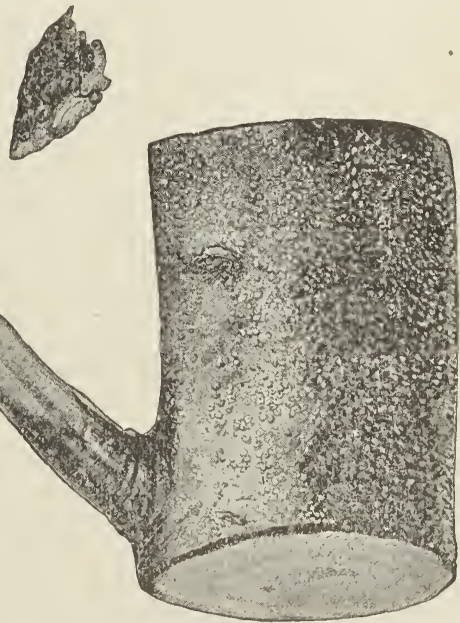

Fig. 2.

SAN JOSE SCALE.

Apple branch, with scales in situ-natural size; enlarged scales above, at left inch in diameter. It or near the middle of each scale is a small, round, slightly elongated black point; or this point may sometimes appear rellowish. 
When occurring upon the bark of twigs or leaves in large numbers the scales lie close to each other, frequently overlapping, and they are at such times difficult to distinguish without a magnifying glass. The general appearance which they present is a grayish, very slightly roughened, scurfy deposit. This is much more prominent on trees like the peach, or those varieties of apple and pear that have a reddish color, and when these are thickly infested they seem to be coated with dust or ashes. When the scales are crushed by scraping, a yellowish, oily liquid will appear, coming from the soft yellow insects beneath the scales, and this will at once indicate to one who is not familiar with their appearance the existence of healthy living insects beneath the scaly covering.

They are easily scraped off with the finger nail, and the bark beneath them will be seen to be darker in color. The natural

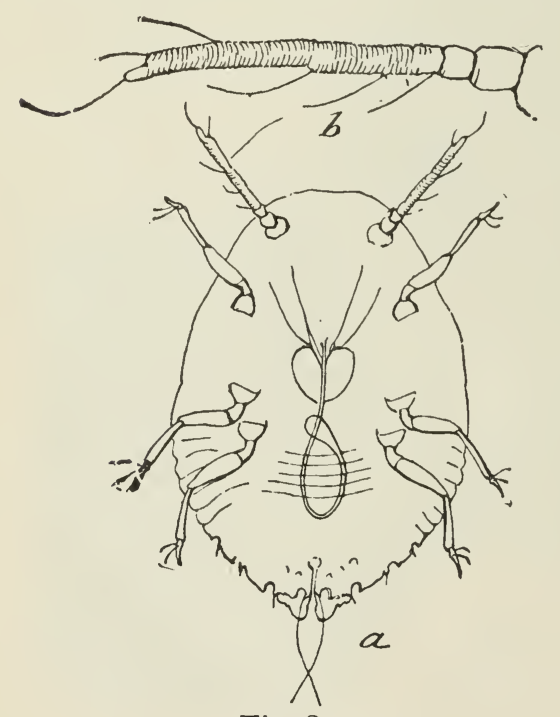

Fig. 3.

SAN JOSE SCALE.

$a$, young larva-greatly enlarged; $b$, antenna of same-still more enlarged. color of the bark is also somewhat changed, as will be seen by comparing the places from which the scales have been removed with the spots upon which the scales do not occur, while the circumference beyond the scales frequently becomes changed in color to a somewhat purplish or crimson shade. Where the scales do not. occur so thickly they are more perceptible, and upon young, reddish twigs the contrast is quite noticeable as the scales there appear light gray. Younger and smaller scales are darker in color than the older and larger ones, and sometimes appear quite black; while on the other hand, those that are just set may be white or yellowish.

During the winter the insect is to be found in the half or 
nearly full-grown condition, and as soon as the trees resume activity in spring the insects resume their feeding. In New Jersey they reach their full growth during the latter part of May, and the young begin to hatch and to crawl from under the female scales during the first week in June, and from this time through the summer there is a constant succession of generations. The first living larvæ that I received reached me June 11th, having been gathered June 10th, and at that time I found on the twigs a number of young scales that had just set, indicating that active larvæ had been about at least three or four days previously. Up to June 15th every infested tree examined showed active young larvæ, and after that time there seemed to

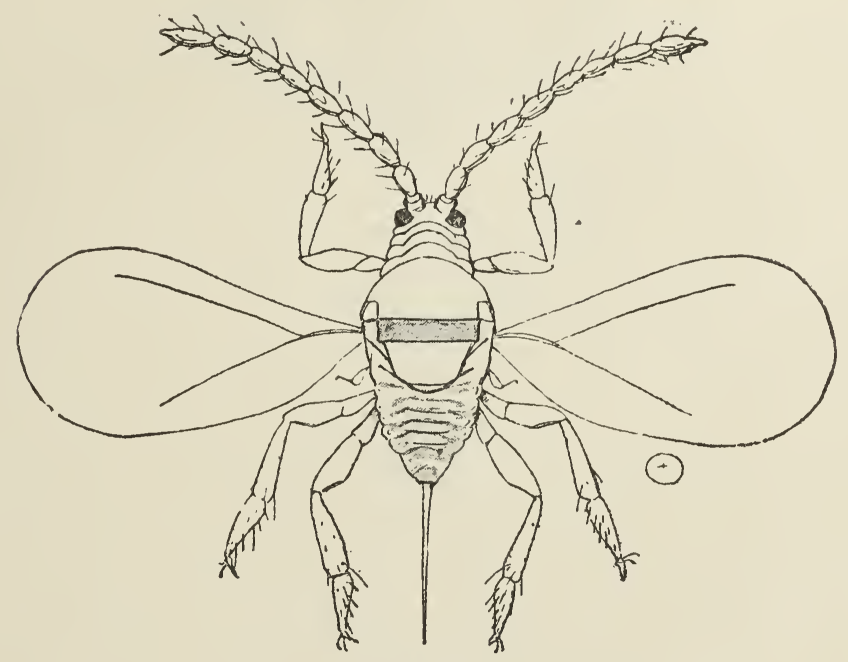

Fig. 4.

SAN JOSE SCALE.

Male adult-greatly enlarged.

be a period of about a week or ten days during which no larvæ were noticed. Early in July, however, young larvæ were again active and crawling about everywhere, and this condition of affairs continued throughout the balance of the summer, extending through October, and even into the first part of November; until, in other words, the trees had become quite dormant. The young louse is an active, crawling creature, very minute and 
yellowish in color. The young spread out upon the new growth of the tree, settle down, and each begins to secrete a scale. The male is an active two-winged insect, while the full-grown female loses her legs and antennæ, and bears a very slight resemblance to a living creature.

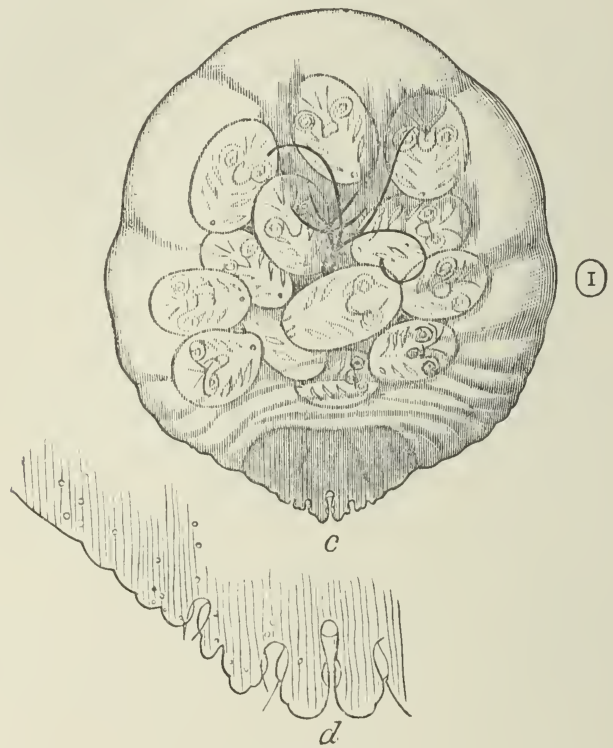

Fig. 5.

SAN JOSE SCALE.

$c$, adult female containing young - greatly enlarged; $d$, anal fringe of same-still more enlarged.

The insect affects not only the young twigs and limbs, but covers as well the trunk to the surface of the ground, and exists upon the leaves and upon the fruit. When it is abundant the fruit is destroyed, or at least rendered unfit for market. One of the most characteristic points in the appearance of the insect upon fruit is the purple discoloration around the edge of each scale. So far as we know, this result is confined to this species alone. Upon the leaves the insects have a tendency to collect along the midrib on the upper side of the leaf in one or more quite regular rows, and also to some extent along the side ribs. The infested leaves turn brown; but do not have a tendency to fall as a result of the damage. 
There are two points of interest and importance to be noted in this life history. The first is, that the insect passes the winter beneath the scales in a partly-grown condition. Usually they are about half grown; but some will be younger and some will be older. They seem to continue reproduction until the tree is entirely dormant, and no further food is obtainable. On the other hand, they do not seem to renew growth very early in spring, but are slow to begin reproduction; no larvæ having been noted until June, as has been already stated. The second point is, that once they begin there is practically no period during the summer at which the young, active, crawling lice are not to be found upon the tree. The length of time during which a given female will continue to reproduce has not been ascertained; but it seems likely from what has been observed that breeding continues for quite a long time, and that the female scales that have lived during the winter may continue to live on and reproduce during the greatest portion of the summer, when their daughters and grand-daughters are already full grown, with nearly full-grown progeny. There may be, therefore, upon a plant at one time, young born of as many as three or even four distinct generations. As nearly as I have been able to ascertain from my observations during the present season, a little less than a month is required to bring an insect to maturity. That is, a larva hatched to-day will be ready one month hence to bring forth living young in turn, and this will allow at least four if not five distinct broods during the summer and fall.

\section{How the Insect Spreads.}

It has been stated that the male of this species is a winged insect. It is very minute, scarcely noticeable without a lens, very light and frail, at the mercy of the least puff of wind, and incapable of any great journey. The female has no perceptible legs, and is utterly incapable of motion. She resembles a yellowish or orange, flattened seed, in bulk many times that of the male; but firmly fixed to one point by the scaly covering which is at once her protection and her grave. The young are active for a very brief time, two or three days at most, and they crawl 
with considerable rapidity and great persistence, so that they might possibly descend from one tree and crawl for a number of ${ }^{-}$ yards to another; but the spread in this manner is insignificant. Where trees are close together they may pass from the branches of one to the branches of another; but I have found that they rarely crawl long in any one direction ; they rather move around, rapidly enough, yet irregularly and at random. Usually they do not go farther than is necessary to find a good place to fix, and at once begin to form a scale. This process is rather interesting and can be watched. As soon as the young louse has inserted its beak into the plant, and has begun to feed, a change comes over it, and within a few hours it is entirely covered by a fine, white, waxy film. This turns first yellow and then gray or even black, and the creature is a fixture, absolutely incapable thereafter of shifting its location under any possible circumstances. Strong winds may carry the young bodily from one tree to another; but the principal method of spread is by means of other insects which are winged, and by birds. The active young lice will soon crawl upon any small winged insect, particularly if the latter is of a dark color, and they may be carried by it to considerable distances. They also crawl upon the feet of birds which visit the trees, and may thus be carried for miles. They are often found upon ants, and ants, as everyone knows, are great travelers. This difficulty in moving from one place to another, and the dependence upon external agency for their distribution, will account for the fact that trees here and there in an orchard newly set out, may be very badly infested, while not a trace will be seen on the trees on either side. Few birds or insects visit a young orchard that is at all well kept, and the distance between the trees, especially if the land is cultivated, is altogether too great to be covered by the young lice, even did they know enough to make a bee-line for the nearest point. The result is that everything fixes upon the tree on which it was hatched, killing it more rapidly than would otherwise be the case; but at all events confining and preventing spread to points not theretofore infested. This also explains why nursery stock is so evenly troubled: here the trees are grown just as closely together as is possible, in rows, and there is no hindrance to crawling from one to the other. 
As the insects must feed for a time in spring before attaining their full growth, it follows that only such as are fixed to thetree itself have any chance of reprodncing their kind. Those that fix to the leaves fall with them, and as these dry or decay the insect dies for want of food before attaining maturity. We have, thus, to consider only the wood, free of all leaves, when attempting the destruction of the insect.

\section{Varieties of Fruit Infested.}

All our deciduous fruit trees are attacked by this insect; though not to the same extent. In addition, currant, gooseberry and rose-bushes are infested, and it is probable that the entire natural order Rosacex will support the species. In addition, a single specimen of a European variety of elm was found densely covered by it, and I found a few specimens apparently of this species on an English walnut, growing next an infested pear tree. Comparatively few scaly peach trees were found in my observations. This is due to the fact that the infested nurseries do not grow their own stock of this fruit, but have it grown elsewhere. It is shipped to them in bulk, heeled in, and reshipped as ordered. Anything left over is destroyed. Apples, pears, plums and cherries are the usual victims, and pear trees more than any others. Quince is more rarely troubled. Among the plums the Japanese varieties are favorites, while those of American and European origin suffer much less. The apples seem to be equally affected, and I noticed no markedly exempt varieties. Pears differ greatly in susceptibility. European stocks and varieties are nearly equally subject; Idahos, in my experience suffer most, closely followed by the Lawson, Garber, Madam von Siebold, Sin-Sin, Lawrence and Bartlett. The varieties of pears are legion, and all of them support the scale. The Japan Golden Russet is a vigorous grower, and is not a favorite with the insect. Still less infested is the Leconte, while the Keiffer is almost exempt. A striking example of this difference I found in a tree upon which both Lawson and Keiffer were grafted; the Lawson branches, leaves and fruit were completely covered, while the Keiffer portion was entirely free from scales. In several instances. 
where Keiffers were set in trial-rows with other varieties, the branches intermingling, the Keiffers were entirely clear, while all the others were more or less infested. The Leconte was nearly as fortunate, and where there is opportunity for choice these varieties will be exempt. I was inclined to believe that the Keiffer was scale-proof until October, when I received specimens of infested twigs of this variety, and learnt of an orchard of these trees in which the insects were abundantly present. I have learnt since that time of several instances where this variety has been more or less troubled, and no further doubt exists, therefore, that under proper conditions-unfortunately we do not yet know what these conditions are-the insects will exist and multiply on it as readily as on any other. Yet withal, the Keiffer is least likely to be attacked in my experience where other varieties are at hand. But it is not exempt, and no variety is entirely immune.

\section{Natural Enemies.}

I have been asked on several occasions whether this insect had no parasites. It has. I have bred specimens of Aphelinus fuscipennis, Howard, a very minute, yellowish, parasitic wasp, from the scales in moderate numbers, and this same species has been bred from it in California. I am informed by Mr. Howard, U. s. Entomologist, that up to September no parasites had been bred in the East by any investigator other than myself, and also that this little Aphelinus occurs all over the country, and is a foe to scale insects generally. Not one per cent. of the scales collected by me and carried through in the laboratory were parasitized, and in the field it was difficult to find a destroyed specimen. As a slight check to increase, this little species has a value; but no actual reduction, or even a restriction to present numbers, is to be hoped for from its efforts. It is only fair to add, however, that in one case in California the insect "had been found doing such effective work in subduing the species in an orchard in the neighborhood of Los Angeles that a complete restoration of the orchard was confidently expected."

Two species of lady-birds were also observed in some numbers feeding on the scale. The most prominent was Chilocorus 
bivulnerus, the "twice-stabbed larly-bird," which is black, almost hemispherical above, one-eighth of an inch in length, and has a blood-red spot in the middle of each wing-cover. The other species is Pentilia misella, to which no common name has been applied, and which is a minute black creature, scarcely as large as the scale itself. These beetles and their larvæ undoubtedly devour many of the scales and their larva; but they do not occur in numbers great enough to check the increase and further spread of the pernicious scale.

No trust can be safely placed in these natural enemies. A little active winter work now, will benefit the farmer more than all the "natural enemies" can possibly adrantage him in ten years to come.

\section{Remedies.}

This scale can be so much more satisfactorily treated in winter that I strongly urge an attack upon it during the present season. No fruit-grower, on ever so small a scale, can afford to allow this insect to remain on his trees, and all furmers should carefully examine every tree received and set out within the six years last past, to make sure that the pest loes not exist upon any of them.

Our large orchardists are, as a rule, careful of their trees, and many are in the habit of winter-treating them. In two or possibly three instances, I feel convinced that the scale has been killed off where it was present, without the knowledge of the owner. In one case the trees were washed with a saturated solution of commercial potash; in another the trees were kept constantly whitewasher ; in the third, and doubtful case, whaleoil soap was used, and here I am not so certain that the scales had been really present. In another instance I found a number of apple trees with a few scales near the tip of the twigs, and a very few on the fruit. In this case the arsenites and Borleaux mixture are used each year, and whenever the trees are sprayed the trunks and larger branches receive a special coating. No scales were found there, and though the trees had been set out five or six years, and must have been infested when receiverl, they were thrifty and vigorous. The scale har barely main- 
tained itself, and there were probably fewer specimens than when the trees left the nursery.

If such good results follow from what is considered by some of our horticulturists merely proper care of an orchard, we may reasonably hope that special treatment directed to the extermination of this particular scale may be even more successful.

In selecting materials to use for the destruction of scales, we have to consider, first, the character of the creatures to be reached, and second, the way in which we expect to reach them. The insect itself lies close to the bark, completely covered and protected by the scaly secretion which is closely applied to the surface by its entire circumference. We must, before we can get at the living creature, either corrode or dissolve the scale; we must employ an agent subtile enough to penetrate any minute opening, able also to kill the specimens when it reaches them; or we must coat the scale with a wash which will fix it permanently to the tree and which cannot be penetrated by the males when they seek to emerge, or by the larvæ should the female scale be fertilized.

As a solvent or corrodent, lime is of some use; but only when freshly slaked and to a small extent. It is not sufficiently certain for use in this case. Caustic soda and crude potash are very much better and more reliable. Potash is used by a number of our growers as a winter wash, and it has proved effective in destroying the scurfy scale, and the oyster-shell bark-louse. In California, so it is stated in Dr. Riley's Report as U. S. Entomologist, for 1893, "A seriously infested orchard was treated with absolutely complete success, by means of a wash composed of one-half pound of commercial potash, one-half pound of caustic soda, and five quarts of water. This was applied when the trees were in a dormant condition."

Both potash and soda corrode the scales, and when they reach the insect, burn through it as well. Potash is used in my laboratory practice to destroy rapidly all muscular and other tissues of the insects I wish to prepare for study, leaving only the chitinous framework, and even this is dissolved in time. This substance is, therefore, theoretically and practically a good one for the destruction of scale insects. Potash alone will act as well as 
in combination with soda, and may be purchased in one hundredpound lots at seven cents per pound. If this is used, it should be as a saturated solution; $i$. e., use only water enough to fully dissolve all the potash, and this will be facilitated by heating the water. Apply thoroughly to the entire tree when it is dormant.

As a penetrating material nothing is better than kerosene. It will find its way through the smallest opening, and where used pure, will kill every insect with which it comes into contact. To dormant trees it may be applied pure, and where thoroughly used will prove effective. It is, however, even more effective when emulsified with soapsuds and somewhat diluted. The formula is as follows:

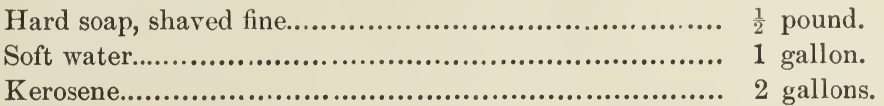

Dissolve the soap in boiling water, add to the kerosene, and chur'n with a force-pump until a smooth, white, butter-like mass is formed which adheres to glass without oiliness. The hotter the liquids are when they are joined, the sooner the emulsion will be formed. If the kerosene is warm, the soapsuds boiling hot, the pump or syringe not cold, from three to five minutes will perfect the emulsion. Stirring with a stick will not answer, nor will any agitation less violent than that obtainable with a syringe or pump produce a satisfactory result.

For application against this scale dilute with five parts of water and apply liberally. The kerosene in this mixture does not evaporate so readily as when applied pure, and more opportunity is given to penetrate the scale. The caustic of the soap is also of use in loosening the scale and facilitating the entrance of the oil. An excess of soap in the emulsion is therefore no fault, and the emulsion is apt to be more readily made. The water should be soft for best results in making the emulsion; but hard water can be used to dilute.

The resin washes, which are general favorites in California, act by forming an impervious coat over the insects, and also through the caustic they contain. They would not be as satisfactory with us, because our frequent rains would wash off the 
mixtures before they had an opportunity to become fully effective. They are also better for use in summer, when the young are active, than in winter, when, in my opinion, the most radical measures are possible.

A great many experiments have been made by the United States Department of Agriculture with all the substances recommended for use in California, and which have proved more or less successful there. In all cases they have proved rery much less effective in the East. Mr. L. O. Howard, United States Entomologist, wrote me Norember 19th, "I have pretty well determined, however, that we will be obliged to abandon the lines generally worked on in California-that is, lime, salt and sulphur; lime, sulphur and blue vitriol; winter resin wash, and strong kerosene emulsion. None of these killed off all of the scales, although all reduced their numbers to a greater or less extent. There is unquestionably, a more perfect dormancy on the part of the scales here than there is in California, which probably alone accounts for the comparatively poor success of these washes. The only thing which I have found, so far, which I can say is almost absolutely complete in its work, is a solution of two pounds of whale-oil soap to one gallon of water. A tree which Mr. Coquillett sprayed with this mixture the third week in October was examined by me yesterday, and although I spent nearly an hour going over the tree, I failed to find a single living scale. Eren those which had worked their way down between the scales of the buds were killed." Whale-oil soap is rather expensive, and especially if it is to be used at the strength recommended-that is, two pounds to one gallon of water. A fish-oil soap can be made, however, without difficulty by farmers themselves according to the following formula:

Crystal potash lye 1 pound.

Fish oil. 3 pints.

Soft water....... 2 gallons.

Dissolve the lye in the water, and when brought to a boil add the oil. It should boil about two hours, and when done can be filled up to make up the loss by evaporation. 
This will make a batch of about twenty-five pounds, or enough for thirteen gallons of water. It should be applied with very great thoroughness, so as to wet to dripping every portion of the tree. The cost will be about one cent per pound.

It remains, finally, to mention the gas treatment. This has ibeen much used in California against scale insects infesting Citrus trees, and is extremely effective. It is also quite expensive; not so much in the materials used as in the outfit required. Essentially it means inclosing the tree to be treated by an oiled canvas tent, and producing in this confined space hydrocyanic acid gas, by means of the action of diluted sulphuric acid on fused cyanide of potassium. The proportions are, one ounce by weight of not above sixty per cent. cyanide of potassium, one fluid ounce commercial sulphuric acid, and three ounces water. This is sufficient for an inclosed space of one hundred and fifty cubic feet. After a tree is inclosed, the water is first poured into any glazed earthenware vessel ; the acid follows and the receptacle is placed under the tent. The cyanide is then added, and the gas at once begins to arise. It is lighter than air, and displaces the latter in a very short time. It is also excessively poisonous, and deadly to all animals, including man, and care should be taken not to breathe it. The trees should remain exposed to the action of the gas about one hour, and this will generally kill all the scale insects infesting it, and will rid it also of all other sorts of insect life that is not in the egg or pupa stage.

It has been found that warmth and daylight affect the action of the gas, making it more dangerous to plants and less deadly to insects. Fumigation, therefore, is best made at night, or late in the afternoon of a cool day, when its action on insects is at its maximum and its effect on plants at a minimum.

This treatment is not recommended in New Jersey, because no orchard known to me is sufficiently infested to authorize the expense required to supply the necessary outfit.

A modification of it, however, should be adopted by the nurseries. All stock infested or suspected of infestation should be fumigated before being sent out. The trees should be either heeled in or made up in bundles, the roots wrapped to retain moisture, and the mass, covered by oiled canvas or other gas- 
tight material, should be fumigated one hour. The material' should be used at the rate given-i. e., one ounce of cyanide to. one hundred and fifty cubic feet of space.

\section{Recommendations.}

On consideration of all that has been said above, concerning life history and available remedies, the following suggestions for practice are made :

First. Every orchard that has been set out within the last six years should be thoroughly examined to ascertain whether or not the scale is present.

Second. If it proves to be present and is confined to a few trees, the trees had better be taken out and destroyed, unless the infestation is so slight that the trees can be gone over with a stiff brush and all the scales actually brushed off.

Third. If the orchard is young, and the trees are not too large. to be handled, it will be best to use a stiff brush and, taking each tree separately, brush off all the scales. This looks like a good deal of mechanical work; but it will pay in the end. It can be done at any time during the winter; it will be absolutely effective and, with care, there need be no further trouble from this insect in an orchard so treated.

Fourth. If the trees are too numerous to be treated by hand, or are too large to be conveniently handled, prune back liberally, removing as much wood as the tree can easily spare. The cuttings should be carted off and burnt as a matter of precaution, and what remains of the trees should be washed with the potash solution above described. This should be done as soon as may be, and a month later, during a moderately mild spell, the trees should be again treated, this time with the kerosene emulsion, made as above described and diluted five times. The object of this double treatment is, first, by means of the potash to dissolve or corrode the scales to a greater or less extent, and to kill off a considerable proportion of the insects themselves. At the end of a month the potash will probably have been washed down and all dissolved away, so as to exert no further action. The scales. 
however, will be thinned down, riddled or loosened from their hold, and an application of the kerosene emulsion then made will give it abundant opportunity to reach the insect. If both these materials are applied thoroughly, the kerosene will finish any work left undone by the potash and not a single specimen need escape.

Fifth. Large or bearing trees should be treated much as described under the previous heading - that is to say, they should be cut back as far as it is possible to do without endangering the tree. If the bark of the tree is rough, it should be first scraped in order to get rid of all loose material. Then the potash should be applied, and afterward the kerosene emulsion, as described under the previous heading. Properly carried out, these recommendations should enable any orchardist to rid his trees completely, not only of the San José, but of all other scale insects infesting his orchards.

In place of the suggestions above. made, the whale-oil soap treatment, described in a previous paragraph, may be adopted; but this also should be applied twice in order to make it certainly effective.

All these recommendations are, of course, for winter treatment, when there is no foliage to interfere with the application of the material. If for any reason winter treatment is not possible, then spring treatment should be delayed until the young larvæ are observed crawling about. The kerosene emulsion should then be used, diluted with nine parts of water, and the spraying should be thorough. Two additional sprayings should be made at intervals of not more than a week, in order to kill off the young that are continually hatching, and to destroy the young scales that have just set. Three such applications, properly made, should be effective, and should be all that is necessary; but if young larvæ are again noticed later on, and it is evident that scales are still alive, the application should be repeated as often as may be necessary until no further larvæ are seen on the tree. I would again, however, urge most strongly immediate attention to orchards, and the winter treatment above outlined. The trees when dormant will stand a great deal more than when 
they are active, while the insects are not more resistant than they are during the summer. Applications, therefore, that are impossible in summer can be readily made in winter, and the winter treatment is not only more effective, but is on the whole cheaper.

This scale is in some respects the most important insect that has been introduced into our State within recent years. Its wide range of food plants, its marvelous powers of multiplication, and its deadly effect upon the infested trees, all make it a pest of the first rank. No farmer ought to consider the matter unimportant enough to neglect, even though he has only a single tree. It is, I think, still possible to exterminate this insect in our State, and by care to prevent its re-introduction, and this leads me to my last, which was also my first, recommendation: carefully and thoroughly examine every tree and every shrub received from. nurseries before setting them out, and whenever anything suspicious is noticed reject the stock rather than put it into the field, and run the risk of losing not only that which has been just planted, but also everything else that may be in the vicinity. 





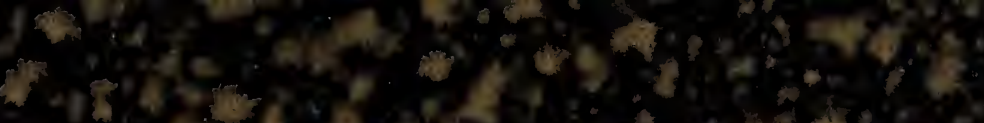

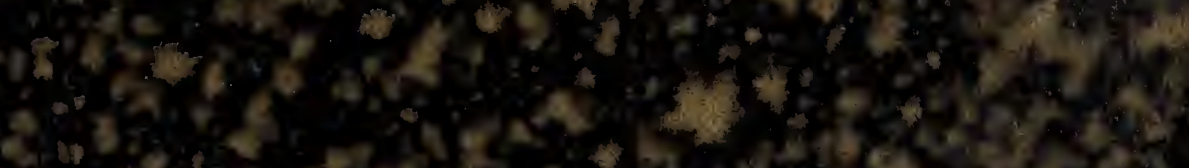

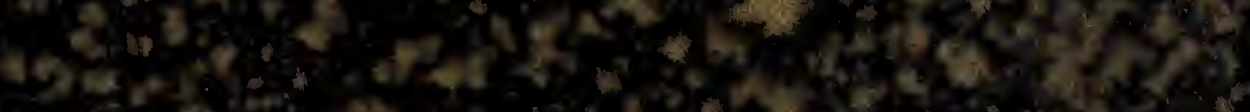

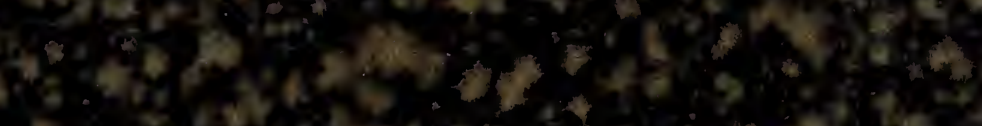

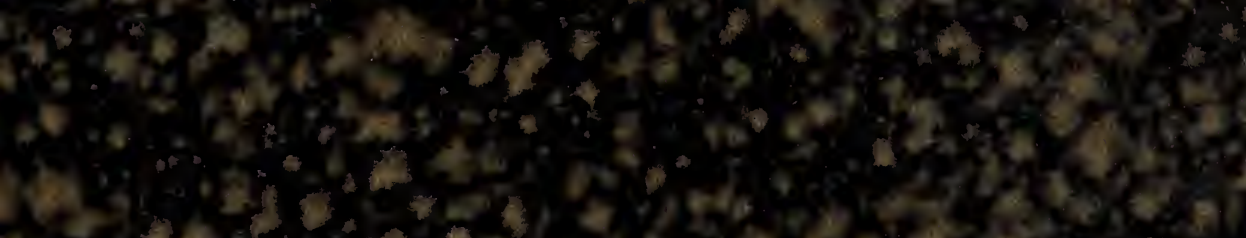

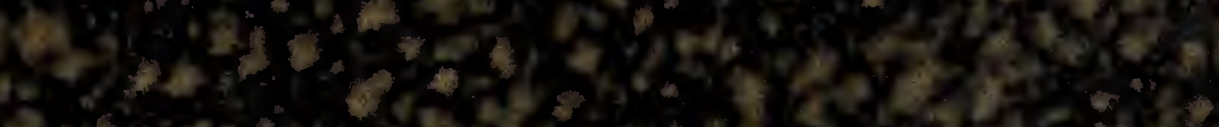

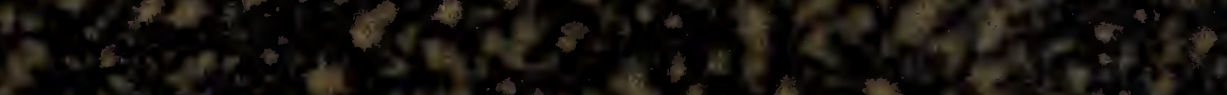

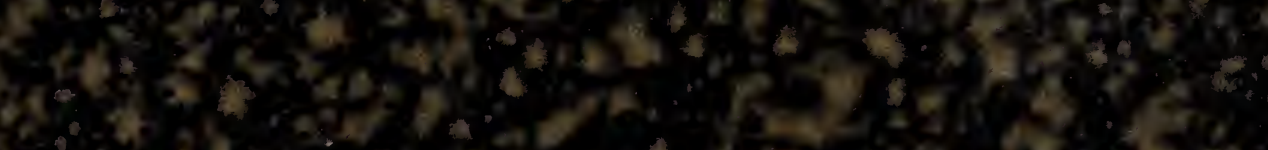

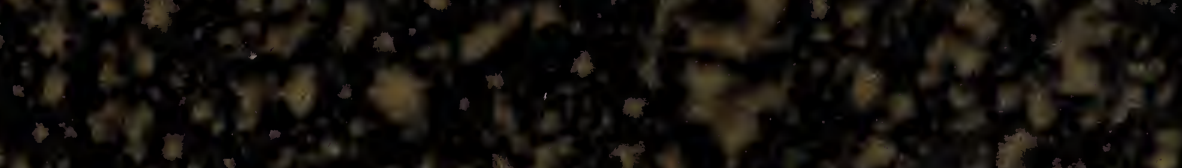

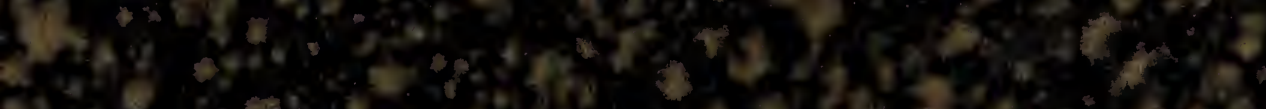

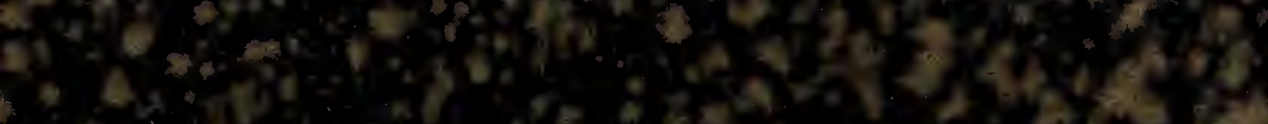

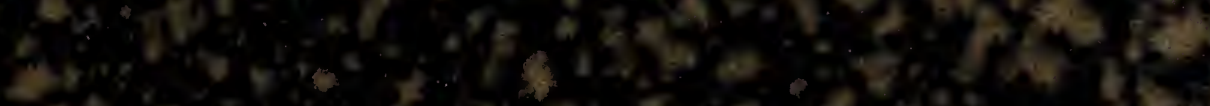

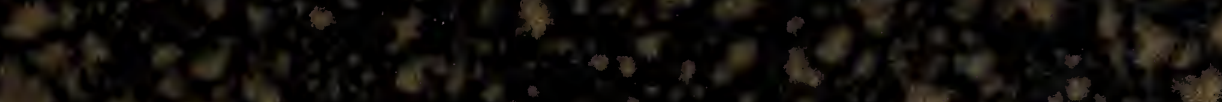

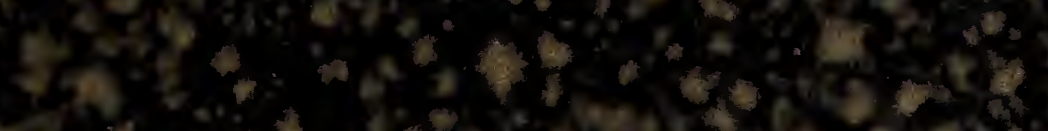

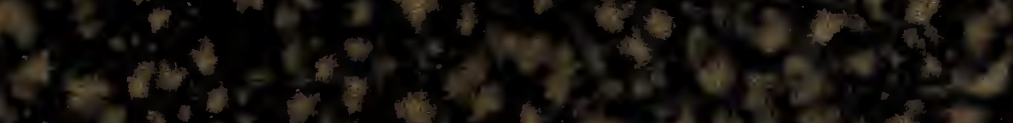

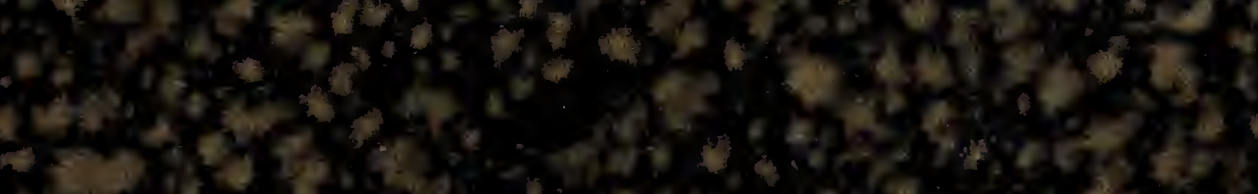

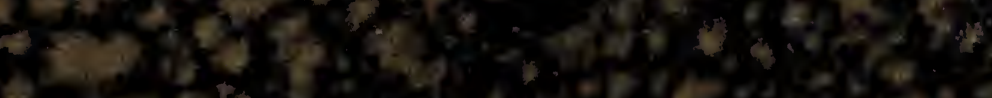

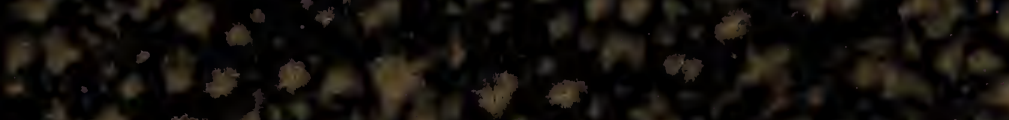

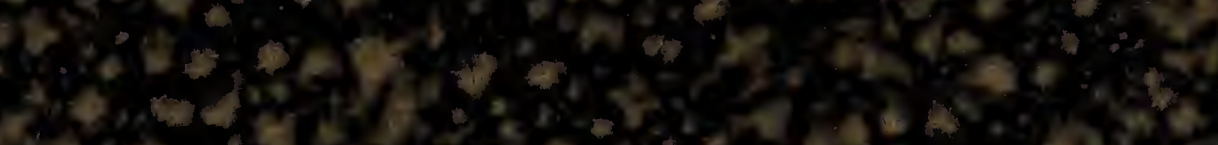

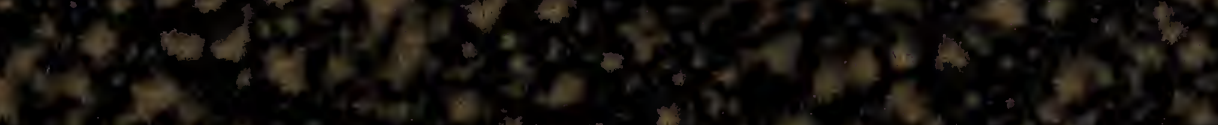

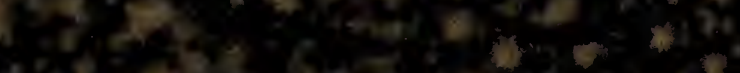

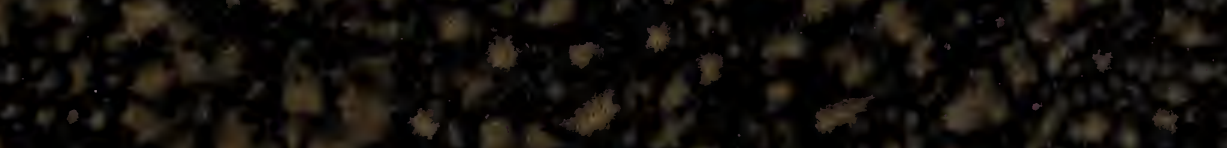
Les

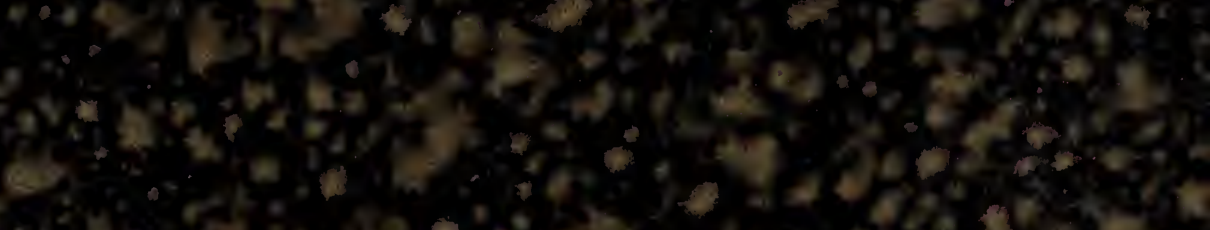

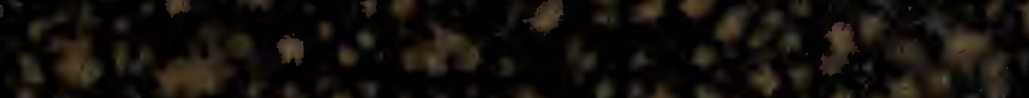

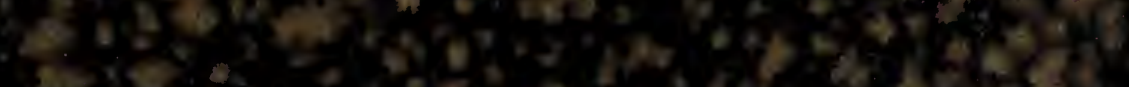

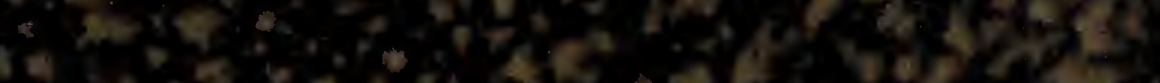

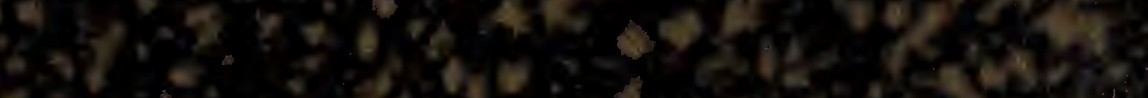

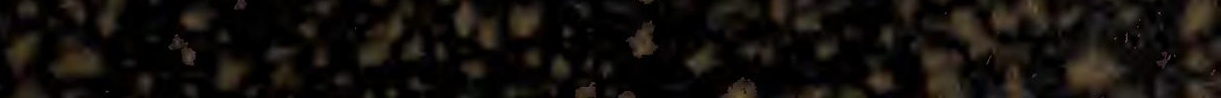




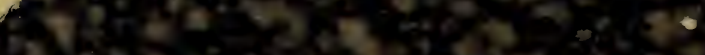

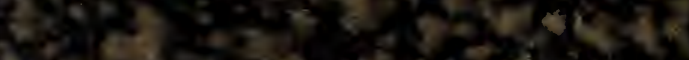

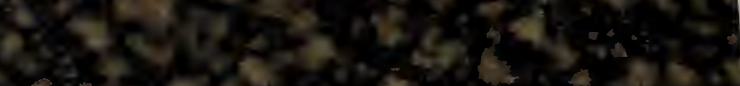

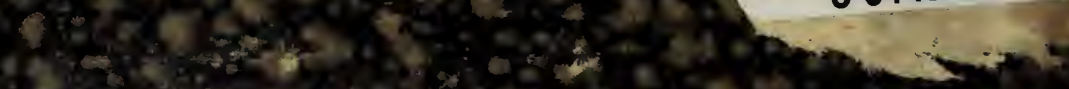

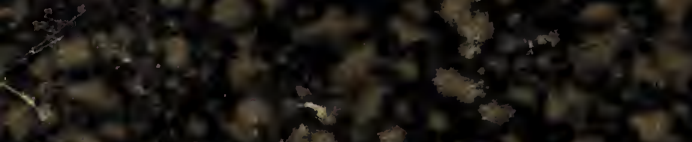

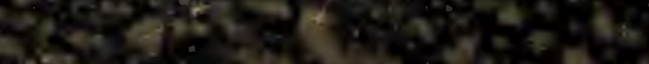

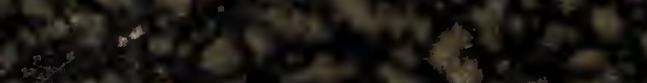

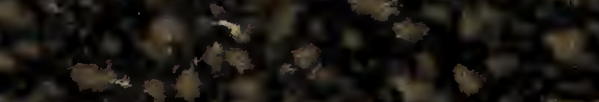

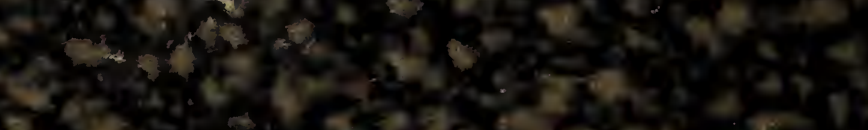

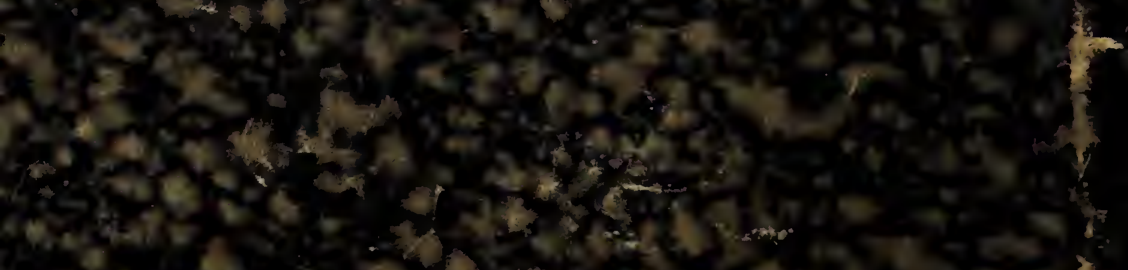

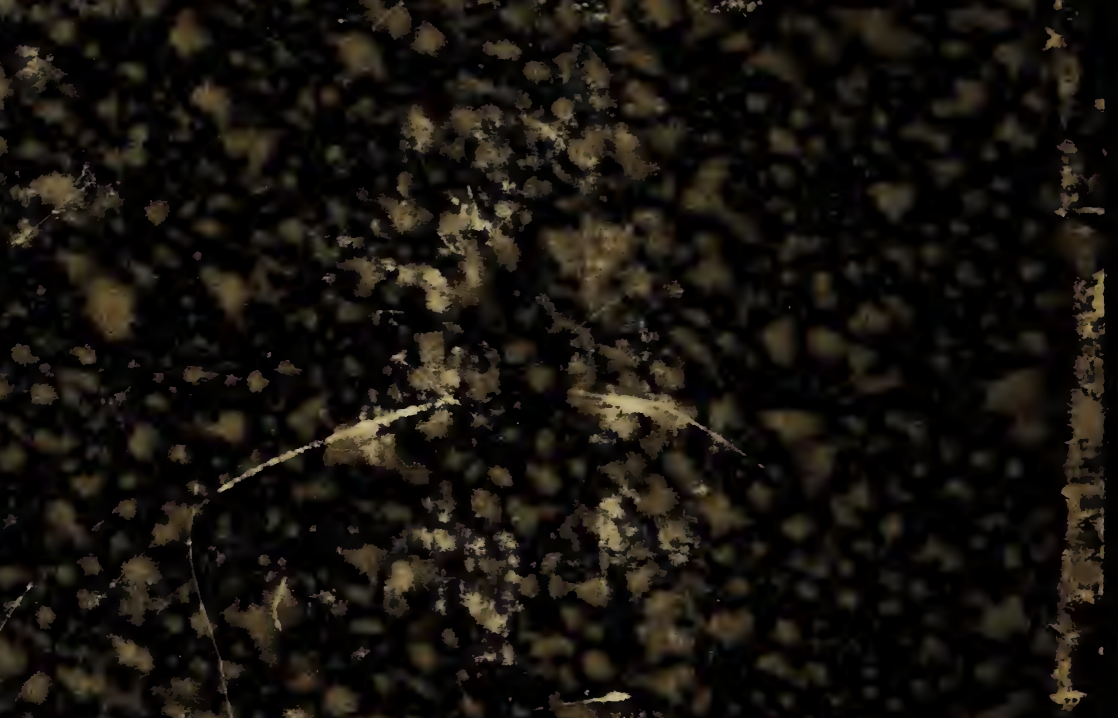

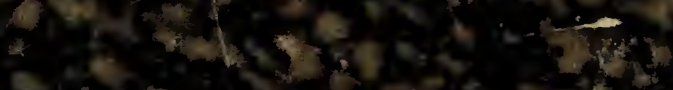

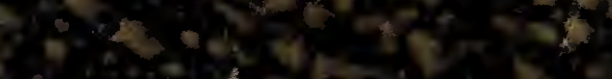

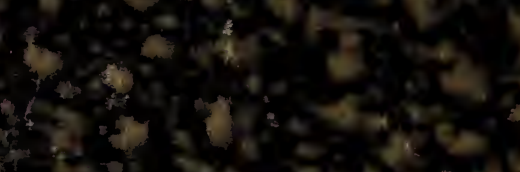

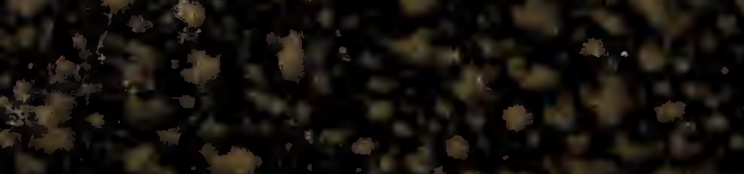

i.

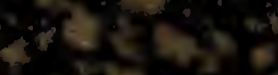

$8 \rightarrow x^{2}+x^{2}+x^{2}$ 